\title{
VERTEDEROS DEL CAMPAMENTO
}

DE LA LEGIO VII GEMINA EN LEÓN:

EL MATERIAL CERÁMICO 
“Espera mil años y verás que se vuelve preciosa hasta la basura dejada atrás por una civilización extinta "

Isaac Asimov 
A mi adorado padre

In Memoriam 



\section{ÍNDICE}

\section{I.- INTRODUCCIÓN}

II.- METODOLOGÍA

III.- CONTEXTO ARQUEOLÓGICO

IV.- ESTUDIO DE LOS MATERIALES CERÁMICOS

A) DEPÓSITO-VERTEDERO DE “SAN PEDRO”

1.- TERRA SIGILLATA HISPÁNICA

2.- TERRA SIGILLATA HISPÁNICA TARDÍA

3.- CERÁMICA COMÚN

4.- MORTEROS

5.- ÁNFORAS

6.- MATERIALES ESTUDIADOS EN OTROS TRABAJOS DE INVESTIGACIÓN

6.1.- Lucernas

6.2.- Cerámica de Paredes Finas

B) COMPLEJO TERMAL DE SAN LORENZO

1.- TERRA SIGILLATA HISPÁNICA

2.- TERRA SIGILLATA HISPÁNICA TARDÍA

3.- CERÁMICA COMÚN

4.- MATERIAL ESTUDIADO EN OTROS TRABAJOS DE INVESTIGACIÓN

4.1 Material Latericio sellado

C) VERTEDERO DE LA C/PILOTOS REGUERAL

1.- TERRA SIGILLATA HISPÁNICA

2.- CERÁMICA DE PAREDES FINAS

3.- CERÁMICA COMÚN

4.- MORTEROS

5.- LUCERNAS

6.- ÁNFORAS

V.- CONSIDERACIONES FINALES

VI.- BIBLIOGRAFÍA

VII.- APÉNDICES

APÉNDICE I: RELACIÓN DE INFORMES ARQUEOLÓGICOS CONSULTADOS (Servicio de Cultura. Delegación Territorial de León. Junta de Castilla y León)

APÉNDICE II: ANÁLISIS ARQUEOMÉTRICOS 
I.- INTRODUCCIÓN 


\section{1.- EL MEDIO FÍSICO Y LA TOPOGRAFÍA URBANA}

El territorio ocupado por los asentamientos campamentales de época romana que dan origen a la actual ciudad de León, se extendió en el interfluvio que en este punto geográfico forman los ríos Bernesga y Torío, ubicándose en el área de mayor altura, dentro de este espacio aterrazado.

Perteneciente a la unidad morfológica de la Submeseta Norte, se caracteriza en primer lugar por una considerable altitud (sobre los 830 metros), lo que facilita una amplia visibilidad y el control estratégico del territorio.

Desde el punto de vista geológico y litológico, esta zona llana se asienta en los sedimentos miocénicos de arcillas, arenas, margas, yesíferas y microconglomerados, coronados por un nivel de calizas de origen lacustre de espesor variable (Cabero, 1983: 25). Estas características edafológicas permiten la extensión de importantes zonas de cultivos, a lo que hay que añadir la peculiar hidrología, con los dos cercanos grandes cauces antes mencionados, que, además de garantizar el abastecimiento al enclave castrense, contribuyen al desarrollo de un terreno fértil (Tomé, 1997: 13), e incluso se ha añadido la posibilidad de aprovechar los cursos de agua como fosos naturales (Reguera, 1996: 89). En esta valoración no deja de pesar la denominada "dominante hidráulica" que desde la geografía considera el agua el primer condicionante de los asentamientos, aspecto indiscutible desde las primeras culturas históricas, pero que ya en época romana ha de contemplarse en un conjunto de variables que configuran, siguiendo los términos de los principales autores de la denominada arqueología espacial, "el área de captación de un yacimiento" (Butzer: 1989; Hodder y Orton: 1990).

Así, además de los numerosos cauces de agua que habrían de surcar el campamento, y sobre todo el área extramuros, ya que las condiciones edafológicas del suelo leonés hacen que el manto freático aflore con rapidez, propiciarían la acción antrópica traducida en acciones de relleno y nivelación en zonas anegadas. Ello se realiza a través sobre todo de la ubicación de vertederos, que constituyen un elemento de primer orden para transformar determinados factores problemáticos de la topografía urbana como este carácter endorreico y periódicamente inundable que obliga a salvar estos obstáculos generalmente con niveles de vertidos de diferentes materiales, y cuyo contenido resulta esencial para determinar la cultura material de las diferentes etapas de ocupación del campamento.

Con todo ello, los adecuados factores para la instalación de este recinto campamental son también valorados por algunos investigadores que afirman desde postulados estrictamente geográficos que "en el campamento de Legio nos encontraríamos un modelo de urbanización reticular relacionado de forma genérica con la maximización de la eficiencia y la racionalización en la distribución espacial de los hombres y efectivos vinculados a una actividad militar" (Reguera, 1996: 91).

Ya en los primeros estudios, como el de Gómez Moreno en el capítulo dedicado a los orígenes de León, se hace hincapié en esta apropiada ubicación del campamento, "escogiendo la ribera del Bernesga, sobre la calzada de Astorga a Zaragoza, en derechura al puerto principal de Asturias, dentro del enorme triángulo que forma la cuenca del Esla, antes de la confluencia de Benavente, y a distancias aproximadamente iguales entre Astorga y Lancia, metrópolis de aquella región. Centralidad, buen suelo y expeditos caminos justifican la elección del sitio" (1925: 23). 


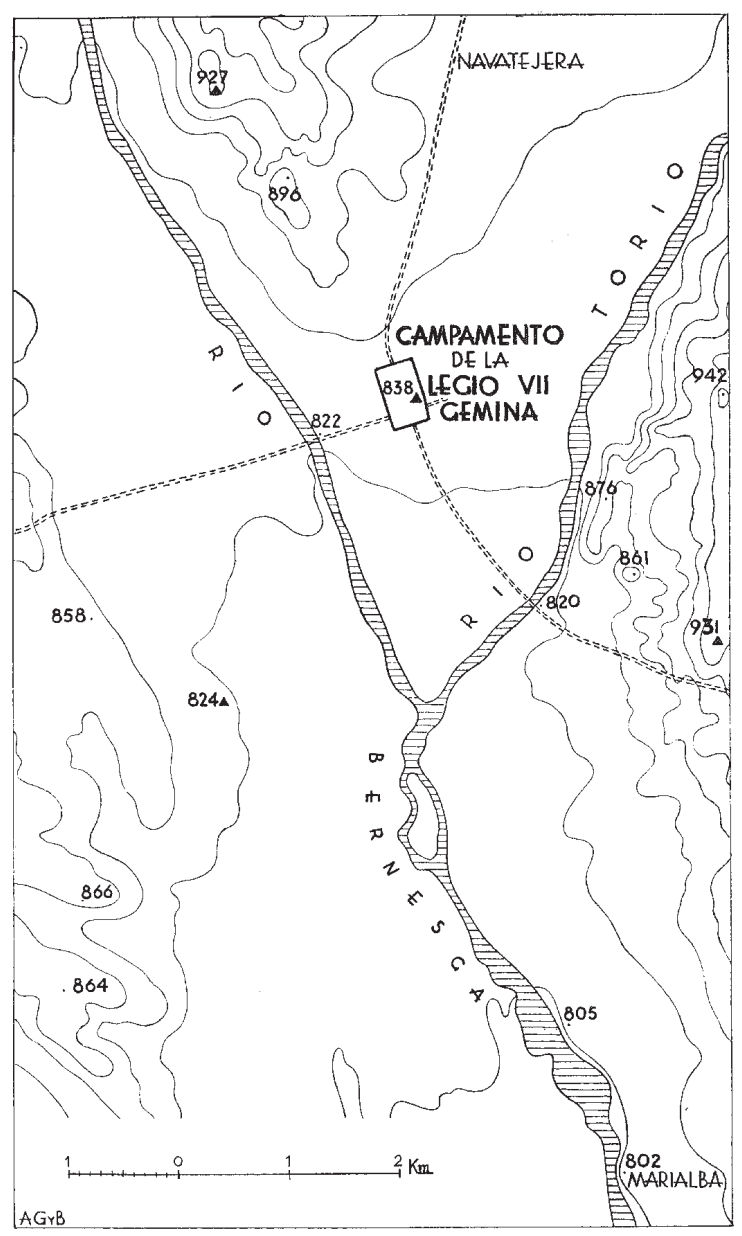

Fig. 1: Plano topográfico de Legio (según A. García y Bellido)

De esta manera, además de los recursos hídricos, otra variable fundamental en la que inciden todos los investigadores y más cuando se trata de un enclave castrense romano, es el dominio de las rutas y vías de comunicación, que hacen del mismo un punto estratégico de primer orden.

En este sentido, Legio ocupa un emplazamiento privilegiado, ya que constituye en primer lugar un punto de unión entre el área de la Meseta Norte y los territorios transcantábricos, a través de pasos naturales o vías de comunicación construidas al efecto, además de mantener una fluida comunicación con la zona galaica y otros territorios más orientales. Además de esta excelente ubicación natural, el recinto campamental legionario se encuentra en una posición óptima respecto al entramado de vías de comunicación del área septentrional, ya que supone un punto intermedio, con fácil acceso a estos ejes que canalizan la actividad económica, a la vez que son principales transmisores de múltiples aspectos culturales.

Así, por una parte, Legio es el punto final de la vía Italia in Hispanias, según el Itinerario de Antonino, y por otra parte, se encuentran en sus proximidades las vías que unen la capital del Conventus - Asturica Augusta- con los principales núcleos urbanos del territorio hispano (Bracara Augusta, Emerita Augusta, Caesaraugusta, Tarraco...), con lo cual se asegura el control de la extracción y comercialización de los recursos económicos, constituyendo un núcleo estratégico fundamental, no únicamente en su zona de expansión inmediata, sino en todo el Noroeste peninsular. 


\section{2.- EL RECINTO CAMPAMENTAL DE LEGIO Y SUS ETAPAS DE OCUPACIÓN.}

Tras el final de las guerras cántabro-astures, a partir del año 19 a. C. el Estado romano lleva a cabo una reorganización de las legiones y unidades auxiliares que habían tomado parte en las mismas, enviando algunas de ellas a otros puntos conflictivos del Imperio, mientras en el norte de Hispania se articula un "ejército estacionario" en términos de Roldán (1974: 183), con el fin de garantizar la estabilidad en estos territorios, participar en la construcción de la red de vías de comunicación de la zona y sobre todo, ejercer un control sobre la explotación de los recursos económicos, especialmente auríferos, esenciales para la economía del Imperio en esta época.

Esta planificación militar de la ocupación del ejército romano en la zona norte en época augustea se basa en el acantonamiento de tres legiones que habían participado en el bellum cantabricum, además de un número indeterminado y más difícil de localizar arqueológicamente, de unidades auxiliares, cohors de infanteria y alae de caballería.

De las tres legiones que permanecerán en Hispania, dos se instalarán en acantonamientos de la zona astur -Legio X Gemina y Legio VI Victrix- y una en el territorio cántabro meridional -Legio IIII Macedonica-, integrando el contingente militar de ocupación estable en el área septentrional de la Península.

La Legio IIII Macedónica es la primera de las legiones que se instala de manera estable en época temprana, hacia el 20/15 a. C. en Herrera de Pisuerga (Palencia), (Pérez González, 1989: 218; Morillo, 1999: 333), con la función principal de controlar el territorio cántabro, durante la época augusteo-tiberiana, hasta el año 39 d. C. en que parte hacia Mogontiacum. Sobre las estructuras campamentales no disponemos de una documentación detallada, pero sus investigadores señalan que hacia el cambio de Era tiene lugar una importante transformación del recinto castrense, sustituyendo las primeras estructuras en madera por otras de piedra y otros materiales más consistentes (Pérez González, 1996: 91). Comienza así una nueva fase que se distingue por el importante nivel en la fabricación de diversos materiales, con numerosos talleres ubicados en el área extramuros (Pérez González, 1998: 553-554). Las excavaciones realizadas ponen de manifiesto la existencia de un centro artesanal de primer orden que elabora diversas manufacturas como producciones cerámicas de las distintas especies, útiles óseos, elementos metálicos, vidrio y demás, que recogen de una forma unificada Pérez González e Illarregui (2006: 111-133), y que estarían dedicadas a abastecer a la propia unidad y también a cubrir la demanda de estos productos a través de distintas rutas comerciales.

Otra de las legiones acantonadas en el norte, la Legio X Gemina, presenta cierta problemática en cuanto a su estancia en dos campamentos, Asturica Augusta y el valle zamorano de Vidriales en lo que sería el campamento de Petavonium. Su presencia en Asturica en un primer momento, que confirma además el origen militar de la ciudad, está avalada por el hallazgo del foso campamental (González Fernández, 1996: 85-90) y la aparición de diversas inscripciones en que aparece mencionada esta legión.

La cuestión en la que disienten algunos investigadores es la fecha de traslado y la instalación de esta unidad al primer campamento de Petavonium. Teniendo en cuenta que se propone como fecha el 15/10 d. C. cronología que presentan los materiales cerámicos de Asturica, surge una cuestión de paridad de estancia. Investigadores de Petavonium como Carrretero (1999: 149) plantean como explicación que las reducidas 
dimensiones de este recinto militar (17,5 hectáreas), no podría albergar a una legión completa, lo que apunta hacia una duplicidad del asentamiento de la Legio X Gemina. Así, teniendo su base en el valle de Rosinos, mantendría desplazados una serie de contingentes, siendo el más importante y numeroso el que se asienta en Asturica Augusta. Esta teoría se vería reafirmada por la cronología de los materiales más antiguos hallados en el campamento legionario de Petavonium, fechados ente el 15/10 a. C. (Carretero y Romero, 2004: 219-220) subrayando así la coetaneidad de ambos asentamientos, cuestión aceptada ya de forma general en el establecimiento de las legiones norteñas en sus primeras etapas.

Independientemente de su lugar de acantonamiento, la Legio X Gemina es trasladada a Carnuntum en el año 63 d. C. para regresar a la Península y abandonarla definitivamente el año $68 \mathrm{~d}$. C. instalándose en el último cuarto de siglo I -quizá después de la ocupación de una vexillatio en este periodo intermedio- el otro cuerpo militar destinado a Petavonium, el Ala II Flavia Hispanorum Civium Romanorum, en un campamento superpuesto en parte al primero, pero con sus propias estructuras en un recinto prácticamente ex novo.

Y ya al tratar de la tercera legión, la VI Victrix, nos hallamos en el contexto del campamento legionense del período anterior a la instalación de la Legio VII Gemina, objeto de nuestro estudio, en el mismo recinto.

Únicamente habríamos de hacer referencia a la problemática que plantea la supuesta estancia de la Legio VI Victrix en lo que será el solar de la ciudad de Lucus Augusti, hipótesis ya antigua, y que han despejado en cierta manera las últimas excavaciones en la ciudad, demostrando un origen militar, cuya unidad acantonada pudo ser la Legio VI Victrix, a juzgar por algunos testimonios epigráficos (Rodríguez Colmenero 1996: 130), pero cuya permanencia sería muy breve, tan sólo una década, antes de la transformación de Lucus en un núcleo civil en una etapa temprana.

Antes de tratar los aspectos arqueológicos del campamento de la Legio VI Victrix, hemos de puntualizar que, hasta mediados del siglo $X X$, momento en que se realizan las primeras excavaciones científicas en diversos puntos del recinto de León por A. García y Bellido en 1961 y, en función de los materiales hallados, se plantea la hipótesis de un campamento anterior al de la Legio VII Gemina, el origen de la ciudad de León estuvo siempre vinculado en la historiografía a este último cuerpo legionario.

Así, los primeros historiadores interesados por la arqueología leonesa ${ }^{1}$, como el Padre Risco a fines del siglo XVIII, que plantea el trazado del campamento y su origen romano asociado al asentamiento de la Legio VII, recopilando algunos materiales o Ceán Bermúdez en el siglo XIX, que lleva a cabo un importante compendio de materiales arqueológicos, ponen las bases para el desarrollo de la arqueología leonesa.

Igualmente la creación de las Comisiones de Monumentos, a mediados del siglo XIX y la fundación del Museo de León, a cargo del Padre Fita (1866) que además realiza una inestimable labor, así como la restauración de la catedral en los años siguientes por Demetrio de los Ríos, que pone al descubierto restos de las termas romanas bajo el templo catedralicio, van perfilando ya claramente las estructuras del campamento romano.

1 Vid. una descripción más amplia y completa sobre el tema en GRAU LOBO (1996: 225-239). 
Ya en el siglo XX, la publicación del Catálogo Monumental de la provincia de León por Gómez Moreno -al que ya hemos hecho referencia supra al tratar el emplazamiento del campamento- supone un hito fundamental para la arqueología romana de León.

Con todo ello, y como ya hemos apuntado, vinculando siempre los orígenes del campamento legionense a la Legio VII Gemina hasta los años sesenta del siglo pasado, el panorama arqueológico leonés experimentará un cambio fundamental a partir de los años ochenta del siglo XX, cuando tienen lugar una serie de excavaciones en puntos decisivos del enclave campamental que demuestran ya de forma decisiva la existencia de un campamento anterior al de la Legio VII, que se instala hacia el año $74 \mathrm{~d}$. C.

\section{1.- EL ORIGEN CAMPAMENTAL DE LEÓN EL ASENTAMIENTO DE LA LEGIO VI VICTRIX}

La unidad legionaria que ocupó el primer recinto campamental sería pues, la Legio VI Victrix, como demuestran algunos materiales hallados: una lucerna con la marca $\mathrm{L}$ V (I)? (Morillo, 1999: 296-297, n 40, Fig. 17), una serie de monedas con contramarcas de esta legión (García de Figuerola y González Alonso, 1998-99: 127-140; Idem: 1999: 367-373; Morillo, 1999b: 78-79) y algunas inscripciones, especialmente una hallada en el propio solar leonés, hoy desaparecida, en la que puede leerse la terminación -trix, haciendo referencia muy probablemente a esta unidad (Alföldy, 1969: 115).

Además de estos testimonios que vienen a corroborar la presencia de la Legio VI Victrix desde el cambio de Era hasta la llegada prácticamente de la Legio VII Gemina, las excavaciones a que hacíamos referencia, realizadas en diversas zonas de la ciudad, y en especial la llevada a cabo en el área septentrional del recinto, próxima a la porta decumana de la muralla de la Legio VII, han puesto de manifiesto la existencia de dos asentamientos en el periodo de ocupación de esta primera unidad legionaria, uno fundacional de época augustea y otro remodelado en la etapa julio-claudia (García Marcos, 2002: 170-181).

En una primera fase el recinto contó con una estructura defensiva realizada en madera, como es propio de los campamentos de esta época, hasta que se produzca una petrificación de las murallas que se generalizará en época flavia. Con todo, se utilizó un sistema bastante efectivo, compuesto por un foso de perfil en V (del tipo fossa fastigata), y un vallum construido con dos paramentos de madera y relleno de tierra y gravas, según el tipo "box rampart". En cuanto a los restos de estructuras, una serie de intervenciones en el área norte del campamento depararon el hallazgo de evidencias de construcciones en madera; igualmente, en uno de los solares colindantes a uno de los vertederos aquí estudiados (C/Pilotos Regueral) aparecieron restos de un solado de madera identificados en principio como un pontón (Miguel y García Marcos, 1993: 194) y, posteriormente, como parte de estructuras de habitación (García Marcos, 1977: 305).

Otros investigadores especifican los hallazgos, en algunos solares de la zona norte del recinto, de trincheras y otras estructuras negativas sobre las que se asentarían construcciones realizadas en materiales perecederos y por tanto no conservadas, pertenecientes a esta primera fase del asentamiento castrense (Campomanes, Muñoz y Álvarez Ordás, 2002: 340-341). 
Especial trascendencia revisten para nuestro estudio los materiales cerámicos hallados en esta primera fase, pues además de las importaciones de terra sigillata itálica, se han documentado una serie de producciones locales de terra sigillata de tradición itálica, habiéndose identificado hasta el momento tres alfareros: C. Licinius Maximus (Morillo y García Marcos, 2001: 151-154; García Marcos, 2002: 175), L. M. Gen (...) y el denominado "Alfarero de la caliga" (García Marcos, 2001: 100-106; 2006: passim). En opinión de los citados autores, y a diferencia del caso del alfarero L. Terentius en Herrera de Pisuerga, que sería un figlinarius militar ligado a la Legio IIII Macedonica (Pérez González, 1989: 199-240), como consta en las marcas de sus productos, estos alfareros legionenses tendrían la condición de civiles encargados de cubrir la demanda de productos cerámicos de la Legio VI Victrix y del contingente civil que constituiría la cannabae del campamento en esta etapa.

Así, teniendo en consideración la cronología, las características de sus piezas y su área de difusión exclusivamente local, algunos investigadores consideran la producción de estos ceramistas dentro del grupo de las "producciones singulares" de terra sigillata (Romero, 1999: 253).

En época julioclaudia se han identificado una serie de transformaciones en el recinto que marcan el inicio de una segunda fase en el asentamiento.

Estas modificaciones, perceptibles también en otros campamentos del área noroeste, afectan en el recinto legionense especialmente al sistema defensivo, con el arrasamiento de parte de las estructuras precedentes y la construcción de un nuevo vallum a base de caespites, documentándose un tramo de paramento del tipo de los muros "de doble revestimiento" (García Marcos, 2002: 176; 2004: 172).

De igual manera, tienen lugar importantes transformaciones en la zona del antiguo vallum, sobre la que se asentarán construcciones correspondientes a barracones o contubernia, tras un complejo proceso para salvar los desniveles topográficos y homogeneizar el terreno.

A ello hay que añadir los restos de una serie de estructuras murarias, de función indeterminada, pertenecientes a esta segunda fase, que han constatado diversos investigadores en distintas zonas del campamento (Campomanes, Muñoz y Álvarez, 2002: 341-342).

En el área extramuros se localizan también importantes testimonios arqueológicos, como un complejo artesanal de carácter metalúrgico ubicado en la zona meridional, en las inmediaciones de lo que sería la porta praetoria en el recinto de la Legio VII y datado en el segundo tercio del siglo I d. C. (Campomanes, 1998/99: 269-280).

En este sentido, el hallazgo de los restos de una lorica segmentata, utilizada por los cuerpos legionarios a partir de la época de Claudio (García Marcos, 2001: 175), constituiría otro argumento a favor de la estancia en este campamento de la Legio VI Victrix.

Por otra parte, en el entorno extramuros se sitúan también en esta etapa dos de los contextos que estudiamos, dado que constituyen áreas de vertidos, aunque con diferente secuencia cronológica, como explicamos detalladamente en capítulo dedicado a los distintos contextos analizados.

Uno de ellos sería el vertedero de la C/ Pilotos Regueral, con una secuencia estratigráfica que abarca el siglo I d. C. y principios del II d. C. indicando así su utilización por los dos cuerpos legionarios. 
Las excavaciones realizadas en solares adyacentes, el Edificio Pallarés (Miguel y García Marcos, 1993) y la Casa Botines (García Marcos, 1997) han puesto de manifiesto la misma secuencia estratigráfica y materiales asociados, con la salvedad de que se han hallado restos de construcciones en madera y algunos restos de muros que evidencian una función ocupacional, cuyo carácter civil (relacionado posiblemente con la cannaba) o militar, resulta aún una cuestión compleja que ha de esclarecerse con nuevas intervenciones en esta zona.

El otro contexto extramuros, una singular construcción a modo de depósito, situada en el lado sudoriental del campamento, y de función aún no completamente determinada (Vidal y Marcos Contreras, 2002-2003: 121-130) es también objeto de nuestro estudio, pues su amortización como vertedero alcanzaría hasta finales del siglo I d C. con lo cual sería utilizado, con distintas funciones, por las dos legiones que se suceden sin solución de continuidad en el campamento leonés.

\section{2.- LA LEGIO VII GEMINA Y SU CAMPAMENTO EN LEÓN}

Un hito fundamental en la historia del ejército romano en Hispania, por su trascendencia posterior, será la creación de una nueva legión por Galba, gobernador de la Tarraconense, con el fin de aumentar su contingente de tropas para tomar parte activa en las luchas por el poder subsiguientes al levantamiento contra el emperador Nerón². El nuevo cuerpo legionario, formado fundamentalmente por efectivos hispanos, recibió sus insignias en Clunia, en una fecha concreta que conocemos en función del hallazgo de dos inscripciones en la localidad de Villalís ${ }^{3}$, cercana a la ciudad de León, en las que se conmemora el natalicio del aquila de la legión (ob natalem aquilae) el diez de junio del año 68 d.C. ${ }^{4}$ En cuanto a su denominación, toma el ordinal correlativo a la Legio VI Victrix, contraviniendo así las normas habituales, pues ya existía una Legio VII Claudia, sin embargo la primera se había encontrado entre los partidarios del ya nuevo emperador Galba. Por ello, en honor a su fundador toma el epíteto de Galbiana y posterior-

2 La cuestión de la creación e historia de la Legio VII Galbiana ha sido objeto de múltiples estudios, que quizá haya que poner en relación con su decisivo papel en el conflictivo año 68 en Roma, y posteriormente con su peculiar significación como única unidad legionaria que permanecerá en Hispania hasta el final del Imperio. Así, destacan los trabajos de GARCíA y BELLIDO (1968; 1970: 303-329; 1970 b: 1521); ROLDÁN (1997, reed.: 201-205; 245-262); LE ROUX (1982: 151-153); MATILLA (1983: 263-271); ABASCAL (1986: 317-328); RABANAL (1990: 73-89); RODRÍGUEZ GONZÁLEZ (2001: 230-235). A todo ello se añade la reciente contribución monográfica de PALAO VICENTE (2006), que constituye una interesante y sumamente documentada puesta al día de los distintos aspectos relacionados con esta legión.

3 CIL II, 2552 y 2554. GARCÍA y BELLIDO (1970: 324) añade otra inscripción muy fragmentada hallada en León en 1961 e inédita, que podría hacer referencia al natalicio; igualmente PALAO cita otro epígrafe más en AE, 1911, 94, León, que por su formulario podría incluirse en la serie de conmemoración del nacimiento de la Legio VII.

4 Partiendo de la documentación citada, esta fecha es comúnmente aceptada por la mayor parte de los investigadores, con excepciones como LE ROUX (1982: 153), quien disiente de la opinión general, considerando que, en función de la legalidad, será a partir del reinado de Vespasiano y probablemente el 10 de junio del año 70, cuando la Legio VII Gemina Felix accede a una existencia plenamente oficial. 
mente, tras el derrocamiento y muerte de éste, pasará a denominarse Hispana ${ }^{5}$ en función de su origen.

La Legio VII Hispana participa en las guerras civiles con campañas en diversas provincias del Imperio, en este breve pero convulso periodo de la historia de Roma que se inicia en el año 68, "el año de los cuatro emperadores" y culmina con el advenimiento de la dinastía Flavia con el emperador Vespasiano. Así, desde Roma es enviada por Galba a Pannonia, probablemente a Carnuntum, y tras la muerte de su caudillo toma partido por Otón, interviniendo en varias luchas. Con la victoria de Vitelio retorna a Carnuntum y con las demás legiones danubianas se une a Vespasiano, participando en la batalla de Bedriacum, en las proximidades de la actual Cremona, donde sufre graves pérdidas y sus efectivos se ven mermados de tal forma que ha de ser complementada con soldados de otras legiones, probablemente británicas o germanas, dando lugar al apelativo de Gemina (doble, acoplada, refundada). Con la instalación en el poder de la dinastía flavia y su exaltación de la felicitas, que puede constatarse en los testimonios numismáticos, la Legio VII Gemina recibiría el epíteto de Felix, por esta razón y por su apoyo a la causa de Vespasiano ${ }^{6}$. Bajo el mando de éste sería enviada al área renana para luchar en las campañas en los denominados Agri Decumates, cuyo objetivo sería crear un limes en un importante sector del territorio germano.

Tras esta etapa de intensa actividad militar, la Legio VII Gemina Felix retorna a Hispania en torno al año 74-75, siendo el único cuerpo legionario que permanecerá en la Península Ibérica hasta el final del Imperio y estableciéndose en el solar de la actual ciudad de León, anteriormente ocupado por el campamento de la Legio VI Victrix. No se trata por tanto de un acantonamiento ex novo, sino que el campamento de la Legio VII se superpone en buena parte al de la legión precedente, según han demostrado recientes excavaciones.

La elección de este asentamiento está relacionada con el ya comentado carácter estratégico de este punto del noroeste hispano, aspecto fundamental para el desarrollo de las funciones de la legión, que incluyen no únicamente su consustancial actividad militar en la defensa, vigilancia y control del territorio, sino también funciones de carácter político-administrativo y económico, en relación con la explotación de los ricos recursos auríferos de esta zona peninsular, esenciales en la estructura económica del Imperio.

El desempeño de estas actividades administrativas y económicas pasaba fundamentalmente por el mantenimiento y control del desarrollo de los trabajos de explotación minera en diversos puntos de la provincia, planteándose, según Domergue (1970: 275), la necesidad de una dirección técnica en las complejas tareas de extracción del mineral,

5 Autores como GARZETTI (1970: 333-339) hacen hincapié en este epíteto, constatado epigráficamente en una inscripción hallada en Brescia, que da a conocer en esta obra colectiva, subrayando además que este apelativo no figura en las principales fuentes clásicas que tratan la historia de la legión, como la obra de Tácito, y resaltando su importancia por la estrecha vinculación a Hispania de la Legio VII Gemina.

6 Generalmente suele atribuirse el apelativo Felix a alguna exitosa campaña en Germania, teoría rebatida por LE ROUX (1982: 153, nota 196), quien propone que la legión ya portaba este apelativo antes de su actuación en los Agri Decumates, como así han confirmado las fuentes epigráficas, y estos títulos característicos de los emperadores flavios. 
especialmente mediante el procedimiento de "ruina montium", que requiere una importante preparación previa y la instalación de una complicada infraestructura hidráulica. Sin duda en el ejército romano existían especialistas en estas tareas, principalmente en aquellas zonas de importante producción minera, como habría de ser por tanto el caso de algunos integrantes de la Legio VII Gemina, a la vez que el control y vigilancia de estos distritos mineros explicaría la presencia en estas zonas como Villalís o Luyego, de vexillationes de la Legio VII (Abascal, 1986: 322; Roldán, 1997 reed.: 203).

Por otra parte y en estrecha relación con esta actividad minera, resultaba prioritario el mantenimiento de una infraestructura viaria que permitiera el envío del metal procesado a Roma, y garantizara además el abastecimiento de los más variados productos, además de dejar expeditas vías de comunicación estratégicas desde el punto de vista militar. En este sentido, además de la participación de la legión en labores de construcción y mantenimiento de la red viaria, hay que contar con su contribución en la construcción de obras de ingeniería, como puentes o acueductos, tal como demuestra la epigrafía en muchos casos, y teniendo en cuenta que el ejército romano contaba entre sus filas con auténticos expertos en estos trabajos ${ }^{7}$. Teniendo en consideración que ya en esta primera etapa de la estancia de la Legión VII, Legio ya supone un punto estratégico fundamental en cuanto a su ubicación en el amplio entramado de las principales rutas peninsulares, a lo que se unen más tramos viarios creados en época flavia -como la vía XVIII del Itinerario de Antonino o Vía Nova (Tranoy, 1981: 215)-, así como la importante actividad viaria emprendida en Hispania por emperadores como Trajano, Adriano o Caracalla, especialmente en esta zona norte peninsular. Ello implicará la importante intervención de efectivos de esta unidad en la construcción y vigilancia de esta densa infraestructura de calzadas, elemento esencial para diversos aspectos de la vida de la legión y para el desarrollo de las principales funciones que le habían sido encomendadas.

Además de estas labores de construcción, mantenimiento y control en los distritos mineros y en las vías de comunicación, se encuentran también testimonios, especialmente epigráficos, de la presencia de vexillationes de la Legio VII en ciudades importantes como Tarraco, Emerita, y las capitales de los tres conventus del noroeste, Asturica, Lucus y Bracara, generalmente realizando funciones administrativas. Asimismo, aunque con menor fiabilidad respecto a las fuentes, se plantea la estancia de otros destacamentos de la legión en Emporiae o Dianium ${ }^{8}$. Más próximos a su lugar de acantonamiento permanente, en el norte peninsular, se han hallado evidencias de la presencia de efectivos de la Legio VII en el campamento de Petavonium (Zamora), en la época de la ocupación de éste por el Ala II Flavia Hispanorum Civium Romanorum, a través del hallazgo de abundante material latericio sellado por la Legio VII, sin que hasta el momento se haya determinado una función específica para este destacamento, barajándose diversas hipótesis

7 Destaca en este sentido la inscripción de Aquae Flaviae, donde efectivos de la legión participan en la construcción de un puente, así como también el epígrafe hallado en Cornoces (Orense), en el que un soldado de esta unidad efectúa una dedicatoria votiva.

8 Sobre la tradicionalmente debatida cuestión de las funciones de una vexillatio de la Legio VII en este punto del litoral levantino (ABASCAL, 1986: 322-323; PALAO, 2006: 308), vid. la reciente contribución de ÁLVAREZ JIMÉNEZ (2009). 
al respecto9 ${ }^{9}$. De igual manera, se localizan guarniciones procedentes del campamento legionense en la statio beneficiarii de Segisamo, un enclave estratégico situado en la vía de unión de Legio y el área minera con Tarraco, por tanto de vital importancia económica, a lo que se añadiría el transporte de diversos productos para el abastecimiento legionario, todo lo cual indica una actividad de vigilancia y control de esta ruta y sus inmediaciones, así como funciones de administración y de distribución de mercancías de avituallamiento. Con las mismas funciones de control de esta ruta puede relacionarse la permanencia de otro destacamento de la legión en Tritium Magallum, si bien en este caso, a través de los epígrafes puede establecerse su periodo de estancia, desde principios del siglo II d.C. hasta el siglo III. A la importancia viaria y estratégica de Tricio, como punto de comunicación del Valle del Ebro con el noroeste, no debemos obviar la decisiva trascendencia de Tritium Magallum como principal complejo productor de manufacturas cerámicas ${ }^{10}$, especialmente terra sigillata hispánica, y centro abastecedor de estas producciones a la práctica totalidad del territorio peninsular. El elevado nivel de producción y los mecanismos de distribución y transporte requerirían así un control y administración de carácter militar, como es característico en otras zonas del Imperio, en los enclaves de singular importancia económica. Por otra parte, la cronología de la estancia de esta guarnición coincide con una etapa de auge en la producción de los talleres riojanos, que constituyen los centros de abastecimiento de TSH del campamento de Legio ${ }^{11}$.

La trascendencia de estas funciones de apoyo, vigilancia y control de actividades económicas y administrativas por parte de diversas vexillationes de la Legio VII Gemina en territorio hispano, sin que se produzcan acontecimientos que impliquen una intervención propiamente militar, ha dado lugar a la denominación del Exercitus Hispanicus en esta época, que está integrado exclusivamente por esta legión y algunas tropas auxiliares, como un "ejército de la paz" (Le Roux, 1982: 169). Según, este mismo autor, su papel se inscribe en un contexto civil y, en una afirmación más polémica, califica su historia como "la historia sin gloria de unos soldados sin guerra" (Le Roux, 1982: 410).

Sin embargo este controvertido planteamiento resulta fácilmente refutable, dado que la Legio VII Gemina no es ajena a la política imperial y parte de sus efectivos abandonarán Hispania para participar en varias e importantes campañas bélicas en distintas zonas del Imperio.

Así, en el año 88-89, un contingente de tropas de la legión interviene, posiblemente, en la revuelta de Saturninus en Germania, si bien la ausencia de testimonios epigráficos y menciones históricas concretas han puesto en tela de juicio esta primera intervención de la legión fuera del territorio hispánico.

9 Vid. CARRETERO y ROMERO (2005); MARTÍN VALLS, ROMERO y CARRETERO (2002: 151152); CARRETERO (1999; 1999b; 2000; 2001; 2002).

10 Este aspecto no es contemplado en ningún momento por NAVARRO CABALLERO al tratar este tema en concreto (1989-1990), concluyendo que "los intereses romanos, dirigidos por el gobernador en Tarraco e influidos tal vez por las revueltas en la Gallia, creyeron conveniente establecer un puesto de control militar sobre la vía del Ebro a partir de mediados del siglo II".

11 Así se ha constado en diversas excavaciones en la ciudad y en estudios más amplios, en los que el gran volumen de TSH procede enteramente de los talleres del complejo alfarero de Tritium Magallum; vid. a este respecto el importante volumen de la terra sigillata tritiense en el estudio del abundante elenco de materiales de un vertedero extramuros (Fernández Freile, 2003, pp. 46-103). 
Más documentada se encuentra la presencia de vexillationes en el limes danubiano con motivo de las guerras dácicas de Trajano, a través de sellos sobre tegulae halladas en los campamentos de Porolissum y Moigrad-Pomet ${ }^{12}$. Esta participación en el conflicto dácico ha sido objeto de polémica y analizado desde diversos puntos de vista por distintos autores 13 , aunque, en el actual estado de la investigación, puede concluirse la presencia de efectivos de la Legio VII Gemina en la primera etapa de la conquista de la Dacia por el emperador Trajano.

Otra de las intervenciones extrapeninsulares de destacamentos de la legión se sitúa en Britannia, hacia el año 122 d. C. bajo el reinado de Adriano, que recurre a varias legiones para hacer frente a la conflictiva situación que presentaba la isla en ese momento debido a las revueltas de los pueblos indígenas y comenzar la gran obra de fortificación conocida como "Muro de Adriano".

Poco después, en época de Antonino Pío, se constata la que será su última intervención de en el exterior de Hispania, en la zona del norte de África, con la presencia de vexillationes en Lambaesis y Carthago, donde además de la acción militar para sofocar las revueltas de mauri, realizó posiblemente otro tipo de funciones de carácter político-administrativo.

Por último, hay que destacar la intervención bélica de la legión en territorio hispano, durante el reinado de Marco Aurelio, cuando se producen incursiones de mauri en la Baetica y parece atestiguada, en función de las inscripciones y estampillas halladas, la presencia de una vexillatio en Italica, aunque ésta sigue siendo una cuestión sometida a debate, sin que exista un acuerdo entre los diferentes investigadores sobre esta intervención y la posible estancia en la ciudad bética.

Ya en época de Septimio Severo la Legio VII Gemina Felix recibirá el epíteto de Pia, por su lealtad al emperador con su neutralidad en la batalla de Lugdunum.

Sobre la actividad de la Legio VII durante la segunda mitad del siglo III y siguientes, las fuentes epigráficas y literarias apenas aportan documentación al respecto, con lo cual puede suponerse un acantonamiento continuado en su campamento de León, pues según los datos de la Notitia Dignitatum (XLII, I, 25) permanecería en Hispania a principios del siglo $\mathrm{V}$ d. C. de manera que el final de la legión mediante procesos de transformación o fusión con elementos civiles, depende en buena parte de lo que deparen los futuros hallazgos arqueológicos en las estructuras del campamento y especialmente en el entorno extramuros, donde se han documentado hasta el momento los testimonios más significativos de la época tardorromana en Legio.

En cuanto al CAMPAMENTO ocupado por la Legio VII, hemos de puntualizar que el conocimiento de su estructura y distribución se basa esencialmente en recientes hallazgos, producto de un gran dinamismo en la actividad arqueológica de la ciudad, con un impulso decisivo de las excavaciones urbanas en las dos últimas décadas.

12 Algunas de estas estampillas aparecen reflejadas en la publicación de GUDEA (1997: 113) sobre el campamento de Moigrad-Pomet.

13 Así, mientras ABASCAL (1986: 319-322; 1989), LE ROUX (1985) o PALAO VICENTE (2006: 66-70) reconocen la presencia de vexillationes de la Legio VII Gemina en las primeras campañas dácicas a principios del siglo II d. C., otros investigadores como ROLDÁN (1997: 204), PISO (2000: 218-220) y GUDEA $(1978 ; 1989 ; 1997)$ ponen en duda la participación de contingentes de esta legión hasta siguientes intervenciones en Dacia, durante el siglo II e incluso a principios del siglo III d. C. 
Así, no incidiremos sobre el valor estratégico y las características generales del recinto castrense, ya comentados al tratar el asentamiento de la Legio VI Victrix, centrándonos en la descripción de las estructuras del nuevo campamento, que se superponen en muchos casos a las del recinto precedente, aunque a la luz de las nuevas intervenciones arqueológicas, podemos afirmar que predominan las transformaciones de obras anteriores y la construcción de nuevas edificaciones e infraestructuras, así como la nueva organización interna de los castra de la Legio VII Gemina.

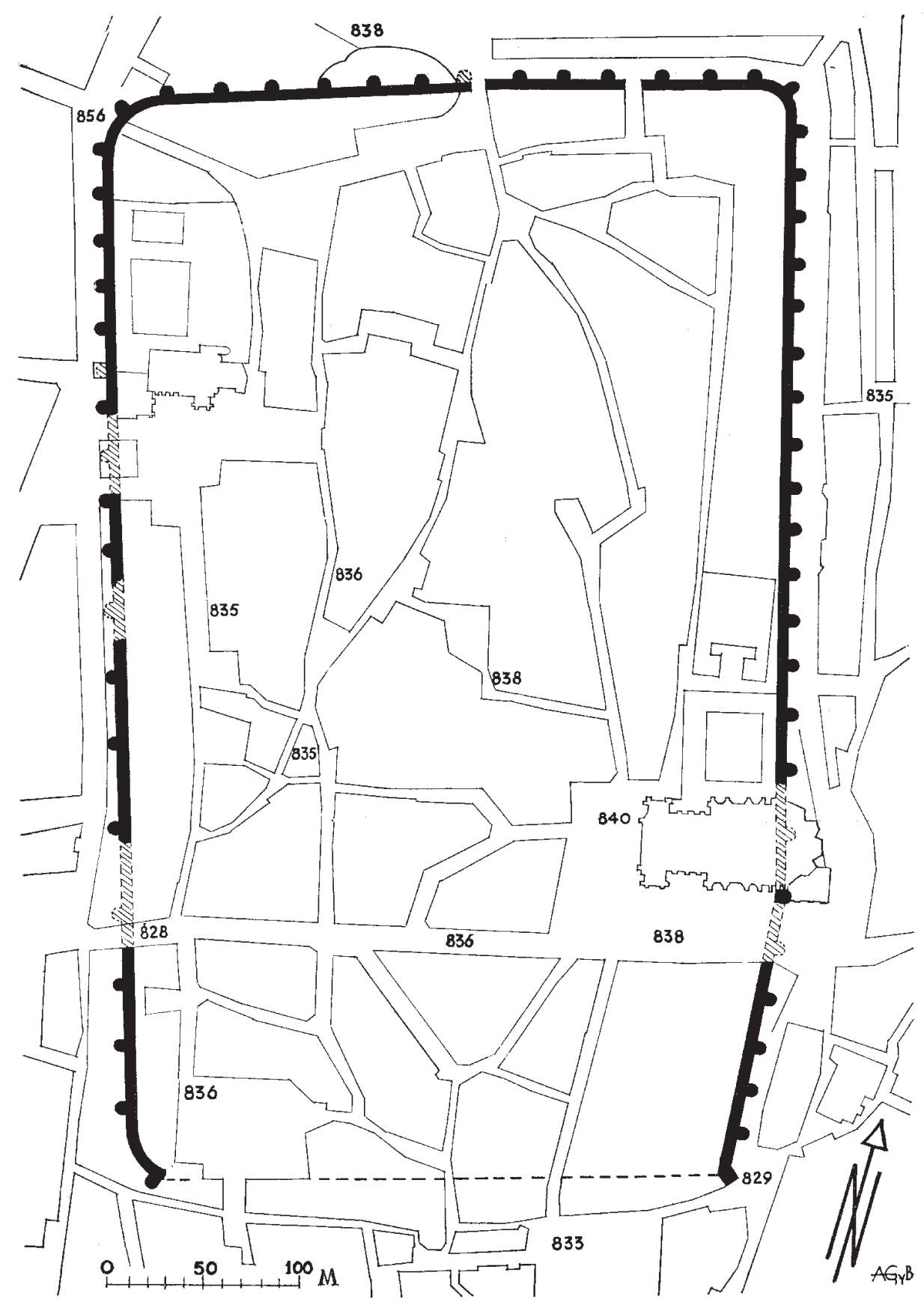

FIG. 2: Recinto amurallado de la Legio VII Gemina (según García y Bellido) 
La planta del campamento de la Legio VII en León, definida por el recinto fortificado al que se adosa la muralla de cubos de época tardía, y cuyo trazado puede reconocerse en algunos tramos, se adapta en líneas generales al patrón clásico de los campamentos altoimperiales, especialmente establecido a partir de la época flavia. Así, presenta forma rectangular con esquinas oblongas y una superficie en torno a las 20 hectáreas, el espacio adecuado para albergar a una legión (Johnson: 1983: 31). Esta "estandarización" y uniformidad de la planta y organización interna de las estructuras campamentales en las diferentes zonas del Imperio es una realidad en sus rasgos generales, sin embargo las numerosas excavaciones arqueológicas realizadas en estos recintos castrenses han puesto de manifiesto las peculiaridades de cada uno de ellos, hasta el punto de considerar que no existen dos campamentos exactamente idénticos. De hecho, en el campamento de la Legio VII tenemos un ejemplo de estas singularidades, dado que el perímetro fortificado presenta una forma rectangular, pero un tanto irregular y con un evidente retranqueo en su ángulo sudoriental.

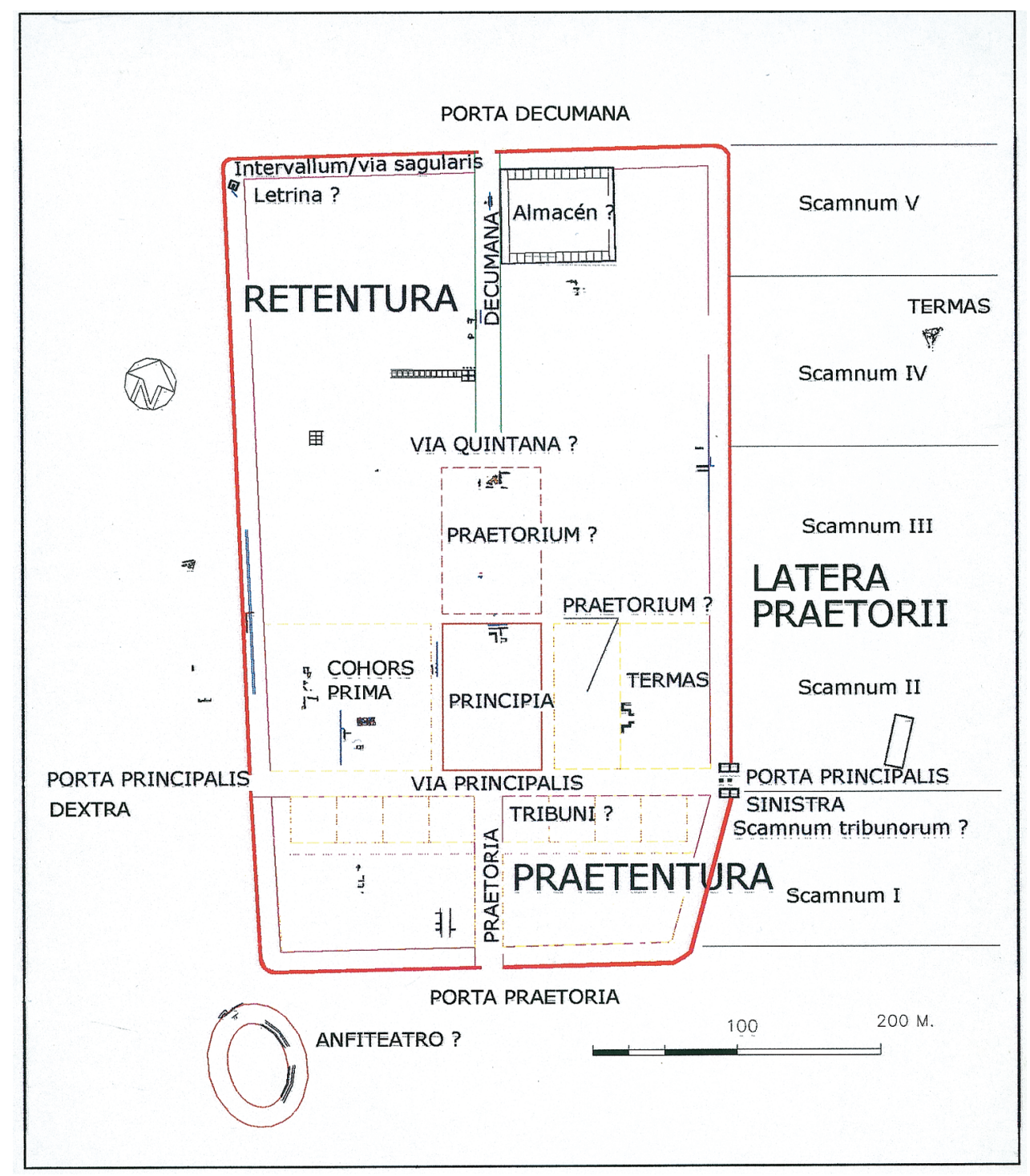

FIG. 3: Plano del campamento de la Legio VII Gemina (según V. García Marcos) 
En el interior de estos castra se disponen los dos ejes viarios principales: la via praetoria, que cruza el recinto longitudinalmente hasta los principia o cuartel general situado en la parte central, continuando su trazado por la denominada vía decumana; y, cruzando este eje en ángulo recto, la via principalis, que atraviesa el recinto de forma transversal. En los extremos de estas dos vías se sitúan las cuatro puertas, una en cada lado del perímetro rectangular fortificado: porta decumana y porta praetoria en el eje nortesur, y porta principalis dextra y porta principalis sinistra en la dirección oeste-este.

Sobre este esquema canónico hemos de situar los hallazgos en el perímetro campamental legionense, que comprenden parte del trazado de la vía principalis en las proximidades de la porta principalis sinistra, y la vía decumana, mejor identificada. Sin embargo se han documentado tramos más amplios de vías secundarias, viae vicinariae, uno en el área occidental y otro en las inmediaciones de la porta praetoria, mientras que el trazado de la via quintana no se ha identificado con absoluta claridad, aunque existen indicios bastante indicativos al respecto. Por lo que se refiere a la vía sagularis, se encuentra bien documentada, ya que circunda en el interior el trazado del perímetro amurallado (García Marcos y Morillo, 2000-2001: 106).

Sobre las puertas, únicamente se conservan restos de la porta principalis sinistra que han permitido la reconstrucción ideal de su estructura.

La organización de las estructuras del campamento seguiría una disposición per scam$n a$, siguiendo el esquema que distribuye estas grandes zonas rectangulares donde se sitúan las construcciones, de forma paralela a la vía principalis. Sin embargo en la zona meridional, los principales investigadores, basándose en la distribución interna de campamentos contemporáneos de otras áreas del Imperio, proponen una organización de las estructuras (principalmente barracones) dispuestas per strigas, perpendiculares a la via principalis (García Marcos y Morillo, 2000-2001: 107; García Marcos, 2002: 185).

En cuanto al recinto amurallado, representa sin duda la obra más representativa del asentamiento legionense, si bien su proceso de fortificación en dos períodos cronológicos diferentes, ha determinado que el perímetro visible hoy día, construido con grandes torres semicirculares en época bajoimperial, haya dificultado la definición del trazado y características constructivas de la primera muralla de la Legio VII.

A este respecto, los primeros conocimientos sobre la estructura y peculiares características del encintado del campamento se deben a las excavaciones de A. García y Bellido en diferentes puntos de su perímetro. Así, en palabras de este primer investigador de los restos legionenses, "Las murallas de León tienen un espesor de unos 5,25 m. Pues bien, parece ser que, directamente adosada a ellas, por su parte interna, corría otro lienzo de muralla de sólo 1,80 m. de grosor, cuya faz es de sillarejos muy bien escuadrados, con juntas encintadas y realzadas cuidadosamente. Este aparejo que, sin duda, debió de estar así cuidado porque era la cara visible de la cerca de 1,80 m. quedó cubierto por la gran muralla de los cubos hoy a la vista, de modo que pudiéramos decir que el recinto visible de León está literalmente forrado por un muro continuo de 1,80 m. de grueso cuya cara externa toca directamente con la interna de la muralla de cubos" (García y Bellido, 1970 b: 572-573, Figs. 5-14) ${ }^{14}$.

14 El punto donde pueden apreciarse con total claridad y amplitud las estructuras de ambos paramentos murarios y su perfecto adosamiento se sitúa en el lienzo occidental, en la excavación realizada por este investigador al pie de la escalinata de la basílica románica de San Isidoro. Recientes excavaciones en diversas zonas de la ciudad han sacado a la luz otros tramos de este peculiar sistema de doble amurallamiento aunque de menor entidad que el anteriormente citado. 
Mediante diferentes catas en los cuatro lados del recinto, el citado autor pudo comprobar que la estructura era idéntica en todo el perímetro (Ibid.: 573-574, fig 4), proponiendo finalmente una cronología para esta primera muralla interna -en función de la semejanza con los paramentos murarios de la cercana basílica paleocristiana de Marialba- de finales del siglo III d. C. o principios del siglo IV, reforzándose una centuria más tarde con el lienzo torreado (Ibid.: 575). Esta atribución a época tardía de ambas murallas habría de ser revisada por el autor en una de sus obras posteriores (1976: 76), situando el primer recinto en época flavia y el exterior en época tardía, tal como se acepta en la actualidad, tras décadas de excavaciones arqueológicas que han corroborado estos términos estructurales y cronológicos en sus rasgos generales, añadiendo más información sobre su sistema constructivo y especialmente sobre su relación con el sistema de amurallamiento erigido por la legión predecesora.

De esta manera, a partir de las intervenciones realizadas en la parte norte del recinto, se han podido determinar varias fases en el proceso de construcción de esta primera muralla de fines del siglo I d. C., identificándose en primer lugar la realización de una trinchera que supuso la destrucción de parte del vallum del campamento anterior, ocupado por la Legio VI Victrix y perteneciente a su segunda etapa datada en época julio-claudia15. En el interior se dispuso un relleno como base de cimentación del muro, cuyo espesor fue perfectamente verificado por García y Bellido en 1,80 m. (en torno a 6 pies romanos) y su alzado se estima sobre los $4 \mathrm{~m}$. En cuanto a su técnica constructiva ${ }^{16}$, el muro presenta en su frente exterior un paramento de opus vittatum integrado por sillarejos de arenisca rellenándose el interior con obra de opus caementicium y adosado a su cara interna se situaría un terraplén que contaría en su construcción con parte de la estructura del vallum del recinto precedente.

Aunque no existen evidencias arqueológicas, en el exterior de la muralla, rodeando la totalidad de su perímetro, se dispondrían uno o varios fosos, siguiendo el esquema general de las fortificaciones en los campamentos altoimperiales ${ }^{17}$.

15 A partir de esta etapa comenzará, primeramente en algunos campamentos de los limites germano y británico, un proceso de sustitución de las primeras fortificaciones realizadas con madera y tierra por sólidas murallas de piedra, generalizándose esta "petrificación" de los recintos defensivos en el último cuarto del siglo d. C. o principios del siglo II d. C. (JOHNSON, 1983: 66-69). Así, la Legio VII Gemina levantaría ya con fábrica de sillares pétreos la primera muralla de su campamento, construida a su regreso a Hispania desde el área renana, donde habría asimilado las nuevas técnicas constructivas. De la misma forma, la configuración de la estructura defensiva del recinto leonés en el que se asienta la única legión permanente en Hispania, influirá en los acantonamientos de las unidades auxiliares a ella vinculadas en el noroeste peninsular. Ello puede apreciarse en los campamentos del Ala II Flavia en Petavonium (Zamora), de la Cohors I Celtiberorum en Cidadela (La Coruña), y en el acantonamiento de Aquis Querquennis (Orense), probablemente ocupado por la Cohors I Gallica equitata.

16 Sobre las características de la construcción de esta primera muralla del campamento de la Legio VII Gemina, vid. las aportaciones de CAMPOMANES (1997; 1999; 2001) y especialmente los análisis más recientes de DURÁN (2006; 2009: 794-798) y MORILLO Y DURÁN (2009), que suponen un estudio de carácter integral sobre las diferentes fases de fortificación de Legio, con un completo y pormenorizado análisis de materiales y técnicas constructivas, así como de otros aspectos fundamentales como metrología y relaciones estratigráficas.

17 Vid. GARCÍA MARCOS Y MORILLO (2001-2002: 109); GARCÍA MARCOS (2002: 186-188); MORILLO Y GARCÍA MARCOS (2003: 277). 
Por otra parte, el recinto amurallado se reforzaría mediante pequeñas torres dispuestas a intervalos regulares. En la fortificación legionense se han descubierto hasta el momento tres, situadas a intervalos de 60-70 m. que presentan planta rectangular y una escasa proyección al exterior. Probablemente existirían también torres de mayores dimensiones en los ángulos del perímetro fortificado, como es habitual en los campamentos de esta época, sin embargo no contamos con testimonios arqueológicos fehacientes, a excepción de una antigua referencia en la obra de Gómez Moreno, que ha sido en cierto modo corroborada como perteneciente a la que sería la torre del ángulo noroccidental del campamento (García Marcos y Morillo, 2000-2001: 110-111).

Como ya hemos comentado supra, de las cuatro puertas que tendría el campamento de la Legio VII, únicamente se conservan restos importantes de la porta principalis sinistra, aparecidos en recientes excavaciones. Su planta se determinó a partir de las sólidas cimentaciones realizadas en opus caementicium, sobre las que se levantarían los muros en opus quadratum con grandes sillares de caliza. Se trataba de una puerta bífora, flanqueada por dos grandes torres rectangulares que sobresalían de la línea amurallada unos $5 \mathrm{~m}$. Los accesos se realizaban a través de sendos vanos abovedados, rematados con arcos de medio punto al exterior, que contarían con puertas de madera de doble hoja. La reconstrucción realizada (García Marcos y Morillo, 2001-2002: 111-112, Fig. 10; García Marcos, 2002: 189195, Fig.5; García Marcos, Campomanes y Miguel, 2004: 25-27; García Marcos, 2005b: 181185), basada en los tipos de accesos en los campamentos contemporáneos de otras zonas del Imperio ${ }^{18}$ indica que esta construcción constaría de tres pisos de altura. Desde el punto de vista cronológico se han propuesto diversas fechas para esta estructura, pero, a la luz de las últimas investigaciones, basadas en los materiales cerámicos aparecidos en la excavación, habría que datarla a principios o mediados del siglo II d. C. ${ }^{19}$, teniendo en cuenta las diversas transformaciones que experimenta a lo largo de la etapa altoimperial y más tarde, cuando queda integrada en el trazado de la muralla tardorromana.

En efecto, en época bajoimpeial, a finales del siglo III d. C. o principios del IV, el sistema defensivo del campamento de la Legio VII Gemina sufre una profunda transformación ${ }^{20}$-hecho que es común a otros núcleos urbanos como Asturica Augusta, Lucus Augusti o Bracara Augusta, en el área noroccidental21- con la construcción de una nueva

18 En concreto hemos hallado importantes similitudes con las puertas del campamento británico de Arbeia (South Shiedls).

19 Sobre las características y cronología de esta estructura, vid. el estudio detallado de MORILLO y GARCÍA MARCOS (2003 b; 2005).

20 Además de las importantes transformaciones en el recinto defensivo, y a pesar de la continuidad del campamento en los siglos III y IV, según señalan autores como CEPAS (1997: 178), partiendo de los resultados de recientes excavaciones arqueológicas (MUÑOZ et alii, 2002), en Legio tendrían lugar también modificaciones en algunas estructuras internas (barracones, termas...) que son reutilizadas con otras funciones, así como en el urbanismo, con sobreelevación de pavimentos y la presencia de hoyos con función de basureros en el interior de la ciudad, contrastando con el sistema de eliminación de residuos propio de la etapa altoimperial, utilizando vertederos extramuros.

21 Sobre las murallas bajoimperiales de estos tres núcleos urbanos, capitales de conventus en la etapa altoimperial, vid., además de las obras generales citadas, algunos estudios específicos sobre los recintos de Asturica (GONZÁLEZ FERNÁNDEZ, 1997; GARCÍA MARCOS, MORILLO y CAMPOMANES, 1997; GUTIÉRREZ GONZÁLEZ y ARIAS PÁRAMO, 2009), Lucus (GONZÁLEZ FERNÁNDEZ et alii, 2002) y Bracara (SANDE LEMOS et alii, 2002). 
muralla que se adosa a la precedente en todo su perímetro externo. Esta nueva fortificación, actualmente visible, conserva una gran parte de su trazado, destacando las torres semicirculares dispuestas a intervalos regulares de unos $14 \mathrm{~m}$. El muro defensivo, construido con opus caementicium de escasa calidad, presenta unos $5 \mathrm{~m}$. de anchura y una altura de $10 \mathrm{~m}$. aproximadamente, e integra las dos torres avanzadas de la porta principalis sinistra de la antigua muralla altoimperial. Con todo ello, constituye una obra de gran envergadura, similar a las que se acometen en numerosas ciudades de carácter civil o militar en Hispania y que responden a las nuevas directrices político-administrativas del Imperio, así como a necesidades económicas y a la diferente configuración y papel del ejército en esta etapa. Se trataría de fortificaciones de carácter defensivo ante posibles amenazas, aunque con un valor añadido como elementos de prestigio. Estos aspectos de la época tardorromana que se plasman de forma evidente en los restos arqueológicos, especialmente en las murallas, han sido abordados con exhaustividad por investigadores como Fernández Ochoa y Morillo (1991; 1992; 1994; 1997; 2002), que destacan la nueva concepción geoestratégica del Imperio en esta etapa. Ello exige en primer término la presencia de unidades militares, con el mantenimiento de algunos cuerpos legionarios en sus campamentos, como es el caso de la Legio VII Gemina en el siglo V, tal como se desprende de la Notitia Dignitatum (XLII, I, 25) así como una intensa actividad en el mantenimiento de la red viaria que facilite las conexiones entre los diferentes puntos de Hispania y Gallia, destinados al abastecimiento de las unidades militares de los limites germánico y británico, a través del sistema de la annona militaris (Fernández Ochoa, 2002: 584-585).

A pesar de la problemática que presentan las fortificaciones de este periodo, en cuanto a su cronología, a la intervención del ejército en estas obras o a su carácter civil, hemos de señalar que la muralla tetrárquica de Legio se encuentra bien datada a fines del siglo III d. C. o principios de la cuarta centuria, y parece evidente la impronta militar en sus rasgos constructivos 22 .

En este contexto, es preciso hacer referencia a un reciente e importante hallazgo de más de cincuenta epígrafes hallados en este encintado legionense ${ }^{23}$ que sin duda aportarán datos relevantes sobre estos aspectos cronológicos, político-militares, sociales y económicos que plantean aún diversas controversias en la investigación sobre esta época tardorromana.

\section{- TERMAS INTERIORES}

Los diferentes restos constructivos romanos hallados con motivo de diversas fases en las obras de restauración de la catedral gótica ${ }^{24}$, en cuyo subsuelo permanecen

$22 \mathrm{Vid}$. un análisis pormenorizado sobre el sistema constructivo de esta muralla tardía en GARCÍA MARCOS, DURÁN y MORILLO (2007) y DURÁN (2009: 798-800).

23 Este conjunto de restos epigráficos se encuentran actualmente en fase de estudio en la Universidad de León.

24 Estas obras fueron realizadas en una primera fase por el arquitecto Laviña (1859-1868), quien halló las primeras evidencias de una construcción romana. Posteriormente, los trabajos del arquitecto Demetrio de los Ríos (1884-1888), proporcionaron hallazgos más importantes asignables indudablemente a unas termas romanas. 
actualmente, permitieron identificarlos ya en las primeras intervenciones como parte de un amplio edificio termal, que habría de determinarse más tarde como correspondiente a las termas del campamento de la Legio VII Gemina.

Estos primeros hallazgos, recogidos en el estudio de García y Bellido (1970b: 576577, Figs. 16-26), consistieron en un muro de ladrillo, restos de un mosaico con decoración de temática marina y tres estancias con hypocausta, separadas por gruesos muros y cubiertas por una suspensura sobre la que se asentaba un pavimento de opus signinum. En las paredes de estas salas podían distinguirse las concamerationes o conductos de calor propios de los edificios balnearios. En un tramo más alejado se localizó otra sala -quizá una cámara de calor- cubierta con bóvedas de arista.

Ya a mediados del siglo XX, se pusieron al descubierto nuevos restos arquitectónicos en las obras acometidas por el arquitecto Menéndez Pidal, que también documenta García y Bellido en la obra citada.

Por último, en recientes excavaciones llevadas a cabo con metodología arqueológica, y en la zona que sobresale de la planta del edificio catedralicio, en las inmediaciones de la porta principalis sinistra, fueron descubiertas unas letrinas que serían construidas sobre una estructura anterior con muros de sólido mortero hidraúlico y pavimentadas con opus spicatum, hallándose posteriormente dos canales de evacuación de agua. Estos restos constituyen la única parte visible del conjunto termal, albergada en una cripta arqueológica junto con las estructuras de cimentación de la porta principalis sinistra del campamento.

A pesar de que carecemos de los suficientes datos para conocer con exactitud el esquema y recorrido de las termas legionenses, partiendo de los rasgos peculiares que señalan algunos autores en la construcción y estructura de las termas militares en otras zonas el Imperio, como Brödner (1992: 179-186), Hanel (2000: 23-32), Bidwell (1997: 7782), Bidwell et alii (2002: 53-56), que describen los principales complejos termales de los campamentos de Germania (Novaesium, Mogontiacum, Aventicum, Coriovallum o Vindonissa) y Britannia25 (Cilurnum (Chester), Segedunum (Wallsend), Arbeia (South Shields), Cordbridge o Bewcastle), podemos establecer algunos paralelos, dado que presentan las mismas características y funcionalidad, creándose una cierta estandarización en el modelo constructivo de las termas de los limites germánico y británico, como por ejemplo la disposición de un nuevo espacio cubierto formado por tres naves -la basilica thermarum- destinado a los ejercicios gimnásticos de los soldados, y que muy probablemente se encontraría también en las termas campamentales de Legio.

\section{- PRINCIPIA}

Los recientes hallazgos de restos de estructuras constructivas en el área central del campamento de la Legio VII Gemina, han permitido identificarlos con una parte de los principia 26 , el cuartel general de la legión que constituía el centro administrativo y espiritual en todos los asentamientos militares romanos. Ello explica la monumentali-

25 Sobre las termas de los asentamientos militares en Britannia, vid. VEGA AVELAIRA (2001: 51-76; 2010: 299-324).

26 Vid., una exposición detallada de estos hallazgos en GONZÁLEZ FERNÁNDEZ y VIDAL (2005). 
dad y gran extensión espacial de este edificio, como se pone de manifiesto en aquellos campamentos de los limites germánico, británico y danubiano, en que se han conservado partes importantes de esta estructura o bien se ha procedido a su reconstrucción, destacando en este sentido la del campamento de Saalburg en Germania. La entrada principal se abría hacia un patio columnado rodeado por distintas estancias dedicadas a fines administrativos, y tras él se disponía una gran sala transversal o basílica con columnas en la que se situaban estatuas de los emperadores y se celebraban diferentes actos ceremoniales. En el muro del fondo se encontraba la entrada al aedes o sacellum, en el que se guardaban los estandartes, las imagines, los signa, las vexillae y el águila de la legión. Generalmente, en esta estancia se situaba una cámara subterránea más o menos monumental, que albergaba los fondos monetarios de la legión 27.

Este esquema constructivo resulta uniforme en la mayor parte de los campamentos de época flavia (Chester, Caerleon, Novaesium, Carnuntum), si bien existen variaciones en cuanto a las dimensiones y la disposición de algún elemento estructural.

En cuanto a la identificación de los hallazgos legionenses con esta edificación y su ubicación en la distribución espacial del recinto castrense (González Fernández y Vidal, 2005: passim), destaca en primer lugar la situación de estos restos en el área central del campamento, en el cruce de la via praetoria con la via pricipalis, siguiendo en este sentido el esquema canónico de la situación de los principia en los asentamientos militares romanos. Por otra parte, la delimitación de dos de sus lados permite estimar una superficie de unos $7000 \mathrm{~m}^{2}$, que también se adapta a las dimensiones habituales en otros establecimientos legionarios.

En el conjunto de restos constructivos exhumados se distinguen muros de sillería en opus vittatum y especialmente un pavimento de opus signinum sobreelevado que se ha identificado con las estancias situadas en la parte posterior de los principia y más concretamente con el aedes, ya que esta cámara suele presentar una mayor entidad constructiva y un pavimento de mayor altura. Según los citados investigadores, se trataría de un aedes exento, estructura que no aparece en campamentos legionarios 28 , y por tanto, esta identificación queda sometida a nuevas intervenciones que proporcionen datos relevantes para completar la distribución de los espacios de los principia del campamento legionense.

Además hay que añadir el hallazgo en este contexto de una inscripción honorífica dedicada a Antonino Pío, que constituye un importante dato cronológico.

Con todo ello, los resultados de esta intervención arqueológica han resultado cruciales para definir la planta del campamento, con la situación de los principia en el área central del recinto, y partiendo de esta base, elaborar una aproximación a la ubicación del praetorium (residencia del legado) y a la configuración de los latera praetorii en el campamento de la Legio VII Gemina.

27 Vid. JOHNSON (1983: 105-132) sobre los principia de los campamentos romanos, y más concretamente BIDWELL (1997: 67-71) sobre esta construcción en los principales campamentos británicos.

28 En campamentos de unidades auxiliares adscritas a la Legio VII Gemina, como el de la Cohors Prima Celtiberorum en Cidadela (La Coruña) se ha documentado también un aedes exento (CAAMAÑO (1998; CAAMAÑO y FERNÁNDEZ RODRÍGUEZ, 2002); por otra parte la excavación de una parte considerable de los principia del campamento de otra unidad auxiliar en Aquae Querquennae (Orense), demuestra según sus investigadores que seguiría igualmente el modelo legionense (VEGA, FERRER y RODRÍGUEZ COLMENERO, 2009). 


\section{- BARRACONES}

Hasta el momento, los hallazgos arqueológicos en Legio que pueden atribuirse a barracones para el alojamiento de las unidades legionarias (contubernia, centuriae) son fragmentarios, sin que se haya exhumado ninguna estructura completa (García Marcos, 2002: 200; 2005: 188). Únicamente se han documentado partes de estas edificaciones, fundamentalmente en la retentura del campamento y en algunos casos se han localizado restos constructivos pertenecientes a sectores de estos barracones superpuestos a las de los mismos edificios del campamento precedente de la Legio VI Victrix. Como la generalidad de las estructuras constructivas de los campamentos romanos altoimperiales, los barracones presentan también un esquema estandarizado, en cuanto a su ubicación en el recinto (generalmente a lo largo del perímetro interior, adyacentes a la via sagularis) y a sus dimensiones y distribución interna ${ }^{29}$, todo lo cual facilitará la identificación de estas estructuras en próximas intervenciones arqueológicas.

\section{- ALMACÉN}

Las excavaciones llevadas a cabo en la zona norte del recinto campamental, en las proximidades del tramo amurallado, han deparado el hallazgo de una importante construcción de considerables dimensiones, en la que puede distinguirse una compartimentación en espacios rectangulares de idéntica superficie, con pavimento de arcilla apisonada. El acceso se realizaba a través de un espacio abierto, posiblemente porticado (García Marcos, 2002: 199-200; 2005: 187-188). Sobre la identificación de esta construcción se han propuesto varias hipótesis. La primera de ellas adscribiéndola al valetudinarium $\mathrm{u}$ hospital, edificio importante y presente en la mayoría de los campamentos legionarios de la época y que aún no ha sido localizado en Legio. Sin embargo la ubicación en la planta del recinto campamental no coincide con el esquema tipo, ya que este edificio suele situarse en la zona central o bien en el área más meridional, como en los casos de Inchtuthil, Vetera, Novaesium o Vindonissa (Johnson, 1983: 157-161). Por ello, ha cobrado más cuerpo la propuesta de que se trate de una estructura constructiva dedicada al almacenaje ${ }^{30}$, también documentada en varios campamentos legionarios, en los que se dispone en espacios variables, pero siempre en los extremos, próxima a la via sagularis o al intervallum, pudiendo identificarse además con la variante, según la tipología de Petrikovits (1975: 85-86) de "almacenes con patio". En el área central de una de las estancias tuvo lugar un importante hallazgo de elementos metálicos, pertenecientes a armaduras militares de época altoimperial. En este conjunto destaca una

29 Vid. la completa monografía de DAVISON (1989) sobre este tipo de construcciones en los diferentes tipos de asentamientos militares romanos.

30 La estructura de este edificio de almacenaje tampoco se ajustaría a la de los graneros u horrea, que constituyen asimismo una de las construcciones importantes en las fortalezas legionarias, dedicados al almacenaje de grano y otros productos alimenticios para el abastecimiento de la legión, y que presentan también diversa tipología (JONHSON, 1983: 142-157; BIDWELL, 1997: 85-90). Recientemente se han publicado estudios sobre los horrea en establecimientos militares de Hispania (SALIDO, 2009) y en relación con el aprovisionamiento del ejército, haciendo hincapié en los procesos de transporte, almacenaje y redistribución (SALIDO y MORILLO, 2010). 
manica o protector laminado para el brazo, así como otros fragmentos de loricae segmentatae, cuya cronología, teniendo en cuenta la datación de los materiales cerámicos aparecidos, coincidiría con el abandono de esta construcción, hacia el tercer cuarto del siglo III d. C. (Aurrecochea et alii, 2008: 258). Mayor trascendencia reviste el hecho de que la elaboración de estas armas defensivas haya de buscarse muy probablemente en el propio campamento legionense o sus inmediaciones, a tenor de los talleres de este tipo de elementos que han sido localizados y que trataremos en el siguiente apartado.

\section{- FABRICAE}

Después de comentar la probable fabricación de piezas metálicas del equipamiento legionario en talleres o fabricae campamentales, hemos de aludir al hallazgo de dos importantes espacios para el tratamiento del metal datados en época claudioneroniana, por tanto correspondientes a la etapa de ocupación de la Legio VI Victrix. El primero de estos complejos metalúrgicos se localizó en el área extramuros, muy próximo al recinto fortificado en su sector meridional frente a la porta praetoria (Campomanes, 1999). Las estructuras de adobe y los restos de escorias y otros elementos utilizados en el procesado del mineral permitieron identificarlo con un taller especializado en la forja de hierro.

Otro espacio artesanal de la misma época ubicado en el interior del campamento, en las inmediaciones de la via sagularis, ha sido interpretado, en función de los restos estructurales hallados (canal de vertido y otras evidencias de actividades de fundición), de los materiales cerámicos y de los fragmentos de piezas metálicas laminadas, como un taller relacionado con el trabajo del bronce (Aurrecochea, 2006: 316-317).

Con estos precedentes, que sitúan al campamento legionense en su primera etapa de ocupación como uno de los primeros, si no el único, de los recintos castrenses hispanos en los que se constata la fabricación de elementos metálicos que formarían parte importante del equipamiento legionario ${ }^{31}$, no resulta excesivamente extraño que en la fase posterior, a partir de la instalación de la Legio VII Gemina, se mantenga de algún modo esta "tradición" artesanal. Así lo han corroborado las excavaciones arqueológicas en un área situada intramuros, en el ángulo suroccidental del nuevo campamento, donde ha aparecido un taller especializado en la fabricación, reparación y reciclaje de loricae segmentatae, que está activo a mediados del siglo III, para ser desmantelado a finales de esta centuria (Aurrecochea, 2006; 2007; 2009), por causas desconocidas, pero evidenciando, según el citado autor (2006: 330-331), una cierta urgencia, como demuestra la presencia en la zona de vertedero, de fragmentos de piezas inacabadas y otras preparadas para su reciclaje $\mathrm{e}^{32}$.

31 Así, en el campamento de Herrera de Pisuerga (Palencia), se ha localizado un importante conjunto de talleres dedicados a la fabricación de diversos productos (cerámica de diversos tipos -terra sigillata, cerámica de paredes finas, cerámica común, lucernas- vidrio, útiles de hueso y madera, industria latericia e industrias metálicas), (PÉREZ GONZÁLEZ e ILLARREGUI 2006: 111-133). Por tanto, aunque los investigadores de los talleres de Legio no han considerado las evidencias de los talleres hallados en el campamento de la Legio IIII Macedonica, dedicados a la fabricación de útiles metálicos, los autores citados hacen hincapié en la utilización de esta metalistería en el equipamiento militar (FERNÁNDEZ IBÁÑEZ, 2002), (PÉREZ GONZÁLEZ e ILLARREGUI, 2006:126-128).

32 El reciclaje del metal mediante la refundición de piezas -sin necesidad de talleres especializadosconstituía un proceso habitual en los asentamientos militares de las distintas zonas del Imperio, en función del aprovechamiento de recursos difíciles de conseguir. Por ello se hallan escasísimos testimonios arqueológicos de este tipo de materiales en los vertederos, como hemos podido comprobar en las áreas de vertidos aquí estudiadas, pertenecientes a la Legio VII Gemina. 
Con todo ello se pone de manifiesto la temprana instalación en el campamento legionense de fabricae dedicadas a la producción de piezas para el armamento legionario, hecho frecuente en asentamientos castrenses de los limites británico y germánico, pero completamente inusual en Hispania, según los testimonios arqueológicos conocidos hasta el momento.

Por otra parte, hemos de subrayar el hecho de que en Legio únicamente se han localizado talleres de fabricación de estos elementos relacionados con el armamento militar, sin que existan evidencias de espacios destinados a la producción de otro tipo de manufacturas, cuyo abastecimiento se articularía en función de las relaciones comerciales con los principales centros de producción peninsulares.

\section{- INFRAESTRUCTURA HIDRÁULICA. ACUEDUCTO}

Los numerosos hallazgos de tramos de canalizaciones y atarjeas dedicadas al abastecimiento de agua se han producido en la zona septentrional del campamento, partiendo el canal principal de un punto situado en la zona noroeste del recinto. Ello responde a la existencia de un acueducto del que se han documentado pequeños tramos desde los años setenta, los primeros a una distancia de 1,5 Km. del recinto (Santander, 1970: 467-474), y otros más próximos a la fortificación (García y Bellido, 1970b: 586587; Campomanes y Sánchez Mora: 1989: 59-67; García Marcos, 1996: 77). Este castellum aquae acometería al campamento en las inmediaciones del ángulo noroccidental y, a partir de un canal principal cubierto con bóveda de mortero, se dividiría en el área de la porta decumana en diversas conducciones, generalmente de sección cuadrangular y cubierta adintelada (Vidal, 1986: 380; Avello, 1985: 132), para abastecer a todo el asentamiento castrense.

Estas conjeturas sobre la situación y características del acueducto quedaron despejadas en 1999, con el hallazgo y excavación de un importante tramo de esta construcción, situado a unos $3 \mathrm{~km}$. del campamento, en un relativo buen estado de conservación, que ha permitido una completa descripción de las características constructivas de la obra (Campomanes: 2006a; 2006b).

Esta estructura estaba formada por un canal de sección cuadrangular de 0,5 m. de anchura y 1,10 m. de alzado, cubierto por una bóveda de mortero, conservada sólo en determinados tramos.

Su trazado se adapta a la suave orografía del terreno, sin necesidad de salvar importantes desniveles, pero alternando tramos rectos y curvos que indican esta adaptación y anulan prácticamente la pendiente.

El canal se asentaba sobre un empedrado de cantos rodados trabados con arcilla a modo de cimentación para uniformizar el terreno, y sobre éste se disponían los ladrillos (en su mayoría bipedales) que constituían el specum de la canalización. En el tramo excavado se localizaron además dos cistae limariae para la decantación. Los muros laterales estaban igualmente construidos con ladrillos (en este caso pedales) con mezcla de argamasa, y sobre ellos se disponía la bóveda de mortero de escasa consistencia.

Mención especial merece, por su carácter anómalo, el hecho de no haberse documentado resto alguno, ni en la base del canal ni en los muros laterales, de revestimiento de opus signinum, utilizado de forma habitual en la mayoría de las construcciones hidráulicas romanas. 
Los ladrillos utilizados en la construcción portaban las marcas de la Legión en dos tipos: uno en cartela rectangular con la marca LEG VII G F; y un segundo en cartela en forma de tabula ansata de extremos trapezoidales y la leyenda dividida en dos registros LEGVII/G F, con la peculiaridad de que la línea inferior está ejecutada en impresión retrógrada 33 . Así, los datos que ofrecen los sellos del material latericio con estos dos únicos epítetos de la legión, con los que ya contaba al instalarse en Legio suponen un margen muy amplio de cara a establecer una cronología para esta estructura. Por ello se ha tomado como base la cronología del vertedero en que se documentó el mismo sello del segundo tipo, esto es, hacia la primera mitad del siglo II d. C.

Por otra parte, la estampilla completa que aparece en el acueducto presenta en sus ansae también dos registros: en el superior una sucesión de líneas oblicuas y en el inferior, en la izquierda, la leyenda $V A L$, y en la derecha $P A$. La presencia de nombres en el material latericio de la Legio VII es sumamente infrecuente, y se ha interpretado como el nombre de un posible magister figulorum, cargo que aparece en otras zonas del Imperio y al que aludirían marcas legionarias acompañadas de un tria nomina abreviado (Peacock, 1982: 143). Con todo, se conservan algunas de estas estampillas en Legio, algunas citadas por García y Bellido (1970b: 598-599) quien hace hincapié en su difícil interpretación y otras aparecidas en la necrópolis de Vegazana (Liz y Amaré, 1993: 56) en las que a la marca $L E G$ VII GE se añaden abreviaturas de nombres como $L V C I, P R I$, $S E V, R E B$, que, en opinión de los citados autores, harían mención a algún artesano relacionado con el proceso de producción del material constructivo latericio.

\section{- EL ESPACIO EXTRAMUROS}

En el exterior del perímetro amurallado de los campamentos se asienta un contingente de población civil que acompaña siempre a las tropas y que se encuentra integrado por mercaderes, artesanos, familias de soldados, gentes dedicadas a actividades lúdicas y servidores. Este hecho es inherente a todos los asentamientos de unidades militares romanas, y además cobra una especial relevancia en la vida del campamento, pues abastece a los soldados de los más variados productos, satisface sus necesidades de ocio y mantiene vinculados a sus familias a aquellos que las han formado de forma ilegítima durante su período de servicio en que tenían prohibido el matrimonio. A todo ello suele añadirse el asentamiento en este núcleo civil de algunos veteranos $^{34}$ que constituirán un importante factor de integración entre ambos colectivos.

De forma genérica se conoce a este asentamiento de población civil como cannabae, ubicado en las proximidades del recinto militar amurallado. Sin embargo, se ha docu-

33 Un ejemplar similar a este sello, aunque fragmentado, faltándole gran parte de las ansae, fue catalogado como inédito en nuestro estudio sobre los materiales de un vertedero extramuros situado en la C/Maestro Copín c/v San Salvador del Nido, datado a mediados del siglo II d. C. (FERNÁNDEZ FREILE, 2003: 37-38, lám. 6, n 5). Sin embargo, con la excavación del acueducto, previa a esta publicación, pudimos comprobar la similitud de esta estampilla latericia hasta el momento única, con el numeroso grupo que aparecía en los ladrillos de la conducción hidráulica, aspecto que hacemos constar en Ibid. p. 38 , nota 51 .

34 La presencia de veteranos asentados en Legio es escasa según constata Palao (1998: 186), a tenor de los datos proporcionados fundamentalmente por las fuentes epigráficas. 
mentado en numerosos campamentos de las diversas zonas del Imperio, además de esta cannaba, otro tipo de aglomeración civil situada a una distancia dispar del recinto castrense, conocida como vicus.

Esta duplicidad de los asentamientos civiles en torno a los campamentos militares ha provocado un debate historiográfico no sólamente sobre las características y peculiaridades que los diferencian, sino también y principalmente, sobre el empleo de uno u otro término, aspecto que ha generado una importante controversia especialmente en los primeros momentos de la investigación ${ }^{35}$. Algunos investigadores han recopilado parte de estos estudios y la peculiar terminología y diferente concepto de estas aglomeraciones civiles (Vega Avelaira, 1998). En este aspecto hemos de destacar la decisiva contribución de autores como Bérard $(1992 ; 1993)$ quien señala que las cannabae tuvieron una organización completamente civil -incluso aunque estuvieran bajo la supervisión de las autoridades de la legión- y progresivamente irían adquiriendo una organización casi municipal (1992: 88). En esta sentido abunda Vithingoff, sobre la cannabae de León (1970: 346).

De la misma manera, Bérard (1993) incide en las diferencias entre los términos vica$n i$, kanabensis y consistentes, que aparecen en la epigrafía en relación al gobierno de estas aglomeraciones, analizando las kanabae de las provincias danubianas, los vici de Germania y otras provincias, y planteando la distinción entre vici militares y vici civiles, que resulta sumamente compleja. Con todas estas propuestas, el investigador francés concluye que el debate no está cerrado y que las diferentes explicaciones no son excluyentes, pues es preciso tener en consideración las peculiaridades regionales y locales, así como la distinta evolución cronológica de estos núcleos civiles.

En suma, los dos términos cannabae y vicus se emplean indistintamente cuando se trata de un único asentamiento civil (como podemos apreciar en la bibliografía al respecto), pero en el caso frecuente de que existan dos aglomeraciones civiles simultáneas en las proximidades de un campamento -como es el caso de León-, la cannaba hace referencia al núcleo ubicado en las inmediaciones de las murallas y puertas del recinto militar, y el vicus se situaría a una distancia de 1,5 o $2 \mathrm{~km}$. (Bérard, 1993: 63) ${ }^{36}$.

35 Así, algunos autores distinguen estos núcleos civiles utilizando el término cannaba cuando se trata de campamentos legionarios, y vicus en el caso de fuertes auxiliares (POULTER, 1989: 74). Otros investigadores efectúan una diferenciación poco esclarecedora, afirmando que las cannabae legionarias podían subdividirse en vici (VITTINGHOFF, 1971: 305-306; MASON, 1987: 143; CAMPBELL, 1994: 141, 151). En el extremo contrario se pronuncia KERN (1998: 201-215), quien habla de "le vicus des Canabae" para el campamento de Argentorate (Estrasburgo), esto es, que varias cannabae surgidas en torno al campamento se agrupan para formar un vicus canabarum. Por su parte, GOLDSWORTHY (2003: 106) plantea que con el tiempo las cannabae evolucionaron hasta formar vici, con un urbanismo más planificado. La contribución de SOMMER (1984) fue definitiva en el sentido de que propuso un único término para definir estas aglomeraciones, el vicus militaris. Este término fue adoptado en la historiogrrafía británica (JOHNSON, 1989; BLAGG and KIND (ed.), 1984; BIDWELL, 1997: 73-76) así como también en los estudios sobre estos asentamientos en Germania y Raetia, en los que se utiliza el término kastellvicus (KELLER, 1998; JÄGER, 1995; KELLER, 1999) y también en las principales investigaciones en Dacia se habla de vici militares (OLTEAN y HANSON, 2001).

36 Esta misma distinción establece ROLDÁN (1986: 35), para el campamento legionense, aunque en ese momento el vicus no se encontraba localizado arqueológicamente, subrayando la ausencia de cualquier elemento de población indígena en los vici, vinculándolos también estrechamente a la legión y señalando la dificultad de deslindar las funciones de estos dos tipos de núcleos civiles.

Por su parte LE ROUX (1998: 200, nota 23) indica también para el caso de Legio, la existencia de este doble asentamiento civil, si bien establece que la cannaba correspondía a una aglomeración controlada por las autoridades legionarias, mientras que el vicus sería un hábitat indígena alejado del campamento, pero manteniendo relación con los soldados. 
Desde el punto de vista de la investigación arqueológica, la ubicación y estudio de estos núcleos civiles se ha visto por completo relegada, centrándose en las estructuras internas y los sistemas de fortificación de los campamentos. Esta situación se ha dado sobre todo en Hispania, donde sólo desde hace muy poco tiempo se presta más atención a estas aglomeraciones civiles, contrastando con otras áreas del Imperio, fundamentalmente Britannia y Germania, donde la Arqueología Militar cuenta con una gran tradición y podemos encontrar incluso estudios monográficos sobre estos asentamientos en importantes campamentos, como Caerleon (Evans, 2000), o bien trabajos muy documentados como los de Chester (Mason, 1987) o Nimegen (Haalebos, 1997; Franzen, 2009).

En este punto tenemos que destacar que la cannaba de Legio fue ya objeto de temprana investigación por Vittinghoff (1970: 337-352)37, paralela al descubrimiento de los primeros hallazgos arqueológicos fundamentales para definir la estructura del campamento de la Legio VII.

Así, podemos afirmar que fue uno de los primeros campamentos hispanos en los que se planteó la existencia de estos núcleos civiles y se definieron pautas importantes para su estudio.

En efecto, la investigación en este aspecto ha continuado, sin embargo, siempre en un segundo plano respecto a las estructuras de las dos fases campamentales de Legio. En ello también hemos de tener en cuenta la dificultad de definir, además de la localización, la extensión, los límites y sobre todo la organización interna de estos núcleos civiles, ya que no cuentan con un urbanismo planificado, y además las construcciones se realizan fundamentalmente con materiales perecederos que no se han conservado sino fragmentariamente, a lo que hemos de añadir la escasez de fuentes epigráficas y literarias en la mayor parte de los casos. Con todo, los avances en este tipo de investigaciones se han hecho extensivos a otros campamentos hispanos (Palao, 2009), entre los que destacan Petavonium (Romero y Carretero, 1998; Carretero y Romero, 1999; Romero y Carretero, 2006), Cidadela (Caamaño y Fernández, 2000; 2002; 2006), Aquis Querquennis (Pérez Losada, 2002) o Herrera de Pisuerga (Pérez González, 1996; Fernández Ibáñez, 2002), que cuentan con importantes núcleos civiles, cada uno de ellos con sus características propias y distintivas, sin seguir por tanto, -a diferencia de las estructuras campamentales- un esquema definido. Aún así, por las causas que hemos enunciado, resulta problemática la definición arqueológica de las construcciones y la explicación de algunos elementos hallados en estos espacios, carencias que puede suplir en muchos casos el registro material. En suma, podemos afirmar que tanto en el ámbito hispánico como en otras zonas del Imperio, continúan las investigaciones y las nuevas aportaciones, de carácter particular o general (Hanel, 2007), sobre la reconstrucción arqueológica de estas aglomeraciones civiles inherentes a los establecimientos militares romanos.

En el caso de Legio, la definición del espacio extramuros constituye un elemento esencial para nuestro trabajo, centrado en esta área circundante al campamento de la

\footnotetext{
37 En esta contribución el investigador alemán trata ya la diferencia entre cannabae y vicus, así como la organización de la cannaba legionense y otras cuestiones como el papel de los veteranos de la legión en estos asentamientos, estableciendo en estos aspectos paralelos con otros campamentos de los limites raetico, germano y danubiano, como Vindobona, Vetera (Xanten) Mogontiacum, Reginum, Carnuntum, Aquinqum, Potaissa, etc...
} 
Legio VII, ya que en ella se ubican los vertederos, objeto de nuestra investigación.

Hasta hace poco tiempo, algunas evidencias arqueológicas, un buen número de testimonios epigráficos referidos concretamente a estas cannabae (García Martínez, 1999) y determinadas fuentes literarias, habían contribuido a situar el espacio de la cannaba, próxima a las murallas y la puerta praetoria del recinto fortificado. Este núcleo civil se extendería hacia la zona suroccidental, en un área que en época medieval constituiría el barrio gremial de San Martín y, en la actualidad, el casco histórico de la ciudad (vid. Fig. 4).

No obstante, recientes excavaciones llevadas cabo en las afueras de la ciudad, en un amplio espacio, ya excavado en otros de sus puntos en campañas anteriores, han puesto de manifiesto la existencia de un vicus, situado a $2 \mathrm{~km}$. del campamento, en el término de Puente Castro.

Con todo ello, podemos afirmar que el campamento legionense consta de dos núcleos de población civil extramuros, cannaba y vicus, siendo el único en Hispania y siguiendo en este sentido el modelo canónico de las fortificaciones legionarias de otras zonas del Imperio, especialmente las situadas en los limites germano y danubiano.

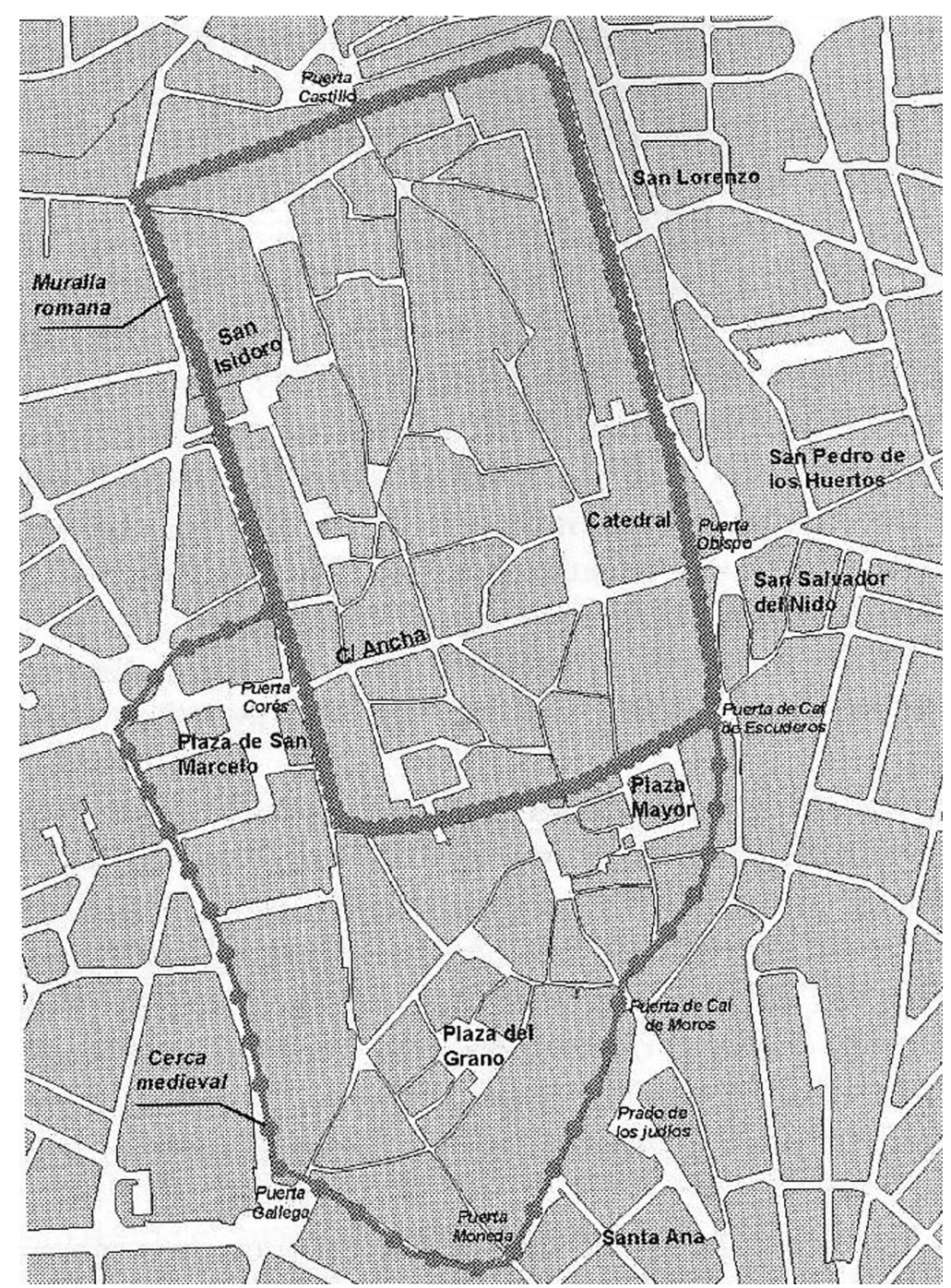

FIG. 4: Plano de la supuesta extensión de la "cannaba", basado en el esquema del Barrio de San Martín (casco antiguo de la actual ciudad de León (según López Trigal et alii, 2002) 


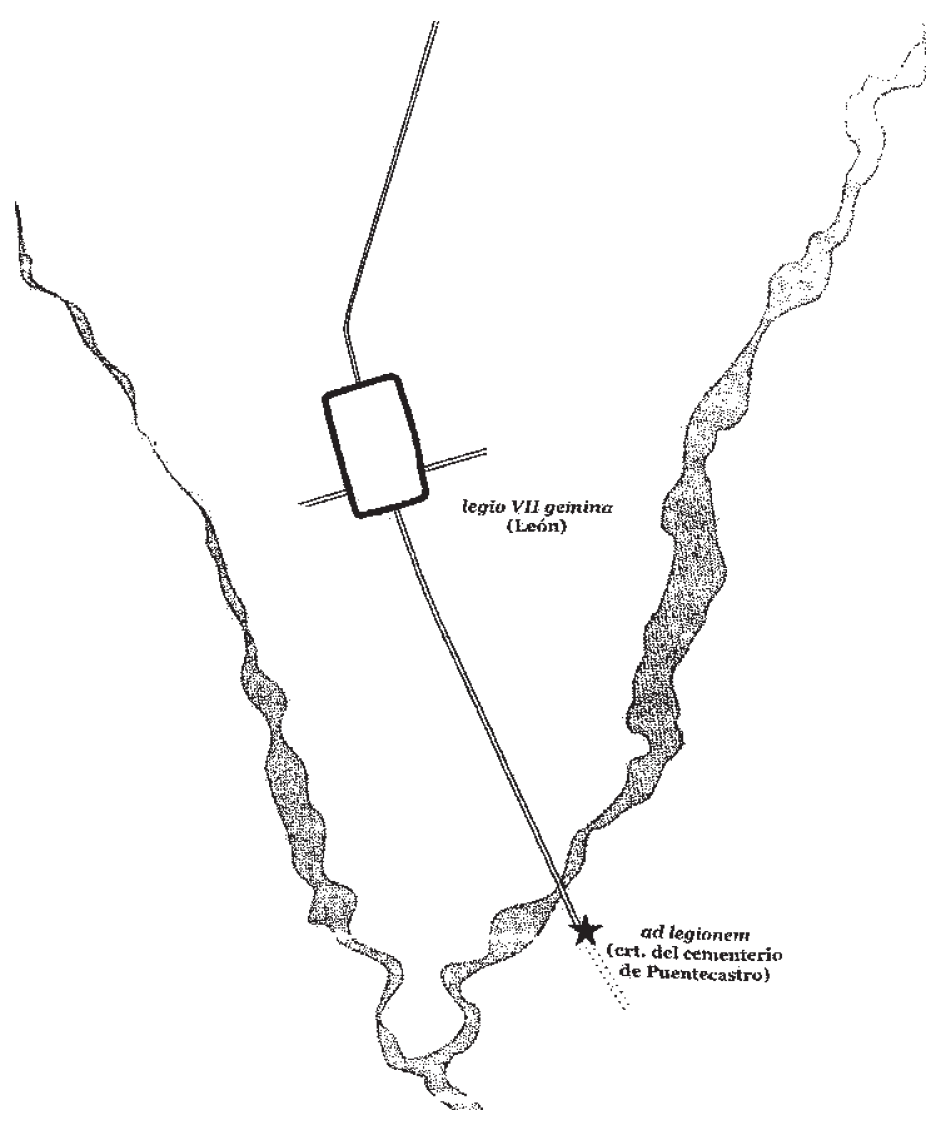

FIG. 5: Plano del "vicus" situado en Puente Castro (según A. Morillo)

En cuanto a la estructura del VICUS, a tenor de las excavaciones llevadas a cabo hace una década y las campañas más recientes, en las que se ha identificado ya como este tipo de aglomeración civil dependiente del campamento de la Legio VII, hemos de destacar que se trata de un terreno próximo al río Torío, amplio y llano, lo que ha facilitado las labores arqueológicas.

Se han hallado cimentaciones de cantos rodados trabados con barro, pertenecientes probablemente a viviendas, de planta cuadrada o rectangular, si bien pueden tratarse también de talleres, tiendas $\mathrm{u}$ otro tipo de edificios dedicados a actividades artesanales.

Como elementos arquitectónicos singulares destacan una construcción con patio porticado y otra de planta basilical terminando la hipotética nave central en un ábside de planta cuadrada (Álvarez Ordás et alii, 2000-2001: 142).

Un aspecto importante es la identificación de un cierto trazado ortogonal, que implicaría una incipiente planificación urbana, organizándose las construcciones en torno a un eje viario que se dispone de Sureste a Noroeste. Así, esta vía podría enlazar con la vía I del Itinerario de Antonino (De Italia in Hispanias), que atraviesa Puente Castro para entrar en León (Legio VII Gemina), punto final de esta vía que, viniendo desde Italia, entra en Hispania por el Pirineo gerundense (Rabanal, 1988: 30-31).

Las menciones, tanto en el Itinerario de Antonino (Ad Legionem VII Geminam), como en otro documento sumamente importante para las comunidades cristianas de algu- 
nos núcleos38, la Epístola 67 de San Cipriano de Cartago (.....ad Legionem et Asturicae.......), hacen pensar en núcleos cercanos y dependientes del campamento. El segundo caso es especialmente indicativo, pues se marca una clara diferencia entre el empleo del acusativo para referirse a Legio y el locativo para Asturica. De esta manera, en palabras de uno de los principales investigadores de este documento, este "hápax" gramatical en la correspondencia de Cipriano obedece a un uso consciente por parte del autor en el que se refleja un dato histórico, geográfico y jurídico: la comunidad cristiana a la que se dirige estaba asentada "junto a" la legión, es decir en las cannabae. Así pues la fórmula ad Legionem en vez del locativo Legionis es sinónimo de cannabae Legionis (Teja, 1990; 2005: 306).

La consideración de este autor que habla de cannabae, bien puede referirse igualmente al vicus, que parece tener mayor importancia en cuanto a la organización urbana.

De cualquier modo, la inclusión del vicus legionense en el entramado viario peninsular da idea de la relevancia del campamento de la Legio VII, y los núcleos civiles que lo circundan, no en vano es el único acantonamiento militar legionario en Hispania, y por tanto un punto fundamental en la red de comunicaciones de la zona norte de la Península.

En cuanto a la entidad de este vicus legionario, a las estructuras ya enunciadas, hemos de añadir un importante elenco de materiales de distintos tipos exhumados en las excavaciones, cuya cronología avala el periodo de establecimiento y permanencia de este núcleo de población civil.

Entre estos materiales destaca especialmente un conjunto de elementos metálicos que forman parte del instrumental médico de la época romana, entre los que se encuentran escalpelos, cinceles, sondas, agujas, pinzas, flebótomos y demás (Álvarez Ordás et alii, 2000-2001: 142-147), aparecidos en el mismo estrato, con lo cual, y en el plano meramente hipotético, podríamos encontrarnos ante la vivienda de un posible galeno, o quizá un taller de fabricación de estos utensilios.

Además de este instrumental metálico, en las intervenciones realizadas en el vicus se han hallado diversos materiales cerámicos ${ }^{39}$ (Ibid.: 147) especialmente terra sigillata

38 Esta Carta, dirigida a varias comunidades cristianas en el año 255-256, como respuesta a los casos de cristianos libellatici, entre los que se encontraban los obispos de León-Astorga y Mérida, contiene importante información -aparte de las cuestiones exclusivamente religiosas, tratadas en trabajos como el de VELADO GRAÑA (1986: 289-295)- sobre aspectos como la entidad y el estatus jurídico de estas aglomeraciones civiles en torno al campamento de la Legio VII. En esta cuestión han incidido autores como POULTER (1989: 69) y sobre todo VITTINGHOFF (1970: 346-352), que se refiere en concreto al caso de la cannaba y el vicus de Legio, señalando la ausencia de cualquier categoría jurídica a tenor de las fuentes, y por tanto de una municipalización, haciendo hincapié en la escasa promoción municipal en los asentamientos del noroeste hispánico. Así, la Carta de San Cipriano, que con la diferenciación terminológica demuestra la existencia de otro enclave civil (vicus) en Legio, deja también constancia de la escasa entidad jurídica del mismo respecto a Asturica Augusta, núcleo de mayor categoría jurídica y urbanística, donde se asentó la sede episcopal, aunque considerando la mayor antigüedad de la comunidad cristiana de Legio, se mantuvo el nombre de las dos localidades en la denominación de la diócesis (Teja: 2005: 305).

Por otra parte, respecto a la organización de ambos asentamientos, la situación más común -teniendo en cuenta la regulación en otros campamentos del Imperio con la misma estructura- es que la cannaba se encontraría bajo la autoridad legionaria, mientras que el vicus tendría una cierta independencia, con una organización propia, menos sometida al control militar.

39 En este trabajo no se hacen constar los porcentajes numéricos de las distintas especies cerámicas citadas. 
hispánica, predominando entre las producciones lisas el plato Drag. 15/17 y el cuenco Drag. 27, así como el servicio Drag. 35 y 36. En los ejemplares decorados domina la forma Drag. 37, con estilo de círculos. Todo ello permite atribuir estas piezas al siglo II d. C. y primera mitad del siglo III.

Junto a las producciones de sigillata hispánica se han localizado varias piezas de cerámica común, fundamentalmente ollas, jarras y vasijas de almacenaje, así como algunos ejemplares de platos de engobe interior rojo pompeyano y fragmentos de ánforas. Mucho menor es el número de ejemplares de cerámica de paredes finas, con escasos fragmentos decorados.

A todo ello hay que añadir un importante conjunto numismático, compuesto esencialmente por monedas de bronce, encontradas en deficiente estado de conservación, de manera que en la mayoría de los casos no permite su lectura. La posible atribución de parte de este numerario a la época de los Antoninos, permite una datación que coincide con la de los materiales anteriormente citados, desde el siglo II a la primera mitad del siglo III.

Las estructuras y organización de la CANNABA presentan mayores dificultades de identificación, dada su ubicación bajo el actual casco urbano de la ciudad, a diferencia del vicus situado en campo abierto. Aún así, se han podido determinar importantes edificaciones en su espacio, si bien las construcciones atribuibles a viviendas han dejado un escaso testimonio arqueológico.

\section{- ESTRUCTURAS DE OCUPACIÓN}

Los escasos restos que pueden adscribirse a edificios de habitación han sido hallados en una misma zona del perímetro de la cannaba, en las excavaciones realizadas en varios solares colindantes a uno de los vertederos estudiados en este trabajo (Calle Pilotos Regueral $\left.n^{\circ} 4\right)$. Estos se sitúan cercanos a la muralla, en su lienzo occidental, muy próximos a la porta principalis dextra. Desde el punto de vista cronológico, resulta significativo que tanto el vertedero como las parcelas en las que se han localizado estructuras constructivas (Edificio Pallarés y Edificio Botines), presentan idéntica secuencia estratigráfica, con tres fases diferenciadas, con abundante material, abarcando desde principios del siglo I d. C. hasta época flavia y comienzos del siglo II. Las estructuras constructivas halladas en las intervenciones en el Edificio Pallarés consistían en restos de muros con cimentación de cantos rodados trabados con barro y en algunos casos conservando parte del alzado de tapial (Miguel Hernández y García Marcos, 1993: 191, 192), y como elemento singular, una construcción realizada con tablones de madera, identificada en un primer momento como un pontón (Ibid.: 193), y revisada posteriormente en otra campaña, en la que se definió como un amplio pavimento, además de hallarse otros restos lígneos correspondientes a muros de cañizo revestidos con argamasa (García Marcos, 1997: 305). La inusual conservación de estas estructuras construidas con estos materiales perecederos, indicaría una cronología en los primeros momentos de la formación de este núcleo civil, sin embargo hemos de considerar que en la construcción de las viviendas de las cannabae se emplearon habitualmente este tipo de materiales, con lo cual su valor cronológico es sumamente relativo. 
En el contiguo Edificio Botines se localizaron asimismo estructuras en madera y una importante edificación con cimientos de cantos rodados y pavimento de guijarros (García Marcos, 1997: 309-310).

Intervenciones más recientes en la misma zona, como la realizada en el patio del Instituto Juan del Enzina deparó el hallazgo de una serie de muros, identificados como parte de un patio de un edificio de importantes dimensiones (San Román et alii, 2006: 736).

Mayor relevancia para la progresiva delimitación del espacio ocupado por la cannaba tiene la excavación en un área más alejada, situada en dirección occidental de los anteriores solares, con los que forma un contexto unificado. En esta intervención, en el solar de la Calle General Lafuente c/v Calle la Rúa, se hallaron restos de cimentaciones de muros, destacando en el conjunto de materiales exhumados la gran proporción de jarras y fichas de juego, lo que ha dado lugar a interpretar esta zona como un espacio de ocio en que convivirían la población civil y militar (San Román et alii, 2006: 737).

A partir de esta serie de hallazgos, aunque fragmentarios, puede determinarse un espacio habitacional que por su situación correspondería al otro enclave civil junto con el vicus, la cannaba ${ }^{40}$, que tiene la peculiaridad de asociarse a todos los establecimiento militares romanos y se asienta por tanto, de forma coetánea a la Legio VII en su campamento.

\section{- ANFITEATRO}

Uno de los hallazgos más relevantes del espacio extramuros del campamento legionense ha sido la localización, en un punto próximo al ángulo suroccidental del perímetro fortificado (vid. Fig. 3), de una monumental construcción formada por un muro de sillería con una bóveda semicircular de opus caementicium, interpretada en principio como un criptopórtico (Vidal, 1996: 314; García Marcos, 1997: 304; 2002: 202; 2005b: 190). Posteriormente, la aparición en un solar frontal de una edificación de similares características, permitió interpretar estos restos como parte de un anfiteatro (Vidal, 2005). La edificación de anfiteatros en el área extramuros es habitual en los principales campamentos romanos de época altoimperial, si bien su estructura constructiva difería de los grandes anfiteatros urbanos, edificándose generalmente en madera la parte superior correspondiente al graderío, que por tanto no se ha conservado. Sobre su uso, se estima que sería compartido por la unidad militar y la población civil, destinándose tanto a los juegos y luchas de gladiadores, como a otras actividades relacionadas con prácticas militares ${ }^{41}$, como desfiles, ejercicios de adiestramiento o instrucción y exhibición en la utilización de determinadas armas y tácticas de combate. Los testimonios arqueológicos de anfiteatros en ámbitos militares son muy numerosos en las diferentes regiones del Imperio. Así, en Britannia destacan los de Caerleon (Isca) (Evans, 2000: 495, 503, Fig. 125) y Chester (Deva) (Thompson, 1959:

40 Sobre la diferente composición demográfica de este núcleo y características de la vida social y religiosa, a partir de diversas fuentes epigráficas, vid. GARCÍA MARTÍNEZ, 1999. (1990).

41 El papel del anfiteatro en la vida del soldado romano ha sido tratado ampliamente por LE ROUX 
32-33, Fig. 1, Pl. XV; Mason, 1987: 150-151, Fig. 4)42. En las áreas extramuros de los campamentos legionarios ubicados en el limes renano-danubiano se encuentran también importantes edificaciones con esta función, como los de Nimega (Franzen, 2009: 1279, Fig. 1.C), Vindonissa (Hartmann, 1984: 12-13), el cual presenta un corredor de servicio paralelo a la arena, que presenta gran similitud con la estructura conservada en Legio (Vidal, 2005: 58-59) y sobre todo, merecen especial mención los anfiteatros de los extensos asentamientos civiles de Carnuntum destinados principalmente a un uso militar (Pérez y Echegaray, 1987: 24). Igualmente, en Dacia se han localizado anfiteatros en los principales asentamientos militares como Micia (Oltean y Hanson, 2001: 124, Fig. 1), dejando patente la importancia de esta construcción en la mayor parte de las áreas extramuros de los acantonamientos militares que, con sus peculiares funciones habrían de fomentar la relación entre el contingente militar y la población civil de los vici y las cannabae.

\section{- TERMAS}

Más desplazada de la que se ha venido definiendo como área de ocupación de la zona extramuros, paralela a la mitad del lienzo oriental de la muralla, se encuentra una edificación correspondiente a unas termas de reducidas dimensiones y conocidas como termas de "San Lorenzo". Dado que constituyen uno de los contextos estudiados en el presente trabajo, no incidiremos en su estructura, tratada ampliamente en el correspondiente capítulo de este estudio, ni en la cantidad y tipo de materiales hallados en su excavación. El rasgo que caracteriza a todo el conjunto es su deficiente estado de conservación, de manera que las estructuras, sumamente arrasadas, una vez documentadas y recogidos los materiales arqueológicos, fueron posteriormente demolidas para permitir la continuación de las obras proyectadas en el polígono de "La Palomera" (Vidal y Marcos Contreras, 2002-2003).

Con todo, a pesar de su precario estado de conservación, las pequeñas termas de "San Lorenzo" constituyen un testimonio esencial de esta situación que se produce, como en Legio, en varios asentamientos militares de otras zonas del Imperio: la presencia de dos edificaciones balnearias, por lo general, una en el interior del campamento, de mayores dimensiones y mejor calidad en la construcción (sin duda para uso de los legionarios o sus oficiales) y otra, en el área extramuros, donde se asienta la cannaba, cuyo uso exclusivamente civil, militar o mixto, aún constituye una incógnita en la investigación. Así, ejemplos de estos complejos termales "dobles" podemos hallar en campamentos de Britannia, como en Caerleon, donde el material hallado atestigua su uso por mujeres y niños (Bidwell, 1997: 82; Evans, 2000: 491, Fig. 125; Goldsworty, 2005: 107), Balmuildy (Sommer, 1984: 129, Fig. 1; Johnson, 1983: 277, Fig. 205) o Beardssen, (Johnson, 1983: 278, Fig. 206) donde las termas extramuros se encuentran en un anexo parcialmente amurallado, y el llamativo caso de los campamentos de Vindolanda y Ravenglass, cuyas únicas termas se hallan extramuros (Sommer, 1984: Fig. 6-7; 1989: 93, Fig.66; Bidwell, 1997: 78-79, 81). También aparecen este tipo de ter-

42 Este anfiteatro, situado en la cannaba del campamento de la Legio XX Valeria Victrix, próximo al ángulo suroriental del recinto amurallado, ha sido objeto de importantes y periódicas campañas de excavación, como demuestran recientes aportaciones (WILMOTT, 2009). 
mas en aglomeraciones secundarias de campamentos de la Gallia como el de Mirebeau-sur-Bèze (Reddé, 1996; Bouet, 2003: 189, Fig. 140), o en Germania ${ }^{43}$, como Saalburg (VV.AA. 1993: 13, Figs. p.12 y 8), en que el establecimiento termal extramuros supera en entidad al interior del asentamiento militar, o el caso más indicativo aún de las grandes termas de Weissemburg, ubicadas en el núcleo civil del Kastell Biriciana, en la frontera del limes germánico y el limes raetico, que presentan unas grandes proporciones en relación a los edificios del perímetro fortificado. En este último caso, las termas estarían en un primer momento destinadas a los militares de la guarnición. Sin embargo, a medida que aumentaba el tamaño de la aglomeración civil, servirían igualmente a esta población. Su construcción, debido a las mayores necesidades civiles y militares, se realiza pues, en tres grandes fases, que dan lugar a un complejo de gran extensión.

Asimismo, en el limes danubiano se encuentran asentamientos militares como Carnuntum, cuyas termas se localizan en el centro del asentamiento civil circundante (Pérez y Echegaray, 1987: 30), constituyendo una edificación de grandes dimensiones con todas las estancias e instalaciones propias del modelo canónico romano.

Como podemos observar, en la ubicación de los edificios termales en los asentamientos militares se produce una diversa casuística, siempre en relación con el espacio civil o cannaba circundante, donde en ocasiones se asientan las únicas termas. Ello lleva a considerar la intervención de las unidades militares en estas construcciones suburbanas, de manera que cabe pensar en un uso mixto de estas termas situadas en el asentamiento civil como es el caso que nos ocupa.

De cualquier modo, sobre éstos y otros aspectos, será el estudio del conjunto de materiales hallado el que nos pueda proporcionar información sobre el régimen de utilización y sobre todo, sobre la cronología de la construcción y el período de uso de estas pequeñas termas y su amortización.

\section{- NECRÓPOLIS}

Además de los vertederos, objeto fundamental de nuestro estudio, situados siempre extramuros, tanto de los enclaves civiles como de los asentamientos militares, también las necrópolis ocupan este espacio, como dicta toda legislación ciudadana.

En Legio se han localizado dos necrópolis de época tardía, ambas de inhumación y situadas muy alejadas del recinto campamental y de la cannaba circundante.

Una de ellas, hallada en la C/Monasterio, al suroeste del perímetro amurallado, presentó una variada tipología en las inhumaciones, distinguiéndose sepulcros en fosa, sepulcros con ataúd, enterramientos con tégulas a doble vertiente y sepulcros construidos con bloques de piedra. Como materiales asociados destaca la gran cantidad de material latericio sellado, correspondiente a diversas etapas de la Legio VII, lo que indica una reutilización de materiales constructivos que dificulta el ajuste cronológico, si bien el conjunto de materiales cerámicos señala una época tardía, proponiéndose un arco cronológico del siglo IV al VII d. C. (González Fernández, 1994).

43 Un panorama exhaustivo de las termas militares en la región de la Germania Inferior, en sus principales campamentos y aglomeraciones civiles lo encontramos en HANEL (2000: 23-33). 


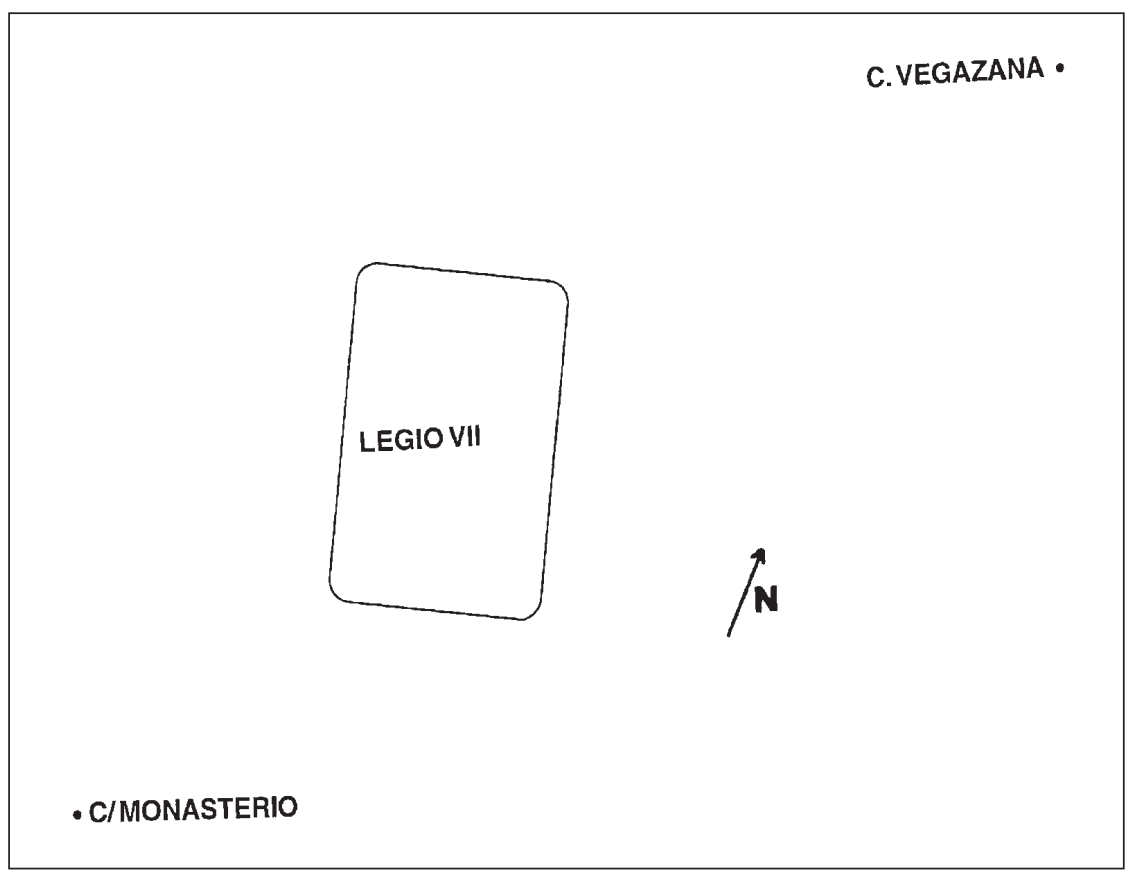

FIG. 6: Áreas de necrópolis localizadas en Legio (según Liz y Amaré)

Por otra parte, fue descubierta otra necrópolis tardorromana en el solar del actual campus universitario de Vegazana (Liz y Amaré, 1993), con inhumaciones de similares características a la anterior, de variada morfología, predominando aquí las tumbas "a capuchina" y de cubierta plana. Construidas con material latericio sellado por la Legio VII, pero con escasa asociación de materiales arqueológicos de otro tipo (los hallazgos cerámicos son mínimos), han sido datadas en los siglos IV-V d. C. sin mayores precisiones. Dada la gran distancia al campamento se ha planteado (Vidal, 1994) si esta necrópolis pertenece al ámbito de la Legio VII y sus cannabae o bien puede asociarse a núcleos romanos de carácter rural más próximos.

Como puede despenderse de lo hasta ahora expuesto, la visión general del asentamiento de Legio en sus diferentes etapas de ocupación por dos cuerpos legionarios, nos permite apreciar en primer lugar, los considerables avances en el conocimiento de las características de cada una de estas etapas, fruto de la intensa actividad arqueológica desarrollada en los últimos años. Aún contando con el siempre negativo condicionante que suponen las intervenciones en el medio urbano, algunos hallazgos se han revelado como decisivos para la confirmación de determinadas exposiciones teóricas presentes desde antiguo en la historiografía y hasta el momento, meramente hipotéticas. Desde esta perspectiva, hemos de considerar que las futuras excavaciones arqueológicas permitan seguir completando el plano del campamento legionense, con sus diferentes estructuras edilicias, así como también definir de forma más precisa la extensión y características de las aglomeraciones civiles -cannaba y vicus- y otros elementos urbanos que se ubican en el espacio extramuros.

Con todo ello, podemos afirmar que a través de los hallazgos arqueológicos, más o menos relevantes, pero siempre indicativos, y de la aplicación de una metodología cada vez más especializada al estudio de los diferentes tipos de materiales, se está reescribiendo progresivamente una etapa fundamental de la historia romana de la ciudad. 
II. METODOLOGÍA 
Desde el punto de vista metodológico hemos de señalar en primer término los límites y dimensiones del presente trabajo, ya que abarca una parte muy determinada de los estudios sobre el León romano. Esta acotación es, en primer lugar, espacial (el entorno extramuros del campamento), por otra parte cronológica (a partir de la etapa de ocupación de la Legio VII Gemina), y finalmente, ergológica, ya que se restringe al estudio de los materiales cerámicos.

Un aspecto esencial que afectará a los recursos metodológicos es la división del estudio en tres capítulos fundamentales, correspondientes a los solares de procedencia de los materiales, que determinan contextos arqueológicos individualizados.

En los tres casos se trata de áreas de vertidos, bien desde su inicio, bien tras un proceso de amortización de otro tipo de edificaciones, como trataremos en cada caso, así como su origen, cronología o las implicaciones de su ubicación en el contexto urbano.

El análisis del conjunto de estos tres vertederos estará estrechamente relacionado con nuestro trabajo de investigación precedente, reseñado en el capítulo siguiente a efectos de contextualización (Fernández Freile, 2003), en el que se estudia exhaustivamente otro vertedero que constituye el punto de partida y la base de la línea de investigación que aquí continuaremos, con las notas diferenciales y las aportaciones pertinentes.

En efecto, la importancia cuantitativa y cualitativa de los materiales de este yacimiento puso de manifiesto el importante valor arqueológico de las zonas de vertidos de los núcleos urbanos -especialmente en aquellos que, como Legio-, carecían de estudios de conjunto de materiales de un mismo contexto. Las perspectivas que se abrían con respecto al progresivo conocimiento de los hábitos de consumo y sistemas de abastecimiento de los distintos productos en un centro receptor de la importancia político-territorial de Legio, en función de su carácter de único asentamiento legionario en Hispania en esta época, nos impulsaron a seguir este camino en nuestra investigación, planteando un estudio en profundidad de mayor amplitud que incluyera otros tipos de vertederos hallados en el entorno del campamento, con la finalidad de obtener datos relevantes para la reconstrucción de aspectos fundamentales de la realidad socioeconómica de este enclave castrense.

Un punto fundamental que hemos de contemplar desde la metodología de estudio es el hecho de que tanto la estructura de los vertederos como su contenido ofrecen una excepcional riqueza informativa, y si bien hasta hace poco tiempo constituyeron yacimientos relegados o escasamente investigados, la importancia que hoy ha cobrado su análisis hace que se pueda hablar de una "arqueología de los vertederos".

Por ello, la historiografía sobre este tipo de contextos presenta una breve trayectoria 44 , teniendo como punto de partida en España los estudios sobre diversos vertede-

44 De hecho, las primeras contribuciones que hemos hallado sobre este tipo de contextos son escuetos informes en publicaciones de carácter no estrictamente arqueológico, como la breve reseña de J. C. SERRA-RAFOLS en 1965 sobre un "vertedero de época romana en el cerro de la Trinitat Barcelona" publicado en el Boletín de la Sección de Estudios del Centro Excursionista de Puig de Castellar, 1, pp. 10-11. A pesar de su brevedad, se hacen constar los principales rasgos geomorfológicos y los materiales aparecidos, aportando datos tipológicos y cronología. Con ello parece iniciarse un interés por este tipo de yacimientos en el área catalana, donde puede afirmarse que comenzaron los primeros estudios científicos sobre vertederos urbanos, alcanzando un importante desarrollo que continúa en la actualidad con yacimientos de primer orden en este aspecto como Tarraco, Barcino, Baetulo y otros enclaves, aunque ya en un contexto más general que comprende este tipo de estudios en múltiples áreas del territorio hispano. 
ros en Tarraco, llevados a cabo bajo la dirección de X. Dupré Raventós, auténtico impulsor de los estudios científicos sobre la problemática de investigación de estas áreas de vertidos e investigador pionero en el análisis del contenido de las mismas (TED'A, 1989; Dupré y Carreté, 1993), profundizando en la abundante y valiosa información que proporcionan para la reconstrucción del proceso arqueológico e histórico de los núcleos urbanos.

Un hito fundamental en este sentido lo constituyó la Reunión Científica celebrada en Roma en 1996 sobre el tema de las Sordes Urbis y la eliminación de residuos en la ciudad romana. La publicación de sus actas en 2000, con este mismo título, se convirtió en una obra emblemática y punto de referencia esencial para los investigadores interesados en este tema, pues la gestión de los residuos en la ciudad antigua es abordada por especialistas en diferentes campos y, por tanto, desde distintos puntos de vista, ofreciendo una visión amplia y completa. Si bien ofrece un panorama más descriptivo de la ciudad de Roma, se plantea también la gestión de los vertidos en ciudades de la Hispania Citerior, con el caso de Tarraco como uno de los ejemplos más indicativos y con mayor trayectoria en este tipo de estudios, así como también en núcleos del Africa Proconsularis, Syria o Aegyptus. De esta manera, el análisis e interpretación de los distintos tipos de residuos, su ubicación, legislación promulgada al efecto, influencia en la dinámica de la topografía urbana, aspectos socioeconómicos, y otras cuestiones que traspasan incluso el ámbito de lo puramente material, son tratadas en esta obra con el rigor científico y la visión ecléctica de los cuales habían carecido hasta el momento los estudios de este tipo de yacimientos. Se inaugura así una nueva y prometedora línea de investigación, con sus propios criterios, problemática interpretativa y metodología arqueológica.

Con todo, los especialistas españoles Dupré y Remolà, en su artículo sobre la gestión de los residuos en Hispania (2002), hicieron constar la escasa atención general prestada a este tipo de estudios en territorio hispano, con una documentación desigual e insuficiente para las distintas ciudades, abundando en el valor de la "arqueología de los residuos" para la investigación histórica y, por tanto, en la necesidad de incentivar estas investigaciones en los principales núcleos urbanos de las regiones hispanas.

Por su parte, en Francia tiene lugar, a partir del Coloquio en la ciudad de Poitiers en 2002, una publicación de conjunto en 2003 (Ballet et alii) sobre la ciudad y sus residuos en el mundo romano, centrándose en los diferentes tipos de aglomeraciones galorromanas en distintas etapas históricas, sin obviar algunos ejemplos de ciudades egipcias por sus peculiaridades en este campo, y prestando especial atención a los procesos de reciclaje y reutilización, aspectos básicos en el estudio de los vertederos. De esta forma, se conseguía reunir y comparar la información referente a la gestión de los residuos en las principales ciudades de la Gallia romana, hecho que supuso un cualitativo avance en esta "especialidad" arqueológica.

Finalmente, y de forma reciente y muy esperada, como hemos comentado, ha aparecido una obra que trata en conjunto la gestión de los residuos urbanos en Hispania (Remolà y Acero (eds.), 2011), que supone un póstumo homenaje al Dr. Dupré, figura señera en estos estudios. La organización de dicha publicación, resultado de la Reunión Científica realizada en Mérida en 2009, resulta sumamente indicativa, pues los distintos núcleos urbanos, con sus peculiares mecanismos de eliminación de residuos líquidos y sólidos (con mayor o menor "monumentalidad" arqueológica en cada 
caso, generalmente referente a las aguas residuales, ya que contamos con importantes conjuntos arqueológicos de cloacas y colectores magníficamente conservados respecto), se encuentran agrupados según las distintas provincias hispanas (Baetica, Lusitania y Tarraconensis), ofreciendo así la oportunidad de establecer comparaciones que afectan no sólo a la vida cotidiana, sino a aspectos socioeconómicos y a otras cuestiones que indican la función de algunas ciudades y en general los distintos niveles de "romanización" en estas ciudades hispanas.

Ni que decir tiene que, si bien un tanto tardíamente, ya que el trabajo que aquí presentamos se encontraba bastante avanzado, esta obra ha significado un referente fundamental para nuestro análisis, prestándonos especial ayuda en cuestiones de interpretación problemática en acumulaciones de residuos sólidos, que han quedado solventadas en buena parte en función de esta inestimable contribución a este campo arqueológico en la Península Ibérica.

Si tenemos en consideración que la eliminación de residuos ha constituido un problema desde la aparición de las primeras sociedades sedentarias, igualmente podemos apreciar las diferentes estrategias de los grupos humanos por mantener alejados de su zona de hábitat los residuos producidos por el desarrollo de diversas tareas. Desde el punto de vista de la etnoarqueología, investigadores como Binford (1988: 199-200), han conseguido dilucidar, al examinar la organización del espacio en estas sociedades, que en los yacimientos de un solo uso no se advierte esta preocupación por la eliminación de desperdicios, mientras que aquellos de ocupación permanente y los de reutilización ocasional, son objeto de organizados mecanismos de limpieza, transportándolos a zonas alejadas y en ocasiones aprovechando determinadas condiciones orográficas, evitando así que los residuos dificulten el normal desarrollo de la vida en los núcleos de hábitat.

Siguiendo el curso de la Historia, encontramos asimismo documentación en las fuentes escritas y en testimonios arqueológicos de la organización de las sociedades Egipcia, Mesopotámica y del Próximo Oriente, para hacer frente a este problema, más acuciante ya que se trata de sociedades plenamente urbanas.

Así, ya en época romana, cuando la gestión de residuos en la Urbs y en las populosas ciudades del Imperio se convierte en una cuestión fundamental de higiene y salud pública, asistimos al surgimiento de diversas formas de gestión de los desechos sólidos y líquidos, que se plasman en construcciones al efecto, en el caso de las aguas residuales, con una importantísima red de cloacas, así como en la existencia de una estructura organizada y responsables municipales de la limpieza de la ciudad. Esta labor de gestión de los residuos toma carta de naturaleza con la promulgación de numerosas ordenanzas particulares -que se hallan reflejadas en las obras de varios escritores de la época, y por supuesto, en una legislación detallada sobre esta cuestión esencial para la vida de la Urbs, como la Lex Tabulae Heraclensis, la Lex Iulia Municipalis o la Lex Libertinaria de Pozzuoli (Panciera, 2000: 95-105). Para el caso concreto de Hispania, estos aspectos están contemplados en la Lex Ursonensis, la Lex Irnitana o la Lex Flavia Municipalis, vigentes para estas colonias y municipios, pero extensivas por su efectividad, a la totalidad del territorio hispano, en especial la primera de ellas decretada para la colonia de Urso.

Desde el punto de vista de su estructura, las áreas de vertidos de restos sólidos ofrecen datos relevantes sobre la topografía urbana y los sistemas de eliminación de residuos, ateniéndose siempre, siguiendo una norma establecida de forma consuetudina- 
ria, pero también como primer dictamen en la legislación citada al respecto -ya sea en la propia ciudad de Roma como en las provincias- a la ubicación de estos vertederos en el exterior de los núcleos urbanos (extra moenia). Así se especifica, como ejemplo más próximo para Hispania, en la Lex Ursonensis $76^{45}$, que obliga a situar alejadas del perímetro de las ciudades todas aquellas actividades (vertidos, talleres de fabricación de cerámica y especialmente de material latericio) que puedan afectar al orden y salubridad de los centros de población.

Por otra parte, su amplio y variado contenido, que incluye materiales de muy diferente clase, hace de los vertederos uno de los tipos de yacimientos de mayor caudal informativo, aportando valiosa documentación sobre hábitos de consumo, producción, importaciones, circulación de bienes, procesos de reciclaje de determinados materiales, etc..., además de proporcionar -por ser en muchos casos yacimientos cerrados ("ensembles clos")-, estratigrafías ininterrumpidas, materiales en buen estado de conservación y cronologías sumamente precisas.

Con todo, en la metodología de estudio de los vertederos es preciso tener presentes determinados fenómenos particulares de estos contextos que pueden afectar a la objetividad de algunos datos sobre los materiales que contienen.

Por una parte, hay que valorar las prácticas de reciclaje y reutilización de materiales, muy común en el mundo antiguo, como medio de aprovechamiento máximo de los recursos, y que tienen su reflejo en la ausencia o escasez de determinados materiales en los vertederos, como el vidrio, los metales, el material arquitectónico o algunos elementos cerámicos.

A estas actividades se presta una especial atención en la obra conjunta sobre vertederos en las ciudades galorromanas (Ballet et alii, 2003), incluyendo en primer lugar una serie de precisiones terminológicas, diferenciando "reciclaje", "reutilización", "recuperación", "regeneración", y otros, que constituyen procesos diferentes en la transformación de los distintos materiales (op. cit.: 14-16).

Así, destaca el pormenorizado estudio de los procesos de reciclaje de vidrio y metal, cerámica y elementos arquitectónicos en los vertederos de Augustodunum (Autun) (op. cit.: 104-106), Nîmes, donde prima no tanto el reciclaje como la reutilización (op. cit.: 128) y especialmente en Aix-en Provence (op. cit.: 141-152), en el que se concluye planteando la cuestión de un carácter mercantil y una organización y control de estas prácticas.

Por lo que se refiere a las ciudades hispanas, no contamos hasta el momento con información tan detallada sobre estas actividades de recuperación de los residuos sólidos en las áreas de vertidos periurbanas, pues en el caso citado es posible incluso determinar el nuevo destino de algunos de estos materiales procedentes de vertederos y reutilizados en otros contextos del mismo núcleo urbano.

El progreso en la investigación sobre la gestión de los residuos urbanos en Hispania quizá permita alcanzar niveles similares en el estudio de estos procesos, lo cual supondría un análisis arqueológico integrador del ciclo de vida de la cultura material de los distintos núcleos de hábitat.

45 Figlinas teglarias maiores tegularum CCC tegulariumque in oppido coloniae Iuliae ne quis habeto. Qui habuerit it aedificium isque locus publicus coloniae Iuliae esto, eiusque aedificii quicumque in Colonia Genetiva Iulia iure difundo praerit, sine dolo malo eam pecuniam in publicum redigito. 
Por otra parte, es necesario tener en cuenta algunos aspectos que pueden afectar a los datos cronológicos que proporcionan los vertederos. Así, aunque estos contextos constituyen un agente datador de suma importancia, dada la variedad de materiales que contienen, que permiten el cotejo de los diferentes datos tipológicos contribuyendo a precisar la secuencia cronológica, hay que tener presente la incidencia de factores, difíciles de determinar, que pueden distorsionar la datación atribuida, como por ejemplo la perduración en el uso de determinadas piezas, cuya presencia en el vertedero puede estar más o menos próxima al momento de su producción, así como la problemática que supone diferenciar la fecha de uso de las piezas y el momento en que fueron arrojadas al vertedero.

Teniendo presentes estas características propias de los contextos de vertidos, que es necesario valorar en el proceso de interpretación de los materiales extraídos, el criterio básico que preside la metodología de este estudio es la referencia constante a la secuencia cronoestratigráfica de cada una de las áreas estudiadas, basándonos para ello en los informes elaborados por los arqueólogos que efectuaron las excavaciones, cuya información constituye la base para reconstruir la estructura y morfología de estos contextos, aspecto que tratamos ampliamente en el siguiente capítulo del presente estudio.

Cabe subrayar en este punto la disparidad existente en la metodología, aspectos formales y nivel científico de estos informes, hecho que hemos tenido la oportunidad de comprobar en el proceso de consulta de los numerosos informes sobre intervenciones arqueológicas de interés para nuestro trabajo, y que recogemos en una relación en uno de los apéndices finales de este estudio.

Afortunadamente, y como casos que podemos considerar excepcionales, hemos de destacar la calidad científica de los dos informes sobre los contextos arqueológicos estudiados, en los que se siguen con rigor las pautas del método arqueológico, aportando una amplia descripción de los diferentes espacios y estratigrafías, complementado con una completa documentación gráfica, todo lo cual ha supuesto un gran apoyo para ya nuestro trabajo a la hora de interpretar estructuras y materiales.

Con estas diferencias en la información y documentación de base para acometer nuestro trabajo de investigación, queda patente una problemática que afecta de forma general a la arqueología urbana, ya que la mayor parte de estos yacimientos se encuentran en el ámbito de las ciudades modernas superpuestas a las antiguas, como es el caso de León.

Esta cuestión comenzó a contemplarse de forma conjunta en 1983, con la celebración de una Reunión científica celebrada en Zaragoza sobre "Arqueología de las ciudades modernas superpuestas a las antiguas", cuyas actas publicadas en 1985 constituyen el punto de partida para la valoración de esta difícil coyuntura, que atañe a un gran número de importantes yacimientos peninsulares soterrados bajo las ciudades actuales y que hoy sigue generando polémica en cuanto a la gestión de las intervenciones arqueológicas y la organización de las investigaciones posteriores con la publicación de los resultados de las mismas, que debería ser el obligado final de todo el proceso.

En efecto, en las últimas décadas y especialmente a raíz del traspaso de competencias en materia de Patrimonio Histórico a las Comunidades Autónomas, ha tenido lugar en los núcleos urbanos antedichos una proliferación de empresas y profesionales libres en el campo de la Arqueología, como respuesta a la demanda que la dinámi- 
ca urbanística -un proceso en continua transformación en todas las ciudades- exigía para cumplir la normativa al respecto.

Surge así un panorama completamente nuevo en la disciplina arqueológica, en el sentido de que por vez primera se desvinculan las intervenciones del contexto académico -universidades e instituciones especializadas- en el que siempre se habían desarrollado los proyectos de excavación de importantes yacimientos, generalmente en sucesivas campañas y por el mismo equipo, y las investigaciones científicas en todos los aspectos del ámbito arqueológico.

Esta disociación será indudablemente uno de los factores decisivos en las carencias y problemática que presenta la arqueología urbana o arqueología de gestión.

Así, el nuevo modelo de actuación arqueológica en el medio urbano se supedita esencialmente a la demanda del sector inmobiliario o de las obras públicas, que exigen la realización de excavaciones de urgencia en las que prima el factor tiempo para llegar al cumplimiento de unos plazos fijados de antemano y en ocasiones mínimos que no permiten prolongaciones, independientemente de la importancia del yacimiento.

En estas circunstancias, se produce un notabilísimo incremento de estas intervenciones 46 , llevadas a cabo por diversas empresas y profesionales libres, adoptando los procesos y criterios de otras actividades económicas (licitaciones, adjudicaciones, etc...) para el trabajo arqueológico, de manera que éste pierde el interés exclusivamente científico que lo había caracterizado hasta el momento, en aras de otra serie de expectativas.

Estos condicionantes actúan indudablemente en detrimento de la calidad del trabajo arqueológico, comenzando por el registro de datos, que ha de realizarse con la mayor premura, lo que implica la posible pérdida de información ya irrecuperable, y finalizando con la elaboración de informes que son el resultado de una labor de mera documentación de los restos, poniendo atención en lo más llamativo, sin profundizar en un análisis detallado de todo el conjunto material que permita una correcta interpretación en el contexto arqueológico general de la ciudad.

A todo ello hay que añadir la falta de homogeneidad que supone la realización de estas excavaciones por diferentes profesionales, con distintos objetivos, criterios y metodología, sin que exista una planificación única y general que posibilite la integración de todas las intervenciones en la ciudad como parte de un yacimiento único, evitando la percepción de la actividad arqueológica en el núcleo urbano como una serie de intervenciones inconexas.

Esta es, en suma, la situación que encuentra el investigador que pretende realizar, desde una perspectiva exclusivamente científica, un estudio arqueológico de conjunto sobre determinada etapa histórica de la ciudad, en este caso la época romana, que constituye nuestro campo de investigación. El proceso de recopilación de la información procedente de estas intervenciones, que supone lógicamente el primer paso para el desarrollo de la investigación posterior, presenta numerosas dificultades y limitaciones, como la falta de informes, o su escaso nivel científico, reduciéndose en ocasiones a meras reseñas con una deficiente documentación, si bien en este complicado

46 Como ejemplo ilustrativo más próximo, vid. la reseña del importante número de excavaciones de urgencia realizadas durante el bienio 1993-1995 en la ciudad de León (GARCÍA MARCOS, 1997), teniendo en cuenta que el área de protección del casco histórico no es demasiado extensa en este caso. 
panorama se encuentran en ocasiones como ya hemos señalado, informes de intervenciones elaborados con sólidos criterios científicos que sobrepasan el nivel de la simple documentación, ofreciendo la información desde los planteamientos de la investigación arqueológica y constituyendo así una valiosa aportación para el desarrollo del trabajo de investigación.

De igual manera, la falta de organización en el estudio de los materiales implica que, del conjunto de materiales de una misma excavación, algunos se encuentren publicados y otros inéditos, o hayan sido estudiados y publicados por distintos autores, como sucede con algunos de los contextos que estudiamos, de manera que en función de sus aportaciones a nuestra investigación, incluiremos una reseña con sus resultados.

Este cúmulo de deficiencias que permanecen sin resolver en el ámbito de la arqueología urbana ha llevado a plantear a los principales investigadores sobre esta particular rama de la actividad arqueológica algunos cambios esenciales para superar esta situación, ya que no se ha producido en los últimos años la esperada evolución positiva en la dinámica de la arqueología de gestión. En este punto todos los autores coinciden en subrayar como causas fundamentales de esta crisis la separación entre gestión e investigación (Rodríguez Tremiño, 2004: 62-63; 119) y la excesiva mercantilización de los trabajos arqueológicos en el medio urbano (Vidal, 2005: 78). De igual manera, proponen también soluciones unánimes, basadas en la elaboración de un proyecto global de investigación arqueológica en las distintas ciudades, con unos objetivos, metodología y marco temporal idóneos y vinculado a los medios académicos (Rodríguez Tremiño, 2004: 123; Vidal, 2005: 82; Martín Bueno, 2002), de forma que la finalidad de este proyecto integral y planificado ha de ser, según proponen, entre otros, Fernández Ochoa y Querol (2000: 12) desvelar la historia de la ciudad a lo largo del espacio y del tiempo, concibiendo la ciudad como un único yacimiento que puede tener múltiples superposiciones.

Como nota final a este respecto hemos de señalar la diferente dinámica en la implantación de esta nueva planificación de la arqueología urbana en las distintas ciudades españolas, pues si en algunas como Mérida existe desde hace tiempo un marco general de actuación arqueológica, incluyendo la compleja cuestión de la conservación de los restos y los recursos divulgativos, en nuestro ámbito de trabajo persiste la problemática y, lamentablemente, no parece próxima una normalización de la arqueología urbana leonesa.

Además de los criterios y condicionantes hasta ahora señalados en el plano metodológico, hemos de añadir otro aspecto fundamental, derivado de la adscripción del presente estudio al ámbito de la denominada "Arqueología Militar", una especialidad arqueológica que ha experimentado un notable avance en la Península Ibérica en los últimos años, con una revitalización y actualización metodológica de los estudios sobre asentamientos militares romanos, tanto en lo referente a sus características estructurales, como a las peculiares producciones materiales de carácter castrense y a las múltiples y diversas implicaciones que en el plano arqueológico conlleva la presencia del ejército romano en Hispania.

Tradicionalmente, esta línea de investigación ha experimentado en el ámbito peninsular un considerable retraso respecto a otros países, fundamentalmente Alemania y Reino Unido, en los que los estudios científicos sobre los numerosos yacimientos de carácter militar ubicados en los limites germánico y británico gozan de una gran tradición e interés, constituyendo un campo esencial en el desarrollo de las investigaciones y puesta en valor de su patrimonio arqueológico. 
De esta manera, puede afirmarse que los primeros pasos de la arqueología militar romana en Hispania se encuentran en los estudios e intervenciones del arqueólogo alemán A. Schulten $(1927 ; 1928 ; 1929)$ sobre campamentos de época republicana y en especial sobre los recintos de Numancia. Sin embargo, a pesar de las valiosas aportaciones de la obra de este investigador, la metodología empleada adolece de importantes deficiencias sobre todo en cuanto al sistema de datación, basado no en las secuencias estratigráficas y el detallado registro de datos en los trabajos de excavación, sino fundamentalmente en los testimonios literarios que aportan las fuentes clásicas, de forma que su obra representa un claro exponente de la denominada "arqueología filológica" (Morillo y Martín, 2005: 177-179).

No será hasta mediados del siglo XX cuando se asienten las bases científicas de la arqueología militar hispana, con las investigaciones de A. García y Bellido sobre diversos aspectos del exercitus hispanicus, y sus intervenciones arqueológicas en ambientes castrenses, destacando principalmente las excavaciones llevadas a cabo en diversos puntos del recinto de Legio. Su obra supone un hito fundamental en el desarrollo de estos estudios 47 (Fernández Ochoa, 2002), que continuarán experimentando importantes avances en las siguientes décadas, con el descubrimiento de numerosos asentamientos militares estables, tanto campamentos legionarios como de unidades auxiliares, localizados fundamentalmente en el área noroccidental peninsular y pertenecientes a la época altoimperial. Así, la proliferación de excavaciones en enclaves como Herrera de Pisuerga, León, Rosinos de Vidriales, Cidadela, etc..., con el análisis de sus estructuras constructivas y del gran volumen de materiales extraídos, plasmados en diversas publicaciones científicas, han permitido reconstruir progresivamente la implantación y el papel del ejército romano en la estructura urbanística, económica y sociocultural del territorio peninsular como factor esencial en el proceso de "romanización".

Por otra parte, la celebración en los últimos años de congresos y reuniones científicas específicos sobre esta disciplina, tanto de carácter nacional (I y II Congreso de Arqueología Militar Romana en Hispania, celebrados en 1998 en Segovia y en 2004 en León), como internacional (Reunión sobre Arqueología Romana en Europa en 2001 en Segovia y XX International Congress of Roman Frontier Studies en 2006 en León) han contribuido decisivamente a la difusión del estado de la investigación y a la puesta en común de los resultados en el marco de las aportaciones de otros países. Con todo ello, hemos asistido últimamente a una dinamización de las trabajos en este campo, ofreciendo una perspectiva cada vez más globalizadora, de cara a una integración de los estudios arqueológicos sobre el ejército romano en Hispania, a un nivel similar al de otras áreas del Imperio, en el panorama general de la Arqueologia Militar Romana.

Partiendo de estas consideraciones y teniendo en cuenta los factores condicionantes expuestos, trataremos los aspectos principales de la metodología empleada en el estudio del material cerámico procedente de estos tres vertederos.

La elección por nuestra parte del material cerámico para, a través de su análisis, acometer el trabajo de investigación arqueológica de estos contextos legionenses,

47 Vid. a este respecto en FERNÁNDEZ OCHOA et alii (2002), la recopilación de trabajos y el análisis de la significación de la obra de este investigador en el Noroeste peninsular. 
parte de que se trata en primer lugar, del material mejor representado desde el punto de vista cuantitativo y, por ende, con un mayor potencial de información, y sobre todo del hecho de que la cerámica -y en concreto determinadas especies- sigue constituyendo el material guía en todo yacimiento de época romana.

En primer lugar, hemos seguido unos criterios y un proceso de análisis basados en las aportaciones bibliográficas más recientes, especialmente aquellas que plantean el actual estado de la cuestión en la investigación del conjunto de la cerámica hispanorromana, sin dejar por ello de tener como referente las tipologías y estudios más tradicionales.

La clasificación previa de este conjunto ha sido realizada siguiendo los criterios habituales en el estudio de la cerámica romana, en diferentes especies o categorías, que comprenden en este caso: terra sigillata, cerámica de paredes finas, cerámica común, morteros, lucernas, ánforas y otros.

Así, aún a riesgo de resultar reiterativos, puesto que en los tres contextos se encuentran prácticamente los mismos tipos cerámicos, hemos mantenido el mismo orden de clasificación y criterios de exposición, considerando que puede ser este un factor importante a la hora de cotejar y establecer rápidas y efectivas comparaciones entre los conjuntos cerámicos de los tres vertederos, a lo que añadimos gráficos indicativos con los diferentes porcentajes de cada especie cerámica, que contribuyen a facilitar esta tarea.

Por lo que respecta al sistema de cuantificación empleado -sobre el total de piezas registrado e inventariado de cada categoría cerámica- que hacemos constar en el estudio, hemos realizado una selección de aquellos ejemplares más completos y representativos de cada grupo y que se encuentran en mejor estado de conservación, para su descripción y representación gráfica. Teniendo en cuenta el tipo de yacimientos de que se trata, espacios deposicionales, este modo de cuantificación se consideró el más idóneo, basándonos en los planteamientos propuestos en las principales monografías sobre esta cuestión (Arcelin y Tuffreau-Libre, 1998).

En cuanto a la representación gráfica de las piezas, al final de cada de cada uno de los tres apartados en que se divide el capítulo del estudio del material cerámico, correspondiente a cada vertedero, se incluyen las láminas con el dibujo de los materiales pertenecientes a cada contexto. Hemos considerado esta distribución más operativa que la colocación de la totalidad de las láminas como capítulo final del trabajo.

En el plano metodológico, el criterio fundamental en que se asienta el presente estudio, como ya hemos señalado, es la referencia a la secuencia crono-estratigráfica resultante del proceso de excavación, a partir de los datos recogidos al respecto en el informe correspondiente. Ello implica que los diversos aspectos y criterios en el análisis de las piezas (tipología, funcionalidad, tecnología,...), se valorarán en todo momento en el contexto de la relación de las unidades estratigráficas de procedencia de las mismas, en orden a establecer correlaciones y extraer así la mayor cantidad de información que nos permita precisar en lo posible la cronología propuesta para estos conjuntos previa 
al estudio pormenorizado de los materiales ${ }^{48}$, así como llegar a conclusiones fundamentadas sobre una serie de aspectos socioeconómicos y culturales esenciales para reconstruir el modo de vida y su evolución en este asentamiento militar.

Por otra parte, en relación a la proporción de las diferentes especies cerámicas en estos contextos, es preciso tener en consideración una serie de fenómenos que afectan a este material manufacturado y que pueden distorsionar la información que ofrece su volumen en el vertedero. Estos son, por una parte, el reciclaje y la reutilización, ya comentados, que no sólo afectan a materiales como el vidrio o los metales, sino también a la cerámica, particularmente a las ánforas, que a menudo son reutilizadas para un uso funerario (enterramientos infantiles) o también arquitectónico, en muros, canalizaciones o espacios abovedados.

También las demás categorías cerámicas pueden ser objeto de reutilización, como materia prima, siendo triturados los fragmentos para su empleo en la fabricación de pavimentos y revestimientos.

Por otra parte, como también hemos expuesto, en el contexto de un vertedero es preciso tener presentes otros aspectos determinantes, en relación con la cronología, pues, a pesar de la correcta datación de los materiales cerámicos en la secuencia estratigráfica correspondiente, hay que valorar el período de uso de las piezas, que puede ser más prolongado en función de diversos factores (calidad de determinados recipientes que alargan su conservación; situación del mercado y distribución de estas manufacturas, que puede sufrir alteraciones temporales...) retrasando todo ello la llegada de estos productos como residuos al vertedero y alterando, entre otros, los datos cronológicos que derivan del análisis arqueológico.

De igual manera, algunas alteraciones en la estratigrafía, son consecuencia de la particular dinámica de los vertidos, no tanto en los vertederos sistemáticos, en los que los niveles deposicionales se suceden con un cierto orden y regularidad, sino en aquellos denominados "secundarios" con aportaciones desiguales de residuos que no siempre se disponen en el mismo espacio, complicando el análisis del registro estratigráfico.

Estos fenómenos, que forman parte de la problemática de la interpretación de los vertederos, no disminuyen en ningún caso la importancia de la cerámica como material director para establecer secuencias temporales definidas, relacionando la información que proporcionan las distintas especies, sino que, por el contrario, ayudan a esclarecer en muchas ocasiones determinadas cuestiones de difícil explicación que no responden a los criterios establecidos sobre este material, y que encuentran una respuesta en función de los contextos de eliminación de residuos en que se hallan.

48 La cronología propuesta -previa al estudio detallado de los materiales- para los dos vertederos ubicados en estructuras constructivas en la zona sudoriental del espacio extramuros, según los datos del informe correspondiente y de la publicación sobre ambos contextos (VIDAL Y MARCOS CONTRERAS, 2002-2003: 129, 136) se sitúa para el primero, la construcción singular (depósito de San Pedro) desde época de Claudio hasta finales del siglo I d. C., y para el segundo (el pequeño conjunto termal de San Lorenzo), desde su construcción en época flavia -por tanto en la etapa en que la Legio VII Gemina se encuentra ya definitivamente asentada en el campamento- y en uso hasta el siglo III d.C., cuando se produciría su destrucción y abandono. En el vertedero de la C/Pilotos Regueral, los niveles de la última de las tres fases en que se divide la secuencia estratigráfica serían los correspondientes a la época flavia y principios del siglo II d. C. 
Además de estos planteamientos metodológicos de base, aplicamos también una serie de criterios comunes en el estudio de estos diferentes grupos cerámicos, que se basan fundamentalmente en: la técnica, la morfología, la decoración, la funcionalidad, la procedencia (local, regional o importada) y la cronología, prestando asimismo especial atención a los criterios cuantitativos, valorando los porcentajes de cada especie cerámica en los distintos contextos para efectuar el cotejo entre ellos y llegar así a establecer diferencias y analogías en la dinámica de los distintos vertederos extramuros y valorar las implicaciones de carácter social, económico y cultural que de ello pueden derivarse.

Por lo que concierne al estudio de los aspectos técnicos en la fabricación de los diferentes tipos cerámicos, es preciso resaltar el decisivo avance que han experimentado a partir de la aplicación de análisis científicos de pastas y demás aspectos de los estudios arqueométricos, cuyos resultados proporcionan datos concluyentes sobre la composición mineralógica y química de las materias primas y los procesos tecnológicos empleados en los diferentes centros de fabricación, definiendo así los rasgos identificativos de los diferentes talleres y por ende, la procedencia de los distintos materiales cerámicos en los núcleos receptores.

La utilización de la Arqueometría para la caracterización de materiales cerámicos se ha afianzado en España en las últimas décadas, de forma que la mayor parte de los estudios arqueológicos actuales sobre diferentes categorías cerámicas, además de las clasificaciones morfológicas al uso y los análisis tipológicos que proporcionan amplia documentación, suelen incluir un apartado de analítica arqueométrica, en especial de aquellas piezas que presentan mayores dificultades de adscripción, y en general para corroborar, matizar, o incluso modificar radicalmente en algunos casos las percepciones de los análisis de visu tradicionalmente afianzadas.

Como disciplina que utiliza métodos de análisis de distintas ciencias, el conjunto de técnicas y métodos de la Arqueometría es tan extenso como complejo ${ }^{49}$, a la vez que desconocido para los arqueólogos, por rebasar ampliamente nuestro campo de conocimiento.

Con todo, la cuestión fundamental en la que inciden los principales investigadores es la necesaria relación e integración de ambos campos a la hora e valorar los resultados obtenidos. Así, según Gurt Esparraguera y Martínez Ferreras, "la contrastación final entre la información obtenida por vía directa, la arqueológica, y la obtenida por vía indirecta, la arqueométrica, ayudará a la interpretación del registro arqueológico, reconstruyendo información sobre algunas de las etapas de la vida de los individuos cerámicos: dónde y en qué momento han sido fabricados y comercializados, cómo han sido fabricados y cuáles son sus características tecno-funcionales" (2008: 788). En el mismo sentido incide Pérez Arantegui (1996: 4-5), subrayando la formación de equipos interdisciplinares como marco idóneo para el desarrollo de la investigación arqueométrica y la creación de bases de datos para posteriores comparaciones, como elementos fundamentales para la obtención de conclusiones válidas.

49 Vid. sobre las técnicas y métodos de análisis arqueométricos más utilizados para la caracterización de materiales cerámicos, algunos trabajos como los de GARCÍA HERAS y OLAETXEA (1992); ARANTEGUI et alii (1996: 53-72); CAPEL (ed.) (1999); GURT ESPARRAGUERA y MARTÍNEZ FERRERAS (2008: 792-806), en los que se exponen descripciones amplias y detalladas sobre las características y aportaciones de cada una de estas técnicas en el campo arqueológico. 
A estos criterios generales que definen la metodología del estudio del material cerámico, es preciso añadir algunas características metodológicas específicas de cada grupo, si bien expondremos de manera más pormenorizada aquellos criterios empleados en el estudio de la terra sigillata -por ser éste el material director por excelencia en los yacimientos romanos y consecuentemente el más estudiado- y en la cerámica común, pues aunque su valor cronológico es mucho menos indicativo, su elevado porcentaje numérico y las tradicionales carencias en su investigación, justifican la explicación más amplia de algunos aspectos metodológicos utilizados en su estudio.

Igualmente, las demás especies cerámicas (cerámica de paredes finas, morteros, lucernas o ánforas) serán objeto de determinadas precisiones metodológicas, pues todas ellas son sumamente indicativas en los contextos militares.

En cuanto a la terra sigillata, sobre todo la de origen hispánico, ya que nos situamos cronológicamente a partir de época flavia, hemos partido en la descripción morfológica de los distintos tipos, de los criterios y acuerdos terminológicos y tipológicos establecidos en las obras tradicionales ${ }^{50}$, con sus actualizaciones y revisiones contenidas en los estudios generales más recientes sobre estas producciones. Estas últimas obras de conjunto han supuesto un referente fundamental, dado que significan una puesta al día sobre el estado de la investigación de la TSH, un campo cada vez más complejo y diversificado ${ }^{51}$. Así, se proponen secuencias cronológicas más precisas, basadas no únicamente en criterios tipológicos, sino en contextos estratigráficos fiables, a partir de las numerosas excavaciones llevadas a cabo en los últimos años.

De la misma manera, se esclarece progresivamente, con la aportación de nuevos datos, el panorama de las denominadas producciones "precoces" y de las producciones "singulares", que tienen especial significación en cuanto a la definición de los inicios de la producción y la ubicación de talleres en zonas alejadas de la órbita del complejo riojano de Tritium Magallum.

En este sentido hemos de destacar la decisiva contribución de la aplicación, ya prácticamente generalizada, de la tecnología arqueométrica al estudio de la sigillata hispánica, iniciada por M. Picon e incorporada a la obra general de Mayet (1984) y continuada por otros investigadores como Buxeda (1994; 2000-2001), Madrid (2005), Madrid y Buxeda (2007; 2010), así como por Romero, cuyas recientes publicaciones sobre materiales del Valle del Duero $(2008 ; 2012)$ han aportado datos sumamente esclarecedores sobre las clases de sigillata y su procedencia, así como la identificación de nuevos talleres y la definitiva ubicación de algunos alfareros "precoces" -situados tradicionalmente en Tricio- como el caso de VLLO, cuya producción se ha localizado en el taller de Uxama.

50 Fundamentalmente las obras de MEZQUÍRIZ (1983 y 1985); GARABITO (1978); MAYET (1984); ROMERO (1985).

51 Destacan en este sentido las monografías en que colaboran los principales investigadores sobre el tema: FERNÁNDEZ GARCÍA (ed.) (1998); ROCA y FERNÁNDEZ GARCÍA (coords.) (1999), así como alguna contribución en publicaciones de variada temática, como la de SÁENZ PRECIADO, C. (1997) sobre las nuevas perspectivas en el estudio de la TSH. Asimismo se plantea un panorama general, con la problemática y líneas de investigación de estas producciones en capítulos de las últimas obras de carácter general sobre la cerámica romana e hispanorromana: ROMERO y RUÍZ MONTES en ROCA Y FERNÁNDEZ GARCÍA (coords.), (2005: 139-223); FERNÁNDEZ GARCÍA y ROCA en BERNAL y RIBERA (eds), (2008: 307-332). 
Las características técnicas, morfológicas y decorativas que precisamos en la descripción de las piezas, nos han permitido establecer ya una primera atribución de estas producciones a los talleres del área riojana que, con su centro en el complejo alfarero de Tritium Magallum, monopolizan desde mediados del siglo I d. C. la producción de sigillata hispánica en la zona norte peninsular, frente a los talleres de Andújar, cuyas cerámicas hispánicas presentan una difusión mucho más restringida, limitada al área bética.

De la misma manera, un aspecto fundamental en el avance de la investigación ha sido, además del reconocimiento de las peculiaridades de los diferentes alfares de un mismo complejo, como el de Tricio, la identificación de un importante número de nuevos centros de producción 52 , sobre todo en la meseta norte, con un carácter secundario respecto al centro riojano, constituyendo en algunos casos sucursales de éste o bien centros autónomos, con un área de difusión local o regional y con sus respectivas particularidades técnicas, morfológicas o decorativas.

En estos estudios se hace especial hincapié en los aspectos socioeconómicos, como la organización de la producción en los talleres o las relaciones entre ellos, además de analizar las redes de distribución de estas producciones, valorando los factores que inciden decisivamente en este proceso, como las vías de comunicación, el papel de algunos núcleos urbanos importantes como centros de redistribución y el análisis del volumen y características de la TSH hallada en los principales centros receptores.

De esta manera la afirmación de la procedencia tritiense de la TSH en algunos yacimientos deja de ser tan taxativa como hasta hace poco tiempo, en que se desconocía la existencia de estos centros de fabricación ubicados en la zona norte y que han modificado sensiblemente el esquema unívoco de abastecimiento de la terra sigillata hispánica, haciendo más compleja y diversificada la distribución de esta producción.

Por lo que respecta a uno de los primeros criterios de atribución de estas manufacturas, como es la descripción de los colores de pastas y revestimientos, hemos optado por prescindir en este caso de las tablas de colores al uso, por considerar que los datos de su consulta ofrecen un considerable sesgo subjetivo, y por tanto de muy escaso valor para determinar adscripciones seguras, de manera que procedemos efectuando un análisis de visu para identificar tonalidades genéricas y obtener datos macroscópicos sobre la composición, textura y calidad de las pastas y barnices.

Además de la enunciada cuestión de la diversificación de talleres y de las novedades propuestas en cuanto a la relación entre los distintos centros productores, se ha intentado en los últimos años individualizar los rasgos característicos de la producción de los diferentes alfares que componen el complejo tritiense (Sáenz Preciado, P. 1993; 1999). En este sentido, hemos comenzado una línea de investigación por nuestra

52 Estos aspectos se contemplan ya en el estudio de SÁENZ PRECIADO, M. P. y J. C. (1999) sobre el estado de la cuestión de los alfares riojanos, y han continuado siendo objeto de investigación, a la luz de nuevas vías de documentación, reflejados en publicaciones más recientes (SÁENZ PRECIADO, J. C. 2007; SÁENZ PRECIADO y MÍNGUEZ MORALES, 2008) que ponen de manifiesto la complejidad y diversidad en la producción y distribución de la TSH en el norte peninsular, en función de la extraordinaria demanda de estas producciones en la etapa altoimperial. 
parte -analizando aspectos en primer lugar tipológicos y posteriormente arqueométricos- que nos permitan dilucidar la primacía de alguno de estos centros en el abastecimiento de la TSH al asentamiento legionense.

Ello se ha visto confirmado por los análisis de un número significativo de muestras de pastas de los diferentes contextos ${ }^{53}$, realizado en el Departamento de Química Analítica de la Universidad de Zaragoza, donde se encuentra una importante base de datos elaborada a partir de numerosos estudios sobre la terra sigillata riojana, que nos ha revelado interesantes datos para la atribución de estos ejemplares a algunos talleres concretos dentro del complejo tritiense, y que incluimos en el apéndice final de este estudio.

En el ámbito de la sigillata hispánica, revisten especial trascendencia las producciones de la denominada terra sigillata hispánica tardía -en cuya investigación se han producido igualmente significativos avances- en tanto que constituyen un elemento esencial desde el punto de vista cronológico en los yacimientos altoimperiales, para fijar el final de su secuencia temporal. Sobre otros aspectos de la TSHT, efectuamos un comentario más amplio y detallado al realizar la descripción de los escasos fragmentos hallados en dos de los vertederos estudiados.

Por lo que se refiere a la cerámica común, hemos de poner de relieve el hecho de que ha sido un material tradicionalmente postergado en las investigaciones arqueológicas de los diferentes contextos en relación a las demás familias cerámicas, pues su valor como material-guía es menor, dada su escasa variabilidad formal en el tiempo, con una gran perduración de los diferentes tipos, de forma que no permite fijar secuencias cronológicas bien definidas.

Este hecho constituye, entre otros, parte de la problemática específica de la cerámica común, de forma que su datación ha debido de realizarse tradicionalmente en función del resto de materiales presentes en el mismo registro estratigráfico.

Todo ello hace que, a diferencia del resto de las especies cerámicas, el estudio de las producciones comunes carezca de una metodología específica, de aplicación general, con criterios terminológicos y tipológicos firmemente establecidos. Así, aún en la actualidad, en las publicaciones sobre la cerámica común de cada yacimiento aparecen distinta terminología y criterios de clasificación. Esta coyuntura metodológica dificulta notablemente el estudio comparativo de estas producciones, pues impide contrastar adecuadamente los resultados de su investigación en los diferentes contextos arqueológicos.

Partiendo de estas premisas, el estudio de la cerámica común requiere en principio, algunas precisiones y matizaciones en el ámbito terminológico, dadas las diferentes opiniones existentes al respecto y el panorama en ocasiones confuso en que se sitúa aún hoy esta categoría de la cerámica romana desde el punto de vista conceptual.

53 Vid. FERNÁNDEZ FREILE, (2006: 419-429). Tanto desde el punto de vista de algunos peculiares rasgos tipológicos, definidos por M. P. SÁENZ PRECIADO (1993), como desde la confirmación de los análisis arqueométricos, podemos apreciar en Legio, a juzgar por su aparición en distintos vertederos, un predominio de los productos de uno de los alfares del complejo tritiense, de los que presentan una cronología más antigua. 
De esta manera, valorando el distinto contenido de las producciones integradas en el término "cerámica común" según la definición de diferentes autores, que resulta muy desigual, especialmente en los primeros estudios, bien de carácter local (Cabotse, 1962) o de ámbito mucho más amplio (Vegas, 1973), y teniendo en cuenta propuestas más renovadoras en este sentido como la de Alcamo (1986), consideraremos aquí como cerámica común -apelando aún a la convencionalidad del término-, el conjunto de recipientes de uso cotidiano o instrumenta domestica, elaborados con técnicas simples, ya sean de procedencia local, regional o importada. Quedan por tanto excluidas de este grupo las cerámicas de lujo y la vajilla fina de mesa, de manera que englobaría fundamentalmente los recipientes para uso culinario, el servicio común de mesa y los destinados al almacenaje y conservación de diversos productos.

Desde el punto de vista del estado de la investigación se han realizado importantes avances en los últimos años, asistiendo a lo que algunos investigadores califican como "el renacimiento de la denominada cerámica común" (Beltrán, 2008: 23). En efecto, desde la publicación de Alarçao (1975) sobre las cerámicas comunes de Conimbriga, que supuso un hito definitivo al diferenciar claramente la cerámica local y regional de la importada, además de propiciar la aplicación de métodos científicos, siguió una etapa de importante actividad en la identificación de talleres, especialmente en el sur y este peninsular, como el alfar de la Cartuja (Granada) (Serrano, 1976; 1978) y sobre todo el de los Villares de Andújar (Sotomayor et alii, 1976; 1979); también se publican las cerámicas locales de Mérida (Sánchez, 1992) e importantes conjuntos en el área catalana (Casas et alii, 1990).

En este progresivo avance de la investigación, tiene lugar la celebración de una reunión científica (Aquilué y Roca (coords.), 1995), que supuso un importante punto de inflexión, contribuyendo especialmente a la unificación de criterios en el estudio de estas producciones, pues la cerámica común forma ya parte importante de los estudios de diversos conjuntos cerámicos ${ }^{54}$.

Sin embargo, hemos de hacer hincapié en que en este ámbito no contamos aún con estudios generales actualizados 55 , limitándose aún los principales trabajos a áreas

54 En esta línea hay que señalar que son cada vez más numerosos los estudios de conjuntos cerámicos de yacimientos peninsulares que prestan mayor atención al capítulo de la cerámica común, que tienen un importante precedente en la publicación de las producciones de Conimbriga (ALARÇAO, 1975) y entre los que cabe destacar los de Celsa (BELTRAN et alii en VVAA., 1998), Varea (LUEZAS y SÁENZ PRECIADO, 1989), Arcobriga (SÁNCHEZ; AGUAROD et alii, en VVAA, 1992), Emerita (SÁNCHEZ SÁNCHEZ, 1992; ALVARADO y MOLANO, en VVAA, 1995; BUSTAMANTE, 2011) o Petavonium (CARRETERO, 2000: 640-716).

55 Así, en sentido estricto, podemos considerar que la única obra de carácter unificador y de ámbito más general sobre la cerámica común romana ha sido el estudio de VEGAS (1973) para el área del Mediterráneo occidental, que siguió la línea de investigación iniciada por LAMBOGLIA en su publicación sobre las excavaciones de Albintimilium (1950) en la que por primera vez se analizan con rigor las producciones de cerámica común. La aportación de VEGAS marca así un hito fundamental y su clasificación tipológica, aunque ya superada, sigue constituyendo aún hoy un referente importante para los estudios sobre el tema en esta zona del Imperio, que parten ya de la base de nuevos criterios metodológicos de análisis y clasificación, y se circunscriben a ámbitos geográficos mucho más restringidos. 
regionales o locales, destacando, además de los ya citados, los de Aguarod (1995) para el Valle del Ebro, Serrano Ramos para el territorio malacitano (1997; 2000; 2004) o la monografía de Luezas (2002) sobre la cerámica común romana de la Rioja, y en lo que concierne a las producciones locales, merece especial mención el completo estudio de estas producciones en Lucus Augusti (Alcorta, 2001).

Sobre ámbitos más amplios como la provincia Tarraconense, destacan los estudios de Aguarod (1991) sobre las producciones importadas, y la decisiva aportación de Paz Peralta centrada en época tardía (1991), añadiéndose a todo ello la identificación de algunas producciones peculiares de cerámica común, cuya área de extensión no se ajusta a las demarcaciones oficiales (Fernández Ochoa y Zarzalejos, 1999).

De esta manera, con estas diversas contribuciones y considerables avances en el estudio de esta especie de la cerámica romana, la revisión del estado de la investigación sobre el mundo de las cerámicas comunes altoimperiales de Hispania (Serrano, 2008: 471-488), señala las diferencias en la investigación entre las tres provincias hispanas, e incluso dentro de cada una de ellas los progresos en función de su ubicación, para concluir que es necesaria una mayor atención a este material cerámico para avanzar en el conocimiento más exhaustivo de estas producciones. Ello redundará indudablemente en la mayor profundidad en el estudio y en el conocimiento más detallado y completo de los contextos generales en que se hallan estas producciones.

En cuanto a la metodología empleada en la clasificación de la cerámica común, hemos partido de cuatro criterios fundamentales de análisis: la técnica, la funcionalidad, la morfología y la procedencia.

Desde el punto de vista técnico se analiza la tonalidad y composición de las pastas, los sistemas de cocción, así como la calidad y granulometría de los desgrasantes utilizados, prestando especial atención a los revestimientos o tratamientos de las superficies externas y los sencillos esquemas decorativos que pueden presentar algunos de estos recipientes. La clasificación se realiza en función de los rasgos morfológicos más distintivos, especialmente la configuración de los bordes, forma del cuerpo y otros elementos como la presencia de asas.

La funcionalidad ha constituido un criterio básico en las clasificaciones de cerámica común, según el cual se establecen tres apartados fundamentales, diferenciando los recipientes de cocina, de mesa y de almacenaje y englobando en cada uno de ellos los diferentes tipos morfológicos y sus variantes. En nuestro caso hemos recurrido a este criterio funcional en el ya citado estudio precedente de un vertedero legionense (Fernández Freile, 2003). Sin embargo en este trabajo hemos optado por prescindir de esta división tripartita, teniendo en cuenta que algunos recipientes (platos, cuencos, tapaderas, jarras e incluso ollas) ${ }^{56}$, pueden tener una función polivalente, para uso

\footnotetext{
56 Esta cuestión ya es señalada por VEGAS en la descripción de la función de algunos recipientes. Así, en el capítulo dedicado a las vasijas para guardar provisiones, afirma que es probable que determinadas ollas sirvan también para este cometido y no para cocinar, dado que por su forma alta y cerrada no es posible asignarles otro uso que el de guardar las provisiones en la cocina o en el sótano de la casa (1973: 115). En la misma cuestión incide JÁRREGA (2009, SECAH, Bol no 1: 24), quien considera que determinadas ollas de buena factura y con decoración servirían para la despensa e incluso podrían ser utilizadas en la mesa.
} 
culinario y como servicio de mesa, de manera que en la clasificación que hemos propuesto aparecen únicamente los distintos tipos morfológicos con sus diferentes subtipos. En este último aspecto, dada la falta de homogeneidad en los diferentes trabajos, sí hemos tomado como referente la clasificación que elaboramos particularmente para el estudio de este grupo cerámico en el antedicho vertedero, ya que las formas se repiten con bastante asiduidad a pesar de la distancia cronológica, rasgo propio de estas producciones comunes cuyos tipos tienen una larga perduración en el tiempo. Por otra parte esta clasificación permite una visión más general de este conjunto cerámico en cada vertedero, facilitando así las comparaciones entre porcentajes y predominio de las distintas formas.

En la descripción de estos tipos morfológicos se añaden en cada caso algunas cuestiones peculiares sobre funcionalidad o procedencia, subrayando aquellos aspectos susceptibles de proporcionar información desde el punto de vista cronológico, socioeconómico o cultural.

Por otra parte, una cuestión de debate actual en cuanto a la cerámica común, y que ya viene tratándose desde hace tiempo, es la afirmación o presunción de su procedencia local o regional y, raras veces, importada. En este aspecto se sigue insistiendo actualmente, con una tendenciosidad hasta dar lugar a lo que algunos investigadores han dado en llamar un topos historiográfico.

En este sentido será necesario profundizar en el estudio de tipos y de pastas para arrojar luz sobre esta cuestión, recurriendo a los análisis arqueométricos ${ }^{57}$, que también hemos efectuado sobre algunos fragmentos, cuyos resultados se incluyen en el apéndice final de este estudio.

Con todo ello, el estudio de la cerámica común, aunque carece del valor cronológico de otros materiales-guía por los motivos ya expuestos, puede proporcionar datos importantes sobre aspectos formales y tecnológicos propios de las cerámicas del sustrato indígena que perduran durante la etapa romana, así como información sobre áreas de dispersión de los distintos centros productores y algunas aportaciones sobre hábitos de alimentación y preparados culinarios, que en nuestro caso presentarán las connotaciones propias de los ámbitos militares ${ }^{58}$.

El análisis del resto de las producciones cerámicas presentes en estos contextos de vertidos -cerámica de paredes finas, morteros, lucernas y ánforas- no presenta una especial problemática desde el punto de vista metodológico, pues en cada caso conta-

57 En este aspecto, la aplicación de este tipo de técnicas a una serie de cerámicas comunes de Asturica Augusta ha puesto de manifiesto la coexistencia, en torno al cambio de Era, de producciones comunes indígenas y otras importadas (SUÁREZ y BURÓN, 2006: 389-398; 2009: 383).

58 Vid. sobre este aspecto concreto, algunas conclusiones extraídas en este caso del análisis de los restos faunísticos hallados en diversas excavaciones y en el vertedero estudiado por nosotros ya citado, en FERNÁNDEZ RODRÍGUEZ, C., y FUERTES PRIETO, N. (2004): “La alimentación en el campamento de la Legio VII en León: la información arqueológica", Promonumenta VI, León, pp. 34-39 y otros trabajos sobre la dieta de los soldados romanos en el noroeste del Imperio (DAVIS, 1971; MENÉNDEZ ARGUIIN, 2002: 447-457; COSTA GARCÍA y CASAL GARCÍA, 2009). 
mos con obras bibliográficas de referencia fundamentales para la clasificación y caracterización de estas producciones, además de numerosos estudios locales y regionales que nos permiten establecer paralelos interesantes con otros yacimientos ${ }^{59}$. Por otra parte, estas especies cerámicas revisten una especial significación en los contextos militares, ya que, además de proporcionar cronologías precisas, aportan una valiosa información para reconstruir diversos aspectos de la vida en los campamentos. En este sentido, el cotejo de los porcentajes de estos materiales, la determinación de lugares de procedencia, y otros aspectos como el contenido de los envases anfóricos según su tipología (vinos, aceite, salazones...), permiten extraer datos sumamente relevantes sobre las tendencias propias de asentamientos castrenses en cuanto a la utilización de determinados recipientes cerámicos, el consumo de determinados productos, las rutas comerciales, y especialmente sobre el sistema de abastecimiento del ejército romano en Hispania en esta etapa, cuyos efectivos legionarios se limitan ya únicamente al acantonamiento en el solar leonés de la Legio VII Gemina.

Con todo ello, hemos de finalizar incidiendo en que la metodología empleada se encuentra en aras del planteamiento de base que preside este estudio: el análisis de un sector importante -las áreas de vertidos- en el espacio arqueológico extramuros del campamento de la Legio VII Gemina, que conforma parte de las cannabae legionarias, y se supedita a nuestro objetivo principal, basado en obtener cronologías lo más exactas posible y una visión vertebradora del asentamiento a través del estudio del material cerámico de los diferentes contextos analizados en este espacio.

59 Aun así, en el estudio de estas producciones se plantean dificultades desde el punto de vista de la atribución de talleres y áreas de dispersión, además de la aparición de nuevos tipos o el complejo fenómeno de las imitaciones, todo lo cual hace necesario en muchas ocasiones el recurso a los análisis arqueométricos. 
III. CONTEXTO ARQUEOLÓGICO 
En este capítulo abordamos de forma pormenorizada el contexto arqueológico particular de cada uno de los tres vertederos que estudiamos, una vez ubicados en el contexto general del espacio extramuros del campamento de la Legio VII Gemina.

A ello añadiremos los resultados que ha deparado el análisis de otro importante vertedero, objeto de estudio por nuestra parte comenzado en el año 1997 (Fernández Freile, 2003), que viene a constituir en gran manera el referente fundamental para el presente trabajo de investigación en sus aspectos generales, pues cada área de vertidos presenta sus rasgos específicos. Con todo, en el estudio arqueológico de estos contextos se ponen de manifiesto una serie de factores comunes, como son: la incidencia en la topografía urbana, la importante y variada información derivada del estudio de los diferentes tipos de materiales -muy especialmente de la cerámica como material guía- para reconstruir numerosos aspectos de los modos de vida romanos, en este caso los propios de un hábitat militar, y la obtención de datos cronológicos en buena medida concluyentes.

En la descripción de cada uno de los tres vertederos prestamos especial atención a las secuencias cronoestratigráficas de las que partimos, en primer lugar, para delimitar los niveles pertenecientes a la Legio VII en aquellos contextos que abarcan las dos etapas de ocupación del campamento (el depósito de San Pedro y el vertedero de la $\mathrm{C}$ /Pilotos Regueral), y como base esencial para el estudio de materiales, teniendo siempre en cuenta la tipología del vertedero.

Así, si se trata de vertederos sellados, en los que no han intervenido factores externos que alteren la estratigrafía, su estudio responde a unas pautas generales que garantizan más calidad de información. Si por el contrario el área de vertidos ha sido objeto de acciones antrópicas como remociones, vertidos irregulares en espacio y tiempo, etc., su interpretación estratigráfica resulta más compleja, dificultando la adscripción e interpretación de los materiales.

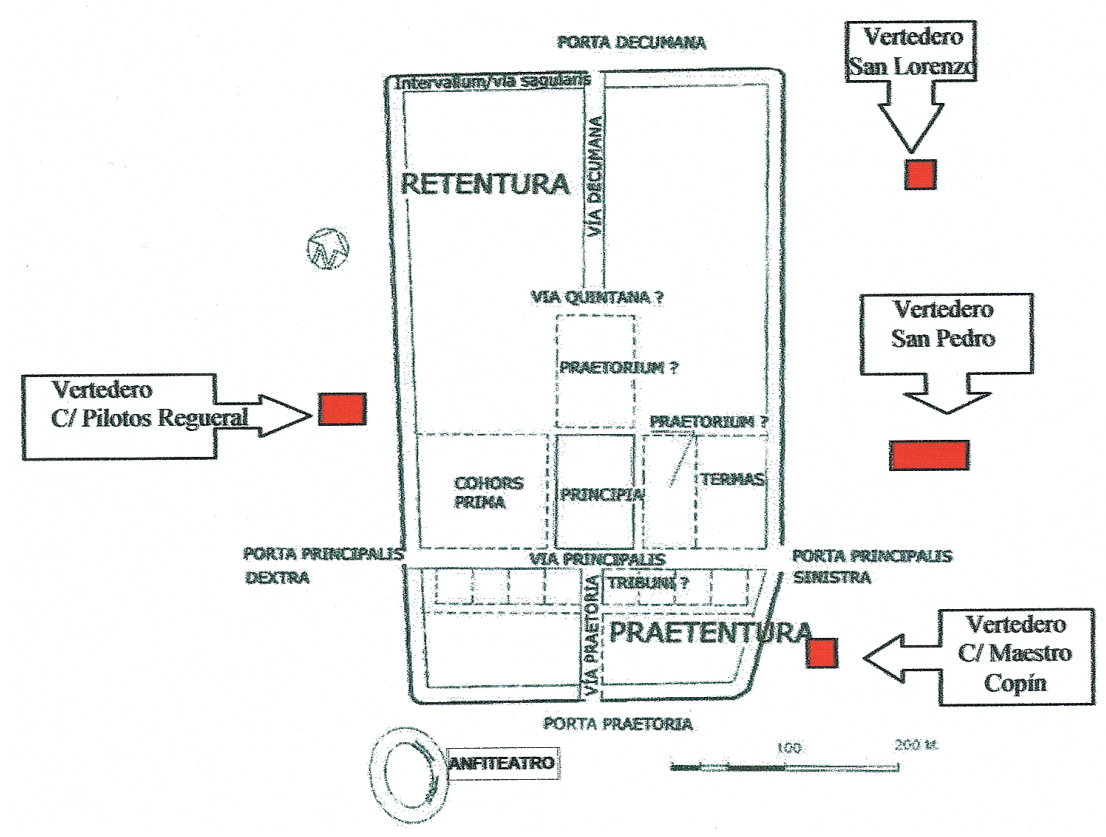

FIG. 7: Vertederos localizados en Legio

(Elaboración propia sobre plano general de V. García Marcos) 
Con todo, el análisis de los vertederos, no se limita únicamente a su papel como contenedores de diversos materiales, sino que en su estudio también debe prestarse especial atención a otros factores determinantes, como su morfología y configuración, etapas de uso, carácter sistemático o eventual, y demás aspectos que configuran una variada tipología en este tipo de yacimientos.

En primer lugar, constituyen contextos de gran valor arqueológico que inciden decisivamente en la topografía urbana, y cuyas distintas características (etapas de formación, configuración, criterios de ubicación, cronología, períodos de amortización,...) resultan fundamentales para determinar los mecanismos de eliminación de los residuos sólidos en un núcleo urbano. En este aspecto hemos de tener siempre en consideración la peculiaridad de Legio como asentamiento militar desde su fundación, con las implicaciones que ello puede conllevar en este aspecto tan determinante para la vida urbana, y las posibles diferencias que puedan existir respecto a esta gestión en los núcleos civiles.

Con este estudio continuamos la línea de investigación sobre la gestión de los residuos sólidos en Legio, que cuenta con importantes testimonios arqueológicos, a diferencia de la eliminación de residuos líquidos, con escasas y muy parciales evidencias arqueológicas (restos de canalizaciones y tramos de cloacas abovedadas de escasa altura y construcción muy sencilla). En este sentido, contrasta con otras ciudades como la próxima Asturica Augusta, en las que el sistema de saneamiento, integrado por una red de cloacas de considerables dimensiones y gran calidad en la construcción, además de su buen estado de conservación, constituye un resto arqueológico de primer orden en el trazado de la ciudad.

Igualmente, contamos en Astorga con un extenso y riquísimo vertedero denominado "Las Lolas", que ha deparado una ingente cantidad y variedad de restos, objeto de un proyecto de investigación interdisciplinar para el estudio de los diferentes materiales, cuyos resultados han sido ya publicados en su mayor parte (Amaré Tafalla, M.T. (dir.): Arqueología Leonesa I. Astorga I, II, III, IV).

Aún así, el citado vertedero adolece de una carencia de registro estratigráfico y de las condiciones adecuadas para la realización de una excavación científica, ya que ha sido objeto durante años de búsqueda de materiales, en su mayor parte para engrosar colecciones privadas, de manera que la excepcional riqueza de los materiales estudiados procedentes de este contexto, únicamente nos permiten conocer aspectos importantes de la vida en la capital asturicense y los tenemos en consideración a la hora de establecer paralelos y relaciones entre diferentes producciones peninsulares, sin embargo hemos de contar siempre con la ausencia de una secuencia cronoestratigráfica que pudiera contextualizar dichos materiales en sus niveles de aparición, y aportar datos singularmente importantes, dada la ubicación del vertedero, extramuros y cercano al recinto fortificado.

Por el contrario, en Legio se han hallado varios vertederos, cuyo análisis, tanto de su morfología como de su contenido, nos ha proporcionado datos de inestimable valor sobre diferentes aspectos de la vida urbana y su organización socioeconómica, con la peculiaridad que conlleva un asentamiento militar, haciendo de estos yacimientos, resultado de la gestión de la eliminación de los residuos sólidos, una fuente arqueológica de especial riqueza informativa.

Su espacio de ubicación es siempre extramuros, al igual que las necrópolis y deter- 
minadas industrias insalubres para la vida urbana como los hornos para la fabricación de material latericio, tal como se especifica en la Lex Ursonensis LXXVII ${ }^{60}$. Al respecto hemos de puntualizar que en el caso del campamento de la Legio VII los vertederos se encuentran muy próximos a la muralla61, mientras que las necrópolis halladas, de época tardorromana, se sitúan a una considerable distancia del recinto amurallado (vid. Fig. 7). En la zona sur del campamento se ha localizado un taller dedicado a la actividad metalúrgica, ubicado también extramuros, éste perteneciente a la época de la Legio VI Victrix, mientras que otras fabricae de armamento y equipo militar de la etapa de la Legio VII Gemina se ubican, aunque muy cercanos a la muralla y a la puerta praetoria, en el interior del recinto campamental (Campomanes, 1999, 269-279; Aurrecochea, 2006: 309-334), quizá porque esta actividad de elaboración final no provocaría excesivas molestias para el desarrollo de la vida castrense, o bien porque estas fabricae están plenamente integradas dentro del plano campamental, como el resto de edificios (termas, principia, contubernia,...).

Por otra parte, además de la cercanía al perímetro fortificado, hemos de hacer notar la ubicación de estas áreas de vertidos en las inmediaciones de dos de las cuatro puertas del mismo (porta principalis dextra y porta principalis sinistra), donde desembocan las principales vías del campamento, sin duda para facilitar el transporte de los desechos.

Son muy escasos hasta el momento los estudios de vertederos en enclaves militares, de manera que carecemos de referencias específicas para establecer paralelos y cotejar los aspectos relativos a estas zonas de vertidos en contextos castrenses.

En Hispania, únicamente en estudios sobre el yacimiento de Herrera de Pisuerga, asentamiento de la Legio IIII Macedonica a principios del siglo I d. C. y posteriormente de otros cuerpos militares, se describen cinco zonas de vertederos, que según uno de sus principales investigadores, "delimitan el asentamiento y en algunos casos colimitan estructuras defensivas" (Pérez González, 1998: 553-555). Los vertederos, diferentes en extensión, potencia y cronología -aunque todos se documentan en época temprana (siglo I a. C. y siglo I d. C.)- se diferencian también en cuanto a su tipología, pues algunos no tienen uso posterior y otros sirven como aterrazamiento para asentar nuevas estructuras. Situados muy próximos al emplazamiento castrense, presentan un rasgo unificador en su contenido, integrado fundamentalmente por residuos de carácter

60 En el texto de la Lex Ursonensis, 76, 25, además de situar los talleres de fabricación de este material a una distancia determinada del campamento, se limita la autorización a los establecimientos inferiores a 300 tegulae, aspecto que según los diferentes investigadores se interpreta de distinta forma. Así, según LE ROUX (1999: 119), la producción de 300 tejas diarias resulta un tanto excesiva, mientras que D'ORS, establece la comparación con la Lex Tarentina para proponer la solución de una superficie del tejado de $75 \mathrm{~m}^{2}$. Este último aspecto es tratado de forma específica en el trabajo de V.G. TSIOLIS (1997): "Las restricciones de la producción tegularia de la Lex Ursonensis", Studia Historica. Historia Antigua 15, pp. 119-136, aclarando estas restricciones y las condiciones de producción de este material latericio.

61 En este aspecto existen diferencias en la cercanía de los vertederos urbanos al perímetro fortificado, si bien resultan en conjunto excepcionales casos como un potente vertedero en Baelo Claudia, cuyos niveles se encuentran en su totalidad adosados al encintado murarlo (Bernal et alii, 2011: 78). 
artesanal, pudiendo identificarse los desechos de talleres de fabricación de una amplia variedad de materiales como distintos tipos de cerámica, vidrio, elementos metálicos, óseos, textiles y demás ${ }^{62}$.

Más recientemente, en este mismo yacimiento de Herrera de Pisuerga se localizó otro importante vertedero (Illarregui y Sarabia, 2008: 119), con varias fases de relleno, que colmataría una gran estructura previamente excavada, probablemente un foso, y cuya formación se produciría en un breve periodo de tiempo, a juzgar por la cronología de los materiales arqueológicos exhumados, fundamentalmente cerámica de las distintas especies, que permite datar el vertedero en fechas anteriores a mediados del siglo I d.C. Este área de vertidos es interpretada como parte del proceso de amortización de un foso del antiguo campamento de la Legio IIII Macedonica, a la llegada del nuevo contingente militar, el Ala Parthorum, que ocuparía parte del anterior recinto.

Con todo ello, en el asentamiento militar herrerense, la excavación y el estudio de los diversos vertederos hallados, que constituirían en su mayor parte áreas de eliminación de residuos "industriales" o "artesanales"63, ha permitido documentar una intensa actividad productiva por parte de los cuerpos militares que lo ocuparon, en especial la Legio IIII Macedonica. Así, se han documentado en el yacimiento numerosas e importantes fabricae militares dedicadas a la elaboración de los más variados productos, necesarios para el abastecimiento del importante contingente de soldados allí acantonado.

A lo largo de las excavaciones realizadas en los últimos años en este complejo yacimiento, además de los estudios ya existentes sobre importantes producciones cerámicas, como la terra sigillata (Pérez González, 1989), las lucernas (Morillo, 1992; 1993), así como otros vasos de época julio-claudia (Pérez González e Illarregui, 1995: 415-430), se han ido localizando, a partir principalmente de los testares, otras importantes producciones de cerámicas locales, como las de cerámica común y mortaria, así como las de paredes finas (Reinoso del Río, 2002: 369-380).

Al mismo tiempo, además del material cerámico, aparecieron otros establecimientos artesanales de cierta envergadura, como los dedicados a la fabricación de útiles óseos (Pérez González e llarregui, 1994: 259-267; 1995: 90-10; Matía Merino, 1999: 5364) y a la producción de objetos de vidrio (Marcos Herrán, 2002; 2006: 455-465), cuyo descubrimiento y estudio se basa en uno de los más importantes vertederos del asentamiento, destacando también testimonios relativamente bien conservados de trabajo en madera, cuero o industria textil.

Como es de esperar en un asentamiento castrense con este nivel de producción local, no podía faltar una importante industria metalúrgica, centrada sobre todo en la

62 Así, en palabras del citado investigador "los basureros de los campamentos suelen ser una buena fuente de información y el estudio de los restos en ellos depositados nos suelen proporcionar numerosas sorpresas" (Id. 2001: 22).

63 Aún así, también la presencia en uno de los vertederos de mayor riqueza material y más claro carácter militar, de restos faunísticos (cornamentas de ciervo, colmillos de jabalí, ostras, caracoles marinos...), nos acercan someramente, según PÉREZ GONZÁLEZ, al tipo de alimentación de algunos militares. De la misma manera, los restos de pintura mural, y otros elementos de construcción, fundamentalmente latericios, nos aportarían datos sobre su hábitat residencial (1996: 554). 
elaboración de objetos de equipamiento militar de hierro, cobre y bronce, y que persiste durante los asentamientos de los diferentes cuerpos militares que ocupan el solar herrerense (Fernández Ibáñez, 2002: 381-394).

Además de las publicaciones aisladas sobre estas producciones, cobra una especial relevancia la exposición de un panorama de conjunto de las diferentes producciones militares en el campamento de la Legio IIII Macedonica en Herrera de Pisuerga (Pérez González e Illarregui, 2006: 111-133; 2006 b: 234-262), que ponen de manifiesto la necesidad de autoabastecimiento en los campamentos militares en los primeros tiempos de su asentamiento en Hispania, antes de la estructuración de la red viaria y el establecimiento de rutas comerciales para el intercambio de los diversos productos, que reducirán notablemente, ya a partir de la primera mitad del siglo I d. C. las manufacturas militares "in situ" en los campamentos. A partir de estos momentos se hará habitual el aprovisionamiento de todo tipo de productos importados en los recintos castrenses, quedando únicamente algunos talleres de fabricación de elementos específicamente militares, como pueden ser determinadas industrias metalúrgicas, como es el caso de la Legio VII Gemina en su asentamiento en León.

Un paralelo más próximo en cuanto a la cronología y función de estos espacios, resulta el vertedero hallado extramuros del campamento galaico de Cidadela (Caamaño y Fernández Rodríguez, 2002: 223), asentamiento desde principios del siglo II d. C. de la Cohors I Celtiberorum, una de las unidades auxiliares de la Legio VII Gemina.

Esta zona de deposición de vertidos se localiza frente a la porta principalis sinistra del recinto, en el punto donde se interrumpe el foso documentado en el resto del perímetro fortificado. Según los investigadores citados, en la ubicación de este vertedero se habría tenido en cuenta la dirección de los vientos dominantes en esta zona (Norte y Suroeste), un factor importante en estos contextos, que se une a otros condicionantes topográficos, evidenciando la rigurosa labor de planificación en la situación de estos espacios en las áreas periurbanas de los núcleos de hábitat.

En lo que respecta a su contenido, presenta una gran afinidad con los vertederos legionenses, por cuanto los materiales hallados -principalmente cerámicas (terra sigillata hispánica y producciones comunes), tégulas, objeto de vidrio y metales- lo incluyen, al igual que en Legio, en la categoría de vertederos mixtos, receptáculos de los residuos de las actividades cotidianas llevadas a cabo en un núcleo urbano y vinculados también en este caso a la actividad militar.

A partir de los estudios sobre el conjunto de la terra sigillata del campamento, compuesto por más de 700 ejemplares, especialmente de TSH que supone el $91 \%$ del total, se ha determinado que un porcentaje importante de esta especie cerámica procede del área de deposición de vertidos (López Pérez, 2006: 432). De hecho, algunas de las piezas aquí localizadas indican, por su cronología, que habrían tenido un largo período de uso hasta que fueron desechadas. Un rasgo común que define a los recipientes procedentes del vertedero es un menor índice de fragmentación y mejor estado de conservación, todo lo cual indicaría el carácter de vertedero sistemático que no ha sufrido alteraciones importantes a lo largo del tiempo y por tanto, con una secuencia estratigráfica regular, propia de estas áreas deposicionales, que ofrece óptimas posibilidades para el estudio completo del conjunto de materiales hallados con vistas a la reconstrucción de la cultura material y los hábitos de consumo propios de un establecimiento militar del noroeste hispánico en los confines del Imperio. 
Así, desde el punto de vista de la investigación arqueológica, al igual que en Legio, se asiste a una valoración progresiva de la importancia de los vertederos en sus distintos tipos -en el caso de Herrera de Pisuerga de carácter más artesanal o industrial- para la identificación de posibles producciones locales o redes de abastecimiento de manufacturas importadas, y documentar sus rasgos específicos, dentro del contexto relativamente uniforme del utillaje de los asentamientos militares romanos en provincias.

Con todo, estos dos ejemplos constituirían, hasta el momento, los únicos paralelos para el campamento de Legio en la Península Ibérica en cuanto a la disposición y la relevancia de los vertederos en un contexto militar, ya que en los recientes estudios más exhaustivos sobre eliminación de residuos en las ciudades hispanas (Remolà y Acero (eds.), 2011) se tratan esencialmente núcleos civiles, al igual que sucede con las principales ciudades galorromanas (Ballet; Cordier; Dieudonné, 2003).

Por lo que respecta a otras zonas del Imperio, es de destacar el conocido "Schuttügel" del campamento de Vindonissa en Germania Superior. Esta zona de deposición de vertidos, excavada en parte a mediados del pasado siglo, se sitúa en las inmediaciones de la puerta norte, próximo al recinto amurallado, en una zona de topografía escarpada, sobre la pendiente que forma el curso del río Aare (Martin Kilcher, 2003: 235, Fig.5). Según esta investigadora, dada la percepción de un aumento de las dimensiones y la potencia de la acumulación de residuos en dirección Este a Oeste, el vertedero sería utilizado durante un largo período de tiempo. Este aspecto se explicaría, teniendo en cuenta la ocupación ininterrumpida del recinto campamental por tres legiones -Legio XIII Gemina, Legio XXI Rapax y Legio XI Claudia Pia Fidelisdesde el año 15 a. C. hasta el 101 d. C. Ello condicionó además el desarrollo de importantes núcleos civiles -cannabae y vicus- y la construcción de varias estructuras en una amplia zona extramuros. Desde esta perspectiva, se hace hincapié en la necesidad de realizar nuevas intervenciones en el vertedero, dado el enorme potencial que encierra respecto a su contenido material, sin embargo en recientes publicaciones sobre excavaciones en este asentamiento (Trumm, 2009) se describen los resultados de las intervenciones en estructuras importantes intramuros y extramuros, mencionando únicamente la presencia del vertedero y su escarpada topografía. Con todo ello, los únicos estudios sobre materiales extraídos del vertedero son los realizados sobre material cerámico por Ettlinger en 1951 y por Ettlinger y Simonett en 1952, en los que se documentan las principales producciones legionarias (terra sigillata, cerámica de paredes finas, recipientes comunes y peculiares vasos rituales), con importantes comparaciones sobre la cerámica de campamentos de otras provincias como Moesia en que estuvieron acantonadas alguna de las tres legiones que ocuparon Vindonissa, constituyendo así las únicas referencias bibliográficas sobre este importante vertedero que precisaría una puesta al día de su estudio en todos los aspectos, partiendo de la metodología actual utilizada en el análisis de este tipo de contextos.

Exceptuando este singular yacimiento, no hemos hallado establecimientos castrenses en otras provincias con vertederos de semejante potencia arqueológica, quizá porque la investigación se ha centrado especialmente en las estructuras arquitectónicas y la distribución urbanística de los campamentos, relegando a un segundo plano la atención a las áreas de vertidos, o bien por el hecho de no haber sido éstas localizadas o identificadas con claridad, dada su ubicación extramuros de los recintos fortificados. 
En esta panorámica, hemos de señalar una aportación relevante con la reciente publicación sobre la vida de los soldados romanos en los establecimientos militares en Britannia (Giles, 2012) en la que, desde los presupuestos metodológicos de la Arqueología Procesual, se realiza un análisis de numerosos asentamientos castrenses, prestando especial atención a su distribución espacial y diferenciando la estructura y función de las distintas áreas y edificaciones de los recintos, en base a la evolución cronológica y a las características de la cultura material procedente de las excavaciones en los mismos. A partir de esta información se establecen diferentes patrones y "grupos funcionales" sobre el conjunto de actividades desarrolladas en estos ámbitos. En este contexto, se aborda la cuestión de la deposición de basuras (op. cit.: 52-53) en áreas específicas de similar tipología -fosos o zanjas- en las inmediaciones de los campamentos, diferenciando también depósitos primarios y secundarios, y valorando la importancia que para la investigación arqueológica de la organización y el modo de vida militar representa el análisis del contenido artefactual de los vertederos.

Un caso aislado y peculiar en el ámbito de los vertederos de asentamientos militares es el sitio arqueológico de Cantegrel en Eysses (Villeneuve-sur-Lot), la antigua Excisum, en el área suroeste de la Gallia, que constituyó un importante punto de confluencia de vías de comunicación. En este yacimiento (Chabrié; Daynès; Garnier (eds.), 2010) las últimas excavaciones han deparado la aparición de un número inusitado de pozos (99), con función de basureros o depósitos de determinados materiales, así como un amplio vertedero bien diferenciado de éstos en su estructura y ubicación, en el que se ha localizado un rico y variado conjunto de materiales arqueológicos. Es precisamente la presencia de numerosos objetos de claro uso militar en estas áreas de vertidos, lo que ha dado lugar a la consideración del establecimiento en este lugar de un posible campamento militar -aspecto aún sometido a debate-, que, en función del espacio ocupado, habría albergado a un ala de caballería.

La zona de ubicación de este yacimiento, de carácter periódicamente inundable, hizo necesaria en la actualidad la construcción de una cuenca de retención de aguas pluviales y canales de eliminación, así como un área de aterrazamiento. En este proceso se localizaron los pozos, mientras que el vertedero fue hallado en el extremo opuesto a la zona aterrazada.

Muy cercano a este espacio se encuentra el emplazamiento de la aglomeración civil galorromana, de época augustea y que puede identificarse con un vicus a partir del reinado de Tiberio, cuando tiene lugar el desarrollo de un importante programa edilicio que se completará con los Flavios. Destacan en esta zona de poblamiento, la presencia de un edificio público de grandes dimensiones y carácter monumental, unas termas, los horrea, el área de viviendas ya construidas según los modelos romanos, un importante barrio artesanal y una necrópolis en la que abundan las inscripciones militares.

En cuanto a las estructuras de recepción de vertidos, es de destacar la importante diferencia entre la tipología y el contenido de los pozos y del vertedero. En los primeros, de notable profundidad, se documenta un numeroso conjunto de restos faunísticos, mientras que el material cerámico presenta una escasa representación, a excepción de las ánforas de muy diferentes tipos, que componen un amplio elenco, permitiendo todo ello aportar una cronología de finales del siglo I d. C. Respecto a la interpretación del uso de estos pozos ha surgido una controversia entre la consideración de su carácter meramente funcional (utilizados como basureros para rellenar pozos de extracción 
de agua o de determinados materiales y ya en desuso) ${ }^{64}$ y su posible función ritual (funeraria o cultual). En este aspecto, como tratamos infra, a algunos vertederos con características similares, localizados también en algunas ciudades de Hispania, pero en ningún caso en entornos militares, se les ha atribuido una función relacionada con determinadas prácticas religiosas o rituales.

Como hemos señalado, en un área próxima al conjunto de pozos se localiza un vertedero en extensión, con escasa profundidad y una clara disposición estratigráfica, cuya excavación proporcionó un numeroso y variado conjunto de materiales arqueológicos: material constructivo, cerámica de las diferentes especies (terra sigillata, cerámica de paredes finas, cerámica común, lucernas, ánforas, terracotas), vidrio, objetos de hueso trabajado, restos de actividades artesanales -principalmente metalurgia-, numismática, restos faunísticos, y elementos metálicos, entre los que destaca un importante conjunto de objetos de indudable carácter militar. Son precisamente las abundantes piezas de armamento ofensivo, defensivo y de caballería, en todo comparables, según sus investigadores, a los hallados en campamentos británicos, del limes germánico o gálicos como Aulnay-de-Saintonge o Mirebeau (op. cit.: 201), los que permiten la denominación de "vertedero militar" (ibid.: 47-48, Figs. 38-39) y plantean la probable existencia de un asentamiento militar en este lugar, ocupado por una guarnición permanente o eventual, pero cuyos límites y extensión no han sido aún localizados.

La cronología de este asentamiento vendría dada por este conjunto de militaria, a principios de época flavia, coincidiendo plenamente con la datación del resto de materiales hallados.

Como ubicación hipotética de este campamento se ha propuesto la zona oeste del vicus, ocupando el vertedero un área próxima al ángulo superior derecho de lo que sería el recinto militar (Ibid.: 21, Figs. 19-20).

Así, el caso de Eysses-Excisum, constituye un claro ejemplo del importante papel que desempeñan los vertederos en los yacimientos arqueológicos, no únicamente como contenedores de materiales que proporcionan importante información en aquellos asentamientos cuyo carácter se encuentra claramente definido, sino también como indicadores de la presencia de determinados tipos de hábitat en su entorno (civil, militar, artesanal...), difícilmente identificables en muchos casos por otros medios.

Es así como se ha llegado a establecer, con muchas probabilidades, la presencia militar en este asentamiento galo, que vendría a suponer una similitud importante con Legio en cuanto a la estructura y contenido de su vertedero "militar".

A partir de esta casuística, podemos deducir en principio, que la gestión de residuos sólidos no presenta diferencias significativas -a excepción de parte del contenido específico de los vertederos- en los asentamientos militares respecto a las demás urbes, siguiendo, como demuestran los testimonios arqueológicos, pautas similares en cuanto a ubicación y relación con los núcleos habitados.

64 Un caso similar, pero con un número mucho más reducido de pozos, podemos hallar en las inmediaciones del campamento germánico de Saalburg, tras cuyo uso primario son también reutilizados como vertederos, con la peculiaridad de facilitar, también por las características del terreno, la conservación de objetos realizados en materiales perecederos como madera o cuero (VV.AA.,1993: 12). 
Así, en la mayoría de las ciudades, al igual que ocurre en Legio, existe una estrecha relación de los vertederos con la dinámica de la topografía urbana, que experimenta modificaciones sustanciales a través de estas áreas de vertidos.

En el contexto legionense, los tres vertederos aquí estudiados, contando también con el analizado previamente que nos ha servido de referencia, presentan al respecto una diferente tipología, con distinto nivel de incidencia sobre el entorno topográfico del recinto campamental.

Por una parte, los vertederos de San Pedro y San Lorenzo constituirían lo que F. Tarrats denomina "vertederos de segundo uso" (2000: 131), cuya creación responde a una actuación derivada de un proceso -más o menos circunstancial- de renovación urbanística o arquitectónica en unos espacios urbanos concretos. Así, el vertedero de San Pedro representaría un vertedero secundario respecto al depósito en que se encuentra, al igual que el de San Lorenzo, localizado en el interior del conjunto termal, ocupando en ambos casos estructuras o edificios abandonados o en proceso de abandono (Remolà, 2000: 112).

En cuanto a los otros dos vertederos, su génesis sí comporta modificaciones e intervenciones más o menos determinantes en la dinámica de la configuración geológica y topográfica de estos espacios extramuros.

De esta manera, el vertedero de la C/Maestro Copín contribuiría a la regularización del terreno en un espacio con un acusado desnivel preexistente, probablemente de origen natural. Así, esta zona de vertidos, de considerables dimensiones, actuaría como factor regulador en la topografía de esta zona, con un período de formación además relativamente breve, -en el comedio del siglo II d. C.-, pudiendo interpretarse esta rápida creación del vertedero como una necesidad de homogeneizar la configuración del terreno, con diversos fines, como la realización de actividades constructivas posteriores o únicamente llevar a cabo la progresiva uniformización del espacio que circunda el campamento.

En el caso del vertedero de la C/Pilotos Regueral, resulta evidente su papel como agente de transformación de la especial estructura geológica de esta zona en el lado occidental del perímetro fortificado, dado que se trata de un terreno inundable, con una red de antiguos cauces y una constante anegación, con la consecuente inestabilidad e insalubridad 65 . De esta manera, los vertidos, iniciados ya en una época muy temprana, en los primeros momentos de asentamiento de la Legio VI Victrix y continuando durante la segunda ocupación del campamento, tendrían la función, como niveles de relleno, de desecar y sanear este espacio, en el que, a juzgar por los resultados de excavaciones en solares colindantes (García Marcos 1997: 305-306), en los que se han documentado secuencias estratigráficas coincidentes, con las mismas fases cronológicas, desempeñarían este mismo papel de uniformización del terreno. El único factor diferencial es que en estos dos últimos contextos han aparecido restos de estructuras constructivas, de funcionalidad aún indeterminada, pero que indican niveles de ocupación en esta zona próxima al recinto amurallado.

65 Un caso similar presenta la ubicación de un vertedero de época altoimperial en la ciudad de Pompaelo (MEZQUÍRIZ, 1997-98: 51), donde existió una zona insalubre producida por una depresión geológica rellena de lodos de gran profundidad y que los habitantes de este núcleo urbano solventaron con su utilización como vertedero. 
Con todo ello queda patente la decisiva influencia de los vertederos en la dinámica de la topografía urbana, implicando procesos de transformación que modifican, en ocasiones radicalmente, el entorno geomorfológico, especialmente en las áreas suburbanas, donde tienen su ubicación estas áreas de vertidos.

Además de esta función reguladora del paisaje urbano, y siguiendo con el papel de los vertederos como contenedores, hemos de hacer referencia a otros aspectos en la investigación de los vertederos en los que han incidido algunos investigadores como Arce (2000: XI) o Carandini (2000: 1-2) que consideran no sólo las cuestiones materiales, sino también los aspectos rituales o espirituales en la eliminación de residuos en determinados lugares sacros o espacios muy señalados, ligados a la religión y las creencias, generalmente relacionadas con espíritus malignos y con el mundo funerario, ya que las necrópolis compartían con las áreas de vertidos su ubicación en los espacios periurbanos.

En el ámbito hispano, estos aspectos rituales se han tenido en consideración en la interpretación de determinados vertidos en pozos en ciudades como Valentia, donde estos depósitos de lo que serían residuos sacros, se han vinculado a los ritos y ceremonias fundacionales de la ciudad (Ribera y Romaní, 2011: 315-319).

Sin embargo, estas cuestiones presentan, en contextos arqueológicos aislados, una considerable dificultad para este tipo de interpretaciones, que únicamente pueden esbozarse a raíz de la comparación con yacimientos en otros núcleos de hábitat en que resultan en mayor medida comprobables estas funciones de carácter ritual o cultual.

Una vez expuestos algunos de los aspectos generales que afectan a los yacimientos considerados como vertederos y que contribuyen a explicar muchas de sus características, pasaremos a describir pormenorizadamente cada uno de los tres contextos de procedencia del material cerámico en que se basa el presente estudio.

Igualmente trataremos en último lugar las características y materiales del vertedero estudiado por nosotros en primer lugar en otro trabajo de investigación y que nos ha servido para continuar en Legio con esta línea de investigación, ya implantada plenamente en la arqueología hispánica en los últimos años.

Los dos primeros contextos que expondremos en primer lugar, la construcción singular de opus caementicium, en el barrio de San Pedro y el pequeño complejo termal, en el barrio de San Lorenzo, se hallan vinculados por el hecho de que su excavación fue efectuada de forma conjunta, dada la proximidad de su ubicación y el carácter de urgencia de la intervención, en el año 1993, con motivo de las obras de urbanización en el denominado "Polígono de La Palomera", al noreste del área extramuros del recinto campamental y en la actualidad Calle Ramón Cañas del Río. En este proceso de excavación se pusieron pues, al descubierto dos contextos arqueológicos muy diferentes en todos los aspectos, aunque muy próximos en el ámbito espacial.

Estas intervenciones fueron realizadas por los arqueólogos D. J. M. Vidal Encinas y D. G. J. Marcos Contreras, de manera que la información de que disponemos procede fundamentalmente del informe técnico ("Excavaciones en el Polígono de "La Palomera", Junta de Castilla y León, León, 2002) y de una publicación que viene a constituir un resumen, a la vez que contiene algunas interesantes aportaciones sobre 
dichos trabajos (Vidal Encinas y Marcos Contreras, 2002-2003), además de la primera mención del descubrimiento y trabajos de excavación (Vidal, 1996: 313-314).

Dado que en el presente trabajo de investigación hemos incidido en la individualidad y diferenciación de los tres contextos arqueológicos tratados, y máxime cuando en este caso se trata de construcciones y elementos arqueológicos de cronología claramente diferenciada, trataremos de forma concreta cada uno de ellos, en función de las conclusiones que pueda arrojar el estudio de los materiales cerámicos procedentes de cada estructura constructiva.

\section{1) CONSTRUCCIÓN SINGULAR DE OPUS CAEMENTICIUM SITUADA EN EL POLÍGONO DE LA PALOMERA: DEPÓSITO-VERTEDERO DE “SAN PEDRO”}

Esta construcción, a modo de depósito, se encontraba situada en un solar cercano al polígono a urbanizar y ubicada en el plano romano de Legio en las proximidades de la porta principalis sinistra, en el espacio próximo al lienzo de poniente del perímetro amurallado (Vid. Fig. 7).

La singularidad de este contexto no reside únicamente en las peculiaridades de su fábrica constructiva, sino también en su cronología, ya que se trata de un elemento arquitectónico anterior al asentamiento de la Legio VII Gemina, y por tanto perteneciente a una de las dos fases del establecimiento precedente de la Legio VI Victrix. Con todo, es objeto de nuestro estudio tanto por su situación extramuros -que hubo de tener en las distintas fases campamentales, ya que los asentamientos se superponen de forma prácticamente exacta- como por el proceso de amortización que experimentó ya en fases tempranas, convirtiéndose en un vertedero con una fase de colmatación ya en época flavia, conteniendo un numeroso conjunto de materiales correspondientes a la Legio VII Gemina.

En cuanto a su estructura, se trata de una construcción de planta rectangular realizada en opus caementicium con una dimensiones exteriores de 13,40 metros y de 12,10 metros interiores, equivaliendo -según hacen constar en las publicaciones antedichas los autores de la excavación- a un módulo de 40 pies romanos para el interior y 2 pies romanos para la anchura del muro.

Otro aspecto importante fue el descubrimiento de dos soleras de argamasa, de unos 10 centímetros de espesor, apuntándose la posibilidad de que la segunda correspondiese a una reparación de la primera, si bien la cuestión más relevante al respecto es el hecho de que ambas carecían de cualquier indicio de mortero hidráulico, sin que se hayan encontrado en toda la construcción huellas de la utilización de opus signinum, elemento impermeabilizante tanto en suelos como en revestimiento de muros, muy característico de la arquitectura romana, y que en este caso no presenta ninguna evidencia, no tanto por su posible pérdida o falta de conservación, sino, -como señalan claramente los arqueólogos responsables- porque se han consignado pruebas fehacientes de que en ningún momento fue empleado en su construcción. 


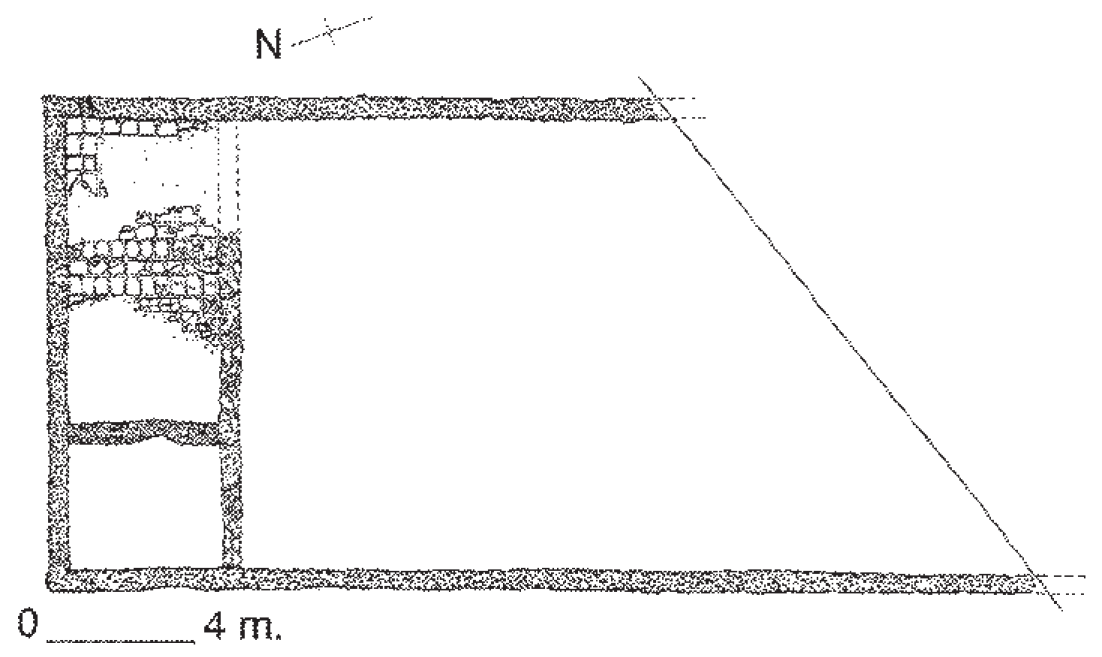

FIG. 8: Planta del depósito (según Vidal y Marcos Contreras)

Durante la intervención, efectuada con carácter de urgencia, como ya hemos señalado, y dadas las dificultades que planteó el proceso de urbanización en curso, la estructura no pudo ser exhumada en su totalidad, completándose la excavación dos años después, en 1995, por parte de D. V. García Marcos (Polígono de la Palomera, Parcela 27.1). Sobre los resultados de estos trabajos carecíamos de la información de los materiales recuperados, existiendo únicamente una noticia de la realización de los mismos en una relación de intervenciones arqueológicas municipales (García Marcos, 1997: 310). Recientemente esta intervención ha sido objeto de estudio en una reciente publicación (Morillo y Martín, 2013), en la que se documentan, en un estrato homogéneo, una importante diversidad de materiales cerámicos (terra sigillata, cerámica de paredes finas, cerámica común, ánforas y algunas lucernas). Destaca especialmente el conjunto de terra sigillata sudgálica, que proporciona una cronología que comprende, según los autores, desde los años 40 al 70 d. C. al igual que algunos ejemplares de TSH "precoz", algunos con marcas ilegibles, a los que se asigna una datación de mediados del siglo I (40-60/65 d. C.), llegándose a plantear una producción local de estas piezas en Legio, en la época del campamento de la Legio VI Victrix en que se data todo el conjunto.

Sobre otras cuestiones planteadas en este trabajo que se relacionan de forma confusa con otras áreas de vertidos objeto de nuestra investigación y de cronología más avanzada (Fernández Freile, 2001; 2003), no entraremos aquí en valoraciones, dada la distorsionada exposición de determinados resultados de esta investigación, que pueden inducir a errores importantes, ya que no se diferencian claramente ambos contextos, poniendo en entredicho tanto algunas características del vertedero como de los resultados del estudio de materiales, realizados mediante la aplicación de la metodología arqueológica pertinente y aprobados por un tribunal experto en su momento (2000), y posteriormente confirmados en función de los análisis arqueométricos efectuados.

Hemos de hacer constar que tanto en el informe de excavación de que disponemos, como en la publicación subsiguiente, los arqueólogos que efectuaron los primeros trabajos exponen una completísima y detallada descripción del proceso constructivo de esta estructura (sistemas de encofrado, cimentación y nivelación, cualidades de los materia- 
les, elementos de drenaje, etc...), aportando además hipótesis y reconstrucciones axonométricas que revelan un trabajo concienzudo y excelentemente documentado sobre determinados aspectos de la construcción romana, sobre todo teniendo en cuenta los problemas que esta estructura plantea desde el punto de vista de su funcionalidad. Así, aunque todo ello resulta de gran interés para nuestra investigación, no incidiremos en exceso aquí en este punto, por centrarse nuestro trabajo esencialmente en el estudio de los materiales cerámicos hallados, hecho para el que contamos con una base de datos efectuada al efecto, partiendo de los datos de las fichas del informe de excavación y consignando su ubicación en las correspondientes secciones estratigráficas.

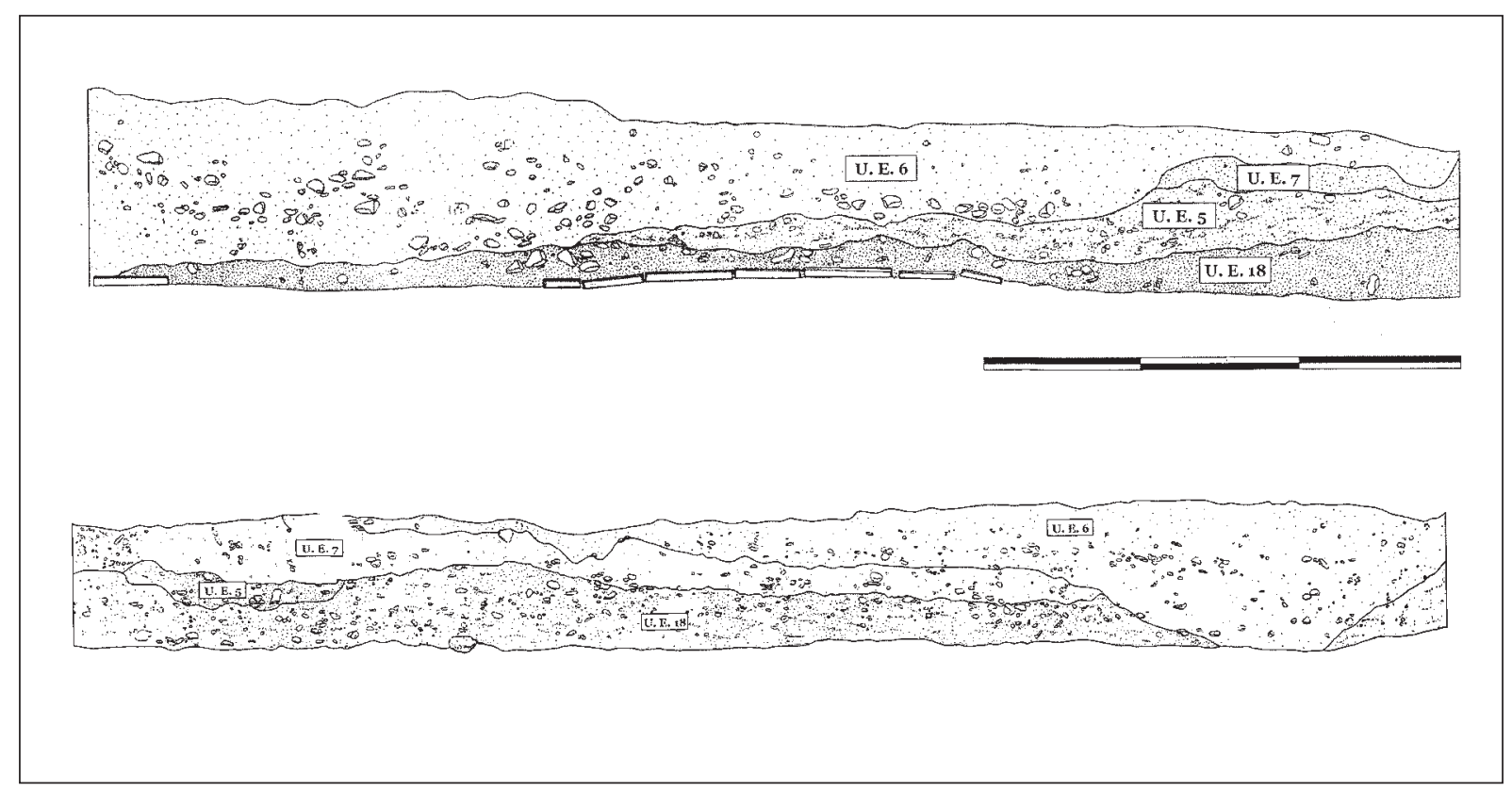

\section{FIG. 9: Estratigrafías depósito E-W. (Vidal y Marcos Contreras) Superior: Norte. Inferior: Sur}

Respecto a la secuencia cronoestratigráfica, es preciso hacer constar la complejidad que presenta, especialmente en algunos niveles, dificultando considerablemente la atribución cronológica de determinados materiales. En ello hemos de valorar la influencia de los procesos de amortización de la estructura original, que la convierten en un vertedero "de segundo uso", con diferentes aportaciones, rellenos y remociones que alteran el orden natural de los niveles deposicionales. Así, la primera fase de amortización se ha datado, en función del estudio de determinados materiales cerámicos como las lucernas (Morillo, 1999: 460-463), en época tiberiana, mientras que la colmatación del depósito se producirá ya en el período flavio, cuando se encuentra ya acantonada en el solar leonés la Legio VII Gemina.

Este peculiar contexto estratigráfico plantea pues, una importante problemática, ya que las diferentes unidades estratigráficas no cuentan con una diferenciación cronológica precisa, de manera que en el proceso de estudio de los materiales no es extraño hallar en un mismo nivel materiales fechados en distintas etapas. Este hecho se pone de manifiesto especialmente en las UUEE de mayor contenido artefactual, como la UE 5, correspondiente a un nivel de relleno y donde se localizan cerámicas de época julioclaudia y de época flavia. 
Estos fenómenos de alteración estratigráfica son habituales en cierto tipo de vertederos como el que nos ocupa, que no han tenido una función original como tales y son producto de diversas fases de reutilización como áreas de eliminación de residuos sólidos urbanos. Es precisamente en estos casos cuando el papel de material guía que ostenta la cerámica dentro de los materiales romanos alcanza su mayor valor para aportar dataciones precisas extensibles al conjunto de materiales asociados. Aún así, y teniendo en cuenta el fenómeno de las perduraciones y el carácter militar de las dos ocupaciones sucesivas, encontramos una notable ambigüedad cronológica que dificulta en ocasiones la adscripción de materiales que carecen de una clara cronología asociada a uno u otro cuerpo legionario en su utilización de esta estructura como vertedero.

La cuestión ya mencionada que se plantea al respecto de esta singular construcción es su funcionalidad, aspecto que en la actualidad dista mucho de estar resuelto y para el que se han propuesto muy diversas hipótesis, comenzando por su uso como depósito de agua (aunque como hemos mencionado supra la ausencia de opus signinum iría en contra de esta supuesta utilidad).

Un aspecto importante a destacar es el hecho de que, en un segundo momento, esta estructura es compartimentada por un muro de mampostería en su extremo

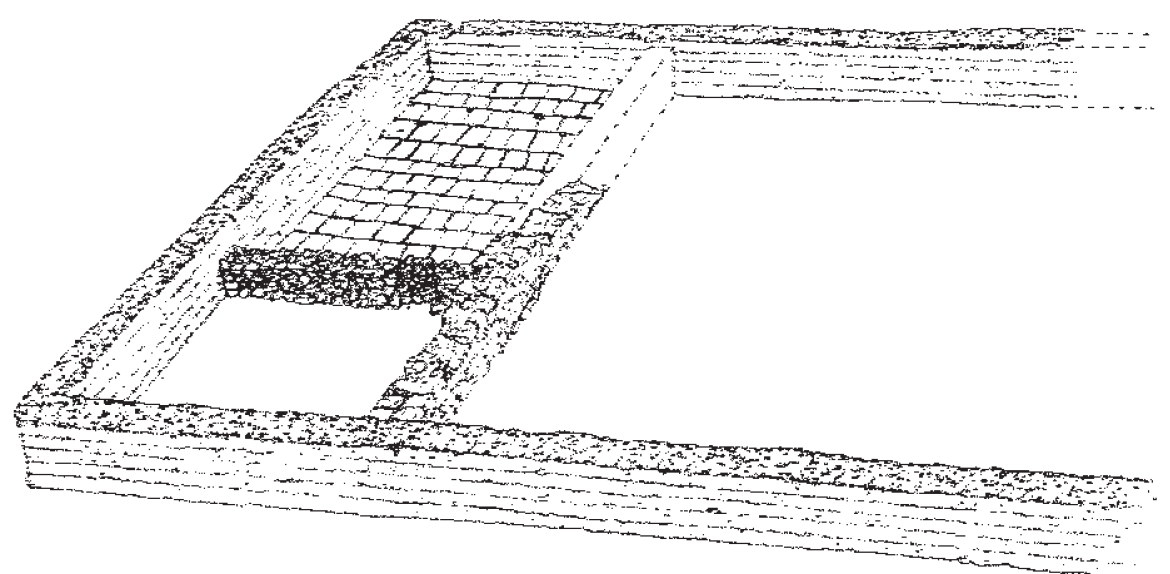

FIG. 10: Axonometría de la construcción (Según Vidal y Marcos Contreras)

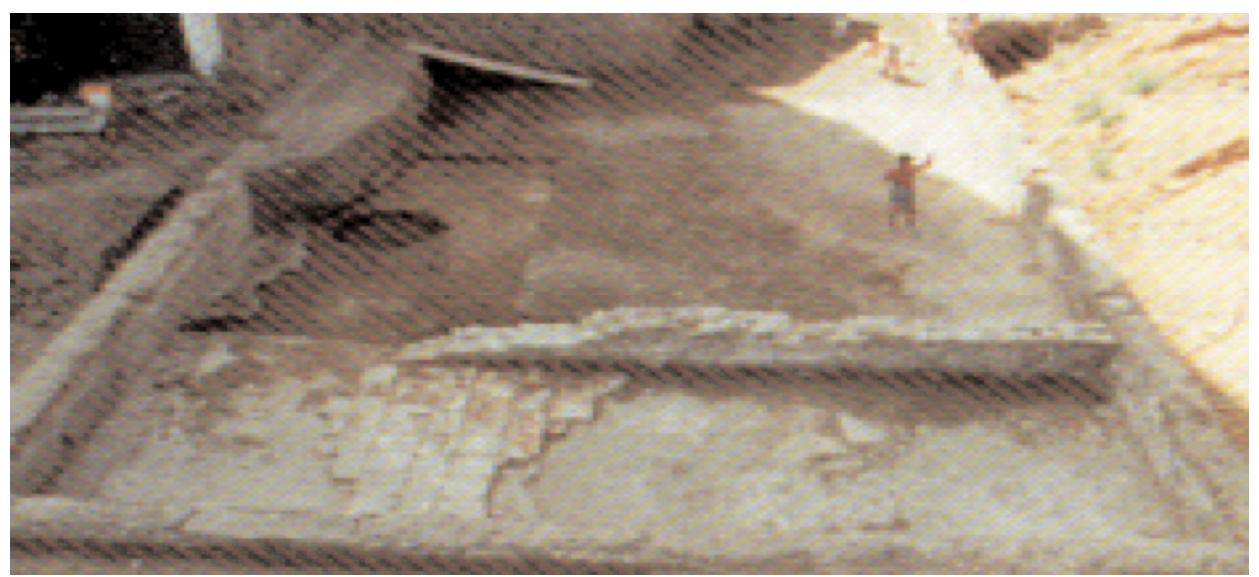

FIG. 11: Fotografía de la excavación 
norte, y además se efectúa un enlosado de tegulae muy regular y sin que ninguna de ellas presentara sellos latericios, característica que remite a momentos anteriores a época flavia.

Más consistente o quizá perteneciente a un segundo momento de utilización, resulta la hipótesis planteada por los arqueólogos que realizaron la excavación, basada en el hallazgo, en la práctica totalidad del espacio de la construcción, de una capa de concreciones blanquecinas carbonatadas que se extendía tanto por la superficie del suelo como por los intersticios de los muros de opus caumenticium y que ha hecho pensar en el uso de esta estructura como depósito para almacenar cal -y llevar a cabo en ella el proceso de su extinción- o bien para almacenar yeso, material profusamente utilizado en la arquitectura romana para el revestimiento y enlucido de muros.

En este estado la cuestión, esperamos que el estudio de los materiales arqueológicos hallados en este contexto, aparte de proporcionar una cronología más exacta de su amortización como zona de vertidos, nos permita asimismo arrojar alguna luz sobre su función.

Para finalizar la somera descripción de este contexto, únicamente nos resta señalar que en la actualidad esta estructura ha sido reubicada y trasladada a un solar cercano al aire libre (situado en la parte posterior de la catedral, al lado del actual aparcamiento de San Pedro), para su conservación y exhibición, formando parte de los restos visitables que integran la denominada Ruta Romana de la ciudad de León.

\section{2) COMPLEJO TERMAL SITUADO EN EL POLÍGONO DE LA PALOMERA: PEQUEÑAS TERMAS DE “SAN LORENZO”.}

El descubrimiento de este conjunto edilicio identificable con un complejo termal de pequeñas dimensiones, perteneciente al período de la Legio VII Gemina, supuso en su momento un importante hallazgo, ya que únicamente se conocían los restos de las grandes termas situadas intramuros del campamento. Su ubicación en el área extramuros -objeto de nuestro estudio- (ver Plano 1) no deja de constituir un elemento esencial en cuanto a su carácter y funcionalidad y más concretamente en lo que se refiere a su posible relación con la cannaba del campamento legionario, cuya estructura y ubicación, como ya hemos aludido reiteradamente en este estudio, se encuentran aún en proceso de investigación.

Un hecho relevante en lo que respecta a la situación de estas pequeñas temas es la ausencia, hasta este momento, de la aparición de otras estructuras de época flavia en esta zona oriental del contexto extramuros, lo cual no deja de ser un dato indicativo desde el punto de vista de su interpretación funcional, pudiendo tratarse, como proponen los autores de la excavación, de una construcción aislada en el área suburbana de Legio, si bien la evolución de la dinámica de la arqueología urbana de la ciudad podrá proporcionar información más concluyente a este respecto. 
La superficie excavada no superaba los 100 metros cuadrados aproximadamente, de ahí su denominación como "pequeñas" termas y presentaba además un deficiente estado de conservación en sus restos murarios, arrasados en gran parte, y condicionados por la topografía de la zona, con un escaso potencial sedimentario que, en otro caso, hubiera podido contribuir a una mejor conservación de estas estructuras.

En cuanto a la estructura y distribución de esta edificación hemos de tener en cuenta a priori un aspecto importante, pues la excavación fue efectuada partiendo de una metodología específica que, distribuyendo las unidades estratigráficas en distintos espacios y estructuras, permite localizar perfectamente diferenciados los distintos espacios del complejo, adjuntándose sus exactas dimensiones así como las fichas de las unidades estratigráficas y los principales hallazgos de materiales arqueológicos, y lo que resulta más indicativo, la determinación de la posible función de cada uno de los espacios, tomando siempre como referencia la estructura de los edificios termales romanos.

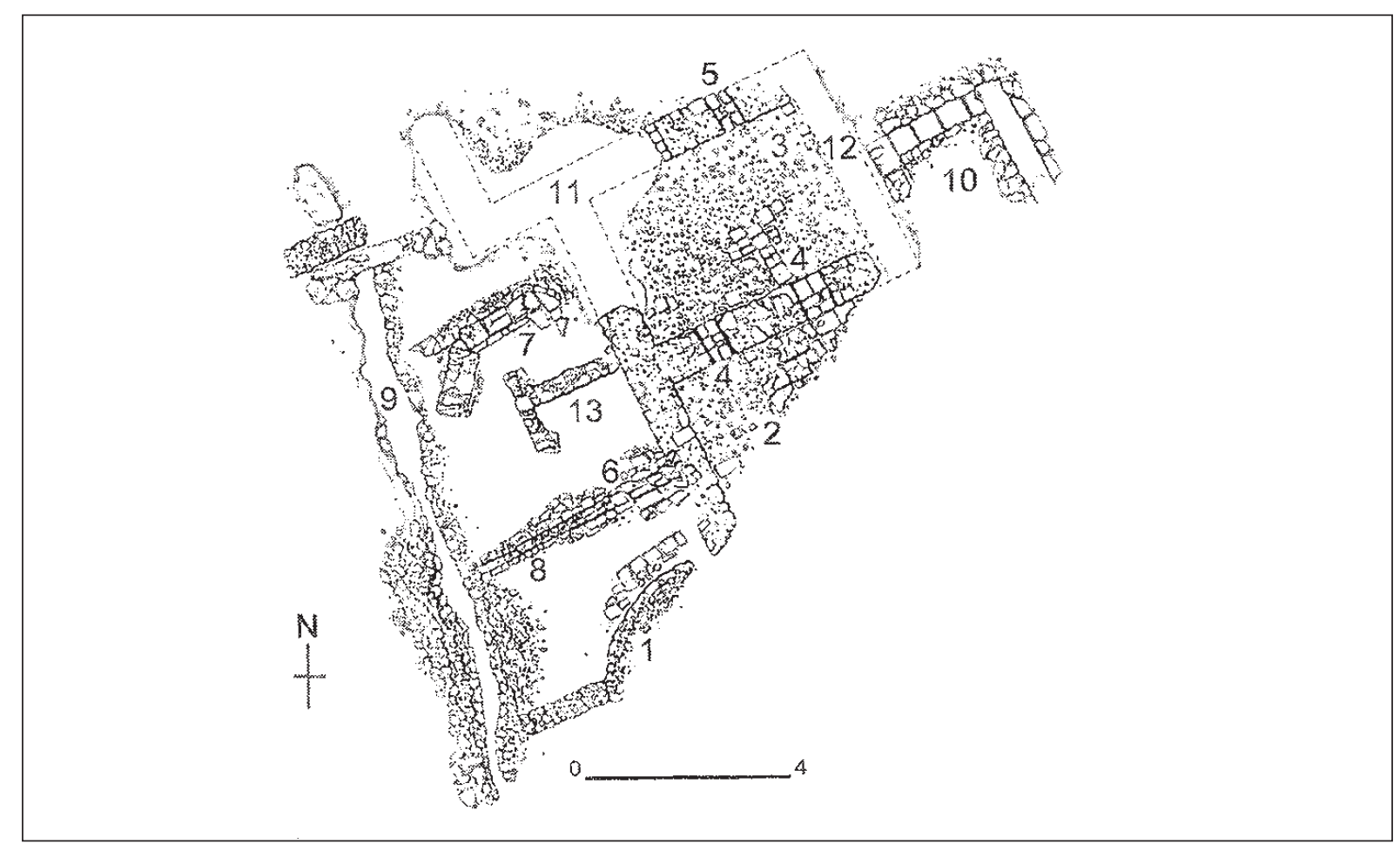

FIG. 12: Planta de las termas de San Lorenzo (Vidal y Marcos Contreras)

1. ESPACIO 1: (¿Laconicum o sudatio?)

2 y 3: Área de hipocaustos (Caldaria)

4 y 5: Pasos de calor en los muros

6 y 7: Preafurnia (i)

8: Atarjea

9: Colector

10: Latrina

11 y 12: Zanjas de saqueo

13: Pequeña dependencia de servicio (i) 
Así, se ha individualizado un espacio cerrado con un muro curvilíneo que pudiera corresponder a la zona del laconicum o sudatio. Por otra parte, se han localizado canalizaciones hidráulicas cubiertas con tégulas, así como canales de desagüe o colectores, además de diversas zonas con suelo de ladrillos y tégulas o bien de encachado de cantos.

En la totalidad de la estructura se encuentran muros de mampostería que sirven para la compartimentación de los espacios, pudiendo aventurarse la presencia de una pequeña piscina, y con más seguridad, la existencia de una construcción cuadrangular que sería utilizada como latrina o más precisamente forica, ya que estas pequeñas termas tendrían carácter público66.

Otros espacios con la misma funcionalidad de letrinas han sido hallados en una de las secciones excavadas de las termas mayores del campamento, ubicadas en las proximidades de la porta principalis sinistra. Asimismo, se conservan letrinas de estructura análoga en las termas del emplazamiento astur-romano de Lancia67, muy cercano a la ciudad de León, detalladamente descritas en el conjunto de los espacios de uso de este complejo termal por uno de sus principales investigadores (Liz Guiral, 2007: 330-331 y 336), quien aporta una cronología para esta edificación en la primera mitad del siglo II d. C.

De singular importancia resultan los diversos ambientes en que se advierte la presencia de huellas de combustión, como cenizas o ladrillos rubefactados, indicando todo ello su función de espacios calefactados, con la presencia de hipocaustos, que hacen suponer la ubicación próxima del praefurnium, si bien esta estructura se hallaría muy arrasada y únicamente se ha podido identificar lo que constituiría su probable solado.
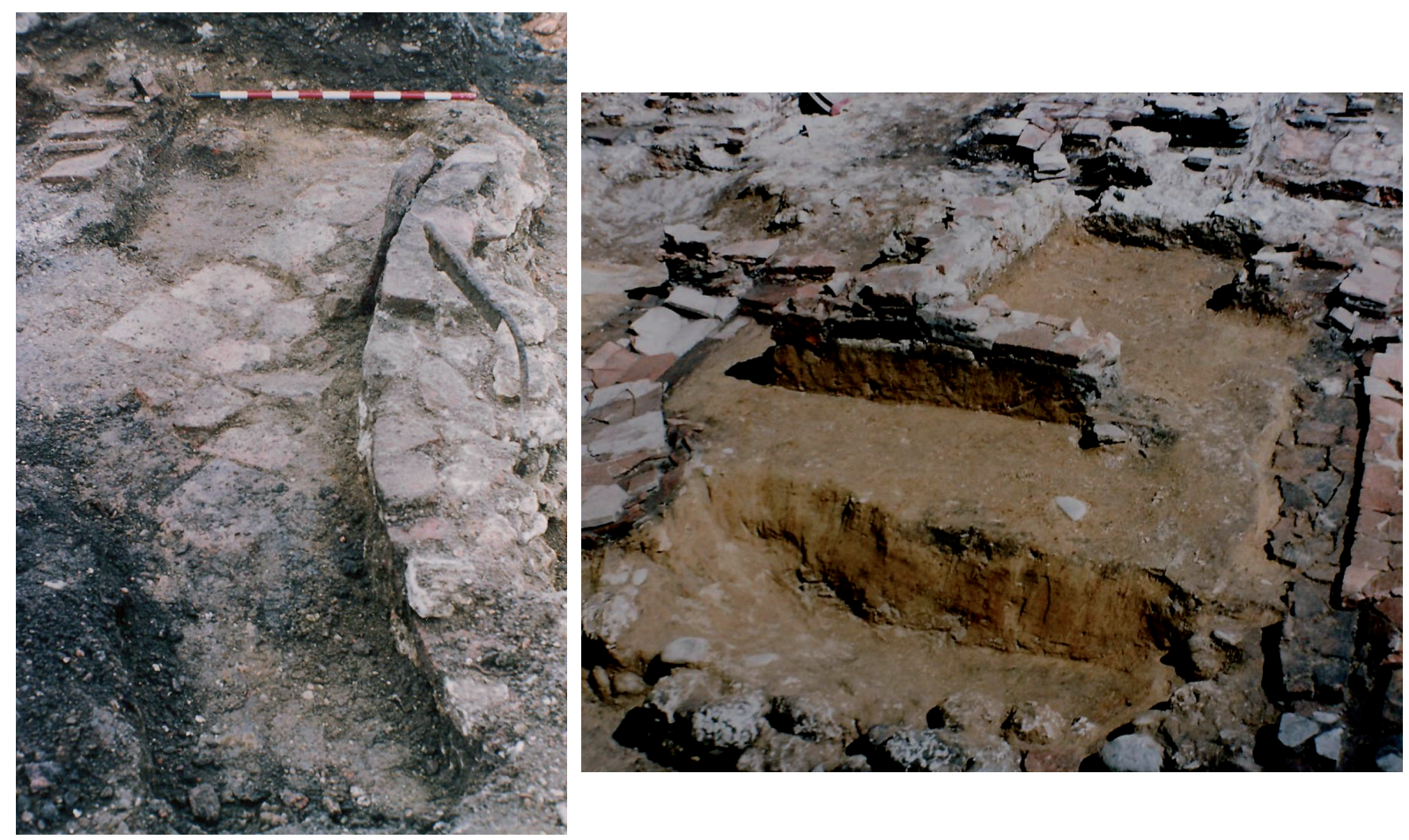

FIGS. 13 y 14: Fotografías de la excavación

66 Para establecer las diferencias, en la estructura entre las letrinas privadas de las domus y las situadas en los espacios públicos, vid. MALISSARD, 2001: 65-68.

67 Vid. LIZ et alii, 2000: 24. 
Desde el punto de vista cronológico, y compensando de alguna manera su estado de arrasamiento, la datación de este conjunto balneario se ha basado hasta el momento en el abundante conjunto de material latericio exhumado, fundamentalmente lateres cocti, tegulae e imbrices, que formarian parte del sistema de cubrición y que portan diversas marcas de la Legio VII Gemina, situando su construcción a partir del asentamiento de este cuerpo militar en el campamento legionense en época flavia, encontrándose marcas con epítetos correspondientes a emperadores que nos llevan cronológicamente hasta el siglo III d. C. Con todo, es materia de una investigación más minuciosa el lapso de tiempo que permanecieron en funcionamiento, y su posterior utilización como área de vertidos 68 , al igual que la cuestión de su uso civil o militar, aspectos éstos que precisan para su esclarecimiento un riguroso análisis de los materiales arqueológicos, especialmente cerámicos, hallados en este contexto, además de un estudio comparado de este tipo de edificaciones balnearias ubicadas extramuros de los campamentos en otras áreas del Imperio.

\section{3) VERTEDERO SITUADO EN LA C/PILOTOS REGUERAL, $\mathrm{N}^{\circ} 4$}

El solar objeto de estudio se encuentra situado en el centro del área urbana de León, en la C/ Pilotos Regueral $n^{\circ} 4$ y Plaza de San Marcelo $n^{\circ} 7$, sede del antiguo edificio del Banco Herrero (Ver Plano 1). Con motivo de las proyectadas obras de remodelación del citado inmueble, se llevó a cabo una intervención arqueológica en sendas campañas realizadas a lo largo del año 1999 y dirigidas por D. Emilio Campomanes, de la empresa Talactor S. L. siendo los materiales extraídos depositados en el Museo de León con $\mathrm{n}^{\circ}$ de Expediente 99/4, y cedidos temporalmente por esta institución para nuestro estudio.

En lo que respecta al contexto arqueológico romano de Legio, el área excavada se localiza en el sector suroccidental extramuros del recinto campamental, en las inmediaciones del lugar donde se alzaría la porta principalis dextra, de cuya estructura y ubicación exacta carecemos de evidencias hasta el momento, a diferencia del caso de la porta principalis sinistra, cuyos restos se encuentran en la cripta arqueológica habilitada al efecto en las inmediaciones de la catedral, albergando asimismo una mínima parte de los restos de las termas mayores del campamento.

En el ámbito cronológico, la secuencia estratigráfica, claramente definida -a tenor de los datos contenidos en el informe de excavación- comprende una fase medieval de escasa potencia arqueológica, si bien de gran interés histórico-arqueológico debido a la exhumación de un tramo de la cerca medieval de la ciudad, correspondiendo el

68 Esta función ulterior como área de vertidos -una vez que el edificio termal se halla en proceso de destrucción y abandono- ha sido deducida en función de los datos del registro estratigráfico, en el que se consigna la presencia de estructuras vacuas, como hoyos, zanjas o canales que han sido objeto de relleno con materiales de épocas diferentes, y resultado de acciones antrópicas, todo lo cual nos ha llevado a considerar esta estructura en su última fase como vertedero de tipo "ocasional", con vertidos circunstanciales, y en ningún caso como vertedero sistemático con deposición natural de los residuos. Por otra parte, esta hipótesis se vería avalada por la cronología de esta segunda utilización del complejo termal ya en desuso, propia de muchos espacios urbanos en épocas tardías. 
resto de la secuencia a niveles romanos altoimperiales, bien documentados en función de los distintos tipos de materiales hallados, que permiten delimitarla a priori, a lo largo del siglo I d. C. y principios del siglo II.

Respecto a la caracterización de este contexto, hemos de señalar que una serie de factores, como la disposición y características de las unidades estratigráficas, la propia configuración topográfica del terreno, así como la cantidad (unas 9000 piezas aproximadamente) y la variedad de los materiales hallados -que incluyen esencialmente restos cerámicos (terra sigillata, paredes finas, cerámica común, lucernas, ánforas,...) además de material constructivo, vidrio, metales, numismática y abundantes restos faunísticos- y muy especialmente, la ausencia de restos de estructuras arquitectónicas, han permitido calificarlo como un área de recepción de vertidos.

Con todo, no se descarta la posibilidad de una función posterior como base para el asentamiento de algún tipo de estructura arquitectónica, dadas las especiales características topográficas de esta zona extramuros al recinto campamental, aunque hasta el momento no se han hallado evidencias que corroboren esta hipótesis.

Un aspecto importante a destacar desde el punto de vista geológico, en el que hacemos hincapié por su posible influencia en la génesis del vertedero, es que se trata de una zona endorreica, pues se encuentra situada en la vega baja del río Bernesga, discurriendo en su entorno una red de antiguos cauces y constituyendo una zona de inundaciones periódicas.

Esta peculiaridad topográfica ha sido objeto de comprobación en diversas intervenciones arqueológicas llevadas a cabo en la zona, en las cuales la capa freática aflora a muy escasa profundidad, e indudablemente ha constituido un importante condicionante para el asentamiento humano, dada su constante anegación y sus consecuentes inestabilidad e insalubridad.

En dichas excavaciones, cobra especial relevancia la realizada en un solar colindante, el patio del Centro Cultural Pallarés (Miguel Hernández y García Marcos, 1993), que puso al descubierto una secuencia completa desde la época moderna hasta los primeros niveles romanos del asentamiento legionense. En cada período se diferencian diversas fases de colmatación, identificadas no únicamente por los restos de abundantes materiales arqueológicos, sino también por la presencia de acumulaciones de cenizas, restos de material constructivo, arena, gravas o manto arcilloso, claramente identificables como capas de relleno para uniformizar e impermeabilizar el que fue durante los siglos de la época moderna un importante vertedero, y posteriormente solar del Pósito Municipal, cuya cimentación también fue hallada en los primeros niveles de la excavación.

Más significativa, de cara a nuestra investigación, es la secuencia de colmatación de la época romana, dividida en tres fases en las que aparece abundante material arqueológico que permitiría datar la secuencia completa entre principios el siglo I d. C. y el tercer cuarto de la misma centuria, pero cuya característica diferencial respecto a otras fases del vertedero posterior y de las áreas de vertidos en general, es la presencia en algunos niveles de estructuras arquitectónicas, que están indicando una ocupación o la realización de otras actividades en esta zona. Así, en las dos fases superiores se localizaron sendas estructuras murarias, y en la primera una construcción de tablones de madera y refuerzo de piedra que sus excavadores interpretan como un pontón para vadear esta zona pantanosa, y posteriormente como un pavimento, situándose su cronología en las primeras décadas del siglo I d. C. por tanto, durante la ocupación del campamento por la Legio VI Victrix. 
Con ello, los excavadores de este solar extramuros subrayan su posible función, no como vertedero del asentamiento romano, sino como zona de ocupación en función de las estructuras de habitación halladas que, dada la ubicación del solar, resultaría factible relacionar con la cannaba del recinto castrense.

En este punto, resulta de singular trascendencia para nuestro estudio del solar contiguo -que como hemos mencionado no ha deparado hallazgos de estructuras arquitectónicas- el hecho de que estas características geológicas hayan podido propiciar la ubicación en este lugar de un vertedero, con la posible intención de desecar, sanear y uniformizar este entorno extramuros, corroborando así la decisiva influencia de los vertederos en la dinámica de la topografía urbana.

En cuanto a la secuencia cronoestratigráfica de este contexto, la intervención fue realizada en área abierta siguiendo el método Harris de registro de datos en fichas individualizadas que corresponden a las distintas unidades estratigráficas identificadas en el proceso de excavación. El análisis de la documentación contenida en dichas fichas, referente a las características morfoestructurales, contenido artefactual y ubicación en relación con el resto de unidades estratigráficas, ha posibilitado la elaboración de un diagrama o matrix en el que se plasma la secuencia estratigráfica resultante, y que constituye el único documento disponible para elaborar el estudio de materiales.

DIAGRAMA ESTRATIGRAFICO

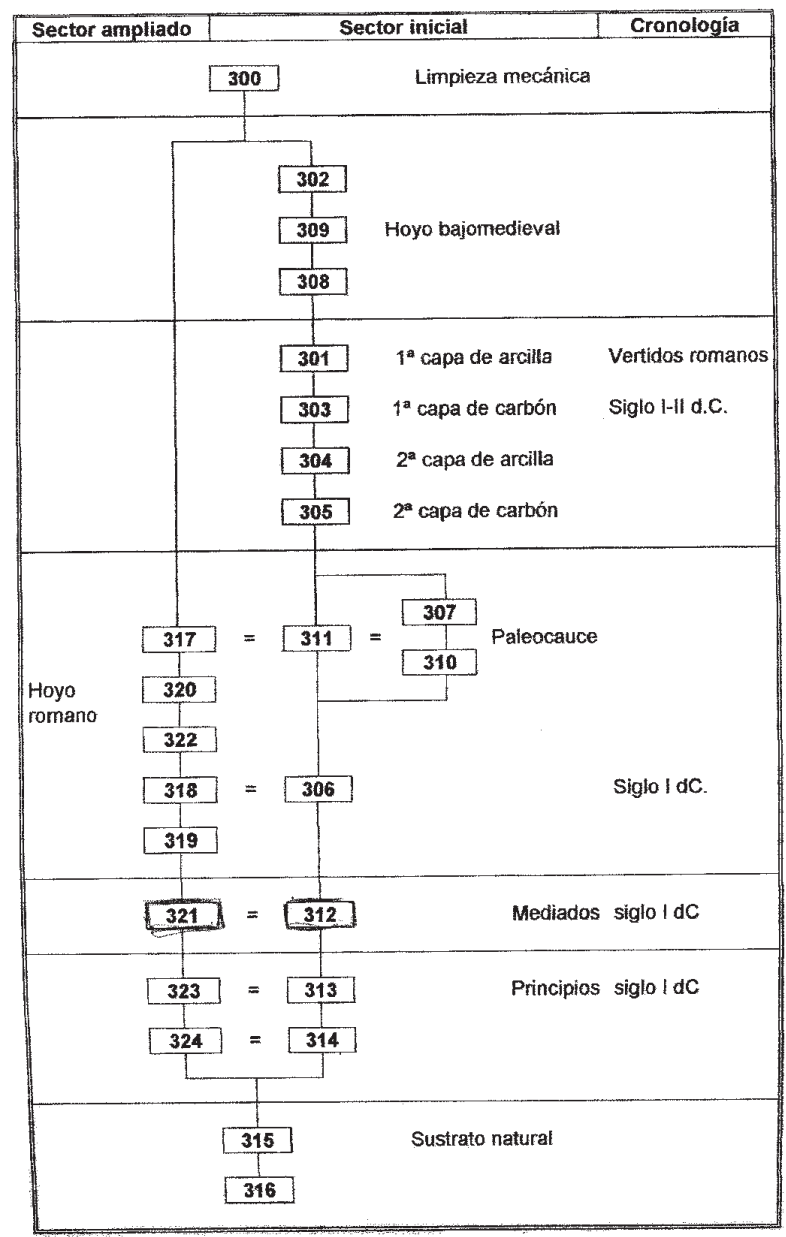

FIG. 15: Matrix Harris de la excavación de la C/Pilotos Regueral n ${ }^{0} 4$ 
La intervención se llevó a cabo en dos fases, siendo excavado inicialmente un sector de superficie rectangular de unos $30 \mathrm{~m}^{2}$ y posteriormente, tras la demolición de los restos de la cerca medieval, se procedió a una ampliación en un área trapezoidal de 10 $\mathrm{m}^{2}$ aproximadamente. En ambos sectores se documentaron secuencias arqueológicas completamente equiparables, de manera que tanto para el registro estratigráfico como para el estudio de materiales no se establece diferenciación alguna, considerándose ambas intervenciones de forma unitaria.

En este aspecto hallamos una similitud importante con el vertedero estudiado por nosotros citado supra, ya que se extiende también a lo largo de dos sectores (Calle Maestro Copín y Calle San Salvador del Nido), cuya correlación entre las unidades estratigráficas de cada uno de ellos pudimos establecer de forma exacta.

En cuanto al sistema de numeración de unidades estratigraficas, se tomaron como referencia las intervenciones anteriormente desarrolladas en el solar de la Casa Botines (designadas como área 100 y área 200), de forma que se fijó el número 300 como punto de partida para la numeración correlativa de las unidades estratigráficas subsiguientes.

Así, en los primeros niveles, correspondientes a la etapa medieval, se documentan por una parte la UE 308, identificada como un hoyo -una de las estructuras características en las excavaciones arqueológicas de este período-, mientras que las UUEE 302 y 309 pertenecen a sendos niveles de relleno del mismo. Estas últimas presentan una contextura arenosa y arcillosa con restos de carbones vegetales, cifrándose su contenido en fragmentos de elementos constructivos, piezas de las etapas pleno y bajomedieval, así como importantes intrusiones de material romano.

En cuanto a la etapa romana propiamente dicha, presenta una considerable potencia estratigráfica, llegando a configurar una secuencia arqueológica prácticamente completa que abarca un extenso lapso cronológico, desde principios del siglo I d. C. hasta los primeros decenios de la segunda centuria.

Esta circunstancia le concede un gran potencial de información, además de otorgarle un carácter excepcional, puesto que quedarían incluidas en el espectro estratigráfico las distintas fases campamentales de Legio, o lo que es lo mismo, nos ofrece la posibilidad de obtener una perspectiva diacrónica de la evolución del asentamiento a través del conjunto de materiales de uno de sus más importantes vertederos extramuros.

En este sentido hemos de hacer notar la diferencia con otros contextos de vertidos como el anteriormente aludido que, con un similar volumen de materiales, presenta una secuencia cronológica mucho más restringida, en este caso a la mitad del siglo II d.C.

Por el contrario la amplitud y continuidad temporal de la secuencia romana del vertedero en la C/ Pilotos Regueral ha permitido diferenciar claramente tres etapas en su formación:

1.- Etapa de principios del siglo I d. C.

2.- Etapa de mediados del siglo I d. C.

3.- Etapa de finales del siglo I d. C. y principios del siglo II d. C.

Este esquema evolutivo, propuesto en función de los datos cronológicos que aportan los materiales asociados a cada uno de los tres grupos de unidades estratigráficas cuya morfología -en lo que respecta a los materiales cerámicos- describiremos de forma pormenorizada en el siguiente capítulo, viene avalado además por las excavaciones realizadas en dos solares contiguos ya citados -el Edificio Pallarés y la Casa 
Botines- que proporcionaron en ambos casos idéntica dinámica estratigráfica, y por tanto una exacta correlación en la división tripartita de la secuencia, con la salvedad de que en el solar de la Casa Botines no se identificó ningún tipo de estructura constructiva, aunque sí restos aislados de maderas bien conservados. Por otra parte, en cuanto a los materiales extraídos, especialmente en los procedentes del solar del Edificio Pallarés, cuyos ejemplares más significativos han sido publicados en la obra ya citada, antes de que sea abordado el estudio de su totalidad, permiten apreciar asimismo una notable similitud con los de este vertedero colindante.
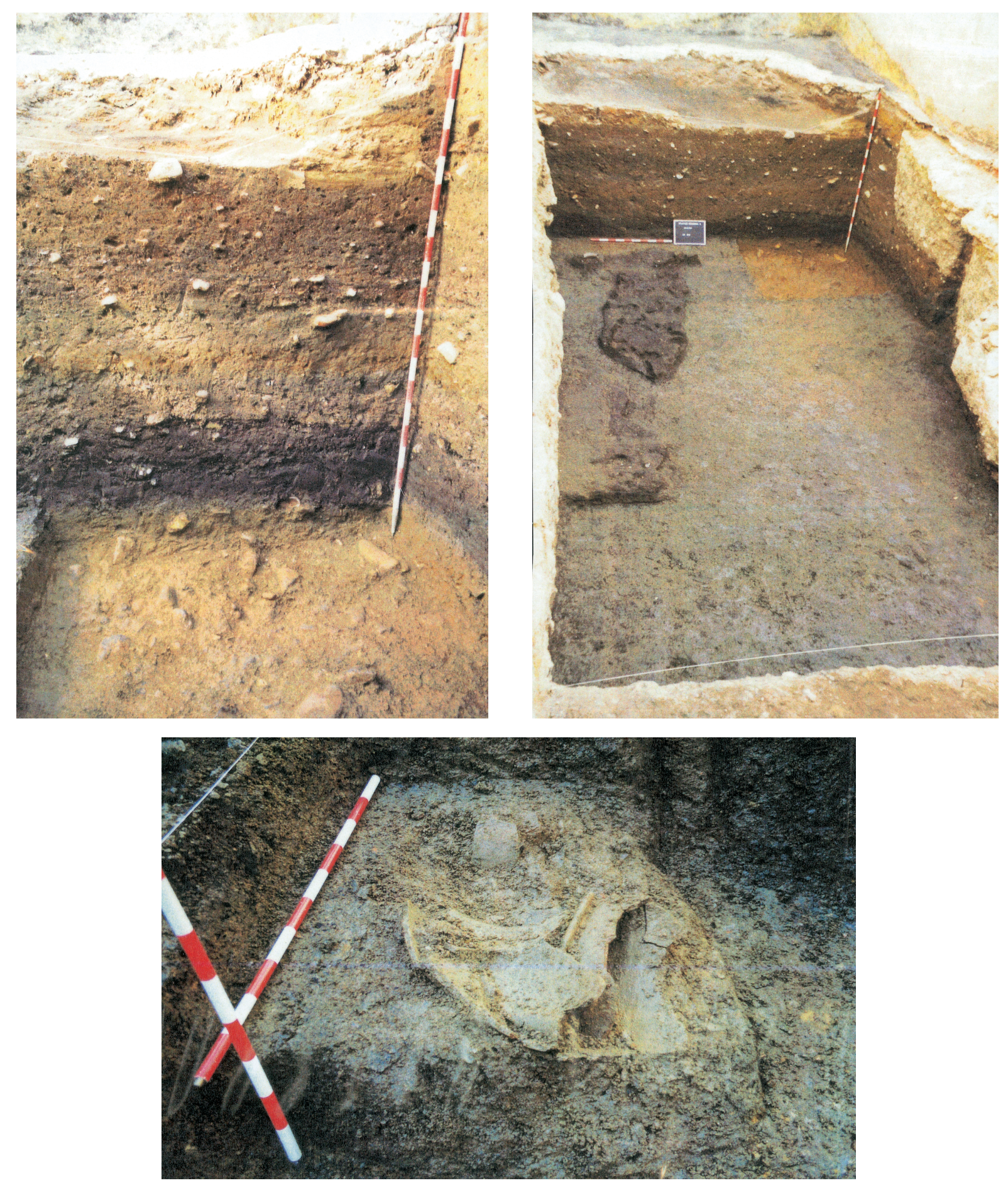

FIGS. 16, 17, 18: Fotografías de la excavación 
En cuanto al contexto cronoestratigráfico del vertedero que estudiamos, describiremos lo más ampliamente posible la evolución de la secuencia y su contenido artefactual, ya que en el informe de excavación se aprecia una cierta carencia de representaciones gráficas de la estratigrafía y planimétria del solar.

\section{$1^{\text {a }}$ ETAPA}

El contenido arqueológico del primer nivel estratigráfico se encontraría ya fuera de los límites cronológicos de nuestro estudio, en tanto que abarca los primeros decenios del siglo I d. C. Con todo, el análisis de los materiales de los estratos más modernos, representados por las unidades 313 y su equivalente 323, será importante para determinar con mayor precisión el momento final de esta fase y con ello los inicios de la segunda. En este nivel destaca el conjunto de ejemplares de terra sigillata ítálica, la abundancia de fragmentos de cerámica de paredes finas, la presencia de lucernas de volutas y un importante volumen de cerámica común.

El estrato inferior, integrado por las unidades 314 y sus correspondientes 324 y 324a, marca el final de la secuencia arqueológica, apoyándose directamente sobre los niveles del sustrato natural formado por una capa arcillosa (UE 315) y una capa de gravas (UE 316).

Esta última capa presenta singulares características desde el punto de vista de su composición, pues fue documentada una importante concentración de restos de materia orgánica, fundamentalmente de carácter lígneo (Fig. 17), si bien en un precario estado de conservación que dificultará sumamente los análisis pertinentes que pudieran arrojar luz sobre este material tan poco frecuente y de gran potencial informativo.

La presencia de este nivel con restos de madera, además de las implicaciones de carácter ocupacional, constituye otro elemento que subraya la homogeneidad de esta zona, ya que ha sido hallado también en las intervenciones de los solares adyacentes ya aludidos de Pallarés y Botines, si bien en el primero de ellos han aparecido restos de las propias estructuras realizadas en madera, y no únicamente una acumulación de residuos sin posibilidad alguna de restitución como en el vertedero que estudiamos.

Por otra parte, mientras la composición de este último nivel muestra, como acabamos de exponer, una considerable peculiaridad, su contenido material es más usual, esto es, menos singular, y no plantea mayores problemas de atribución cronológica, dado que las características de las diferentes especies cerámicas convergen en los momentos iniciales del siglo I d. C.

Así, en el amplio conjunto de terra sigillata itálica se localizan marcas de alfarero in planta pedis, en la cerámica de paredes finas predominan las decoraciones arenosa y de hojas de piña, las lucernas son en su práctica totalidad ejemplares de volutas que muestran en sus discos un variado repertorio decorativo de gran calidad y en el numeroso volumen de cerámica común se pone de manifiesto una gran variedad morfológica, destacando la presencia de platos de engobe interior rojo pompeyano de importación itálica.

A estos datos provenientes del material cerámico hay que añadir la decisiva aportación de un testimonio numismático hallado en este nivel, identificado como un as de Tiberio, que corrobora por tanto la cronología propuesta, marcando así esta fecha el inicio de la formación del vertedero. Si bien la numismática en los vertederos y en los yacimientos en general plantea sus característicos problemas de atribución cronológica, en este caso, dada su aparición en los primeros niveles, parece clara su situación en los inicios del vertedero. 
Con estos indicios cronológicos, cabría atribuir los comienzos de la formación de este vertedero a la etapa de ocupación del campamento por la Legio VI Victrix, ubicado en este lugar muy probablemente por las mismas razones y con la misma función que ya hemos explicado para la etapa correspondiente a la Legio VII Gemina, es decir sanear, desecar y uniformizar el terreno en esta zona inundable del espacio extramuros, problemas que han de solventarse con cierta continuidad y que explicarían su perduración como vertedero en la época de la Legio VII Gemina.

\section{$2^{\mathrm{a}}$ ETAPA}

A partir de los niveles subyacentes se delimita la segunda etapa en la secuencia estratigráfica, representada por la unidad 312, equivalente a la 321 en el área de la ampliación. Este nivel, de importante potencia arqueológica, diferenciado por su color grisáceo y su diversificada composición (cenizas, carbones vegetales, intrusiones arenosas, cantos rodados...), se caracteriza asimismo por la abundancia de materiales arqueológicos, destacando el gran volumen de hallazgos cerámicos. El estudio detallado de este conjunto es un elemento clave para ajustar y definir más concretamente los límites del difuso lapso cronológico propuesto para esta segunda fase, situada a mediados del siglo I d C. En este sentido, siguiendo la información proporcionada por la terra sigillata como material guía, se valora la presencia de numerosos ejemplares de terra sigillata gálica y algunos fragmentos de itálica, que remiten a estos años centrales de la primera centuria, si bien será el análisis de la terra sigillata hispánica el que nos ofrecerá datos cronológicos más concretos. Es, pues, esencial dilucidar aquí la presencia de ejemplares que puedan corresponder a los primeros momentos de la producción hispánica de sigillata y que se han dado en llamar por ello "precoces", dada su trascendental importancia para la datación de la llegada a Legio de estas primeras producciones.

A todo ello hay que añadir la información derivada del estudio de las demás especies cerámicas presentes en este nivel, especialmente la cerámica de paredes finas y las lucernas, que pueden aportar mayores precisiones cronológicas. Así, en el caso de las paredes finas, además del examen de ejemplares propios de la Península Ibérica, y dada la zona en que nos encontramos, hemos de prestar especial atención a aquellas piezas de procedencia atribuible al taller zamorano de Melgar de Tera, pues corresponderían igualmente a los momentos iniciales de su producción.

Con todo ello se impone en este punto una minuciosa labor de investigación en cuanto a la posibilidad de que esta segunda fase en la estratigrafía pueda extenderse hasta la etapa flavia, llegando así a coincidir con los primeros momentos de la presencia de la Legio VII Gemina en León, o bien ha de situarse en la primera etapa, en la mitad del siglo I d. C., correspondiendo por tanto esta fase intermedia a la estancia del cuerpo legionario precedente que ocupó el solar leonés, la Legio VI Victrix.

\section{$3^{\mathrm{a}}$ ETAPA}

En la tercera etapa de la secuencia romana se documenta en primer lugar una serie de cinco capas deposicionales, tres de matriz fundamentalmente arcillosa conteniendo abundantes restos de material constructivo (UUEE 301, 304 y 311), alternando con otros dos niveles de carbones y cenizas de escaso espesor (UUEE 303 y 305), pudiendo considerarse como el primer bloque diferenciado en la secuencia estratigráfica.

Las primeras unidades estratigráficas como la 301 y 303, dada su escasa potencia, resultaron arqueológicamente estériles, mientras que en las tres subsiguientes se halla- 
ron, aunque no en abundancia, fragmentos de cerámica romana (fundamentalmente TSH, cerámica de paredes finas atribuibles al taller de Melgar de Tera, cerámicas comunes, ánforas, etc...) que situarían estos niveles en los momentos iniciales del siglo II d. C.

Teniendo en consideración la ya comentada absoluta correspondencia con la disposición estratigráfica del sector ampliado de la excavación, es en éste donde el primero de los estratos excavados, la UE 317, permitió corroborar esta homogeneidad, siendo en todo equiparable a la UE 311. Con todo, el mayor volumen de materiales no sólo cerámicos (mayor muestra de TSH lisa y decorada, paredes finas de Melgar de Tera, cerámicas comunes y ánforas), sino también la tipología de los restos de vidrio, hueso trabajado y metales, permitieron reafirmar la cronología de principios de la segunda centuria.

En este mismo espacio de la ampliación se registró un elemento identificado como un hoyo (UE 322), cuya capa de colmatación (UE 320) resultó homologable a la UE 317, tanto por la morfología y composición como por el contenido de materiales arqueológicos, entre los que destaca una gran vasija de almacenaje conservada completa en su mitad superior.

Llegados a este punto de la tercera fase de la secuencia del vertedero se documenta en la estratigrafía la presencia de un elemento interfacial, en este caso de origen natural, constituido por un cauce de agua de escasa entidad (UE 310) y su nivel de relleno de textura arenosa (UE 307), relacionados cronológicamente con las UUEE 311 y 306 en función de la disposición estratigráfica y de los escasos materiales asociados.

La localización de este pequeño curso de agua, unido a la documentación de otros cauces de diversa magnitud en las excavaciones de los solares limítrofes de Pallarés y Botines, así como de zonas de inundación periódica o permanente, viene a poner de manifiesto el carácter endorreico de este contexto del área extramuros, como ya hemos subrayado anteriormente, al incidir en la relación causa-efecto entre la singular ubicación de áreas de vertidos como elemento de uniformización y saneamiento y por tanto de vital trascendencia en la dinámica de la topografía de los núcleos urbanos.

Las implicaciones arqueológicas a este respecto son de diversa índole, pues si por una parte conlleva la formación de niveles de sedimentación de gran potencia arqueológica, por otra entraña la dificultad de ubicar cronoestratigráficamente los materiales procedentes de estos cauces, dada la escasa estabilidad del terreno y por tanto la probable movilidad de los mismos, cuya primitiva ubicación no siempre ha de corresponderse con el lugar de depósito en que son hallados.

El siguiente nivel estratigráfico se encuentra representado por la UE 306, equivalente a la UE 318 en el sector de la ampliación. Destaca por su configuración arcillosa mezclada con carbones y cúmulos de cenizas, así como por su abundancia de materiales arqueológicos, deparando un amplio conjunto de cerámicas en un óptimo estado de conservación, especialmente piezas de TSH y lucernas, que aportan datos significativos para fijar su cronología a finales del siglo I d. C.

Por último, esta tercera fase de la secuencia estratigráfica se completaría con un nivel de echadizo compuesto de gravas (UE 319 en el sector ampliado) que resultó improductivo arqueológicamente. 


\section{4) VERTEDERO SITUADO EN LA C/MAESTRO COPÍN C/V SAN SALVADOR DEL NIDO}

Con el fin de realizar una visión de conjunto de los vertederos de Legio excavados y estudiados hasta el momento, que nos permitan efectuar comparaciones en cuanto a estructuras y ubicación de los mismos, con las implicaciones que ello conlleva a nivel urbanístico, cronológico y sobre todo en cuanto a los conjuntos de materiales de cada uno de ellos, hemos optado por incluir aquí, aunque ha sido objeto de una publicación monográfica (Fernández Freile, 2003), algunos de los rasgos más relevantes de este vertedero, el primero que analizamos, estableciendo unas bases metodológicas que hemos seguido en la investigación de los otros tres contextos, contando además con la ventaja de haber obtenido unos resultados sumamente precisos en cuanto a tipologías de materiales y cronología asociada.

Por ello, no faltarán en las descripciones del material cerámico del presente estudio, numerosas alusiones a este contexto, que ha supuesto nuestro referente esencial a la hora de acometer esta investigación más amplia, puesto que nos proporcionó información de primer orden sobre las variadas producciones cerámicas halladas y datos relevantes en cuanto a los centros de producción de las mismas y el abastecimiento del campamento de la Legio VII Gemina.

Su ubicación, en las inmediaciones del ángulo suroriental del recinto fortificado, muy próximo a lo que sería la porta principalis sinistra (vid. Fig. 7), habría de influir decisivamente en la configuración topográfica de esta zona, dado que contribuiría a nivelar el marcado declive del terreno en este espacio respecto al área amurallada, con una cota más elevada. Este aspecto nos permite inferir la configuración de un área de vertidos de ningún modo fortuita, sino intencional, con la finalidad de regularizar el entorno extramuros del campamento, abundando en el papel de los vertederos como dinamizadores de la topografía urbana.

En cuanto a las características de la secuencia estratigráfica, destaca su gran homogeneidad, sin que se detecten elementos interfaciales, presentando una superposición natural de los niveles de deposición de los restos, sin que se perciban alteraciones de carácter natural o antrópico que hubieran podido complicar la secuencia arqueológica.

Por otra parte, dado que el área excavada incluye dos parcelas contiguas (C/Maestro Copín y C/San Salvador del Nido), hemos podido establecer una perfecta correlación entre ambas secuencias estratigráficas, en función de la similitud de los perfiles y de los materiales contenidos en las distintas unidades estratigráficas. En este sentido, se produce una situación similar a la del vertedero aquí estudiado de la C/Pilotos Regueral y la de sus solares contiguos (Edificio Pallarés y Edificio Botines) que, como ya hemos señalado, presentan secuencias estratigráficas también correlativas, si bien el hallazgo de restos de estructuras arquitectónicas en estos últimos implicaría la existencia de niveles de ocupación, mientras que el primero constituye únicamente un área de vertidos. 

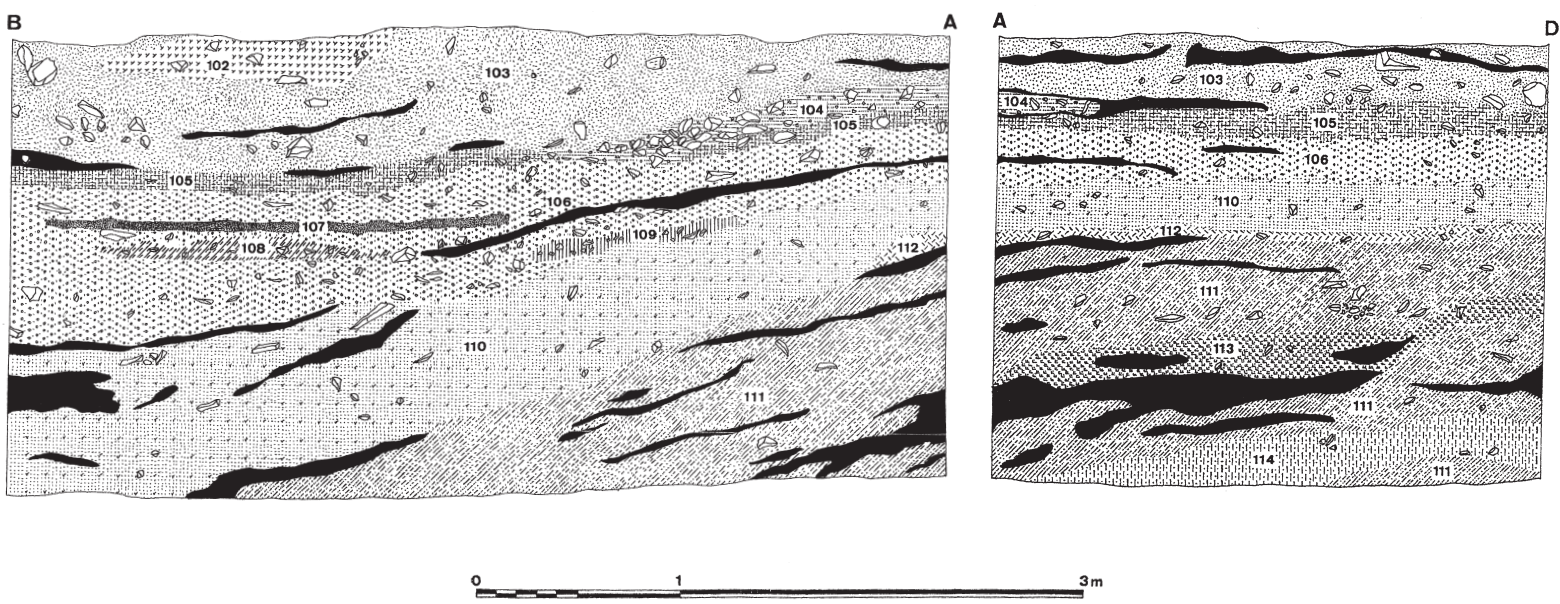

FIG. 19 A: Estratigrafía del área de la C/Maestro Copín

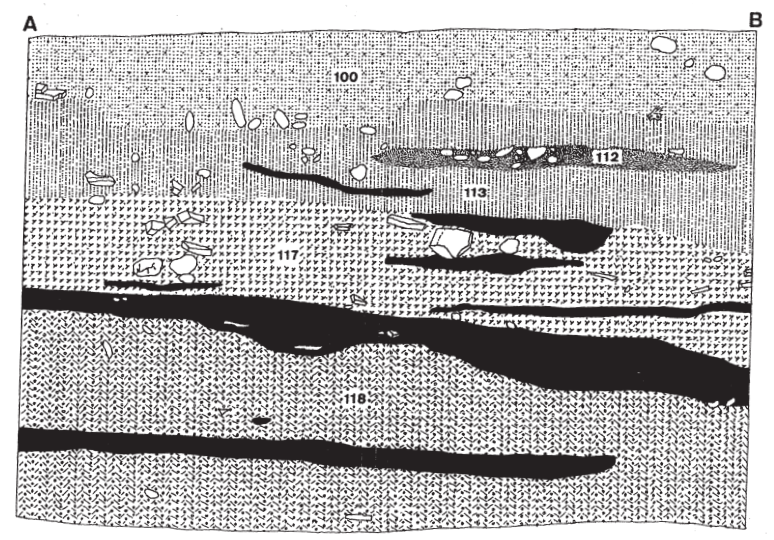

FIG. 19 B: Estratigrafía del área de la C/San Salvador del Nido

Otro aspecto destacable del contexto estratigráfico de este vertedero que formaría parte de un área de acumulación de residuos sólidos más extensa es, además de una considerable potencia arqueológica, la disposición de la secuencia, cronológicamente breve y con los niveles bien delimitados y sin contaminar por factores externos, de manera que formaría un depósito sellado, manteniendo los restos la disposición original de la acumulación.

Todo ello, unido a una evidente homogeneidad cronológica de los materiales en un primer análisis, permite deducir que la formación del vertedero tendría lugar en un reducido espacio de tiempo. Ello constituye otro importante rasgo diferencial con los tres vertederos objeto de este estudio, puesto que, exceptuando el caso excepcional de los dos vertederos de segundo uso (depósito de San Pedro y termas de San Lorenzo), el vertedero de la C/Pilotos Regueral ocupa una secuencia cronológica mucho más amplia y por ende, más compleja en cuanto a la delimitación exacta de las diferentes etapas. 


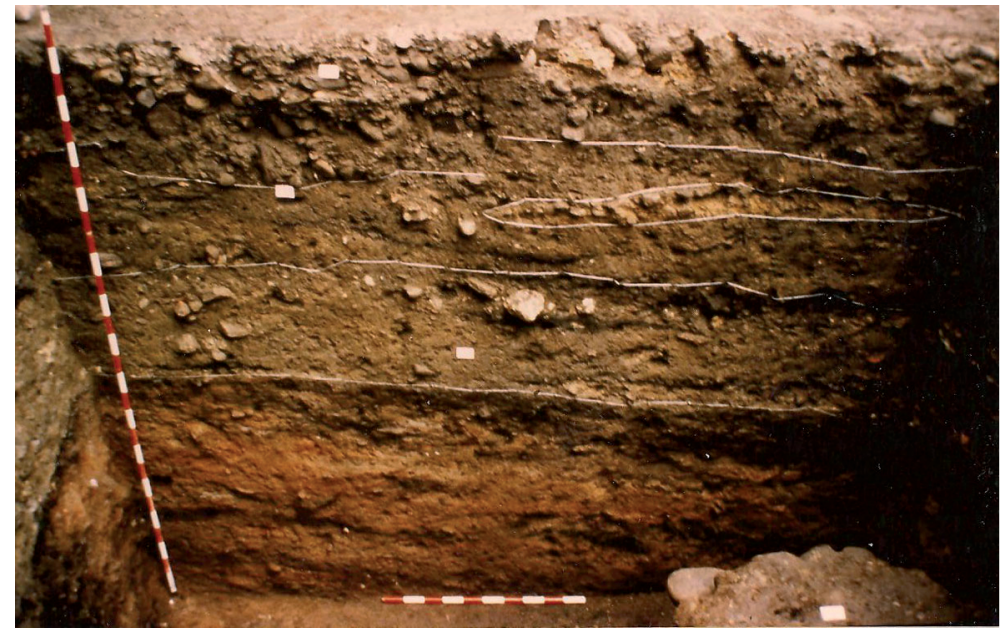

FIG. 20: Estratigrafía del vertedero C/Maestro Copín c/v San Salvador del Nido (Foto: V. García Marcos)

Respecto al conjunto de materiales exhumados, destaca, desde el punto de vista cuantitativo, el importante volumen de restos recuperados y en el plano cualitativo, la gran variedad de éstos y su óptimo estado de conservación. Así, se documentaron los tipos de materiales cuya representación porcentual se refleja en el siguiente gráfico:

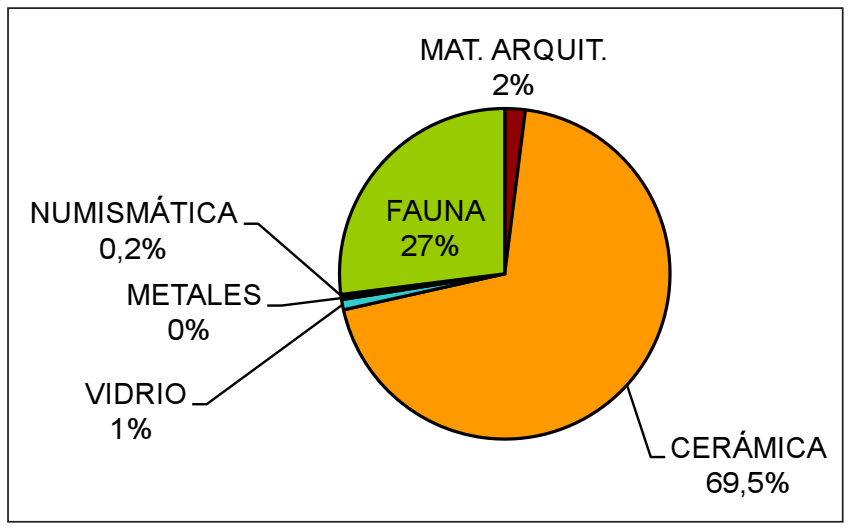

FIG. 21: Distribución de materiales en el vertedero de la C/Maestro Copín C/V San Salvador del Nido

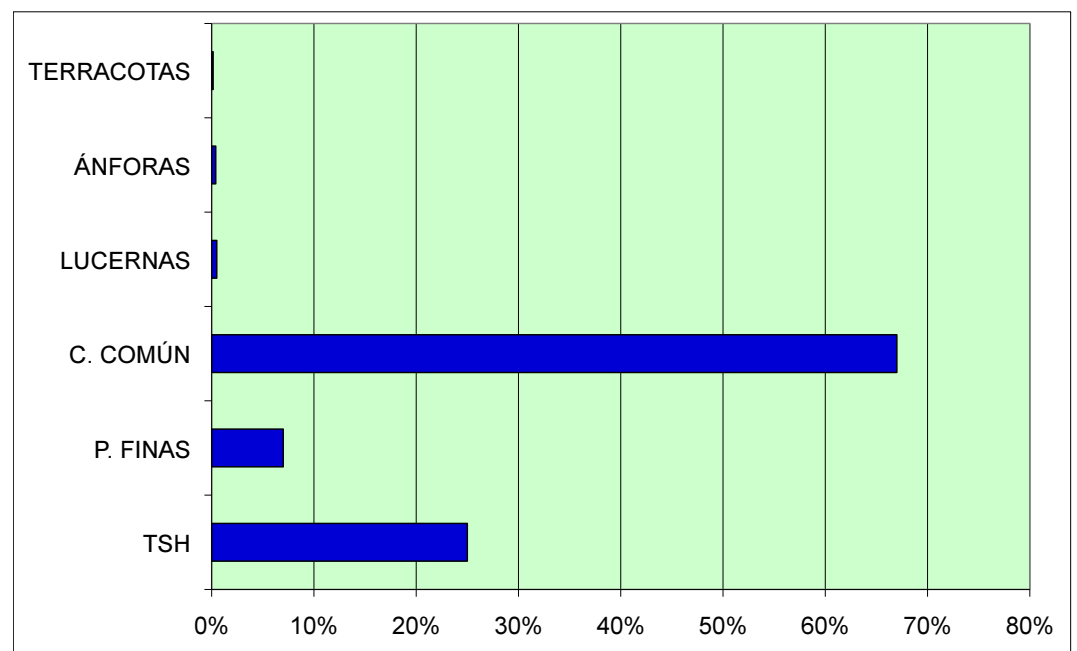

FIG. 22: Distribución del material cerámico en el vertedero de la C/Maestro Copín C/V San Salvador del Nido. 
En esta distribución se reflejan, al igual que en el resto de vertederos que aquí estudiamos (Ver Gráficos 1, 6 y 9), una gran diversidad de materiales, propias de las áreas de eliminación de desechos urbanos de carácter doméstico, y con unos porcentajes similares en cierta medida, aspecto que evidenciaría, - puesto que dos de los vertederos pertenecen a la etapa de la Legio VII y en los dos restantes, de cronología más amplia desde el punto de vista de su formación, nos hemos ceñido a la época de esta misma unidad militar-, algunas tendencias propias del consumo de este cuerpo legionario. A todo ello es preciso añadir que en algunos casos estas diferentes áreas de vertidos presentan una cronología relativamente próxima y en algunos decenios concretos pueden resultar coincidentes, si bien el vertedero de la C/Maestro Copín presenta una génesis rápida, a la vez que una importante potencia material, mientras que en los aquí estudiados el ritmo de la deposición resulta ser más dilatado.

Ahora bien, el principal factor diferenciador en la investigación de este primer vertedero legionense con respecto al resto, es el planteamiento de un estudio de la totalidad de los distintos tipos de materiales hallados, independientemente de su entidad cuantitativa, con el fin de obtener una visión lo más completa posible de una etapa bien determinada, pues como hemos comentado, la formación de esta área de vertidos tendría lugar en un breve período de tiempo y, por tanto, los materiales se datarían en un lapso cronológico relativamente reducido y preciso, convergiendo en el segundo y tercer cuartos del siglo II d. C.

En efecto, el conjunto de material cerámico, en sus especies más significativas, como la terra sigillata, la cerámica de peredes finas, así como lucernas y ánforas, presenta una evidente uniformidad desde diferentes puntos de vista, no únicamente el cronológico, sino también de procedencia y manifestación de determinados hábitos de consumo.

Así, la terra sigillata corresponde en su totalidad a producciones hispánicas, mostrando los rasgos característicos, técnicos, morfológicos y decorativos, que indican una procedencia de los alfares tritienses, en una época de esplendor de su producción (Fig. 23). Un aspecto sumamente relevante que nos ha ofrecido este conjunto de recipientes de terra sigillata es la documentación de un número importante de marcas de alfarero que confirman su origen riojano y especialmente un conjunto de veinte marcas de lectura $O F \cdot F A \cdot A E$, correspondientes a un alfarero inédito, que consideramos en un primer momento de exclusiva presencia en Legio, planteando diversas hipótesis al respecto (Fernández Freile, 2001: 89-115), aunque posteriormente hemos constatado la existencia de otro ejemplar en Ercavica (Sánchez- Lafuente, 1990: 336).

Este importante conjunto de estampillas contrasta con la representación mínima de las mismas en los tres vertederos que estudiamos. Ello podría explicarse por la diferente tipología de estas últimas áreas de vertidos, en las que se han producido remociones del terreno y depósitos irregulares que, a la vez que han alterado la estratigrafía, han ocasionado un índice de fragmentación mucho mayor en los recipientes cerámicos.

La homogeneidad cronológica de los materiales cerámicos de este vertedero viene corroborada asimismo por el elenco de cerámica de paredes finas (Fig. 24) procedente en su totalidad del taller zamorano de Melgar de Tera, centro abastecedor del campamento de Petavonium y cuyas manufacturas se extienden progresivamente por todo el territorio noroeste peninsular.

Partiendo de esta marcada definición de los centros de abastecimiento de los principales productos cerámicos, podemos inferir la existencia en este momento en Legio de una 
serie de redes de distribución de manufacturas de origen importado claramente establecidas y consolidadas. Ello indica un importante desarrollo urbano de este asentamiento militar, que representa un punto esencial en la recepción y posible redistribución de estas producciones, en función de su decisivo papel político-estratégico en el norte peninsular.

Paralelamente a estos productos importados, se añade un voluminoso y variado conjunto de cerámicas comunes (Fig. 25), y una escasa pero representativa muestra de lucernas y ánforas (Fig. 26).

Además del material cerámico vascular, hay que señalar la existencia en el propio ámbito legionense de talleres locales destinados al aprovisionamiento de determinados productos propios de un contexto militar, como los materiales constructivos latericios sellados por la legión, cuyo lugar de fabricación no se encuentra aún ubicado con exactitud, o los elementos metálicos, generalmente integrantes de piezas de armamento, cuyos talleres de fabricación en este último caso se han localizado en la zona sur del recinto campamental, aunque su representación cuantitativa es sumamente reducida, debido a los procesos de refundición y reciclaje que conlleva la dificultad de abastecimiento de este material en acantonamientos castrenses.

Del mismo modo puede atribuirse un origen local o regional al numeroso conjunto de cerámica común, en el que se incluyen, además de los recipientes de cocina, algunas piezas que se han considerado características de ámbitos militares, en función de su importante presencia en otros campamentos contemporáneos en diferentes áreas del Imperio y en Hispania, como el de Petavonium (Carretero: 2002: 359-368). Entre estos últimos ejemplares adscritos a las tendencias del consumo cerámico militar cabe destacar las jarras de boca estrecha con gollete, los platos de borde sencillo con engobe rojo o los cuencos troncocónicos de borde vuelto, así como los morteros, que constituyen un elemento importante en la impedimenta del soldado romano.

Dada la variedad y singularidad de este conjunto cerámico hemos considerado interesante para facilitar una primera visión, aunque de ningún modo exhaustiva, incluir al final de este capítulo, la representación gráfica de algunas de las producciones cerámicas más significativas de este vertedero, como hemos ido señalando (Figs. 23-26), aunque en el capítulo IV de este trabajo, dedicado al estudio de materiales, haremos ya referencia detallada al texto e imágenes de la publicación.

En cuanto a los restos de material vítreo, aunque se registran variados tipos morfológicos y fragmentos de piezas con representación de motivos decorativos e inscripciones ${ }^{69}$, hay que destacar su escasa proporción cuantitativa, prácticamente irrelevante respecto al conjunto total. En ello es preciso valorar la importancia de los procesos de refundición y reutilización que, al igual que otros materiales como el ya citado utillaje metáli$\mathrm{co}$, experimentan los objetos de vidrio, aspecto que constatan investigadores como Isings (1957: 6) o Forbes (1966: 182), con lo cual, su presencia en los contextos de vertidos no resulta en absoluto representativa del nivel de utilización de estos materiales. Con todo, esta reducida muestra de fragmentos de vidrio, además de aportar una cronología coincidente con el resto de materiales del vertedero, nos permite conocer algunas pautas en los hábitos socio-económicos de la población legionense en este momento, al igual que otras características del conjunto, como el predominio de los recipientes de almacenamiento y transporte, el sencillo servicio de mesa y algunos elementos constructivos,

$69 \mathrm{Vid}$. un análisis individualizado de este material procedente del vertedero en FERNÁNDEZ FREILE, $1999 \mathrm{~b}$. 
detectándose una significativa ausencia de objetos de lujo u ornamentales, habitualmente abundantes en los yacimientos arqueológicos de esta etapa altoimperial.

En este sentido, el paralelo más cercano se encuentra en el material vítreo del campamento de Petavonium, objeto de un estudio monográfico (Martínez García, 1999), exceptuando la proporción considerablemente mayor de vidrio hallado en este recinto castrense, así como el contexto, ya que procede en su mayor parte de diversas edificaciones de la amplia superficie excavada. Por lo demás, la tipología de los recipientes presenta claras similitudes con los legionenses, especialmente en los datados en el segundo momento de ocupación del campamento, a partir de la segunda mitad del siglo I d. C. en que se documentan esencialmente ejemplares de servicio de mesa en tonos azul verdoso, con carácter más funcional. En este momento se hacen mucho más escasos los objetos decorativos y de adorno personal (piezas realizadas con la técnica millefiori, ungüentarios o numerosas cuentas de pasta vítrea), más propios de la primera etapa de este asentamiento militar y que como hemos señalado, no se encuentran en la reducida muestra de vidrio de este vertedero leonés.

Así, esta preponderancia de ejemplares de uso cotidiano y marcadamente funcional, carentes de todo matiz suntuario está en consonancia con las tendencias de la sobriedad de los ámbitos militares -en los que además se emplean esencialmente manufacturas cerámicas-, a la vez que permite plantear que se trate en su mayor parte de producciones de importación de carácter esporádico. De hecho, no se ha documentado la existencia de talleres de fabricación de vidrio en las proximidades de estos asentamientos militares ${ }^{70}$. Únicamente se tiene constancia de la presencia de un pequeño taller ubicado en la villa romana de El Soldán (Santa Colomba de Somoza, León), pero cuya infraestructura y nivel de producción (VV.AA. 1995: 281) hacen difícil pensar en una distribución regular a otros asentamientos castrenses como Legio, que recurrirían a la importación de estas manufacturas.

De singular importancia resultan siempre en los contextos arqueológicos los hallazgos numismáticos exhumados, sin embargo, en este caso su reducido número (seis ejemplares), y sobre todo el muy deficiente estado de conservación de este numerario de bronce, no nos ha permitido lamentablemente obtener datos concretos en su estudio como peso, módulos o cuños, sino únicamente retazos de algunos tipos y leyendas, que no contribuyen a establecer cronologías concluyentes, si exceptuamos un as de Antonino Pío con el anverso identificable. Con todo, hemos de reseñar que este aspecto característico de los testimonios numismáticos, en cuanto a su valor como portadores de dataciones absolutas ha sido progresivamente revisado en el actual estado de la investigación, en función de los diferentes tipos de yacimientos y numerosos condicionantes que contribuyen a matizar y precisar esta, hasta hace poco decisiva, aportación cronológica de los restos monetales.

En este caso hemos de tener en cuenta además la particular significación de este material en los vertederos, siempre escaso lógicamente, que presenta una especial problemática, ya que su posición estratigráfica requiere de una profunda investigación y un extremo cuidado en su interpretación para poder obtener no únicamente conclusiones cronológicas, sino también información sobre su significado (moneda perdida

70 Exceptuando el ya citado situado en las inmediaciones del campamento de Herrera de Pisuerga (Palencia), orientado fundamentalmente al abastecimiento local. Igualmente, los restos de escorias de fundición de este material halladas en Petavonium, permiten suponer la existencia de algún espacio destinado al reciclaje y fabricación de objetos vítreos para el campamento. 
en determinadas épocas, parte de la circulación monetaria del momento en que se producen algunos niveles de vertido, etc...) todo ello en el contexto de la formación, características, ubicación y amplitud cronológica de los vertederos urbanos.

Aún así, los hallazgos numismáticos de mayor volumen y procedentes de otros contextos, adquieren especial relevancia en los enclaves militares, viniendo a considerarse por los principales investigadores (García- Bellido: 1996: 104) junto con la terra sigillata, un excepcional material guía para definir fechas de asentamiento de los diversos cuerpos legionarios, datación de abandono de estos establecimientos, así como diferentes tipos y factores que determinan la circulación del numerario en estos ámbitos, todo ello basado en el estudio del caso paradigmático de los campamentos del limes germánico. En efecto, la moneda desempeña un papel fundamental en los emplazamientos castrenses, como medio de estipendio a las tropas y como elemento de intercambio con los núcleos civiles circundantes -cannabae y vici-, determinando en cada caso necesidades y respuestas específicas que influyen de manera determinante en los cambios y procesos que se producen en la política monetaria altoimperial. Todo ello tiene su reflejo en la circulación de moneda en las diferentes áreas de acantonamiento de tropas de las distintas regiones del Imperio, como podemos ya constatar también en Hispania, a la luz de recientes investigaciones de conjunto (García - Bellido (coord.), 2006), sobre el abastecimiento y circulación de numerario en los campamentos romanos hispanos.

En el conjunto de materiales recuperados en los vertederos urbanos que son receptáculo de residuos de carácter doméstico, se encuentra indefectiblemente una importante proporción de restos faunísticos, conjunto de materiales que ha recibido hasta épocas recientes una escasa importancia en la investigación arqueológica en los contextos romanos, en comparación a los diversos restos manufacturados. En efecto, éstos últimos ofrecen cronologías definidas, a la vez que pautas para determinar puntos de fabricación y redes de distribución y comercialización, sin obviar datos relevantes en cuanto a ciertos rasgos en el consumo de estos materiales que, como ya hemos señalado, permiten diferenciar a partir del predominio de determinadas producciones cerámicas por ejemplo, los vertederos localizados en ambientes militares.

Por el contrario, puede apreciarse la especial importancia que se otorga a los restos de fauna en estudios de vertederos franceses, tanto de carácter doméstico, como público o artesanal, llegando a plantearse la cuestión, en algunos estudios de conjunto, si los desechos faunísticos se depositan en vertederos especiales y estudiando su distribución en los espacios urbanos (Ballet et alii, 2003).

Igualmente, en los trabajos científicos que inician la metodología de estudio de los vertederos en Hispania (T'EDA, 1989), se realiza un estudio aparte de los restos faunísticos hallados en este vertedero de Tarraco.

Siguiendo este modelo, hemos incluído en nuestro trabajo como apéndice, el estudio de la fauna hallada en el vertedero, realizado por especialistas en la materia (Fernández y Fuertes), con el fin de valorar los datos obtenidos en el contexto general.

El valor del estudio científico de los restos de fauna procedentes de un vertedero radica -además de la información para la reconstrucción paleozoológica y paleoecológica de una determinada zona-, en proporcionar datos fiables en los hábitos de consumo en la alimentación del enclave urbano, en este caso un asentamiento militar ${ }^{71}$. La cuestión no

71 En este sentido, estos datos contribuirían a complementar la información tratada en determinados estudios sobre la dieta de los legionarios romanos en provincias, como los de MENÉNDEZ ARGÜIN (2002) y COSTA Y CASAL (2009). 
es baladí, ya que además de las especies autóctonas que configuran la mayor parte de la dieta (macromamíferos de carácter doméstico), se han encontrado testimonios del consumo de especies exógenas, fundamentalmente restos malacológicos marinos, especialmente ostras, en mucha menor proporción, pero sumamente significativos, ya que están indicando la existencia de rutas de comercio a larga distancia para abastecerse de estos productos de difícil conservación y a los que cabe atribuir un matiz de reconocimiento social, como productos de lujo, al igual que sucedería con otros elementos de carácter importado, como salazones o determinados tipos de vino, según demuestra la presencia de restos anfóricos y otros envases de transporte cerámicos.

En este aspecto, cabe destacar la correlación existente entre algunos hábitos de la alimentación castrense y la presencia en los vertederos de determinados recipientes cerámicos, empleados no sólo en el transporte, sino en los procesos culinarios, en el servicio de mesa o en el almacenamiento de distintas sustancias alimenticias. Es así como el estudio de los restos faunísticos contribuye a complementar en muchas ocasiones la información que proporciona el resto de los materiales de un vertedero, influyendo incluso en una datación más precisa.

Además de los datos sobre la generalidad de hábitos de alimentación, se identifican en el vertedero algunos restos de especies (ciervo, corzo, jabalí, conejo) cuyo número es muy reducido, aunque complementarían en cierto grado la dieta alimenticia. Se trata de restos procedentes de prácticas cinegéticas, que constituirían actividades de tipo socioeconómico, con connotaciones de prestigio social, y que junto a la importación de especies exógenas, son propias de ámbitos militares y en general de núcleos de población ya plenamente "romanizados".

Con todo ello, el estudio de este vertedero legionense constituye un valioso punto de partida, especialmente a la hora de acometer el presente trabajo, puesto que además de las peculiaridades ya comentadas que hacen de este área de vertidos un yacimiento sumamente completo en lo que respecta a las aportaciones de este tipo de contextos, hemos de hacer hincapié en el estudio de los diferentes tipos de materiales exhumados, que han permitido determinar un lapso cronológico muy preciso en la etapa de uso del vertedero. Por otra parte, este análisis de la totalidad de los materiales nos presenta un panorama más completo y diversificado de múltiples aspectos de la vida castrense que complementan aquellos que aportan los materiales guía, especialmente los distintos tipos cerámicos, en los que centraremos el presente trabajo.

De esta manera, a partir de los materiales arrojados al vertedero de la C/Maestro Copín c/v San Salvador del Nido, se ponen de manifiesto numerosas cuestiones sumamente indicativas para el conocimiento del modo de vida en un asentamiento legionario, incluyendo la propia planificación urbanística del área extramuros del recinto, y revelando hábitos específicos de consumo de determinados productos, así como su sistema de abastecimiento y distribución a lo largo de un determinado período de tiempo, con claras implicaciones en el ámbito político, socioeconómico y cultural, respondiendo claramente a las pautas de un contexto militar, que marca en este caso la presencia de la Legio VII Gemina en su campamento de León. 

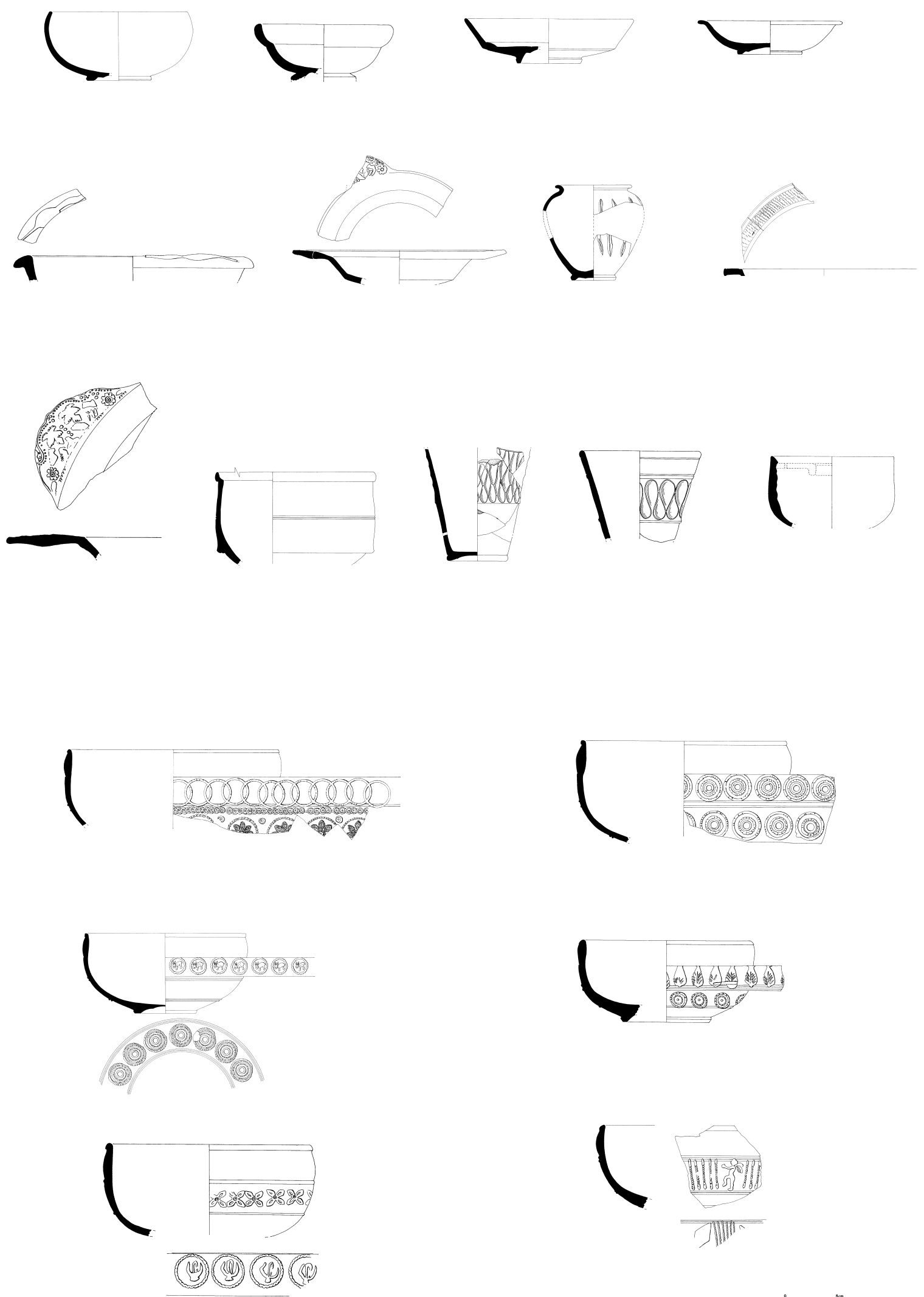

FIG. 23 - PRODUCCIONES DE TSH 

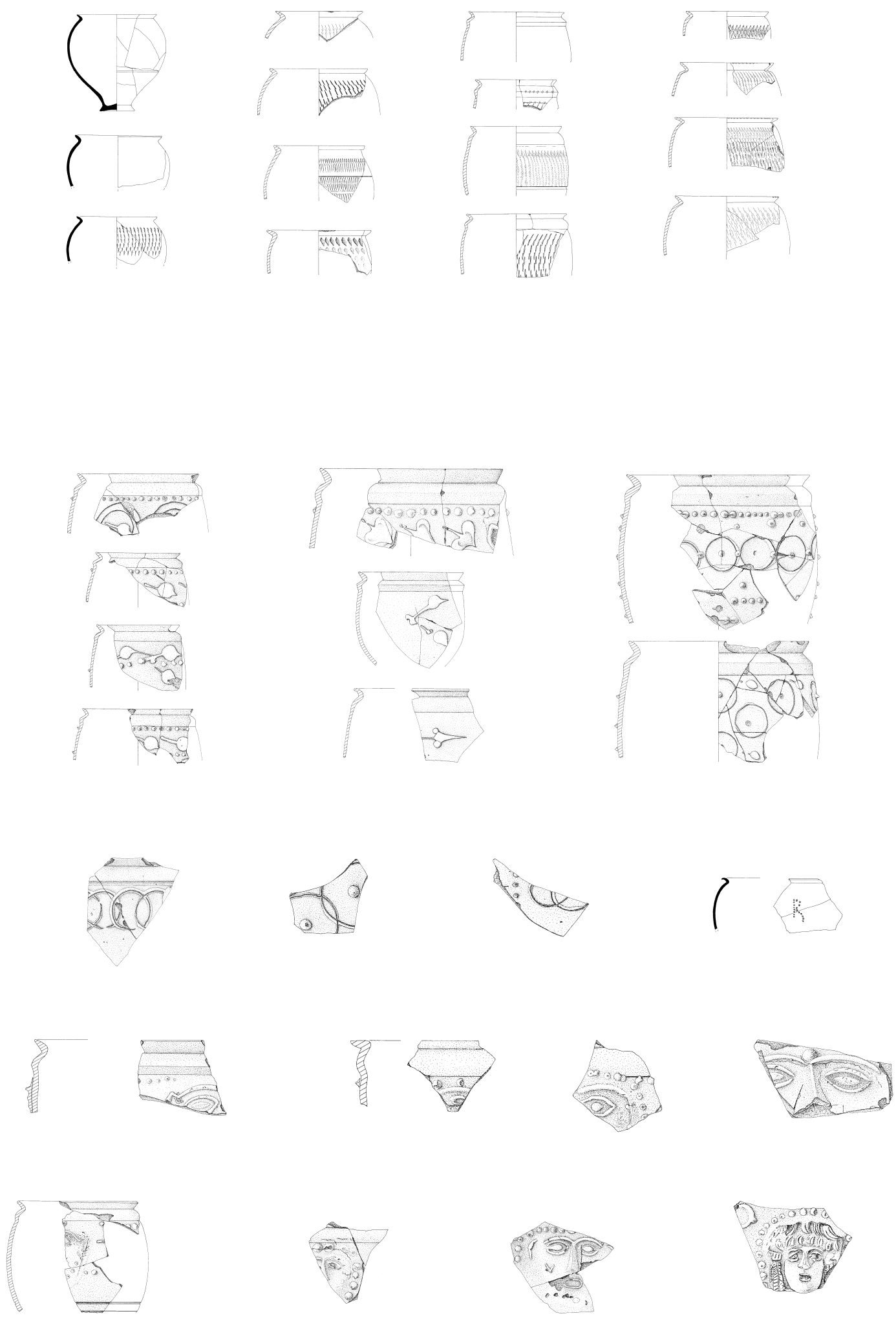

FIG. 24 - CERÁMICA DE PAREDES FINAS 

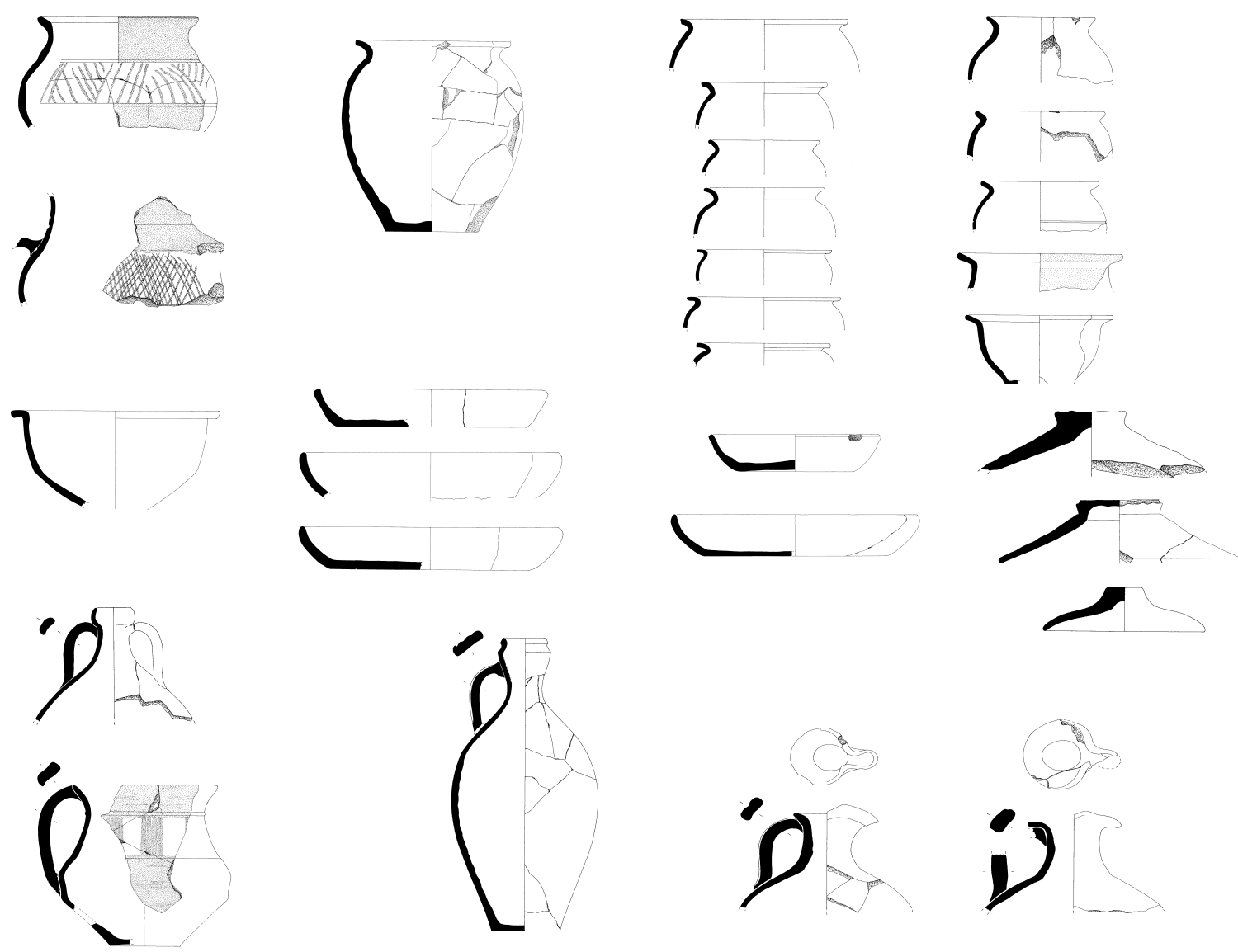

'D
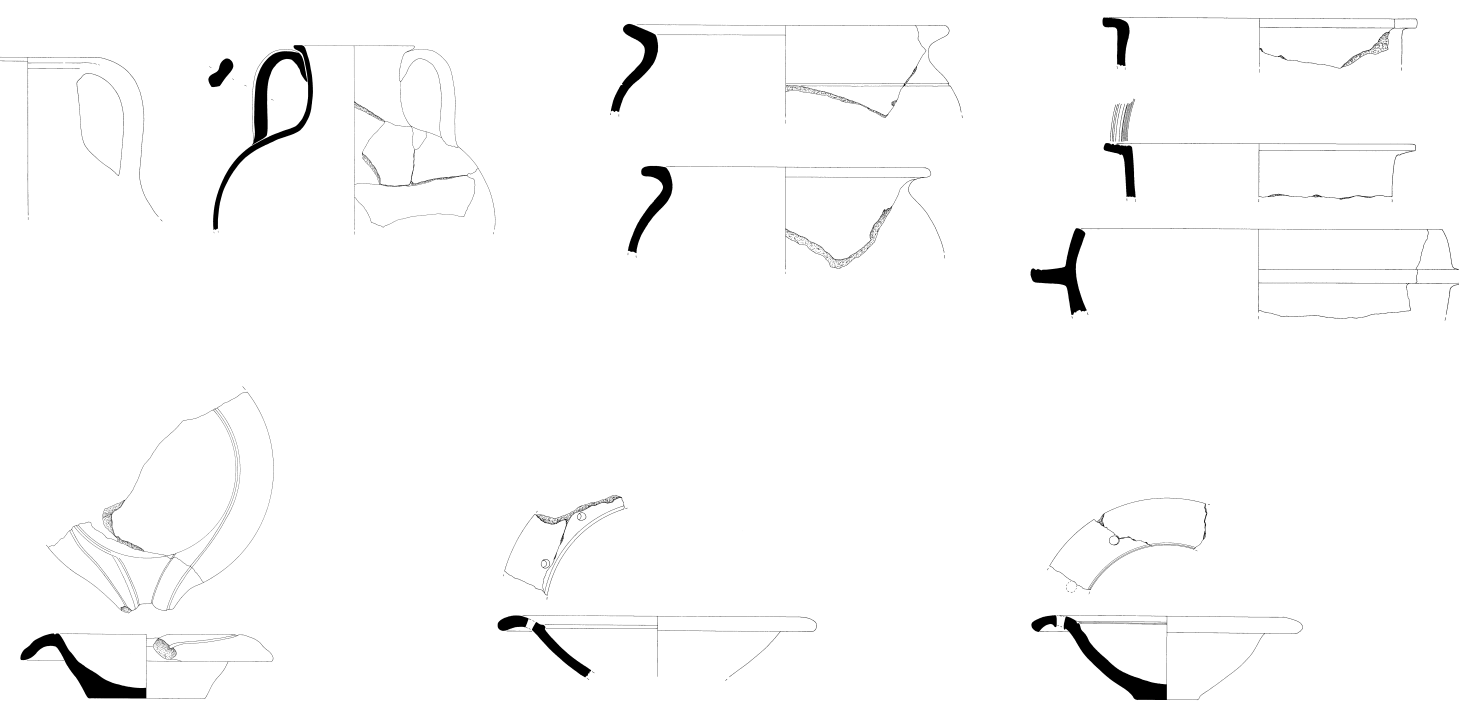

FIG. 25 - CERÁMICA COMÚN Y MORTEROS 

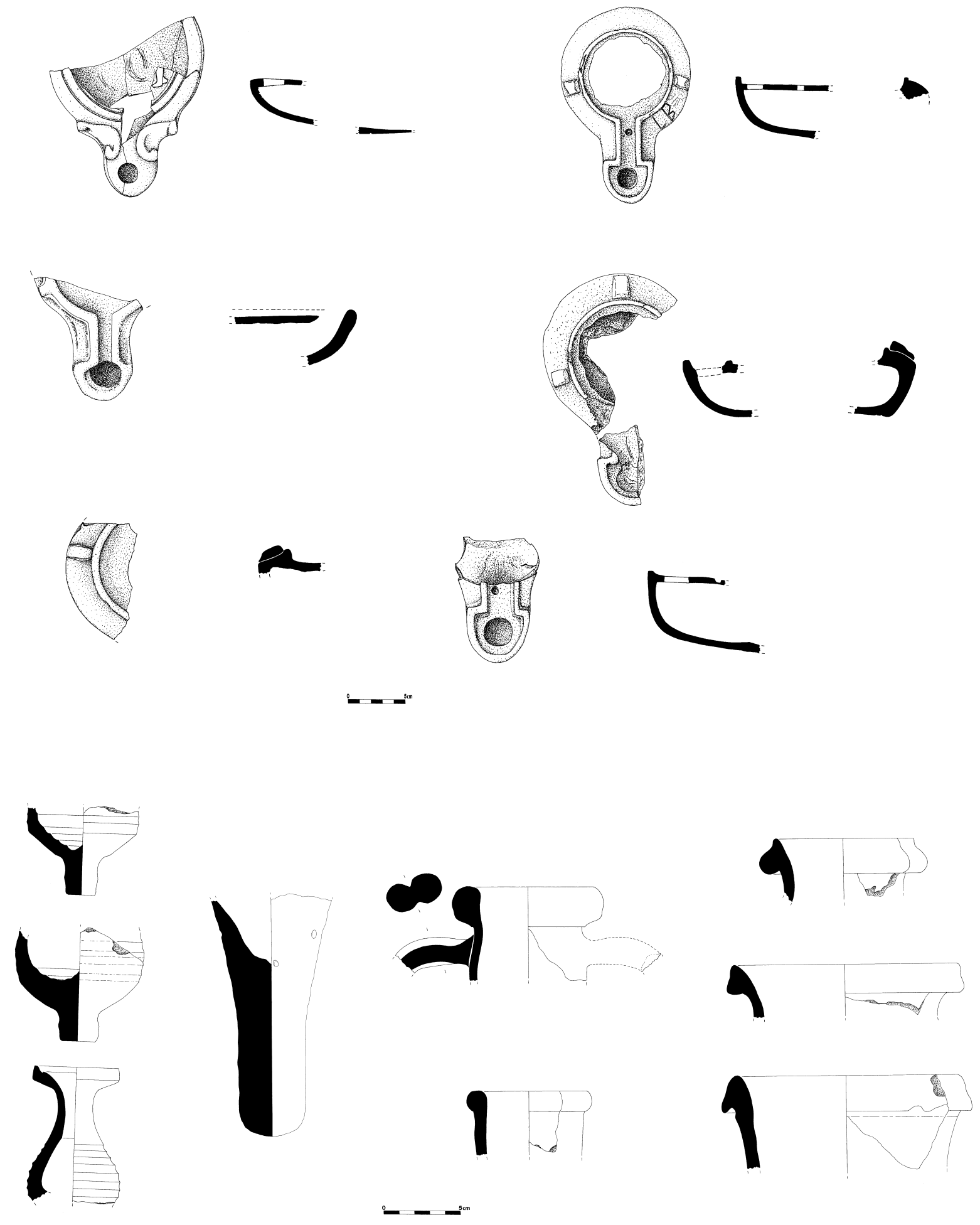

FIG. 26 - LUCERNAS Y ÁNFORAS 
Con el fin de completar la contextualización del entorno que estudiamos, hemos considerado necesaria la búsqueda de información sobre intervenciones arqueológicas llevadas a cabo en esta zona meridional del espacio extramuros, generalmente de escasa aportación arqueológica y que han sido objeto de escasa o nula difusión. Ello contrasta con otras áreas extramuros, como se pone de manifiesto en el capítulo introductorio, que cuentan con una amplia bibliografía que nos ha permitido la descripción de algunas estructuras situadas extramuros de especial relevancia, como el anfiteatro, las necrópolis y otros elementos ubicados en el vicus y las cannabae.

Ello ha determinado la obligada consulta de un buen número de informes inéditos sobre estas actuaciones -que se recogen en uno de los apéndices finales de este trabajo- cuyos datos han contribuido a definir las características y aspectos funcionales de las áreas próximas a los contextos objeto de nuestro estudio.

Cabe destacar en este sentido los resultados de la excavación en la Plaza de San Salvador del Nido, 2 (Talactor, 2001), cuya fase romana viene a constituir una extensión del vertedero estudiado situado en la C/Maestro Copín c/v San Salvador del Nido, apreciándose la coincidencia en la disposición los niveles estratigráficos y en el conjunto de materiales hallados, muy abundantes, homogéneos y de gran calidad. A todo ello se añade la constatación de "su formación a base de pequeños vertidos realizados de forma sucesiva y rápida", todo lo cual confirmaría la tipología y cronología del gran vertedero adyacente.

Una disposición muy similar presenta la etapa romana de la intervención en la cercana zona de la C/San Pedro c/v C / Panaderos (Talactor, 2001) constituyendo también un área de vertidos, con niveles de cenizas y arcillas en que aparecen materiales en todo similares a los dos contextos anteriores, mientras que en los estratos arenosos se localizan abundantes restos constructivos, probablemente procedentes de reformas o remociones de alguna de las estructuras del recinto castrense.

Con estas aportaciones podemos constatar la existencia de una extensa zona situada en el ángulo surocidental del campamento en que se ubican importantes áreas de vertidos, aspecto que quizá haya de relacionarse con la irregular configuración del terreno en este sector, actuando los vertederos como agente regulador, uniformizando la topografía.

Únicamente hemos de hacer referencia, en este entorno tan homogéneo, al factor diferencial respecto al vertedero estudiado, que supone la presencia en estos vertederos inéditos de importantes niveles calificados como cenizales. Ello ha hecho plantear a los arqueólogos que realizaron estas excavaciones que en la génesis de estos contextos pudieron intervenir de forma importante los vertidos procedentes de estructuras en las que se llevaran a cabo actividades de combustión, como podrían ser los cercanos complejos termales, tanto las grandes termas del interior del campamento, como el pequeño edificio balneario extramuros de San Lorenzo.

Por otra parte, la ausencia de otras estructuras constructivas en el área en que se ubican el depósito de San Pedro y las termas de San Lorenzo, que constituirían así edificaciones aisladas respecto a la zona de ocupación de la cannaba, según señalan los directores de sendas excavaciones (Vidal y Marcos Contreras, 2002-2003: 130-131) ha sido corroborada en varias excavaciones realizadas en este espacio, como las de la C/San Pedro c/v Ramón Cañas del Río (Talactor S. L. 1997) o la C/San Lorenzo 6 y 8 (Talactor S. L. 2003), en las cuales no se ha documentado ninguna evidencia de restos edilicios en el registro estratigráfico de época romana. 
A diferencia de esta zona oriental y suroriental del espacio extramuros del campamento, situada en las inmediaciones de la porta principalis sinistra, ocupada fundamentalmente por áreas de vertidos, en el extremo opuesto, en el entorno cercano al lugar que ocuparía la porta principalis dextra, donde se localiza otro de los importantes vertederos que aquí estudiamos (C/ Pilotos Regueral, 4) se ha puesto de manifiesto la coexistencia de estas zonas de vertidos con estructuras de ocupación. Así, en los informes de dos importantes intervenciones efectuadas en solares contiguos, el Centro Cultural Pallarés (Miguel y García Marcos, 1994) y el Edificio Botines (García Marcos y Campomanes, 1995), que presentan idéntica disposición estratigráfica y materiales similares a los del vertedero, se han localizado restos de pavimentos y estructuras con un claro uso ocupacional que puede ponerse en relación con edificaciones pertenecientes a las cannabae legionarias, en lo que constituiría su sector más próximo al recinto amurallado, si bien no conocemos aún con exactitud la extensión y delimitación exactas de este asentamiento civil.

Todo ello sugiere un cierto nivel de planificación urbanística extensiva al espacio extramuros del campamento, que implica la delimitación de áreas para usos determinados (vertederos, emplazamiento de termas suburbanas, ubicación de estructuras de ocupación...), aspecto acorde con la precisión y regularidad en la organización urbana de los recintos castrenses romanos.

Por lo demás, el resto de los informes consultados no nos ha aportado datos relevantes, ya que en muchos casos los restos materiales son exiguos o bien las áreas excavadas no alcanzan estratigráficamente la etapa romana, como en C/Misericordia c/v C/Santa Cruz (Fernández Ordás, 2007), C/Tarifa, 9 (Rodríguez González, 2004), o C/Rúa 30 (Talactor, 2009), a lo que hemos de añadir que, especialmente los informes de intervenciones intramuros que han sacado a la luz las principales construcciones campamentales, ubicadas en el área norte ya han sido objeto de estudio y/o publicación, integrando buena parte de la bibliografía consultada. 
IV.- ESTUDIO DE LOS MATERIALES CERÁMICOS 


\section{A) DEPÓSITO-VERTEDERO DE “SAN PEDRO”}

En el contexto de esta construcción singular a modo de depósito, amortizada ya tempranamente como área de vertidos, se ha documentado un extenso volumen de materiales cerámicos, destacando además su buen estado de conservación, que se cifra en un total de 11.127 piezas, de las cuales 9.530 corresponden a materiales cerámicos de época romana ${ }^{72}$. El resto lo componen materiales de las etapas medieval y postmedieval, que se encuentran en los primeros niveles de colmatación del depósito. Por lo que respecta al conjunto total de restos romanos, se han hallado, además de la cerámica, que representa el 92\% del total, escasos restos de material constructivo, así como de vidrio y metales, que suponen una mínima proporción, a la vez que un considerable número de restos faunísticos (5\%) (Gráfico 1) que, al igual que en los demás vertederos analizados, indican que se trata de áreas de recepción de vertidos procedentes de las actividades de la vida cotidiana de la población legionense en diferentes momentos.

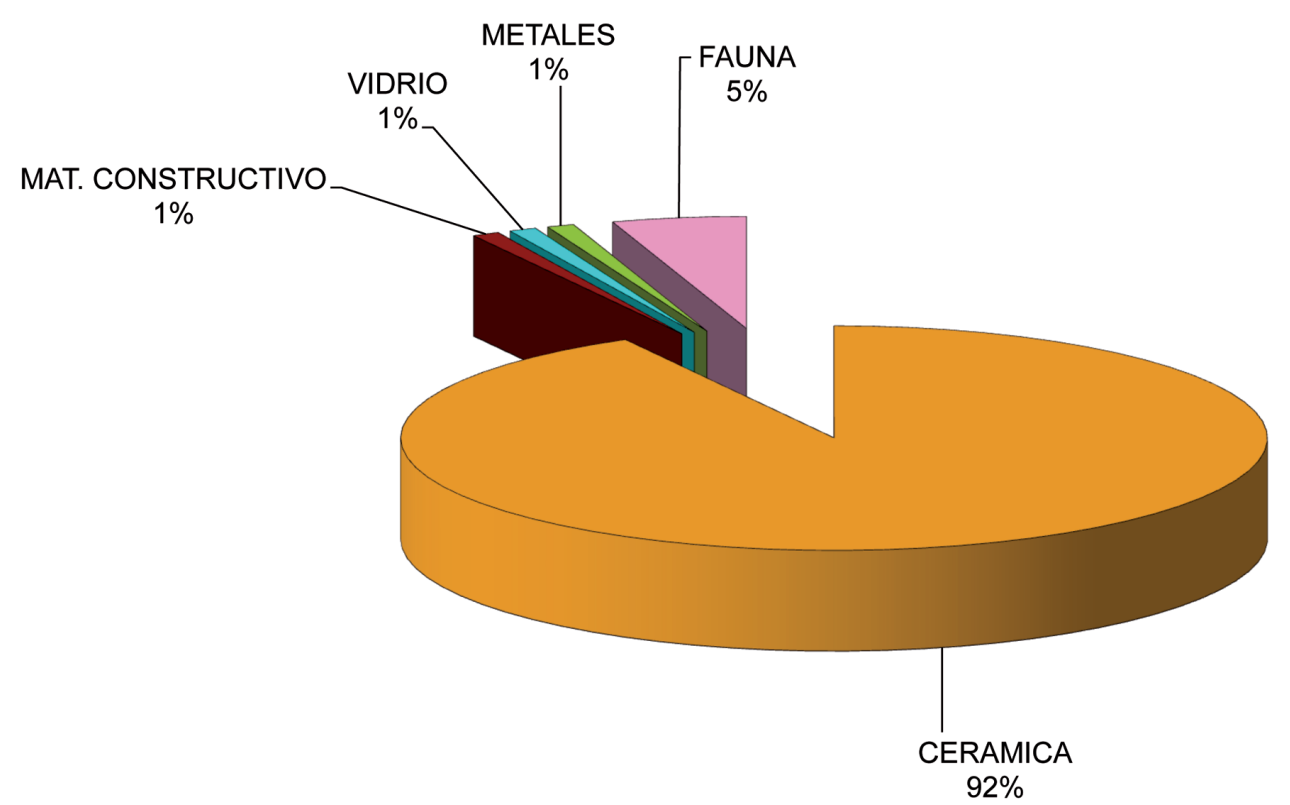

GRÁFICO 1: Categorías de materiales hallados en el vertedero de "San Pedro"

En lo que respecta a nuestro campo de estudio, resulta de gran valor el conjunto de terra sigillata hispánica -aunque también contamos con un volumen significativo de terra sigillata itálica y gálica que no entran en nuestro marco de investigación cronológico- que presenta una excelente calidad en la fabricación, con indudable atribución en su mayor parte a los talleres riojanos del complejo de Tritium Magallum o a algunas de sus sucursales más cercanas. Así, tanto los ejemplares lisos como los decorados y la presencia de ejemplares magníficamente conservados de terra sigillata hispánica tardía, nos ofrecen una importante información cronológica sobre las diferentes fases funcionales de este contexto.

72 En este espectro cuantitativo hemos localizado, siguiendo el registro estratigráfico, 5297 piezas correspondientes a la segunda etapa de ocupación del cuerpo legionario que estudiamos. Únicamente hemos considerado el volumen de terra sigillata hispánica, datada en su práctica totalidad a partir de la etapa vespasianea respecto al conjunto total de ejemplares. 
Mención especial merece el grupo de cerámicas comunes, tanto por su significación cuantitativa, con un porcentaje de un $75 \%$, como por su buen estado de conservación y la gran calidad de las piezas, que no deja de resultar un tanto inusual en este tipo de materiales.

Otro tipo de material de gran valor no únicamente cronológico, sino también como elemento indicativo de las redes de comercialización y abastecimiento, además de otras implicaciones, especialmente en el ámbito militar, son las ánforas. Aunque bien representadas en este contexto, su valor arqueológico viene proporcionado principalmente por su variedad formal, ya que al tratarse de contenedores de muy diversos productos, nos permiten definir y atribuir puntos de procedencia de estos productos, consumo de los mismos y redes de distribución y transporte.

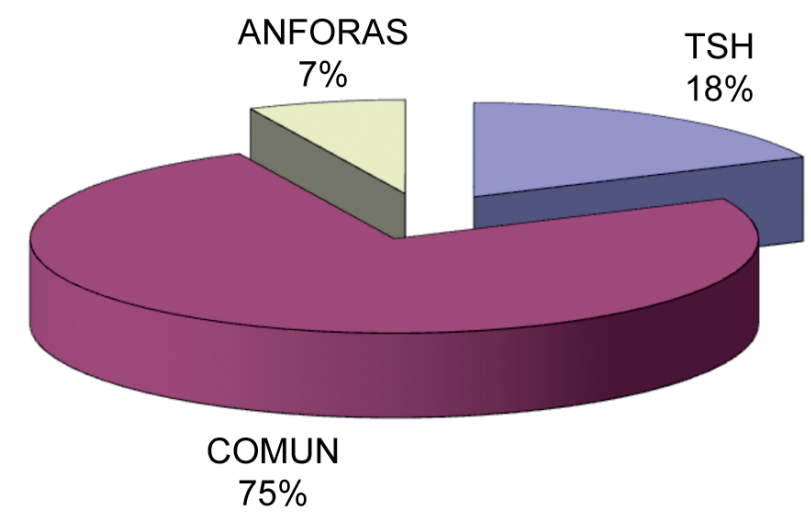

GRÁFICO 2: Especies cerámicas estudiadas en este conjunto del vertedero de "San Pedro"

\section{1.-TERRA SIGILLATA HISPÁNICA}

La terra sigillata hispánica constituye el material guía por excelencia, como en cualquier yacimiento romano, ofreciendo las directrices cronológicas fundamentales que pueden verse precisadas posteriormente por el análisis del resto de familias cerámicas y otros tipos de materiales.

Para las fases inmediatamente anteriores, este yacimiento ha deparado también un importante conjunto de piezas de terra sigillata itálica y gálica, objeto de estudio por parte de otros investigadores.

En cuanto a las producciones hispánicas, destaca su fabricación con pastas de buena calidad, conseguidas con el empleo de arcillas calcáreas muy decantadas en las que se aprecian muy finos desgrasantes de naturaleza cuarcítica o micácea, proporcionando así unas secciones de fractura bastante rectilíneas. El color varía de los tonos anaranjados a los rojizos, en una gama no muy amplia, predominando estos últimos, y el revestimiento, de textura un tanto granulosa y buena adherencia, presenta una tonalidad anaranjada oscura, más o menos brillante, dependiendo también del estado de conservación de las piezas.

Con todo ello, podemos afirmar que el conjunto de ejemplares de TSH proceden en su práctica totalidad del complejo alfarero riojano de Tritium Magallum, principal centro productor y abastecedor de estas manufacturas para toda la Península Ibérica, no únicamente en la zona norte sino incluso en la Bética y la Mauritania Tingitana, superando con creces la difusión de los talleres de Andújar, el otro gran centro productor de la Península. 
A esta dicotomía hemos de añadir, a la luz de las últimas investigaciones, como hemos referido más detalladamente en el capítulo dedicado a la metodología, la existencia de un gran número de talleres de carácter secundario, regional y / o local, que imitan la producción de los grandes centros, y que proliferan sobre todo en el área septentrional.

Aún así, contamos ya en el solar leonés con otros importantes conjuntos de TSH de origen riojano, aprovisionamiento que se encontraría facilitado por el itinerario de la vía de comunicación Italia in Hispanias, que, pasando por Tricio, desemboca precisamente en Legio.

Respecto al aprovisionamiento de indudable origen tritiense, la realización de análisis arqueométricos, aspecto que tratamos asimismo en el apartado metodológico, además de corroborar esta procedencia, ha puesto de manifiesto la primacía de algunos centros dentro del gran complejo riojano en el abastecimiento al asentamiento leonés, a lo que haremos referencia en la correspondiente descripción de piezas.

Cuantitativamente, la TSH de este vertedero constituye un $19 \%$ del total del material cerámico, predominando los ejemplares lisos (1147 fragmentos) sobre los decorados (663 fragmentos), aspecto que suele ser habitual en la mayor parte de los yacimientos romanos peninsulares.

Por otra parte, un rasgo importante a destacar es, independientemente de su buena calidad original, el deficiente estado de conservación de las piezas de TSH en general, con pérdida del revestimiento y apariencia muy degradada, aunque contamos con ejemplares que mantienen los rasgos originales de la sigillata tritiense. De la misma manera, hemos de destacar la existencia de un elevado índice de fragmentación, que dificulta enormemente la reintegración de piezas completas y la identificación de muchas formas, así como la localización de marcas de alfarero.

Desde el punto de vista del contexto, estas características apuntarían hacia el movimiento y traslado de materiales resultado de la acción antrópica o igualmente, nos indicarían que se trata de un vertedero no sellado, sino con vertidos de diferentes etapas, remociones y alteraciones de diverso tipo, todo ello acorde con el dilatado lapso cronológico en que el depósito ha de estar en uso como tal, lo que se desprende de la presencia de un conjunto de terra sigillata hispánica tardía.

1.1.-TSH. Formas lisas (Láms. 1-3)

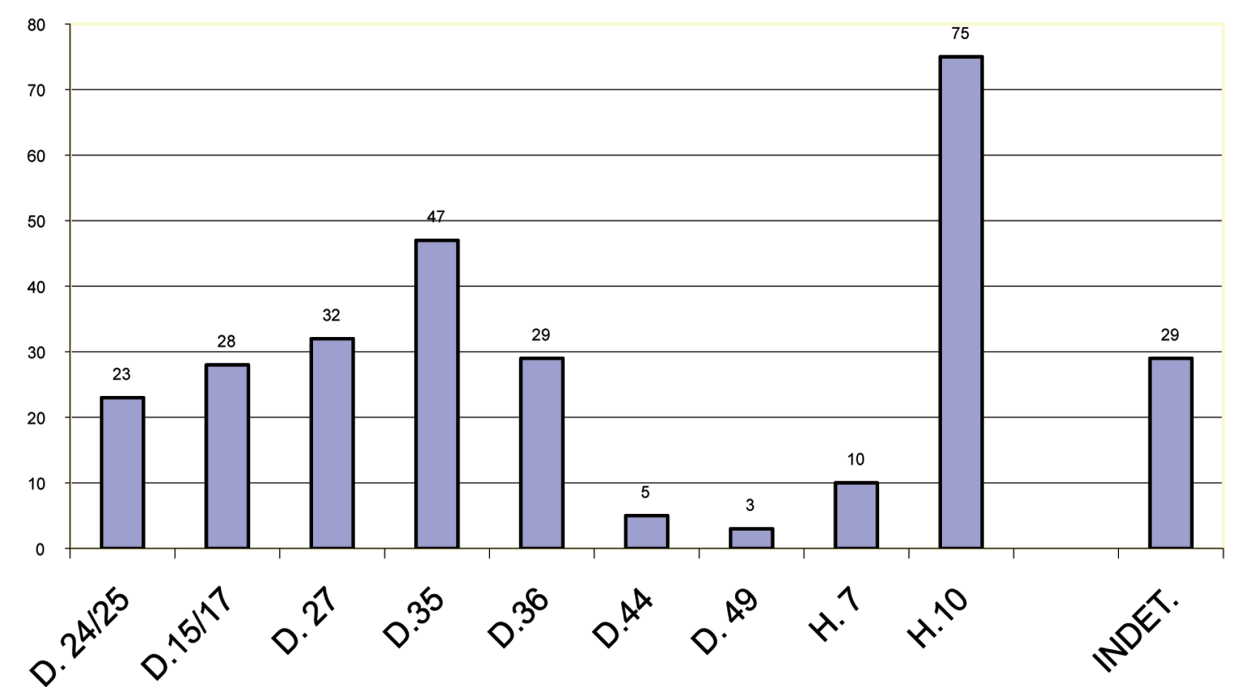

GRÁFICO 3: Formas de TSH Lisa 
Entre los ejemplares lisos mejor conservados se encuentran cuatro fragmentos del cuenco Dragendorff 27 (Lám. 1, no 1-4), todos ellos pertenecientes a la parte superior, pudiéndose apreciar rasgos propios de la evolución de esta forma. Destacan así el labio de la pieza $\mathrm{n}^{\circ} 1$ o la trayectoria tendente a la verticalidad de las molduras en cuarto de círculo, que muestran aún algunos indicios de los precedentes itálicos y sobre todo sudgálicos, situándonos todo ello en un momento temprano de su fabricación, con una cronología atribuible a la mitad de la primera centuria de la Era y, con más precisión, en el tercer tercio, como señala Romero (1985: 193) basándose en los ejemplares de la capa I del yacimiento leonés de Huerña.

Desde el punto de vista estratigráfico se han localizado en su mayor parte en la UE 5, una de las más ricas en producciones cerámicas datadas en época julio-claudia, lo que pone de manifiesto la complejidad ya comentada de la secuencia estratigráfica de este vertedero, con niveles que contienen materiales de distintas etapas con un amplio marco temporal.

Estos ejemplares destacan por su reducidas dimensiones, al igual que en el caso de las tres formas de la copa Drag. 24/ 25 (Lám. 1, n 5, 6, 7), de las que no conservamos la parte inferior ni la base en ninguno de los casos. Presentan una gran heterogeneidad, tanto en la sección del borde como en el baquetón central, teniendo como rasgo común la ausencia de decoración burilada o a ruedecilla en la parte superior. Esta forma, cuya vigencia se extiende desde la mitad del siglo I d. C. hasta principios del siglo II, puede datarse, a tenor de la estratigrafía, en una etapa ya inicial de la época flavia.

En cuanto a los platos (Lám. 1, no 8-11; Lám. 2, n 12), presentan normalmente un estado sumamente fragmentario, sin que hayamos podido reconstruir ninguna forma completa. Aún así, algunos rasgos característicos nos permiten identificar en algunos casos las formas a que pertenecen. Así, el fragmento $\mathrm{n}^{\circ}$ 8, de paredes oblicuas, con labio muy poco marcado y sin moldura interior, presenta una adscripción dudosa, puesto que combina características de las formas Drag. 18 y 15/17, dado que la forma 18 posee paredes curvas y labio muy marcado. Con todo, Mayet recoge algunos ejemplares de paredes oblicuas como típicos de la producción hispánica (1984: 71, Pl. LXI, 53-59), señalando su corto período de producción, que prácticamente se reduciría a la etapa flavia (1984: 72).

La pieza $n^{\circ}$, de pared oblicua, con labio acentuado -rasgo inusual en esta forma-, muestra una moldura interior de unión entre las dos paredes con un perfil poligonal, que se traduce al exterior en una pequeña concavidad. Estas características son propias del plato Drag. 15/17, si bien en función de los rasgos descritos, este ejemplar pertenecería a un momento muy temprano de la producción. Un paso más en la larga evolución tipológico-cronológica que experimenta esta forma subrayada por Mayet, que diferencia cuatro grupos (1984: 72) y por Romero (1985: 188-191), estaría representado por la pieza $\mathrm{n}^{\mathrm{o}} 11$, en la que la moldura interior adquiere ya una forma semicircular abierta, con una acanaladura en el exterior y la pared inferior más perfectamente diferenciada del pie.

En cuanto a la pieza $\mathrm{n}^{\mathrm{o}} 12$, correspondiente a un pie de plato, la escasa superficie conservada no permite incluirlo dentro de una forma determinada. Sin embargo, destaca por poseer un grafito ilegible situado en su zona basal externa, hecho poco frecuente en el conjunto general de las cerámicas que estudiamos, en el que apenas documentamos marcas de ceramista y epigráficas.

Más numerosos y completos son los ejemplares que conservamos del servicio de cuenco y plato Drag. 35 y 36 (Lám. 2, no 13-20), cuyo origen se sitúa en el servicio A de La Graufesenque, creado en época flavia. 
Los cuencos, representados por la pieza $\mathrm{n}^{\circ} 15$, de pequeño tamaño -con $4,5 \mathrm{~cm}$. de diámetro de boca- $\mathrm{y}$ a los que cabe atribuir los fragmentos $\mathrm{n}^{\circ} 17$ y 20, presentan paredes curvas y borde curvo saliente más o menos colgante, típico de la primera fase de la producción, evolucionando hacia la horizontalidad y, como rasgo más característico, la decoración de hojas de agua a la barbotina a lo largo del borde, aspecto que contiene además implicaciones cronológicas, ya que comienza a desaparecer a finales del siglo I d. C.

Similares características, pero con un tamaño muy superior, presentan los platos de la forma Drag. 36, representados por el ejemplar $\mathrm{n}^{\mathrm{o}} 13$, con 16,5 $\mathrm{cm}$. de diámetro de boca, y los fragmentos $n^{\circ} 14,16,18$ y 20. Estos aparecen en el vertedero en menor número que los cuencos, al contrario de lo que sucede con esta proporción en otros yacimientos como Numancia (Romero, 1985: 198) o Petavonium (Carretero, 2000: 378-370).

Con todo ello, estas dos formas se situarían cronológicamente en el último cuarto de la primera centuria, ya que, surgidas poco antes de la época flavia (algunos investigadores proponen como fecha inicial el reinado de Vespasiano), muestran los rasgos típicos de los primeros momentos de la producción.

Un fragmento a destacar en el conjunto de formas lisas es el galbo con decoración facetada de la pieza $n^{\circ} 21$ (Lám. 3), correspondiente a la forma Hispánica 49 en su denominación más actual y comúnmente aceptada, siendo éste el único ejemplar que conservamos de esta forma. Su nomenclatura planteó en su momento una cierta controversia, a partir de los primeros hallazgos de Mezquíriz en los talleres de Bezares en 1961, que recibieron la denominación de Hispánica 48 (1976: 303-304). Posteriormente, en la clasificación de esta misma autora, aparece catalogada ya como Hispánica 49 (Mezquíriz, 1985: 173), tal como actualmente la definimos.

Con todo, hemos de tener en consideración, ya que puede llevar a confusión, a la hora de establecer atribuciones y paralelos, que en algunos estudios pasados de ciertos investigadores no se reconoce aún la existencia de esta forma (Mayet, 1984), y otros siguen manteniendo la antigua denominación de Hispánica 48 en alguna de sus publicaciones (Romero, 1980: 188-193; 1985: 239-232). Sin embargo, en los trabajos más recientes, ya sean guías tipológicas, revisiones o puestas al día sobre la TSH, se han unificado criterios y aparecen ya nomenclatura y morfología de la Hispánica 49 plenamente consolidadas (Beltrán, 1990: 132; Roca y Fernández García (coords.), 1999: 279; Romero, en Roca y Fernández García (coords.), 2005: 190; Fernández García y Roca, en Bernal y Ribera (coords), 2008: 324).

Los rasgos morfológicos de estas singulares piezas presentan una clara uniformidad, constituyendo un tipo perfectamente definido. Se trata de vasos de perfil troncocónico, con pie anular y paredes rectas y oblicuas y borde con labio redondeado. Su pared externa se encuentra dividida en tres registros diferenciados por finas acanaladuras y / o baquetones, con dos bandas lisas -la inferior más ancha- que delimitan un espacio central más amplio en el que se dispone la decoración de facetas, generalmente ovaladas. Este tipo de decoración en facetas rehundidas sigue claramente los modelos de los vasos de vidrio, especialmente los de la forma Isings 21, según ha subrayado Romero (1980: 188-193; 1985: 239-242)73.

73 Hemos de hacer constar que este tipo de decoración no es privativa de esta forma, sino que aparece también, aunque muy esporádicamente, en las formas Hisp. 2, Drag. 30 o Drag. 37, que integrarían el grupo de los denominados "tipos facetados". 
El fragmento que analizamos pertenecería a este registro central decorado, aunque presenta facetas irregulares y muestra importantes similitudes con otra pieza legionense aparecida en el vertedero de la C/Maestro Copín (Fernández Freile, 2003: 63-64, Lám. 27), en el que se localizaron otros tres ejemplares de esta forma (Ibid.: Lám. 28), si bien uno de ellos -el mejor conservado (118/8)- presenta la decoración de facetas más regulares y cuidadas, que parecen indicar una evolución de la forma y un mayor perfeccionamiento en el proceso de fabricación.

En cuanto a la procedencia de la Hisp. 49, se ha constatado su fabricación en los talleres de Tricio, Bezares y Bronchales, aunque las manufacturas riojanas son las predominantes en la mayoría de los contextos en que se encuentran.

De esta forma, que alcanza una notable difusión en la zona norte, hallamos paralelos destacables con ejemplares procedentes de Herrera de Pisuerga (Pérez González, 1989: fig. 68, no 241-243), Petavonium (Carretero, 2000: 399, fig. 249, n ${ }^{\circ}$ 169-170), Asturica Augusta (Franco, en Amaré (dir.), 2003: 93, lám. XXIII, no 88); Sasamón, (Abásolo y García, 1993: 59, fig. 20, nº 4), Arcaya (Ciprés, 1987: 63, lám. 19, n 200-202), Uralde (Filloy y Gil, 1993: 226-227, fig. 66, n 181), Bílbilis (Sáenz Preciado, J. C. 1997, lám. 43, n 306310), Arcobriga (Juan Tovar, 1992: 45-46 y 58, fig. 1.3.9, no 108-109). En todos estos casos las piezas presentan semejante disposición de las facetas que en este ejemplar legionense, cifrándose su cronología entre el último tercio del siglo I d. C. y el siglo II ${ }^{74}$.

La siguiente pieza (Lám. 3, n 22), corresponde a un fragmento de la parte superior de una forma Drag. 44 (por encima del baquetón central, que no se ha conservado), con un borde convexo que se ha interpretado para la recepción de una tapadera. Este tipo, que se ha supuesto continuación o sustitución de la forma Drag. 24/25, presenta en general grandes dimensiones, aspecto éste que la diferenciaría de su predecesora. Aún así, las reducidas dimensiones del fragmento no nos permiten mayores consideraciones. Únicamente, la decoración a ruedecilla que portan algunos ejemplares en la banda superior, resulta más propio de las producciones de los centros meridionales, con lo cual su ausencia viene a redundar en la procedencia norteña $\mathrm{y}$, más concretamente, riojana. La fabricación de estos cuencos, de variado calibre (Mayet, 1984: Pl. LXXII-LXXIIII, $\mathrm{n}^{\circ}$ 194-201), se iniciaría a principios del siglo II d. C. con una amplia perduración en las siguientes centurias, generalmente hasta el siglo III (Romero, 1985: 209; Sáenz Preciado, J. C. 1999: 238), mientras otros investigadores proponen que llega a alcanzar incluso el siglo IV (Mezquíriz: 1961: 67; Roca, 1976: 43).

En la misma unidad estratigráfica (UE 2), lo que quizás permitiría ponerlo en relación con la pieza anterior, aparece un ejemplar de tapadera de pequeñas dimensiones (Lám. 3, n ${ }^{\circ} 23$ ). Con un cierto engrosamiento en la parte superior de la línea oblicua de las paredes, carece del elemento de aprehensión que, en esta forma, correspondiente a la Hispánica 7, presenta una forma discoidal, en ocasiones con pequeñas ranuras o acanaladuras en su parte central.

74 De esta manera, y de modo meramente hipotético, podríamos plantear una cierta evolución cronológica que comenzaría con las piezas de facetas irregulares de época flavia -realizadas a ruedecilla o a mano alzada- hasta los vasos más modernos datados a mediados del siglo II como el del ejemplar citado del vertedero leonés, en el que la regularidad en el diseño del facetado permitiría pensar incluso en una posible utilización del molde. De todas formas, aunque carecemos de otros argumentos o hallazgos que puedan avalar este planteamiento, nos ha parecido digna de subrayar esta diferencia dentro de los tipos habituales. 
En este reducido conjunto de formas lisas destacan por su inusual abundancia los ejemplares de la forma Hispánica 10 (Lám. 3, n 24-28), vasos de perfil troncocónico, en los que podemos apreciar diferencias en la oblicuidad de las paredes (cóncavas como en el $\mathrm{n}^{\circ} 26$, o rectilíneas como en $\operatorname{los} \mathrm{n}^{\mathrm{o}} 24,25,27$ y 28) y en los bordes y labios más o menos engrosados al exterior, sin que en ninguno de ellos se conserve la base ${ }^{75}$.

Teniendo en consideración que se trata de una forma ya propiamente hispánica, si bien algunos investigadores han señalado cierta influencia de prototipos gálicos (Romero, 1985: 236), podemos establecer su cronología en plena época flavia y posterior. Además, en este vertedero la práctica totalidad de los ejemplares se localizan en la UE 2, donde se encuentran materiales de finales del siglo I d. C. y principios de la siguiente centuria.

Como paralelo más cercano a este conjunto destacan las piezas halladas en Petavonium (Carretero, 2000: 394-396), de similar morfología, y datadas hasta la segunda mitad del siglo II d. C.

Aunque la función de esta forma no se encuentra aún dilucidada claramente, teniendo en consideración los rasgos morfológicos descritos, así como su tamaño, podría establecerse una funcionalidad como vasos para beber, tanto más cuanto que, en esta fase del vertedero correspondiente a la etapa flavia, no aparece ningún ejemplar de cerámica de paredes finas cuya función sea la de vasa potoria. Esta propuesta no deja de rebasar el terreno de lo meramente hipotético, y se apoya básicamente en los porcentajes de ambos tipos cerámicos, que resultan inusuales por igual.

Finalmente, hemos de hacer referencia a una serie de fragmentos de bases pertenecientes a formas lisas indeterminadas (Lám. 3, n 29-31), algunos con pie (n² 29) y otros de base más plana, donde se produce un engrosamiento de las paredes de estos vasos de tendencia cóncava en el fondo ( $n^{\circ} 30$ y 31$)$.

\subsection{TSH. Formas decoradas (Láms. 4-9)}

El conjunto de formas decoradas de terra sigillata hispánica procedente del vertedero de San Pedro se caracteriza en primer lugar por su escasez cuantitativa (un 36,6\% del total), así como por un elevado índice de fragmentación de las piezas y, en un primer análisis, por el predominio de las formas tempranas de la producción.

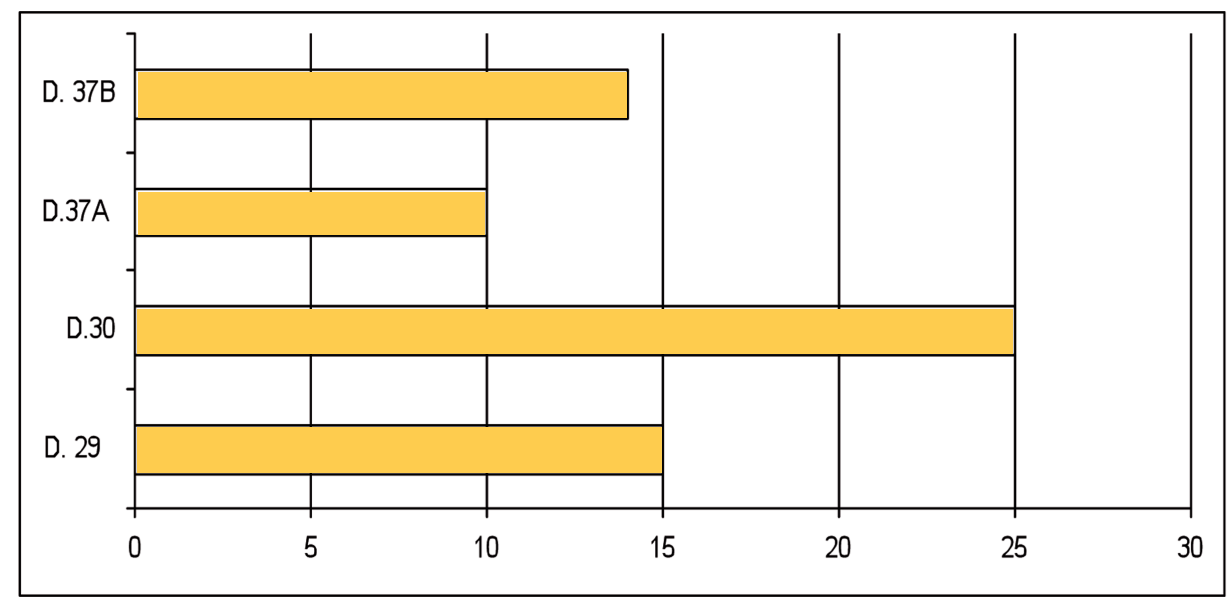

\section{GRÁFICO 4: Formas de TSH decorada}

75 La mayor parte de los investigadores coinciden en los inicios de esta forma hispánica en época flavia, y, en particular, ROMERO (1985: 235-236) hace hincapié en la influencia de determinadas piezas que integran los seis servicios rutenos (VERHET, 1976), perdurando algunos ejemplares a lo largo de la segunda centuria. 
Destacan así los ejemplares de las formas Drag. 29 y Drag. 30, que suponen el porcentaje mayoritario. De la forma Drag. 29 contamos con dos ejemplares completos y muy bien conservados (Lám. 4, no 32 y 33), que se caracterizan además por presentar una tonalidad anaranjada y un barniz mate, aspectos todos ellos que los diferencian del resto de fragmentos decorados.

La pieza $\mathrm{n}^{\mathrm{o}} 32$ conserva su perfil completo, con 18,7 cm. de diámetro de boca, apreciándose un borde poco engrosado y la carencia de las dos estrías características en el borde interno. La decoración se organiza en dos frisos separados por un baquetón. En el friso superior se dispone un esquema metopado, en el que aparecen dos series de palmetas y, separadas por tres líneas verticales onduladas, un motivo zoomórfico flanqueado por cuatro rosetas en los ángulos. En el registro inferior aparecen alternativamente dos figuras zoomórficas similares a las del friso superior y un motivo vegetal con dos hojas lanceoladas y otras dos más redondeadas en forma similar a una palmeta.

Una característica peculiar es la presencia en este friso inferior de dos marcas intradecorativas in planta pedis, presentando restos de una grafía que resulta incompleta y de momento, ilegible, dado el mal estado de conservación de la pieza en esta parte.

Este tipo de marca es sumamente infrecuente en el norte, habiéndose localizado únicamente dos ejemplares, uno en el yacimiento zamorano de Villalazán (Romero, 1978: 112-113, Fig. 14, nº 8) y otro, menos definido, en Arcobriga (Juan Tovar, 1992: 65, Fig. 1.3.43, $\mathrm{n}^{\circ} 20$ ), pertenecientes ambos al ceramista $V L L O$, uno de los mas destacados del grupo de los denominados alfareros "precoces"76, por suponer sus manufacturas los inicios de la producción hispánica (Mayet, 1984: 185-186) a mediados del siglo I d. C. La utilización de esta forma de marca refleja la influencia de la sigillata itálica y tardoitálica, más patente en las primeras producciones del centro de Andújar y otros talleres meridionales (Sotomayor, 1977; Roca, 1978; 1980; Serrano, 1999: 231-233; Amores y Keay, 199: 235-252), mientras las producciones precoces del ámbito septentrional se caracterizan por el acusado predominio de los rasgos de los prototipos gálicos, especialmente evidentes en las formas decoradas.

Estrechamente relacionado con la pieza anterior, aunque con ausencia de marca, se encuentra el vaso $\mathrm{n}^{\circ} 33$, una forma Drag. 29 con $20 \mathrm{~cm}$. de diámetro de boca, presentando las dos ranuras muy marcadas en el borde interno. La tonalidad es anaranjada un poco más oscura, y la decoración se dispone igualmente en dos bandas o frisos separados por un baquetón. En el friso superior, metopado, se representan tres paneles decorativos separados por dos líneas verticales onduladas: en el primero una serie de triángulos en relieve que ocupan todo el espacio decorativo; en el segundo, un motivo zoomórfico -probablemente un ave con las alas desplegadas- entre dos figuras humanas, una de ellas en actitud de caminar, y en el tercer panel metopado aparece el mismo motivo zoomórfico que en la pieza anterior, pudiendo afirmar que se trata del mismo punzón, con las implicaciones que ello conlleva respecto a la procedencia y

76 Las características de la producción de los alfareros "precoces" hispánicos, entre los que destacan, además del citado VLLO, otros como ASIATICUS, MATERNVS o M.C.R. (MARCVS CORNELIVS REBVRRINVS), han sido objeto de diversos estudios específicos por parte de investigadores como ROMERO (1984; 1984 b) y J. C. SÁENZ PRECIADO (1995: 229-239; 2000: 283-294). Desde el punto de vista terminológico hemos de reseñar que para el término "precoz", tradicionalmente utilizado en la historiografía de la TSH, se ha propuesto recientemente una nueva denominación, acuñada en el ámbito de los Rei Cretariae Romanae Fautores, que califica a estas primeras producciones hispánicas como "terra sigillata local de tradición gálica". 
relación entre talleres. En el friso inferior se dispone una guirnalda destrógira rematada en hojas lanceoladas y palmetas, similares a las del friso inferior de la pieza $\mathrm{n}^{\mathrm{o}} 32 \mathrm{y}$ subrayando claramente la relación entre ambos vasos.

Así, tanto en los aspectos técnicos como decorativos, hallamos una evidente afinidad entre ambas piezas que, aparte de indicar una probable procedencia común, presentan importantes similitudes con algunos vasos de esta forma de la producción del ceramista VLLO, particularmente estudiada por M. V. Romero (1979; 1984; 1984b) en sus diversos aspectos, constituyendo su más reciente y decisiva aportación la determinación de la ubicación concreta del taller de este alfarero, que se contemplaba en el complejo de Tritium Magallum. Sin embargo, una profunda investigación basada en los resultados de análisis arqueométricos, ha permitido localizar su centro de fabricación en Uxama (El Burgo de Osma, Soria) (Romero et alii: 2008; 2012).

Como rasgos definitorios de la producción decorada de este alfarero, que podemos apreciar en estos dos ejemplares leoneses, destacan, además de las características técnicas en cuanto a tonalidad de pastas y revestimientos, la distribución del esquema decorativo en dos frisos, separados por un grueso baquetón, así como la presencia de motivos decorativos que imitan los tipos gálicos, especialmente las guirnaldas, su motivo más distintivo, que se encuentra en el friso inferior de estas dos piezas. Del mismo modo, la irregularidad de las marcas también supondría otro rasgo común con las manufacturas de este alfarero, cuya combinación de estilos y motivos da lugar a un repertorio formal y decorativo peculiar y distintivo en el conjunto de las producciones hispánicas tempranas.

Así, desde su taller uxamense, aunque no se descarta una relación con el centro de Tricio en los primeros momentos, como demuestran algunos punzones, los productos de $V L L O$ con los hallazgos de los últimos años, han trazado una línea de difusión por toda la meseta septentrional, desde que los primeros ejemplares dispersos procedentes de Mérida, Numancia, Alcalá de Henares, Villalazán y Tiermes fueran agrupados por Romero (1979; 1985: 73-74, 90, fig. 16). Posteriormente han aparecido vasos de este ceramista en Complutum (Sánchez-Lafuente, 1989: 225), Herrera de Pisuerga (Pérez González, 329-330, fig .40, nº 1 y 7), Arcobriga (Juan Tovar, 1992: 65), por citar solamente algunos ejemplos. A ellos podríamos añadir un ejemplar de Petavonium (Carretero, 2000: 405, fig. $251 \mathrm{n}^{\circ}$ 183) y, con las necesarias reservas, que esperamos resolver con un estudio más profundo que incluya análisis arqueométricos, posiblemente estos dos vasos legionenses.

Ambos han sido hallados en la UE 5, de donde procede una buena parte de los vasos de paredes finas datados en época julioclaudia (Martín Hernández, 2008), de manera que la cronología propuesta para estas manufacturas, en torno al 55-60 d. C. quedaría en cierto modo avalada estratigráficamente y reincidiría en el hecho de situar la producción de estos alfareros en los inicios de la fabricación de la terra sigillata hispánica entre las denominadas "producciones precoces". Ahora bien, en este punto nos encontramos ante la disyuntiva que presentan determinadas piezas de calidad arrojadas a los vertederos, y con una cronología asociada, ya que se les puede asignar un dilatado período de uso y conservación, sin que por supuesto esta sea una afirmación extrapolable a todas las producciones. Así, en este caso, el momento de su fabricación y primeros años de difusión se situarían en época neroniana, en la etapa de ocupación del campamento por la Legio VI Victrix, aunque el fenómeno de las perduraciones, constatado en otras categorías cerámicas procedentes de esta misma unidad estratigráfica, correspondiente a un nivel de relleno y en la que se detecta una especial com- 
plejidad, dificulta la adscripción de estos ejemplares, pudiendo prolongarse su periodo de utilización durante un lapso temporal difícil de determinar.

Además de las piezas citadas, la forma Drag. 29 está representada también por varios bordes (Lám. 5, n 39-43), destacando el no 39 por su decoración burilada, propia de los prototipos gálicos, que nos situaría asimismo en estos primeros momentos de las manufacturas hispánicas. En el resto se aprecia alguna decoración metopada con motivo vegetal central ( $\left.n^{\circ} 40\right)$ que seguiría el estilo de imitación, y más abundantes son los ejemplares de borde más abierto u oblicuo y decoraciones a base de círculos concéntricos $\left(\mathrm{n}^{\circ} 42\right)$ o sogueados y segmentados con roseta o palmeta central $\left(\mathrm{n}^{\circ}\right.$ $41,43)$, que pueden adscribirse ya cronológicamente a la época flavia.

En el conjunto de las formas decoradas destaca especialmente la preeminencia de la forma Drag. 30 (Lám. 5, n 34-38; Lám. 6, n 46-49), con 22 ejemplares adscritos, conservando más bordes y fragmentos de galbo atribuibles que su contemporánea, la forma Drag. 29, aspecto que no suele ser habitual en los conjuntos de TSH decorada y que quizá hayamos de atribuir a la ya aludida fragmentación de los materiales en este contexto, de manera que sean más reconocibles aquellos galbos más rectos o cilíndricos así como los de curvatura inferior -algunos con moldura de cuarto de círculo-, propios de la forma Drag. 30. En los bordes ( $n^{\circ} 35$ y 36) se aprecia una tendencia cilíndrica que sigue la trayectoria de la pared, mientras que en las piezas $n^{\circ} 34,37$ y 38 se observan unos bordes más exvasados y oblicuos. En todos ellos aparecen las dos ranuras situadas en el borde interno, excepto en los n 35 y 36, y en todos se encuentran más juntas que en la Drag. 29, ocupando la zona intermedia del borde. Este rasgo ha dado lugar a un amplio debate sobre la existencia de una forma, la Knorr 48 hispánica, en el que no entraremos aquí por carecer del número suficiente de piezas que nos permitieran tomar una u otra postura.

En cuanto al tamaño de las piezas, éste oscila entre los $11 \mathrm{~cm}$. de diámetro de boca del ejemplar $n^{\circ} 34$, mientras que de los siguientes ( $\left.n^{\circ} 35-38\right)$, aunque no conservamos el borde completo, se pueden intuir unas mayores dimensiones. Por lo demás, carecemos de los datos necesarios para efectuar una estimación fiable del tamaño de este grupo de formas.

Desde el punto de vista decorativo, aparecen dos ejemplares con decoración burilada en el borde: en el $n^{\circ} 36$, con dos baquetones de transición, se observa lo que parece ser una figura humana; en el n $n^{\circ} 38$ en cambio, la transición está marcada por un friso horizontal de bifoliáceas, percibiéndose motivos aviformes que quizá formaran parte de un esquema metopado. Los ejemplares de borde liso ( $n^{\circ} 34,35$ y 37), permiten ver en el primer caso, una composición metopada con tres líneas verticales de dos bastones segmentados verticales coronados por un círculo y, a continuación, un águila con las alas desplegadas; la misma composición se dispondría en el friso inferior. En el $n^{\circ}$ 37 la banda superior de metopas sólo se intuye por los elementos de separación, formados por tres líneas verticales onduladas y otra de bifoliáceas. En cuanto al no 35, el pésimo estado de conservación de la pieza sólo permite apreciar bajo el borde liso un friso con motivos probablemente vegetales ${ }^{77}$.

77 El mismo friso está recogido por P. SÁENZ PRECIADO (1993 s/p) con el no 4 en la tabla no 14 de motivos vegetales del taller de La Cereceda, dentro del complejo tritiense, lo que supone otra vinculación con este taller concreto, cuyos productos parecen tener una especial aceptación en Legio, como hemos podido comprobar en ejemplares de otros vertederos (vid. FERNÁNDEZ FREILE, 2004). 
En la pieza $n^{\circ} 46$, sobre un baquetón que la separaría del reflejo de la moldura en cuarto de círculo al exterior, se dispone una decoración metopada, con motivos cruciformes, propios de los prototipos gálicos, en paneles separados por series de bifoliáceas verticales enmarcadas por líneas onduladas. En el ejemplar $n^{\circ} 49$, de menor tamaño, se aprecia una decoración basada en motivos vegetales y arboriformes. Mayor relevancia adquieren los ejemplares $\mathrm{n}^{\circ} 47$ y 48, pues en ambos aparecen -aunque en distinta disposición- los mismos motivos que en los dos vasos de la forma Drag. 29 que hemos equiparado al estilo de los ceramistas "precoces", el motivo zoomórfico y las pequeñas palmetas, a lo que hemos de añadir su contemporaneidad estratigráfica, localizándose como los anteriores en la UE 5, pudiendo incluir igualmente estos ejemplares en el conjunto de producciones "precoces".

Como fragmentos pertenecientes a esta forma Drag. 30 hemos de contemplar una serie de galbos incluidos en la Lámina 7 ( $n^{\circ} 53-59$ y 62), en los que se aprecia ya una cierta evolución de la forma, a tenor de los motivos decorativos, pues predominan los temas zoomórficos elaborados con detallismo (aves, lagomorfos, felinos componiendo escenas...) y un amorcillo ( $n^{\circ} 59$ ), dispuestos generalmente en composiciones metopadas separadas por motivos verticales sencillos, por frisos de ángulos, de bifoliáceas o de pequeños círculos. Con todo ello, podríamos situar cronológicamente el período de uso de estas formas, que surgen hacia el año 60-65, ya en época flavia.

Otra forma decorada muy presente en los yacimientos romanos de época altoimperial es la Drag. 37, en sus dos variedades Drag. 37A, de borde sencillo y Drag 37B o de borde almendrado, surgidas de forma sincrónica a principios de la etapa flavia, y que suelen acaparar, con diferencia, la mayor parte de los fragmentos decorados. Resulta sumamente inusual por tanto, la escasez de ambas formas en este vertedero, en los tres estilos básicos decorativos (de imitación, metopado y de círculos), que representan únicamente el 32\% de las producciones decoradas, cuando lo habitual es que su porcentaje ronde valores próximos al 90\%. De hecho, así lo hemos podido constatar en otros contextos legionenses, como en el vertedero de la C/Maestro Copín, fechado a mediados del siglo II (Fernández Freile, 2003: 75; nota 91), donde estas formas suponen un $95 \%$ de la terra sigillata decorada.

La explicación de este escasísimo porcentaje no resulta sencilla, si bien hemos de tener en consideración el elevado nivel de fragmentación y el mal estado del material, que en muchos casos no permite distinguir elementos morfológicos o motivos decorativos que pudieran pertenecer a dichas formas. Por otra parte, esta área de vertidos no constituye un conjunto cerrado o "sellado", como ya hemos constatado, sino que presenta una secuencia estratigráfica sumamente compleja, que abarca un amplio lapso temporal, con diversos tipos de intrusiones interfaciales, como niveles de echadizo o de relleno en espacios aislados, amortización con materiales de desecho de parte de estructuras arquitectónicas, remociones y otros factores que han contribuido sin duda a alterar la sucesión cronológica "natural" de los niveles estratigráficos y su contenido artefactual, dando lugar a la presencia o ausencia inusual de determinado tipo de materiales cerámicos en unidades estratigráficas cronológicamente bien definidas.

Así, únicamente se conservan en buen estado un borde de 37A ( $\left.\mathrm{n}^{\circ} 44\right)$ con decoración metopada en la que se reconoce la figura de Mercurio con sus atributos, enmarcado por bandas de cuatro líneas onduladas verticales. El otro borde $\left(n^{\circ} 45\right)$ pertenece a una 37 de borde almendrado que presenta decoración burilada en la franja del borde 
y, bajo dos baquetones de separación, un friso de ovas muy esquematizadas o más bien semicírculos, con una línea inferior de perlitas.

Atribuibles a la forma 37 serían las piezas $n^{\circ}$ 50, 51 y 52, correspondientes a la mitad inferior de los vasos. Destaca por su originalidad la decoración del n ${ }^{\circ} 52$, de la que se conservan tres frisos: uno inferior de festones o grandes ovas con una palmeta intercalada y un círculo en espiral en el centro de cada una; el friso intermedio formado por una hilera de palmetas horizontales; y el superior por ovas o círculos con motivos de separación verticales. Este último esquema decorativo presenta una clara influencia sudgálica, que puede percibirse también en algún rasgo morfológico de la pieza, si bien la pasta es característicamente hispánica. Composiciones decorativas paralelas a este gran friso inferior encontramos en piezas de terra sigillata sudgálica de Asturica Augusta (Amaré Tafalla (dir.) (2003): tabla 1, n 2 y 23), aplicado sobre una forma Drag. 29, con la diferencia de que el motivo central es una roseta. En los otros dos fragmentos basales se aprecia una decoración de círculos concéntricos ( $\left.n^{\circ} 50\right)$ y de círculos concéntricos segmentados $\left(n^{\circ} 51\right)$.

Por otra parte, dada la escasez de ejemplares de adscripción segura, recogemos una serie de fragmentos de pared ( $n^{\circ} 60,64$, y Láminas 8 y 9) pertenecientes con toda probabilidad a la forma 37 en sus dos variantes y diferentes estilos decorativos, cuya evolución abarcaría desde sus inicios en la época flavia 78 y un floruit, a principios del siglo II, momento en el que coexisten los estilos metopado y de series de círculos, como señaló Mayet (1984: 86-88), descartando una sucesión de los mismos, hasta un momento avanzado de la segunda centuria, cuando se encuentra ya plenamente vigente el estilo decorativo de series de círculos ${ }^{79}$.

En las composiciones metopadas, desarrolladas en ocasiones bajo un friso de ovas $\left(n^{\circ} 60\right)$, pueden determinarse los paneles mediante un hilera horizontal de ángulos y un grupo de líneas de separación verticales onduladas, sin que se pueda apreciar el motivo decorativo encuadrado en la metopa, mientras que en el $n^{\circ} 61$, con la misma estructura de las metopas, reforzada además por un cuadro de perlitas, aparece un ave como motivo central. Exceptuando aquellos fragmentos que conservan únicamente motivos vegetales ( $\left.n^{\circ} 64,72-74\right)$, en los demás se aprecia la presencia de series de círculos en múltiples variedades, y en ocasiones combinándose con el estilo de metopas. En este punto cabe aclarar que, más que una sucesión, ha de considerarse un origen

78 La cuestión sobre el surgimiento sincrónico de ambas formas, que ha continuado corroborándose arqueológicamente en la mayor parte de los yacimientos romanos peninsulares, fue ya ampliamente tratada por ROMERO (1985: 158-159), trazando las líneas maestras de este tipo hemiesférico a partir de los tipos carenados ya existentes, principalmente la forma Drag. 29 y su continuadora la Drag. 29/37. Esta aún controvertida forma -como trataremos más ampliamente en el análisis de la TSH de otro de los vertederos estudiados- marcaría la transición hacia la variante 37A de borde sencillo, mientras que la 37B, de borde almendrado y mayores dimensiones, tendría su precedente más directo en la Hispánica 40. De esta manera se mantendría en las dos variantes de la forma 37 la diferencia en los calibres de los recipientes precedentes.

79 En este sentido contamos con un importante precedente en la ciudad de León en el vertedero de la C/Maestro Copín (FERNÁNDEZ FREILE, 2003: 75-82, láms. 36-46). Allí aparece un importante conjunto de estas dos formas, datado a mediados del siglo II d. C., y en el que coexisten los dos estilos, constatándose escasos ejemplares metopados, y un gran predominio de la decoración a base de series de círculos, en piezas de gran calidad. Ello marca así un importante indicador cronológico respecto a la evolución de la forma, ya que en los momentos finales las composiciones circulares experimentan una clara decadencia formal y morfológica que da paso a las producciones tardías. 
coetáneo para ambos estilos (Mezquíriz, 1961: 107; Mayet, 1984: 87), como quedaría demostrado por el hecho de que los punzones que aparecen en el centro de los círculos coinciden en ocasiones con los que se encuentran en las metopas. No por ello tienen una misma perduración, pues mientras el estilo metopado no sobrepasaría la mitad del siglo II, en que comienza la reducción de los ejemplares de 37B, el de las composiciones circulares se mantendrá hasta la siguiente centuria.

Piezas que ejemplifican claramente esta fusión serían la $\mathrm{n}^{0} 66$, con un friso de círculos ondulados conteniendo lagomorfos, separados por una línea vertical de ángulos bifoliáceos entre dos líneas onduladas, y la $\mathrm{n}^{\circ} 71$, en la que dentro de un círculo doble se representa un grifo, situándose a ambos lados motivos de separación verticales alternando con pequeños círculos y en la línea inferior un friso de ángulos.

El fragmento $n^{\circ} 70$ presenta una composición a base de círculos exclusivamente, con un friso inferior de círculos concéntricos ondulados y segmentados, separados por un motivo vertical, y en la banda superior, sobre la línea de ovas, un círculo segmentado. En las piezas $n^{\circ} 67$ y 68 aparece igualmente este tipo de decoración: en la primera de ellas se representan cérvidos inscritos en círculos sogueados como motivo central, mientras que en la $\mathrm{n}^{\circ} 68$, aparece un friso central de círculos ondulados enmarcando figuras de cérvidos y separados por elementos verticales en forma de hoja lanceolada.

Asimismo cabe destacar, a pesar de su escaso tamaño, el fragmento $n^{\circ} 69$, en el que se representan círculos concéntricos y un elemento de separación vertical en forma de bastón segmentado, uno de los motivos característicos del taller tritiense de La Cereceda, aportando más elementos para determinar una presencia mayoritaria en Legio de los productos de este alfar.

Un fragmento singular, tanto por el tamaño de los motivos de ángulos en diversas posiciones -como friso horizontal y sobre éste una línea horizontal de grandes ángulos que cobijan motivos vegetales-, como por una cierta tosquedad en la factura, es el $\mathrm{n}^{\mathrm{o}} 65$, en el que también pueden apreciarse en los extremos superior e inferior la presencia de círculos de diversos tamaños.

Antes de analizar otras piezas que componen el reducido elenco de los galbos atribuibles a las formas 37A y 37B, hemos de hacer referencia a algunos fragmentos con motivos singulares, propios también de esta forma y que nos pueden proporcionar criterios de atribución cronológicos. Por ejemplo la pieza $n^{\circ} 76$, en la que aparece representado un friso con caras humanas, pudiendo tratarse de máscaras teatrales (vid. Mayet, 1984: Pl. CC I, n 2472-2483). Este motivo se encuentra también en la sigillata hispánica de Asturica Augusta (Amaré Tafalla (dir.) (2003): lám. XXXIII, nº 241), en Bilbilis (Sáenz Preciado, J. C. 1997s/p: lám. 192, no 149), en La Cereceda (Sáenz Preciado, M. P. 1993: tabla B8 n 1, 2, 3) o Tricio (Garabito, 1978: fig. 83, nº 79).

El ejemplar $\mathrm{n}^{\circ} 78$ destaca por la representación sumamente detallista de un cérvido, que denota una etapa de esplendor del estilo.

Como único ejemplo de la presencia de la figura humana en este conjunto contamos con el pequeño fragmento $n^{\circ} 75$, en el que aparece parte de una figura posiblemente femenina con palma o lanza.

Finalmente, se encuentran dos ejemplos de motivos vegetales florales en los que se representan capullos de flor estilizados $\left(n^{\circ} 77\right)$ y una roseta octopétala $\left(n^{\circ} 79\right)$.

Desde el punto de vista cronológico, y aunque carecemos de ejemplares completos que pudieran aportar datos sobre las tendencias en la evolución estilística de esta forma, hemos de prestar especial atención a aquellos fragmentos en los que las com- 
posiciones de series de círculos aparecen ya sin motivos intermedios de separación, en forma simplemente yuxtapuesta, predominando los círculos segmentados, combinados generalmente con rosetas $\left(n^{\circ} 81\right.$ y 82$)$, y en los que puede apreciarse una clara decadencia en la factura, con trazos y disposición de los motivos poco uniforme. De esta manera, podrían situarse en un momento de transición, ya iniciada la tercera centuria, que preludia el surgimiento de la fase tardía de la forma. Un esquema evolutivo similar en esta última etapa -aunque con distintos motivos decorativos- muestran un grupo de ejemplares numantinos, cuya investigadora sitúa en un momento probablemente posterior a la mitad del siglo III (Romero, 1985: 168), señalando que ellos constituirán el eslabón necesario para el surgimiento de la forma 37 tardía, desarrollada en los siglos IV y V. d. C.

\section{2.- TERRA SIGILLATA HISPÁNICA TARDÍA (Lám. 10)}

En función de los radicales cambios que se producen en el ámbito socioeconómico en la época bajoimperial, la producción de terra sigillata hispánica tardía, que se desarrolla a partir del siglo III d. C. experimenta una mayor diversificación territorial en cuanto a estilos decorativos, pastas y revestimientos, repertorio formal, y otros aspectos determinantes en el plano morfotipológico. Estas transformaciones afectarán directamente a las estructuras de fabricación y distribución de estas manufacturas, que constituyen una especie cerámica sumamente elocuente para dilucidar cuestiones de especial complejidad, fundamentalmente en el aspecto cronológico, proporcionando importantes datos para la definición de las secuencias temporales finales en aquellos yacimientos de época romana que experimentan una continuidad hasta etapas postreras.

En este sentido, hemos de señalar que la presencia de piezas de TSHT tanto en el vertedero de San Pedro, como en el del pequeño complejo termal de San Lorenzo, aún siendo mínima numéricamente, posee un gran valor cronológico como término ante quem en el periodo de uso del depósito y de las instalaciones de las pequeñas termas.

Antes de describir estos escasos fragmentos, hemos de hacer constar -como ya avanzamos sumariamente en el capítulo dedicado a la metodología- que la investigación sobre la TSHT ha experimentado un importante avance en las últimas décadas, pese a que en relación con las producciones de TSH altoimperial, representaba una variante mucho menos interesante y además, con mayor dificultad de clasificación, dada la falta de estudios generales. Por ello, ha constituido hasta hace poco tiempo un grupo de material postergado en las investigaciones sobre terra sigillata, con escasa atención al potencial informativo que contiene para esta etapa tardorromana.

Así, aunque ya tratada por Mayet (1984: 249; Pl. CCXXXIX-CCLXIII), que plantea aspectos generales y elabora una tipología sobre estas producciones, serán, sin embargo, trabajos entre los que destacamos el de López Rodríguez (1985), sobre la clasificación de la TSHT decorada a molde en la Península Ibérica y la definición de los diferentes estilos, con un gran periodo de vigencia, los que se van a erigir en obra de referencia prácticamente única y que aún hoy constituye un elemento de trabajo fundamental en el estudio de este tipo cerámico.

A la par que progresaban los estudios arqueológicos sobre la etapa bajoimperial, 
avanzaban también las investigaciones sobre la TSHT, destacando las obras de Paz Peralta $(1991 ; 2008)$ y especialmente la sistematización elaborada por Juan Tovar (1997), apareciendo así en las publicaciones como un capítulo de igual importancia que el resto de familias cerámicas.

Con todo ello, en la actualidad esta producción ha alcanzado un importante nivel en la interpretación de su presencia en los yacimientos, siendo a nuestro juicio el material guía por excelencia para ello en los contextos a partir de la tercera centuria y hasta los siglos IV y V.

Por lo que respecta a Legio, la presencia de TSHT y otras producciones cerámicas tardías es sumamente escasa, dado que son muy limitadas las intervenciones arqueológicas realizadas en el espacio urbano a partir del siglo III d. C., momento en el que se producirán importantes transformaciones urbanas, así como cambios esenciales en la relación entre los elementos poblacionales militar y civil, aspecto éste que dista aún de estar esclarecido histórica y arqueológicamente ${ }^{80}$.

En el vertedero de San Pedro hemos contabilizado muy escasos fragmentos identificables de TSHT, en estado muy fragmentario, sin poder determinar si se trata de formas lisas o decoradas, y que suponen un porcentaje mínimo, estimado en un $2 \%$ de la TSH y un $0,5 \%$ del total.

Las formas representadas, dos bases con pie poco alzado (Lám. 10, nº 85 y 86) y un ejemplar de la forma más característica de la TSHT decorada, una $37 t$ ( $n^{\circ} 83$ y 84), presentan una coloración anaranjada, con pasta porosa y barniz muy poco adherente, de escasa calidad, que se encuentra perdido en algunas partes de los recipientes.

El único ejemplar hallado de $37 \mathrm{t}\left(\mathrm{n}^{\circ} 83\right.$ y 84$)$ conserva el perfil completo a excepción de la base y presenta los rasgos morfológicos característicos de esta forma, con un cuerpo de movimiento curvilíneo, prácticamente hemiesférico, donde se sitúa la decoración, y un borde alto y oblicuo exvasado con labio engrosado.

El esquema decorativo, realizado a molde, consiste en un ancho friso horizontal con varias hileras de rosetas de distintos tamaños, separado por un baquetón. En la parte superior de transición al borde se dispone una estrecha banda de pequeños círculos más regulares.

Para la ubicación de esta pieza en el aspecto decorativo seguiremos la clasificación de estilos y las tablas de motivos de López Rodríguez (1985) que se encuentra aún como ya hemos señalado, plenamente vigente para la decoración de estas produccio-

80 El fenómeno de las transformaciones urbanas a partir de la tercera centuria y durante toda la etapa bajoimperial es común a los principales núcleos urbanos peninsulares, como han puesto de manifiesto los principales investigadores de esta época de la romanidad tardía, como FUENTES (1996; 1997) o ABÁSOLO (1999), incidiendo en los cambios y refacciones que experimentan las ciudades, tanto en el urbanismo como en su papel administrativo.

Para el caso de Legio contamos además con el trabajo de CAMPOMANES et alii (2002), en el que se exponen las intervenciones realizadas en contextos tardoantiguos y la escasez de materiales extraídos, a la vez que se plantean las reformas y reutilizaciones de estructuras de época altoimperial, que provocan una importante remodelación del espacio urbano campamental. De estas intervenciones quedarían excluidas las dos necrópolis, situadas extramuros, que sí han proporcionado una importante cantidad de materiales arqueológicos, especialmente latericios (vid. los trabajos de GONZÁLEZ FERNÁNDEZ sobre la necrópolis tardorromana en el solar del Monasterio de San Claudio (1994) y el de LIZ y AMARÉ sobre la localizada en el Campus de Vegazana (1993). 
nes, y que emplean asimismo autores como Zarzalejos (2002: 123 y ss.) o Juan Tovar (1997: 564 y ss.). Con todo, otros investigadores, aún utilizando este sistema de clasificación, hacen hincapié en la carencia de exhaustividad descriptiva de algunos motivos y sobre todo, en la falta de atribución de estos motivos a talleres concretos o zonas geográficas (Paz Peralta, 1991: 104 y ss.). De esta manera, algunas de las conclusiones de este autor para las formas decoradas de TSHT de la provincia de Zaragoza pueden extrapolarse a otras áreas y aportarnos importante información sobre la procedencia de estas manufacturas y su cronología.

Una de las últimas aportaciones de este investigador es la atribución de algunos motivos a la inspiración en los emblemas militares (2008: 505), poniendo así de manifiesto otro campo en el que se extiende la influencia del ejército, elemento básico de difusión de tendencias y vertebrador de la vida política, social, económica y cultural, también durante la época tardorrorromana.

La pieza que analizamos se inscribiría en el primer estilo de López, correspondiente a la decoración con rosetas y motivos circulares, que, en opinión del autor, destacan nítidamente del resto, y constituirían el grupo que Mezquíriz denominó "de Corella" (1958: 257). El tipo de roseta que aparece en la pieza leonesa, no inscrita en círculo, sino exenta, pertenecería al tipo 1A/3 en la tabla de López, aunque en este caso carece del círculo interno.

Realmente presenta rasgos muy similares con el ejemplar de la lámina 49, $\mathrm{n}^{\circ} 859$ (López, 1985: 323). Según Paz Peralta, teniendo en cuenta los dos estilos en que Mayet clasifica estas producciones, esta pieza se encuadraría en el primer estilo decorativo (Mayet, 1984: 258, Pl. CCLI a CCLIV) y ello implicaría la fabricación de estos productos en talleres de Tricio, descubiertos en el siglo IV y también en Nájera, que se convierte en esta época en un importante centro productor.

Dado que el motivo de las rosetas, en sus distintas variantes, es el más difundido en todos los yacimientos peninsulares, encontramos paralelos en muchos de ellos, sin embargo únicamente hemos hallado un ejemplar con decoración de rosetas idénticas en el cercano yacimiento de Lancia (Martínez Martín, 1992: fig. 131, n 1084), hecho que indicaría muy posiblemente la procedencia del mismo taller.

Por lo que respecta a la cronología de esta pieza, teniendo en cuenta su decoración a molde y los rasgos estilísticos, podemos situarla hacia la segunda mitad del siglo IV o ya en el V, en función de la división propuesta por Juan Tovar (1997: 558) en dos grandes períodos, evolutivos y expansivos, adscribiéndose al segundo de éstos ${ }^{81}$.

Un dato relevante desde el punto de vista del contexto que estudiamos -una estructura amortizada como vertedero- es el hallazgo en esta época tardoantigua de hoyos rellenos de basura en el interior de la ciudad (Campomanes et alii, 2002: 625) hecho que contraviene las normas al respecto vigentes en la etapa altoimperial, que obligan a situar los vertederos extramuros, pero que es común a la mayor parte de los núcleos urbanos en este momento. De esta manera, en el periodo bajoimperial coexistirían ambos tipos de áreas de vertidos, en un momento en que se reforman las estructuras altoimperiales en todos los ámbitos, perfilándose la transición al inicio de la etapa medieval.

81 Al igual que en el contexto que aquí estudiamos, los restos de TSHT han aportado importantes datos cronológicos en otros vertederos, como el de Uralde (Filloy, 1995: 1079-1090), en el que estas producciones permiten señalar una segunda etapa en el vertedero, desde el siglo III hasta finales del siglo IV. 


\section{3- CERÁMICA COMÚN}

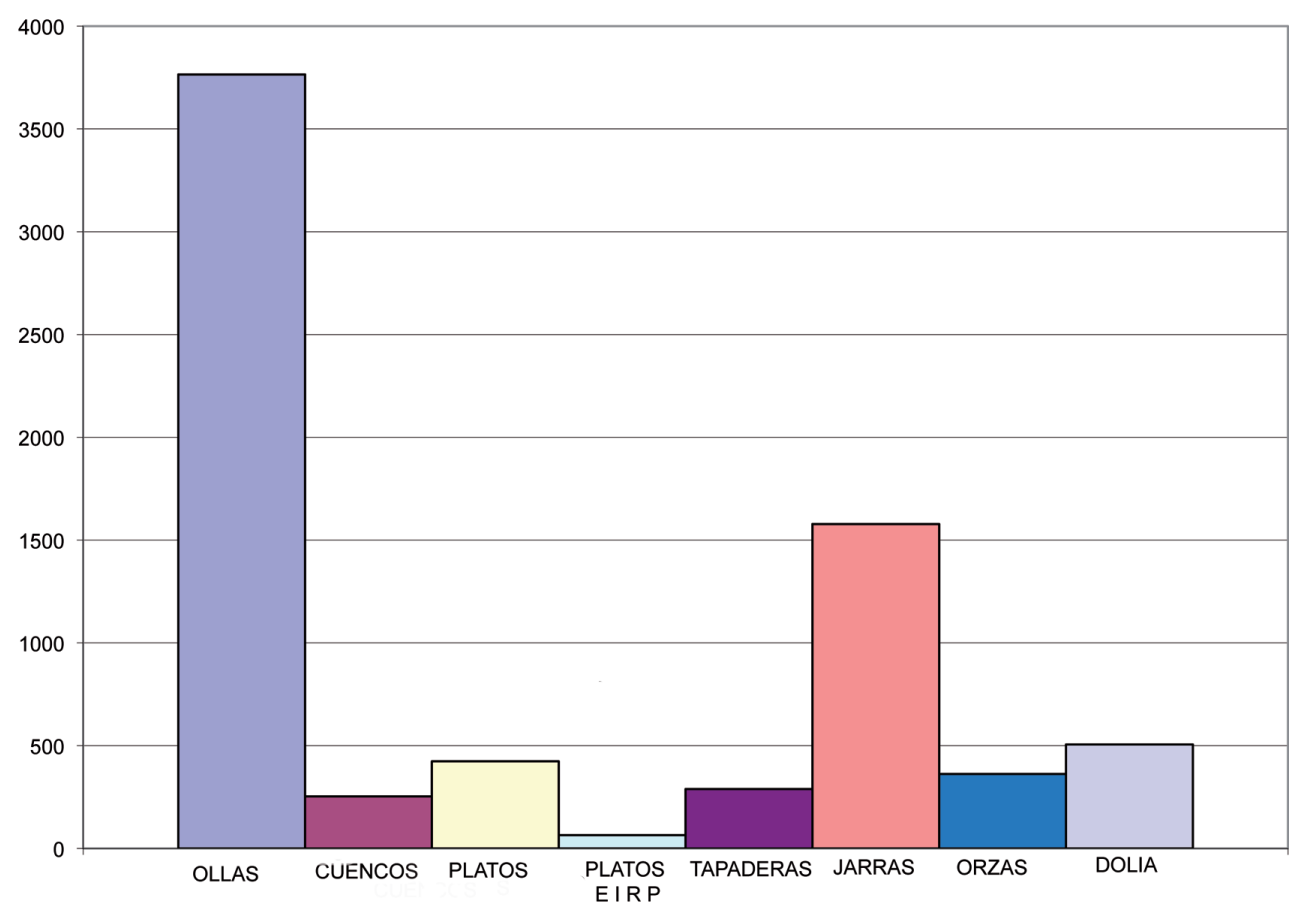

GRÁFICO 5 : Distribución de tipos en la cerámica común

\subsection{OLLAS (Láms. 11-14)}

En el vertedero de San Pedro se ha hallado un elevado porcentaje de recipientes de uso culinario, si bien, a diferencia de la mayoría de los yacimientos romanos en que los ejemplares de este tipo son claramente mayoritarios, en esta área de vertidos se documenta una proporción bastante pareja con las piezas de la vajilla de mesa, también muy abundantes. Así, mientras los recipientes de cocina representan un porcentaje del 38,5\%, los adscritos al servicio de mesa suponen un 36,3\%.

En cuanto a los diferentes tipos de ollas -2834 fragmentos que suponen el $39 \%$ de la cerámica común-, seguiremos la clasificación propuesta por nuestra parte para la cerámica común leonesa, al igual que hemos hecho en los demás vertederos, presentando en el espacio de San Pedro la siguiente distribución formal y cuantitativa:

\subsubsection{Ollas de borde exvasado curvo (Láms. 11 -12)}

Bajo esta denominación incluimos aquellos recipientes cuyo elemento más característico es la existencia de un borde exvasado de perfil curvilíneo rematado generalmente en labios rectos u oblicuos. Es el grupo más numeroso con diferencia dentro de la categoría de las ollas, con una representación del 91\%, y en él se incluyen las piezas $n^{\circ}$ 87-99, destacando los tres ejemplares que se conservan completos ( $n^{\circ} 87,88$ y 89). Estos presentan un marcado perfil ovoide o de tendencia piriforme y fondo plano, con 
diferencia en cuanto al calibre y diámetros de boca, que oscilan entre los $14 \mathrm{~cm}$. del $\mathrm{n}^{\circ}$ $87, \operatorname{los} 12,5 \mathrm{~cm}$. del no 89 y los $10 \mathrm{~cm}$. del nº 88 .

El resto de vasijas, de las que conservamos únicamente la parte superior, permiten conocer únicamente las dimensiones del diámetro de la boca, detectándose una acusada uniformidad en este rasgo, con una media de $12 \mathrm{~cm}$. que presenta el $\mathrm{n}^{\circ}$ 91, cifrándose el resto en 11,3 y 11,5 cm. ( $n^{\circ} 92$ y 98) y 13,5, 13,7 y 13, 9 cm. ( $n^{\circ} 90,93,96$ y 98), y desde el punto de vista morfológico, el arranque del galbo permite intuir en su mayoría perfiles globulares $\mathrm{u}$ ovoides.

En cuanto a la tecnología, estas ollas destacan por su cuidada factura en general, presentando cocción oxidante o reductora y en ambos casos pastas con desgrasantes de fina granulometría y acabados muy cuidados, en ocasiones con un ligero bruñido o espatulado.

Se trata del conjunto más numeroso y habitual en los yacimientos romanos y correspondería al tipo 1 en la clasificación de Vegas (1973: 11-14).

Como paralelos más cercanos en el área noroeste cabe citar algunas ollas de este mismo tipo halladas en Lucus Augusti (Alcorta, 200: 198), a las que este autor denomina "Ollas de borde curvo sin decoración" o en Petavonium (Carretero, 2000: 669, fig. 336, nº 98).

\subsubsection{Ollas de borde exvasado recto y oblicuo (Lám. 13)}

Esta forma está representada en el vertedero por escasos ejemplares, pues hemos contabilizado únicamente 29 piezas (un 1,10\% del total). Además del rasgo común en la configuración del borde ( $\left.\mathrm{n}^{\circ} 100-102\right)$, puede apreciarse una tendencia globular en los galbos, pero con una clara diferenciación en los tamaños, que presentan 13 y 9,7 cm. de diámetro de boca en los ejemplares $\mathrm{n}^{\circ} 100$ y 101 respectivamente. Las pastas son un tanto menos decantadas que en los recipientes de la forma 1, predominando las cocciones reductoras o alternas. Igualmente encontramos paralelos en Lucus Augusti (Alcorta, 2001: 193-196, figs. 80-81), aunque en este yacimiento se documenta una gran abundancia de este tipo, tratándose además en su mayoría de ejemplares completos.

\subsubsection{Ollas de borde recto horizontal (Lám. 13)}

A diferencia de otros vertederos de la ciudad de León, especialmente el de Maestro Copín (Fernández Freile 2003: 126-127, Lám. 87) en que es cuantitavamente significativo este tipo de ollas, aquí únicamente conservamos tres ejemplares ( $n^{\circ} 103,104$ y 105) que presentan como rasgo común una pequeña ranura en el borde destinada a asiento de la tapadera ${ }^{82}$, destacando por sus considerables dimensiones la pieza $\mathrm{n}^{\circ} 103$, con $22,5 \mathrm{~cm}$. de diámetro de boca. Esta variante se encuentra presente de forma abundante en yacimientos como Celsa (Aguarod, 1998b: 110-113), donde se les asigna una cronología de mediados del siglo I d. C.

82 En este tipo de ollas de borde recto horizontal no hemos hallado ningún ejemplar que muestre incisiones o decoraciones en el borde, como es común en la zona norte, sobre todo en el País Vasco (Salcedo, 2004: 207-240) o en otros puntos como Gijón (Fernández Ochoa y Zarzalejos, 1999: figs 1-3). En este último trabajo se hace referencia a piezas de estas características halladas en Asturica Augusta (p. 258, nota 5), encontrándose también en el Valle del Ebro (Aguarod, en VV.AA, 1995: 142, fig.17). 
3.1.4. Ollas de borde exvasado oblicuo con labio de sección triangular (Lám. 13)

A esta forma se adscriben dos ejemplares ( $\mathrm{n}^{\circ} 106$ y 107) de cuerpo globular, que destacan por su gran calibre, ya que ambas superan los $22 \mathrm{~cm}$. de diámetro de boca, presentando un borde desarrollado al exterior engrosado y labio de perfil triangular. Sus amplias dimensiones las aproxima en varios casos a las vasijas de almacenaje, si bien las huellas de exposición al fuego confirman su función como grandes ollas de uso en la cocción de alimentos.

Desde el punto de vista tecnológico presentan cocción oxidante, con desgrasantes micáceos visibles en superficie. Representamos únicamente estas dos piezas, pues el resto (54 ejemplares, correspondientes a un $2 \%$ del total) presentan un estado mucho más fragmentario.

\subsubsection{Ollas de borde vertical de perfil el "L" (Lám. 14)}

En este tipo morfológico englobamos aquellas ollas cuyo borde presenta una concavidad interna destinada al soporte de la tapadera, rasgo evidente en ejemplares como el $\mathrm{n}^{\mathrm{o}} 108$. Con una hendidura menos marcada y borde reentrante, con la misma función de recepción de la tapadera, incluimos en esta categoría otras tres piezas de similares características ( ${ }^{\circ}$ 109-111). Se trataría de piezas de gran capacidad en general, aunque únicamente disponemos de la medida del diámetro de boca del ejemplar $\mathrm{n}^{\mathrm{o}} 109$, que alcanza los $22,8 \mathrm{~cm}$. De esta variante contamos con una nutrida representación, con 43 ejemplares, el 1,53\% del total, habida cuenta de la extensa difusión cronológica y espacial de esta variante. Los paralelos más próximos para este tipo de ollas los hallamos en Arcobriga (Sánchez, M. A. 1992b: fig. 822, n 15) y hemos de citar el ejemplar, destacable también por su gran tamaño, hallado en el vertedero leonés de la C/Maestro Copín (Fernández Freile, 2003: 127, Lám. 89, 114/35).

\subsubsection{Ollitas (Lám. 15)}

Con esta denominación se ha dado en calificar a los recipientes con forma de ollas, de cuerpo globular y diferentes tipos de bordes, cuya característica principal es su pequeño tamaño -la de mayor calibre de las que aquí recogemos ( $\left.n^{\circ} 112\right)$ no sobrepasa los $10 \mathrm{~cm}$. de diámetro de boca-, así como también la delgadez de sus paredes, con desgrasantes de fina granulometría. Presentan indistintamente cocción oxidante y reductora y muestran exteriores cuidados, careciendo en todos los casos que hemos analizado de marcas de exposición al fuego. Este último aspecto hace albergar dudas sobre su función precisa en los procesos culinarios, haciendo que se vinculen, bien al servicio de mesa, bien a guardar determinados productos como sal o especias. En opinión de Carretero sobre los ejemplares de Petavonium, la morfología de estos ejemplares presenta gran afinidad con los cubiletes de paredes finas de la forma Melgar I, que proporcionaría una cronología de finales del siglo I d. C. hasta principios de la siguiente centuria, y que permitiría considerar una influencia de la cerámica de paredes finas en la cerámica común, quizá resultado de su fabricación en los mismos talleres (Carretero, 2000: 707), en este caso los ubicados en la localidad de Melgar de Tera. 


\subsection{CUENCOS (Lám. 16)}

Los cuencos constituyen uno de los elementos más utilizados tanto entre los utensilios de cocina como en la vajilla de mesa. Si en otros trabajos hemos diferenciado ambos tipos en función de esta dicotomía, hemos tenido ahora en consideración la dificultad de elaborar esta distinción, dado que en los cuencos atribuidos al servicio de mesa no hay que descartar su utilización en la preparación de alimentos o en otras tareas culinarias que pueden incluir o no su exposición directa al fuego, de manera que la presencia o no de marcas de hollín no constituye un elemento diferenciador consistente. Así, contabilizamos 253 ejemplares, un $9 \%$ en el conjunto de la cerámica común.

En cuanto a la morfología de estos recipientes, es sumamente variada, portando en ocasiones elementos decorativos sencillos o un recubrimiento de engobe rojo -como es frecuente en Petavonium o Lucus Augusti-, pero que en el conjunto que estudiamos está completamente ausente. Las cocciones son mayoritariamente reductoras, aunque también abundan las de tonalidades anaranjadas, y las pastas medianamente gruesas, con desgrasantes cuarcíticos y sobre todo micáceos, visibles en superficie, presentando en ocasiones tratamientos exteriores como el alisado o espatulado.

En este conjunto predominan las formas hemiesféricas lisas, con ranura en el borde $\left(\mathrm{n}^{\mathrm{o}} 118\right.$ y 128) y una ligera incisión en la parte inferior $\left(\mathrm{n}^{\circ} 118\right)$, o bien con labio engrosado y dos incisiones en el galbo ( $\left.\mathrm{n}^{\circ} 122\right)$, además de otras formas también globulares con borde recto saliente con pequeñas ranuras ( $n^{\circ} 120$ y 125). A estas formas que hay que añadir otras piezas de perfil también globular, con borde engrosado y reentrante y carena inferior ( $\left.\mathrm{n}^{\circ} 119\right)$. Algunos de estos cuencos presentan un grosor irregular en sus paredes y borde recto ( $\mathrm{n}^{\mathrm{o}} 126$ y 127), mientras otros destacan por su gran labio engrosado ( $\left.n^{\circ} 129\right)$.

Por último, los cuencos n ${ }^{\circ} 123$ y 124, aunque con diferentes dimensiones, presentan una morfología peculiar, con borde reentrante y paredes oblicuas más o menos rectilíneas.

Por lo que respecta al tamaño de estos recipientes, se aprecia asimismo una cierta diversidad, con medidas de diámetro de boca de 9 y $10 \mathrm{~cm}$. en las piezas de menor calibre ( $\mathrm{n}^{\circ} 121$ y 128), otro grupo que puede considerarse de tamaño mediano, con 11 a 11,5 cm. ( $\left.\mathrm{n}^{\mathrm{o}} 123,125,126,127\right)$ y 13 a $13,5 \mathrm{~cm}$. ( $\mathrm{n}^{\mathrm{o}} 118$ y 119), y destacando las mayores dimensiones que presenta el único ejemplar de perfil completo $\left(\mathrm{n}^{\circ} 124\right)$, con $16 \mathrm{~cm}$. de diámetro de boca, $6 \mathrm{~cm}$. de altura y una base con pequeño pie de $5 \mathrm{~cm}$. de diámetro.

Esta variedad en la tipología de este conjunto de cuencos encuentra paralelos en numerosos yacimientos peninsulares, por ejemplo en el Noreste, en Lugo (Alcorta, 2001: 330-332, fig. 138-139), en el Valle del Ebro en Celsa (Beltrán et alii, 1998: figs. 193195), en Mérida (Sánchez Sánchez, 1992: 31, fig. 6; Bustamante, 2011: 70, fig. 55) o en Petavonium (Carretero 2000: 668, fig. 335, no 939).

En cuanto a la cronología, según señala este último autor, la presencia de estos recipientes en la capa II de Huerña permite situarlos en el siglo I d. C. También hemos localizado ejemplares similares en la capa IV (nivel de hábitat 1) de este mismo yacimiento leonés (Domergue y Martin, 1977: 56, fig. 13 n 183), fechados por tanto en el tercer cuarto del siglo I d. C. si bien como propone Carretero, su auge se produce en la siguiente centuria (Ibid. 2000: 668). Esta misma cronología propone Vegas para el 
yacimiento de Pollentia (Vegas, 1973: 35). Hemos de añadir igualmente que una muestra de cuencos, con predominio de las formas carenadas, aparece en León (Fernández Freile, 2003: 127-128, Lám. 90), datados a mediados de la segunda centuria.

Con todo, como ya hemos tratado, la gran pervivencia de las formas de la cerámica común complica el panorama de su adscripción cronológica, ya que puede perdurar sin apenas cambios durante varias centurias, conviviendo con otros materiales en contextos muy diferentes.

\section{3.-PLATOS (Lám. 17)}

Los platos, de base plana y paredes exvasadas, representan un porcentaje importante, con un $15 \%$, en el total de la cerámica común.

En su fabricación predominan las cocciones reductoras y alternantes y las pastas con desgrasantes cuarcíticos y micáceos de considerable tamaño y muy apreciables en superficie, especialmente en lo que se refiere al desgrasante micáceo, rasgo predominante en ejemplares como el $\mathrm{n}^{\mathrm{o}} 133$, con cocción alterna (reductora en el exterior), aspecto que puede llegar a constituir un efecto decorativo, a la par que un rasgo propio de las producciones cerámicas de ámbitos militares (Carretero, 2002: 363).

Los rasgos diferenciales en este conjunto vienen dados por la configuración de las paredes y los bordes, predominando los ejemplares de paredes convexas y borde sencillo con labio redondeado que sigue la trayectoria de la pared $\left(n^{\circ} 130,133,135,141\right.$ al 144).

En algunos casos la pared convexa presenta un engrosamiento y bajo el borde una pequeña inflexión, con borde de labio curvo o biselado ( $n^{\circ} 136,137$ al 139) y como rasgo específico, aparece en algunas piezas la base diferenciada del perfil de la pared $\left(n^{\circ} 131\right)$.

Como ejemplares menos frecuentes por su configuración hemos de mencionar los $\mathrm{n}^{\mathrm{o}} 132$ y 140 de paredes rectas y oblicuas y borde plano.

Asimismo se constatan notables diferencias en cuanto a las dimensiones de estas recipientes, de forma que pueden distinguirse dos grupos: aquellos cuyo diámetro oscila entre 12 y $15 \mathrm{~cm}$. ( $\left.\mathrm{n}^{\mathrm{o}} 130,140,142,145\right)$ que tendrían un uso individual, y los que presentan diámetros entre 18 y $20 \mathrm{~cm}$. (n'131 al 134) que podrían encuadrarse en la categoría de fuentes.

En general, estos platos de borde sencillo están presentes en numerosos yacimientos de la Península como Petavonium (Carretero, 2000: 664, fig. 332, nº 71, 73-77), Varea (Luezas Pascual y Sáenz Preciado 1994: 171-172, lám. XV) o Sasamón (Abásolo y García, 1992: 92, fig. 46), Emerita Augusta, en el vertedero de la calle Constantino (Alvarado Molano, 1995: 210-211, fig. 119; 290-291, fig. 11). Según estos últimos investigadores, esta forma presenta una gran dispersión en la Lusitania y la Betica, teniendo como precedente el tipo itálico Vegas 15.

Por el contrario, no tenemos constancia en este vertedero legionense de platos con borde escalonado o borde bífido, muy abundantes en otros yacimientos peninsulares.

Por último, es de destacar la pieza $n^{\circ} 145$, que constituye una imitación de un plato de terra sigillata, que presenta una cuidada elaboración. Este tipo de imitaciones, tanto 
de cerámica campaniense como de terra sigillata que, según Vegas (1973: 57) son abundantes en Gallia y Germania, donde se establecieron industrias prósperas de estos sustitutos, son, sin embargo, mucho menos frecuentes en la cuenca mediterránea, destacando únicamente en este sentido los yacimientos de Jávea y Pollentia, donde se localizan este tipo de imitaciones desde época preaugustea hasta la etapa bajoimperial.

Por lo que se refiere al área noroeste peninsular, el factor exógeno por excelencia que propiciará la presencia de estas imitaciones de diferentes formas de terra sigillata en sus diferentes etapas de producción será la presencia del ejército. Con todo, hemos de diferenciar las primeras etapas de acantonamiento de ciertas unidades, como la Legio IIII Macedonica en Herrera de Pisuerga o la Legio VI Victrix en León, que cuentan con un figlinarius encargado de elaborar producciones de terra sigillata, siguiendo los modelos itálicos, para abastecer a parte de la población de dichos campamentos, y un momento posterior -en los últimos decenios de la primera centuria e inicios de la segunda- en el que se encuentra ya consolidada una importante red de aprovisionamiento general de estos productos cerámicos, hispánicos en su práctica totalidad, a los recintos castrenses, como es el caso de la Legio VII Gemina.

De esta manera, estas piezas de imitación de sigillata, de las que se conservan escasos ejemplares, procedentes hasta el momento de ámbitos militares, vendrían a significar una producción espóradica, de cuya elaboración o función carecemos de datos precisos, ya que presentan un carácter claramente residual, si bien a partir de algunos de sus rasgos morfólógicos pueden proporcionar algunos elementos de datación.

Destacan en este sentido las piezas halladas en el campamento de Petavonium (Carretero, 2000: 445-447, fig. 270), atribuibles por su técnica y morfología al primer momento de ocupación del recinto por la Legio X Gemina. Perteneciente a este mismo cuerpo legionario se ha localizado en niveles fundacionales de Asturica Augusta un fragmento de plato de TSI (Burón, 1997: 34, fig. 24 n 175), y en otros puntos del noroeste como Lucus Augusti (Alcorta, 2001: 365-468, fig. 154) se localizan ejemplares de imitación de diversas épocas.

Con todo, el paralelo más cercano lo encontramos en el propio espacio de Legio, en uno de los solares excavados en el área sudoccidental de la muralla, el correspondiente al edificio Cultural Pallarés (Miguel y García Marcos, 1993: 191, fig. 9.7), con una pieza prácticamente completa de imitación de un plato $15 / 17$, con una cronología fijada a finales del siglo I d. C. o principios del siguiente.

Con todo ello, queda plenamente de manifiesto la vinculación de estas producciones de imitación a los ambientes militares, pudiendo considerarlas, dada su relación e intercambio con los núcleos civiles, como un típico elemento de "romanización", de modo que sus imitaciones supondrían un signo de "status" y a la vez -aunque desconozcamos el desarrollo de procedimientos-, un paso importante en el proceso de aculturación que toda imitación de los rasgos de una cultura superior conlleva.

Desde el punto de vista cronológico, la adscripción de este diversificado conjunto de platos de cerámica común, localizados en su mayor parte en la UE 6, perteneciente a un espacio de relleno, resulta sumamente dificultosa, ya que son formas muy usuales y difundidas, con una amplia perduración, como demuestran los ejemplares similares del vertedero de la C/Maestro Copín, datados en la mitad del siglo II d. C. (Fernández Freile, 2003: 128-129, Lám. 98) en el mismo entorno legionense. 


\section{4.- PLATOS DE IMITACIÓN DE ENGOBE INTERIOR ROJO POMPEYANO (Lám. 18)}

La presencia de estas producciones en el yacimiento es sumamente escasa, con solamente 28 fragmentos documentados (un 0,10\% del total), siendo el tipo cerámico menos representado en el conjunto de la cerámica común. Se trata de platos de paredes convexas y borde reentrante, a veces engrosado, fabricados con pastas medianamente decantadas, con desgrasante micáceo de granulometría fina, y cuya característica definitoria es el engobe que recubre su superficie interna y la franja del borde en su parte exterior. Este engobe, espeso y consistente, es mate y presenta una tonalidad rojo-acastañada que recuerda las pinturas pompeyanas, de donde toman el nombre estas manufacturas.

Su origen se localiza en el área centroitálica, en Etruria y Campania, y fueron objeto de una gran difusión, de manera que las primeras producciones en las provincias son importadas, como sucede a modo de ejemplo en Hispania, en los yacimientos del Valle del Ebro, donde alcanzan una abundante presencia ya desde épocas tempranas, en el siglo II a. C. (Aguarod, 1995: 132-135), si bien el máximo nivel de importaciones de estos productos, ya en su mayoría procedentes de los talleres campanos, tiene lugar en época augustea, con una dispersión generalizada en todos los territorios del Imperio.

Con todo, según Vegas (1973: 48), pronto comienzan a realizarse imitaciones en yacimientos como Gergovia, Novaesium y Oberaden. Así, según esta autora, "hacia mediados del siglo I d. C. parece cesar la exportación desde Italia de las fuentes con barniz interior rojo-pompeyano, siendo entonces fabricadas en las provincias siguiendo el proceso de descentralización de la producción que se generaliza precisamente en esa época" (Ibidem).

La utilización de estos peculiares recipientes es fundamentalmente culinaria, como muestran las huellas de exposición al fuego que conservan en su mayor parte, indicando su empleo en la preparación de alimentos ${ }^{83}$. Algunos autores como Goudineau, teniendo en cuenta su frecuente presencia en los campamentos militares, señalan que debieron utilizarse para preparar la "polenta", comida elaborada a base de harina, muy propia de la alimentación diaria de los soldados (Goudineau, 1970: 159-186).

Así, el hecho de constituir objetos utilizados mayormente por los legionarios romanos, como demuestra su aparición en contextos militares tempranos, supone, según afirman Girón y Costa en su estudio sobre estas producciones en los yacimientos militares romanos peninsulares, la creación en los territorios recientemente conquistados de una demanda que se solventará con la creación de talleres locales o regionales para la fabricación de imitaciones de estas cerámicas (2006: 498).

A este respecto, hemos de hacer hincapié en la hipótesis de Carretero sobre este tipo de producciones aparecidas en el campamento de Petavonium (2000: 646), proponiendo su posible fabricación en talleres del Valle del Ebro o bien de Conimbriga, en fun-

83 Su función culinaria ha sido reafirmada por diversos investigadores como PUCCI, identificándolos con las tradicionales "cumana testae", recipientes cerámicos de color rojizo y uso popular, utilizados desde antiguo en el ajuar de cocina romano, así como también con las denominadas "patinae", piezas destinadas a preparar el alimento del mismo nombre (1975: 368-371). 
ción del característico desgrasante micáceo utilizado en su fabricación, y que también encontramos en las producciones halladas en Legio.

En cuanto a los rasgos morfológicos, son platos de paredes oblicuas, de escasa altura y fondo plano, con borde apuntado o reentrante y dimensiones variables, aunque se advierte un predominio de los de tamaño mediano, con un diámetro de 13 a $16 \mathrm{~cm}$. $\left(n^{\circ} 146\right.$ al 149)84, con algunas excepciones como el ejemplar $n^{\circ} 150$, que por su amplio diámetro de $25 \mathrm{~cm}$. podría considerarse una fuente. Desde el punto de vista tipológico, la forma más difundida de estas producciones, a la que se adscriben los platos que estudiamos, es la forma Luni 3 (equivalente a Vegas C).

Cronológicamente, aunque los comienzos de su fabricación son anteriores y su perduración mucho más prolongada, el período de máxima difusión de estas piezas se sitúa a finales el siglo I a. C. y la siguiente centuria, constituyendo para algunos autores como Girón y Costa (2006), un elemento de datación de primer orden y prácticamente un fósil-guía en los yacimientos peninsulares de carácter militar.

\section{5.- TAPADERAS (Lám. 19)}

En el conjunto cerámico que estudiamos, las tapaderas no representan, como suele ser usual en estos casos, un porcentaje destacable, ya que únicamente suponen el $4 \%$ del total, teniendo en consideración que pueden ser elementos de cubierta de recipientes de cocina, mesa o almacenaje.

Predominan las pastas de cocción oxidante, y, en función de su grado de decantación o de la granulometría de los desgrasantes, podemos atribuirlas a la vajilla de cocina o de mesa.

Por su morfología ( $n^{\circ} 158$ al 162) se incluyen en el tipo Vegas 17 (1973: 53-54). Presentan un cuerpo troncocónico, y las diferencias se establecen fundamentalmente en función de la trayectoria de las paredes y su grado de convexidad. Así, mientras el ejemplar $\mathrm{n}^{\mathrm{o}} 158$, el de mayor tamaño $(23,8 \mathrm{~cm}$. de diámetro y $4,5 \mathrm{~cm}$. de altura), presenta unas paredes rectas, en $\operatorname{los}^{\circ} 159$ y $160(16$ y 9,5 cm. de diámetro y 4,5 y 2,2 cm. de altura respectivamente) se aprecia una cierta concavidad, mientras que el $\mathrm{n}^{\circ} 161$ se define por una trayectoria más convexa, que determina un perfil más cerrado, y el operculum $\mathrm{n}^{\circ} 162$, de perfil sinuoso, considerable altura $(3,6 \mathrm{~cm}$.) y pequeño tamaño (7,5 cm. de diámetro), hace pensar que su uso sería el de la cobertura de un fino recipiente de la vajilla de mesa o incluso para un objeto de tocador.

En estos elementos se aprecian también diferencias en la configuración de bordes y labios. Así, observamos en los n 158 y 159 bordes terminados en labios rectos, mientras que los ejemplares $\mathrm{n}^{\mathrm{o}} 160$ y 162 presentan bordes con labios curvos y vueltos hacia arriba.

El pomo superior, discoidal, puede ser macizo o bien hueco en su interior. En gran parte de ejemplares presenta en su superficie una serie de estrías concéntricas, producidas, según algunos autores, por el cordel con que la pieza se separó del torno (Aguarod, 1988: 122). En las piezas analizadas destaca el $n^{\circ} 161$ con una perforación circular en el centro.

84 Según S. CARRETERO, estos platos estaban adaptados por su tamaño a un uso individual, como es propio de los ambientes militares (2000: 363) 
El tamaño de estos pivotes de asidero es también variable y se encuentra en relación con las dimensiones de la tapadera.

Las variantes morfológicas de este elemento cerámico son numerosas, y aparecen de forma abundante en los yacimientos romanos peninsulares, como Petavonium (Carretero, 2000: 685-688), Lucus Augusti (Alcorta, 2001: 256-260), Celsa (Aguarod, 1998: 122-124), Conimbriga (Alarçao, 1975, láms. XXI nº 421-422b y XXVI, nº 527-529), Uralde (Filloy y Gil, 1993: 284, fig. 116) o Emerita Augusta (Sánchez Sánchez, 1992: 2729, fig. 5), destacando en este último punto la importante diversidad de tipos de estas tapaderas, de fabricación local, incorporadas a uno de los más recientes estudios sobre la cerámica altoimperial de la capital lusitana (Bustamante, 2011: 66-67, fig. 51).

\subsection{JARRAS (Láms. 20-22)}

Entre los recipientes que integran la cerámica común, las jarras son, junto con las ollas, los ejemplares más numerosos y diversificados y particularmente en este yacimiento, donde destaca tanto su alto porcentaje (el 21,8\%) como la calidad de su factura y su buen estado de conservación.

En cuanto a su función, suele considerarse principalmente la de contenedores de líquidos, si bien resulta difícil precisar si cada forma estaba destinada a un contenido específico (vino, agua, leche $\mathrm{u}$ otros) ${ }^{85}$, al igual que se contempla asimismo su utilización en los procesos culinarios, como utensilios auxiliares en la preparación de alimentos, o como recipientes de almacenaje y conservación de determinados productos. ${ }^{86}$

En cuanto a su morfología, encontramos una gran variedad de tipos, en función especialmente de la boca y el cuello, que agruparemos en nuestra clasificación de formas propuesta para las jarras de otro contexto de vertidos legionense estudiado previamente ${ }^{87}$.

\subsection{1.- Jarras de cuello largo y estrecho (Láms. 20 y 21)}

Constituyen un tipo muy abundante (el 45,8\% del total), en el que a los rasgos generales se añaden peculiaridades que definen distintos subtipos.

Se trata de jarras con un cuello muy desarrollado, perfectamente diferenciado del cuerpo del recipiente, que presenta sección cilíndrica o ligeramente cónica o bitroncocónica y reducido diámetro, al igual que el de la boca.

85 Hilgers, W. (1969): Lateinesche Gefässnamen.Bezeichnungen, FunktionundForm Römischer Gefässe nach den antiken Sriftkellen, Düseldorf.

86 A este respecto, resulta significativa la clasificación de las jarras que propone Beltrán (1990: 193), diferenciando dos tipos fundamentales en función de la presencia de una o dos asas. Esta distinción atendería a un carácter funcional, pues estaría en relación con el peso a contener, de modo que las monoansadas se destinarían para el contenido de líquidos, mientras que las biansadas servirían además para el transporte y conservación de estos líquidos y otros fluidos como la miel y otros preparados alimenticios.

87 Vertedero situado en la calle Maestro Copín c/v San Salvador del Nido (Fernández Freile, 2003). 
Están elaboradas con pastas muy finas y decantadas, predominando los tonos anaranjados y ocres y en algunos casos algún tipo de ornamentación en el cuerpo, aunque desconocemos aquí este rasgo, ya que no conservamos ningún ejemplar de perfil completo.

Se corresponderían con piezas del tipo Vegas 38 (1973: 92-94, figs. 31 y 32), una forma sumamente difundida, en la que se pueden distinguir diversos subtipos o variantes.

Así, incluiríamos en un primer subtipo los ejemplares $n^{\circ} 163,164$ y 171 al 174, monoansados y con un arranque de cuerpo globular, cuya boca presenta un reducido diámetro, en torno a los $3 \mathrm{~cm}$. similar al del cuello. Se inscribirían en el tipo que Carretero denomina "con gollete" para las piezas de Petavonium (2000: 653), con borde estrangulado y labio exvasado curvo ( $\left.n^{\circ} 163\right)$, estriado $\left(n^{\circ} 164\right)$, recto $\left(n^{\circ} 172\right.$ y 173$)$ o reentrante oblicuo $\left(n^{\circ} 174\right)$. Se trataría, según este autor, de recipientes de difusión muy restringida y propios además de los asentamientos militares, señalando asimismo la delgadez de sus paredes y su aspecto cuidado, rasgos que, unidos a sus tonalidades, las asimilan a los vasos ovoides de paredes finas de Melgar de Tera, con los que cabría la posibilidad de que formaran servicio (Id. 2002: 363).

Para estas producciones podemos encontrar algunos paralelos en Lucus Augusti (Alcorta, 2001: 144-147, fig. 62), en las piezas que este investigador denomina "jarras tempranas", por su cronología de fines de la primera centuria, y también en Legio, en un solar excavado extramuros (Miguel y García Marcos, 1993: 193, fig. 15), datado en las primeras décadas del siglo I d. C. También se ha recuperado un ejemplar prácticamente completo, con similares características en el vertedero de la C/Maestro Copín, aunque con una cronología de mediados del siglo II d. C. (Fernández Freile, 2003: 136137, Lám. 102), lo que ampliaría un tanto la temprana cronología propuesta.

Paralelos muy próximos hallamos asimismo en el yacimiento leonés de Huerña (Domergue y Martin, 1977: 81, fig. 20, $\mathrm{n}^{\circ}$ 332-333) con dos ejemplares que presentan idéntica morfología, localizados en el nivel intermedio que separa los dos momentos de hábitat del poblado, por tanto entre finales del siglo I y mediados del siglo II d. C.

Un segundo subtipo, no excesivamente diferenciado del anterior, estaría integrado por las piezas de cuello largo, pero no recto (a excepción del $\mathrm{n}^{\circ} 167$ ) sino de trayectoria cónica o bitroncocónica ( $\left.{ }^{\circ} 166,168,170,175\right)$ y, en algún caso, con estrías anulares $\left(n^{\circ} 166\right)$, cuyo borde moldurado se ensancha notablemente en la parte superior alcanzando los 4 y 4,5 cm. de diámetro.

En un tercer grupo, más ligado al primer subtipo, se incluirían las jarras de cuello largo de diversas formas y boca de dimensiones más reducidas, entre los 2 y $3 \mathrm{~cm}$. de anchura, como el ejemplar $\mathrm{n}^{\mathrm{o}} 169$, con cuello de paredes de trayectoria convexa y borde moldurado, y los bordes $\mathrm{n}^{\circ} 176$ y 177 también con remate notablemente moldurado.

Desde el punto de vista estratigráfico, una buena parte de estos ejemplares de jarras de la forma 1 se localizan en la U E. 6, nivel de relleno que se sitúa en la parte superior de la estructura, por tanto en niveles relativamente modernos, que podemos atribuir a época flavia y por tanto adscribir su uso a la Legio VII Gemina. 
3.6.2.- Jarras de cuello estrecho y boca trilobulada con pico vertedor (Lám. 21)

Estas jarras de cuerpo globular o piriforme, un asa -generalmente de cinta con marcada acanaladura central- que arranca bajo el borde, y boca trilobulada con pico vertedor, no resultan especialmente abundantes en este contexto (representan el 18,3\% del total), en comparación con el primer tipo, y también cotejando su número con el de otros contextos legionenses en los que suponen el conjunto mayoritario (Fernández Freile, 2003: 138-139, Láms. 103-105)

Esta forma de jarra deriva directamente del oinochoe griego, muy difundido en época helenística, incorporándose sin apenas modificaciones a la vajilla de mesa romana.

Con estos rasgos morfológicos, estos recipientes se incluirían en el tipo 46 de Vegas (1973: 108-111, fig. 39), quien los sitúa ya en época augustea en Haltern, Hofheim y Vindonissa, señalando la longevidad del tipo y la escasa variabilidad de sus rasgos hasta época tardorromana.

Aunque entre los ejemplares hallados ninguno conserva el perfil completo, puede suponerse un cuerpo globular para el $\mathrm{n}^{\circ} 178$, otros carenados con una acanaladura que la remarca como en el $n^{\circ} 179$, mientras que el $n^{\circ} 180$ presenta un cuello más esbelto y un cuerpo más alargado como prefigura el arranque del galbo.

Rasgo común a este grupo de piezas es su cocción oxidante, presentando tonalidades ocres y anaranjadas, destacando las paredes gruesas y las pastas poco depuradas con desgrasantes cuarcíticos y micáceos de granulometría gruesa, sin que se aprecie ningún tipo de tratamiento exterior, todo lo cual les confiere un aspecto rugoso, mate y en conjunto tosco. No en vano, algunos investigadores como Carretero en su clasificación de la cerámica común de Petavonium, incluyen estos recipientes en la variante de "cerámica común vulgar o tosca" (2000: 673-675, fig. 338).

Teniendo en consideración la amplia difusión del tipo, encontramos múltiples paralelos en diversos yacimientos hispanorromanos, como Emerita (Sánchez Sánchez, 1992: 50-52, fig. 12; Alvarado y Molano, 1995: 287, fig. 6; Bustamante, 2011: 68, fig. 52, $\mathrm{n}^{\circ}$ 18), Petavonium (Carretero, 2000: 673-675, fig. 338), Varea (Luezas Pascual y Sáenz Preciado, 1989, lám. XXXI, 131), Conimbriga (Alarçao, 1975: láms XXIII, n 455; XXV, $n^{\circ}$ 505; XLIV, n 847; XLV, nº 853), el Chao Samartín (Benéitez, Hevia y Montes, 1999: 22-23, fig. 3, no 12 y 14 y fig. $4 \mathrm{n}^{\circ}$ 1-6), Arcobriga, aunque con escasa representación (Sánchez, M. A. 1992b: 253, fig. 8.2.12, nº 109 y 110). En este sentido, no deja de resultar un tanto excepcional la escasez de esta forma en la cerámica común de Lucus Augusti, con muy contados ejemplares (Alcorta, 2001: 167-168, 287, figs. 118 y 120). Con todo, aún reconociendo la escasa representación de estas jarras en Lucus, su investigador destaca la importante presencia de este tipo como recipiente de uso individual en el campamento de Aquis Querquennis (Orense) y de forma general, en todo el convento jurídico bracaraugustano, añadiendo esta diferencia a las varias discrepancias registradas en los catálogos de cerámica común de estas regiones colindantes (2001: 289). 
3.6.3.- Jarras de cuello diferenciado y boca ancha (Lám. 22)

Este tercer tipo de jarras cuenta con una amplia representación en el vertedero, en sus distintas variantes, suponiendo el 35,9\% del total.

Se trata de recipientes de cuello y boca anchos, con diámetros que oscilan entre los 8 y $9 \mathrm{~cm}$. y bien diferenciados del cuerpo, que, en la única pieza de perfil completo que se conserva ( $\left.\mathrm{n}^{\mathrm{o}} 182\right)$, presenta una acusada forma piriforme y un considerable tamaño, con unas dimensiones de $14 \mathrm{~cm}$. en la parte más ancha del galbo, característica común a la mayor parte de ejemplares, a juzgar por la forma y medidas del arranque de los galbos.

Cuentan con un asa con acanaladuras que arranca bajo el borde y se apoya en el hombro de la pieza y, en general, sirve de soporte a recipientes de gran capacidad.

Las pastas presentan una elaboración más cuidada, con finos desgrasantes y, como rasgo peculiar, destaca la tonalidad blanquecina -similar a la de algunas ánforas- de buena parte de estos ejemplares.

Atendiendo a la morfología del cuello y, en especial del borde, podemos diferenciar dos subtipos:

-Por una parte, aquellas jarras de cuello cilíndrico y borde recto horizontal con labio redondeado o apuntado ( $\left.\mathrm{n}^{\mathrm{o}} 182\right)$.

Esta variante presenta ciertas similitudes con el tipo 43 de Vegas (1973: 101, fig. 35), si bien las piezas que aquí analizamos poseen una mayor esbeltez en todos sus rasgos.

-Por otra parte, las jarras de cuello cilíndrico o con ligera tendencia cónica, que presentan bordes marcadamente moldurados ( $\mathrm{n}^{\circ} 183$ al 188), constituyendo este el subtipo preponderante y la variante más difundida dentro del tipo de jarras de boca ancha.

Por tanto, los paralelos son numerosos en diversos yacimientos peninsulares, destacando los ejemplares de Celsa (Aguarod, 1998: figs. 109, $\mathrm{n}^{\circ} 1$ y 2; 212, $\mathrm{n}^{\circ} 2$ y 3; 216), Arcobriga (Sánchez, M. A. 1992b: fig. 8.2.11, n 93), o Petavonium (Carretero, 2000: 677681, fig. 342, n $\mathrm{n}^{\mathrm{O}}$ 123-125).

\section{7.- CERÁMICA COMÚN DE ALMACENAJE (Láms. 23-24)}

El conjunto de recipientes destinados al almacenaje de diversos productos alimenticios representa el porcentaje más bajo en el conjunto de la cerámica común del vertedero, con 869 fragmentos que suponen el 12,5\% del total de los restos de cerámica común.

Se trata de vasijas de gran tamaño, fabricadas con pastas muy toscas y gruesas, cuya división en dos tipos fundamentales, orzas o tinajas y dolia, se basa en la estructura morfológica del cuerpo, según sea de tendencia cilíndrica o troncocónica, o más bien globular u ovoide, existiendo también diferencias apreciables en la configuración de los bordes.

Partiendo de los ejemplares que conservan parte del galbo, podemos establecer una proporción numérica similar entre ambas formas, aunque la presencia de un importante número de bordes fragmentados dificulta en muchas ocasiones la adscripción a uno u otro tipo. 
Estos recipientes de gran tamaño (los ejemplares n ${ }^{\circ} 189$ y 190 superan los $18-20 \mathrm{~cm}$. de diámetro de boca, si bien serían una variante de tamaño mediano si consideramos las dimensiones mucho más amplias que llegan a alcanzar estas vasijas) presentan bordes exvasados y engrosados, rectos u oblicuos, sin que se aprecien en ningún caso elementos decorativos en la zona del hombro, rasgo habitual en este tipo de piezas.

Están fabricados en pastas de cocción siempre oxidante, con tonalidades amarillentas, blanquecinas o anaranjadas, y abundante desgrasante cuarcítico y especialmente micáceo, con acabados exteriores escasamente cuidados.

Estos grandes recipientes alcanzaron gran difusión a lo largo de todo el Imperio, y su cronología resulta por tanto difícil de establecer, pues el tipo se mantuvo sin variaciones morfológicas apreciables, como podemos constatar en diferentes enclaves peninsulares, como el Portus illicitanus (Sánchez, 1983: 302, fig. 12), Arcobriga (Sánchez, M. A. 1992b: 254, fig. 8.2.17, no 130), Petavonium (Carretero, 2000: 711-712, fig. 370-372, no 252, 255 al 259, 264) Lucus Augusti (Alcorta, 2001: 214-217, fig. 90-91), o el propio solar legionense (Fernández Freile, 2003: 143, Lám. 111), correspondientes en todos los casos a niveles datados en las dos primeras centurias de la Era.

\subsection{2.-Dolia (Lám. 24)}

Este segundo tipo de recipientes destinados a guardar provisiones, realizados con similares tipos de pasta que las orzas, cuenta con mayor número de variantes en lo que a la morfología del borde se refiere.

Se han localizado cuatro ejemplares con borde reentrante ( $\mathrm{n}^{\circ} 199$ al 202), que se adscriben al tipo 49 de Vegas (1973: 117-118, fig. 42), y son abundantes en Lucus Augusti (Alcorta, 2001: 218-222, figs. 92-93), Varea (Luezas Pascual y Sáenz Preciado, 1989: 189191, láms. XXXVII-XXXIX) y en el estudio general sobre la cerámica común en La Rioja (Luezas, 2002: 133-143), destacando en este último la presencia de dolia estampillados.

En los ejemplares hallados en Legio no aparecen elementos decorativos y tampoco las características asas circulares situadas en la parte superior de estos recipientes.

Además de esta variante de borde engrosado reentrante apenas diferenciado del cuerpo, hemos incluido en la categoría de dolia una serie de piezas de borde recto horizontal más o menos desarrollado ( $\mathrm{n}^{\circ}$ 203-210), una de ellas con ranuras en el borde ( $\left.\mathrm{n}^{\circ} 206\right)$, lo cual facilitaría el asiento de la tapadera, así como también el último de los ejemplares $\left(n^{\circ} 210\right)$, que presenta un elemento saliente recto horizontal a modo de visera, localizado en la parte alta del cuerpo, próximo al borde y que muestra evidentes similitudes con una pieza hallada en el vertedero leonés de la C/Maestro Copín (Fernández Freile, 2003: 144, lám. 112, 121/40).

$\mathrm{Al}$ igual que las orzas, el dolium constituye un tipo muy extendido en los contextos romanos, con precedentes también en las cerámicas indígenas y con una dilatada perduración en el tiempo, lo que dificulta notablemente su adscripción cronológica. 


\section{4.- MORTEROS (Láms. 25-26)}

Los morteros constituyen en este yacimiento uno de los elementos más representativos, tanto por su elevada cantidad -como ponen de manifiesto los numerosos fragmentos de estas piezas que representan el 3\% del total del material cerámico-, como por la calidad en su factura, tal y como podemos apreciar en los ejemplares más completos.

Estos recipientes, cuya presencia se hace especialmente notable en los ámbitos militares $^{88}$, ya que formaban parte importante de la impedimenta de los soldados romanos, eran utilizados para triturar diversas sustancias y preparar alimentos en frío 89 .

Su morfología, definida en el tipo 7 de la clasificación de Vegas (1973: 28-34, figs. 9 y 10), se caracteriza por unas paredes gruesas y muy abiertas -convexas u oblicuascon un borde amplio y vuelto al exterior, que puede adoptar diversas formas y en cuyo contorno se localiza el característico pico vertedor, y una base amplia y plana. Su superficie interior es hemiesférica y aparece cubierta de pequeñas partículas de rocas duras, más o menos salientes, que se incrustan para crear una superficie de frotación.

Pese a estos rasgos morfológicos comunes, estas piezas adoptan, sin embargo, diversas variantes en función de la forma del borde, del cuerpo o del pico vertedor, así como del tamaño, algunos elementos decorativos, la presencia o no de marcas de ceramista, etc... Todo ello ha dado lugar a una extensa variedad tipológica de estos recipientes que contribuye a aportar datos cronológicos.

Sobre la función de los mortaria se han esgrimido numerosas y muy diferentes teorías que proponen usos específicos. Dejando aparte algunas hipótesis menos verosímiles, las principales propuestas son recogidas por Aguarod (1985: 29), que los define como vasijas de cocina empleadas tanto para machacar y moler semillas, especias, etc..., como para mezclar, rallar y amasar, en la elaboración de diversas salsas, del queso y otros derivados lácteos, añadiendo también su utilización en el proceso de pulverización de colores para usos industriales y en la preparación de medicinas a base de hierbas.

En nuestro caso podemos hablar de un uso predominantemente culinario, relacionado con los hábitos de alimentación de los soldados romanos, tal como se localiza igualmente en diversos campamentos militares de la Península y de otras zonas del Imperio, como Britannia o el limes renano.

El conjunto de morteros procedentes de este vertedero esta fabricado con pastas de buena calidad, con abundante desgrasante micáceo y cuarcítico, con cocciones oxidantes que definen una amplia gama de tonalidades.

88 Sobre esta cuestión, ya M. Vegas apunta que "los morteros son muy abundantes en los campamentos militares romanos, mientras que en las ciudades o aglomeraciones civiles son mucho menos frecuentes, si bien se encuentran regularmente. Probablemente el gran número hallado en los campamentos militares está en relación con la alimentación de los soldados, a los que debía servir de escudilla, mientras que en las casas particulares su empleo casi exclusivo como mortero determina que su número sea más reducido" (1973: 32).

89 Con todo, como señalan algunos investigadores, el hallazgo de estos recipientes no implica necesariamente el carácter castrense de su entorno, siendo necesarios otros argumentos más poderosos basados en otro tipo de materiales, como es el caso de Lucus Augusti (Alcorta, 2001: 150, nota 319). 
En cuanto a su morfología, un rasgo definitorio es su similitud con los modelos de imitación de los morteros itálicos, presentando características típicas de los morteros del tipo Dramont D1 y Dramont D2 (Hartley, 1973, Jonqueray, 1972 1973)90 combinando en ocasiones rasgos de ambos tipos en una misma pieza, aspecto propio de algunas producciones regionales.

Atendiendo a estas características podemos elaborar una clasificación para estos ejemplares legionenses, partiendo en primer lugar de las piezas más completas.

Forma 1.- Morteros de borde plano horizontal (Láms. 25 y 26)

Presentan borde horizontal plano ( $\left.\mathrm{n}^{\circ} 211\right)$, siendo el rasgo más característico la moldura o baquetón con que se une al cuerpo y rodea todo su perímetro (característica de los morteros Dramont D1) observándose el arranque de las paredes no muy gruesas. Con un diámetro de boca de $26,5 \mathrm{~cm}$. se incluiría en los tipos de tamaño pequeño, posiblemente con un uso individual y propios de ambientes castrenses. Esta característica vendría corroborada por el pequeño orificio que se aprecia en el borde y que con la ubicación de otro similar diametralmente opuesto, serviría para introducir una cuerda que permitiera su transporte en el conjunto de la impedimenta del soldado. En el mismo grupo podemos incluir el ejemplar $\mathrm{n}^{\circ} 213$, de más deficiente factura, con un diámetro de $22,5 \mathrm{~cm}$. y paredes de grosor irregular con un baquetón muy pronunciado que remarca la forma rectangular de la vertedera. Ésta no sobresale del contorno del borde, indicando así una cronología posterior al año 70 d. C. Igualmente cabría situar en ese primer tipo la pieza $\mathrm{n}^{\circ} 218$, con $20 \mathrm{~cm}$. de diámetro de boca, que muestra una profunda acanaladura que finaliza en el inicio del pico vertedor, así como los fragmentos $n^{\circ} 219$, de perfil completo, que presenta una ligera carena bajo el borde, el $n^{\circ}$ 221 , y el nº 220, de paredes más finas y perfil más rectilíneo, con el borde menos diferenciado del cuerpo y que muestra una incisión en la parte superior del galbo.

Paralelos significativos con esta tipología de morteros que permanece vigente al menos hasta finales del siglo I d .C. aunque con perduraciones, son los hallados en el campamento de Petavonium (Carretero, 2000: 720, figs. 1-4), en el campamento de Cidadela (Doval, 1997: figs 3-4) o en Lucus Augusti (Alcorta, 2001: 147-150), donde los ejemplares presentan estampillas.

En cuanto a la cronología, una gran parte de las piezas de esta Forma 1 se localizan en la UE 11, un nivel de relleno, caracterizado por la aparición de un conjunto de materiales de cronología temprana que vienen a indicar una pronta amortización de esta parte de la estructura.

Forma 2: Morteros de borde vuelto al exterior con labio colgante (Láms. 25 y 26)

Son muy numerosos en este contexto los ejemplares de mortaria con estas caracte-

90 Esta primera clasificación dicotómica proviene del análisis del importantísimo cargamento de morteros itálicos hallados en el pecio D de Cap Dramont, en las costas de la Provenza francesa que, junto con otros elementos cerámicos como ánforas o tégulas, habrían de distribuirse hacia el interior de las provincias de Gallia y Britannia. 
rísticas, superando ampliamente al grupo de la Forma 1, presentando una mayoría de rasgos propios de los morteros Dramont D2. En este conjunto se incluyen ejemplares bien conservados pero que no nos permiten apreciar rasgos definitorios como la vertedera, -a excepción del $n^{\circ} 216$, muy fragmentado- aunque sí una acanaladura que recorre el borde y un engrosamiento de las paredes en la base como en las piezas $\mathrm{n}^{\circ}$ 212 y 217, con 22 y 20,5 cm. de diámetro de boca respectivamente. Otros ejemplares como el no 214 y 215 presentan este mismo tipo de borde colgante, aunque con sensibles diferencias en la trayectoria de sus paredes, más curvilínea en el primero y ligeramente carenada en el segundo.

El resto de las numerosos recipientes de esta forma aparecen sumamente fragmentados ( $\left.n^{\circ} 222-229\right)$, pero indican una importante presencia de este tipo morfológico que perduraría hasta bien entrada la segunda centuria. De hecho en el vertedero de la C/Maestro Copín, datado con precisión a mediados del siglo II, hallamos algunos ejemplares completos de esta forma (clasificados aquí como Forma 4) que señalarían la continuidad de su uso en el campamento (Fernández Freile, 2003: 132, Lám. 96), dado que el lapso cronológico de este segundo tipo se extiende en algunos yacimientos hasta principios del siglo III d. C.

Esta segunda forma se encuentra ampliamente representada en yacimientos peninsulares -campamentales o no-, como por ejemplo en Arcobriga (Sánchez, M. A. 1992: 249, fig. 8.2.5, n 30), La Rioja (Luezas, 2001: 180-181, fig. 70), Valle del Ebro (Aguarod, 1995: 143, fig. 19), Lucus Augusti (Alcorta, 2001: 150-152, fig. 65) en el campamento de Petavonium (Carretero, 2000: 723-727, fig. 375), el campamento de Cidadela (Doval, 1997: fig. 5) o en el vertedero romano de Uralde (Filloy y Gil, 1993: 137, fig. 15). Son también muy abundantes en Augusta Emerita (Alvarado Molano, 1995: 289, fig. 10), destacando la importante variedad morfológica (cinco tipos diferentes en función del borde) que propone Bustamante (2011: 64, Fig.44) para los morteros producidos en la capital lusitana, en una de las últimas contribuciones sobre la cerámica altoimperial en este centro.

Todo ello pone de manifiesto el importante nivel de difusión y comercialización de este tipo de morteros hasta época tardía, siendo además, desde los primeros momentos, importantes indicadores del nivel de aculturación y romanización de los distintos núcleos, pues su uso atestigua la adopción de los hábitos culinarios romanos.

\section{5.- ÁNFORAS (Láms. 27-29)}

El material anfórico recuperado en el vertedero de San Pedro, con 476 fragmentos, supone un 5\% del total del material cerámico. Con todo, a pesar de este escaso porcentaje, hemos de hacer hincapié en el importante nivel de información arqueológica que proporcionan las ánforas, si bien hasta hace relativamente poco tiempo en la zona noroeste constituían un material relegado en la investigación de las distintas excavaciones, en relación con otras especies cerámicas, especialmente la terra sigillata, con el consiguiente vacío bibliográfico comparativo sobre este material

Sin embargo, en las investigaciones de las últimas décadas y a medida que avanzan los conocimientos sobre la actividad comercial en el mundo romano, se ha prestado especial atención al material anfórico, pues la información que ofrece no se limita 
exclusivamente a sus rasgos tipológicos y la consiguiente cronología asociada, sino que también desde el punto de vista de su contenido (aceite, vino, salazones...), estos recipientes son valiosos indicadores para reconstruir determinados aspectos de la economía del mundo hispanorromano, pues como envases de transporte de estos productos, nos indican unas determinadas procedencias y las rutas de su distribución.

Así, estos envases siguen unas determinadas redes de abastecimiento, que nos aportan importantes datos sobre las características del comercio, los intermediarios, beneficiarii ${ }^{91}$ o encargados del control administrativo, las vías de comunicación y los hábitos de consumo en las diferentes áreas del Imperio en época romana.

Estas referencias son aún más indicativas cuando se trata -como en el caso que nos ocupa -de un campamento militar-, ya que el avituallamiento del ejército romano en las provincias seguirá unas pautas muy definidas con el sistema de la annonna militaris para la distribución de éstos y otros productos, a lo que hemos de añadir otros intercambios comerciales de índole privada, facilitados ya en esta época de finales del siglo I d. C. a través del denso entramado viario creado en el área noroeste.

En el vertedero que estudiamos no hemos hallado ningún ejemplar completo, por lo cual prestaremos especial atención a los bordes, la parte mejor conservada, en alguna ocasión con las dos asas características, de cara a la clasificación morfológica.

Antes de comenzar con las variedades tipológicas, hemos de hacer referencia a la importancia que en estos recipientes adquieren los tipos de pastas empleados en su fabricación, ya que informan sobre su área de procedencia. Por otra parte, resultan fundamentales los elementos epigráficos que suelen portar, ya que en las superficies de las ánforas, son frecuentes las inscripciones, sellos o tituli picti, en las que aparecen nombres de alfareros, contenido del envase, y en ocasiones centros de fabricación, constituyendo una valiosa fuente de conocimiento, pero, lamentablemente, no conservamos ningún ejemplo en este conjunto de material anfórico, a la vez que carecemos de cualquier tipo de opérculo, por lo cual hemos de extraer los principales datos, en su mayor parte, de los rasgos morfotipológicos.

En cuanto a las características de las pastas, se advierte un porcentaje importante de las de tonalidad amarillenta o blanquecina, constituidas por una matriz bastante depurada, con escaso y fino desgrasante cuarcítico y micáceo, de fractura regular, alisadas ligeramente al exterior. En este mismo tipo, en cuanto a textura y composición mineralógica, podemos incluir una variante caracterizada por su tono anaranjado, con una engalba exterior amarillenta o grisácea. Estos rasgos responden en conjunto a las producciones de origen en diferentes áreas de la Bética.

En menor proporción, aunque también significativa, se encuentran ejemplares que presentan pasta de color anaranjado o rojizo, con abundancia de desgrasantes y factura menos elaborada, que indican una procedencia de diversos centros de fabricación situados en la Tarraconense, especialmente en su área nororiental.

91 Según CARRERAS, los beneficiarii constituyen una figura fundamental para la supervisión y el control administrativo del abastecimiento de productos esenciales como el aceite a los campamentos militares en provincias como Britannia, donde se localiza una importante presencia de ánforas olearias de origen bético $(1993 ; 1997)$. 
Por otra parte, hemos de señalar la presencia de un buen número de fragmentos (aproximadamente un 30\%), cuya pasta presenta una coloración gris anaranjada o rojo ladrillo, con aspecto granuloso y fácilmente deleznable, en la que se aprecian abundantes desgrasantes de gran tamaño, de origen calizo, cuarcítico y micáceo, y sin ningún tipo de tratamiento exterior.

Este último caso, que aparecía como excepcional -con un único ejemplar- en nuestro estudio de un vertedero del siglo II (Fernández Freile, 2003: 144-145, Lám. 116), ha sido documentado por Carreras y Berni en su estudio sobre las ánforas de Astorga, haciendo también referencia a la misma composición de la pasta que presentan algunas piezas halladas en Legio y Petavonium.

La presencia de estos ejemplares en estos tres principales centros de origen militar del noroeste indicaría muy posiblemente, a tenor de su composición y aspecto más tosco, una fabricación local o regional en talleres ubicados en puntos aún no localizados del Valle del Duero (aspecto que demostrarán futuros análisis petrográficos), siendo utilizados estos envases, de muy limitada circulación, fundamentalmente para el contenido de líquidos. A la singularidad de estas piezas se añade en varios casos una difícil adscripción a los tipos de las clasificaciones morfológicas al uso, aspecto que quizá redunde en este posible carácter local o regional.

\section{1.- DRESSEL 2-4 ( Láms. 27 y 28)}

Este tipo de ánfora vinaria se caracteriza por un cuerpo cilíndrico rematado en un hombro carenado, un cuello también cilíndrico más o menos largo y labio de sección semicircular. Presenta unas características asas bífidas -en su mayoría con sección en forma de ocho- y como remate inferior, un sólido pivote.

Se trata de un tipo antiguo, con antecedentes ya en el ámbito griego (Cnido y Cos) en el siglo III a. C., localizándose los primeros tipos itálicos en Albintimilium en la primera centuria antes de la Era (Beltrán, 1970: 362), para alcanzar su floruit en época julio-claudia, y sobre todo en la etapa flavia, cuando experimentan una amplia difusión, con hallazgos en importantes campamentos del Imperio como Oberaden, Haltern o Hofheim, así como en numerosos yacimientos de las provincias occidentales y norteafricanas (Vegas, 1973: 127). Su trayectoria como envase contenedor de vino es dilatada, perdurando hasta momentos avanzados, pudiendo documentarse su desaparición durante el siglo II d. C. -de hecho, en el vertedero leonés de la C/Maestro Copín, únicamente localizamos dos ejemplares de este tipo (Fernández Freile, 2003: 145, Lám. 113)-, aunque algunos investigadores, como Vegas, sitúan su final ya en la tercera centuria.

En el vertedero de San Pedro constituye una forma relativamente abundante, apareciendo varios fragmentos de bordes (Lám. 27, n 233, 235, 236, 237; Lám. 28, nº 240 y 243) con diámetro de boca uniforme en torno a los $11 \mathrm{~cm}$. dotados de sus típicas asas (Lám. 28, no 244 al 246). Todos ellos se localizan en las UU.EE 5 y 11, dos niveles de relleno de la estructura, lo que complica una atribución cronológica precisa.

En cuanto a las características de las pastas, hallamos una importante variedad en un número tan exiguo de piezas, conviviendo las de tonalidad amarillenta o blanquecina (propia de los talleres béticos), con otras de color rojizo con desgrasantes cuarcíticos y micáceos muy visibles en superficie, con lo cual, teniendo en cuenta el fenóme- 
no de las imitaciones, podemos situar la fabricación de estos ejemplares en la zona oriental de la Tarraconense (López Mullor y Martín Menéndez, 2008: passim), donde se ubican diversos talleres que abastecen principalmente a la mitad norte de Hispania.

Con estas características, los paralelos más próximos para las Dressel 2-4 legionenses se encontrarían en Asturica (Carreras, 2003: 642, 645, 649, 650, Fig. 4, nº 38-40) y en el campamento de Petavonium (Carretero, 2000: 733-734, Fig. 376, nº 4).

\section{2.- BELTRÁN II A (Lám. 28)}

Este tipo anfórico, del cual sólo conservamos un fragmento de borde ( $\left.\mathrm{n}^{\mathrm{o}} 238\right)$, se caracteriza fundamentalmente por un cuerpo de tendencia piriforme, con pivote individualizado del cuerpo, largo y estrecho y cuello ancho, cilíndrico, con labio engrosado y colgante. Son envases fabricados en la Bética, en los talleres costeros del área gaditana (Beltrán, 1990: 223-224) con la función de contenedores de salazones como garum, muria o liquamen.

En cuanto a su cronología, comienzan a difundirse en época flavia, de manera que según García y Bernal (2008: 668), puede situarse la plena sustitución del grupo 7-11 por las Beltrán IIA y IIB entre fines de la época julio-claudia e inicio de los Flavios, hasta mediados del siglo II d. C. En opinión de los citados autores, además de los talleres gaditanos hay que añadir la importancia de la producción de estos tipos anfóricos en la bahía de Algeciras, donde se localizan varios alfares, aunque con una cronología más avanzada.

El fragmento que conservamos se localiza en la UE 5 del vertedero, en un nivel de relleno de arcilla que ocupa el interior de la estructura, y por tanto con una compleja adscripción cronológica, pero ya en niveles de época flavia y, consiguientemente, cuando ya la Legio VII Gemina se encuentra definitivamente asentada en el solar leonés. Este hecho podría explicar la importación de estos productos de calidad, especialmente por la oficialidad militar, como sucede en numerosos campamentos militares a lo largo de las diferentes provincias del Imperio, en que las salazones hispanas, al igual que en diferentes ciudades o en la propia Roma, constituyen productos sumamente apreciados.

\section{3.- HALTERN 70 (Lám. 27)}

En la fase del vertedero que estudiamos hemos hallado únicamente un fragmento de borde que puede adscribirse a este tipo anfórico $\left(\mathrm{n}^{\circ} 234\right)$, pues presenta un borde exvasado, con $12,5 \mathrm{~cm}$. de diámetro, y labio en forma de collarín, si bien en esta parte de su morfología se producirán modificaciones apreciables a lo largo de su período de vigencia (Peacock y Williams, 1986: 115; García y Bernal, 2008: 674). Estos cambios han llevado a relacionarlo con otros tipos galos e incluso a considerar algunos tipos anfóricos béticos como predecesores de esta forma (Carreras, 2003: 640). Por lo demás, presenta un cuerpo ovoide con pivote macizo y asas con acanaladura central.

El tipo de pasta implica, por su constitución y tonalidad clara, la fabricación de este tipo en figlinae béticas, desde donde alcanzarían una extensa difusión, como demuestra su presencia en yacimientos de las principales provincias del Imperio. 
Estos envases son también significativos por su contenido, ya que se ha determinado que consistía en olivas preservadas en vino cocido, el denominado defructum o sapa, que se comercializaría como un apreciado ingrediente culinario.

En cuanto a su cronología, abarca desde mediados del siglo I a. C. hasta posiblemente la etapa flavia (década de los 70-80 d. C.) según Carreras (2003: 640), hecho que explicaría la escasez de estos ejemplares en este vertedero legionense, aunque este fragmento localizado en la UE 5, viene a atestiguar la difusión de este tipo anfórico en los momentos finales de su fabricación. La misma situación se registra en otro de los principales campamentos del Noroeste, como Petavonium, con similar cronología -en su segunda fase de ocupación por el Ala II Flavia- y donde sólo se han registrado dos fragmentos de este tipo de envase (Carretero, 2000: 734-735, fig. 376, no 5 y 6).

Por el contrario, en el cercano yacimiento de Asturica las ánforas Haltern 70 son las más abundantes (Carreras y Berni, 2003: fig. I, n 1-10), aspecto que el citado investigador atribuye a que la mayor parte de los hallazgos se sitúan en época julioclaudia, la etapa de esplendor de la comercialización de este envase; hecho que se repite, también en otros puntos del noroeste, especialmente en la Campa Torres. Por ello quizá sea preciso proseguir la investigación de la presencia de estos envases en función no únicamente de la cronología, sino teniendo en consideración otros aspectos, como la facilidad del transporte o los gustos específicos por el contenido de estas ánforas que determinan su presencia mayoritaria en determinados puntos del noroeste hispánico.

\section{4.- PASCUAL I (Lám. 28)}

De este tipo de ánfora contamos con tres ejemplares en el vertedero $\left(n^{\circ} 239,241\right.$ y 242) correspondientes únicamente a fragmentos de bordes. Un rasgo distintivo es el tipo de pasta, de color anaranjado o rojizo, con abundante desgrasante, especialmente cuarcítico de considerable tamaño, que indica su fabricación en la Tarraconense, en numerosos talleres situados en su mayor parte en el actual área catalana. Morfológicamente se caracteriza por un cuerpo ovoide con pivote macizo, cuello largo, asas de sección ovalada y borde vertical o exvasado, con labio que presenta un característico engrosamiento interior.

En cuanto a la cronología de este envase, existen ciertas discrepancias entre los investigadores, especialmente en lo que respecta a su etapa final y su desaparición. Los inicios de esta forma se sitúan a mediados del siglo I a. C. alcanzando su etapa de esplendor en época de Augusto y desapareciendo, según Carreras y Berni, de forma gradual en época de Tiberio (2003: 650). Por el contrario, López Mullor y Martín Menéndez (2008: 698, 700) consideran que, aunque se detecta una caída en la producción tras la etapa tiberiana, esta forma no deja de llegar al resto de la Península Ibérica y otros lugares del Imperio hasta comienzos de la época flavia, para desaparecer definitivamente en un momento poco preciso de finales del siglo I d. C. Si seguimos esta segunda opinión las ánforas Pascual I de este vertedero, ubicadas en la UE 11, pudieron estar en uso en época de la Legio VI, o bien ya en la etapa flavia, con la presencia de la Legio VII Gemina, con un carácter residual.

La difusión de este tipo anfórico es sumamente amplia, extendiéndose su comercio por las provincias de Gallia, Germania y Britannia. En Hispania, los paralelos más cerca- 
nos los hallamos en Asturica (Carreras y Berni, 2003: 650, fig. IV, $\mathrm{n}^{\circ}$ 35-37) y en Celsa (Beltrán, 1998: 69-70, Fig. 25, 26 y 27, n 1-3), ya que se encuentra principalmente en los yacimientos del norte peninsular.

\section{5.- RODIA (Lám. 27)}

Como procedente de la isla de Rodas, aunque su fabricación se extiende a otros centros del área del Egeo, hemos clasificado la pieza $n^{\circ} 232$, con un diámetro de boca de $10,8 \mathrm{~cm}$. ya que responde a los principales rasgos morfológicos de este tipo anfórico empleado para transportar vino, que correspondería a la forma Camulodunum 184 en la tipología de Beltrán (1990: fig. 114, n ${ }^{\circ}$ 982). De los dos tipos de pasta utilizados en su elaboración, este ejemplar presenta una textura rugosa, de tonalidad cremosa, con abundantes intrusiones de desgrasante calizo. Las características que definen este tipo de ánfora son fundamentalmente un cuello alto y cilíndrico rematado con un borde exvasado de labio curvo y asas apuntadas.

Cronológicamente, las denominadas ánforas rodias tienen un amplio período de vigencia, desde sus inicios en época helenística -si bien en el área occidental comienzan a documentarse en época augustea- hasta mediados del siglo II d. C. Durante este lapso de tiempo se registra una importante expansión de estos envases en las provincias occidentales y, según han constatado varios investigadores (Peacock, 1977; Carreras y Berni, 2003), su presencia es especialmente abundante en los campamentos militares del limes germánico, como Haltern, Oberaden o Rödgen, de manera que se han propuesto diversas teorías basadas en acontecimientos históricos para explicar este fenómeno. En este sentido, en los campamentos hispanos del noroeste no se ha registrado hasta el momento -quizá por falta de excavaciones e investigaciones al respecto- una documentación mayoritaria de este tipo anfórico, aunque sí se hallan en los principales recintos militares, como Petavonium (Carretero, 2000: 732-733, fig. 376, $\mathrm{n}^{\mathrm{o}} 1$-3) y en otros yacimientos de origen militar como Asturica (Carreras y Berni, 2003: 646-647, fig. II, n 17-19), que constituyen los paralelos más próximos para este ejemplar legionense, siendo su proporción numérica meramente testimonial.

\section{6.- PIEZAS DE DUDOSA ADSCRIPCIÓN (Láms. 27 y 29)}

En este apartado incluimos fragmentos de pivotes y bordes que, bien por su estado fragmentario, bien por su singularidad morfológica, no cabe adscribir en la totalidad de sus rasgos a ninguna de las formas incluidas en las tablas tipológicas anfóricas elaboradas por diversos investigadores.

En primer lugar, consideramos pertenecientes a formas indeterminadas los cuatro ejemplares de pivotes (Lám. 29, n 247-250), si bien, en función de las características de las pastas es posible determinar su procedencia. Así, la pieza $n^{\circ} 247$ presenta una pasta dura blanquecina- amarillenta y la pieza $\mathrm{n}^{\circ} 250$, correspondiente a un pivote de muy escasas dimensiones, muestra una pasta rosada con engalba exterior de color cremoso, de manera que ambos fragmentos pertenecerían a ánforas fabricadas en la Bética. Por el contrario, el ejemplar $n^{\circ} 249$ está elaborado con pasta muy grosera de color rojizo, que quizá corresponda a un envase fabricado en los talleres de la Tarraconense. Por 
último, la pieza $\mathrm{n}^{\circ} 248$, un pivote macizo de considerable longitud, presenta un tipo de pasta característico, muy rugosa, de tonalidad rojo-ladrillo y con desgrasantes cuarcíticos y calizos de gran tamaño, que ha sido considerada por los principales investigadores de este material cerámico en el área noroeste (Carretero, 2000: 736-738; Carreras y Berni, 2003. 650-651) como de posible origen local, habiendo sido constatada hasta el momento en ejemplares de Asturica, Petavonium y Legio.

Otra de las piezas de dudosa atribución es la $\mathrm{n}^{\circ} 231$, un fragmento que presenta cuello alto, borde moldurado con labio exvasado redondeado y asas de sección ovalada con tres acanaladuras poco profundas cuyo arranque se sitúa adosado a la parte inferior del borde. Está fabricada con pasta de color rojo ladrillo y presenta cocción alterna que da lugar a la denominada "pasta sandwich", con la sección intermedia de color gris oscuro. Los desgrasantes, cuarcíticos y micáceos, de granulometría media, son muy visibles en superficie, sin embargo la textura rugosa se atenúa con un leve alisado en la cara externa. Desde el punto de vista tipológico se aproxima en algunos rasgos a las formas Dressel 28 y Oberaden 74, aunque no puede adscribirse de forma decisiva a ninguna de ellas. Paralelos más cercanos encontramos en una pieza también de atribución dudosa de Petavonium (Carretero, 2000: fig. 377, n ${ }^{\circ} 15$ ), con la diferencia de que ésta presenta labio apuntado, y en otro fragmento de Asturica (Carreras y Berni, 2003: fig. V, $\mathrm{n}^{\mathrm{o}} 50$ ), fabricada con un tipo de pasta y cocción muy similar a la de Legio y cuyos investigadores incluyen en el grupo de ánforas del Valle del Duero, de manera que, al igual que los ejemplares de Petavonium elaborados con este tipo de pasta, es considerada de fabricación local o regional. Los elementos morfológicos que definirían este tipo de envase local serían un grueso pivote o una base plana, similar a la de algunas formas gálicas, un cuerpo ovoide, asas planas con acanaladura central y borde moldurado con diferentes tipos de labio, tal como proponen Carreras y Berni (2003: 651) examinando y comparando las características de los ejemplares de los tres enclaves citados, dejando como cuestión pendiente, a falta de datos concluyentes, el contenido de estos envases y su adscripción cronológica precisa.

Finalmente la pieza $\mathrm{n}^{\circ} 230$, a pesar de conservar completa la parte superior, plantea dificultades de atribución tipológica. El cuello es corto y forma con el borde, recto y oblicuo, de $13 \mathrm{~cm}$. de diámetro, un perfil troncocónico, rematando en un labio no diferenciado que se integra en esta trayectoria. Las asas, de sección circular, cuyo arranque se sitúa muy próximo al borde, son cortas y de forma curva, apoyándose en el hombro del recipiente, con una morfología similar a las de las ánforas olearias. Desde el punto de vista tipológico presenta algunas semejanzas con las formas Dressel 32, Almagro 55 o Keay XXXIX, limitadas lógicamente a la parte superior de estos envases, y por tanto difícilmente adscribibles a un tipo determinado.

En cuanto al tipo de pasta, presenta la misma textura y tonalidad rojiza que las piezas anteriormente descritas y a las que hemos supuesto una procedencia local o regional.

Una vez analizado el conjunto del material anfórico hallado en el vertedero de San Pedro, podemos constatar una notable variedad tipológica, indicativa del consumo de distintos productos -fundamentalmente salazones, diferentes tipos de vino y preparados culinarios a base de estas sustancias- por parte del cuerpo legionario acantonado en León que, en función de la datación de los envases, puede identificarse con la Legio VII Gemina ya que en su mayor parte alcanzan la etapa flavia y los siglos posteriores. Aún así, hemos de valorar la amplia perduración en el tiempo de estos tipos anfóri- 
cos, que en algunos casos se localizan en unidades estratigráficas con importante volumen de materiales tempranos correspondientes a la época de la Legio VI Victrix. Por otra parte, el hecho de tratarse de un vertedero acentúa esta problemática, ya que se trata de materiales no en uso, sino ya desechados, en momentos difíciles de precisar.

Teniendo en consideración esta relativa diversidad morfológica, resulta sumamente significativa la total ausencia de ánforas del tipo Dressel 20, envase de distribución del aceite de la Bética, toda vez que el consumo de este producto queda atestiguado por el importante número de lucernas documentadas en diferentes puntos de Legio, y más aún valorando que se trata de un asentamiento militar que habría de recibir el suministro de aceite a través de la denominada annona militaris, medio de abastecimiento del ejército en época imperial. Este sistema de aprovisionamiento explicaría la gran concentración de ánforas Dressel 20 en campamentos militares de provincias como Germania ${ }^{92}$ o Britannia ${ }^{93}$, testimonio del consumo, prácticamente en exclusiva, de abundantes cantidades de aceite bético por las unidades militares del Limes.

En este sentido, la escasez o la nula presencia de este tipo anfórico en los enclaves militares del área noroeste como Asturica en su primera etapa y posteriormente capital del Conventus, con cinco ejemplares (Carreras y Berni, 2003: 641, fig.II, $\mathrm{n}^{\mathrm{o}}$ 12-16), el campamento de Petavonium, con una única pieza documentada (Carretero, 2000: 736, fig. 376, $\mathrm{n}^{\circ}$ 9) y Legio, donde hasta el momento no se ha hallado ningún resto, hace que algunos investigadores cuestionen la vigencia de la annona militaris en estos enclaves, ya que no han proporcionado ninguna evidencia clara de este sistema administrativo de distribución oleícola (Carreras, 1996: 206; 1997: 168).

Para explicar este fenómeno tan irregular propio de los núcleos del noroeste hispano se han propuesto diversas hipótesis:

-En primer lugar se hace referencia a la reducida extensión excavada en estos asentamientos, que condiciona la densidad del material anfórico hallado ${ }^{94}$, así como también a la diferente localización de los materiales cerámicos, pues, según señala Carretero (2000: 744) estableciendo la comparación entre ánforas y lucernas, estas últimas se encuentran en mayor cantidad en el interior de las edificaciones, mientras que

92 Vid. Remesal, 1986.

Un ejemplo de yacimiento germano estudiado recientemente en que se pone de manifiesto una abrumadora mayoría del tipo Dressel 20 en el material anfórico se encuentra en HANEL: 2010, gráfico 1.

93 Según Carreras (1997: 168), en Britannia y otras provincias occidentales, las ánforas béticas Dressel 20 constituyen un "fósil director" para la identificación de la red de aprovisionamiento público en la provincia.

94 Este aspecto es subrayado por investigadores como Carretero (2000: 744) y Carreras (1996: 205), quien hace hincapié en este hecho para explicar la exigua densidad de ánforas olearias, así como para documentar el método de cuantificación utilizado, especificando que el sector de procedencia del material anfórico es en todos los casos respecto al potencial arqueológico de cada yacimiento, de manera que en el caso de León esta superficie representaría sólo un 0,33\% de la Legio romana. Así, las densidades de ánforas obtenidas son por tanto, bajas y es preciso pues, tener en consideración la relativa provisionalidad de estos datos, de cara a la comparación con otras áreas del Imperio y las implicaciones que ello conlleva desde el punto de vista de los medios de abastecimiento y las rutas comerciales de estos productos. 
las ánforas se hallarían en recintos de almacenaje y una vez consumido el producto contenido serían desechadas en vertederos. Dado que nos encontramos en uno de estos contextos de vertidos, podemos constatar que la proporción de material anfórico es similar a la hallada en el interior de las construcciones de otros núcleos septentrionales como Petavonium y Asturica, ya que en Legio la mayor parte de los materiales cerámicos hallados procede de vertederos extramuros.

-Otra explicación apuntada por algunos autores (Carreras, 1996: 206) para esta escasez en el consumo de aceite en estas áreas sería la utilización por parte de los habitantes del territorio astur de grasas vegetales y animales, como refiere Estrabón (Geographia, III. 3.7), así como también el consumo de zytos, una especie de cerveza que puede sustituir en parte el consumo de vino y hacer por tanto descender también la densidad de ánforas vinarias en este territorio. En nuestra opinión, éstas serían arraigadas costumbres locales de estos pueblos indígenas, pero indudablemente debieron experimentar un gran cambio con el asentamiento de las tropas romanas que demandarían un consumo mucho más amplio de vino y aceite.

-Por otra parte, una hipótesis más plausible, que manejan la mayor parte de los investigadores citados, serían los elevados costes del transporte terrestre, de manera que los productos importados llegarían al interior de la zona noroeste a través de rutas marítimas atlánticas y cantábricas, con puertos y puntos de redistribución fluvial o terrestre (Carreras, 1996: 206-207; Carretero, 2000: 742). En cuanto al aprovisionamiento de aceite, se ha pensado en otras regiones peninsulares alternativas que suplirían el aceite bético, principalmente la zona del Alto valle del Ebro, mucho más próxima a los asentamientos militares, y que además en época romana estaba dedicada al cultivo del olivo, según señalan los principales historiadores de la época. Arqueológicamente, esta hipótesis puede verse confirmada con la aparición, cada vez más frecuente de instalaciones, fundamentalmente prensas 95 , para la elaboración de aceite en esta zona, cuyo envío hacia los campamentos del noroeste supondría precios mucho más asequibles y una mayor facilidad en el transporte. Únicamente cabría plantearse el tipo de envases utilizados que, muy posiblemente, serían contenedores no cerámicos, como odres (cullae) que, por su carácter perecedero, no dejan evidencias en el registro arqueológico (Carreras, 1997: 170; Morillo, 2000: 628-629) aspecto éste ya contemplado desde hace tiempo como explicación (Blázquez et alii, 1985: 461).

Siguiendo con esta teoría de la fabricación y transporte oleario con origen en el alto Valle del Ebro, podemos añadir, a modo de corroboración, el hecho de que en yacimientos civiles más próximos, como Celsa (Beltrán, 1998: 77-78, fig. 43, nº 2) o Arcobriga (Sánchez, J. C., 1992: 289, fig. 10.1.9), tampoco se constata la presencia de ánforas olearias Dressel 20 o bien ésta es meramente testimonial (un fragmento en cada caso), confirmando la escasa penetración del aceite bético en las áreas interiores peninsulares, que seguiría rutas fundamentalmente costeras para su distribución en otras provincias imperiales.

95 Vid. FERNÁNDEZ CASTRO, M.C. (1984): “Fábricas de aceite en el campo hispano-romano”, en VVAA: 569-601; y la aportación más reciente sobre esta cuestión en PEÑA CERVANTES (2010). 


\section{6.- MATERIALES PROCEDENTES DEL VERTEDERO DE “SAN PEDRO” ESTUDIADOS EN OTROS TRABAJOS DE INVESTIGACIÓN}

Teniendo en consideración algunas características de la investigación arqueológica en la ciudad de León, ya comentadas en el capítulo dedicado a la metodología, en que poníamos de manifiesto las dificultades y obstáculos que ocasiona para el investigador de los distintos contextos la realización de las intervenciones por parte de diferentes equipos -lo que da lugar a una gran heterogeneidad en métodos y elaboración de informes-, así como la atribución del estudio de los materiales procedentes de una misma excavación a distintos investigadores -generalmente según su especialidadresulta evidente que no es posible realizar una investigación completa de cada contexto al no disponer de la totalidad de los datos necesarios para elaborar una interpretación conjunta y llegar a resultados totalmente concluyentes.

Por ello, aunque de forma muy somera, incluimos aquí algunos datos relevantes extraídos de los trabajos sobre dos especies cerámicas del depósito de San Pedro -cerámica de paredes finas y lucernas- estudiadas por otros investigadores, con el fin de completar, aunque muy sucintamente, nuestro estudio sobre las demás especies cerámicas de este contexto.

\section{1.- CERÁMICA DE PAREDES FINAS}

El estudio de la cerámica de paredes finas del depósito de San Pedro ha sido abordado por $D^{a}$. E. Martín Hernández y publicado en 2008, si bien se trata de un trabajo centrado únicamente en la cerámica de paredes finas de época julio-claudia, correspondiente por tanto a la etapa del campamento de la Legio VI Victrix en León. Por ello, las aportaciones de este estudio, aunque siempre interesantes para poder establecer paralelos y comparaciones con la etapa anterior a la que comprende nuestro estudio, responden a los planteamientos propios de cada investigador en función de las líneas que definen los puntos esenciales de su investigación. En este caso, al igual que en el que trataremos posteriormente, se trata de trabajos de investigación centrados en un único material cerámico en una zona peninsular concreta, con el fin de obtener conclusiones de muy diverso orden en función de la importante riqueza informativa que ofrece la cerámica romana. De esta manera, esta línea de investigación difiere sustancialmente de la que nosotros llevamos a cabo, basada en el estudio de la totalidad de los materiales que se encuentran en los diferentes vertederos romanos de Legio, y últimamente restringida al estudio exclusivamente del material cerámico de estos contextos extramuros.

Dado que en el vertedero del depósito de San Pedro hemos hallado un importantísimo volumen de material cerámico que presentamos en este estudio, nos resultaban de interés los datos aportados por el estudio de la cerámica de paredes finas, habida cuenta de que la autora no se somete estrictamente a la etapa julioclaudia. En efecto, se tratan asimismo en el citado estudio algunas producciones propias de la etapa flavia, esto es, ya en la época de ocupación campamental por la Legio VII Gemina, y además con una especial atención a las producciones del alfar zamorano de Melgar de Tera, presentes en la mayor parte de las excavacio- 
nes legionenses -con una cronología incluso más avanzada-, pero cuya interpretación, tanto como centro abastecedor de Legio y su período de vigencia, dista con mucho de la que planteamos en los capítulos correspondientes de estas producciones en otros vertederos.

Por lo demás, resulta de gran valor el minucioso análisis tipológico y el estudio sobre la procedencia de este conjunto de cerámica de paredes finas en la etapa julioclaudia en este vertedero leonés, integrado por 265 ejemplares y un gran número de fragmentos inidentificables, debido a la ya comentada compleja estructura estratigráfica de este contexto, que afecta igualmente, como hemos podido comprobar, al material de las fases posteriores.

La clasificación morfológica incluye 26 categorías formales, con un predominio de las formas Mayet XXXIV, XXXV y XXXVII y las producciones denominadas “tipo Melgar".

En cuanto a la procedencia, se localizan algunas manufacturas itálicas y gálicas, correspondiendo la mayor parte del conjunto a producciones hispánicas. En éstas, se detecta la variedad de los centros de fabricación, con una mayoría de producciones béticas, localizándose también ejemplares emeritenses, tarraconenses, del Valle del Ebro, con una menor representación de los procedentes de Lucus Augusti y los que la autora denomina "tipo Herrera de Pisuerga" y destacando el porcentaje mayoritario de las manufacturas denominadas "tipo Melgar" en el que se incluyen los principales tipos formales y motivos decorativos del taller zamorano (mamelones, lúnulas, impregnación arenosa y barbotina).

Este predominio de piezas melgarenses plantearía una problemática cronológica, por cuanto las fechas para los inicios de la producción de este alfar se sitúan a finales de la etapa julio-claudia. Así, se incluyen en el estudio análisis arqueométricos sobre este conjunto en el que la autora expone una diferenciación entre piezas procedentes de Melgar de Tera y otras que, en su opinión, podrían tener su origen en un centro productor de carácter local situado en la propia ciudad de León, hipótesis que hasta el momento no cuenta con evidencias arqueológicas reconocidas.

\section{2.- LUCERNAS}

El numeroso conjunto de lucernas hallado en el depósito de San Pedro fue objeto de estudio por D. Á. Morillo Cerdán en su tesis de Doctorado "Lucernas romanas en la región septentrional de la Península Ibérica", publicada en 1999.

En lo que respecta al depósito de San Pedro, se analizan un total de 97 fragmentos, de los que más de la mitad corresponden a lucernas de volutas, localizándose también varios ejemplares de lucernas "tipo Andújar", y muy escasos de disco y Firmalampen.

El exhaustivo análisis que se presenta sobre características morfológicas, iconográficas y cronológicas posee un inestimable valor, y de ello se infieren importantes datos sobre la producción, las áreas de distribución peninsular y el abastecimiento de estas producciones en el campamento legionense en sus diferentes etapas.

Así, a partir del análisis de los distintos tipos y sus variantes en el contexto estratigráfico del depósito, el autor ha establecido una cronología de época tiberiana y clau- 
dia en la que se englobaría la mayor parte del material lucernario recuperado. Sin embargo, la presencia de algunas lucernas de canal de importación, así como las variantes de disco más antiguas (Dressel 17 o Dressel 20) indican ya una evolución, adscribiéndose a la época de la Legio VII Gemina.

Especial relevancia adquieren los ejemplares de lucernas derivadas del tipo Dressel 3 , conocidas como "tipo Andújar", presentes en niveles claudio-neronianos, que proporcionan datos sobre la importación de estos productos meridionales en el asentamiento legionense ya en su primera fase. En este sentido cabría relacionar la controvertida cuestión del abastecimiento del combustible utilizado para la iluminación, mayoritariamente aceite bético, ya tratada anteriormente.

Todo ello pone de manifiesto la importancia de los resultados del estudio del material lucernario, especialmente en contextos en que el aprovisionamiento de determinados productos adquiere una singular importancia desde el punto de vista político y socioeconómico, como es el caso de los campamentos militares. 
LÁMINAS 

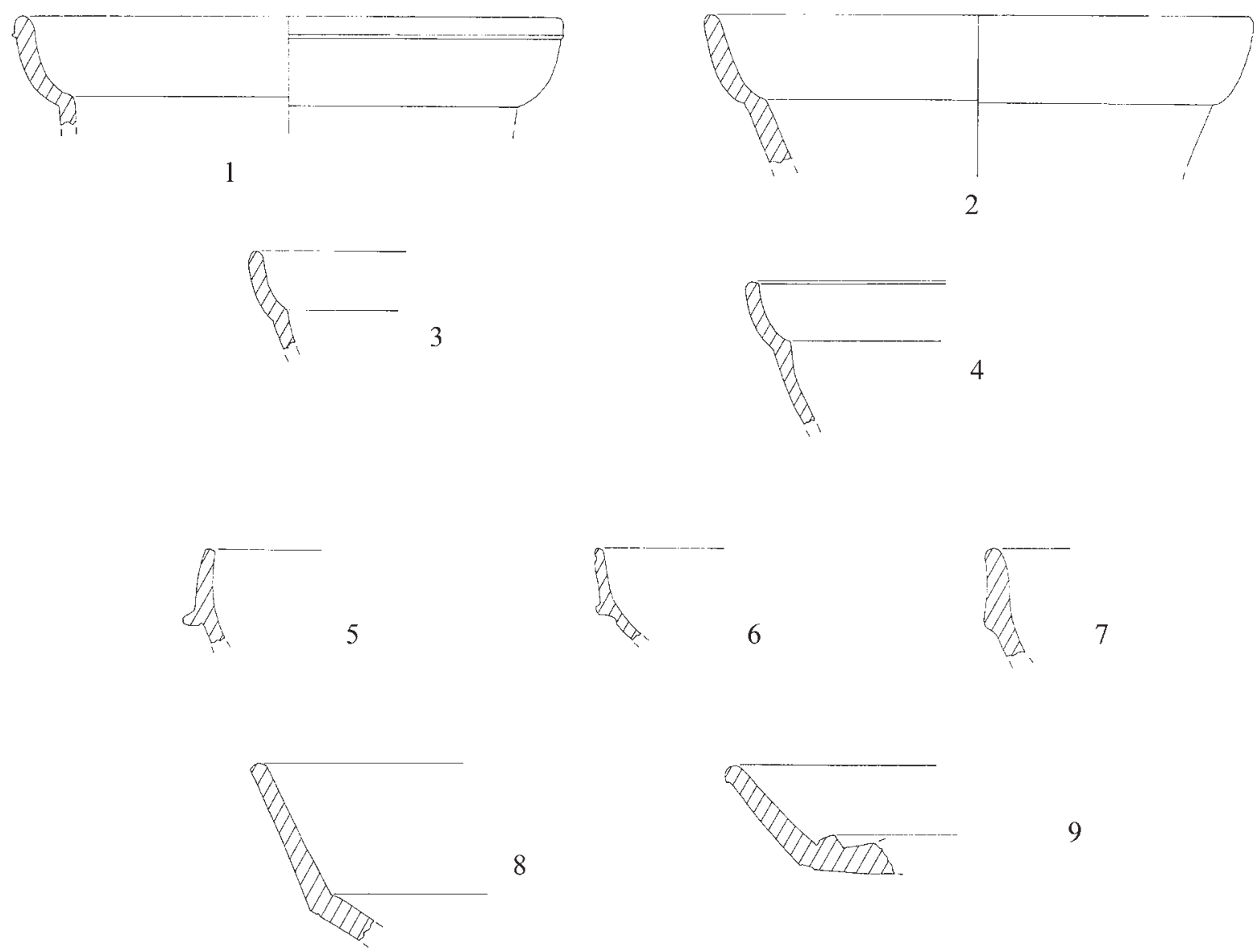

9
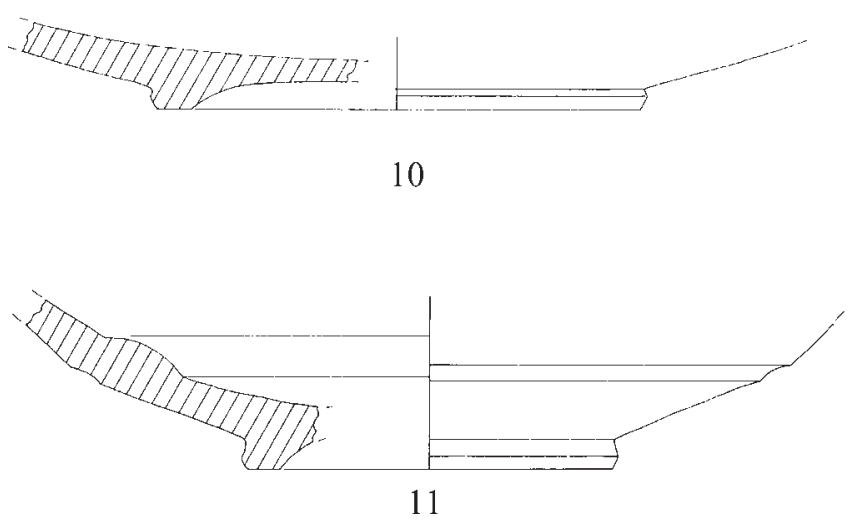

$---$

Lámina 1 

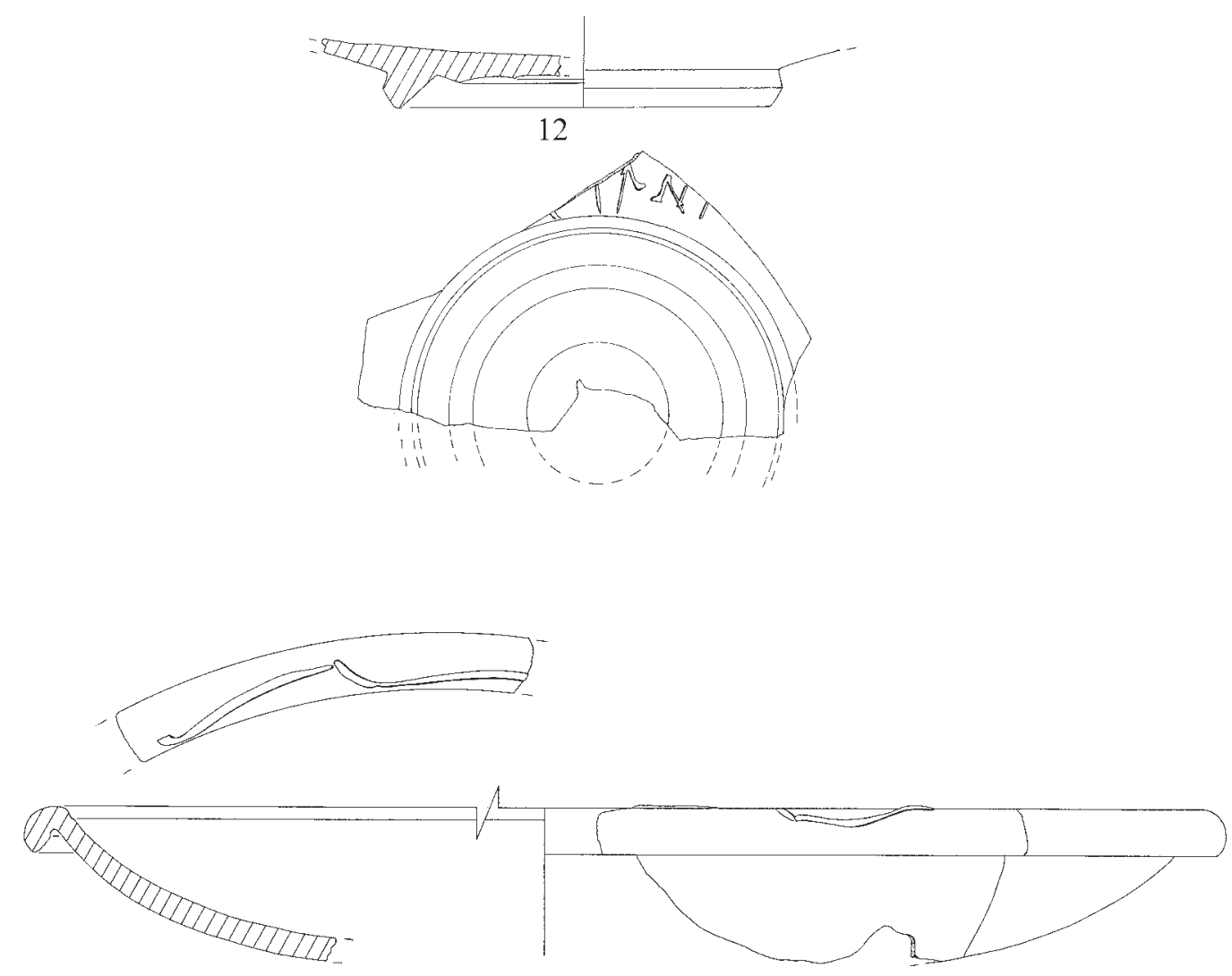

13

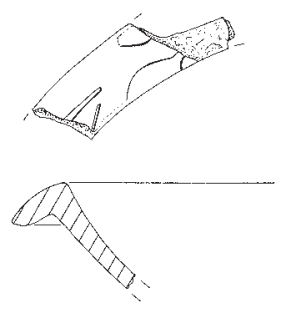

14

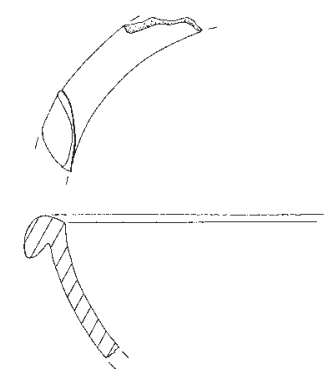

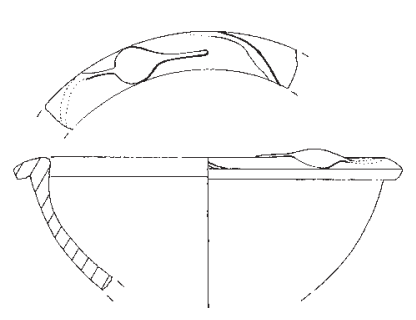

15

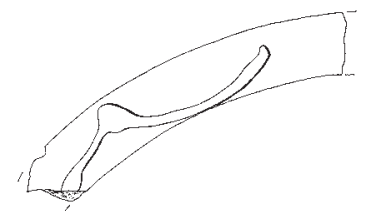

17

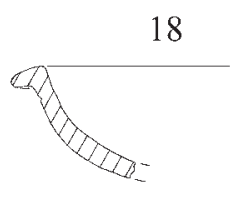

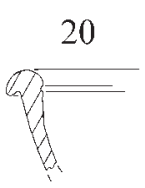

16

Lámina 2 


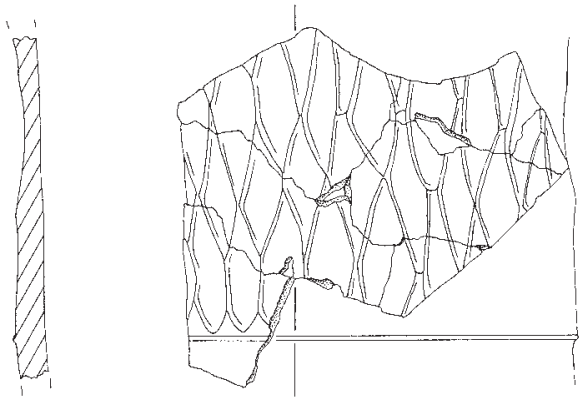

21

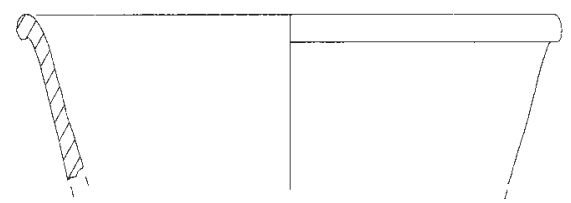

24

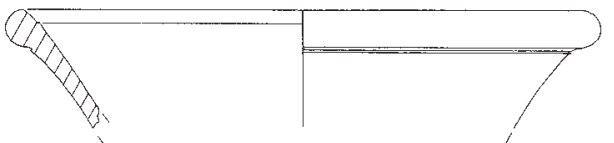

26

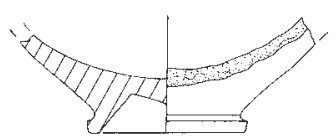

29

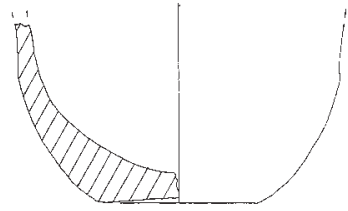

30

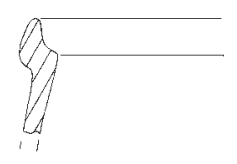

22

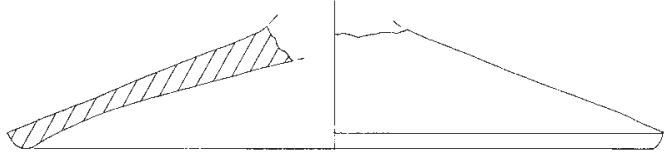

23

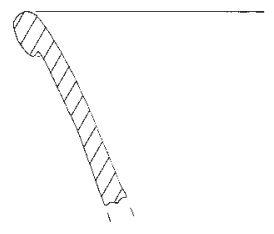

25

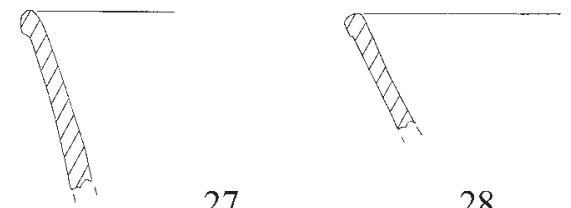

27

28

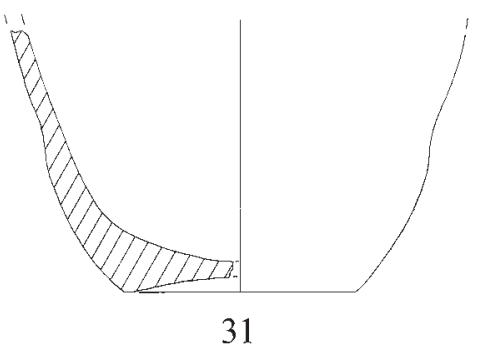

- …다.

Lámina 3 

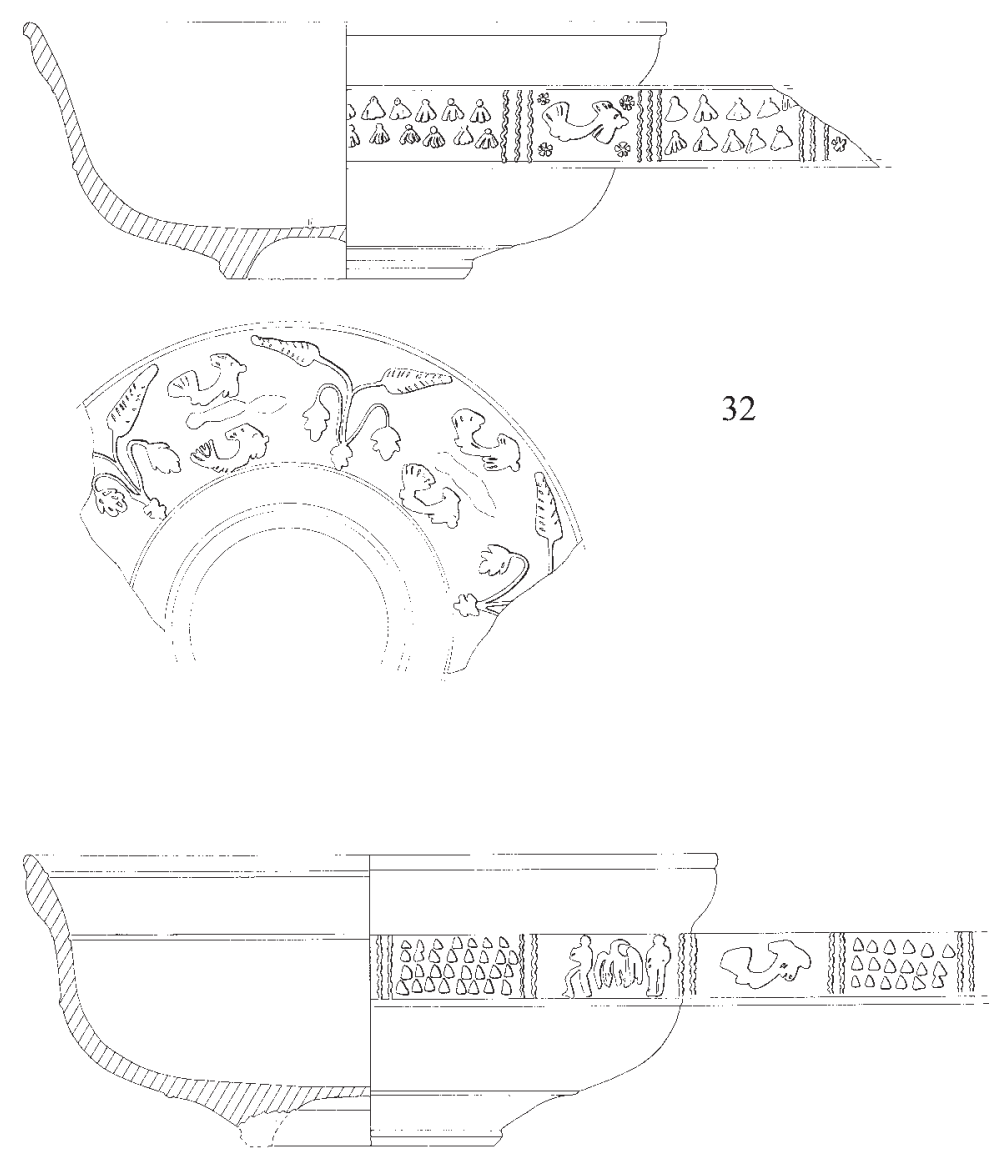

33

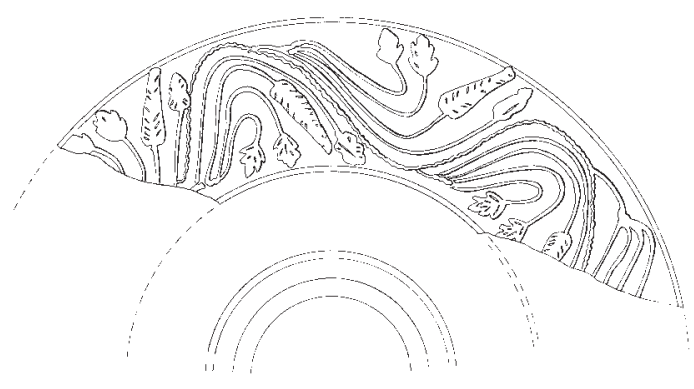

Lámina 4 


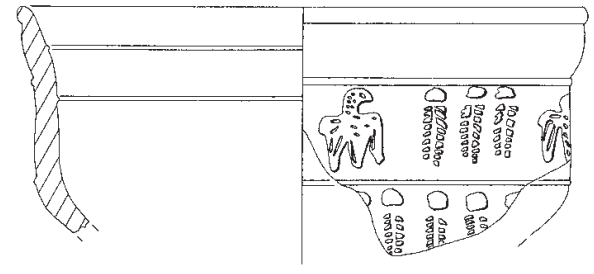

34

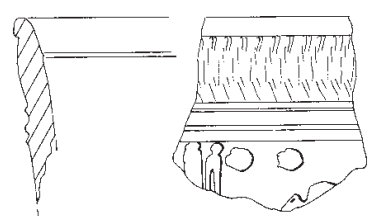

36
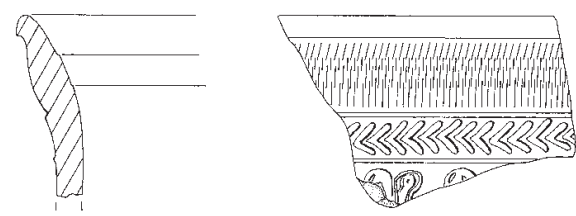

38
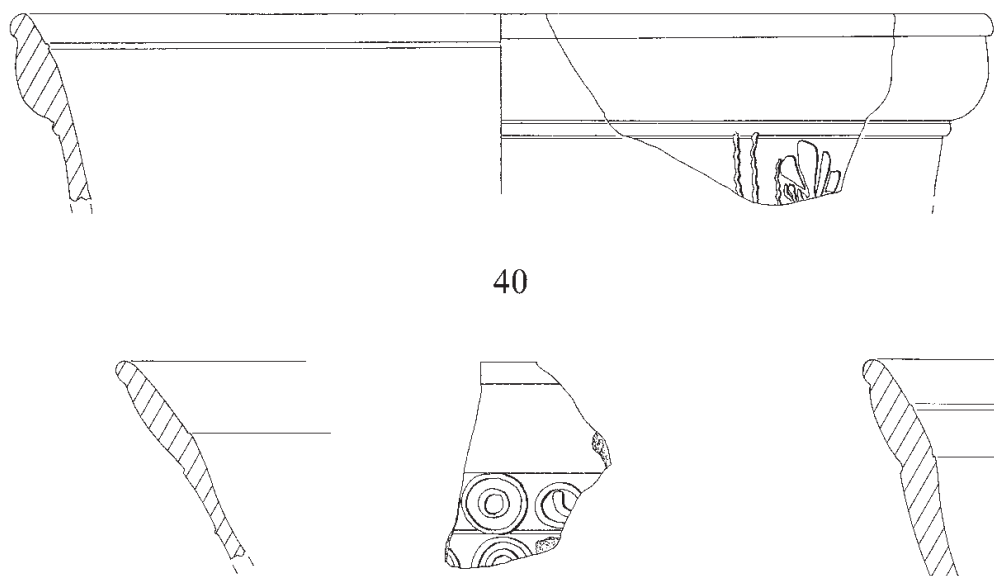

40
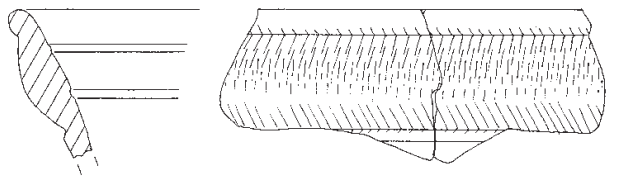

39

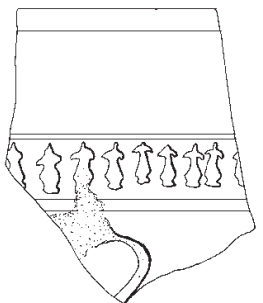

35

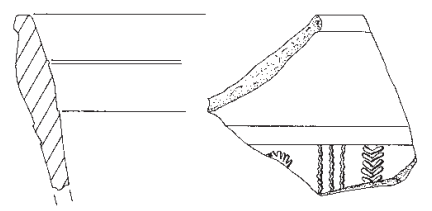

37 


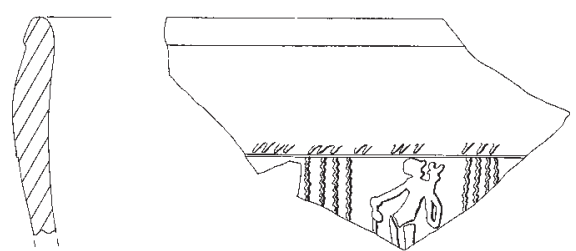

44

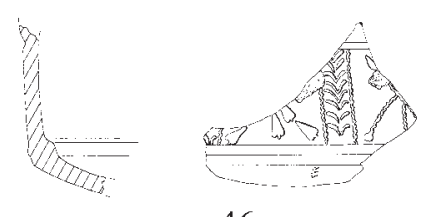

46
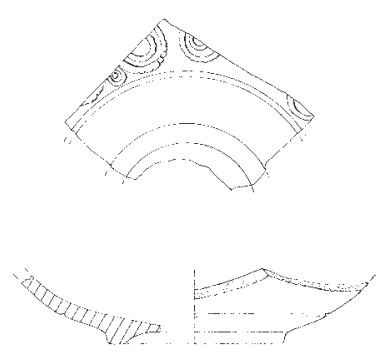

50

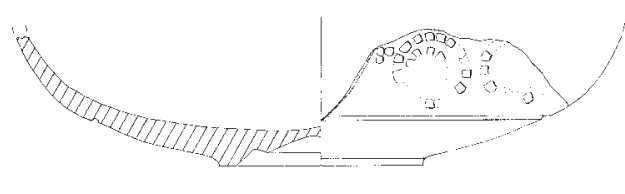

51
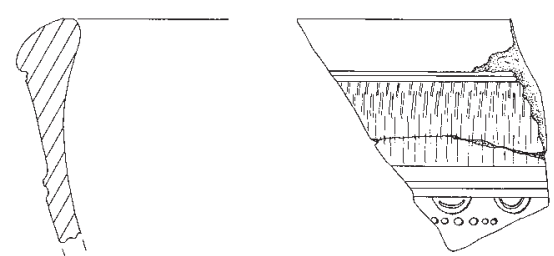

45

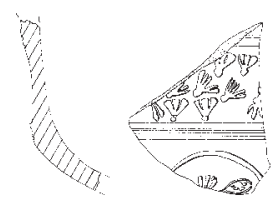

48

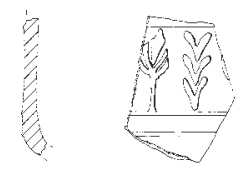

49

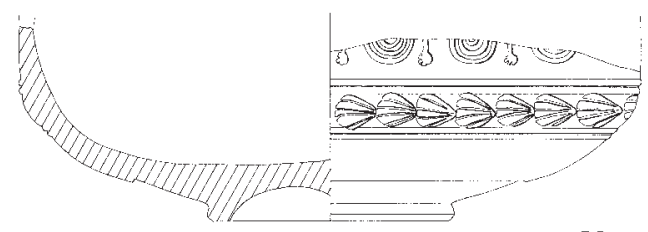

52

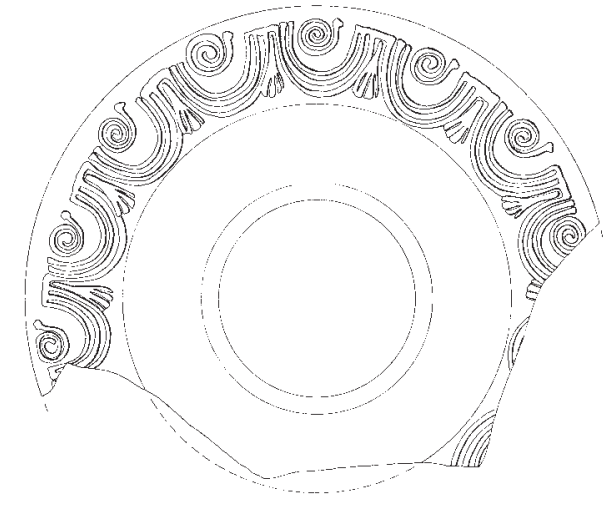

$-$

\section{Lámina 6}



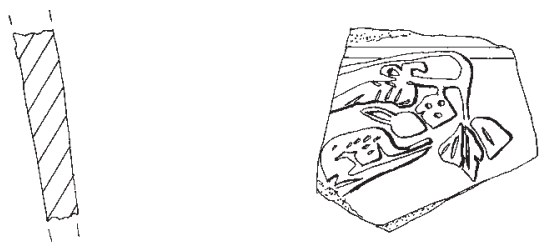

53

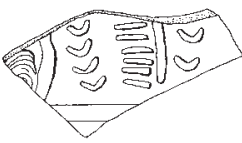

55
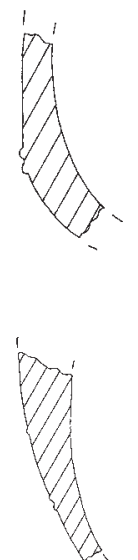

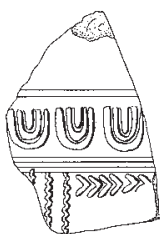

60
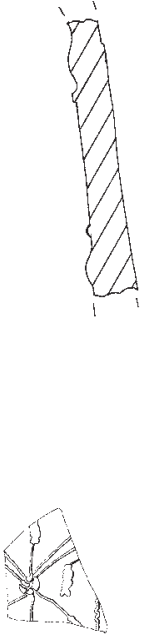

56
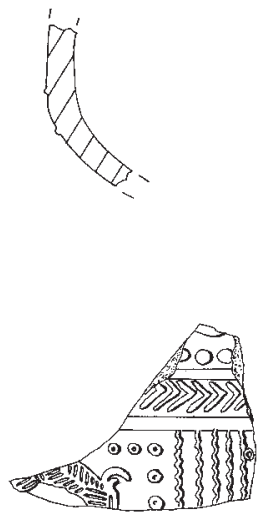

61

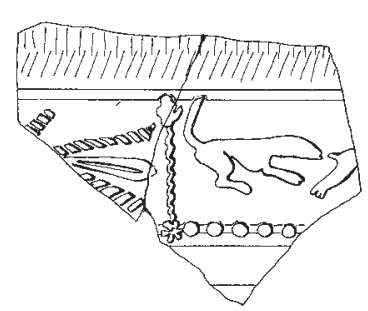

54

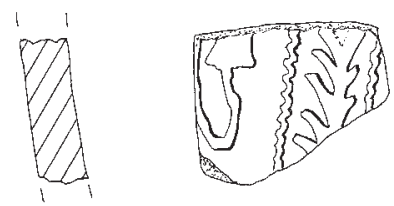

57

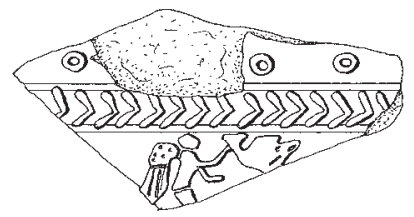

59

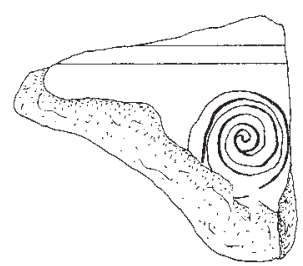

63

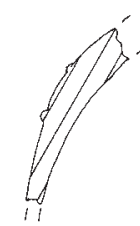

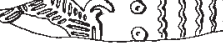
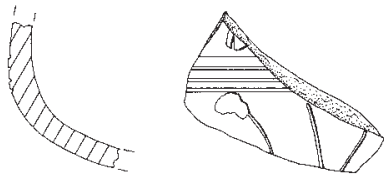

62

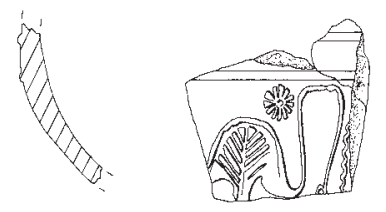

64 

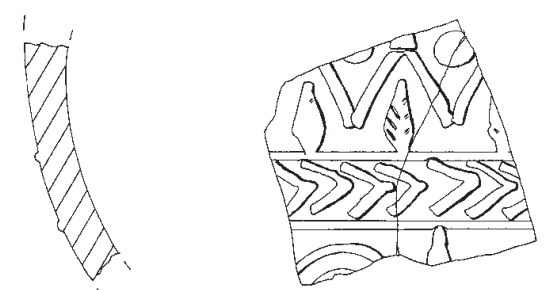

65

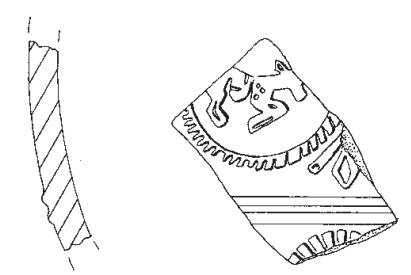

67

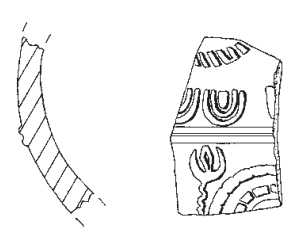

70

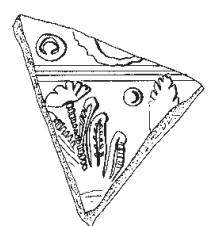

73
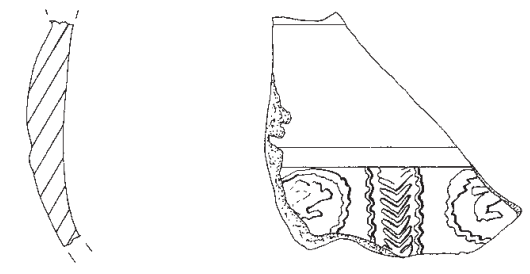

66

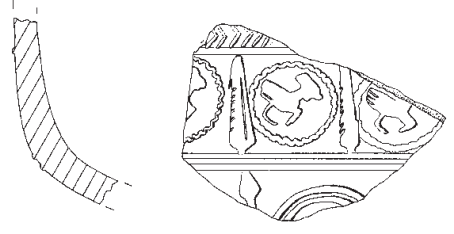

68

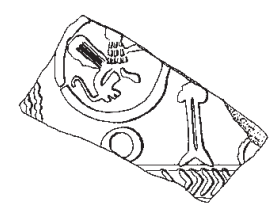

71

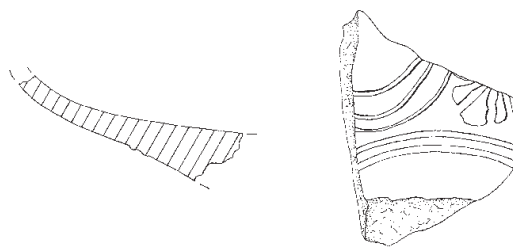

72
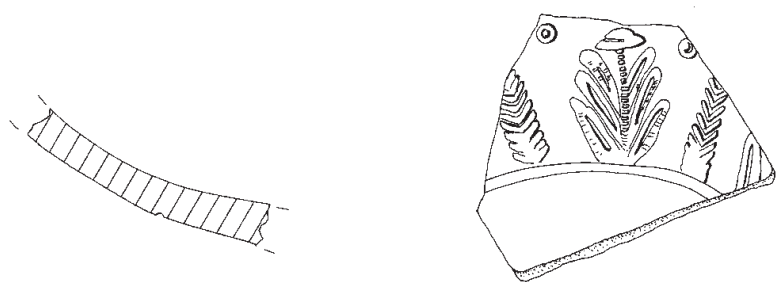

74 


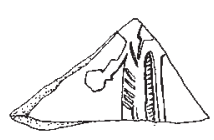

75

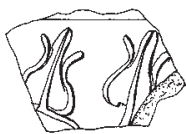

77

绾 79
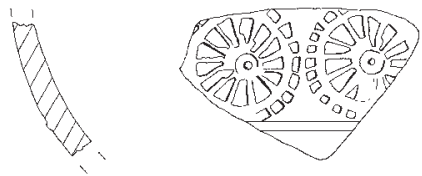

81
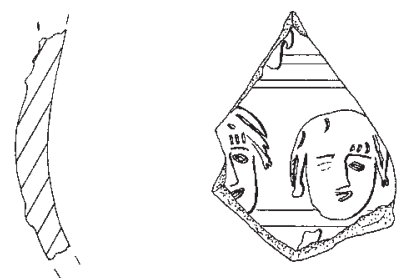

76

78

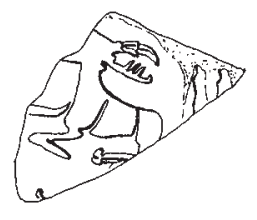

80
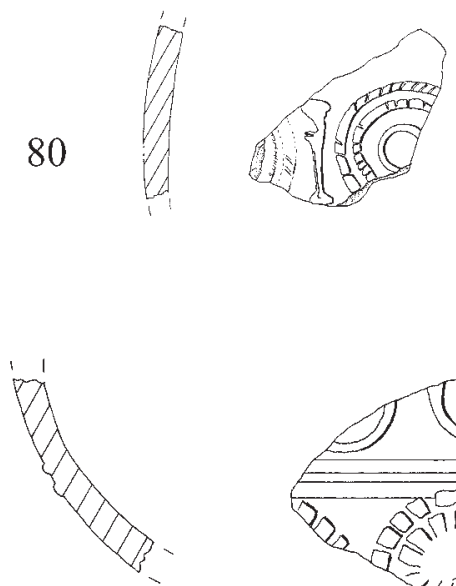

82

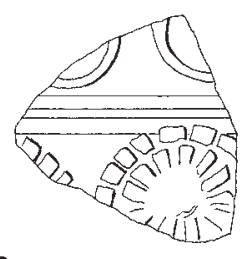



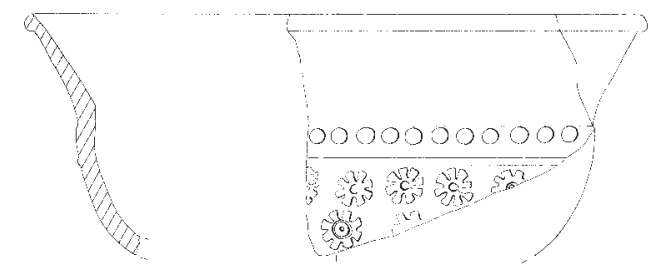

83

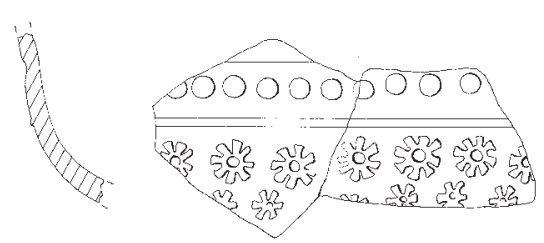

84

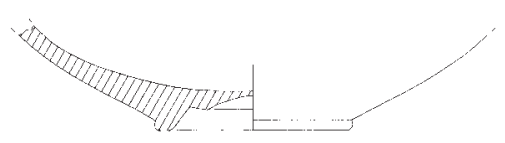

85

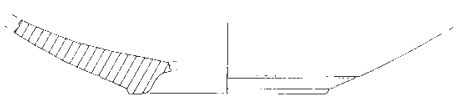

86

Lámina 10 


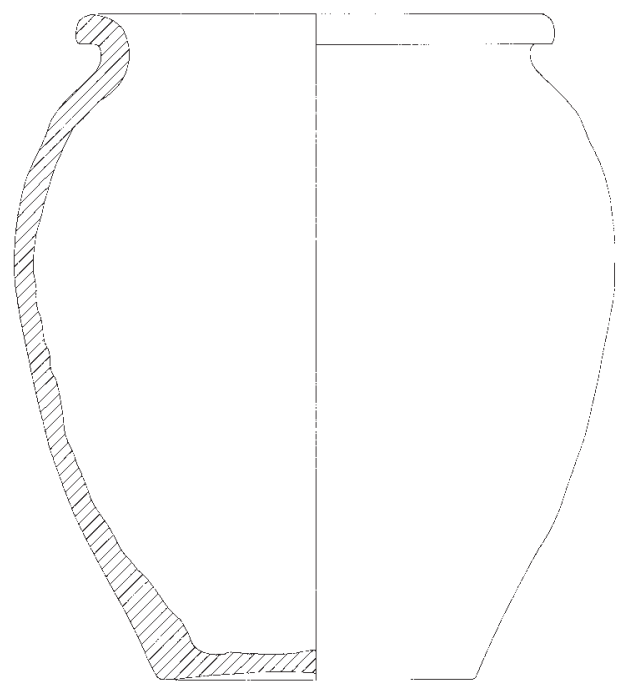

87

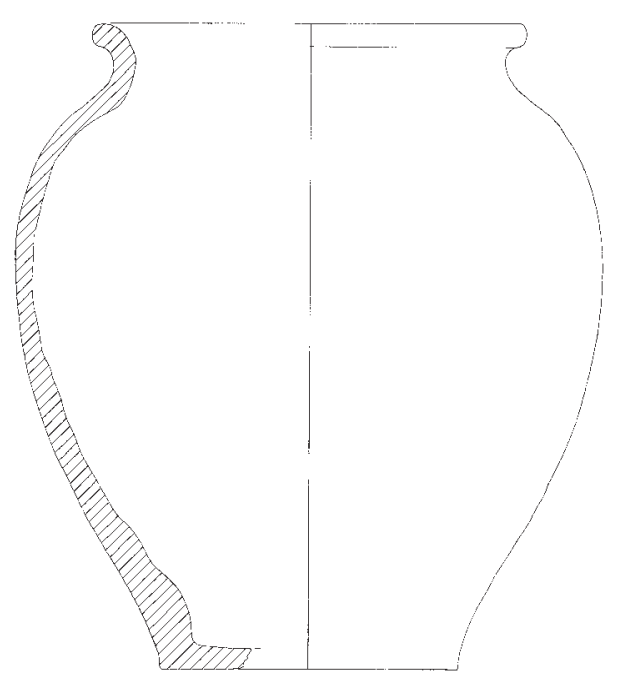

89

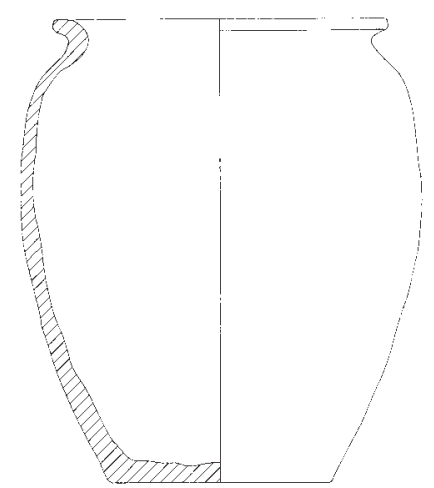

88

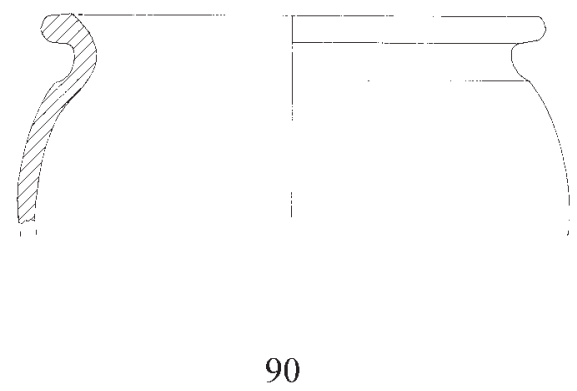

90

$--$ 


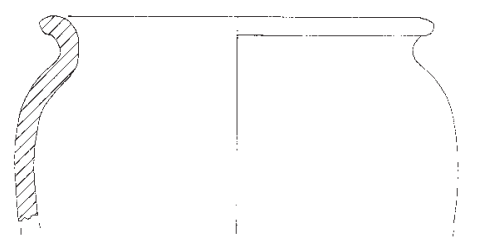

91

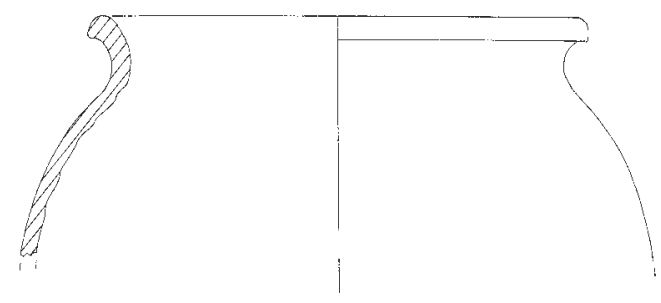

93

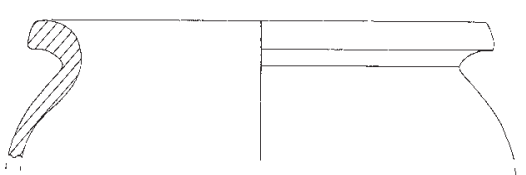

95

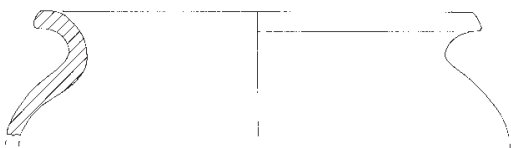

97

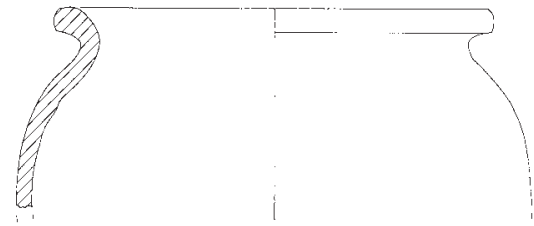

92

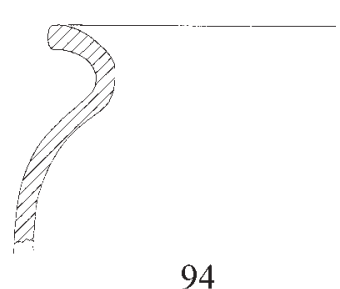

94

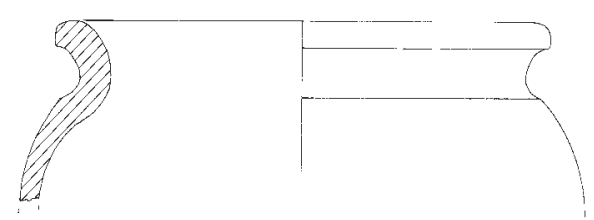

96

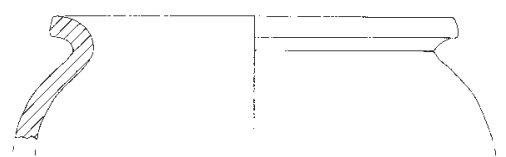

98

99

$$
\cdots
$$

Lámina 12 


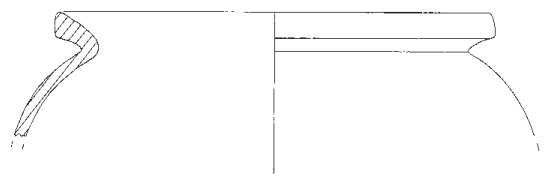

100

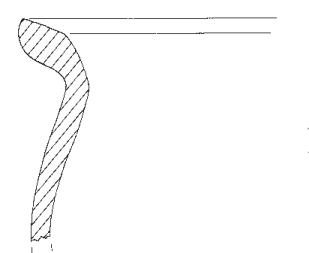

102

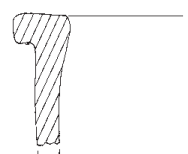

104

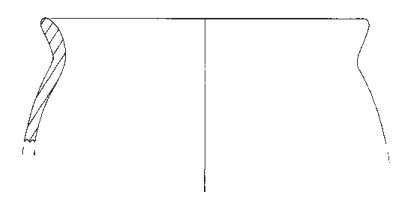

101

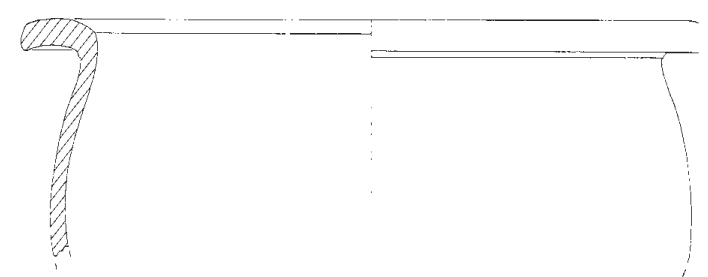

103

105

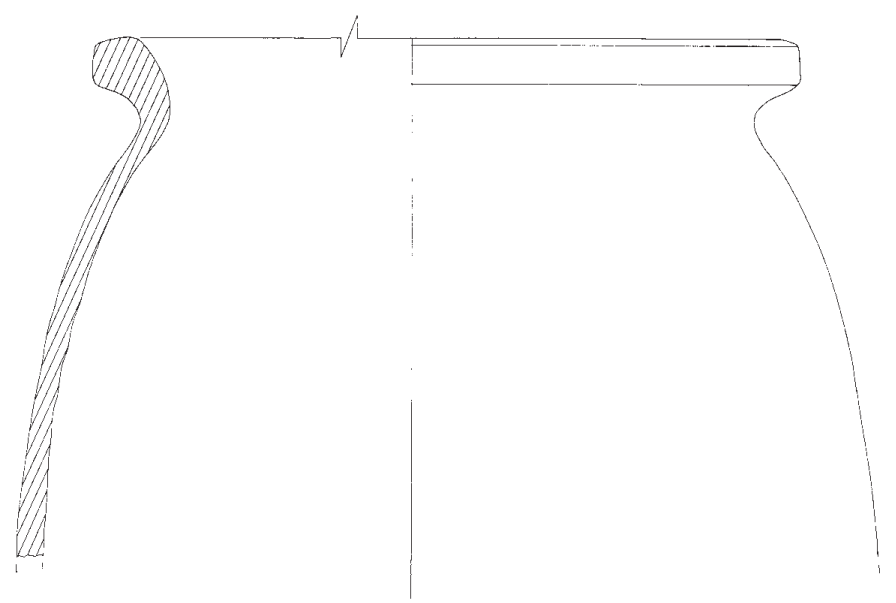

106

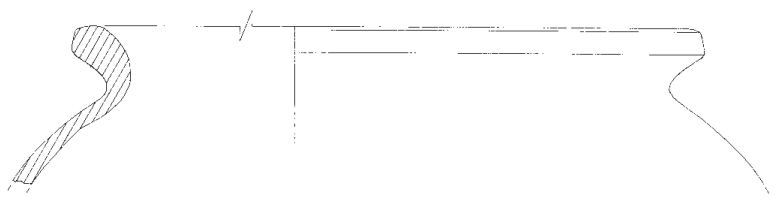

107

Lámina 13

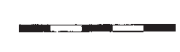




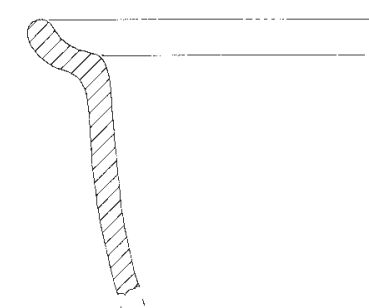

108

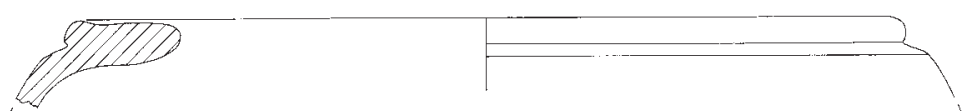

109

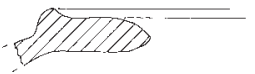

110

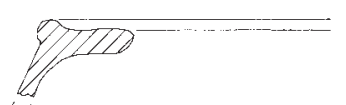

111 


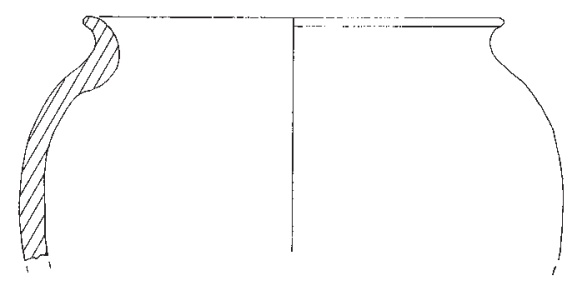

112

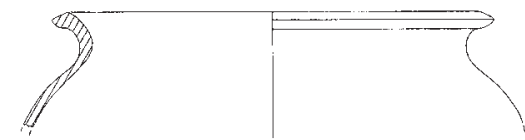

114

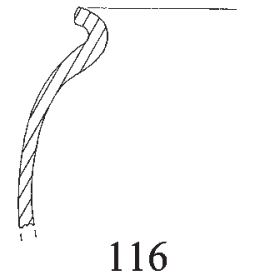

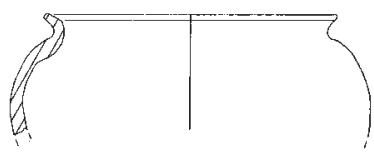

113

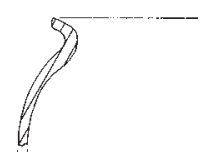

115

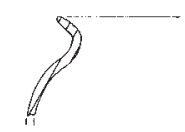

117<smiles>C=CC=C</smiles> 

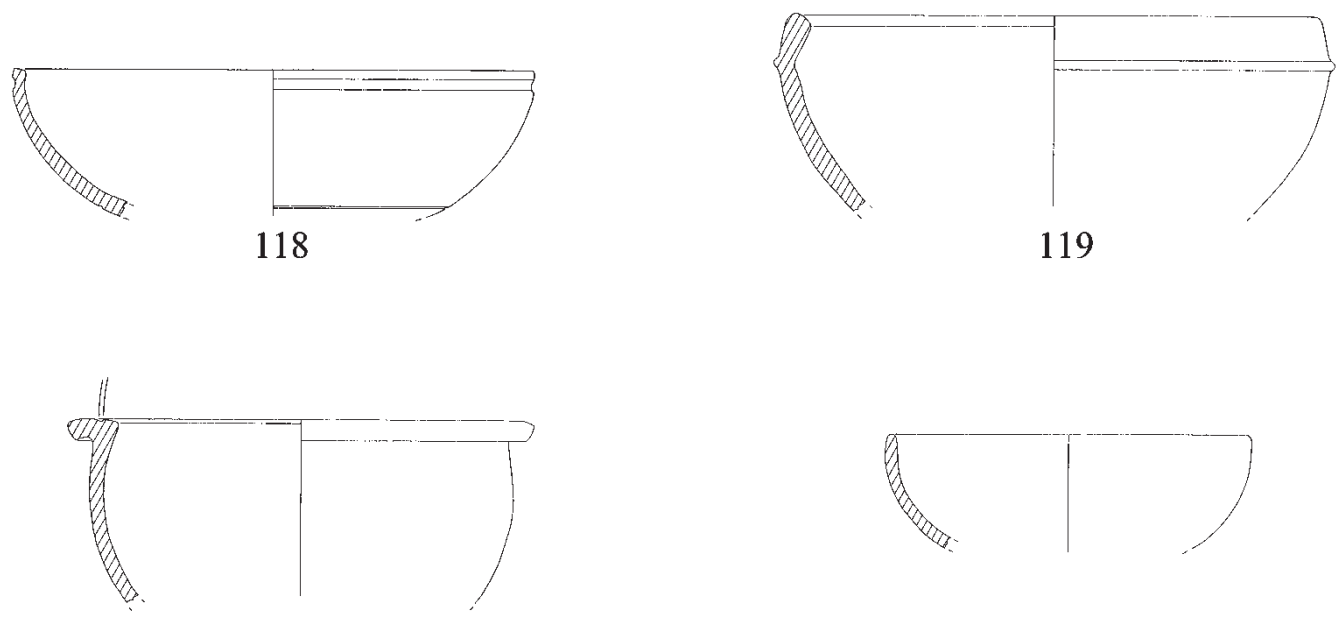

120

121

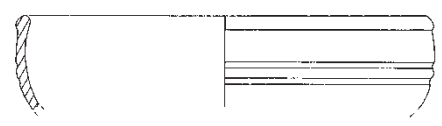

122

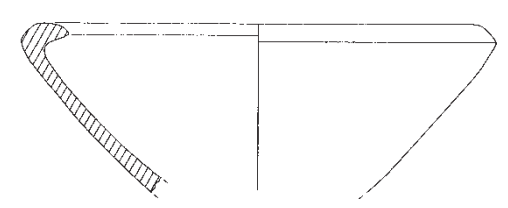

123
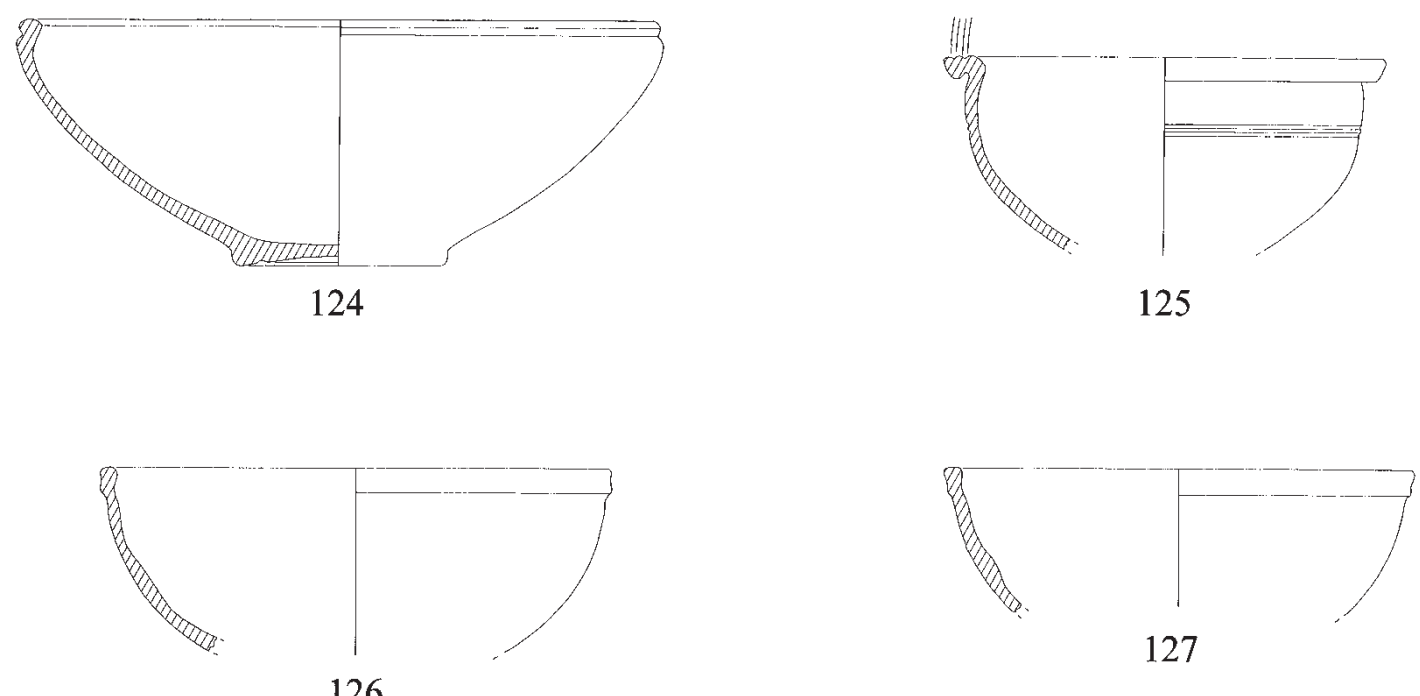

126
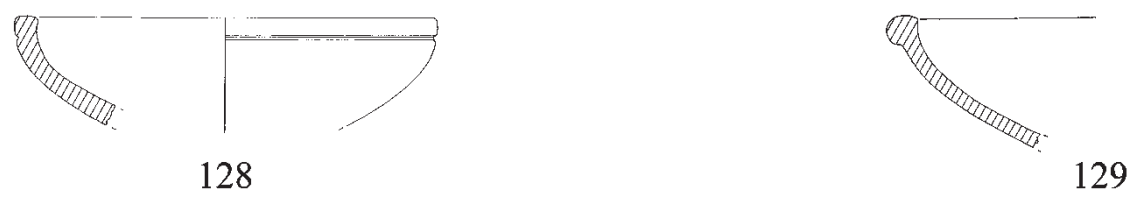

Lámina 16 


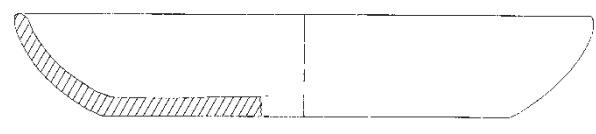

130

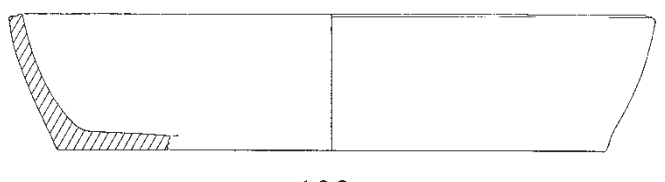

132

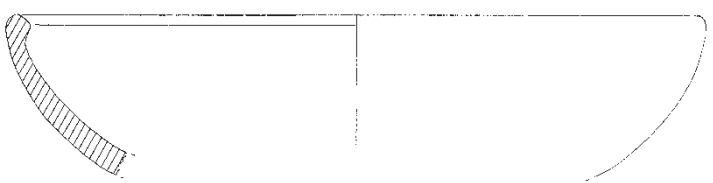

134
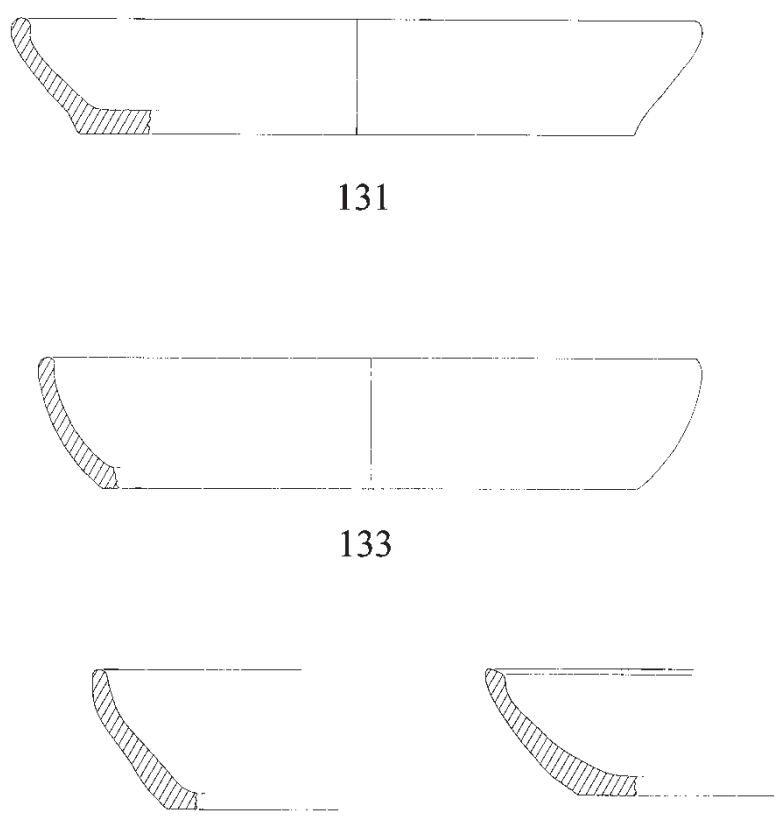

135

136
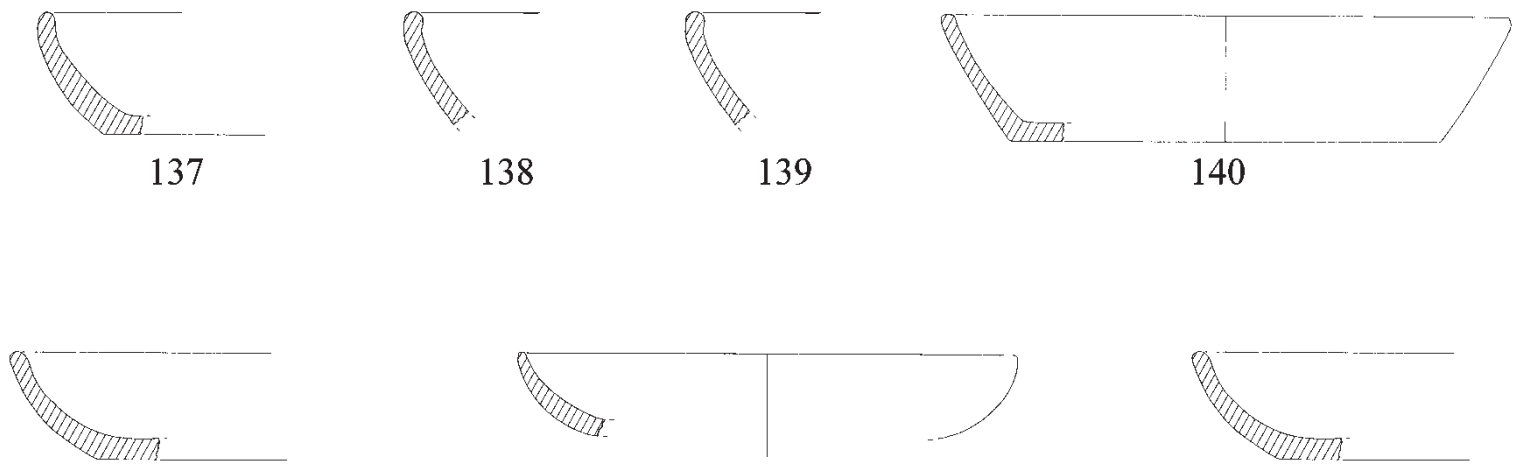

142

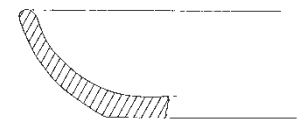

141

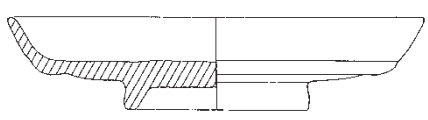

144

145

Lámina 17 

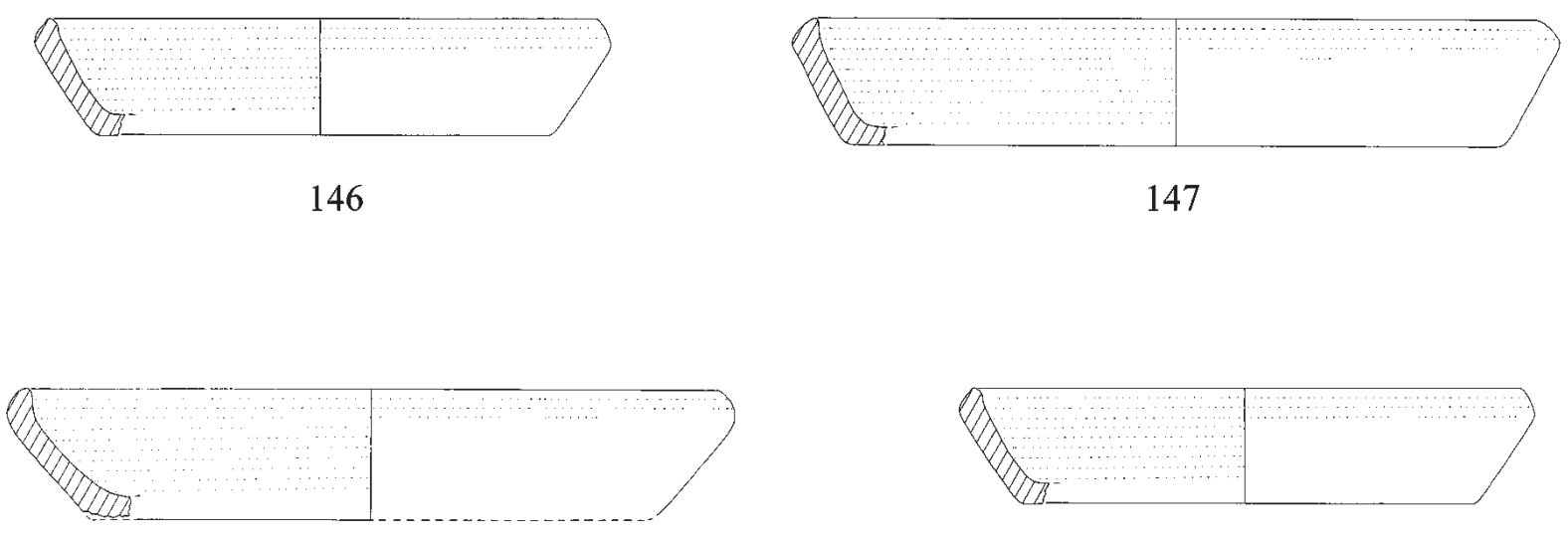

148

149

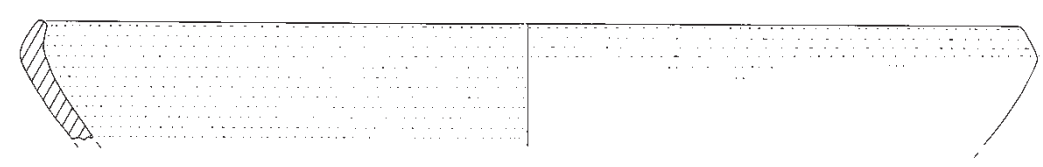

150
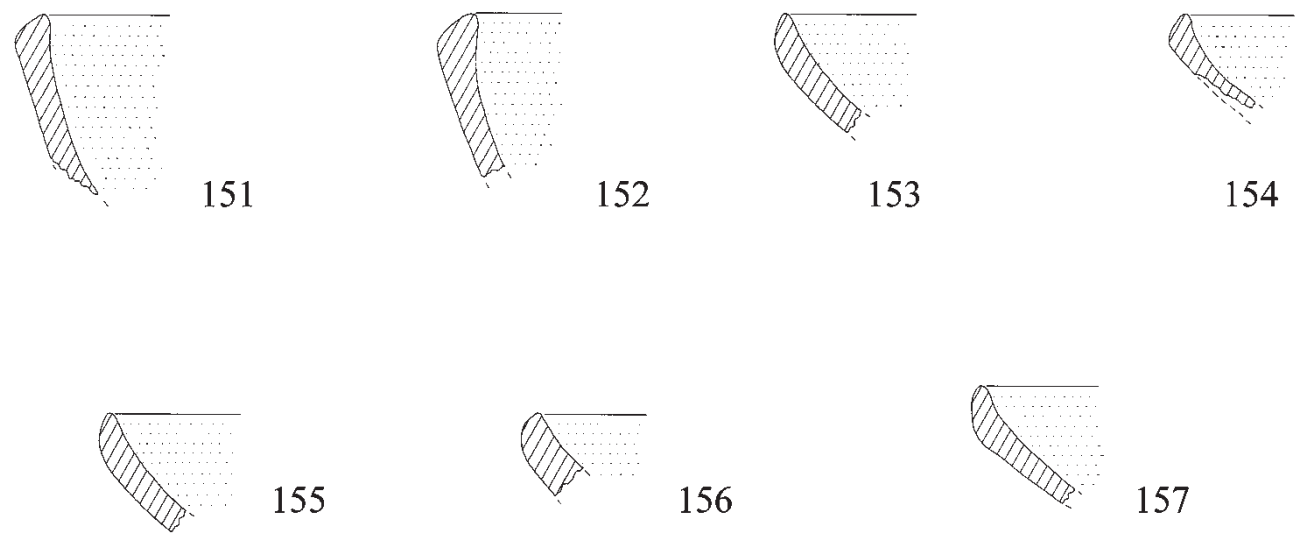

156

157

Lámina 18

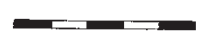




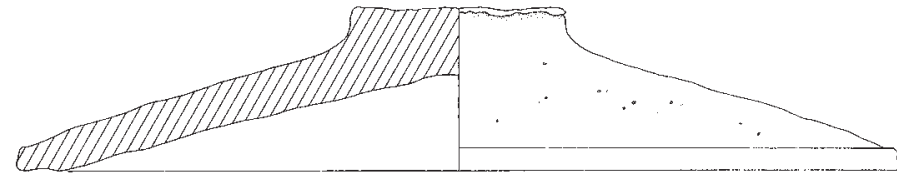

158
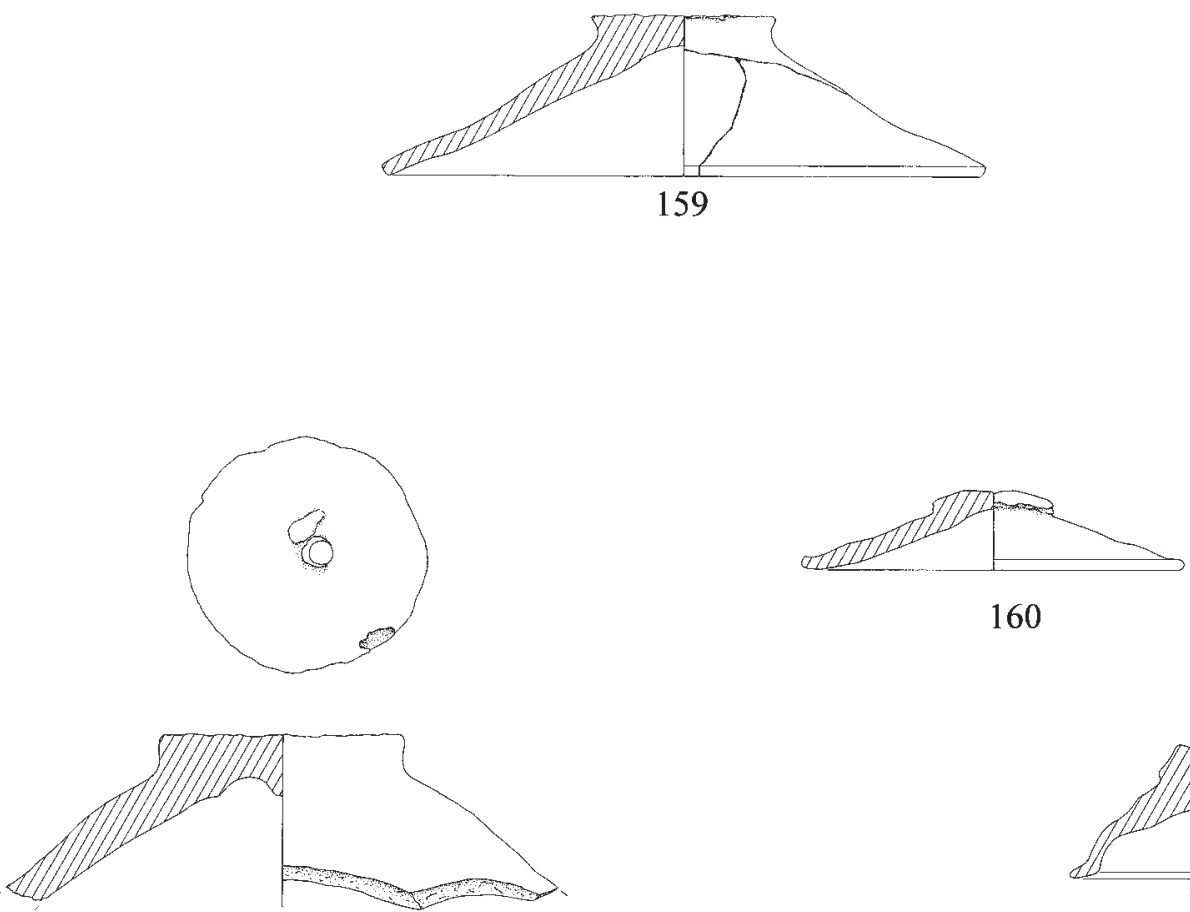

161

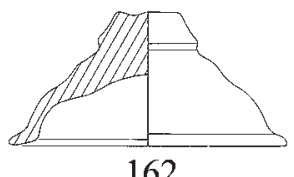

$-1-$

Lámina 19 


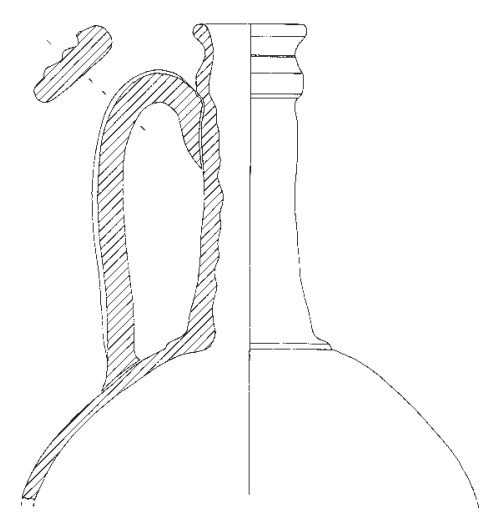

163

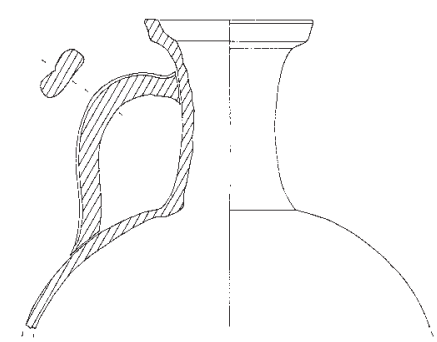

165
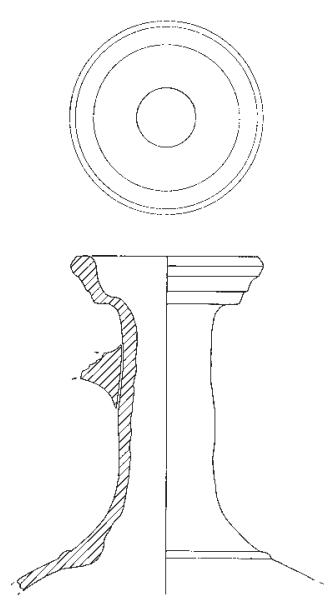

167

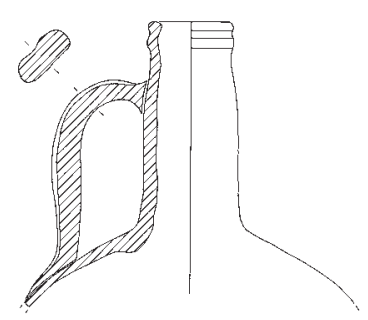

164

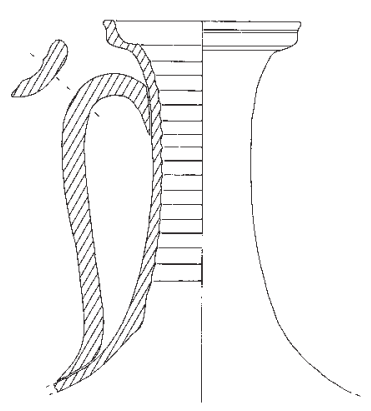

166

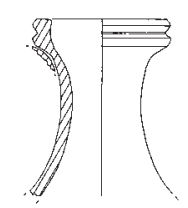

168

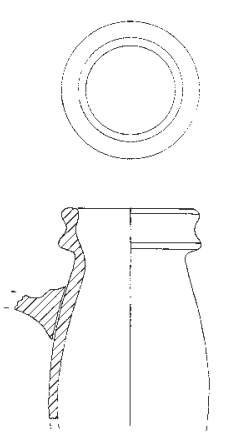

169

Lámina 20 


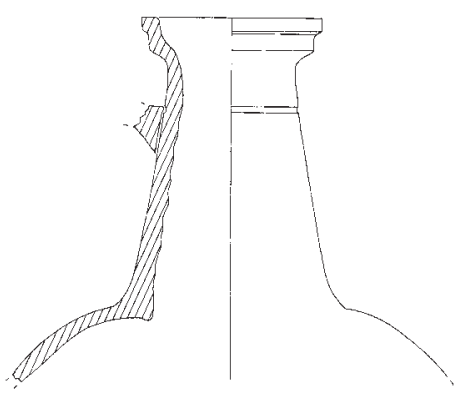

171

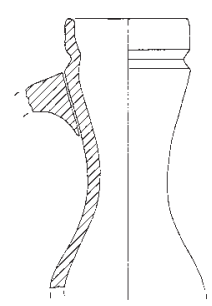

173

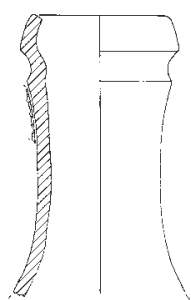

174

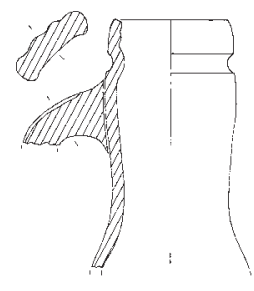

170

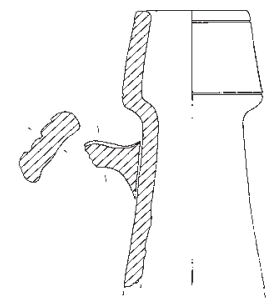

172

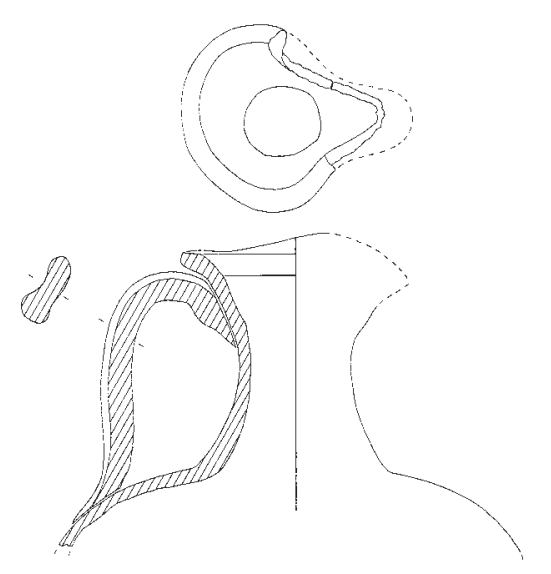

178

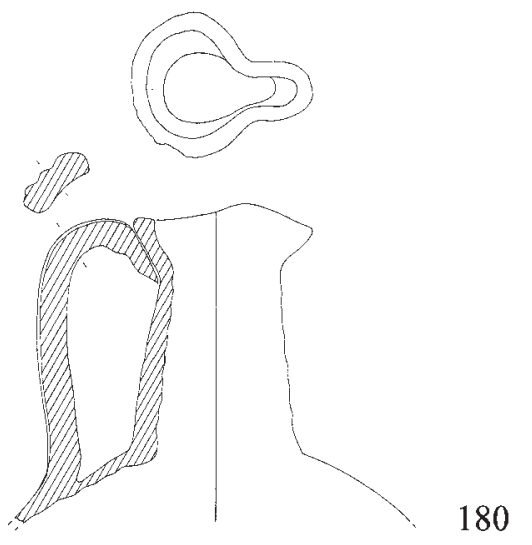

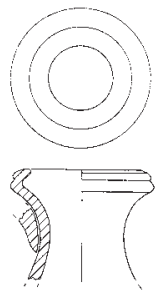

175

176 177

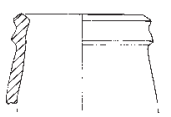

$\stackrel{\square}{\square}$
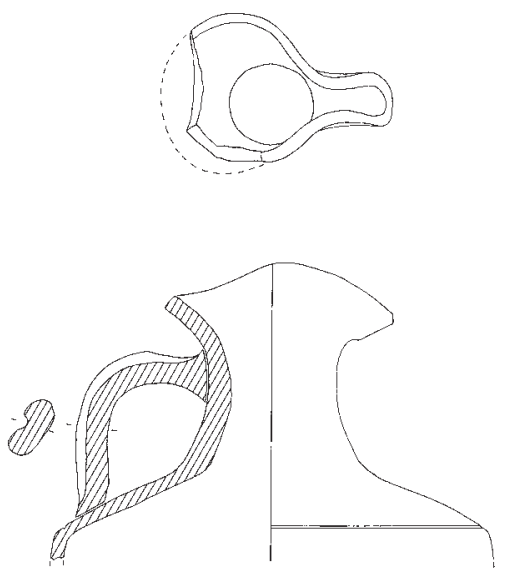

179

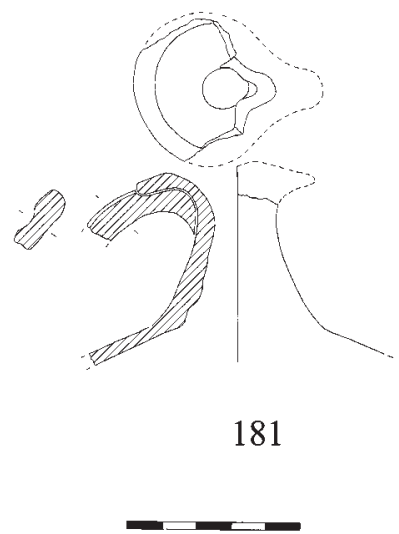

Lámina 21 


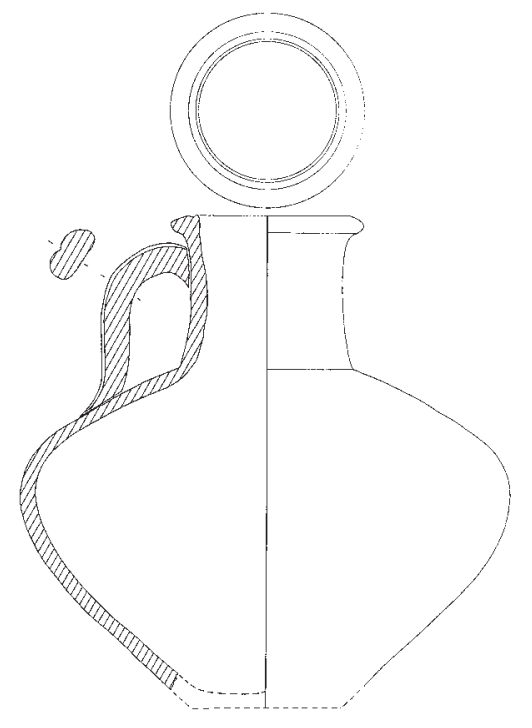

182

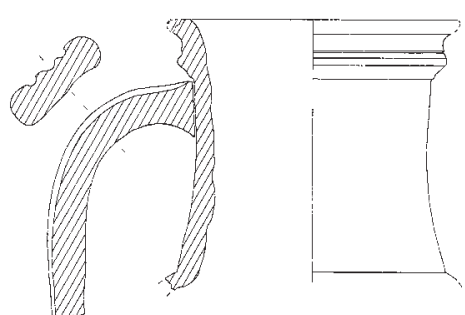

184

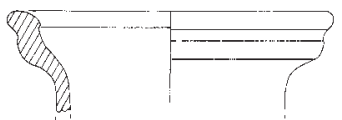

186

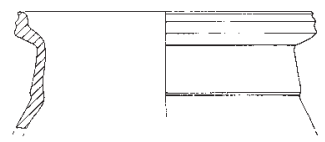

188

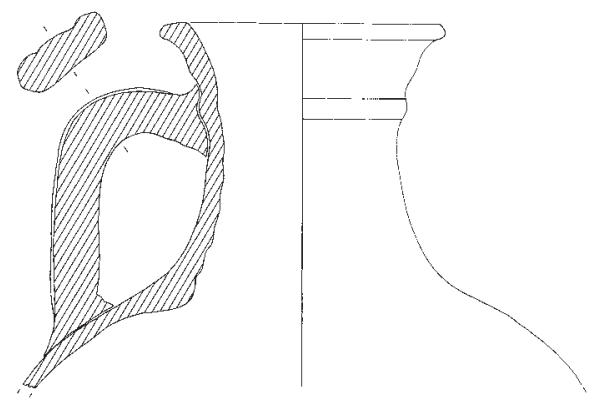

183

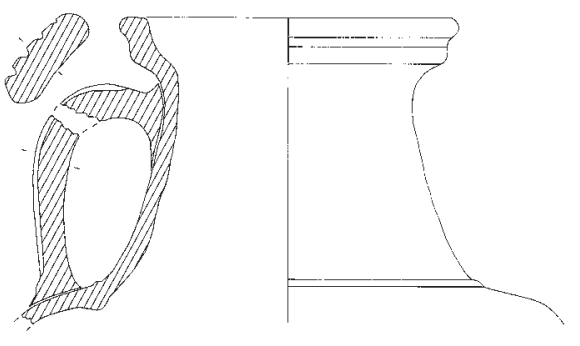

185

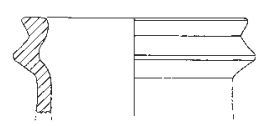

187

Lámina 22 


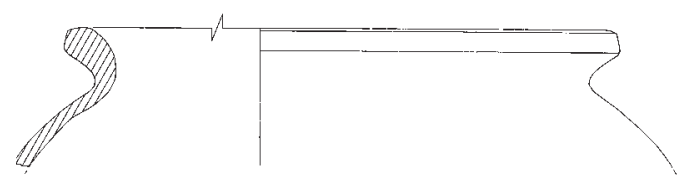

189

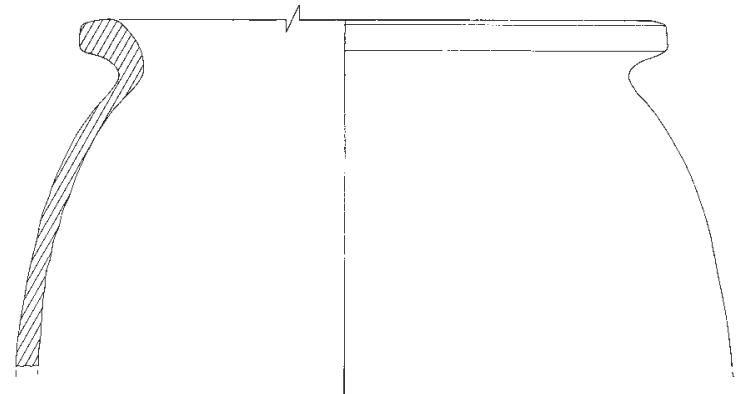

190

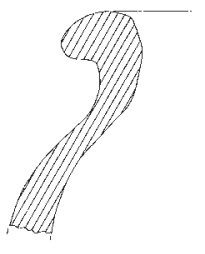

191

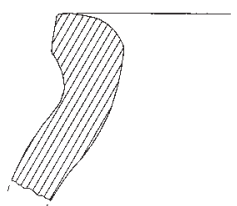

192

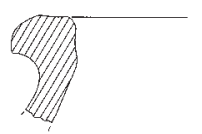

194

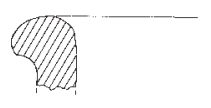

195

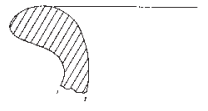

193

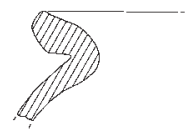

196

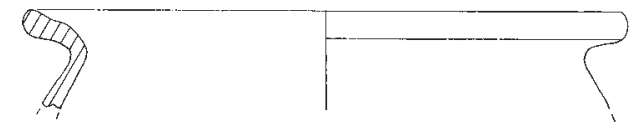

197

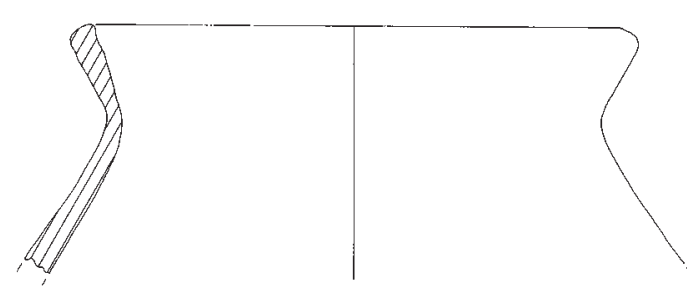

198

Lámina 23 


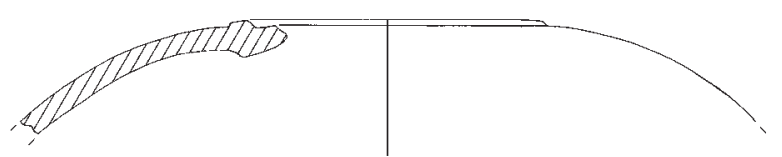

199

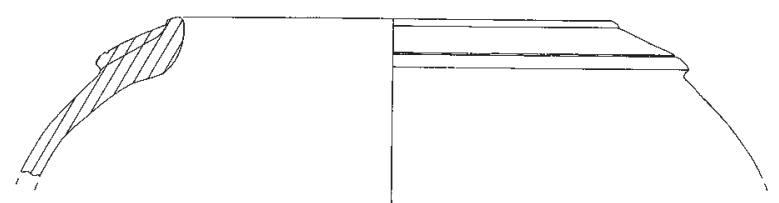

200

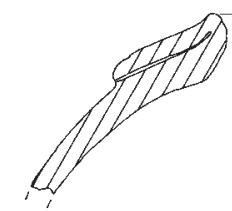

201

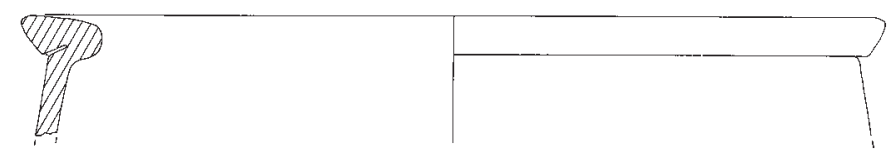

203

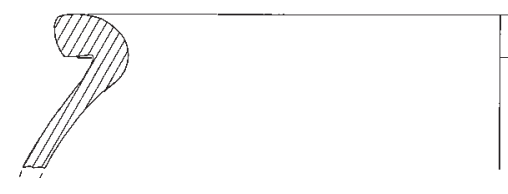

204

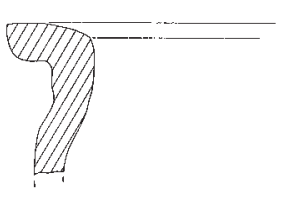

205

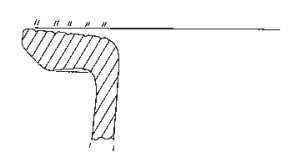

206

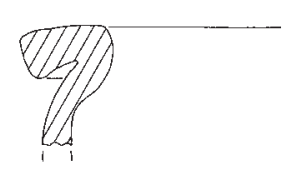

207

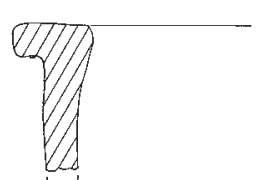

208

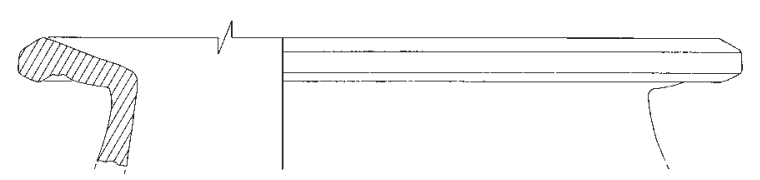

209
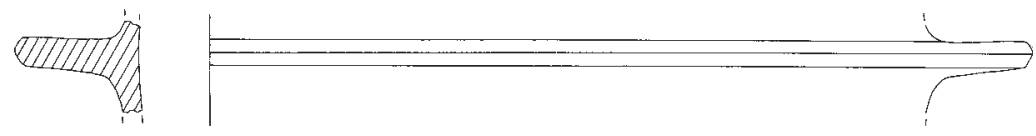

210

Lámina 24 

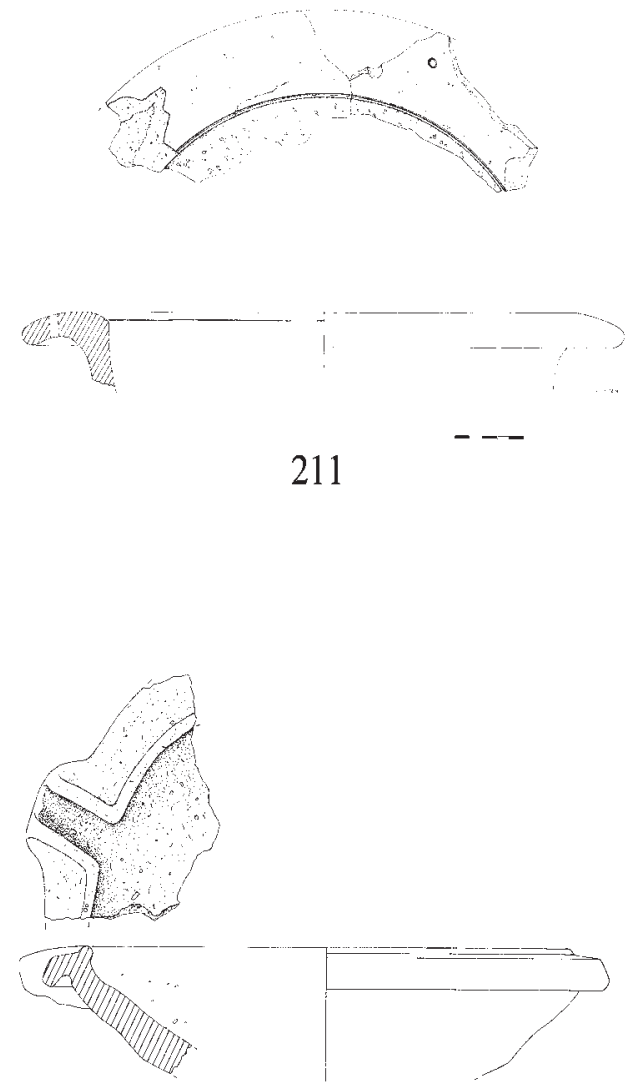

213

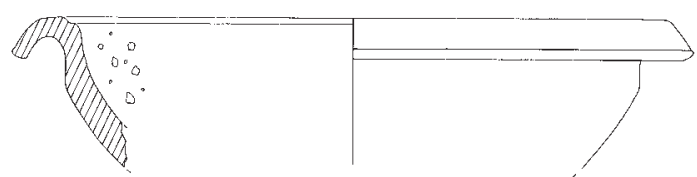

215

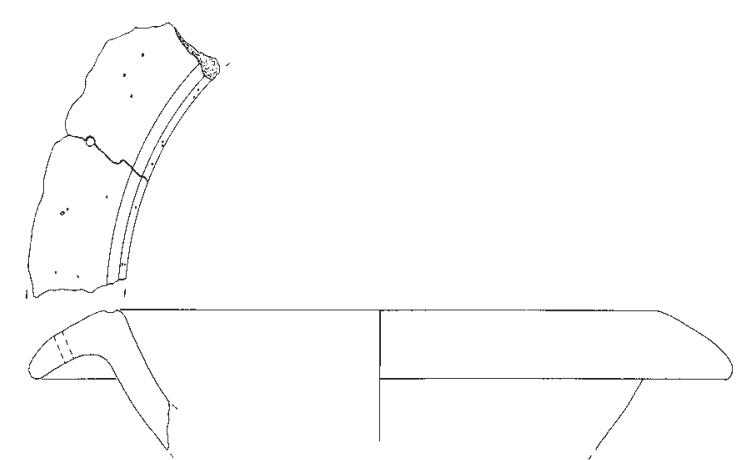

217
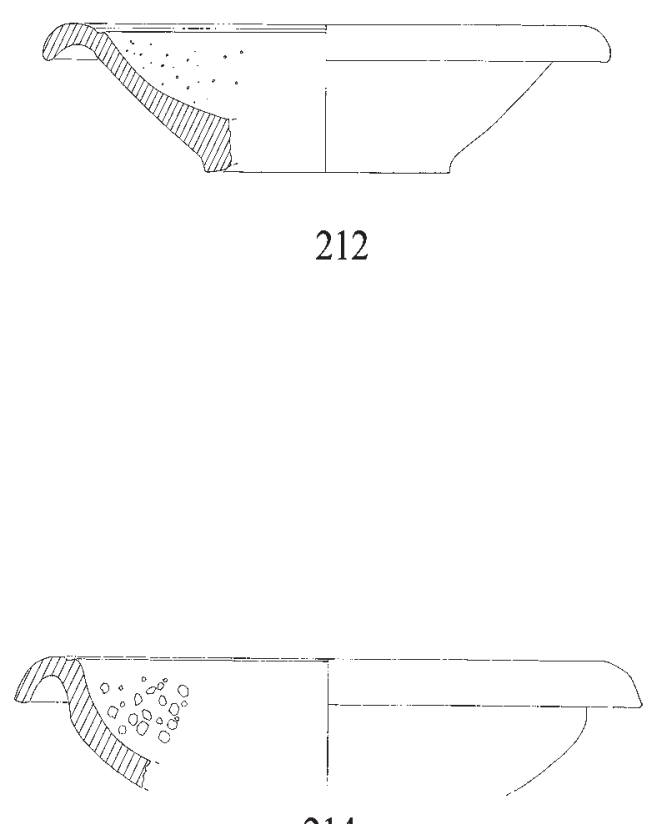

214
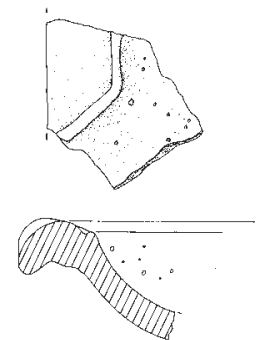

216

Lámina 25 


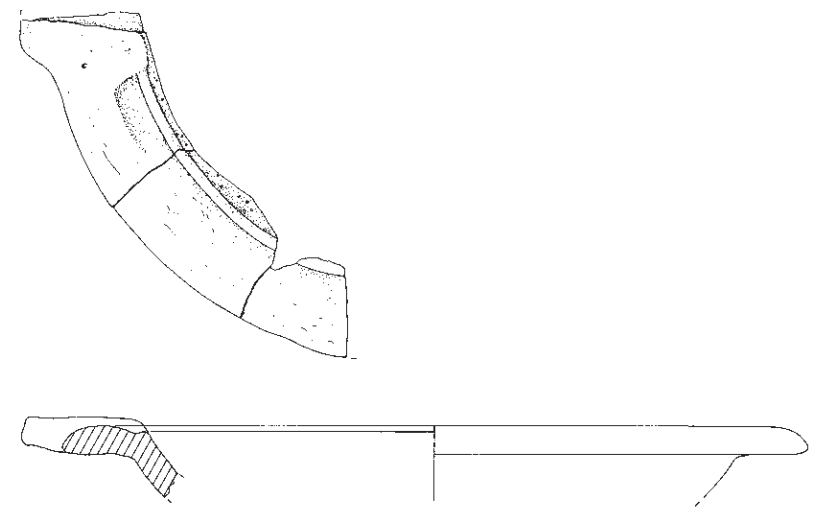

218

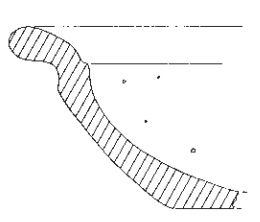

219

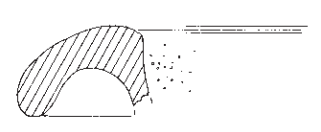

222

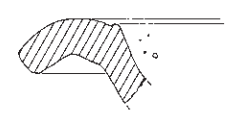

225

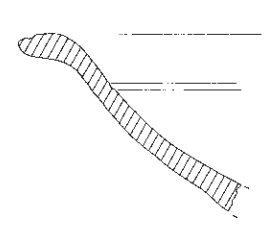

220

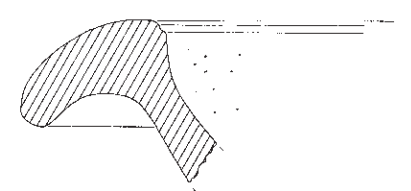

223

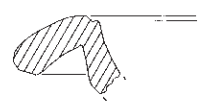

226

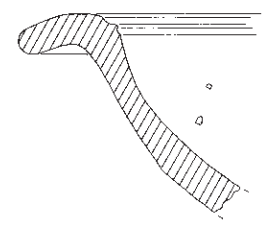

221

224

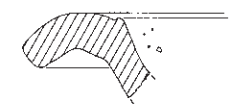

228

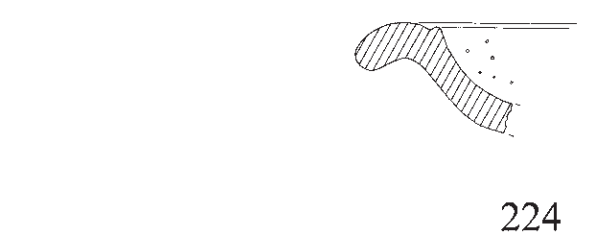

DIII)

229
AtE:

227 


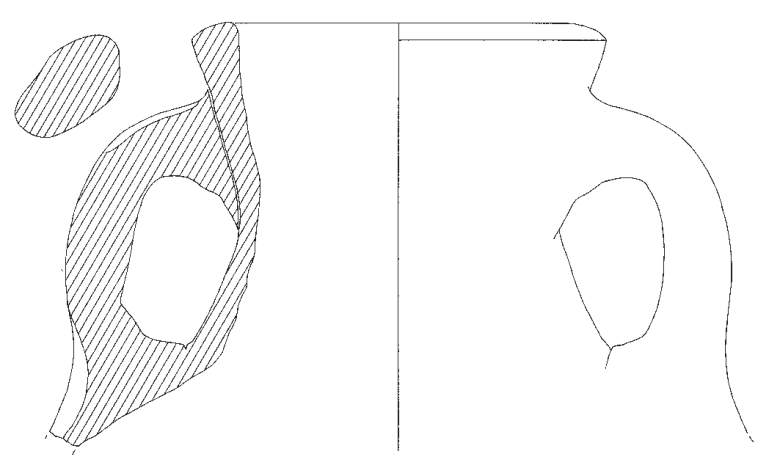

230

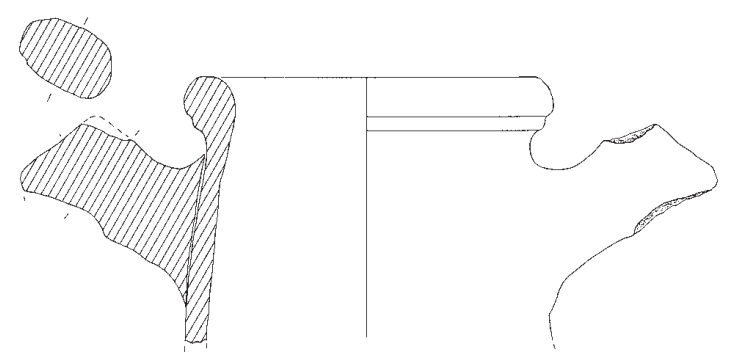

232

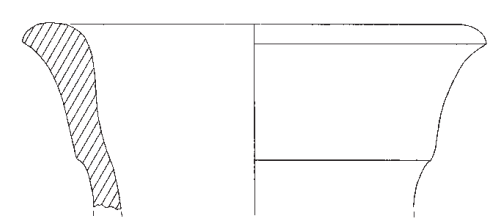

234

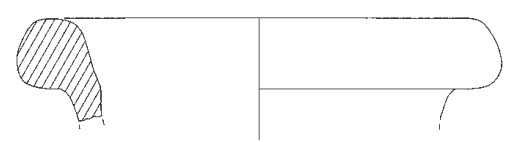

236

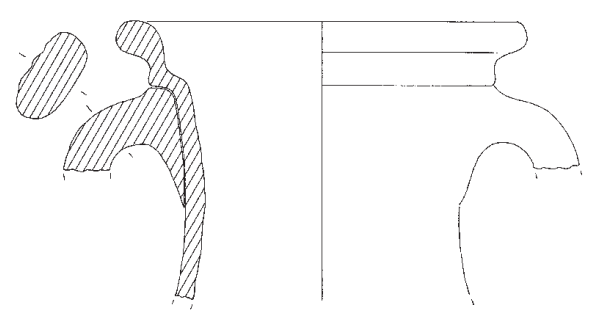

231

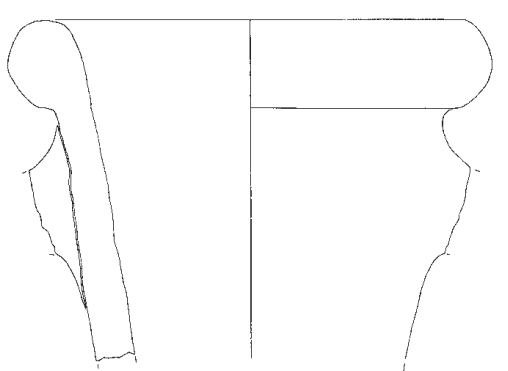

233

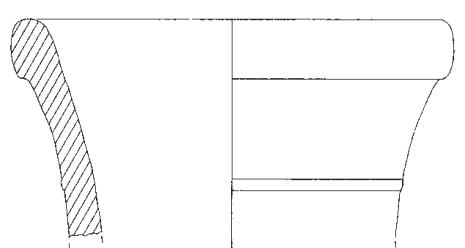

235

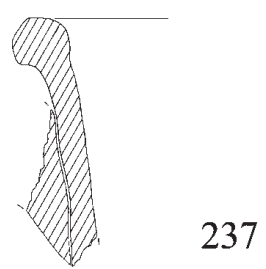

Lámina 27

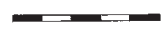




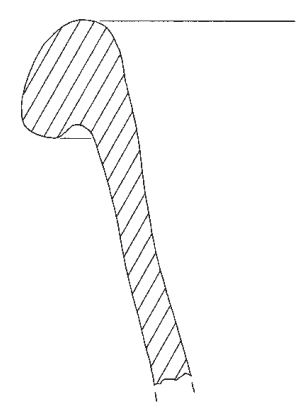

238

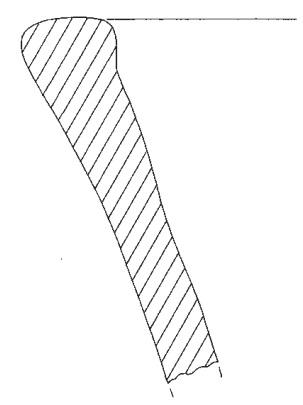

239

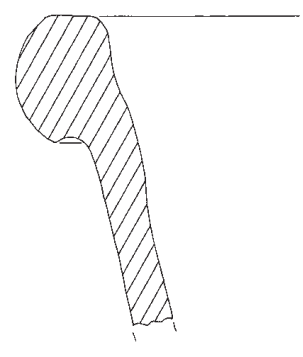

240

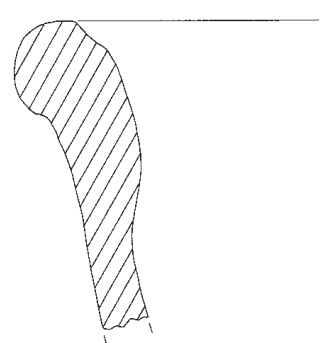

241

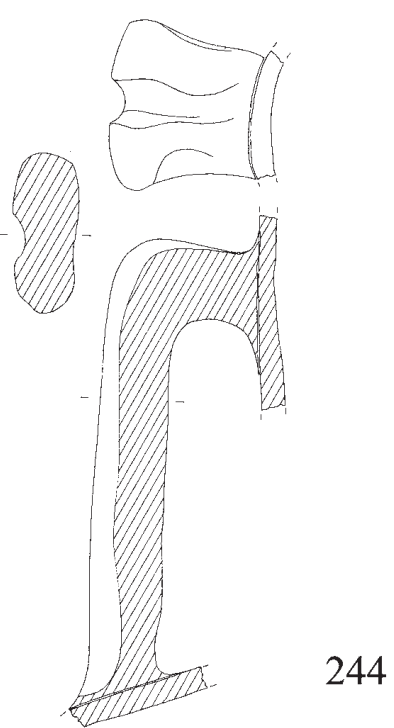

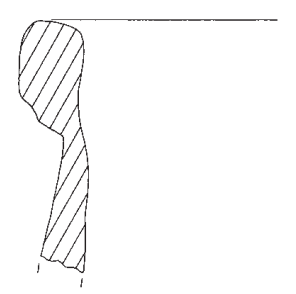

242

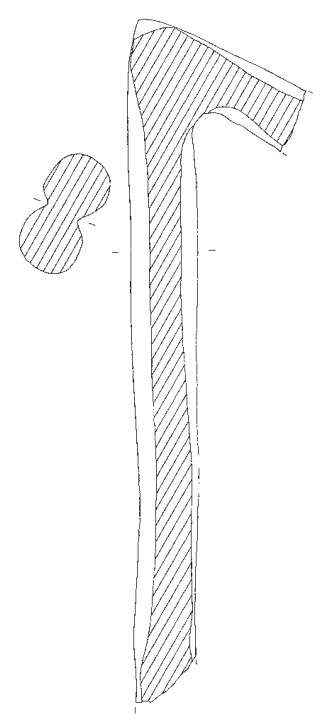

245

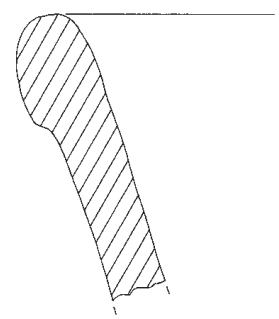

243

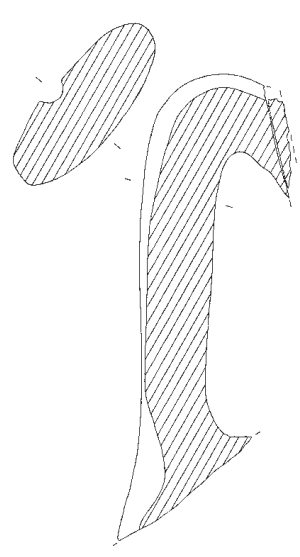

246

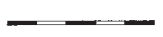

Lámina 28 


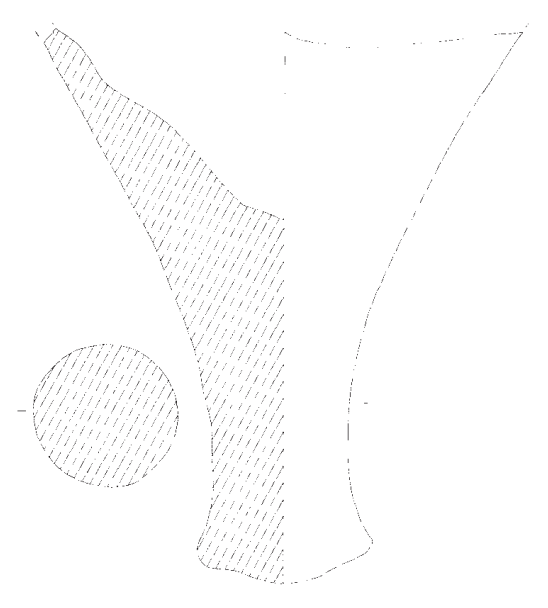

247

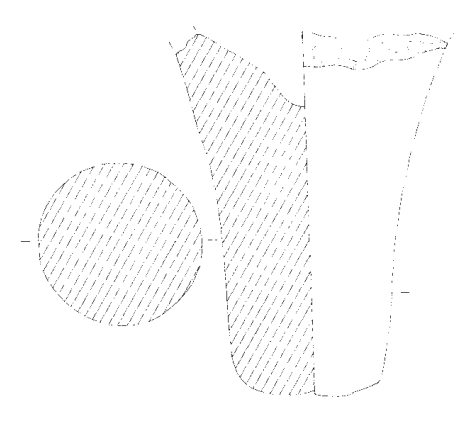

248

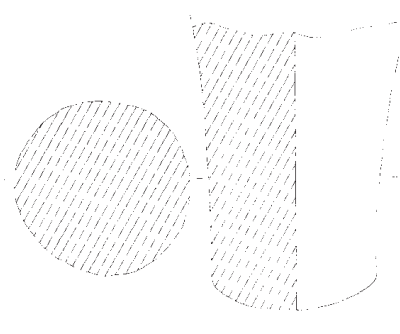

249

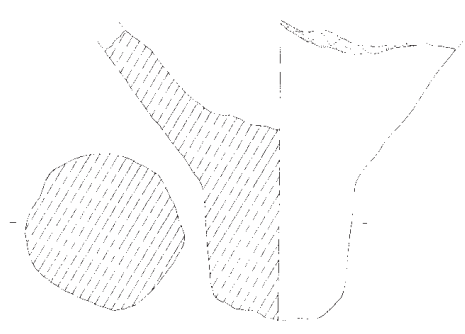




\section{B) COMPLEJO TERMAL DE “SAN LORENZO}

El conjunto de material cerámico recuperado en la intervención arqueológica llevada a cabo en este espacio está integrado por 2.512 fragmentos, resultando muy parejos los porcentajes correspondientes a la época romana (un 51,71\%) y a las etapas posteriores.

Respecto a los materiales de época romana, la mitad del total corresponde a restos cerámicos, lo que constituye una escasa entidad cuantitativa, en comparación con la proporción mayoritaria que supone en el resto de los contextos analizados.

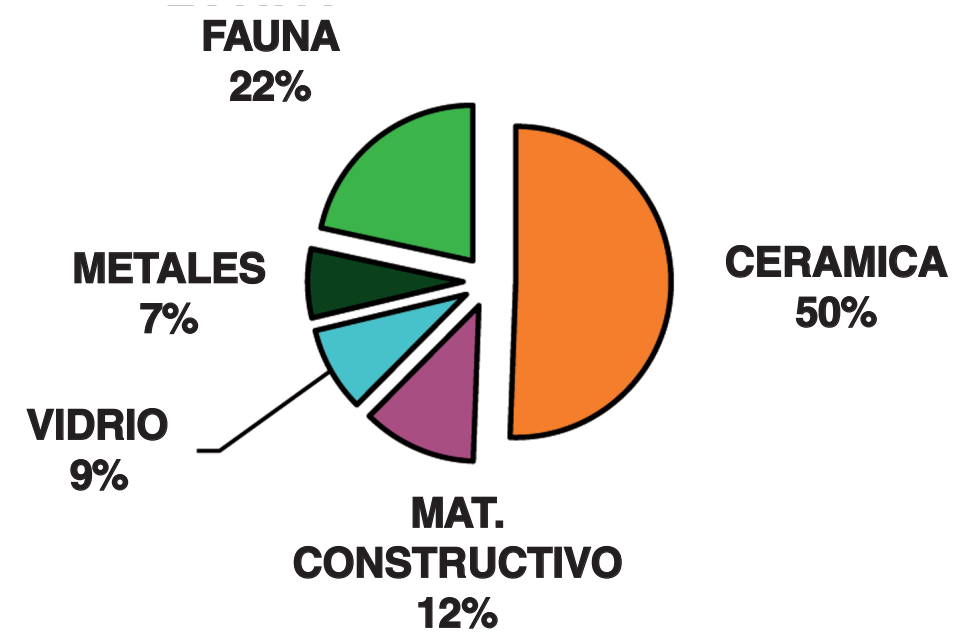

GRÁFICO 6: Materiales procedentes del complejo termal de “San Lorenzo"

En este sentido, es preciso valorar este dato en relación a las características del contexto arqueológico de procedencia ${ }^{96}$. Se trata de un ámbito termal claramente identificado, con un área excavada de reducida superficie (100 $\mathrm{m}^{2}$ aproximadamente) y destacando el deficiente estado de conservación de sus estructuras, hecho que permite inferir procesos de arrasamiento, además de la propia configuración topográfica de la zona -que ha implicado niveles de sedimentación de carácter antrópico de muy escasa potencia, a diferencia del espacio intramuros- aspectos que vendrían a incidir, a nuestro juicio, de forma determinante en este escaso volumen de hallazgos.

Por otra parte, la representación de materiales cerámicos en este contexto resulta igualmente escaso desde el punto de vista cualitativo, pues se reduce a fragmentos escasamente representativos de TSH, TSHT, cerámica común y morteros, sin contar la cerámica de paredes finas, cuya proporción es realmente insignificante y que forman parte de otro proyecto de investigación del cual desconocemos aún los resultados, e incluso la naturaleza de estas piezas.

96 Datos extraídos del informe de excavación realizada por VIDAL y MARCOS (2002), así como de la publicación de los mismos autores "Una construcción romana singular y unas pequeñas termas en el área suburbana de León" (2002-2003). 


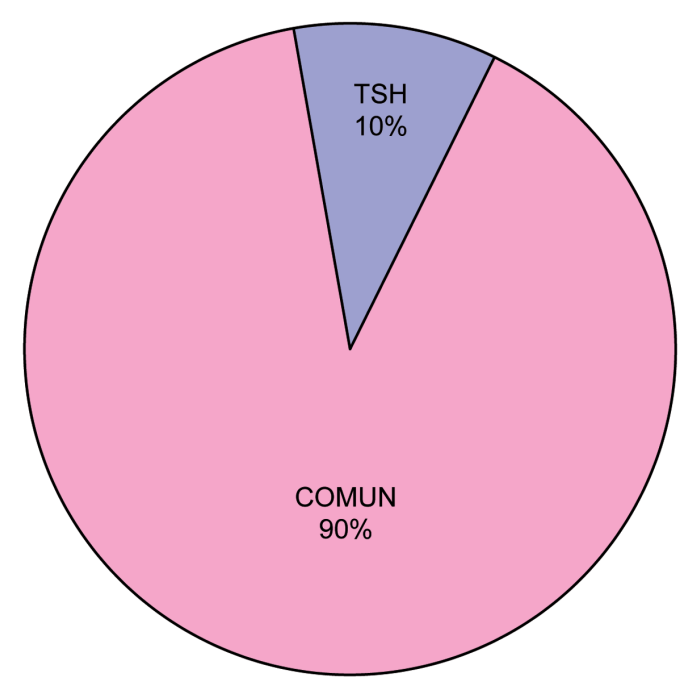

\section{GRÁFICO 7 : Distribución del material cerámico}

Una cuestión esencial que ha de tenerse en consideración cuando se estudia un contexto termal desde el punto de vista de los materiales "mobiliares"93, es el propio proceso investigador de las termas. Éste implica generalmente en primer término, el estudio de las evidencias arquitectónicas, estructurales y restos constructivos que permiten reconstruir la planimetría del edificio balneario, sus dimensiones, volumetría, distribución funcional y esquema de circulación, aportando los datos cronológicos pertinentes en función de la evolución de los contextos termales imperiales. Sumamente importante es también el número y la ubicación de estas edificaciones en el núcleo urbano en determinadas áreas de los asentamientos romanos provinciales, dada su preeminencia como símbolo de asimilación de las costumbres romanas.

En el ámbito militar, las construcciones termales suelen tener menor entidad edilicia, con algunas importantes excepciones ${ }^{94}$, que en los grandes establecimientos civiles de los núcleos urbanos. Aún así, son varios los campamentos del limes renano y británi$\mathrm{co}^{95}$, además del ejemplo que nos ocupa, que dispusieron de dos complejos termales,

97 Un término que hemos tomado de A. BOUET en su obra Thermae Gallicae (2003), en que diferencia en una primera parte la historia y arquitectura del sector termal y en una segunda, "les mobiliers", o materiales hallados en el contexto. Este último aspecto, relegado hasta hace poco en las investigaciones sobre edificios termales, prevaleciendo el estudio de los aspectos arquitectónicos y de los materiales estrictamente constructivos, se encuentra ya plenamente integrado en los estudios generales, dado que su naturaleza (cerámica, vidrio, metales, joyería...), presentes en mayor o menor abundancia, proporcionan importantes elementos para fijar más detalladamente la cronología del contexto balneario y en algunos casos ofrecen información sobre determinadas peculiaridades en el uso de estos "balnea".

98 Por ejemplo las grandes termas germanas de Weissenburg, emplazadas extramuros de la fortificación de Biriciana, con otros establecimientos termales menores, y consideradas para uso del vicus que rodea este emplazamiento militar renano. Por lo que respecta al limes británico, son numerosos los ejemplos de campamentos con establecimientos termales para uso mixto, civil y militar.

99 Vid. sobre esta y otras cuestiones el estudio de REDDÉ (2006) sobre las termas en fortificaciones militares de Gallia, y los trabajos de ROOK (1992) y VEGA AVELAIRA (2001; 2010) sobre las termas legionarias romanas en Britannia. 
generalmente situados intra y extramuros. Esta dualidad, que constituye una cuestión muchas veces problemática en cuanto al aspecto fundamental que las diferencia, puede verse aclarado en ciertos puntos a partir de los materiales hallados en cada contexto.

Ahora bien, si en Legio la situación extramuros de este conjunto termal resultaría a primera vista más relacionada con el contingente de población civil que habita el área extramuros (aunque su asentamiento se considera situado en el área noroccidental), siendo las grandes termas del campamento destinadas al uso de los legionarios, hemos de incidir en que no siempre este esquema es taxativo, detectándose en varios recintos castrenses una utilización mixta por parte de militares y civiles en los establecimientos extramuros.

En Legio, las "termas mayores", situadas intramuros del campamento y ubicadas en el subsuelo de la catedral (vid. supra Plano 2), fueron descubiertas a finales del siglo XIX por Demetrio de los Ríos ${ }^{100}$ y objeto de excavación por A. García y Bellido en los años sesenta del pasado siglo, quien realizó los primeros diseños de plantas y perfiles, documentando tres hypocausta y elaborando un plano bastante completo de la extensión de estas "grandes termas", teniendo en cuenta las dificultades que implica su situación subyacente a otro gran edificio posterior. Con todo, los materiales hallados fueron también escasos, limitándose a columnillas o pilae, un fragmento decorado de mosaico con temas marinos, ladrillos, y otras tres piezas latericias con inscripciones LEG VII G F (García y Bellido, 1970: Figs. 25 y 26).

En los últimos años se han realizado intervenciones arqueológicas en la zona (García Marcos y Campomanes, 1996), si bien los resultados definitivos permanecen aún inéditos, a excepción de algunas breves notas en publicaciones locales (García Marcos y Campomanes, 1998: 43-47).

Todo ello hace del presente trabajo sobre las termas menores extramuros una importante aportación desde el punto de vista ergológico, pues su estructura y elementos constructivos fueron ya estudiados detalladamente con motivo de su excavación (Vidal y Marcos, 2002-2003: 130-139), cuyos datos más relevantes hemos descrito ampliamente en el capítulo dedicado al contexto arqueológico, para efectuar la correlación de las UUEE con los distintos espacios y localizar con exactitud los elementos materiales cerámicos.

Basándonos en estos datos estructurales plantearemos el estudio de los materiales cerámicos, teniendo siempre presente la dificultad que puede presentar el hecho de deslindar el material procedente de las termas en su etapa de funcionamiento y aquel que es resultado del proceso de abandono de distintas partes del edificio termal que, con aportes de residuos circunstanciales, van convirtiendo estos espacios en áreas de vertidos. En este sentido, tanto el espacio concreto de localización de los objetos y su disposición estratigráfica, como, sobre todo, su atribución cronológica, especialmente en lo que respecta a los materiales-guía como la terra sigillata, nos permitirán diferenciar los principales ámbitos, si bien la posibilidad de que los vertidos tardíos hayan interferido en la deposición de los niveles en los distintos espacios termales supone una importante dificultad que no deja de estar ligada al análisis arqueológico de los vertederos.

100 Sobre las vicisitudes del descubrimiento y primeros hallazgos de las termas del campamento legionense vid. TARRADELLAS, 1997: 503-510. 
En esta presentación del material analizado hay que valorar asimismo otro de los rasgos distintivos de este elenco: el estado sumamente fragmentario de los restos, que hace imposible la restitución de los perfiles completos de las piezas y, por consiguiente, la identificación de formas concretas. A ello se añade el deteriorado estado de conservación de los fragmentos, que se presentan desintegrados y muy degradados en su superficie externa.

Estos aspectos que dificultan la labor de análisis y limitan notablemente la extracción de conclusiones, nos proporcionan, por otra parte, información sobre diversas fases en el desarrollo cronológico y la evolución en el uso de este ámbito termal, reflejando la existencia de niveles de arrasamiento, aportaciones antrópicas, vertidos eventuales y áreas de amortización, aportando todo ello importantes datos para la diferenciación y caracterización del área de vertedero en que se transforma en sus fases finales.

Otra cuestión relevante a considerar en este reducido conjunto es la presencia diferencial de las distintas categorías de la cerámica romana,

En cuanto a la terra sigillata, hispánica en su totalidad, hay que poner en evidencia lo exigüo de su representación cuantitativa, al igual que los fragmentos de terra sigillata hispánica tardía, aunque éstos poseen un valor especialmente relevante, en tanto que suponen un término cronológico ante quem, de cara a determinar los momentos finales del período de uso de este contexto.

Igualmente, se documenta una reducida cantidad de cerámicas comunes -con todo, y como es habitual, las más abundantes porcentualmente-, aunque no están presentes todos los tipos y subtipos de recipientes que se registran en los demás vertederos, así como algunos morteros, sin que se haya registrado ningún fragmento perteneciente a lucernas o ánforas. Este último aspecto es sumamente significativo, puesto que se trata de materiales, tanto los de iluminación como los de transporte, muy presentes en las termas, que atestiguan, como ya se ha explicado anteriormente, un importante consumo de aceite. En los baños romanos el aceite es un producto utilizado con asiduidad en los ejercicios gimnásticos, en la palestra y en otras actividades llevadas a cabo en diversas estancias, por lo cual, la ausencia de ánforas olearias quizá responda a los mismos criterios ya mencionados para su ausencia en el resto del recinto militar.

$\mathrm{Al}$ igual que en el vertedero anteriormente estudiado, recurriremos a los resultados de los análisis de materiales procedentes de este contexto estudiados en otros proyectos de investigación, principalmente el material constructivo sellado (Amaré y Díez Robla, 2006), que puede considerarse un verdadero material guía en la edilicia termal, en tanto que ofrece datos sobre las características estructurales y la configuración volumétrica del edificio, facilitando información funcional, a la par que proporciona referencias cronológicas de primer orden que resultan imprescindibles para definir el arco cronológico y el período de utilización de este reducido ámbito balneario.

La información arqueológica de un conjunto tan exiguo y degradado de materiales ha de proceder necesariamente de la imbricación de los datos cuantitativos y tipológicos extraídos del estudio analítico de estas distintas categorías cerámicas en el contexto general de la secuencia estratigráfica del yacimiento.

Así, en una primera visión de conjunto, puede constatarse una mayor presencia de material cerámico en determinados espacios, como en el ambiente calefactado -el 
denominado Espacio 4 (UE 6)-, identificado con un posible tepidarium o caldarium; en el Espacio 5 (UUEE 51-56), interpretado como una estancia de ubicación de letrinas; en suelos de circulación (UE 13), y en estructuras como canales (UUEE 31, 51-53) o muros de cierre que contienen conductos de calor (UE 41).

Especialmente indicativo es el registro de cerámica romana en niveles de destrucción, derrumbe, relleno o amortización (UUEE 16, 17, 19, 25...), de manera que, al igual que hemos constatado en el cercano depósito de San Pedro, ambas construcciones no han constituido áreas de vertidos concebidas en principio como tales. Si el depósito supone un claro ejemplo de vertedero secundario, pero con potentes niveles de relleno, el espacio de las pequeñas termas constituye en su etapa final un área de vertidos ocasionales, depositándose materiales de diferentes épocas en hoyos, zanjas, zonas de relleno, etc..., de forma circunstancial y no sistemática, como así refleja la estratigrafía.

\section{1.- TERRA SIGILLATA HISPÁNICA}

El conjunto de producciones de TSH documentadas en este contexto se reduce a 150 fragmentos, una representación exigua, que supone únicamente un $12 \%$ del total. Este limitado porcentaje numérico representa la totalidad de la terra sigillata hallada, ya que no han aparecido restos de de terra sigillata itálica o gálica, ni aún con carácter residual.

Este último dato presenta importantes implicaciones cronológicas, pues nos permite situar el contexto a partir de la época flavia y por tanto su construcción "ex novo", sin estructuras precedentes, en un momento determinado del asentamiento de la Legio VII Gemina en el solar legionense.

\section{1.- Formas Lisas (Lám. 30)}

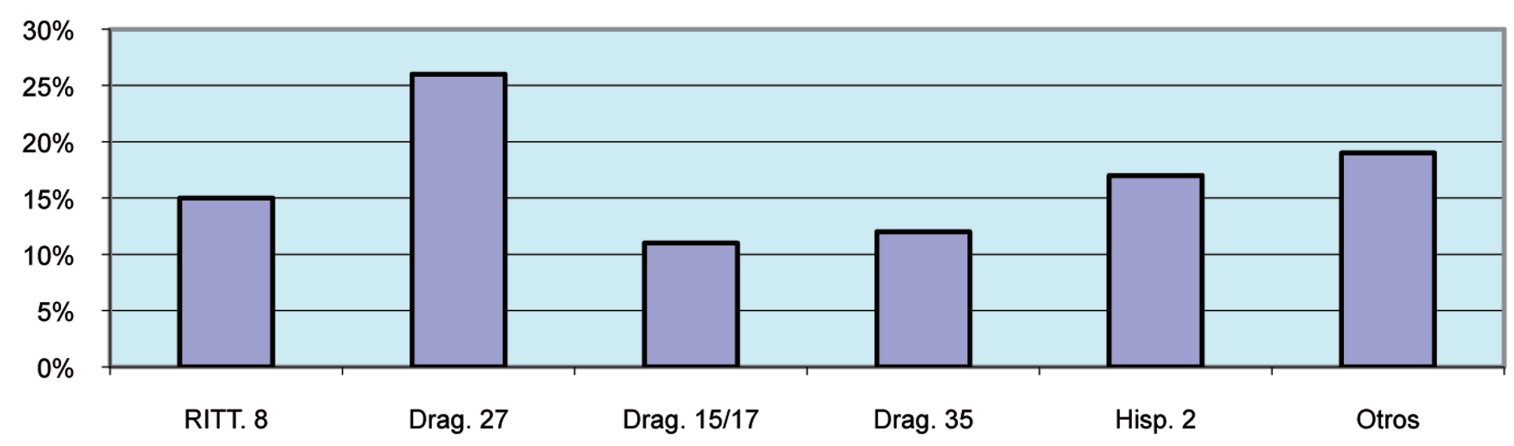

GRÁFICO 8: Formas Lisas de TSH 
En el escaso elenco de formas de sigillata de este contexto termal se documentan multitud de fragmentos de galbos, bases y bordes de muy pequeño tamaño que, en la mayoría de los casos, no nos permiten identificar las formas a las que pertenecen. Pese a ello, hemos hallado algunas formas completas y otros bordes bien definidos que nos han permitido determinar la presencia de ciertas formas concretas y en algunos casos una descripción más completa de sus características morfológicas.

A pesar de su reducido porcentaje, se aprecia un claro predominio de los ejemplares lisos sobre las formas decoradas, siguiendo en este aspecto la pauta de los contextos arqueológicos romanos en general.

Se conservan dos fragmentos de cuencos Ritterling 8 ( $\mathrm{n}^{\circ} 251$ y 252 ) de tamaño mediano (con una medida de $11,30 \mathrm{~cm}$. de diámetro de boca en el primer fragmento) y fabricados en pasta fina y decantada. Ambos presentan borde simple, sin labio, si bien en el ejemplar $n^{\circ} 252$ se percibe una ligera incurvación hacia el interior, característica que, según Romero (1985: 185), denota una mayor antigüedad en la evolución de la forma. En ninguno de los ejemplares se ha conservado el pie bajo, muy poco marcado, propio de este tipo.

Desde el punto de vista cronológico, la presencia de estos ejemplares ofrece escasas precisiones, ya que tienen una larga perduración en el tiempo, desde el comienzo de la fabricación de los productos hispánicos hasta épocas tardías, llegando a alcanzar el siglo IV. Con todo, su fase de mayor expansión tiene lugar a partir de mediados de la segunda centuria.

En este contexto, su localización en la UE 47, ya en las fases más modernas de la secuencia estratigráfica, donde también se encuentran producciones tardías, permite datarlos entre finales del siglo II d. C. y la tercera centuria.

Mejor representada se encuentra la forma Drag. 27, con dos ejemplares completos $\left(n^{\circ} 253\right.$ y 255) y otro que conserva únicamente la parte superior $\left(n^{\circ} 254\right)$. Teniendo en consideración los rasgos que marcan la evolución tipológica de esta forma -la más abundante en este contexto a raíz de los fragmentos contabilizados, que suponen un $39 \%$ del total-, y dado que se trata de piezas completas, es posible efectuar una datación relativamente precisa, que resulta de especial importancia en este contexto, en función de la escasez y fragmentación del resto de los ejemplares de TSH.

Ambas piezas presentan el cuarto de círculo superior sensiblemente más corto que el inferior, con ausencia de labio y un perfil de tendencia recta en el ejemplar $\mathrm{n}^{\circ} 255$, mientras que en el 253 es curvo y exvasado. Otro rasgo diferenciador es el pie, más alto y de sección triangular en el n ${ }^{\circ} 255$, recordando aún los prototipos gálicos, y más bajo y de sección redondeada en el $n^{\circ} 253$, como es característico de la forma en un momento más avanzado de su evolución. Por otra parte, estas copas presentan un reducido tamaño, con un diámetro de boca entre los 9 y los $6,50 \mathrm{~cm}$., rasgo que indicaría un estadio medio en el desarrollo de la forma y que, unido al resto de elementos morfológicos, permite situar cronológicamente estos ejemplares en los primeros decenios de la segunda centuria. Esta cronología estaría avalada por la comparación de estas piezas con las características más evolucionadas de las copas Drag. 27 halladas en el vertedero de la C/Maestro Copín, datado a mediados del siglo II d. C. Estas últimas, más abundantes y en mejor estado de conservación, presentan en su totalidad la moldura en cuarto de círculo superior curva y de mayor longitud, generalmente sin 
labio, además de caracterizarse, especialmente los recipientes clasificados en un segundo grupo, por unas mayores dimensiones (Fernández Freile, 2003: 52-54; Láms. $13,15,16)$.

En cuanto a su ubicación en el contexto estratigráfico, estos ejemplares de Drag. 27 se localizan en las UUEE 51 y 55, que corresponden según el informe de excavación al Espacio 5, un recinto cuadrangular rodeado por una canalización, identificado como una latrina.

Otros ejemplares de TSH identificables y en relativo buen estado de conservación son dos bordes y una pieza completa del cuenco Drag. 35, caracterizada por su perfil hemiesférico y borde vuelto, que muy frecuentemente porta decoración con el motivo de hojas de agua a la barbotina ( $\mathrm{n}^{\mathrm{o}}$ 256-258). Esta forma tiene una clara evolución cronológica en función de diferentes rasgos como la trayectoria del borde, del perfil, la relación entre altura y diámetro o la presencia de elementos fitomorficos a la barbotina en el borde. Basándonos en las características que presentan estas piezas -borde vuelto, decoración-, podemos asignarles una pertenencia a una fase temprana de la producción, cuyo inicio se sitúa en época flavia, formando un servicio junto con el plato o fuente Drag. 36, del que no existen evidencias claras en este yacimiento, y con una perduración a lo largo de toda la segunda centuria.

Así, en el yacimiento leonés de Huerña las piezas de este servicio se localizan en el segundo nivel de hábitat, datado en la segunda mitad del siglo II, presentando bordes horizontales o ascendentes y sin decoración (Domergue y Martín, 1977: 101-102; Fig. 25, $n^{\circ} 485-487$ ), al igual que en el vertedero legionense de la C / Maestro Copín, con una cronología de mediados del siglo II, si bien se detecta en este último una perduración de la decoración de hojas de agua a la barbotina, especialmente en las piezas de mayor tamaño y en la forma Drag. 36 (Fernández Freile, 2003: 57-59, Láms. 20-21).

En este escaso conjunto de piezas de TSH destacan tres fragmentos de bordes con similar configuración del labio, vuelto hacia el exterior y colgante ( $\left.\mathrm{n}^{\mathrm{o}} 259-261\right)$, siendo más completo el ejemplar $\mathrm{n}^{\circ} 261$, que conserva la parte superior del galbo de tendencia rectilínea oblicua con dos marcadas acanaladuras bajo el borde. Tomando como referencia este último ejemplar, hemos de considerar estas tres piezas como pertenecientes a una forma de dudosa adscripción, pues no hemos hallado elementos morfológicos parangonables en los estudios y catálogos más completos de TSH.

Para finalizar, se encuentran dos bordes de atribución más clara, el fragmento $\mathrm{n}^{\circ}$ 262 correspondiente a la parte superior de un galbo recto y oblicuo que termina en un borde sencillo, pudiendo pertenecer a una forma Drag. 15/17 o a una forma Drag. 33, y el fragmento $\mathrm{n}^{\circ} 263$, atribuible con menos dudas a una forma Hispánica 2, original de la producción hispánica. A esta última se adscriben cubiletes de pequeño tamaño, con cuerpo globular, aunque puede establecerse una diferenciación entre los de perfil claramente redondeado y las de contorno ovoidal o fusiforme. El borde es exvasado, bien curvo, propio de los de cuerpo ovoide, o bien recto y oblicuo, que aparece en las de cuerpo redondeado.

Uno de los rasgos más definitorios de esta forma es que puede portar decoración, predominando los elementos realizados con técnica a la barbotina, como las gotas o mamelones, y también elementos losángicos verticales con una línea divisoria central rugosa. En todo ello se advierte un claro seguimiento de los prototipos que suponen los vasos de paredes finas (Mayet, 1975a: 79, Pl. XLII-XLVI, LVII-LXX) y, en concreto, 
del tipo XLV, que, en opinión de la citada autora, representa el modelo más directo de la Hisp. 2.

Si en la variante decorada resulta evidente la influencia de la cerámica de paredes finas, en el aspecto puramente formal la Hisp. 2 no parece ser una creación exclusiva y originalmente hispánica, como sostenían autores como Mezquíriz (1961: 63) o Garabito (1978: 60), sino que existen claros precedentes en la terra sigillata gálica, en concreto es la forma Déchelete 67 en sus ejemplares moldeados (Oswald y Price, 1966: 126-127, lám. XXI no 8-13), tal como propone Mayet (1984: 79) y corrobora Romero en su estudio de los ejemplares numantinos (1985: 218-219).

Desde el punto de vista cronológico, se sitúan sus inicios en época flavia (Mayet, 1984: 79), siendo fabricados durante todo el siglo II d. C. para decaer y desaparecer en la tercera centuria.

Como paralelos más próximos hemos de citar los ejemplares legionenses del vertedero de la C/ Maestro Copín, donde se documentan ejemplares lisos y decorados, con una cronología de mediados del siglo II d. C. (Fernández Freile, 2003: 64-65, Lám. 29), así como también las piezas de esta forma -también muy escasas y fragmentadashalladas en Petavonium y datadas en la etapa comprendida entre la época flavia y la primera mitad del siglo II d. C. (Carretero, 2000: 387-389, Fig. 246, no 125-128).

1.2 Formas Decoradas (Lám. 31)

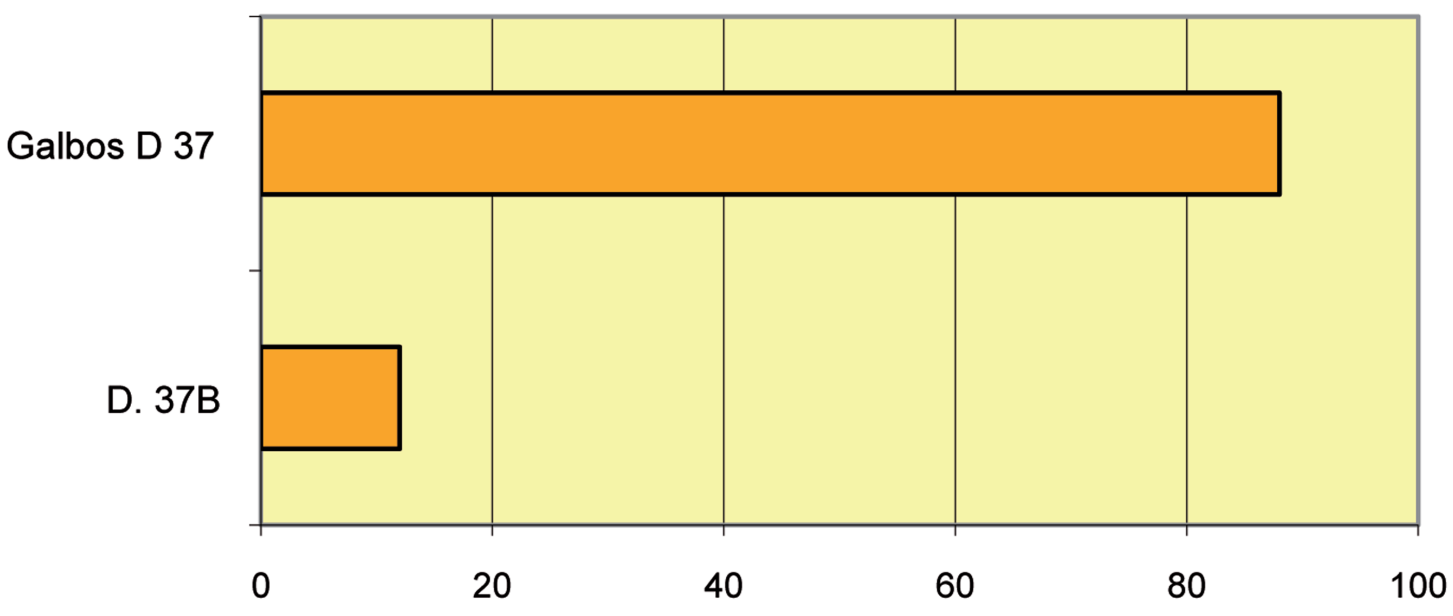

GRÁFICO 9: Formas de TSH decorada

Al igual que los fragmentos lisos, los decorados ( $\left.n^{\circ} 264-273\right)$ presentan un reducidísimo porcentaje y únicamente contamos con el borde de una forma identificable, una Drag. 37 B de borde almendrado, bajo el que se situa una banda con decoración burilada y una hilera de bifoliáceas $\left(n^{\circ} 266\right)$. El resto, de muy pequeño tamaño, pertenecen a galbos que no permiten su adscripción a una forma determinada. Con ello, hemos de ceñirnos a los motivos decorativos para efectuar alguna aproximación cronológica, aunque con las evidentes limitaciones que ello supone. Así, frente a los motivos de figuras humanas $\left(\mathrm{n}^{\mathrm{o}} 272\right)$, de un ave con elementos vegetales ( $\left.\mathrm{n}^{\mathrm{o}} 273\right)$, y motivos vegetales de hojas lanceoladas ( $\mathrm{n}^{\mathrm{o}} 270$ y 271), predomina la decoración a base de motivos circulares, yuxtapuestos ( $n^{\circ} 269$ ) o en composiciones más complejas, a base de círculos con- 
céntricos y segmentados delimitados por motivos verticales $\left(\mathrm{n}^{\mathrm{o}} 264\right)$ y con esta misma estructura con una palmeta en el centro ( $\left.n^{\circ} 267\right)$. Estos esquemas decorativos, probablemente atribuibles a formas 37A y B -especialmente el predominio de los círculos en diversas composiciones-, estarían indicando una etapa cronológica media-tardía en la producción, que podría situarse, a grandes rasgos, a mediados del siglo II de la Era.

\section{2.-TERRA SIGILLATA HISPÁNICA TARDÍA (Lám. 31)}

En el valor numérico de la TSH se encuentran incluidos los ejemplares de TSH altoimperial y de terra sigillata hispánica tardía, representando estos últimos un 4,6\%, del conjunto de la TSH.

Con ello, las producciones de TSHT presentan un valor cuantitativo prácticamente irrelevante en este complejo termal, con una proporción similar a la que hemos hallado en el vertedero de San Pedro (en torno a un 1\%) cuestión ya tratada ampliamente en el capítulo dedicado a este material cerámico en el yacimiento antedicho.

En este caso contamos con cuatro fragmentos de bordes, probablemente pertenecientes a formas lisas, si bien su exiguo tamaño no nos permite una información definitiva al respecto. Se encuentran elaborados con pastas relativamente decantadas, pero de naturaleza deleznable y desgrasantes de tamaño medio, encontrándose su revestimiento en un precario estado de conservación.

En este conjunto de tan sólo cuatro piezas torneadas, todas ellas enmarcadas en la categoría de cuencos, podemos establecer dos grupos en función de sus características morfológicas. Por una parte los fragmentos $\mathrm{n}^{\mathrm{o}} 276$ y 277, correspondientes a la parte superior del borde con marcado labio exvasado y colgante, siguiendo el tipo que presenta Mayet (1984: Pl. CCXXXIX, n 11), y que aparece más tarde en la mayor parte de los estudios morfológicos sobre estas producciones tardías, basados en los de Mezquíriz y Palol, como los de Juan Tovar (1997: 256, perfiles 3 y 4) o Paz Peralta (1991: Fig. 3, no 9).

Un segundo grupo estaría constituído por los dos bordes ( ${ }^{\circ} 274$ y 275), de trayectoria oblicua, con labio horizontal o completamente redondeado, también atribuibles a cuencos, y bien representados en algunos yacimientos peninsulares como el alfar de Villamanta (Zarzalejos: 2002, Fig. 102, n 66 -68), al igual que en otros enclaves campamentales norteños como Petavonium (Carretero, 2000: Fig. 268, $n^{\circ}$ 6, 8) extendiéndose su cronología desde mediados-finales del siglo III, hasta la centuria siguiente, de manera que se marca en este sentido una clara diferencia con las producciones tardías decoradas a molde, que surgen a finales del siglo IV y en el siglo $\mathrm{V} \mathrm{d}$. C.

Desde el punto de vista de la ubicación de estas piezas en el proceso cronológico de este pequeño complejo balneario, puede afirmarse que corresponden ya a la etapa de comienzo de destrucción y transformación del mismo, pues su principal localización en los niveles estratigráficos más modernos de la secuencia indicarían su pertenencia a las últimas fases de vertidos ocasionales, o bien, en zonas de remociones en que se ha producido una importante alteración de la estratigrafía, algunos fragmentos podrían corresponder al período final de utilización de las termas, aunque formarían parte de niveles intrusivos, con un carácter marcadamente residual. 


\section{3.- CERÁMICA COMÚN}

Al igual que la terra sigillata procedente de este contexto, la cerámica común, aún ostentando el mayor porcentaje de piezas, está igualmente representada por un grupo reducido de ejemplares, de muy escasa calidad, con pastas deleznables y un elevado índice de fragmentación.

Con vistas a la clasificación de las diversas formas, hemos seleccionado los bordes mejor conservados, ya que constituyen el elemento diferenciador, aunque carecemos en la mayoría de los casos de otras partes que permitirán su correcta clasificación e incluso identificación.

Por otra parte, por lo que respecta a los paralelos de estas producciones, obviaremos excesivas reiteraciones, dado que se han señalado con amplitud en el vertedero precedente, si bien tendremos en consideración aquellas piezas más significativas con rasgos peculiares.

Por ello, nos centraremos con más atención en las comparaciones que podemos establecer entre las formas de los distintos vertederos estudiados en Legio, en cuanto a datos indicativos sobre sus características técnicas, volumen y tipología.

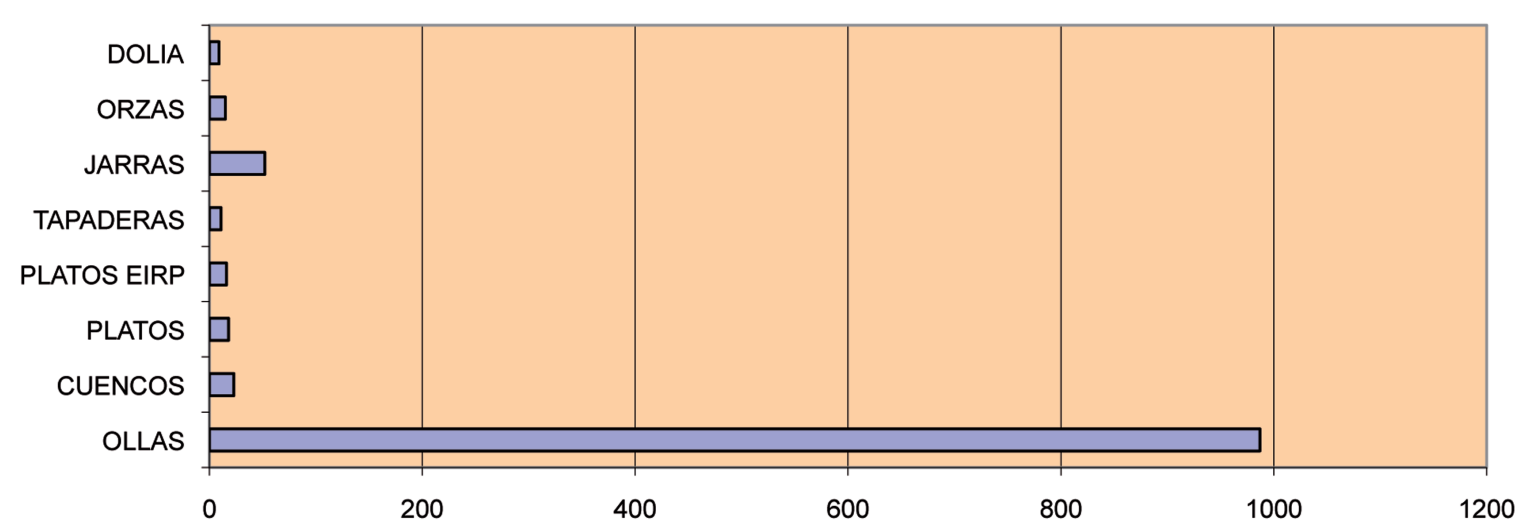

GRÁFICO 10: Formas de cerámica común

\section{1.-OLLAS (Láms. 32-34)}

Las ollas representan el mayor número de recipientes de la cerámica común, como es habitual en los contextos romanos. Además, en este caso particular resulta sumamente significativa su elevada proporción, que supone un $90 \%$ del total frente al resto de producciones comunes, que se encuentran muy escasamente representadas, con porcentajes mínimos.

\subsection{1.- Ollas de borde exvasado curvo (Lám. 32)}

En este tipo se incluyen el mayor número de ejemplares (un 64\%) y algunos de los más completos, como la pieza ${ }^{\circ} 279$, de perfil globular, con $12,5 \mathrm{~cm}$. de diámetro de boca. Se aprecia un marcado predominio de las tonalidades negruzcas y grisáceas resultado de cocciones reductoras y paredes de escaso grosor mientras que la configu- 
ración de los bordes presenta diferencias apreciables, como en las piezas $n^{\circ} 281$ y 282 con bordes notablemente engrosados en su extremo. Igualmente cabe destacar el pequeño rehundimiento que se observa en los ejemplares $\mathrm{n}^{\mathrm{o}} 284$ y 286, probablemente destinado al asiento de la tapadera. Por el contrario, en cuanto a sus dimensiones, se aprecia una tendencia homogénea, con diámetros de boca que oscilan entre los 9,5 cm. $\left(\mathrm{n}^{\mathrm{o}} 283\right)$ y los $10,5 \mathrm{~cm}$. (n 286$)$.

\subsection{2.- Ollas de borde exvasado recto y oblicuo (Lám. 33)}

Entre las piezas clasificadas en esta segunda forma ( $\left.n^{\circ} 286-290\right)$, caracterizadas por paredes más gruesas y en las que se encuentran también un importante número de cocciones oxidantes, destacan, en los casos que puede definirse, en un amplio diámetro de boca $\left(10 \mathrm{~cm}\right.$. en la $\mathrm{n}^{\mathrm{o}} 287 ; 8 \mathrm{~cm}$. en la $\mathrm{n}^{\mathrm{o}} 290$ y $7 \mathrm{~cm}$. en la $\left.\mathrm{n}^{\mathrm{o}} 289\right)$. En algunos ejemplares, como el $\mathrm{n}^{\circ} 289$, aparecen rasgos distintivos, como una marcada acanaladura a la altura del hombro.

\subsection{3.- Ollas de borde recto horizontal (Lám. 33)}

Como adscribibles a esta forma únicamente hemos localizado dos ejmplares, con muy distinta configuración del borde, pues si en la pieza $\mathrm{n}^{\circ} 291$ presenta paredes finas y trayectoria muy recta, en el ejemplar $n^{\circ} 292$ la línea es asimismo recta, pero destaca el marcado engrosamiento en el extremo del borde.

\subsection{4.- Ollas de borde vertical de perfil en "L" (Lám. 33)}

Este tipo de ollas, definido por la marcada concavidad interna en el borde para la recepción de la tapadera, resulta bastante abundante en los yacimientos altoimperiales, y de hecho se encuentra localizado en los cuatro vertederos legionenses. En esta peculiar forma se inscriben recipientes de muy diverso calibre en sus diversos rasgos Así, el ejemplar n 296 con 9,3 cm. de diámetro de boca, presenta paredes de escaso grosor, mientras que el fragmento $n^{\circ} 294$ se caracteriza por un borde de tendencia horizontal y alargada y la pieza n ${ }^{\circ} 295$ destaca por el acentuado grosor de su borde y paredes.

\subsubsection{Formas de dudosa adscripción (lám. 34)}

En este apartado hemos incluido cinco piezas, ( $\left.\mathrm{n}^{\circ} 297-301\right)$, de las cuales dos ( $\mathrm{n}^{\circ} 298$ y 301), presentan un perfil muy similar, con borde exvasado y un pequeño cuello que lo une a un galbo globular. Se trata de recipientes de mediano calibre $(7,5 \mathrm{~cm}$. y 11,5 $\mathrm{cm}$. de diámetro de boca respectivamente), que presentan escasos paralelos en los yacimientos del noroeste, a excepción de algunos ejemplares lucenses (Alcorta: 2001, 205, Figs. 86- 87), con bordes similares y decoración incisa ondulada en la parte superior del galbo.

En lo que se refiere a este conjunto de ollas, resulta significativo que, a pesar de su escaso número y el deficiente estado de conservación, aparecen los mismos tipos que en la clasificación del resto de vertederos legionenses analizados, con características técnicas y morfológicas similares y, por tanto, con paralelos semejantes en los mismos yacimientos. 


\section{2.- CUENCOS (Lám. 34)}

Los cuencos, como instrumentos polivalentes en el uso culinario y en la vajilla de mesa, suelen ser muy frecuentes en los conjuntos de cerámica común romana, sin embargo, y por las razones ya expuestas, representan en este contexto únicamente un $2 \%$. Destacan dos ejemplares bien conservados de muy variados tamaños y tipología.

Fabricados en pastas de color ocre, de buena calidad, la pieza $\mathrm{n}^{\circ} 302$ presenta borde exvasado horizontal, con $14 \mathrm{~cm}$. de diámetro de boca, con paredes no demasiado incurvadas y una acanaladura perimetral hacia la mitad del galbo.

Por el contrario, el segundo de los cuencos que aquí recogemos ( $\left.\mathrm{n}^{\circ} 303\right)$ supera ampliamente el tamaño del anterior, con $18 \mathrm{~cm}$. de diámetro de boca, destacando un borde corto con labio engrosado bajo el cual se sitúa una marcada acanaladura.

Un aspecto indicativo es que no se han documentado huellas de hollín en ninguno de ambos recipientes, lo cual indicaría una función más relacionada con el servicio de alimentos -a modo de fuentes- en la vajilla de mesa.

\section{3.- PLATOS (Lám. 35)}

A pesar de la deficiente conservación de estos recipientes, muy fragmentados, hemos de destacar que de la escasísima proporción que representan respecto al total $(1,60 \%)$, la presencia de algunos bordes y parte de las bases nos han permitido reconstruir algunas formas, aunque sin poder determinar en ningún caso el diámetro de boca. Se trata de ejemplares de escasa altura de (3 a $4 \mathrm{~cm}$.) y paredes abiertas de tendencia rectilínea, si bien en algunas piezas $\left(n^{\circ} 306\right)$ se aprecia una trayectoria más curvilínea, y bases planas. Con dimensiones similares, las diferencias vienen marcadas fundamentalmente por la forma del extremo de los bordes, que puede ser recto $\left(\mathrm{n}^{\circ} 307\right.$ y 309) o reentrante con mayor o menor engrosamiento ( $\mathrm{n}^{\circ}$ 304-306). Respecto a la factura de estos recipientes, predominan las tonalidades rojizas, resultado de cocciones oxidantes y su elaboración con pastas poco decantadas con desgrasante visible en superficie. Por otra parte, algunas piezas como la $n^{\circ} 309$, permiten apreciar signos de exposición al fuego, aspecto éste que, al igual que en el caso de los cuencos, indica la plurifuncionalidad de determinadas formas de la cerámica común como instrumentos de preparación de los alimentos y de su uso en el servicio de mesa.

\section{4.- PLATOS DE IMITACIÓN DE ENGOBE INTERIOR ROJO POMPEYANO (Lám. 35)}

Con un proporción semejante a los platos sin engobe $(1,40 \%$ del total), hallamos en este contexto un escasísimo número de platos con engobe interior rojo pompeyano. Conviene señalar que presentan una alta calidad en su elaboración, con pastas muy decantadas de finísimos desgrasantes, extendiéndose el engobe rojizo por toda la superficie externa y en parte del interior.

En cuanto a la morfología, se advierte una cierta homogeneidad, predominando las paredes verticales, más o menos abiertas, y el labio integrado en las mismas, siguien- 
do su misma trayectoria. Únicamente el ejemplar $n^{\circ} 313$ presenta un perfil un tanto más complejo, con un pronunciado estrechamiento en la parte media del galbo.

Cronológicamente, estos ejemplares de origen centroitálico, que constituyen en principio productos de importación, comienzan pronto una elevada difusión, para fabricarse en las distintas provincias del Imperio imitaciones ya en la primera mitad del siglo I d. C.

A tenor de las características de las pastas, y más en concreto de los desgrasantes micáceos utilizados, se ha propuesto para estas piezas legionenses la posibilidad de su procedencia de otros talleres instalados con posterioridad en Hispania, como en el Valle del Duero o algunas áreas del noroeste peninsular (Carretero, 2000: 646).

Generalmente van acompañados de tapaderas y sobre su funcionalidad se han propuesto diversas hipótesis, si bien, en función de su importante presencia en los recintos castrenses, como ya hemos comentado, se consideran piezas propias de ambientes militares, con un uso individual relacionado con el condumio diario de los soldados (Carretero, 2000: 363). De esta manera, partiendo de la extensa perduración cronológica de estas producciones, que desde sus orígenes en torno a época augustea, alcanzan un período de máxima difusión a finales del siglo I d. C. y la siguiente centuria, han pasado a considerarse elementos de singular importancia, como material guía en los enclaves militares peninsulares.

En este contexto termal, a diferencia de una gran parte de recipientes de cerámica común, se localizan en niveles pertenecientes a espacios bien determinados de las termas, como suelos de circulación (UE 13), canalizaciones (UE 31) o en la UE 7, situada en el espacio 4, identificado como un ambiente calefactado.

\section{5.- TAPADERAS (Lám. 36)}

Las tapaderas, con once fragmentos contabilizados, constituyen uno de los elementos mínimamente representados en la cerámica común. Con todo, además de la pieza perteneciente a un pomo cóncavo de sección bitroncocónica $\left(n^{\circ} 320\right)$, de interior hueco y la parte superior alisada, en el resto de ejemplares, correspondientes al tipo 17 en la clasificación de Vegas (1973: 53-54), puede apreciarse una notable variedad, especialmente en función de la la trayectoria de las paredes y los extremos de los bordes. Así, las piezas $\mathrm{n}^{\circ} 315,316$ y 319, presentan una trayectoria fundamentalmente recta, con bordes curvos las dos últimas y de corte recto la $\mathrm{n}^{\circ} 315$.

En cuanto a los ejemplares $n^{\circ} 317$ y 318, comienzan con un pequeño tramo recto para desarrollar una trayectoria convexa. En este pequeño conjunto, en general de pequeñas dimensiones, se aprecia también una clara diversidad en el color y calidad de sus pastas, dado que son objetos aplicados sobre muy diversos tipos de recipientes dentro de las producciones comunes.

\section{6- JARRAS (Láms. 36 y 37)}

Las jarras integran generalmente un conjunto abundante y variado en la cerámica común de los yacimientos altoimperiales y ello se pone de manifiesto en este contexto, en el que, con un 5\% del total, ocupan el segundo lugar después de la exten- 
sa proporción de ollas, aunque, por lo general, sus porcentajes suelen hallarse más próximos.

Sin embargo, al igual que la mayor parte de los materiales de este reducido conjunto termal, los restos de jarras se encuentran sumamente fragmentados, conservándose únicamente los bordes o parte de ellos, sin que contemos con ningún ejemplar completo, dificultando la elaboración de una clasificación formal como hemos realizado en los demás vertederos, de manera que nos limitaremos a la descripción de los rasgos de las piezas halladas sin diferenciar grupos tipológicos como en el resto de contextos, haciendo referencia únicamente a su pertenencia a alguno de ellos en los recipientes que muestran rasgos morfológicos más definidos.

Entre las piezas más completas en cuanto a la configuración de la boca, destacan el ejemplar $\mathrm{n}^{\circ} 321$, con borde de labio curvo y un diámetro de boca de $5 \mathrm{~cm}$. Presenta dos arranques de asa bajo el borde y un cuello, probablemente corto, de paredes cóncavas.

También el fragmento $\mathrm{n}^{\circ} 322$ pertenece a un ejemplar biansado, de borde moldurado, con 2,5 cm. de diámetro de boca, y cuello cilíndrico, todo lo cual permitiría clasificarla en el tipo de jarras de cuello largo y estrecho. En cuanto a la técnica, destaca por su deficiente factura, fabricada con pasta blanquecina muy deleznable, de escasa calidad.

La pieza $n^{\circ} 323$ destaca por su esbelto cuello recto, con paredes de escaso grosor, rematando en un borde recto horizontal con $5 \mathrm{~cm}$. de diámetro de boca, sin que se intuya la presencia de asas.

En la pieza $\mathrm{n}^{\mathrm{O}} 324$, con boca de $6 \mathrm{~cm}$. de diámetro, el borde presenta un característico remate triangular y cuello ancho de paredes cóncavas. Partiendo de sus dimensiones, tanto esta pieza como la $\mathrm{n}^{\mathrm{O}} 334$, de similar morfología, a excepción de su borde moldurado, podrían englobarse en categoría de jarras "de boca ancha".

Las piezas correspondientes a diversos tipos de jarras se completan con el conjunto de bordes en estado sumamente fragmentario, recogido en la Lám. 37 (nº 328-333 y 335-338), si bien su escaso tamaño no permite en ningún caso la reconstrucción del perfil completo o incluso de la parte superior del cuerpo del recipiente. Predominan las piezas de borde recto y oblicuo con distintos tipos de remate: plano $\left(\mathrm{n}^{\mathrm{o}} 327,330\right.$, $331)$, redondeado $\left(n^{\circ} 326,329\right)$ o ranurado $\left(n^{\circ} 335-338\right)$, representando un conjunto de variada morfología.

\section{7- CERÁMICA COMÚN DE ALMACENAJE (Lám. 38)}

\subsection{1.- Orzas o Tinajas}

Las vasijas de almacén se encuentran bien representadas en este pequeño conjunto termal, especialmente las orzas o tinajas, fabricadas en su mayor parte con pasta blanquecina y abundantes desgrasantes micáceos. Destacan por su gran tamaño (de 16 a $24 \mathrm{~cm}$. de diámetro de boca) y un cuerpo de gran capacidad, generalmente globular.

Se aprecia una considerable diversidad en los bordes, como en la pieza $n^{\circ} 339$, de borde recto y oblicuo y con un motivo de finas acanaladuras bajo el mismo. Aparecen 
también bordes rectos y oblicuos de sección triangular ( $\left.\mathrm{n}^{\circ} 340\right)$, horizontales $\left(\mathrm{n}^{\mathrm{o}} 344\right)$ engrosados ( $n^{\circ} 341$ y 345), y otros menos frecuentes como el de la pieza $n^{\circ} 343$, engrosado y moldurado y el de la pieza $\mathrm{n}^{\circ} 342$, engrosado y con un pequeño cuello, reproduciendo la tipología de algunas ollas.

Es de hacer notar en el conjunto de la cerámica común de este contexto, por una parte, la importante representación cuantitativa de este tipo de recipientes de almacén, y por otra el buen estado de conservación de gran parte de las piezas, que permite su adscripción tipológica en comparación al resto del material cerámico.

\subsection{2.- Dolia}

Como ejemplares especialmente destacables de este tipo de recipientes hemos de citar los fragmentos $n^{\circ} 346$ y 347 , de borde recto en el primer caso y reentrante en el segundo.

Las paredes se caracterizan por su considerable grosor, elaboradas con pastas muy poco depuradas y desgrasantes de gran tamaño de diversa composición (cuarzo, mica y algunos fragmentos latericios).

Por otra parte, cabe destacar en estos grandes recipientes, generalmente utilizados para guardar provisiones y otros productos alimenticios elaborados, su mayor consistencia, en relación con la degradación general del resto de los materiales del contexto.

En ninguno de ellos encontramos restos de sellos o estampillas, que solían portar bajo el borde, característica que tampoco aparece en los dolia de los demás vertederos estudiados.

\section{4.- MORTEROS (Lám. 39)}

En este ámbito termal únicamente se han localizado dos bordes de morteros, recipientes que se encuentran presentes en los cuatro contextos que estudiamos -aunque en mayor proporción y variedad tipológica- y cuya especial significación ya hemos comentado, como elementos fundamentales en el instrumentum domesticum romano, con diversas aplicaciones, además de su especial función en el equipamiento de los soldados romanos.

Ambas piezas ( $\mathrm{n}^{\circ} 348$ y 349) presentan 10,5 cm. y 17,8 cm. de diámetro de boca respectivamente y en ninguno de ellos se conserva parte del pico vertedor, lo cual dificulta su clasificación morfológica. El ejemplar de mayor tamaño presenta un borde oblicuo vuelto hacia abajo con labio curvo mientras que en el $n^{\circ} 348$ se localiza un pequeño aplique sobre el borde recto. En ambos casos se trata de recipientes de paredes poco consistentes y escasa calidad en la fabricación, estando quizá su utilización fuera del ámbito culinario, que precisa de piezas más sólidas, y más relacionado con los procesos de preparación de productos usados en los ámbitos termales. 


\section{5.- MATERIALES PROCEDENTES DE LAS TERMAS DE SAN LORENZO ESTUDIADOS EN OTROS TRABAJOS DE INVESTIGACIÓN}

\section{1-MATERIAL LATERICIO SELLADO}

Dada la escasez de material cerámico "mobiliar" en este pequeño complejo termal y su precario estado de conservación, como hemos podido comprobar en el análisis precedente, hemos de recurrir también al material latericio hallado en estas pequeñas termas y cuyo estudio fue elaborado por Amaré y Díez Robla (2006: 725-727). En este se analizan las características y porcentajes de este material sellado en su totalidad con estampillas de la LEGIO VII GEMINA en sus distintas fases, tal como se desprende de los diferentes epítetos grabados en tegulae, imbrices y lateres fundamentalmente. En este sentido, el valor cronológico de este conjunto latericio resulta sumamente importante, dado que, además de la función de cubrición, se utiliza asimismo en numerosas partes de la propia estructura de las termas, como pueden ser los ladrillos, de diferente medidas, en las pilae de los hipocaustos, en arcos, bóvedas, pasos de calor, pavimentos, etc. mientras que las tégulas e ímbrices, además de constituir los elementos fundamentales de las cubiertas, se emplearon también frecuentemente en la construcción de infraestructuras hidráulicas o de base y cubierta de las canalizaciones (Fernández Ochoa y Zarzalejos, 1996: 116).

En el estudio elaborado por las citadas autoras no se incluye únicamente el material latericio de las pequeñas termas de San Lorenzo, sino que se realiza el análisis conjunto con los materiales de esta categoría aparecidos también en el depósito de San Pedro, dado que ambos contextos extramuros se encuentran cercanos y fueron excavados en el mismo momento en el denominado "Polígono de la Palomera" de la ciudad de León.

Así, dentro del conjunto total hemos realizado una selección de los materiales estampillados del conjunto termal de "San Lorenzo", los más numerosos y variados, y para el que, según sus autoras, en función del ámbito cronológico de los sellos, establecen una cronología desde el año 69 d. C. hasta el 244-249 (2006: 726) ${ }^{101}$.

En el pequeño contexto balneario se recuperaron 71 estampillas con leyenda legible, que reseñamos en el siguiente cuadro junto con su porcentaje. Hemos prescindido de las marcas anepígrafas y otros rasgos epigráficos significativos, pero que rebasan nuestro interés específico en esta cuestión.

101 Partiendo de la base de las características y cronología del sellado de estos elementos constructivos por los cuerpos militares, el material latericio exhumado en el depósito de San Pedro, cuyos vertidos alcanzan en principio el último cuarto del siglo I d. C. tras el asentamiento de la Legio VII Gemina, las estampillas no aportan información cronológica relevante, puesto que portan en general los mismos sellos, correspondientes a esta época de la legión, a diferencia del contexto termal, construido ex novo por la Legio VII Gemina durante su dilatada estancia en León y con una cronología poco precisa hasta el momento, que intentaremos aquilatar a partir del contenido epigráfico de estos materiales. 


\begin{tabular}{|l|c|c|}
\hline \multicolumn{1}{|c|}{ LEYENDAS } & $\mathrm{N}^{\mathrm{o}}$ & $\%$ \\
\hline -Legio VII & 9 & 12,6 \\
-Legio VII Gemina & 10 & 14,2 \\
-Legio VII Felix & 3 & 4,2 \\
-Legio VII Gemina Felix & 25 & 35,2 \\
-Legio VII Gemina Pia & 2 & 2,8 \\
-Legio VII Gemina Pia Felix & 3 & 8,2 \\
-Legio VII Gemina Antoniniana Pia Felix & 3 & 4,2 \\
-Legio VII Gemina Maximiana Pia & 5 & 7 \\
\hline -Legio VII Gemina Gordiana Pia Felix & 5 & 7 \\
-Legio VII Gemina Philippiana Pia Felix & 5 & \\
\hline
\end{tabular}

Sobre la frecuencia de sellos en los materiales destacan los consignados en la siguiente tabla:

\begin{tabular}{|l|c|}
\hline MATERIALES & PORCENTAJE \\
\hline Tégulas & $65 \%$ \\
\hline Ímbrices & $10 \%$ \\
\hline Ladrillos & $25 \%$ \\
\hline
\end{tabular}

Estos porcentajes resultan frecuentes en un edificio de estas características, ya que la mayor parte pertenecerían a estructuras de cubrición (tegulae e imbrices), aportando datos cronológicos importantes para determinar el momento aproximado de los inicios de la edificación, que muy probablemente sería llevada a cabo por efectivos militares, como sucede en otros ámbitos termales, aunque éstos de mayor complejidad ${ }^{102}$.

102 Así, en las Termas Menores de Asturica aparece material latericio sellado por la Legio VII, aspecto que implicaría la participación de soldados en dicha construcción. 
Así, podemos colegir a priori de este conjunto de epítetos en el material latericio, una posible construcción de este edificio termal durante época flavia o ya en los primeros decenios del siglo II d. C. teniendo en consideración además los resultados del análisis de los materiales cerámicos extraídos que, en líneas generales, vendrían a corroborar esta datación. Así, las categorías cerámicas más elocuentes como la TSH descrita, a pesar de su degradado estado de conservación, con una datación desde el último cuarto del siglo I d. C. y principalmente en el siglo II, hasta mediados de la tercera centuria, en que aparecen fragmentos de Terra Sigillata Hispánica Tardía definirían el lapso cronológico de uso del espacio balneario.

En cuanto a su etapa final, la presencia de algunos niveles de derrumbe (Vidal y Marcos, 2002-2003: 137) estarían indicando un deterioro y proceso de destrucción de algunos sectores de los espacios termales, quizá con reformas y reconstrucciones parciales, pero que ponen de manifiesto una decadencia que va prefigurando una fase final en su período de utilización. Ésta puede situarse en un momento de la segunda mitad del siglo III, pues los últimos materiales sellados portan los apelativos de los emperadores Gordiano III (238-244) y Filipo el Árabe (245-249). Al tiempo, la estructura termal se irá convirtiendo en una zona de arrasamiento y un área de vertidos circunstanciales e incontrolados, fenómeno propio de buen número de edificaciones romanas en épocas tardías ${ }^{103}$.

De esta manera, estos espacios periurbanos semiabandonados van perdiendo su función original y convirtiéndose progresivamente en vertederos, de forma que zanjas, atarjeas, conducciones de agua y otras estructuras, son colmatadas por vertidos de residuos de muy diversa índole, desde escombros, fragmentos cerámicos, restos de vidrio y metales o restos faunísticos, haciendo de este espacio lo que hemos considerado como un vertedero ocasional.

Además de la valiosa información cronológica, el material latericio presenta otras especiales características, pues se trata de manufacturas fabricadas por el ejército en cada uno de sus asentamientos, si bien existe la posibilidad de su encargo a artesanos civiles, aunque siempre bajo la supervisión militar. La práctica del sellado de estos materiales constructivos, que pone de manifiesto este control de los cuerpos militares, no se generaliza, según Peacock (1982: 136-137), hasta mediados de la primera centuria de la Era, con diferentes momentos de adopción de la misma, según las distintas regiones del Imperio ${ }^{104}$. De hecho, en el presente estudio podemos comprobar cómo en las primeras fases del cercano vertedero de San Pedro, datadas en época de la Legio VI Victrix, el material latericio carece de estampillas. Para el final de esta costumbre legionaria, autores como Le Bohec (1992: 45) proponen una cronología de fines del siglo IV o inicios de la siguiente centuria.

En el contexto arqueológico legionense se ha recuperado, desde las primeras intervenciones, una elevada cantidad de material latericio con sellos pertenecientes a las

103 Como ejemplos próximos de este mismo proceso contamos con edificios termales en Astorga (GARCÍA MARCOS, 1994: 14) y Gijón (FERNÁNDEZ OCHOA, 2002: 28), que en época tardía pierden su función y se transforman en espacios arrasados y basureros.

104 Sobre esta cuestión, que plantea una importante problemática en algunos aspectos en el caso de la Legio VII, y tratando material latericio sellado procedente de un vertedero, vid. FERNÁNDEZ FREILE, 2003: 32-43, notas $n^{\circ} 27-47$ ). 
distintas etapas de la Legio VII Gemina. Así, destaca la recopilación de García y Bellido (1970: 569-599) procedente de las diversas catas efectuadas en el ámbito campamental en los años sesenta. Más recientemente hay que destacar las excavaciones de las necrópolis de época tardía de la C/Monasterio (González, 1994) y especialmente la de Vegazana (Liz y Amaré, 1993), que deparó un abundante conjunto de estos elementos constructivos, así como también las que se pusieron al descubierto como parte del trazado del acueducto que alcanza la zona noroccidental del campamento (Campomanes, 2006: 439-453) cuya construcción se realizó básicamente con estas producciones latericias. Cabe citar asimismo la notable presencia de estos materiales en uno de los vertederos extramuros situado en la C/Maestro Copín (Fernández Freile, 2003: 31-43, Láms. 1-8) y en general, en la práctica totalidad de las intervenciones arqueológicas llevadas a cabo en el área urbana leonesa, donde aparece abundante material latericio sellado por la Legio VII, si bien estos datos permanecen en su mayor parte aún inéditos.

Dado el ingente volumen del material latericio sellado en Legio, disponemos de un elemento de inestimable valor cronológico, ya que en las estampillas se plasman los diferentes títulos y epítetos de la Legio VII, compendiadores de su historia y de sus intervenciones en Hispania y en otras provincias del Imperio y ello especialmente a partir del siglo III d. C. ya que hasta este momento en la producción sellada se reflejan únicamente los epítetos Gemina Felix, que únicamente proporcionan un dato cronológico post quem (posterior al 74 d. C.), abarcando un amplio marco cronológico, hasta que a principios del siglo III toma el apelativo de Pia.

Sobre la dispersión de estos materiales sellados por la Legio VII, hay que destacar diversos enclaves de la provincia de León, así como hallazgos en otros lugares de Hispania y en otras provincias del Imperio como Germania, Dacia y Numidia. En estas últimas serían testimonio de la intervención de este cuerpo legionario en campañas militares en estos territorios, al igual que en los otros puntos de Hispania, como Italica o Petavonium, donde se plantea la presencia de algún destacamento o vexillatio de la legión con distintos fines (Carretero y Romero 1996: 21-22; Martín Valls, Romero y Carretero, 2002: 137-154)105.

En cuanto a esta cuestión de la difusión y de la producción de material latericio militar en la Península Ibérica, el análisis de Le Roux (1999: 111-123) resulta concluyente, descartando la posibilidad de una comercialización de estas manufacturas y afirmando que el destino esencial y prioritario de este volumen de material latericio se encuentra en el autoabastecimiento de los propios campamentos, con el importantísimo nivel de consumo que precisa la construcción y el mantenimiento de la amplia estructura edilicia de estos asentamientos, haciendo también mención a los sectores extramuros de ubicación de las cannabae. En el mismo sentido se pronuncian estudiosos de la Legio VII y sus funciones como Palao Vicente (2006: 327-328) quien subraya el hecho de que no todos los edificios construidos con material sellado por la legión debieran tener un uso militar, sino que estos materiales se emplean también para construcciones de carácter civil.

105 En Petavonium se ha localizado un edificio construido con materiales sellados por la Legio VII, cuya función no ha sido aún determinada con exactitud. 
Con todo ello, además de las aportaciones cronológicas, el material latericio puede ofrecer otro tipo de información de especial interés a la hora de discernir el carácter civil, militar o quizá mixto, del pequeño edificio termal de San Lorenzo situado extramuros del campamento ya que el material latericio sellado se utiliza indistintamente en edificaciones militares y civiles, por lo cual, pudiéramos considerar la tercera posibilidad, esto es, el uso civil y legionario, en función de la época ya tardía, aunque bajo la supervisión militar.

En el contexto arqueológico de este espacio, un pequeño complejo termal, cuyo período de uso puede fijarse durante el siglo II d. C. y primera mitad del siglo III, cuando comienza el proceso de su progresiva destrucción y se va convirtiendo en un vertedero ocasional, se plantea una considerable dificultad al disociar los materiales que pertenecen a la fase de utilización de las termas y los que son resultado de estas aportaciones circunstanciales de desechos. Ello viene motivado en gran parte por la escasa proporción de TSH -datada en el siglo II- y las limitaciones que para la adscripción cronológica presentan las cerámicas comunes, además de una compleja estratigrafía.

Así, con el fin de realizar una adscripción lo más aproximada posible del conjunto de materiales a una $\mathrm{u}$ otra etapa, hemos partido de la descripción de cada una de las unidades de la secuencia estratigráfica, apreciando que las UUEE en que se localizan estos vertidos se sitúan en su mayor parte en los niveles más modernos de la secuencia, y en ellos se hallan los fragmentos de TSHT, que actúan de término post quem a mediados del siglo III d. C. para la etapa de ocupación de las termas.

Con estos datos hemos elaborado una distribución cuantitativa del material cerámico en cuanto a su situación en las distintas unidades estratigráficas, obteniendo unas proporciones, de carácter orientativo -ya que en muchos casos se detectan intrusiones y otras irregularidades en la estratigrafía-, que reflejamos en el siguiente gráfico:

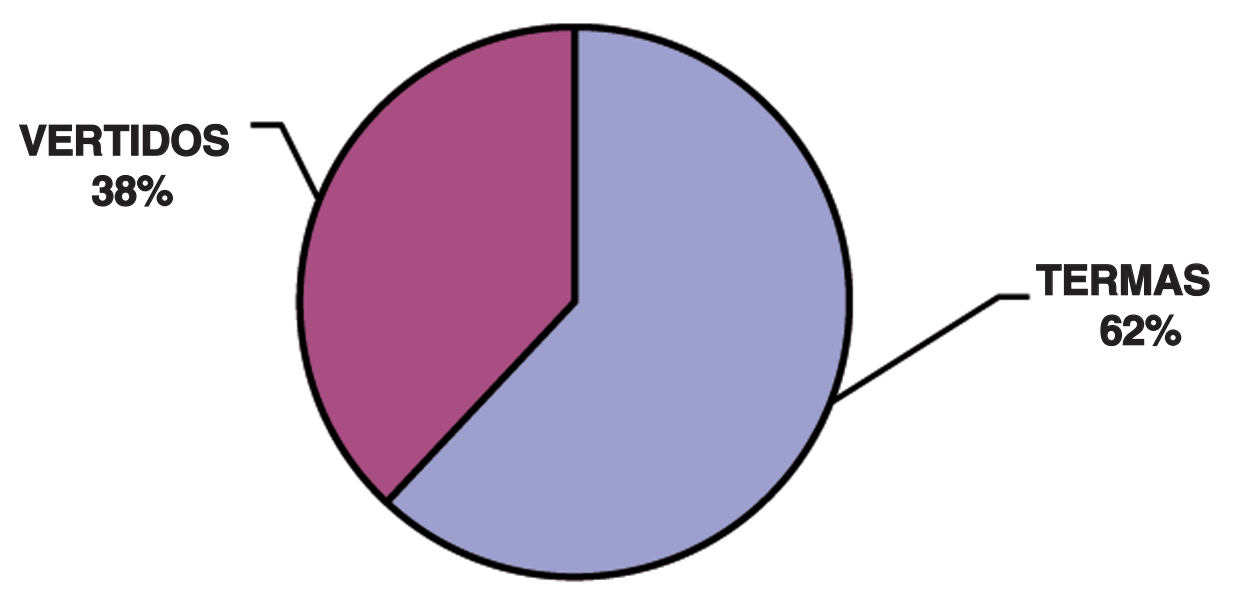

GRÁFICO 11: Distribución del material cerámico en el complejo termal de "San Lorenzo" 
LÁMINAS 


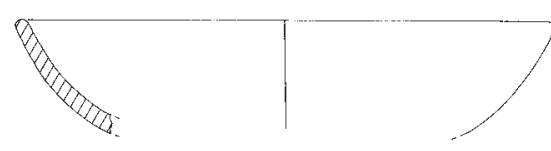

251

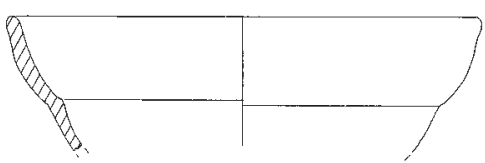

254

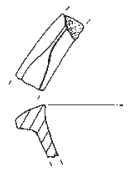

256

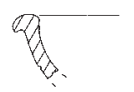

257
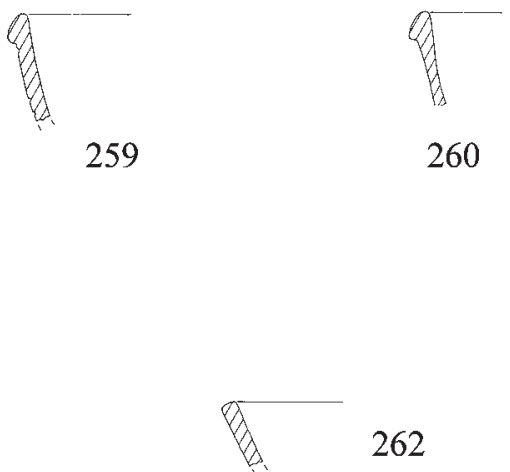

259

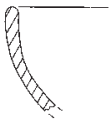

252

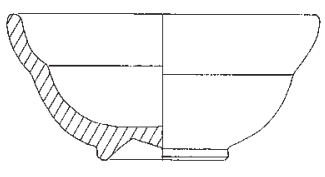

253
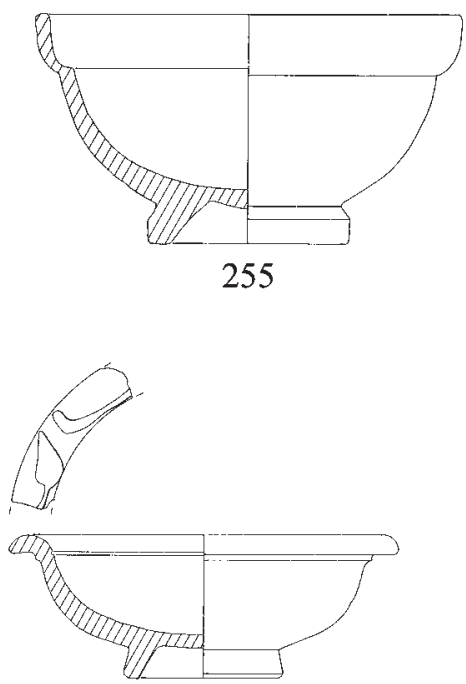

258

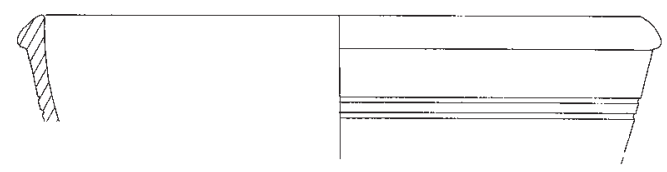

261

Lámina 30 


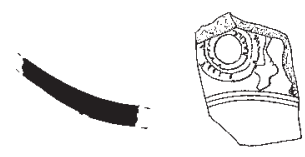

264

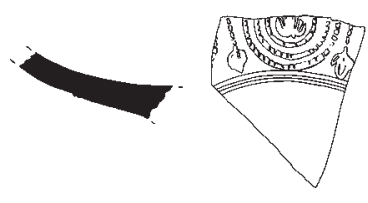

267

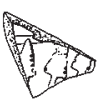

271

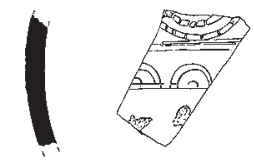

265

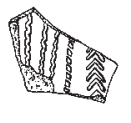

268

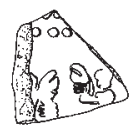

272

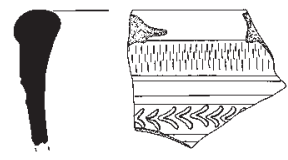

266

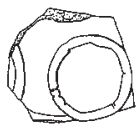

269

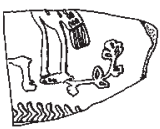

273
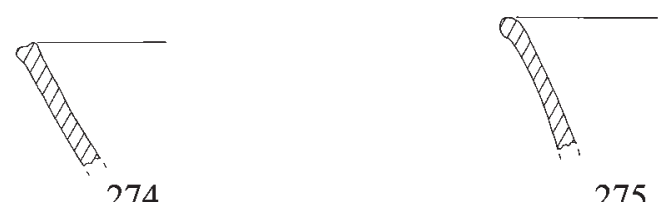

275
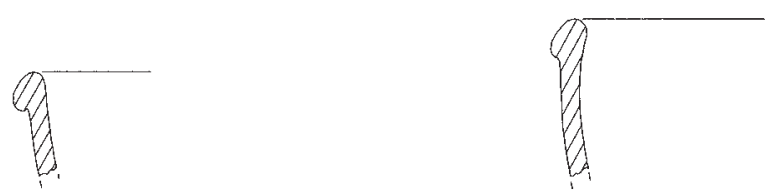

276

277 

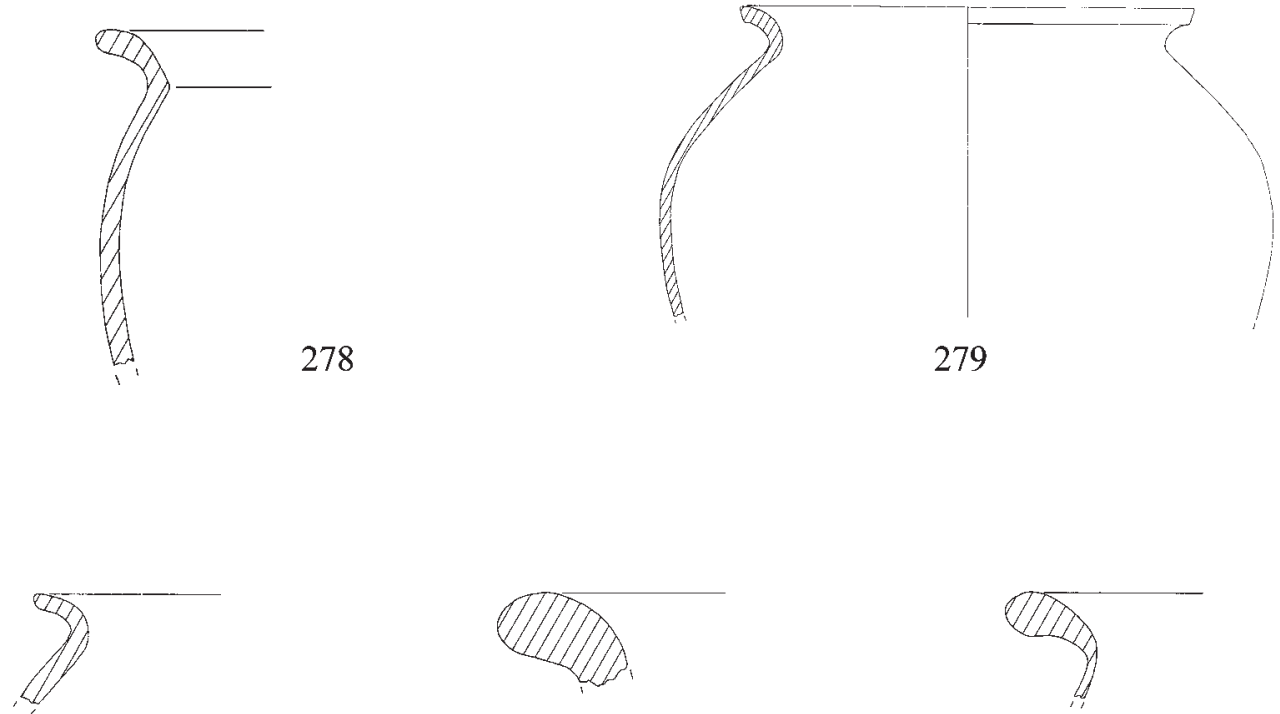

280

281

282

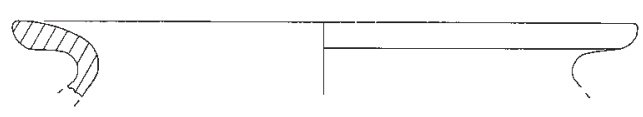

283
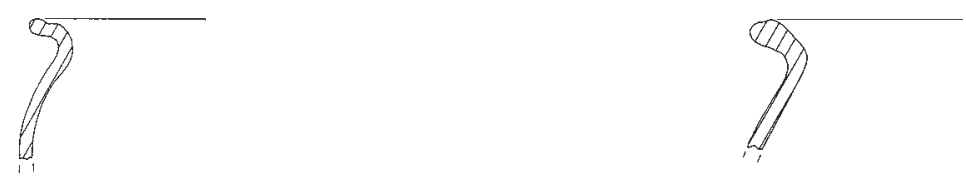

284

285

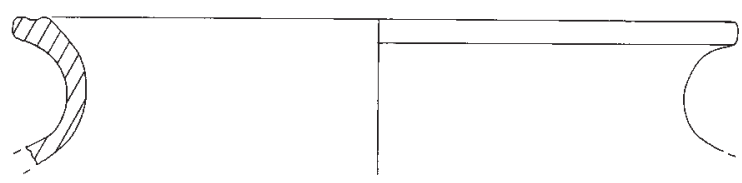

286

Lámina 32 


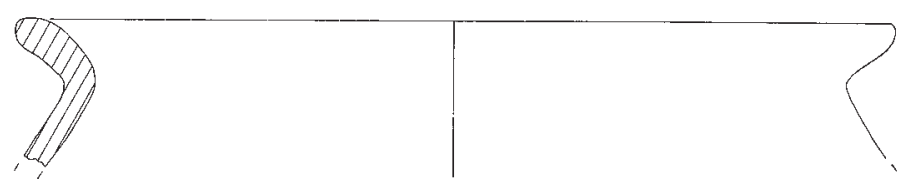

287
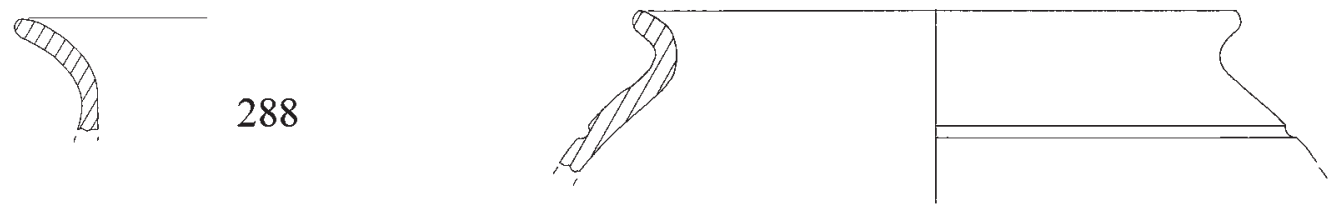

289

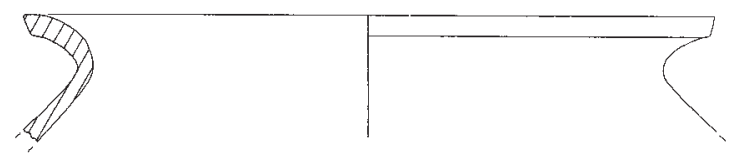

290
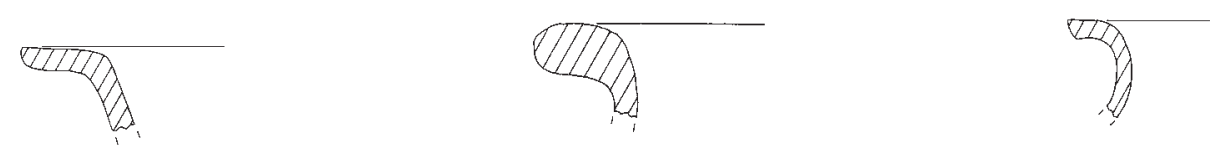

291

292

293

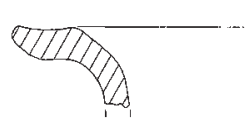

294

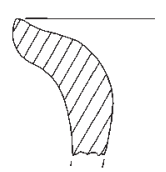

295

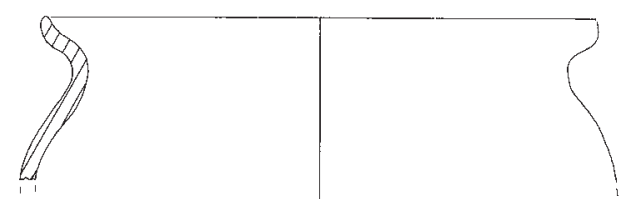

296

Lámina 33 


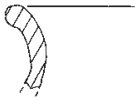

297

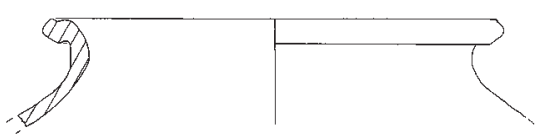

298

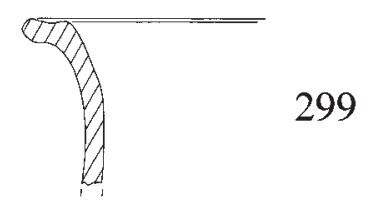

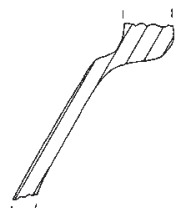

300

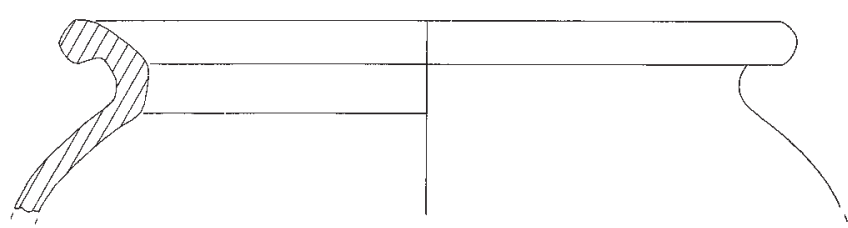

301

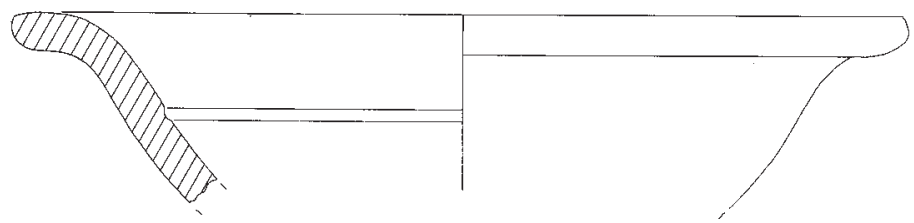

302
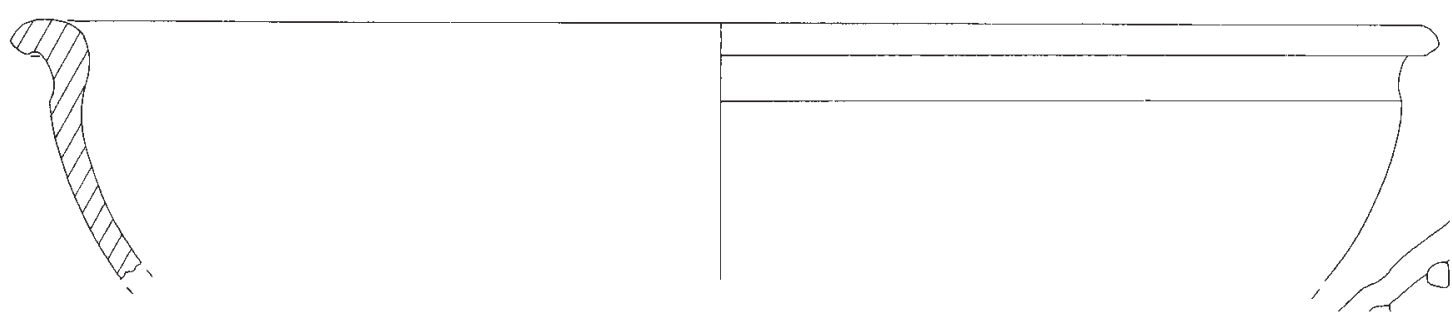

303

Lámina 34 


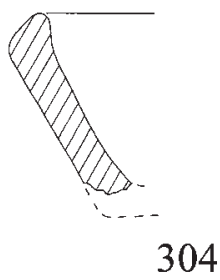

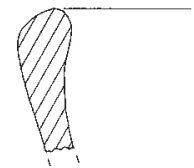

305

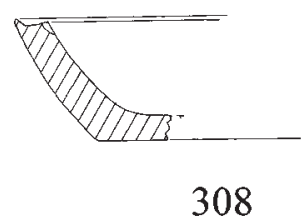

307

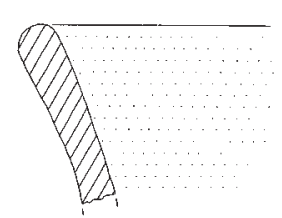

311

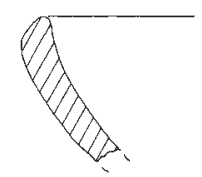

306
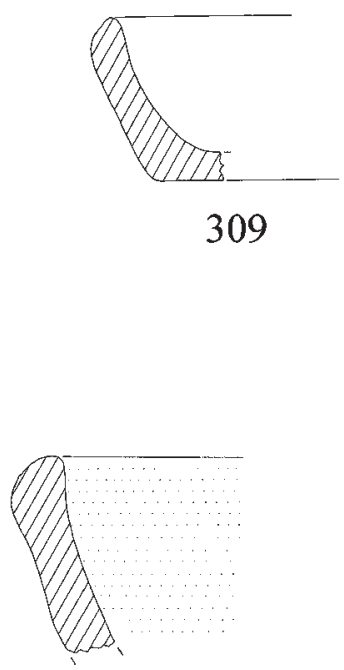

312

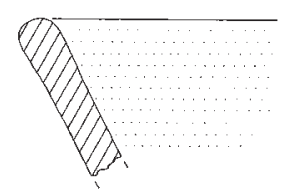

314

313

$---$

Lámina 35 


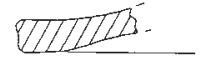

315

VIIIIIS.

318
DIIIIS:

316

OIIIIST:

319
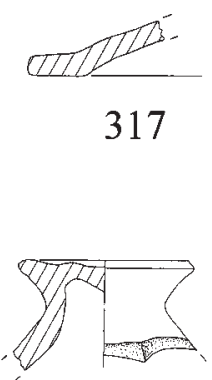

320
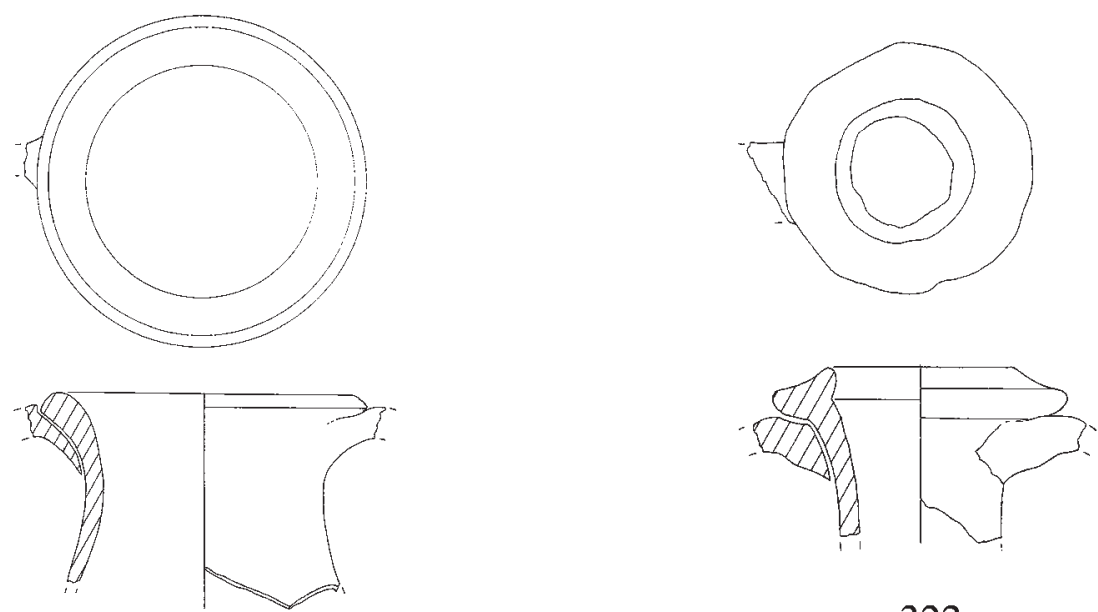

322

321

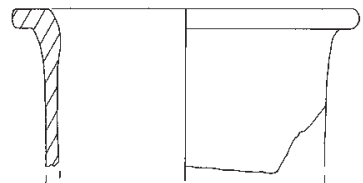

323

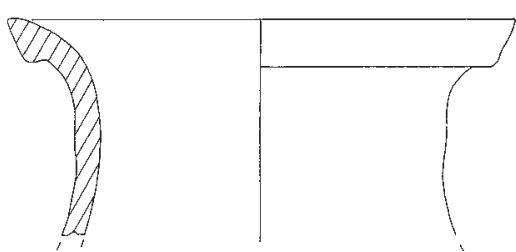

324

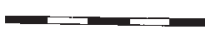

Lámina 36 


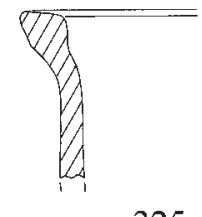

325

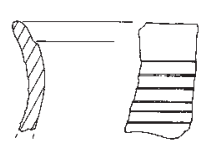

326

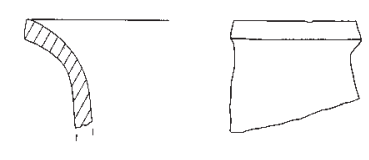

327
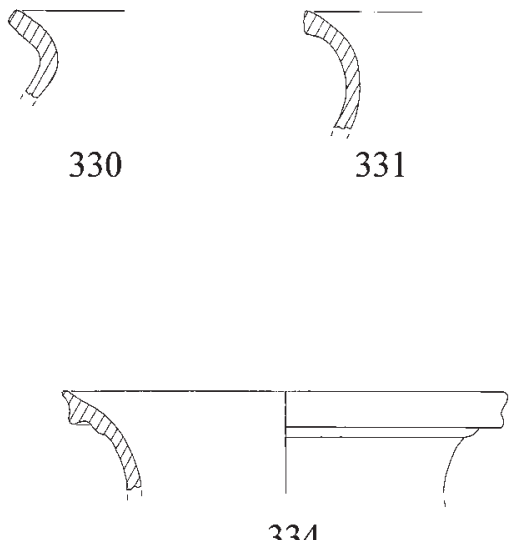

333
334
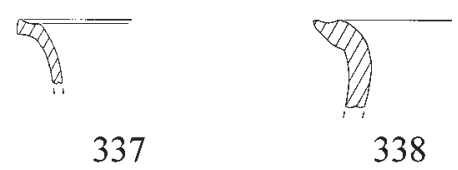

Lámina 37 


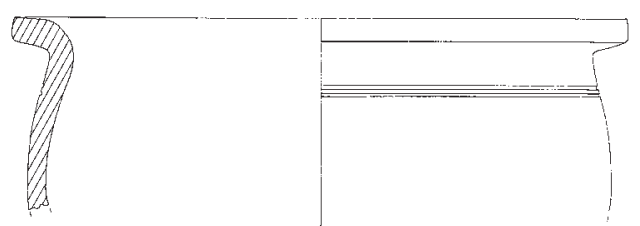

339

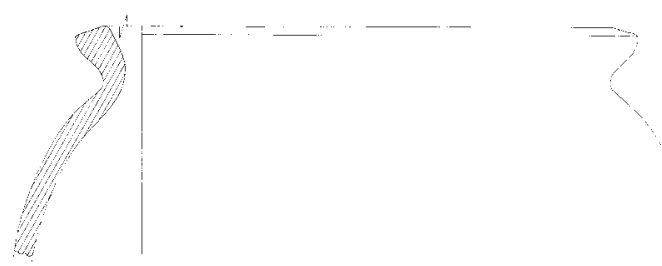

340

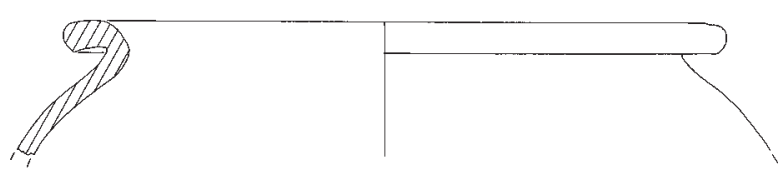

342

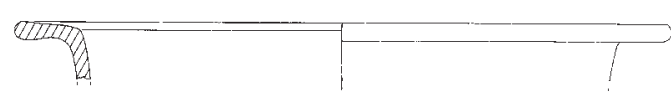

344
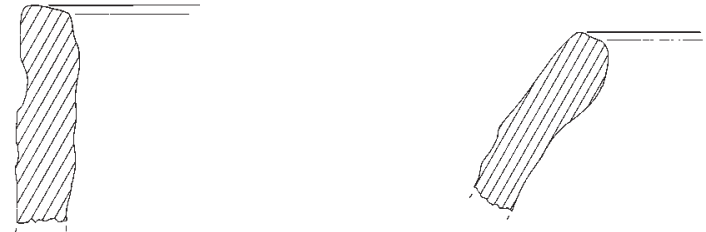

347

Lámina 38 


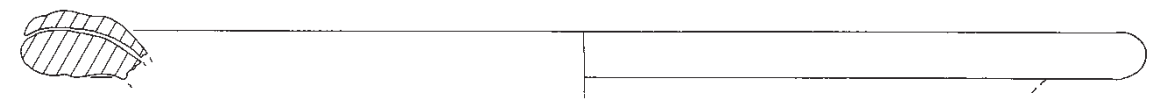

348

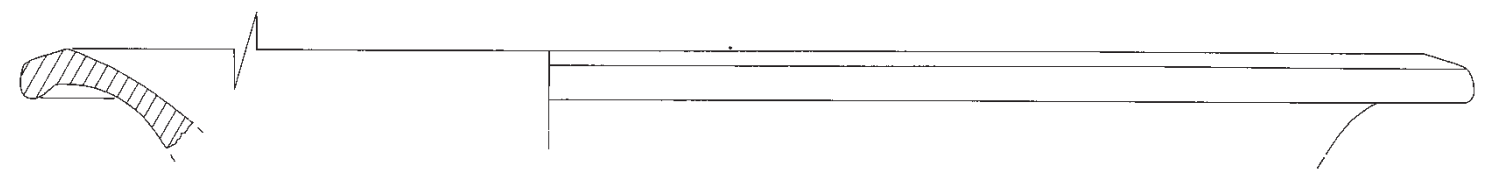

349

Lámina 39 


\section{C) VERTEDERO DE LA C/ PILOTOS REGUERAL, $\mathbf{N}^{\circ} 4$}

Este contexto, ubicado en área suroeste del campamento, en las proximidades de la porta principalis dextra, constituyó desde sus inicios -a diferencia de los dos contextos estudiados previamente- un área de vertidos, a juzgar por la disposición de la estratigrafía y otros factores topográficos, edafológicos y antrópicos que determinan su localización, como hemos analizado más detalladamente en la descripción del contexto arqueológico.

Esta tipología de "vertedero primario" y sistemático influirá decisivamente, no sólo en la ubicación de los materiales, dentro de una secuencia más ordenada y coherente cronológicamente, sino también en su mejor estado de conservación en conjunto, ya que, en general, el contexto no ha sufrido perturbaciones importantes, ni de origen natural ni antrópico (remociones, niveles de depósito ocasionales, capas de relleno...) que alteren la secuencia estratigráfica y deterioren el estado de su contenido artefactual. Únicamente cabe destacar a ese respecto, la existencia de un elemento interfacial en la secuencia estratigráfica, un cauce de agua, si bien su escasa entidad no provocaría una excesiva alteración de los niveles estratigráficos.

Desde el punto de vista cronológico, la secuencia se encuentra bien definida, como ya hemos explicitado en el capítulo del contexto arqueológico, diferenciándose tres fases fundamentales: principios del siglo I d. C. -establecida con seguridad a partir del único testimonio numismático, un as de Tiberio-; mediados de esta centuria; y finales e inicio del siglo II d. C. Esta última fase, y los límites finales de la segunda, constituirán especialmente el objeto de nuestro estudio, ya que corresponden a la etapa de asentamiento de la Legio VII Gemina, poniendo de manifiesto la continuidad también por este nuevo cuerpo legionario en la utilización de algunas zonas de eliminación de residuos periurbanas, ya establecidas en la etapa precedente de ocupación del campamento por la Legio VI Victrix.

En lo que respecta al conjunto de materiales hallados, destacan tanto su cantidad se han contabilizado 10.147 piezas- como su variedad, predominando el material cerámico (terra sigillata, cerámica de paredes finas, cerámica común, lucernas, ánforas) así como también restos de vidrio, metales y abundantes restos faunísticos, como reflejamos en el siguiente gráfico. Entre ambos grupos se establecen unas proporciones cuantitativas similares que se mantienen en las distintas fases establecidas, añadiendo un rasgo más de uniformidad, que caracteriza en general a este vertedero.

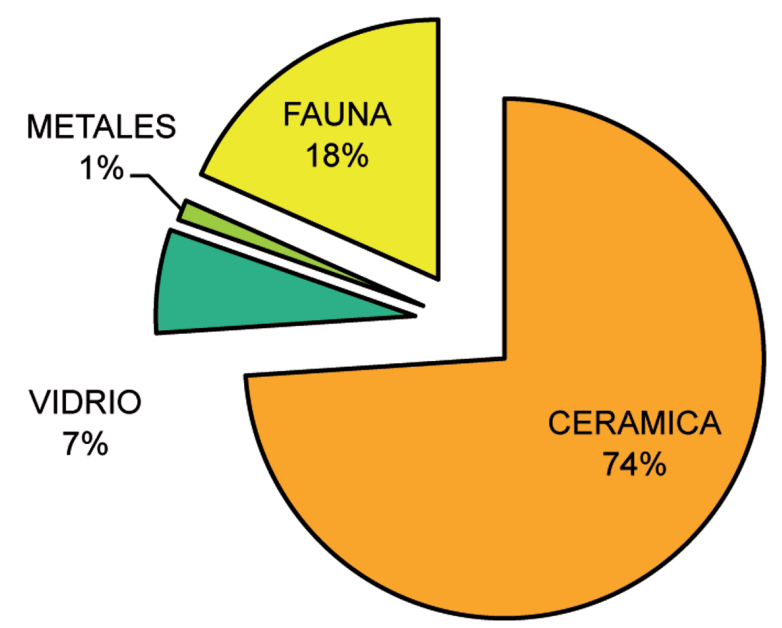

GRÁFICO 12: Distribución de materiales hallados en el vertedero 


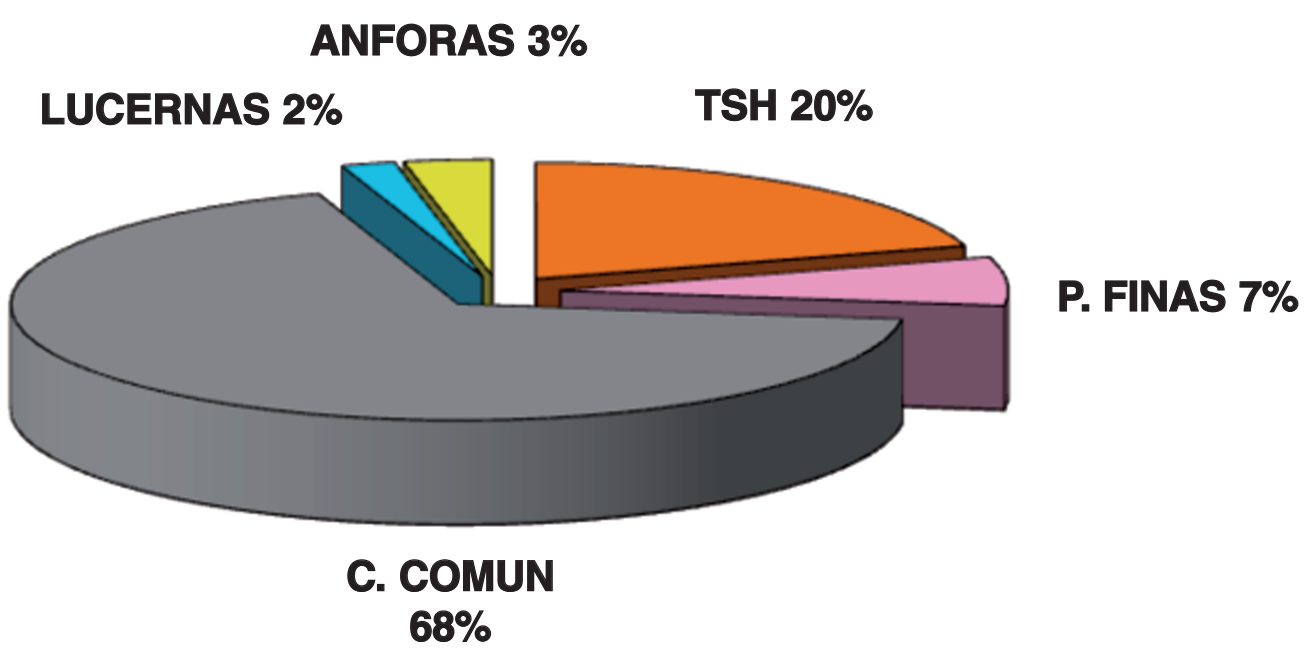

GRÁFICO 13: Distribución de material cerámico

\section{1.- TERRA SIGILLATA HISPÁNICA}

Comenzando por el análisis cuantitativo, hemos contabilizado un total de 1522 fragmentos de terra sigillata hispánica (un 20\% del total), si bien hay que puntualizar que de ellos, algo más del 70\% (unas 1085 piezas) corresponden a formas inidentificables. Con todo, -como ya hemos señalado al tratar los aspectos metodológicos- aunque trabajaremos sobre el número de piezas de atribución precisa, tendremos en consideración este porcentaje a efectos de valoración numérica, puesto que, a la hora de la identificación de formas concretas, hemos de contar con el posible falseamiento que supone, respecto al volumen total, la pertenencia de varios fragmentos a un mismo ejemplar.

Otro aspecto importante a contemplar en el conjunto de fragmentos identificables (437 piezas), es la relación porcentual entre ambos grupos de formas, lisas y decoradas. En este sentido la diferencia no es demasiado significativa, contabilizándose 197 fragmentos lisos y 240 decorados pero destacar el hecho de contravenir los cánones habituales de los conjuntos de TSH en los yacimientos romanos.

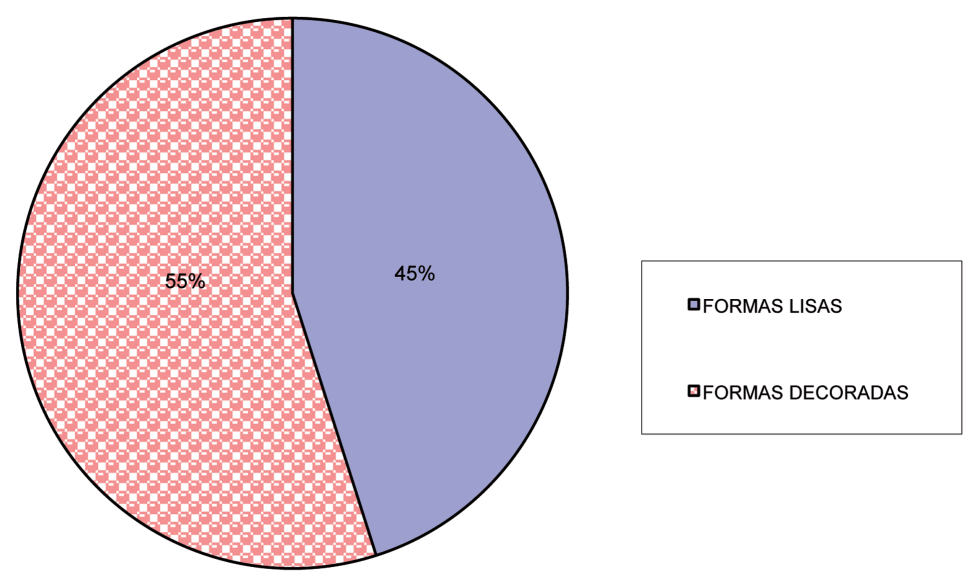

GRÁFICO 14: Proporción de formas de TSH Lisas y Decoradas

Las características técnicas y morfológicas del conjunto, que presenta en general, por las razones ya aludidas, un óptimo estado de conservación y una gran homogeneidad, 
indican su procedencia de los alfares riojanos del complejo alfarero de Tritium Magallum, al igual que en los dos contextos de vertidos aquí estudiados, así como también en el vertedero de la C/Maestro Copín, datado en la mitad del siglo II d. C. Apreciamos así, una notable calidad en las pastas, formadas por arcillas muy decantadas con desgrasantes apenas visibles, y en los revestimientos, que mantienen su adherencia en perfectas condiciones, otorgando a las piezas la característica tonalidad rojiza brillante de los talleres tritienses. Además de estos rasgos definitorios de la producción riojana, hemos de añadir los motivos decorativos y marcas de alfarero, junto a la decisiva aportación de los análisis arqueométricos, que vienen a confirmar la importación de la TSH del complejo alfarero tritiense, y de algunos talleres en particular106.

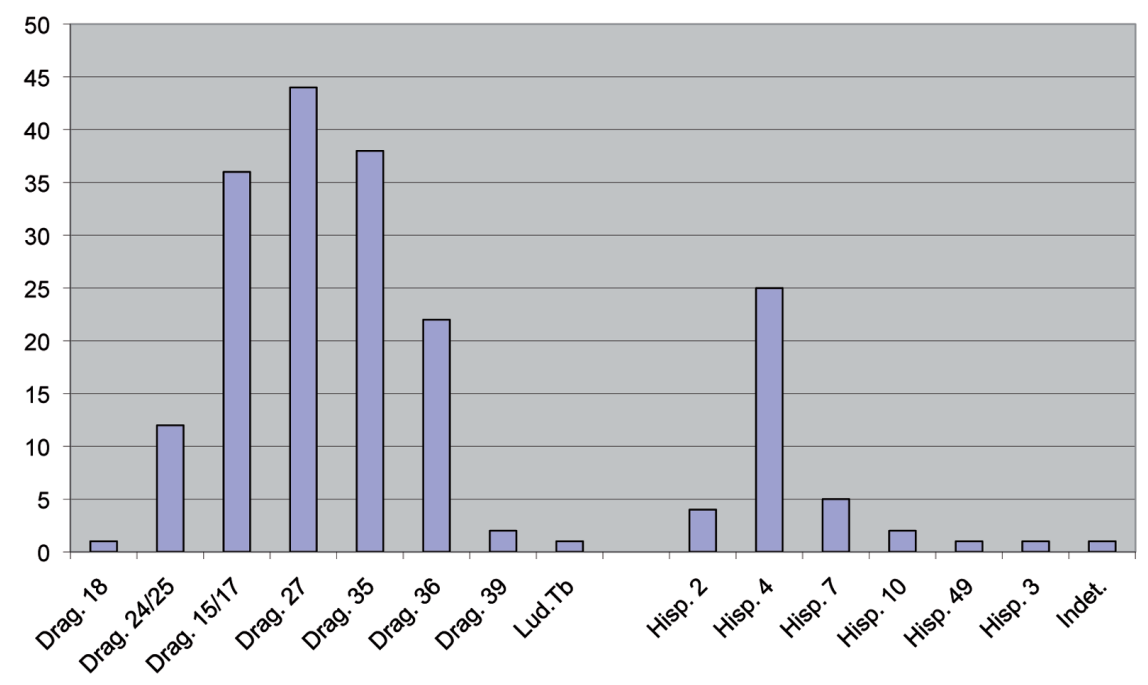

\section{GRÁFICO 15: Formas de TSH Lisa}

\section{1.- Formas Lisas (Láms. 40-43)}

En el conjunto de formas lisas destacan como más abundantes dos de los principales servicios de la producción hispánica, integrados respectivamente por las formas Drag. 15/17 y 27 -que aunque no formaron estrictamente servicio ${ }^{107}$, serían utilizadas como tal- y por las formas Drag. 35 y Drag. 36.

Las formas Drag. 15/17, procedentes de las UUEE 306 y 317, por tanto de la tercera fase diferenciada en la secuencia del vertedero, presentan -especialmente a partir de la pieza $n^{\circ} 350$ que conservamos completa- una serie de rasgos característicos de lo que podría considerarse la fase media de su producción, ya que han ido desapareciendo los rasgos sudgálicos, presentes en los primeros ejemplares. Así, el borde es más alto, oblicuo y carece de labio marcado, con unas dimensiones de diámetro de boca

106 Como ya hemos aludido al tratar la TSH del resto de vertederos estudiados, a partir de los rasgos tipológicos -especialmente determinados motivos decorativos- y corroborado por los análisis arqueométricos, podemos considerar al alfar de La Cereceda dentro del complejo tritiense, uno de los principales centros de abastecimiento de Legio.

107 De hecho no aparecen formando parte de los seis servicios creados en época flavia en el taller gálico de La Graufesenque (VERNHET, 1976). 
que oscilan entre los 16,4 cm. (n 352 ), $15 \mathrm{~cm}$. (n 350$)$ y 14,6 cm. (n 351). En cuanto a la base, presenta una tendencia a elevarse y a adoptar un movimiento más oblicuo, mientras el fondo interno adquiere una forma cóncava ascendente. Por lo que respecta a uno de los rasgos más definitorios de esta forma, la moldura interna en cuarto de círculo, con el tiempo se aprecia una clara tendencia a expandirse, que se refleja en la superficie externa en una moldura de concavidad cada vez menos pronunciada. En este sentido, de los tres ejemplares aquí estudiados, el $\mathrm{n}^{\circ} 352$, a pesar de su estado fragmentario, permite apreciar la evolución de las características citadas, que corresponderían al segundo y tercer grupo individualizados por Mayet (1984: 71, Pl. LVIII y LIX) y a una etapa media en la producción tritiense para los ejemplares numantinos estudiados por Romero (1985: 190, Fig. 72-73). Según la opinión de esta última investigadora, la evolución de esta forma no sigue siempre un esquema uniforme, sino que pueden aparecer rasgos de diferentes períodos en un mismo ejemplar, aspecto que además puede extenderse a la mayor parte de las formas riojanas. Con ello, resulta aún más significativa la aportación estratigráfica para otorgar mayor precisión cronológica a los distintos tipos, lisos y decorados, correspondiendo en este solar a principios del siglo II, pudiendo alcanzar la mitad de esta centuria.

En lo que respecta al cuenco Drag. 27, constituye la forma cuantitativamente mejor representada en este vertedero, representando un $44 \%$ del total de la TSH. A pesar de que no se conserva ningún perfil completo -falta la base en la mayoría de los ejemplares-, podemos establecer unos rasgos tipológico-cronológicos que permitan una datación en este contexto de esta forma que, al igual que la forma Drag. 15/17, mantiene una larga perduración, al menos hasta finales de la tercera centuria y principios de la cuarta (Romero, 1985: 193).

Siguiendo los parámetros de Mayet (1984: 72-73) para establecer la evolución de este cuenco formado por dos molduras semicirculares, quien subraya además que la forma hispánica se encuentra más próxima al prototipo gálico de época flavia que al de época claudioneroniana, consideraremos los cuatro grupos que diferencia esta investigadora, para analizar los ejemplares que aquí consignamos ( $\left.n^{\circ} 353-359\right)$.

En su mayor parte se trata de piezas de pequeño calibre, cuyo diámetro de boca oscila entre $8 \mathrm{~cm}$. ( $\left.\mathrm{n}^{\mathrm{o}} 354\right)$ y $12,5 \mathrm{~cm}$. ( $\mathrm{n}^{\mathrm{o}} 353$ ). En todos ellos, y con más claridad en los de menor tamaño, se advierte claramente cómo el cuarto de círculo superior es notablemente más corto que el inferior, a la vez que presenta un pequeño labio de sección redondeada, que irá desapareciendo con el tiempo a la vez que se van igualando en longitud las dos molduras del galbo y aumentando el tamaño y grosor de las paredes.

Según este esquema evolutivo, estos ejemplares pertenecerían al primero y segundo grupos, aunque con características peculiares. Así, las piezas no 354 y 355 se incluirían en el primer grupo, con una cronología a partir de época flavia, mientras que los ejemplares $n^{\circ} 353,356$ y 357, de mayor tamaño, con el círculo superior más alargado, pero manteniendo el labio, serían característicos de principios de la siguiente centuria, datación que coincide con los niveles que integran la tercera fase del vertedero.

En las mismas unidades estratigráficas (UUEE 317 y 306) se encuentran asimismo los únicos fragmentos hallados de la forma Drag. 24/25. Este cuenco, que presenta una corta vigencia cronológica, desde mediados del siglo I d. C. hasta fines de esta centuria o inicios de la siguiente, plantea no pocas dificultades desde el punto de 
vista de su evolución morfológica, pues hasta el momento, en los yacimientos en que alcanza una presencia representativa, como Conimbriga (Mayet, 1975: 184), Huerña, (Domergue y Martín, 1977: 15) Numancia (Romero: 1985: 192) o Petavonium (Carretero, 2000: 371) se ha comprobado que ejemplares con diferencias tipológicas comparten los mismos niveles estratigráficos, complicando así el proceso evolutivo de esta forma.

Se trata de un cuenco de tamaño variable y paredes curvas, cuyo rasgo más característico es el baquetón central que, adoptando diversos perfiles, rodea el galbo de la pieza.

Una buena parte de los ejemplares de esta forma presenta decoración burilada en su pared superior, como podemos apreciar aquí en las piezas n 360 y 361, sin que de ello se puedan extraer implicaciones cronológicas. De la misma manera, se aprecian notables diferencias en los tamaños de estos cuencos, que oscilan entre los 8,5 cm. de diámetro de boca en los de menor calibre ( $\left.n^{\circ} 359\right)$, hasta los $12 \mathrm{~cm}$. en los de mayor tamaño $\left(n^{\circ} 360\right)$.

Esta forma, aunque en estado mucho más fragmentario y peor estado de conservación, aparece también en el vertedero de San Pedro (Lám. 1, nº 5- 7), y es datada estratigráficamente en época flavia.

Sobre la perduración de esta forma en el siglo II d. C. ya con carácter residual, contamos con una pieza en el vertedero de la C/Maestro Copín, fechado a mediados de la segunda centuria (Fernández Freile, 2003: 54, Lám. 17).

Con todo, a pesar de esta fecha de desaparición de estos pequeños cuencos, sus rasgos morfológicos no desaparecerían totalmente de los esquemas de los talleres hispánicos, de manera que en opinión de algunos investigadores (Sáenz Preciado, J. C. 1997: 222), constituirían la principal fuente de inspiración de otra forma, la Dragendorff 44, que alcanza una importante difusión a lo largo del siglo II d. C. Esta forma tendría por tanto como predecesora a la forma $24 / 25$, aunque con diferentes proporciones y funcionalidad. Esta posible sucesión parece darse también en los vertederos de León, pues si bien en este contexto no hemos localizado ningún ejemplar de Drag. 44, entre los vertidos de la C/Maestro Copín, se halla representada con mayor profusión (Fernández Freile, 2003: 54-56, Láms. 17 y 18), avalando así la cronología y las influencias propuestas.

Dentro de las formas lisas destaca la escasa presencia del plato Drag. 18 (Lám. 38, nº 362), del cual conservamos únicamente un ejemplar reconocible que carece solamente de los extremos del borde y cuyo diámetro de boca oscilaría en torno a los $14 \mathrm{~cm}$. Esta forma que, según Mayet (1984: 71-72, Pl. LXI), alcanza su máximo esplendor en los talleres gálicos en época claudiana, presenta en los ejemplares hispánicos una mayor similitud con los productos gálicos flavios. En efecto, la pieza aquí representada, procedente de la UE 317, por tanto de finales el siglo I d. C. y perteneciente a la tercera etapa del vertedero, muestra, a diferencia de los primeros ejemplares con galbos más curvados, unas paredes de movimiento rectilíneo oblicuo, probablemente ya sin labio redondeado. En el fondo externo aparece además la característica moldura hispánica.

Esta serie de rasgos indicarían por tanto su adscripción a un período avanzado en la evolución de esta forma, cuya vigencia cronológica no es muy dilatada, ya que apenas alcanzará los primeros decenios de la segunda centuria. Tampoco su presencia es demasiado habitual en los yacimientos peninsulares, si exceptuamos algunos casos particulares como el campamento de Petavonium (Carretero, 2000: 369-370, Fig. 239), donde se ha registrado una considerable cantidad de estos platos, en diferentes estadios de su evolución. 
Por otra parte, esta pieza presenta otra importante peculiaridad en cuanto al conjunto total de TSH de los tres vertederos aquí estudiados, que no deja de ser por otra parte una cuestión difícilmente explicable, y es que se trata del único ejemplar que porta marca de ceramista en su fondo interno. El sello, en cartela rectangular de líneas y extremos irregulares, inscrita en un círculo inciso de $4,7 \mathrm{~cm}$. de diámetro y fragmentado en su parte izquierda, presenta una lectura "BRTTON", que debemos interpretar como abreviatura de "BRITTON" (con nexo IT), desconociendo si portaría formas introductorias debido a la fragmentación de la cartela en su extremo inicial.

No constituye una marca muy difundida entre los productos hispánicos, a pesar de su tradición de origen céltico (Mayet, 1984: 197), si bien podemos encontrar un ejemplo muy próximo en una pieza indeterminada de Asturica Augusta (Amaré (dir.), 2003: $99,235)$, con caracteres muy regulares y en cartela rectangular, perfectamente legible "BRITO", y en otra de Lancia, bajo la forma de "ATTI BRIT".

Además, aparece recogida en los catálogos de investigadores como Mayet (1984: 122-123, no 73 y 74), Mezquíriz (1985: 122, nº 40) o Beltrán (1990: 114), citando su localización en Conimbriga (Mayet, 1973: 11-12 n 7), Vaiamonte (Silva Caeiro, 1974-77: 228 $\mathrm{n}^{\mathrm{o}} 4$ ), en lugares del norte de Africa como Cotta (Boube, 1965: 130, $\mathrm{n}^{\circ} 18$ ) y otros yacimientos como Mallén, Lisboa, Braga o Mérida108, según la recopilación efectuada por M. P. y J. C. Sáenz Preciado (Roca y Fernández (Coords.) 1999: 94). En este último “corpus" aparece consignada la forma sobre la que aparece (Drag. 27), y la pertenencia de este alfarero al taller de Arenzana de Arriba (La Puebla), siendo este considerado el alfar más antiguo de los establecidos en Tritium Magallum y trasladado en un momento posterior a la Cereceda.

Asimismo, la presencia de la marca "BRITO" en Caesaraugusta, al analizar la ubicación de los talleres y la extensión del mercado en los inicios de la producción, coincidiría con esta cronología temprana, y según J. C. Sáenz Preciado, correspondería a la etapa inicial de la industria alfarera (2007: 388).

Sin constituir expresamente una marca de ceramista, nos ha parecido interesante hacer constar la presencia de un grafito de lectura "BRITTONIS" en uno de los denominados "jarritos de barro gris", en la capa IV de Huerña (Domergue y Martín, 197273: 61-62, Fig. 15, n 222), y datada a partir de mediados del siglo I d. C., dada la proximidad del yacimiento y una cierta aceptación de este cognomen que hemos determinado en el área leonesa. En este caso expresaría la identidad de su propietario, según una costumbre muy extendida en los contextos provinciales.

El siguiente grupo de piezas lisas está representado por las formas Drag. 35 y Drag. 36, que siguen en representación numérica a las formas Drag. 15/17 y 27, con un porcentaje del 35\% y $45 \%$ respectivamente.

Desde el punto de vista morfológico, los ejemplares de copa -Drag. 35- y plato -Drag. 36-, siguen fielmente los prototipos gálicos, que en este caso configuraron uno de los servicios más populares de la época flavia, especialmente el servicio A ruteno (Vernhet, 1976: 14-15, Fig. 1.A).

108 A los ejemplares emeritenses habría que añadir el conjunto de siete marcas de este ceramista halladas en el numeroso elenco de TSH procedente del vertedero de la C/ Almendralejo, 41 (BUSTAMANTE, 2013: 190, Fig. 196), así como la atribución menos segura a este alfarero de un sello de lectura "B” en una pieza de Valdeorras (MENÉNDEZ, 2000, 53; Lám. 8, Fig. 101). 
Los ejemplares asignables a la forma Drag. 35 ( $\mathrm{n}^{\circ}$ 363-365), de perfil hemiesférico, pie bajo moldurado y borde vuelto con característica decoración de hojas de agua a la barbotina -si bien contamos en este conjunto con una pieza de mayor originalidad en la decoración, pues los hojas de agua han sido sustituidas por mamelones o perlas también en barbotina- $\left(\mathrm{n}^{\circ} 365\right)$, presentan un calibre similar, que oscila entre 8,5 y $9 \mathrm{~cm}$. de diámetro de boca y $4 \mathrm{~cm}$. de altura. En este caso se cumpliría pues esta regularidad en las proporciones propias de esta forma y en la que han incidido investigadores como Romero (1985: 199), además de observarse una clara homogeneidad en la configuración de los bordes, rasgo en el que suelen producirse las mayores diferencias.

En cuanto al plato Drag. 36 ( $\left.\mathrm{n}^{\circ} 366-369\right)$, en este vertedero se mantiene asimismo la homogeneidad en las dimensiones, superando en todos los casos los $15 \mathrm{~cm}$. de diámetro de boca, y una altura que oscilaría -ya que no se conservan las bases en ningún ejemplar-, entre los 4 y 4,5 cm. de altura. Mayores diferencias se aprecian en la configuración de los bordes, apareciendo vuelto y colgante en las piezas $\mathrm{n}^{\circ} 366 \mathrm{y} \mathrm{n}^{\circ} 368$, mientras que en los otros dos ejemplares sigue una trayectoria más plana. De igual manera, las piezas $\mathrm{n}^{\circ} 368$ y n 369 no portan decoración en el borde, mientras la no 366 y $\mathrm{n}^{\circ} 367$ llevan el típico esquema decorativo de hojas de agua a la barbotina, considerado como signo de los ejemplares más tempranos.

Desde el punto de vista cronológico, una vez comentado su origen en los prototipos gálicos de época flavia, fecha en la que coinciden la mayoría de los investigadores (Mayet, 1984: 74; Romero, 1985: 202), su desarrollo abarcaría todo el siglo II d. C. con diversas fases evolutivas, hasta terminar a principios de la tercera centuria.

Así, en el contexto legionense es significativa la presencia de ambas formas en los principales conjuntos estudiados, principalmente los datados en época flavia y principios del siglo II d. C. como el vertedero de San Pedro (vid. Lám. 2, no 13-20) o San Lorenzo (vid. Lám. 28, n 256-258) y otros más tardíos como el de la C/Maestro Copín (Fernández Freile, 2003, Láms 20-21), fechado hacia la mitad de la segunda centuria.

Otro aspecto importante, de cara a la utilización de ambas formas como servicio, es la proporción en la que aparecen en los distintos yacimientos, ya que generalmente suele documentarse el predominio de una sobre otra; así por ejemplo, son mayoritarios los platos en Numancia (Romero, 1985: 198), Petavonium (Carretero, 200: 380), en Bilbilis (Sáenz Preciado, J. C. 1997: 32) o en el vertedero de Uralde (Filloy y Gil, 1993: 201-205), mientras que se advierte un predominio de los cuencos Drag. 35 en Conimbriga (Mayet, 1984: 154, 185), Herrera de Pisuerga (Pérez González, 1991: 342) o Legio, a raíz del estudio de estos tres contextos, si bien en el vertedero de la C/Maestro Copín, (Fernández Freile, 2003: 57) el porcentaje de ambas formas resulta equiparable.

El siguiente fragmento $\left(\mathrm{n}^{\mathrm{o}} 370\right)$ presenta ciertas dificultades de adscripción a causa de su escaso tamaño, si bien podemos reconocer algunos rasgos característicos del plato Ludowici TB o Hispánica 17, que formaría servicio con la copa Drag. 46, no representada en este conjunto. Este fragmento indica un momento evolucionado en la fabricación de la forma, como indican las paredes curvas y el labio engrosado, que supone la pérdida del borde recto y oblicuo característico de los primeros ejemplares, pudiendo situarse cronológicamente a principios del siglo II d. C. 
Una pieza excepcional, por ser la única hallada en los tres vertederos, es el fragmento de Drag. 39 ( $n^{\circ} 371$ ), un plato de pared hemiesférica y borde plano, al que se añaden dos asas decoradas a molde. En ocasiones su notable tamaño permite considerarla como una fuente. La forma curva de las paredes (frente a los tipos ovales elaborados en los talleres gálicos), y especialmente su rasgo más significativo, las asas con decoración a molde y no a la barbotina, representarían, según Mayet (1984: 74), las características de la Drag. 39 hispánica, cuyos inicios serían paralelos a los gálicos (finales del siglo I d. C. y principios del siglo II d. C.), con un floruit en época antonina, datación que mantiene Romero para los ejemplares numantinos (1985: 207). En efecto, esta cronología se confirmaría en los vertederos legionenses, pues en el situado en la C/Maestro Copín, y datado precisamente en época antonina, aparecen varios fragmentos de esta forma con las asas decoradas bien conservadas (Fernández Freile, 2003: 61-62, Lám. 26), de manera que pueden apreciarse lo motivos decorativos, principalmente vegetales (rosetas, hojas de hiedra, pámpanos...) enmarcados por volutas, roleos o hileras de pequeñas perlas que se organizan siguiendo un esquema compositivo basado en la disposición simétrica a ambos lados de un eje central. En todo ello queda patente la influencia de los modelos clásicos, aunque se detecta una falta de paralelos con los motivos de la terra sigillata hispánica decorada, que no deja de ser inusual, y para lo cual algunos investigadores han planteado interesantes hipótesis, como Romero (1985: 205), quien apunta la posibilidad de que los motivos de estas asas fueran trazados a mano alzada sobre el molde, lo cual explicaría también la irregularidad de algunos que se repiten en la misma asa. En nuestro fragmento no es posible advertir estas características, pero sí en las piezas citadas supra halladas en el vertedero del SW leonés.

Como paralelos más cercanos para estas formas, además de estas últimas, de procedencia leonesa pero de cronología más tardía, hemos de citar, además del importante conjunto de ejemplares de Numancia (Romero, 1985: 203-207, Fig. 81), otra importante serie de piezas procedente del cercano yacimiento leonés de Lancia (Martínez, Fig. 43, 432-435 y Fig. 44), así como los fragmentos hallados en Arcaya (Ciprés, 2008: Lám. 40, 180-181), en Herrera de Pisuerga (Pérez González, 1989: Fig. 67, 231-235, Fig. 68, 236-240) y dos pequeños fragmentos aparecidos en Petavonium (Carretero, 2000: 384-385, Fig. 246, 111-112).

En este conjunto de terra sigillata hispánica lisa es de destacar la notable representación de las formas genuinamente hispánicas, que alcanzan una importante significación cuantitativa, representando el $22 \%$ del total de formas lisas.

Así, merece mencionarse la presencia de los pequeños vasos o cubiletes de la forma Hisp. 2 ( $\mathrm{n}^{\circ}$ 372-374), de tendencia circular u ovoide, si bien sólo conservamos la parte superior en que se aprecia un borde recto y oblicuo $\left(\mathrm{n}^{\circ} 372 \mathrm{y} \mathrm{n}^{\circ} 374\right)$ y en otros más grueso y curvado ( $\mathrm{n}^{\mathrm{o}} 373$ ).

Generalmente, un importante número de estos ejemplares llevan decoración, predominando la técnica a la barbotina, mediante la cual se realizan motivos como gotas o mamelones, bastoncillos, hojas de agua, etc..., dispuestos hacia la zona central del galbo. Igualmente son característicos los elementos losángicos verticales con una línea divisoria central rugosa, que en este caso ocupan la totalidad del cuerpo del cubilete. En ello resulta fácil apreciar un seguimiento de los prototipos que suponen los vasos de paredes finas de la Gallia (Mayet, 1975: 79, Pl. XLII-XLVI, LVII-LXX), y en especial 
el tipo XLV que, en opinión de la citada autora, representa el modelo más directo de la Hisp. 2, teniendo también en consideración la influencia de la forma gálica Déchelette 67.

Estos vasos son sumamente frecuentes en los yacimientos hispánicos y citaremos únicamente a modo de ejemplo las piezas del vertedero leonés de la C/Maestro Copín (Fernández Freile, 2003: Lám. 29), Lancia (Martínez, 1992, Fig. 50-51), Numancia (Romero, 1985: Fig. 84) Bilbilis, donde alcanzan una importantísima representación (Sáenz Preciado, J. C. 1997: Láms. 32-35) y numerosos yacimientos de la zona norte, oscilando su cronología entre la época flavia y la primera mitad de la segunda centuria.

Otra de las formas propiamente hispánicas más abundantes en este vertedero es la forma Hisp. 4 (Lám. 42, n $\mathrm{n}^{\circ}$ 377-379), correspondiente a un plato de considerables dimensiones, paredes curvas y borde exvasado plano sobre el que se dispone una decoración burilada, que constituye su elemento más significativo y definitorio. En algunos casos, en la parte exterior del borde se disponen unas asas cordadas sin decoración ( $n^{\circ} 377$ y 379). En ninguno de los ejemplares se conserva la base, que habría de tener pie bajo y la característica moldura hispánica.

Con estos rasgos, podemos afirmar que la forma Hisp. 4 constituye una forma pura y genuinamente hispánica, sin que hasta el momento se hayan encontrado prototipos o concomitancias con otras producciones que pudieran servir de inspiración a los alfareros peninsulares.

En el aspecto cronológico, algunos investigadores (Mezquíriz: 1961: 76) han establecido para esta forma una secuencia evolutiva en función de determinadas características morfotipológicas, principalmente la configuración de los bordes: Esta clasificación fue también contemplada por Romero (1985: 226) para los ejemplares numantinos, diferenciando tres tipos distintos esenciales: bordes planos, bordes inclinados hacia abajo, y los de trayectoria ascendente más o menos acusada, que pertenecerían a la fase más tardía

Las piezas que estudiamos, ubicadas en las UUEE 306 y 317, tienen un considerable tamaño, con diámetros de boca que oscilan entre 15 y 25 cm., rasgo característico de estos platos en su segunda fase evolutiva, situada a finales del siglo I d. C. y principios del siglo II d. C. como la fase de desarrollo y afianzamiento de la forma (Romero, 1985: 228-229). Predominan asimismo los bordes planos horizontales $\left(\mathrm{n}^{\circ}\right.$ $375,376,378)$, sin trayectoria ascendente que determinarían un período más avanzado.

La presencia de la Hisp. 4 es sumamente abundante en los yacimientos peninsulares, destacando los numerosos ejemplares de Bilbilis (Sáenz Preciado, 1997: láms 3638), donde destacan los diversos tipos de burilado que ornamentan los bordes; Petavonium (Carretero, 2000: Fig. 246 n ${ }^{\circ}$ 129-133; Fig. 247; Fig. 248, nº 142-143); Herrera de Pisuerga (Pérez González, 1989: Fig. 57, Fig. 58 no 150-152), o Lancia, donde son también especialmente numerosos (Martínez, 1992: Fig. 52-55), estando también presentes en el vertedero leonés de mediados del siglo II d. C. (Fernández Freile, 2003: Lám. 30), sin que sus rasgos hayan variado sustancialmente.

Menor representación alcanza la forma Hisp. 7, con función de tapadera de diversos recipientes, de ahí su variedad morfológica y su diverso tamaño. De los dos ejemplares más completos que se conservan (nº 380 y 383), ambos carecen del ele- 
mento de aprehensión, de forma discoidal, y presentan un perfil curvilíneo, con labio redondeado, diferenciándose así por ejemplo de la pieza que aparece en el vertedero de San Pedro (Lám. 3 n 23), de perfil más rectilíneo.

Esta forma, considerada hasta hace poco tiempo una más de las producciones propiamente hispánicas, ha sufrido una cierta revisión en este sentido, dado que han sido halladas formas similares en talleres gálicos.

En cuanto a su evolución tipológico-cronológica se han hecho algunas propuestas, especialmente en lo que respecta a su producción en Andújar (Roca, 1976: 49), en función de la inclinación del borde, marcando sus inicios desde mediados del siglo I d. C. y perdurando durante toda la segunda centuria.

En los ejemplares que nos ocupan, su disposición estratigráfica en la UE 306, y el borde recto indicarían una cronología de fines de esta primera centuria e inicios de la siguiente.

En este vertedero hemos hallado una escasa representación de la forma Hisp. 10, una copa de perfil troncocónico, borde vuelto y base plana. En este contexto se han recuperado únicamente dos bases ( $\mathrm{n}^{\circ} 381$ y 382), presentando la segunda una atribución más segura. Al igual que en el caso anterior de la Hisp. 7, se han hallado algunos paralelos en la sigillata gálica de época flavia (Romero, 1985: 235), sin embargo los ejemplares hispánicos conservan ciertos rasgos de identidad peculiares.

Sobre esta forma en particular hemos de hacer una comparación con el elevado número de ejemplares que se documentan, como ya hemos comentado, en el vertedero de San Pedro (Gráfico 4) y que resulta de todo punto inusual, ya que es una forma que no suele aparecer con excesiva abundancia en los yacimientos norteños, si bien destacan algunos casos como el campamento de Petavonium (Carretero, 2000: 395, Fig. $\left.249 \mathrm{n}^{\circ} 156-163\right)$, en que también destaca el amplio conjunto de ejemplares hallados.

La pieza $\mathrm{n}^{\mathrm{o}} 384$ presenta una especial significación, puesto que pertenece a una forma Hisp. 49, cuyas cuestiones de nomenclatura ya hemos tratado al analizar el ejemplar procedente del vertedero de San Pedro. Esta forma, definida por un perfil troncocónico, con pie anular, paredes rectas y oblicuas y borde con labio redondeado, encuentra su rasgo más característico en la división de la pared externa en tres registros separados por finas acanaladuras que delimitan un espacio central más ancho en el que se dispone una decoración de facetas, más o menos regulares.

Este tipo de decoración en facetas rehundidas tendría una clara inspiración en los vasos de vidrio, especialmente en la forma Isings 21 (Romero, 1980: 188-193) al igual que aparece -aunque más esporádicamente- en otras formas hispánicas, como la Hisp. 2, la Drag. 30 y la Drag. 37.

Resulta digno de mención el claro paralelo que presenta esta pieza, de cuidada factura, con otra hallada en el vertedero de la C/Maestro Copín (Fernández Freile, 2003: Lám. 28, n 118/8), reproduciendo ambas idénticos rasgos que las diferencian notablemente de otras piezas con facetas rehundidas más irregulares y de menor calidad, para lo cual hemos propuesto en la obra citada y también en cuanto al conjunto de estas formas en el vertedero de San Pedro, una explicación hipotética (Ibid. 63, nota 85), que conllevaría un mayor perfeccionamiento en el proceso de fabricación de la forma y quizá una estadio evolutivo posterior, situado a mediados el siglo II d. C. aspectos todos ellos que habremos de corroborar con la aparición de otros ejemplares similares en diversos yacimientos. 
Sobre los paralelos y difusión de este tipo, sumamente numerosos en diferentes yacimientos peninsulares, no haremos especial hincapié, en aras de evitar reiteraciones innecesarias, pues hemos recopilado la procedencia de las piezas más significativas en el vertedero anteriormente estudiado.

Para finalizar el conjunto de formas de TSH lisa hemos de mencionar el fragmento $\mathrm{n}^{\mathrm{o}} 385$, perteneciente a un cuenco de paredes curvas con borde plano y labio engrosado, cuya fragmentación no nos permite una adscripción segura.

La pieza $\mathrm{n}^{\mathrm{O}} 386$, correspondiente al cuello de una forma cerrada, plantea asimismo problemas de atribución, pues puede tratarse de un ejemplar liso o decorado. En el primer caso, más frecuente en los yacimientos, podría tratarse de una Hisp. 23, con paralelos en Bilbilis (Saénz Preciado, 1997: 258, Lám. 44, n 316), si bien se trata de un tipo poco difundido entre las formas cerradas.

\section{2.- Formas Decoradas (Láms 44-51)}

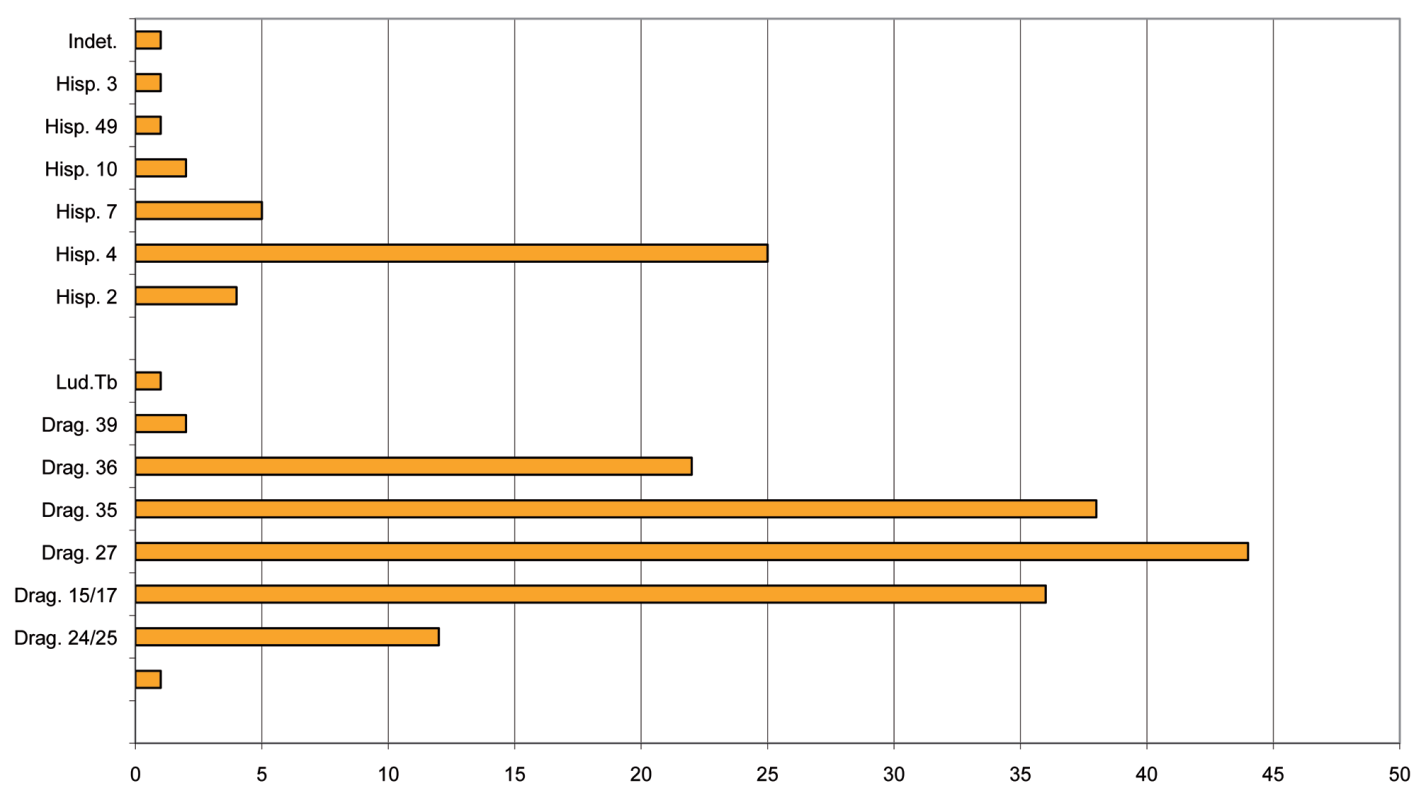

\section{GRÁFICO 16: Formas de TSH Decorada}

Las formas decoradas halladas en este vertedero suponen un porcentaje bastante equiparable respecto a las formas lisas, con un porcentaje de un 54,9\%, aspecto no muy usual en esta distribución, en la que suelen ser claramente mayoritarias las formas lisas. Se caracterizan además por un buen estado de conservación, lo que permite apreciar la gran variedad y calidad en el trazado de los motivos decorativos, destacando además la calidad de las pastas. A ello hay que añadir que las piezas conservan en su mayor parte los revestimientos, aspectos todos ellos que indican su deposición "natural", en un vertedero sistemático, con escasos elementos interfaciales que apenas han afectado a la disposición de la estratigrafía.

Siguiendo las mismas pautas que en el estudio de los ejemplares lisos, hemos valorado la diferenciación entre las formas de imitación y aquellas otras de inspiración genuinamente hispánica, división que se cifra en este caso, no tanto en la creación de nuevos tipos morfológicos, como en la aportación de motivos originales y composicio- 
nes decorativas por parte de los alfareros hispánicos, que permiten diferenciar, en las primeras fases, elementos distintivos, y ya en los momentos de pleno desarrollo de las formas, un estilo único y plenamente hispánico.

Así, en el análisis de la sintaxis decorativa de estas formas, hemos seguido el esquema tradicional de la sucesión de los tres estilos decorativos (de imitación, metopado y de círculos), empleado por la mayor parte de los investigadores, si bien hemos considerado precisar algunas matizaciones que amplían en cierto modo esta rígida clasificación tripartita, a tenor de las últimas investigaciones y aportaciones bibliográficas que incluyen "estilos peculiares", toda vez que se van descubriendo nuevos centros de fabricación en lugares alejados de los complejos alfareros tradicionales.

En cuanto a la presencia de producciones denominadas "precoces", presentes en el vertedero de San Pedro, con una cronología igualmente dilatada durante el siglo I d. C., no se atestiguan en este vertedero fragmentos atribuibles con seguridad a este tipo de manufacturas.

En el conjunto de las formas decoradas, resulta evidente el elevado porcentaje de la forma Drag. 29, al igual que ocurre en el vertedero de San Pedro con la Drag. 30, mientras que en el vertedero mediados del siglo II d. C. estas formas ceden todo el protagonismo a las Drag. 37 (Fernández Freile, 2003: 245, Gráfico V).

En todo ello hemos de ver la natural evolución tipológico-cronológica que experimentan las formas hispánicas desde su mayor o menor dependencia de los tipos gálicos a su progresivo afianzamiento como principal vajilla de uso en los yacimientos peninsulares.

En cuanto a la morfología de los variados ejemplares de Drag. 29, destacan algunos de los vasos por su gran calibre, como la pieza $n^{\circ} 387$, con más de $26,5 \mathrm{~cm}$. de diámetro de boca, o el ejemplar $n^{\circ} 389$, con un diámetro de boca de $23 \mathrm{~cm}$. En todos ellos se aprecia el típico borde exvasado con una moldura exterior más o menos marcada y labio redondeado, y la mayor parte presentan las dos típicas ranuras en el interior. En ninguna de las piezas se conserva la base, con pie anular, si bien queda patente en los ejemplares más completos la morfología del galbo carenado que define a esta forma y que facilita la disposición de la decoración generamente en dos registros, con una importante variedad de temas decorativos.

Desde el punto de vista decorativo, no hemos hallado ningún ejemplo del estilo de imitación, detectándose un absoluto predominio del estilo metopado, siendo abundantes las representaciones de figuras humanas ( $\left.n^{\circ} 387,392,393,394\right)$, ), entre las que destacan principalmente algunas divinidades, como las dos figuras de la diosa Fortuna, enmarcadas en la metopa de la pieza $n^{\circ} 387$, elaboradas con gran detallismo, y en la $n^{\circ} 394$, la figura de Mercurio ( $n^{\circ} 392$ ) y probablemente la diosa Minerva en el ejemplar $n^{\circ} 393$, en el que también aparece una figura de gran tamaño de difícil identificación, posiblemente de carácter mitológico. Los motivos zoomórficos (aves, liebres, felinos, cánidos...) suelen disponerse componiendo escenas ( ${ }^{\circ}$ 391, 393). Como elementos de separación de metopas predominan los compuestos por una línea de bifoliáceas flanqueada por grupos de tres o cuatro líneas onduladas. Únicamente en una de las piezas se dispone bajo el borde una hilera de ovas ( $\left.\mathrm{n}^{\circ} 394\right)$, reminiscencia de los tipos gálicos, apareciendo muy diversos motivos para marcar esta separación, como bifoliáceas horizontales ( $n^{\circ} 389$ y 392), y uno de los más originales, dos hileras de círculos tangentes enmarcando en su parte central una hilera de rosetas ( $\left.n^{\circ} 390\right)$. En el ejemplar $n^{\circ} 388$ podemos apreciar un pequeño rectángulo con algunos trazos en su interior, pudiendo tratarse de una marca intradecorativa, en todo caso ilegible. 
Como motivo decorativo con implicaciones cronológicas, puede apreciarse en el segundo registro del ejemplar $n^{\circ} 387$ la disposición de un círculo, probablemente integrante de una serie, como es habitual, y que, junto al predominio de las composiciones metopadas, están indicando una fase media-avanzada en el desarrollo de la forma, corroborada por la ubicación estratigráfica, en la tercera etapa del vertedero, de finales del siglo I d. C. y principios de la segunda centuria, fecha en que la forma Drag. 29 comienza a ser menos habitual, siendo sustituida por la Drag 37, aunque perdurará como forma residual hasta bien entrado el siglo II d. C.

En cuanto a la forma Drag. 30, presenta menor representación numérica que la Drag. 29 (un 25\% del total), siendo éste un rasgo característico en los yacimientos romanos peninsulares, con algunas excepciones cercanas como el vertedero de San Pedro.

A pesar de su porcentaje más reducido, hemos de destacar que se trata de ejemplares de excepcional calidad en la fabricación y con una importante diversidad en los motivos decorativos.

Esta forma, de cuerpo de tendencia cilíndrica, borde exvasado y labio engrosado con dos ranuras internas en la parte interior del borde, presenta en ocasiones importantes similitudes con la forma Drag. 29 en la parte superior, de manera que pueden inducir al falseamiento de los porcentajes de ambas cuando se trata de piezas con elevado índice de fragmentación.

Sin embargo, la parte inferior de este vaso presenta unas características sumamente peculiares que permiten su fácil identificación, ya que en la zona próxima a la base se localiza en la mayoría de los ejemplares una moldura en cuarto de círculo en el interior, que se refleja en una pequeña concavidad con pequeños baquetones al exterior. Este rasgo ha sido considerado por algunos autores como auténticamente hispánico (Mayet, 1984: 83), mientras que en otros casos, en función de la presencia o ausencia de esta moldura interna se han establecido criterios de adscripción cronológica (Oswald y Price, 1966: 89, Lám. 7 n 1 y 2), considerando su presencia como signo de mayor antigüedad, mientras que los que carecen de ella serían más tardíos. Con todo, creemos preciso analizar conjuntamente, además de este rasgo puramente morfológico, los aspectos decorativos y otros elementos que permiten una seriación cronológica más exacta.

En este conjunto contamos con un rasgo importante, y es el hecho de que la mayoría de las formas conservan buena parte del galbo, de manera que nos permite una mejor definición de los motivos y composiciones decorativas.

En cuanto al tamaño de estos vasos, se observa una acusada heterogeneidad, en lo que respecta al diámetro de boca, que oscila entre los $15 \mathrm{~cm}$. del $\mathrm{n}^{\circ} 398$ que se conserva completo, hasta los 9, 10 o $12 \mathrm{~cm}$. de vasos de menor calibre. En cuanto a la altura, no contamos en ningún caso con la base completa, de manera que no es posible establecer medidas concretas. La variedad en los calibres de las Drag. 30 de este vertedero contrastan con la mayor uniformidad que presentan estas formas en el vertedero de San Pedro (Lám. 6, no 34, 35, 36, 37, 46-49), si bien ambos conjuntos se encontrarían en el segundo grupo de formas, de menor tamaño, que Mayet establece para las Drag. 30 en función de sus dimensiones (1984: 83).

En lo que respecta al aspecto decorativo, en los ejemplares que conservan el borde, podemos apreciar únicamente uno con decoración burilada ( $\left.\mathrm{n}^{\mathrm{o}} 396\right)$, bajo el que se desarrolla una escena con motivos zoomórficos. El resto presentan un borde liso y bajo 
una moldura se dispone un friso de ovas ( $\left.n^{\circ} 395,398\right)$, además de la pieza $n^{\circ} 397$, en la que se aprecia un original friso de aves hacia la derecha.

Si tenemos en cuenta la seriación de los estilos decorativos, advertimos una notable ausencia de los motivos de imitación gálicos, con una clara preponderancia del estilo de metopas, generalmente enmarcadas por series verticales de bifoliáceas, y líneas onduladas conteniendo motivos zoomórficos o círculos ( $\left.n^{\circ} 395,398,401\right)$. En otros galbos el esquema metopado alcanza mayor complicación componiéndose de líneas de bifoliáceas verticales y horizontales, a las que se añaden series de líneas onduladas y de perlitas para formar cuadros con figura humanas y representaciones de sátiros en su interior $\left(n^{\circ} 403,404\right)$. Destaca igualmente por la utilización del esquema de arquerías la pieza $n^{\circ} 405$, en cuyo interior se sitúa un águila con las alas desplegadas.

En la disposición de los esquemas decorativos hemos de hacer especial referencia a tres piezas ( $n^{\circ} 399,400$ y 402), cuyo estilo y disposición de motivos no se adapta a los cánones normalmente establecidos, y que podríamos incluir en el denominado "Estilo Personal" que propone J. C. Sáenz Preciado en su clasificación de determinadas piezas bilbilitanas (1997: 310-311, Lám. 87, 582, 583). Así, en el fragmento nº 399 se disponen diversas líneas verticales con distintos motivos zoomórficos, sin que aparezcan claros motivos de separación, proporcionando una sensación de "horror vacui", al igual que en la pieza $n^{\circ} 400$, con diferentes motivos vegetales colocados verticalmente sobre una ancha banda de bifoliáceas. En este mismo grupo incluiríamos igualmente la pieza $n^{\circ} 402$, en cuyo esquema decorativo aparece un fragmento de guirnalda en la parte superior con dos aves separadas por un baquetón sogueado terminando en una pequeña roseta, todo ello sobre un ancho friso formado por palmetas estilizadas, confiriendo todo ello el abigarrado esquema decorativo característico de estas piezas.

En estos ejemplares parecen unirse elementos de tradición gálica, junto con otros motivos ya consolidados en los talleres hispánicos, de manera que resulta difícil no sólo su clasificación, sino su propia función. En opinión de Sáenz Preciado, debido a estas características, quizá deban considerarse más un capricho o producción propia de un único alfarero que un estilo decorativo como tal (Sáenz Preciado, 1997: 311).

Con todo, hemos de dejar de manifiesto la singularidad de estos ejemplares, su presencia en áreas alejadas de su lugar de producción y quizá pueda explicarse su éxito por su originalidad en el conjunto de formas más tradicionales. De hecho, también algunas de estas piezas de peculiar decoración son recogidas en la obra de Mayet (1984: Pl. C, 414-418) y encontramos algún ejemplar semejante, junto con magníficas Drag. 30, en otra importante área de vertidos, como el basurero romano de Uralde (Filloy y Gil, 1993: Fig. 73, n 227-229).

Desde el punto de vista cronológico, todas las formas Drag. 30 se sitúan en las UUEE $\mathrm{n}^{\mathrm{o}}$ 306, 317 y 318 de la tercera fase del vertedero, y por tanto, en época flavia, teniendo en cuenta que su vigencia no es mucho más dilatada. Así, son muy escasos los fragmentos de esta forma, hallados en el contexto legionense de mediados el siglo II d. C. y éstos con carácter claramente residual.

Antes de comenzar el análisis de las piezas Drag. 37A y 37B, que conforman el grueso del conjunto de la TSH decorada (con un $65 \%$ y un $85 \%$ respectivamente), hemos de prestar especial atención a un ejemplar híbrido o mixto, una forma 29/37, que reúne rasgos de ambas significando una forma de transición, si bien constituye un tipo no aceptado por todos los investigadores en las clasificaciones de la TSH decorada. En 
la única pieza que hemos considerado propia de esta atribución, la $\mathrm{n}^{\circ} 406$, podemos apreciar las características del borde propias de la forma Drag. 29, si bien la carena aparece mucho más marcada, siguiendo ya las pautas de la Drag. 37. Desde el punto de vista de la decoración, ésta se organiza en tres frisos: el superior metopado con motivo de separación de bifoliáceas verticales y dos líneas onduladas, dejando un espacio liso y despejado, donde se dispone el singular motivo de varios cuadrúpedos con dos cabezas opuestas (Mayet, 1984: Pl. CLXXXIV, n 1972-1977); el friso central está constituido por una hilera de hojas lanceoladas verticales y bajo ésta un friso de bifoliáceas horizontales; en el inferior se repite el mismo esquema de separación de metopas que en el superior, ocupadas en este caso por aves de gran tamaño.

En cuanto al tamaño del vaso, con 15,5 cm. de diámetro de boca, presenta un calibre considerable, y en este aspecto se encontraría más próximo a los ejemplares de la forma Drag. 37, que a los de la Drag. 29, generalmente de menor envergadura.

Los prototipos más cercanos para esta peculiar forma se encuentran en su homónima gálica que cronológicamente se desarrolla en un breve espacio de tiempo, dado su carácter transicional. El ejemplar que analizamos, procedente de la UE 317, correspondería a los últimos decenios de la primera centuria.

Al tratar esta peculiar forma Drag. 29/37 no es posible obviar la problemática que plantea su propio reconocimiento como forma individualizada, por parte de algunos investigadores, cuestión que no se encuentra hoy en día absoluto zanjada, manteniendose diversas posturas y valoraciones al respecto, desde el claro soslayamiento de Mayet (1984: 82-83), al tratamiento muy somero en la mayor parte de los corpora tipológicos, o el absoluto rechazo de esta particular forma en las clasificaciones morfológicas más recientes (Bustamante, 2013: 166-167), aduciendo el caos terminológico que produciría considerar cada variante de un tipo en una forma concreta. Desde nuestra limitada perspectiva, pues sólo contamos con un ejemplar adscribible a esta forma, podemos aportar sin embargo algunos rasgos característicos que permiten configurarla como un tipo individualizado, que aún siendo un producto mixto, presenta una entidad propia, no únicamente en la configuración morfológica, sino también en determinados elementos decorativos, con la importancia que todo ello posee, dado que pueden apreciarse los rasgos que conlleva la evolución de un tipo a otro de las formas cerámicas. Otros investigadores han señalado incluso, no sólo sus característicos rasgos tipológicos y decorativos, sino también una determinada calidad de las pastas y revestimientos en esta forma, como Roca para los ejemplares de Andújar (1976: 73). Con todo ello, podemos afirmar que la mayor parte de los investigadores de la TSH, reconoce la existencia de este tipo (Mezquíriz, 1961: 104-105; Garabito, 1978: 39-40), aunque últimamente se plantean algunas propuestas de revisiones terminológicas, como el caso de Juan Tovar en Arcobriga, que propone hablar de "variante" en lugar de forma (1992: 66), y se hace siempre hincapié en el carácter versátil de esta forma, que en una certera definición de Romero constituye "una forma híbrida, mixta, que jalona la evolución de la Drag. 37 y no siempre con reglas formales fijas, sino en buena manera con cierta libertad o espontaneidad" (1985: 97), sin que por ello deje de constituir un tipo más del repertorio hispánico.

En el conjunto de la sigillata decorada de este vertedero destaca el más elevado porcentaje numérico la forma Drag. 37, en sus dos variedades (37 A y 37B o de borde almendrado), si bien, como ya hemos comentado, resulta importante y en cierta manera poco usual el número de formas Drag. 29 (Gráfico 14). 
En cuanto a la distribución de porcentajes de ambas formas, sería la 37A de borde simple la que cuenta con mayor número de ejemplares. Sin embargo, se conservan escasas piezas completas y la mayor parte de los fragmentos corresponden a galbos, por lo cual, a la hora de la representación gráfica se aprecia una clara superioridad de la Drag. 37B, ya que ésta cuenta con rasgos muy característicos, sobre todo en el borde que se conserva en muchos de los casos.

Ambas formas, que presentan unos inicios de producción coetáneos en época flavia, constituirán la principal fuente de motivos y composiciones decorativas que nos permitirá determinar alfares concretos dentro del gran complejo de Tritium Magallum y establecer redes de comercialización y abastecimiento de Legio.

La forma Drag 37A está representada por ejemplares de diverso tamaño, desde los casi $18 \mathrm{~cm}$. de diámetro de boca de la pieza $\mathrm{n}^{\circ} 409$, a los $14 \mathrm{~cm}$. de la $\mathrm{n}^{\circ} 407$. En cuanto a sus características morfológicas, presentan una cierta heterogeneidad, especialmente en la curvatura de la carena, mucho más acusada en ejemplares de mayor tamaño y más evolucionados ( $\left.n^{\circ} 409\right)$, mientras en el resto aparecen más rectilíneas $\left(\mathrm{n}^{\circ} 407\right.$, 408). Algunos investigadores han considerado esta característica como propia de la transición que supone la forma intermedia Drag. 29/37. La parte superior es más uniforme, aunque aparecen ejemplares con el borde exvasado y labio engrosado típicos, y otros con el borde de tendencia más rectilínea ( $n^{\circ} 407$ y 408).

Por lo que respecta a la decoración, se aprecia aún la presencia del estilo de transición, con la disposición de esquemas metopados en los registros inferiores $\left(\mathrm{n}^{\mathrm{o}} 407\right)$, empleándose como motivo de separación una línea vertical de bifoliáceas y tres líneas onduladas, situándose en el registro superior, enmarcada por dos baquetones, una serie de círculos concéntricos de factura irregular. En otras piezas ( $n^{\circ} 408$ ), es el esquema metopado el que ocupa el registro superior, apareciendo como motivo decorativo una palmeta enmarcada en un motivo floral, y como separación cuatro líneas onduladas.

Quizá perteneciente al estilo de metopas pueda clasificarse la pieza $n^{\circ} 410$, sin embargo su fragmentación nos impide corroborarlo. Bajo un friso formado por motivos fitomórficos, aparecen dos figuras, una de ellas con lanza, componiendo una escena.

Por último, es de destacar la sintaxis decorativa del ejemplar $n^{\circ} 409$, pues, separados por dos finos baquetones se diferencian dos registros en los que ya aparecen los círculos como motivo predominante: en el friso superior círculos segmentados conteniendo motivos zoomórficos, y en el inferior círculos concéntricos con palmetas en su interior. En ninguno de los registros aparecen ya motivos de separación, y podemos afirmar que tanto por las dimensiones, los rasgos morfológicos y el esquema decorativo, este ejemplar representaría una fase ya un tanto avanzada en la evolución de la forma, aunque persistan los esquemas metopados y los punzones de gran tamaño, propios de la época inicial en la etapa flavia, marcando ya un momento cronológico que puede situarse en los primeros decenios de la segunda centuria.

Aún así, no es infrecuente que ambos estilos decorativos -metopado y de círculos- convivan en una primera fase, y de hecho, la coexistencia de rasgos estilísticos de diferentes fases quedaría corroborada cronológicamente desde el punto de vista estratigráfico, dado que la mayor parte de las piezas comparten las mismas unidades estratigráficas.

Además de estos ejemplares de la forma 37A de borde simple, que dejan patente su clara evolución en estos primeros decenios de vigencia, hemos de hacer hincapié en la importante presencia de la forma $37 \mathrm{~B}$, pues teniendo un origen sincrónico con la primera, aparece en un mayor porcentaje, siendo la forma decorada mejor representada en el vertedero. 
Desde el punto de vista de la representación numérica hemos constatado rasgos poco comunes en algunos vertederos de Legio, como la ya comentada elevada presencia de la forma Drag. 29 en el vertedero de San Pedro, al igual que ocurre en ambas áreas de vertidos con la forma Drag. 37B o de borde almendrado, que supone en ambos el porcentaje mayoritario, siendo lo más usual el predominio de la 37A. Únicamente en el vertedero de la C/ Maestro Copín, más tardío, datado a mediados del siglo II d. C. los porcentajes cuantitativos de las formas decoradas siguen las pautas generales en la mayoría de los yacimientos peninsulares (Fernández Freile, 2003: 245, Gráfico V).

Como acabamos de comentar, el porcentaje numérico de la forma Drag. 37B en este vertedero de la C/Pilotos Regueral, supera en un $25 \%$ aproximadamente al de la 37A.

En cuanto a su morfología, este cuenco hemiesférico presenta como rasgo distintivo un borde engrosado de perfil almendrado, más o menos saliente, destacando la calidad de las pastas y revestimientos en su fabricación y el considerable espesor de las paredes, en consonancia con la envergadura de estos recipientes, a lo que hay que añadir la perfección y el detallismo en las composiciones decorativas.

Además del borde almendrado, esta variedad puede presentar ciertos elementos que aparecen con menor frecuencia, como las asas cordadas horizontales situadas en el borde o un elemento vertedor.

Otro elemento sumamente diferenciador respecto al subtipo anterior es el tamaño de los vasos, pues se trata en general de cuencos de gran calibre, que suelen superar en dimensiones a todos los demás ejemplares de las manufacturas hispánicas (Mayet: 1984: 84). Este aspecto podemos comprobarlo claramente en los ejemplares de este vertedero, con piezas que presentan un diámetro de boca desde los $27 \mathrm{~cm}$. del ejemplar $\mathrm{n}^{\circ} 415$, mientras el resto oscila entre los 20-25 cm.

Una característica que define asimismo a la mayoría de estos ejemplares es la presencia de una banda de decoración burilada bajo el borde, adoptando una notable variedad de tipos (diagonal, pequeños círculos, forma de $S$, etc...).

En algunas de estas piezas, tanto los peculiares rasgos morfológicos como los motivos decorativos proporcionan importantes indicios cronológicos. Así, las piezas $\mathrm{n}^{\circ} 414$ y 415, que por otra parte son las de mayor tamaño de este conjunto, presentan bajo el borde una trayectoria no tanto curva en el arranque del cuerpo, como es característico, sino más rectilínea, a partir de dos finos baquetones bajo la banda burilada. Por otra parte, la decoración muestra motivos de arquerías, en uno de ellos albergando motivos vegetales $\left(n^{\circ} 414\right)$ y en la otra pieza motivos zoomórficos. Todo ello implica una importante influencia de los prototipos gálicos, que nos permiten situar cronológicamente estos ejemplares en los primeros momentos de la producción hispánica, a lo que hemos de añadir su ubicación estratigráfica, ambas en la UE 312, que abarcaría desde mediados del siglo I d. C. hasta la época flavia, de manera que podríamos considerarlas como los ejemplares más antiguos de la forma Drag. 37 de borde almendrado.

Ya en estratos más modernos, de época flavia y principios del siglo II d. C. se ubican tres ejemplares excelentemente conservados que presentan decoración metopada ( $\left.n^{\circ} 411-413\right)$. En el $n^{\circ} 411$ con dos registros separados por baquetones, se sitúa en el friso superior una figura humana -probablemente la diosa Minerva- enmarcada por tres líneas onduladas a cada lado y una línea de bifoliáceas, mientras en el friso inferior, en un círculo de bifoliáceas aparece un motivo zoomórfico, escasamente visible, que puede pertenecer a un grifo. 
En la pieza $n^{\circ} 412$, bajo el friso burilado se dispone otro más estrecho formado por círculos concéntricos, y bajo éste dos paneles metopados conteniendo figuras humanas, con motivos de separación de tres líneas onduladas, encuadrado uno de ellos por líneas de bifoliáceas que alberga la representación de la diosa Fortuna y otro por pequeños círculos que componen los paneles, en los que aparece la figura de la diosa Minerva. Es un ejemplar que se distingue por su cuidada factura y gran calidad decorativa.

Una pieza de características originales, ya que presenta una decoración abigarrada en la que los motivos no aparecen individualizados, es la $n^{\circ} 413$. En ella pueden distinguirse en el friso superior motivos cruciformes en los que se entrelazan hojas acorazonadas (motivo típico del taller de la Cereceda), y sobre este esquema, sin una clara separación, se intenta una composición metopada con motivo de separación de bifoliáceas verticales enmarcadas por líneas onduladas. Bajo un friso de bifoliáceas horizontales pueden distinguirse fragmentos de guirnaldas y motivos florales. Esta falta de organización de los motivos decorativos, que no es propia de estas piezas, podría indicar una cronología temprana, que, si tenemos en consideración los esquemas decorativos, se extendería a este grupo completo de ejemplares y que podemos ubicar a principios de época flavia, momentos en que aún no ha aparecido el estilo de series de círculos, que caracterizará a esta forma en su periodo de esplendor, ya en la segunda centuria.

En el conjunto de formas decoradas hemos seleccionado algunas por su calidad decorativa, como la pieza $n^{\circ} 422$, correspondiente a una forma cerrada, quizá una jarra Hisp. 1, con decoración alternante de círculos y palmetas, y dos ejmplares $\left(\mathrm{n}^{\mathrm{o}} 423\right.$ y 424) de bases probablemente adscribibles a la forma Hisp. 2, con decoración de bifoliáceas. A estos añadimos tres bases de gran calidad ( $\left.n^{\circ} 425-427\right)$ decoradas con palmetas y metopas, pertenecientes a formas de dudosa filiación.

Para finalizar la descripción de la terra sigillata hispánica decorada de este contexto de vertidos hemos incluido la representación gráfica de varios fragmentos de galbos (Láms 49-51) con el fin de recoger de algún modo los motivos decorativos más abundantes y característicos de este conjunto, incidiendo una vez más en su alta calidad técnica y estética, a la par que en su mayor proporción de un determinado alfar tritiense.

En primer término destacan aún los motivos de arquerías que, siguiendo los tipos gálicos, conservan aún su perfección, manteniéndose bastante tiempo durante los inicios de la producción, a diferencia de otros elementos gálicos que apenas llegan a aparecer en la decoración de las formas hispánicas. En este sentido se distingue especialmente por su cuidada factura la pieza $\mathrm{n}^{\circ} 430$, en la que se representa en este esquema un águila con las alas desplegadas. Se encuentran también otros motivos zoomórficosen este caso palmípedas-, bajo un friso continuo de arquerías ( $n^{\circ} 433$ ), así como figuras humanas de divinidades como Mercurio ( $\left.n^{\circ} 436\right)$ o Victoria $\left(n^{\circ} 437\right)$.

En cuanto a la disposición de los motivos en estos fragmentos de dudosa adscripción, pero que en muchos casos (a excepción de las formas Drag. 30 y otras identificables) pueden atribuirse al repertorio decorativo de la forma Drag. 37 en sus dos variedades, hemos de hacer mención, como ya subrayamos al analizar estas formas individualmente, al absoluto predominio de los esquemas metopados. En ellos se utilizan como motivos de separación fundamentalmente líneas de bifoliáceas y onduladas, si 
bien como motivo más excepcional pueden aparecer series de lúnulas ( $\left.\mathrm{n}^{\circ} 449\right)$ o pequeños círculos ( $n^{\circ} 439$ ). En estos paneles metopados se aprecia especialmente la disposición de motivos zoomórficos, bien en solitario o bien formando escenas, que destacan por la perfección de su factura y la calidad en los punzones, representándose sobre todo cérvidos $\left(\mathrm{n}^{\circ} 440,441,446 \ldots\right)$, grifos $\left(\mathrm{n}^{\circ} 443,444\right)$, lagomorfos $\left(\mathrm{n}^{\circ} 445\right)$ y aves ( $\left.\mathrm{n}^{\circ} 429,447-451\right)$.

En contraposición al claro dominio del estilo de metopas, apenas contamos con composiciones de círculos, como ya hemos también resaltado, de manera que en un conjunto de fragmentos de galbos bastante representativo de la producción decorada, encontramos únicamente algunas representaciones en que aparecen estos motivos, como en la pieza $\left(n^{\circ} 431\right)$, cuya decoración se divide en dos registros: el superior con figuras humanas danzantes separadas por motivos verticales a modo de columnas; y el inferior con una serie de círculos segmentados sin elementos de separación, conteniendo en su interior un motivo vegetal con varias palmetas. Éste sería pues uno de los fragmentos en el que se puede percibir una cierta evolución en el tipo y en la disposición de los motivos decorativos. Únicamente hallamos círculos en otra pieza ( $\mathrm{n}^{\circ}$ 449) en la que aparecen dos círculos conteniendo cada uno de ellos una cigüeña y, como motivo de separación, un ave sobre una línea de lúnulas.

Finalmente, en la pieza $n^{\circ} 438$, en el interior de un doble círculo, el exterior más ancho y ondulado y el interior con pequeños motivos ovalados, aparece un rostro humano elaborado con gran detallismo, que podría tratarse de una máscara teatral, uno de los motivos utilizados con singularidad en la producción hispánica, y presente en varios yacimientos peninsulares. Éste en particular ofrece una especial semejanza con uno de los recogidos por Mayet (1984: Pl. CCI, $\mathrm{n}^{\circ} 2479$ ) y parangonable con otro fragmento procedente del vertedero de San Pedro en que se representa un friso de caras humanas (Lám. 9, $\mathrm{n}^{\circ}$ 76), al igual que en el borde de un recipiente del alfar de La Cereceda (Sáenz Preciado, M. P. ,1992: Lám. 42 n 214).

En lo que se refiere a los motivos vegetales, abundan los arboriformes o "palmas" de notable tamaño $\left(\mathrm{n}^{\circ}, 453,454,455,457\right)$, destacando especialmente el $\mathrm{n}^{\circ} 452$, que compone una escena con un cérvido.

Dentro de los motivos fitomórficos abundan en particular las palmetas, bien de pequeño tamaño, formando frisos o individualizadas, si bien éstas corresponden a la denominación de hojas lanceoladas u hojas treboladas. En este conjunto son representativas las palmetas u "hojas tipo palmeta" ( $\left.\mathrm{n}^{\circ} 434,435,458,459,462 \ldots\right)$, uno de los motivos más característicos de la sigillata hispánica ${ }^{109}$, como podemos comprobar en

109 Hasta el punto que M. V. Romero (1999:169-208) ha dado esta denominación a un taller nuevo que ha identificado en el Valle del Jalón, con sus formas, motivos y punzones característicos, propios de la época flavia, y al que se conoce como "taller de las palmetas".

Sin embargo, los trabajos más recientes llevados a cabo por esta investigadora, centrados especialmente en los estudios arqueométricos de las piezas, han puesto de manifiesto -al igual que sucede con la producción del ceramista VLLO-, una nueva ubicación del denominado "taller de las palmetas", también en el centro de Uxama (Romero: 2008: 319-330; 2012). Aún así, esta autora hace hincapié, basándose en elementos morfotipológicos y otros aspectos peculiares, en la relación que hubieron de mantener en etapas anteriores ambas producciones, ahora reubicadas, con el área de los talleres tritienses. 
los diferentes corpora de motivos decorativos (Mayet: 1984), Romero para los ejemplares numantinos (1985), Sáenz Preciado para la Cereceda (1997) y un gran número de recopilaciones dependiendo de las peculiaridades de los diferentes talleres.

Resulta de especial significación, de cara a establecer criterios de atribución, uno de los motivos vegetales más característicos del alfar de la Cereceda, el denominado "alfarero del trébol" (Sáenz Preciado, 1997: tabla D/7), presente en varios conjuntos de la producción legionense (ver Fernández Freile, 2004) constituyendo en principio un elemento decorativo original, pero cuya notable presencia se ha visto confirmada con los análisis arqueométricos que han determinado la procedencia de varias de estas piezas de este alfar. En este conjunto aparecen únicamente dos ejemplares $\left(n^{\circ} 462,464\right)$, pero se documentan en el resto de vertederos y con cierta profusión en algunas piezas, como en una forma Drag. 30 procedente de una escombrera, por tanto sin contexto arqueológico, recogida por García Marcos (1985: 304, Fig. 46 n²45). Además del “alfarero de las hojas de trébol", son característicos de la Cereceda otros como"el alfarero de los bastones seg-

mentados", de los cuales contamos con algún ejemplar representativo en el conjunto de vertederos legionenses. Además se localizan motivos típicos de este taller realizados a mano alzada y fácilmente reconocibles, generalmente a base de líneas onduladas y motivos cruciformes y romboidales $\left(n^{\circ} 465,466\right)$.

Para finalizar este capítulo de motivos decorativos es preciso hacer hincapié en la singular ausencia de "rosetas" en el conjunto de los motivos fitomórficos, ya que se trata de uno de los motivos más abundantes, diversos y con una trayectoria cronológica más dilatada en la TSH.

La explicación que proponen algunos autores como Garabito (1978: 495) es que las rosetas están presentes en Tricio, Bezares y Arenzana, pero son más utilizadas a partir de la segunda mitad del siglo I d. C. de ahí que sean más frecuentes en Tricio, ya que permanece hasta época tardía. Según M. P. Sáenz Preciado, las rosetas de Bezares son más escasas, pero de mayor cuidado en el diseño, y en "Arenzana son poco corrientes y escasas, aunque suelen ser de buena factura" (1997: 466).

Sin pretender a priori proponer una concreta procedencia de parte de la producción de TSH legionense de un determinado taller, ya que es preciso analizar exhaustivamente los estudios arqueométricos, esta última apreciación -hemos documentado únicamente una roseta (Lám. 9, $\mathrm{n}^{\circ}$ 79) en este conjunto, mientras en el vertedero de mediados del siglo II d. C. son muy abundantes, variadas y combinadas con círculos, podría añadir un elemento más a la línea que venimos siguiendo sobre una mayoritaria presencia de ejemplares en Legio de sigillata fabricados en La Cereceda (Arenzana de Arriba), sin que en ello haya que ver necesariamente una exclusividad de este centro, puesto que hemos de valorar además factores como la cronología, las comunicaciones, las características del abastecimiento, y demás de este alfar tritiense y su relación con el asentamiento castrense de la Legio VII Gemina.

\section{2.- CERÁMICA DE PAREDES FINAS}

El volumen de cerámica de paredes finas recuperado en esta fase del vertedero, a pesar de su reducida representación cuantitativa (134 fragmentos) y de su elevado índice de fragmentación que sólo permite la adscripción tipológica segura de un escaso número de piezas, presenta una gran relevancia para nuestro estudio. 
Este reducido conjunto de cerámica de paredes finas procedente de esta etapa del vertedero que abarca la época flavia e inicios del siglo II d. C., y a pesar de las ya comentadas dificultades de restitución de las piezas, que han dado lugar a una selección tan limitada en la representación gráfica, podemos constatar en una primera visión de conjunto, basándonos en la originalidad de sus rasgos morfológicos y decorativos, una amplia presencia de ejemplares procedentes del taller zamorano de Melgar de Tera (alrededor del 80\% aproximadamente). Esta proporción puede verse precisada a través de un análisis más completo de pastas y otros aspectos técnicos, dado que en algunos casos existen semejanzas apreciables con producciones de otro origen y cronologías generalmente más tempranas.

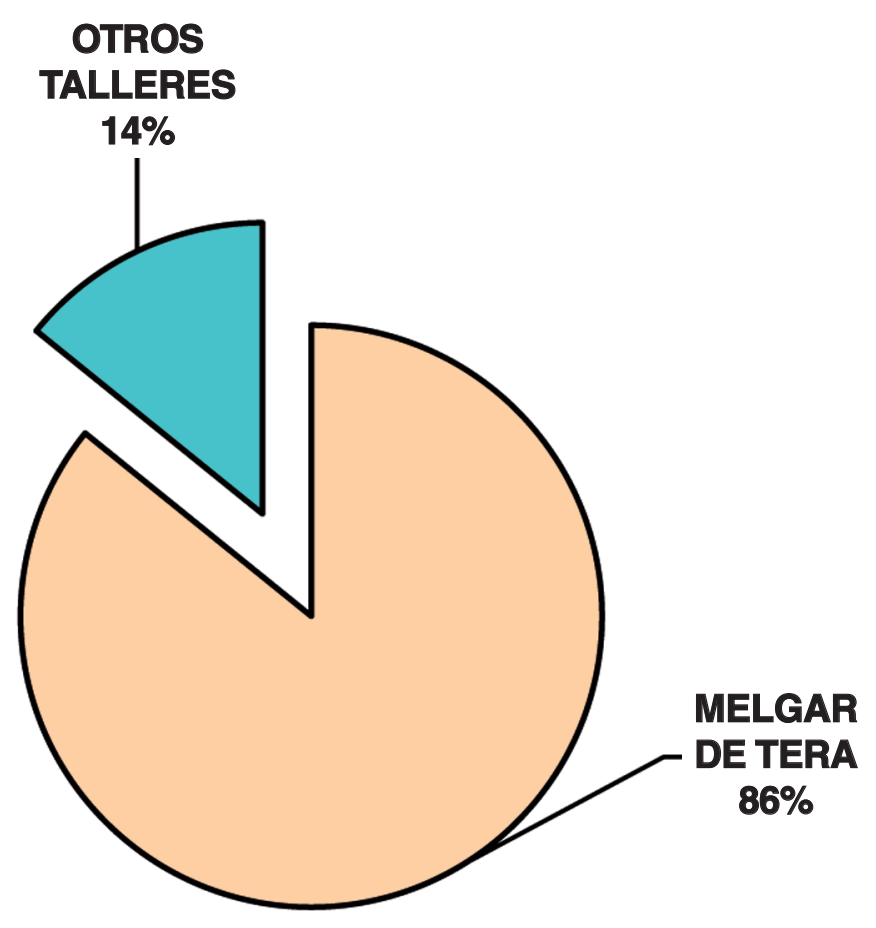

\section{GRÁFICO 17: Procedencia de la cerámica de paredes Finas}

Para el análisis de este conjunto de formas hemos utilizado fundamentalmente las clasificaciones generales de Mayet (1975; 1976), Marabini (1973) y Ricci (1985), así como los trabajos de los principales investigadores de esta producción vascular en Gallia (Bémont, 1976; Grataloup, 1988; Mesplé, 1957; 1966; Vertet, 1969) o Britannia (Anderson, 1982), además de tratar en esta última obra producciones de Renania y Gallia del Norte y ya en el ámbito peninsular, junto a los estudios detallados sobre talleres o producciones individualizadas, nos basamos (sin dejar de lado la extensa bibliografía de ambos sobre el tema), en las últimas contribuciones de especialistas como López Mullor (en Bernal y Ribera (eds.), 2008: 343-383) y Mínguez Morales (2005: 317-404) como más rigurosas y completas por su carácter más reciente.

En cuanto a las piezas de paredes finas halladas en Petavonium, constituye el principal referente para el estudio de los ejemplares del taller de Melgar de Tera, dada su cercana ubicación y el carácter de centro abastecedor por excelencia de cerámica y 
otras manufacturas al recinto castrense del Ala II Flavia Civium Romanorum. Aún así, se encuentra en este ámbito campamental un conjunto nada desdeñable de otras producciones de paredes finas, de forma que emplearemos para ambos grupos los criterios y la exhaustiva clasificación tipológica elaborada por su principal investigador (Carretero, 2000: 452-570), y dada la gran difusión de los productos melgarenses en la zona norte, incluiremos aquellos hallazgos que sean en alguna medida parangonables con los ejemplares de Legio.

Por otra parte, hemos prestado especial atención a los últimos trabajos publicados sobre estas manufacturas 110 , que contienen importantes aportaciones y, en ocasiones, revisiones notables sobre diversos aspectos (origen, nuevos talleres e importaciones, variaciones cronológicas...), intentando a través de ellos valorar estas nuevas propuestas con la necesaria cautela en lo que afecta a nuestra zona de estudio.

Comenzando con la clasificación de las piezas seleccionadas (Láms. 52-56), destaca el fragmento $n^{\circ} 467$, realizado en pasta de tono castaño, sin engobe, con borde recto y decoración en barbotina a base de la aplicación de pequeñas perlas. Uno de los escasos rasgos morfológicos que nos permite apreciar el pequeño tamaño de la pieza es la tendencia rectilínea de sus paredes en la parte superior, pudiendo adscribirse a la forma Mayet XXXVII, correspondiente a pequeños cuencos, en ocasiones con carena baja, datados generalmente en época claudio-neroniana, si bien López Mullor propone su esplendor en época de Nerón, prolongándolo hasta los inicios de la etapa flavia (1990: 384-385). Generalmente se atribuye su fabricación a talleres béticos o emeritenses, teniendo en consideración sus características técnicas, sobre todo pastas y engobes. En este caso, la coloración anaranjada que presenta este ejemplar nos inclinaría hacia una procedencia bética, pudiendo equipararse a los vasos completos con decoración de perlitas bajo el borde que presenta López Mullor (2008: Fig. $15, \mathrm{n}^{\mathrm{o}} 37 \mathrm{~A} 8^{\mathrm{a}}$ y $37 \mathrm{~B} 8^{\mathrm{a}}$ ). Es preciso valorar asimismo la importante contribución de este autor, que en el taller gálico de Fos- sur- Mer (Bouches du Rhône), ha localizado producciones muy similares a las béticas con este tipo de decoración (López Mullor, 2008: 372, Fig.17, nº 20 y 21).

Como paralelos más próximos en Hispania, podemos citar un pequeño fragmento procedente de Celsa (Beltrán et alii, 1998: 367, Fig. 171 n $^{\circ}$ 6), donde este motivo decorativo es especialmente abundante en diferentes combinaciones, y sobre todo, destacar un ejemplar hallado en Petavonium (Carretero, 2000: 477, Fig. 281, n 54), aunque este vaso se conserva completo, presentando un borde reentrante y una carena baja, lo cual permite adscribirlo a la forma Mayet XXXVIIIA.

Este mismo esquema decorativo presente en estos cuencos de pequeño calibre es especialmente abundante en territorio galo, especialmente en Glanum (Bémont, 1976,

110 Como ejemplos significativos de estos trabajos, no exentos de controversia en algunas de sus aportaciones, citaremos las obras de Martín (2008) sobre las paredes finas de época julio-claudia en el depósito de San Pedro de la ciudad de León o los de Martín Hernández y Rodríguez Martín (2008: 385406) sobre estas mismas producciones en la Lusitania y el cuadrante noroccidental peninsular. Igualmente, y más dado que se trata también de un contexto militar, hemos de citar la contribución de Reinoso del Río (2002: 369-380), sobre la cerámica de paredes finas en el asentamiento militar de Herrera de Pisuerga (Palencia), con el aliciente de que hasta el momento existían escasos trabajos sobre esta especie cerámica en este recinto castrense. 
Fig. 3, n ${ }^{\mathrm{o}} 2243,7585,7586,7686,7585,7580,7576$; Fig. 5, $\left.\mathrm{n}^{\mathrm{o}} 7569,7573\right)$ o en las producciones de la Rue des Farges en Lyon (Grataloup, 1988: 168, Type XXXVI (nº 196$\left.201 ; 175, n^{\circ} 238\right)$. A ellos podemos añadir algunos cubiletes de mayor tamaño y de gran perfección decorativa con los mismos esquemas y motivos, procedentes de la Renania Inferior (Anderson: 1982: 41, n 6.2). Cabría reseñar asimismo las singulares piezas que en esta misma zona añaden a este esquema motivos generalmente zoomórficos, componiendo escenas de caza de gran valor decorativo (Ibid. 53, $\mathrm{n}^{\mathrm{o}} 8.1$ ), aunque también hemos encontrado un vaso con las mismas características recogido por Mayet, procedente de la Bética del cual presenta una fotografía en el actual Museo de Lisboa (1975, p. 412).

El siguiente cuenco ( $\left.\mathrm{n}^{\circ} 468\right)$, se muestra igualmente incompleto, estando elaborado en pasta de tonalidad anaranjada con un engobe amarillento al exterior. Morfológicamente es un bol o pequeño cuenco de cuerpo hemiesférico con borde recto y un pequeño labio. La composición decorativa, realizada con técnica a la barbotina, se dispone bajo una franja lisa subyacente al borde. Está compuesta por una línea superior de mamelones y un alineamiento inferior de hojas de agua oblicuas, sin duda el motivo más característico de la decoración en barbotina.

La difusión de este tipo decorativo es sumamente extensa, sin embargo, aún repitiéndose la composición decorativa en vasos de la forma Mayet XXXVII-XXXVIII, muchos de ellos de origen hispano, es realmente difícil hallar un paralelo exacto, puesto que los rasgos morfológicos experimentan numerosas variedades, especialmente en la tipología de los bordes. Al igual que en el fragmento anterior, la composición de las pastas de tono ocre-anaranjado y la presencia de un engobe castaño un tanto brillante, permite adscribir este ejemplar a las producciones más características de los talleres de la Bética.

Así, el paralelo más próximo de que disponemos para esta pieza es un ejemplar procedente de Petavonium (Carretero, 2000, Fig. 281, no 58), también carente de base y cuyas hojas se disponen más regularmente bajo los mamelones, además de no existir una banda lisa tan ancha hasta el borde. Esto sucede con algunos vasos similares hallados en Celsa (Beltrán et alii, 1998, Fig. 172, no 4), incluyéndose además una serie de tablas decorativas con estos elementos (Figs. 180, 184), de manera que ninguno de ellos coincide exactamente con el ejemplar legionense.

Por otra parte, cabe mencionar dos piezas procedentes de la capa IV de Huerña (Domergue y Martin: 43, n 143 y 144) que corresponderían a la parte inferior del recipiente y que son datados ya en época flavia (Ibid: 48). Por su parte, Carretero (2000: 476) incluye el vaso de Petavonium en los ejemplares atribuibles a la forma Mayet XXXVIII, cuya cronología abarcaría el periodo neroniano y la primera etapa flavia.

La siguiente pieza $\left(\mathrm{n}^{\circ} 469\right)$ corresponde a la parte superior de un cubilete, de perfil probablemente globular u ovoide, con borde liso y labio engrosado. Bajo la franja lisa sin decoración, situada bajo el borde, aparecen trazos más o menos rectos a la barbotina y algún punto de impregnación arenosa. La pasta presenta un tono ocre claro en el interior del vaso, y en el exterior se aprecia un engobe gris negruzco. Su ubicación estratigráfica corresponde a aquellas UUEE, que se presentaban conflictivas en el sentido de su atribución a mediados del siglo I d. C. y por tanto pertenecientes a la Legio VI Victrix o ya a la etapa flavia con la presencia de la Legio VII Gemina en León. 
Buscando paralelos cronológicos que puedan indicar datos en este sentido, encontramos un vaso similar en Asturica Augusta (Mínguez y Carro, 2003: 320, Fig. 2, n $\mathrm{n}^{\circ}$, clasificado como forma Mayet XXXVI, (aunque con posteriores precisiones de Mínguez), proponiendo esta autora (1975: 72-73) una cronología desde la época claudio-neroniana hasta los Flavios, de manera que quedaría así aclarada la perduración en el tiempo de estos ejemplares desde mediados de la primera centuria hasta finales de siglo.

El fragmento $n^{\circ} 471$, perteneciente a un cuenco de pasta anaranjada con paredes rectas, dos finos baquetones en el borde liso y decoración arenosa, puede adscribirse a la forma XXXVII de Mayet (1975: Pl. XXXIV-XL), en la que se engloban numerosos ejemplares de rasgos morfológicos similares, destacando especialmente las paredes rectas y la decoración extendida por toda la superficie del vaso. Esta forma es igualmente predominante en los alfares béticos, siendo la característica más variable la configuración del borde -liso o dividido en pequeños frisos-. Un ejemplar con el borde dividido en pequeños frisos aparece en Petavonium (Carretero, 2000: 475, Fig. 281, $\mathrm{n}^{\circ}$ 45) y por las características de la clasificación más precisa de López Mullor, el autor propone una de las cronologías más antiguas, desde principios de la primera centuria hasta la época claudio-neroniana, mientras el ejemplar legionense, teniendo en cuenta su ubicación estratigráfica, pertenecería ya a la etapa flavia.

Por otra parte, los fragmentos $n^{\circ} 470$ y 472 , el primero de mayores dimensiones, realizado en pasta anaranjada con engobe castaño oscuro y decoración de lúnulas aplicadas a la barbotina al igual que el fragmento $n^{\circ} 472$, con las mismas características técnicas y decorativas, podrían adscribirse a la forma Mayet XLII-XLIII. Aunque la elaboración técnica y las características de los engobes nos plantean dudas a la hora de atribuirlos al taller de Melgar de Tera, donde también hallamos este motivo decorativo. De hecho, el fragmento similar aparecido en Petavonium es caracterizado como de dudosa adscripción por el principal investigador de la producción melgarense (Carretero: 2000, Fig. 282, $\mathrm{n}^{\circ}$ 76).

La pieza $n^{\circ} 473$, perteneciente a un vaso de paredes muy finas- próximas a las denominadas "de cáscara de huevo"- rectilíneas de tendencia oblicua, y con un grosor mínimo, está realizado con pasta amarillenta y engobe grisáceo, podría adscribirse a la forma Mayet XXXIV, a pesar de su escaso tamaño. Esta forma con sus peculiares características técnicas, está considerada como genuinamente hispánica y con una fabricación en diversos talleres (Cádiz o Mérida, y más al norte hemos de destacar el alfar de La Maja (Calahorra) y el centro turolense de Rubielos de Mora, (con un amplia tradición en cerámica de paredes finas) y aún resultando su transporte sumamente difícil por su extrema fragilidad, hay que puntualizar que esta cerámica "de cáscara de huevo" se encuentra extendida en la mayoría de los yacimientos peninsulares, con una amplia cronología. En cuanto a su situación estratigráfica en el vertedero, en la UE 318, puede datarse a finales del siglo I d. C. o inicios de la segunda centuria, sin dejar de contemplar la posibilidad de una procedencia de los talleres citados más norteños en el área del Valle del Ebro.

En cuanto al fragmento $n^{\circ} 474$, de paredes rectas y borde engrosado y saliente, está fabricado con pasta de color ocre-amarillento, portando un engobe blanquecino al exterior. La escasa superficie conservada de la pieza dificulta su adscripción tipológi- 
ca concreta y únicamente contamos con su atribución cronológica, procedente de la UE 318 y, por tanto, ya presente en la etapa de los primeros Flavios.

En el análisis descriptivo de este escaso número de formas de cerámica de paredes finas hemos hecho especial hincapié en la cronología propuesta por los principales investigadores, especialmente por Mayet, ya que se trata de un conjunto de procedencia hispana con muy contados y poco seguros productos importados. Así, el fenómeno, amplio y temprano de reproducción de modelos de los diferentes talleres -itálicos y sobre todo de la Gallia lugdunense- debido en gran parte a la fragilidad de estas manufacturas para su transporte, con el elevado coste que ello supone, y la necesidad de cubrir la demanda de este tipo de vasos especialmente en los asentamientos militares peninsulares, dará lugar a una gran proliferación de talleres regionales o locales que fabrican y comercializan estos productos en los diferentes ámbitos del territorio hispano. Por ello, las estimaciones sobre la procedencia de algunos ejemplares, debido al fenómeno de imitación, resultan sumamente complejas, dado que a partir de los tres grandes centros productores hispanos diferenciados en un primer momento por Mayet (1975: 139-170), se ha producido un elevado número de hallazgos de nuevos alfares, sobre todo de difusión regional o local, con un panorama mucho más diversificado. Ello ha ocasionado el surgimiento de rasgos peculiares en la producción de cada uno de estos centros, de manera que la determinación del origen y la adscripción cronológica resultan más precisos a partir de la segunda mitad del siglo I d. C. y sobre todo, a partir de la etapa flavia, en que se produce un auge en la elaboración y difusión de estas manufacturas.

Así, si los aspectos morfológicos y su cronología asociada resultan especialmente relevantes para establecer la etapa flavia del vertedero, el origen de estos productos no deja de ser igualmente importante para determinar redes de comercio y distribución, e incluso determinados gustos militares, en este caso de la Legio VII Gemina.

En efecto, a los centros de producción señalados por Mayet como más importantes (Baleares, Mérida, Bética y Sagunto), habría que añadir hoy un numerosísimo conjunto de talleres de diversa magnitud y capacidad de difusión en la mayor parte del territorio hispano, haciendo una especial referencia, como el ejemplo quizá más destacado, al taller zamorano de Melgar de Tera, en las proximidades de Petavonium, que se convierte lógicamente en su principal centro abastecedor (no únicamente de paredes finas para el campamento), y cuyas manufacturas se encuentran diseminadas por toda la zona norte peninsular, con continuos hallazgos que van ampliando su ya extensa área de difusión.

Ni que decir tiene que en el conjunto de paredes finas aquí estudiado, los vasos procedentes de este taller representan, como ya hemos apuntado, una amplísima mayoría (Gráfico 16), de manera que para establecer la procedencia del resto de estas manufacturas hemos seguido en gran parte los criterios de Mayet, y algunas innovaciones al respecto que proponen Martín y Rodríguez (en Bernal y Ribera (eds.) 2008: 385-406) y Martín (2008b: 219-235) sobre las paredes finas de la Lusitania y del cuadrante noroccidental.

Teniendo en cuenta el absoluto predominio numérico de los vasos de paredes finas 
procedentes del taller melgarense en este vertedero, así como la singularidad de las características técnicas, rasgos morfológicos y peculiares motivos decorativos, que hacen reconocibles las producciones de este centro en su cada vez más amplia área de dispersión, consideramos justificado un estudio individualizado de este taller en un apartado específico.

\subsection{PRODUCCIONES DEL ALFAR DE MELGAR DE TERA (ZAMORA)}

En primer lugar, cabe destacar que las manufacturas procedentes de este taller han sido esenciales en yacimientos como el cercano campamento de Petavonium, que constituye el referente esencial por sus aportaciones, entre otras, de importantes datos cronológicos, económicos, y funcionales, tal y como se desvela a través de los estudios de de sus principales investigadores, Carretero y Romero (1991, 1997, 1998, 2000: 496-570, $2002, . .$.$) , quienes han aportado una amplísima y rigurosa documentación sobre este$ taller y sus características producciones.

El carácter excepcional de este taller zamorano, fue ya señalado por sus descubridores, Martín Valls y Delibes en 1976111, quienes hallaron en el denominado "Pago de los ladrillos", restos de un importante alfar de paredes finas, con un destacado nivel de destrucción, puesto de manifiesto por los restos de material latericio procedente de los hornos y fragmentos de producciones cerámicas.

Posteriormente ha sido objeto de diversas excavaciones y estudios, las primeras por Lión Bustillo112 y, en cuanto a los materiales, se realizó un primer estudio más minucioso por Gimeno (1990: 587-610). En este último, una importante cantidad de ejemplares procede de un testar, lo que explicaría los fallos e irregularidades en la fabricación. La principal aportación de la autora es la clasificación morfológica de los cubiletes de paredes finas, en dos tipos principales: los vasos definidos por un borde exvasado corto y oblicuo, en los que aparece una fina acanaladura en la zona superior bajo el borde y dos en la parte baja, próximas a la base que presenta un pie anular, que constituyen la forma Melgar I (Lám. 51 no 475-481); y el siguiente tipo, más característico, que presenta bajo el borde un hombro abombado, que lo distingue perfectamente de los primeros vasos y que se conoce como forma Melgar II (Lám. 52, n 486-489).

111 MARTÍN VALLS y DELIBES (1976: 426-427), que resaltan la ubicación del taller, tanto por su situación en la importante vía comercial que une Asturica Agusta con Bracara Augusta, como por su proximidad al campamento militar situado en Rosinos de Vidriales (Petavonium), que habría de ser su principal centro de abastecimiento.

112 Realizadas en 1988, se hallaron las estructuras de dos hornos para los que la autora propone una cronología de la segunda mitad de la primera centuria d. C. y menciona ya la posibilidad de ser un centro abastecedor del área noroeste de la Península (1998: 99-100). El conjunto de materiales hallado no se limitó a vasos de paredes finas, sino que se encontraron también fragmentos de cerámica común. En un estudio posterior (Lión Bustillo, 1997: 173-179), la autora se extiende ya de forma mucho más pormenorizada sobre las formas, cronología, dispersión y sobre todo decoraciones del taller de Melgar, prestando una especial atención a los paralelos con los motivos decorativos de las principales producciones de paredes finas de otros lugares del Imperio. 
Además de esta clasificación morfológica, posteriormente tomada como base para una tipología más amplia y completa (Carretero, 2000: 499-514, Fig. 273), la autora incluye un amplio repertorio de motivos decorativos típicos del taller.

Plantean cierta problemática, como señala Carretero (2000: 497), aquellos vasos con líneas verticales rugosas, (Lám. 52, n 488-493), dado que en opinión de Gimeno, la impregnación arenosa actuaría únicamente como elemento consolidador de las líneas de barbotina, mientras que Carretero, basándose en paralelos itálicos, gálicos e hispánicos, considera este recubrimiento arenoso además como un motivo ornamental, corroborando esta hipótesis el hecho de que se extiende por todo el registro decorativo, sin limitarse a las líneas en barbotina. Además de estas cuestiones decorativas, a los vasos con estas características suele atribuirse una cronología temprana, de mediados del siglo I d. C., con numerosos paralelos en yacimientos peninsulares como Arcobriga (Sánchez, M. A. 1992b, Fig. 3.1, n 7-10, 12, 13), Varea (Luezas Pascual y Sáenz Preciado, 1989: Lám. LXX nº 56; Lám LXXI, nº58-64) o Celsa (Beltrán et allii, 1998: Fig. 166, n4-8; Fig. 167, n¹-5), proponiéndose para estos últimos, una lógica procedencia de talleres ubicados en el Valle Medio del Ebro. Por otra parte, además de los ya comentados vasos de esta tipología hallados en este vertedero legionense, se han encontrado otros ejemplares en la zona noroeste, cuya procedencia del taller de Melgar de Tera no ofrecería dudas, si bien con una cronología un tanto más tardía, pero teniendo en cuenta que los vasos descritos constituirían una de las formas más antiguas de la producción de dicho alfar. A este tipo de cubiletes habría que añadir según Carretero (2000: 489-496), aquellos otros vasos de perfil ovoide en "S" lisos o decorados con perlitas formando letras, que constituirían igualmente producciones de la primera etapa del conjunto de las paredes finas del campamento.

Continuando con esta primera etapa de estudios y aportaciones sobre las producciones de Melgar, hemos de hacer referencia a los hallazgos de cubiletes en el Castro de Corporales (Truchas, León) por Sánchez-Palencia y Fernández-Posse (1985: 252255, Figs. 118 y 123), cuyo estudio morfológico les llevó a identificar una tercera forma, que presenta un hombro marcadamente saliente, pero no diferenciado del cuerpo como en la Forma II de Gimeno, dando lugar a un cubilete de perfil más cilíndrico, con lo cual, la tipología melgarense constaba a partir de entonces de tres formas diferenciadas.

Esta Forma III, no presente en la tipología de Gimeno, ha sido reconocida por nosotros en estudios precedentes sobre estas manufacturas del taller de Melgar halladas en la ciudad de León (Fernández Freile, 1998-99, Fig. 3, 109-110; 2003, 107-108, Lám. 69), y por otros autores en estudios sobre estas producciones en lugares próximos como Asturica Augusta (Mínguez y Carro, 2003: 299, Fig. 9, no 94 y 91), contemplando esta denominada Forma III y su característica decoración burilada. Sin embargo, desde el punto de vista tipológico, la mayor parte de los investigadores hemos desechado esta morfología tripartita, eliminando la tercera forma y reduciéndola por tanto a las dos primeras, considerándola una variante de la Forma I o II, con las subvariantes que sobre ellas establece el principal investigador actual del taller, S. Carretero, en un cuadro de forma esquemática sumamente indicativo (Carretero 2000: 501). Sobre éste realiza posteriormente interesantes explicaciones morfológicas, decorativas, técnicas y cronológicas (Ibid.: 496-547), configurando el esquema tipológico y los criterios que hoy utilizamos. Por ello, no deja de ser llamativo que algunos 
autores continúen empleando el esquema de las tres formas y sus proporciones (Martín, 2008: 410), además de denominar a estas producciones "tipo Melgar", poniendo en duda su procedencia del taller melgarense, en función de la posible existencia de un alfar local en Legio que imitara estas manufacturas (Ibid.: 413; Martín Hernández y Rodríguez Martín, 2008: 400). Estas afirmaciones resultan difícilmente sostenibles, a tenor de los datos que aportan hasta el momento las evidencias arqueológicas y los análisis arqueométricos.

Tras esbozar este complejo panorama bibliográfico sobre este taller zamorano y sus producciones, que ha sido objeto de muy diversas y, en ocasiones, no muy acertadas interpretaciones, hemos de subrayar el punto de inflexión que supone en este aspecto, la puesta al día de Carretero (2000: 496-552, Figs. 283-295). Este autor realizó un completo estudio y sistematización de estas producciones dentro del análisis del material cerámico del campamento romano del Ala II Flavia en Petavonium, basándose en el ingente número de ejemplares hallados en este recinto, el principal centro receptor de estas manufacturas, así como en los numerosos hallazgos de estas producciones en la zona noroeste, teniendo siempre presente el contexto estratigráfico de las mismas y los paralelos formales y decorativos con otra producciones hispanas y especialmente gálicas, que permiten establecer con mayor precisión datos cronológicos.

De cara a la clasificación de las escasas piezas melgarenses halladas en este vertedero, partiremos del esquema morfológico ya establecido, añadiendo únicamente las principales variantes de la Forma I (vasos de cuerpo ovoide y vasos de cuerpo globular), así como las de la Forma II (vasos de cuerpo ovoide, de tendencia cilíndrica y de cuerpo piriforme).

En este sentido, y prescindiendo de las decoraciones que trataremos posteriormente, advertimos un porcentaje numérico muy superior de los vasos de la Forma I, si bien la conservación únicamente de la parte superior nos impide determinar la tendencia ovoide o globular de sus galbos, y efectuar una clasificación más concreta, así como establecer paralelos específicos. En la mayoría de los casos presentan un marcado borde vuelto ( $\left.{ }^{\circ} 476,478,480,494,495,503\right)$, y en otros más incipiente ( $n^{\circ} 477,479,483$, 481) con unos diámetros de boca que oscilan entre los 7 y $9 \mathrm{~cm}$.

Por otra parte, la presencia de dos bases en buen estado de conservación ( $n^{\circ} 484$, 485), permite atribuirlas a los característicos vasos ovoides de perfil en "S", que tanta relevancia alcanzan en la producción melgarense de Petavonium (Carretero, 2000: Fig. 283 n 78-79; Figs. 284, 285 y 286 (110-112).

En lo que respecta a la Forma II, sin duda la más representativa del taller, los ejemplares de que disponemos, de los que también se conserva únicamente la parte superior, resultan aún menos significativos numéricamente que los de la primera forma (Lám. 54, no 486, 487, 489), siendo el de mayor calibre este último, con casi $10 \mathrm{~cm}$. de diámetro de boca.

Por lo que se refiere a la capacidad de algunos de los vasos de este alfar pertenecientes a esta segunda forma, tenemos constancia por otros estudios (Fernández Freile, 1998-99: 109; 2003: 109, Lám. 73) de las grandes dimensiones que presentan, con diámetros de boca entre 13 y $19 \mathrm{~cm}$. superando así con creces la clasificación de Gimeno. Estas piezas proceden del vertedero de la C/Maestro Copín, con una cronología de mediados de la segunda centuria, aspecto que quizá tenga alguna relación con estas características.

En el mismo sentido cabe señalar ejemplares hallados en Astorga, también de la Forma II, con las mismas decoraciones que los de León, y con diámetros similares 
(Mínguez y Carro, 2003: 298-299, Fig. 7) y los más numerosos de Petavonium (Carretero, 2000: $\mathrm{n}^{\circ}$ 173, 192, 194-197).

Por otra parte y obviando hasta el momento los motivos decorativos, es preciso destacar asimismo el importante grosor de sus paredes (con una media de $5 \mathrm{~mm}$.), lo cual obliga en cierta manera a reconsiderar la denominación de "paredes finas" para estos vasos, al igual que su admitida funcionalidad como "vasa potoria"113.

Tras el análisis morfológico, que constituiría el primer capítulo, continuaremos enumerando correlativamente, con el fin de facilitar el estudio, el resto de los aspectos que caracterizan a las piezas de Melgar de Tera.

\section{1.- $\underline{\text { Técnica }}$}

Las características técnicas de los vasos de este alfar zamorano se definen en primer término por la homogeneidad en la factura, aspecto que, por otra parte, los hace fácilmente identificables cuando aparecen en otros lugares más alejados.

En cuanto a la composición de las pastas, éstas son muy decantadas y uniformes, de manera que apenas se aprecian desgrasantes (únicamente son visibles en algunos fragmentos partículas de tamaño ínfimo, de naturaleza cuarcítica o micácea). Estos rasgos determinan unas paredes de los vasos de textura dura y compacta, de modo que como podemos apreciar en la mayoría de los casos, las secciones de fractura son sumamente rectilíneas.

Las tonalidades muestran una mayor variedad, con un predominio de los colores anaranjados, si bien la gama se amplía considerablemente con diferentes tonos de colores castaños, y algunos fragmentos que presentan un color grisáceo. Esta diversidad cromática se encuentra en función de la atmósfera de cocción oxidante o reductora, aunque algunas piezas de cocción alternante presentan el típico corte en "pasta sandwich". Con todo, en esta variedad, y valorando los conjuntos de diferentes yacimientos, se advierte una preeminencia de los tonos resultado de cocciones oxidantes.

En el caso de los ejemplares hallados en los vertederos legionenses más tardíos (Fernández Freile, 2003: 106) y, por tanto, con mayor representatividad de piezas melgarenses, hemos detectado en una parte importante de los vasos algunas zonas de ennegrecimiento por una exposición al fuego. La causa hay que buscarla probablemente, en un proceso de quemado en el vertedero. A este rspecto, hemos de tener en cuenta que esta misma característica se hace extensiva a otro tipo de materiales hallados en las mismas unidades estratigráficas, por lo que estos procesos de combustiones espontáneas o intencionadas en los vertederos, a lo que contribuyen los fenómenos de descomposición y putrefacción de la materia orgánica que contienen, son frecuentes y afectan por tanto a los diversos tipos de materiales que en ellos se encuentran, como podremos comprobar en otras piezas cerámicas, ya que nuestro campo de estudio se restringe a este material.

113 En este sentido, estas grandes dimensiones, al igual que las que presentan algunas jarras con gollete, han llevado a interpretar estos recipientes como contenedores, formando parte de un servicio. Sobre esta cuestión, queremos expresar nuestro más sincero agradecimiento al Dr. S. CARRETERO por compartir con nosotros esta interesante propuesta, que consideramos una sólida hipótesis ante un aspecto que personalmente constituyó durante un tiempo en nuestra investigación un punto problemático de difícil explicación. 
Otra de las características técnicas que define las producciones melgarenses es un engobe de gran calidad en su adherencia, y cuyo rasgo distintivo es el brillo metálico que confiere a las paredes de los recipientes, y que ha sido objeto de diversas interpretaciones, desde un efecto de irisaciones metálicas debido a una irregular aplicación (Sánchez Palencia y Fernández Posse, 1985: 254), o incluso a defectos de cocción, sin descartar la imitación de vasos metálicos (Gimeno, 1990: 588-589).

Si bien hemos de contemplar estas diferentes explicaciones, en nuestra opinión se trataría de un aspecto puramente técnico, aplicado con gran perfección, y que otorga a los vasos una notable calidad estética.

\section{2.- $\underline{\text { Decoraciones }}$}

Otro de los rasgos definitorios de las manufacturas del alfar de Melgar es la gran diversidad de técnicas y motivos decorativos, también sumamente característicos, y que suelen combinarse entre sí para dar lugar a composiciones propias y distintivas de este taller zamorano.

En este aspecto, sobre la estructura del completo cuadro de los diferentes tipos decorativos melgarenses elaborado por Carretero (2000: Figs. 274-276) en función de los hallazgos localizados hasta ese momento, hemos añadido, manteniendo los mismos apartados en el esquema organizativo, un numeroso elenco de nuevos motivos decorativos presentes en los hallazgos de las producciones del taller de Melgar de los últimos años, que incluyen importantes conjuntos como los de Asturica o Legio, conformando así un cuadro tipológico más amplio que incluimos al final de este capítulo.

Con todo, el escaso porcentaje numérico de piezas melgarenses procedentes de este vertedero, no nos permite apreciar, como es el caso de otros vertederos legionenses (Fernández Freile, 2003. 105-116; Láms 66-78), algunas de las decoraciones más típicas y variadas, ya que suponen una proporción mucho más importante en el conjunto del material cerámico, además de no presentar un estado tan fragmentario como las piezas que aquí estudiamos.

En este conjunto, además de los vasos decorados con líneas verticales a la barbotina e impregnación arenosa, (n 486-488; 490-493) ya comentados supra, en lo que se refiere fundamentalmente a su cronología114 y paralelos, hemos de hacer mención en este capítulo dedicado a la decoración, en primer lugar, a las diferentes técnicas empleadas, pudiendo resumirse en dos procedimientos esenciales -decoración incisa y aplicada- y, en segundo lugar, a la extensa gama de motivos decorativos. En este último punto, esta amplia variedad se consigue no sólo por la utilización de diversos motivos, sino también por la combinación entre sí de éstos con las diferentes técnicas propias de este alfar.

114 Considerados como las producciones más antiguas del alfar melgarense, aparecen en la tercera fase de este vertedero datado en época flavia y principios de la segunda centuria. En los vertederos citados, como el de la C/Maestro Copín, la proporción de piezas de Melgar es bastante superior, están mejor conservadas y presentan una mayor variedad de técnicas y decoraciones. Fechado a mediados del siglo II d. C., en él no aparecen como dato más significativo, los primeros ejemplares con barbotina e impregnación arenosa, corroborando así la cronología propuesta, al menos para el yacimiento de Legio. 
En lo que respecta al conjunto estudiado, a pesar de su escasa cuantía, están presentes las principales técnicas utilizadas en el taller zamorano, con la proporción que se representa en el siguiente gráfico y que suele mantenerse en conjuntos de mayor volumen de piezas.

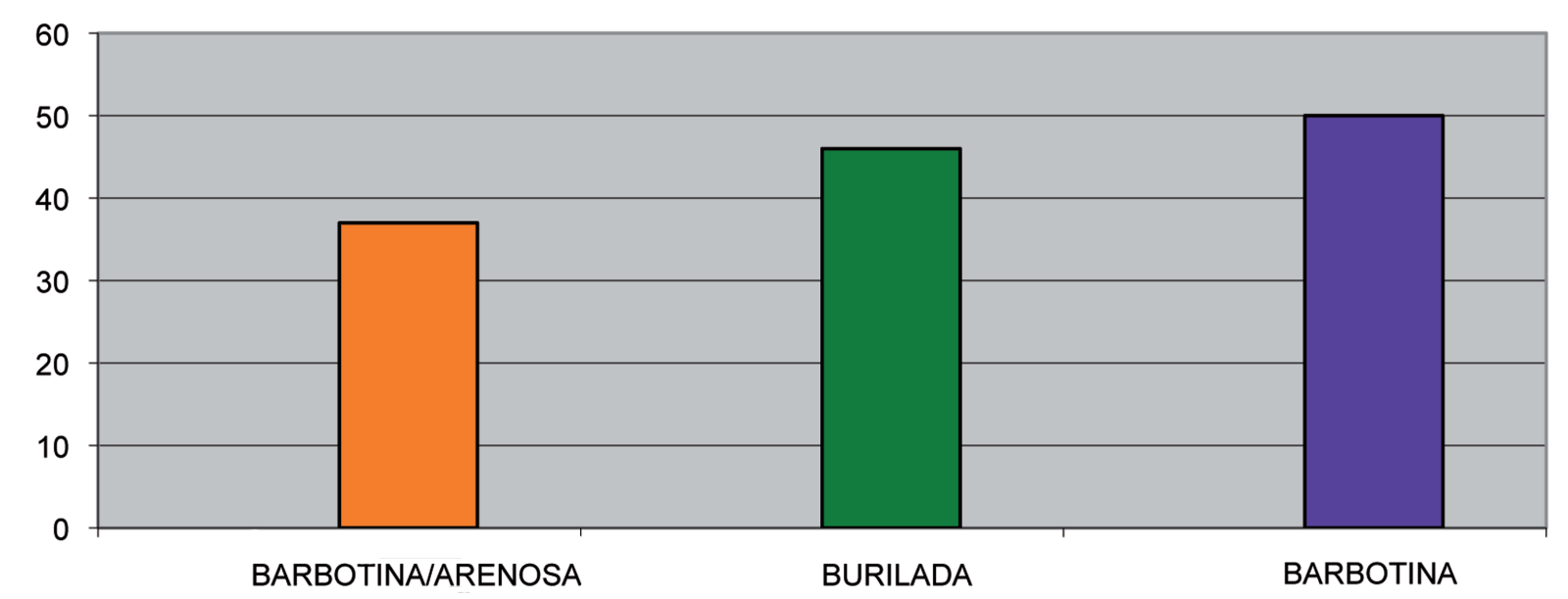

GRÁFICO 18: Técnicas decorativas de la Cerámica de Paredes Finas del taller de Melgar de Tera

La técnica más utilizada es el burilado, aunque únicamente conservamos la parte superior de los vasos sobre los que se aplica y un buen número de fragmentos con diferentes modalidades de esta técnica (Lám. 55). Una característica relevante es el hecho de que esta decoración incisa parece encontrarse exclusivamente en los cubiletes de la Forma I ( $\left.n^{\circ} 494-496\right)$ rasgo que se repite en la mayoría de los yacimientos hasta el momento ${ }^{115}$. A este respecto podemos hacer alusión nuevamente al vertedero legionense del siglo II, con un importante conjunto de piezas melgarenses, en el que se registran numerosos cubiletes burilados de la Forma I (Fernández Freile, 2003: Láms. 66-69).

Así, aunque la variedad en la aplicación de esta técnica es mucho menor en este conjunto de piezas, podemos seguir la clasificación de Carretero (2000: 517-522), en la que diferencia tres tipos esenciales de burilado. En el primer tipo (CI), las incisiones son simples y alargadas, dispuestas oblicuamente; en este primer tipo podemos incluir los fragmentos $n^{\circ} 494,496,499$ y 500.

El segundo tipo (CII), caracterizado por incisiones profundas que proporcionan un aspecto gallonado, podría reconocerse en los fragmentos $\mathrm{n}^{\circ} 497,498$ y 501.

En cuanto al tercer tipo propuesto (CIII), caracterizado por incisiones romboidales, carecemos de ningún ejemplo.

La decoración burilada, en sus diversos tipos, suele presentarse como único motivo en la ornamentación de los vasos de paredes finas; sin embargo, según constata

115 Únicamente hemos encontrado, como pieza excepcional en este sentido, un vaso completo de la Forma II, con decoración burilada que ocupa la parte central del vaso, partiendo bajo el hombro hasta las acanaladuras próximas a la base, en el material procedente de la capa IV de Huerña (DOMERGUE y MARTIN, 1977: 43, n¹28). 
Carretero (2000: 522-523), aparecen ejemplares en Petavonium, aunque muy escasos, en que el burilado se asocia a otros tipos decorativos, especialmente a la barbotina. La misma composición decorativa, igualmente inusual, puede hallarse en algunos vasos de paredes finas de otras áreas del Imperio como Raetia o Britannia, con una cronología que abarcaría el siglo II d. C. como propone el citado investigador, haciendo hincapié además en el hecho de que todos estos hallazgos proceden de zonas militares, vinculándolos así a las tendencias del ejército. En este sentido, se explicaría la fabricación de estos cubiletes en el taller de Melgar y su presencia en el campamento de Petavonium. Corroborando de alguna manera esta afirmación, y tras el análisis de las manufacturas melgarenses halladas en áreas militares, hemos de citar un único ejemplar con este tipo decorativo aparecido en el vertedero de la C/Maestro Copín, con una cronología de mediados del siglo II d. C. en Legio (Fernández Freile, 2003: Lám. $75,120 / 112)$. Se trata de un fragmento con una ancha banda burilada dividida en dos registros en su parte inferior, y en el centro del cuerpo disposición de motivos a la barbotina, como líneas diagonales y mamelones formando triángulos. Con todo ello, y a pesar de los escasos ejemplos, esta asociación decorativa tan poco habitual en los vasos de paredes finas parece constituir otro elemento que forma parte de los gustos cerámicos del ejército romano.

En cuanto a la decoración a la barbotina, es, sin duda, el tipo utilizado en la elaboración de los motivos ornamentales más identificativos del taller de Melgar.

Esta técnica se emplea en la realización de muy diversos motivos:

\section{A) Motivos Geométricos}

A1) Decoración de mamelones (E. I)

La disposición de líneas o composiciones de mamelones se emplea muy asiduamente, marcando la separación de los diferentes registros o paneles decorativos en las paredes de los vasos, si bien aparecen en algunos casos como motivo ornamental en sí. Este tipo es sumamente infrecuente, dado que habitualmente la decoración de mamelones aparece en la parte superior de los cubiletes, formando una línea bajo el borde, de una Forma ${ }^{116}$ ( $n^{\circ} 503$ ), en la zona media ( $\left.n^{\circ} 504\right)$ o inferior ( $\left.n^{\circ} 502\right)$, además de ser un elemento muy abundante en las composiciones ornamentales de los vasos, combinado con otros motivos, como círculos ( $\left.\mathrm{n}^{\mathrm{o}} 505\right)$, hojas de agua $\left(\mathrm{n}^{\mathrm{o}} 508\right)$, etc..., en las que hacen la función de marco, de separación entre frisos o de realce en estos esquemas estéticos.

A2) Decoración de Círculos (E. III)

Constituye un motivo decorativo muy frecuente en las composiciones de barbotina, pudiendo aparecer separados formando frisos, generalmente con mamelones en su interior, o bien de forma tangente o secante o formando círculos concéntricos, conteniendo otro motivo figurativo en su interior. De esta manera, las composiciones a

116 La misma disposición de esta línea de mamelones en la parte superior del vaso se encuentra en un ejemplar procedente de la Capa IV de Huerña, en un cubilete de la Forma II, situados en este caso bajo el hombro (DOMERGUE y MARTÍN, 1977: 43, n 122). 
base de círculos, asociados a otros motivos en barbotina constituyen el más amplio abanico en las decoraciones de los vasos de Melgar.

En el conjunto que estudiamos contamos únicamente con un fragmento con este tipo de decoración, correspondiente a la parte central de un galbo en la que puede observarse un friso de círculos secantes, enmarcado por una línea de mamelones en la zona superior (Lám. 56, n 505). Se trata de una pieza de considerables dimensiones, con unos $9 \mathrm{~cm}$. de diámetro central.

Como paralelos más cercanos con este motivo decorativo, hemos de citar los aparecidos en Petavonium (Carretero, 2000: Fig. 291, $\mathrm{n}^{\mathrm{o}}$ 173-180), el importante conjunto hallado en Asturica Augusta (Carro y Mínguez, 2003: Fig. 7, no 82; Fig. 8, n 58, Fig. 9, $n^{\circ}$ 60; Fig. 10, no 100; Fig 11, no 128 y 203; Fig. 12, no 127, 247 y 125), y especialmente las numerosas piezas legionenses procedentes del vertedero de la C/Maestro Copín (Fernández Freile, 2003: Lám. 71, nº 120/92; Lám. 73 y 74).

Partiendo de las piezas de estos conjuntos, en su mayoría completas, podemos observar, además de la ya comentada diversidad de composiciones, un predominio prácticamente absoluto de esta decoración sobre los vasos de la Forma II, al igual que, por otra parte, resulta sumamente significativo el hecho de que se trate en su mayor parte de vasos de grandes dimensiones (con 13-14 cm. de diámetro de boca y alcanzando hasta los $15 \mathrm{~cm}$. de altura) y un considerable grosor de la paredes. Estas dimensiones nos llevan a "cuestionar" la aplicación a estos ejemplares e la denominación de "paredes finas", así como su funcionalidad como vasa potoria, pudiendo quizá servir estas piezas de gran tamaño, como ya hemos expuesto supra como contenedores de otros productos líquidos o semilíquidos, en todo caso recipientes utilizados en la vajilla de mesa, e incluso empleados en diversos rituales, aspecto que hasta el momento no pasa de ser una mera hipótesis de trabajo, a falta de algún elemento concreto que pudiera corroborar esta teoría.

\section{A3) Lúnulas (E. V)}

Como piezas de dudosa adscripión hemos clasificado los fragmentos de la Lám. 52 ( $n^{\circ} 470$ y 472) que presentan este tipo ornamental de herraduras o lúnulas, ya que su escaso tamaño no permite atribuciones morfológicas. Con todo, como ya comentamos en su descripción, esta decoración está presente en los tipos Mayet XLII-XLIII, sumamente frecuentes sobre todo en los alfares de la Gallia Lugdunense y Narbonense. Sin embargo, las características técnicas de estos dos ejemplares, en lo que respecta a pastas y engobes, indicarían una posible producción en el taller de Melgar de Tera, imitando estos esquemas decorativos. Este tipo de decoración no aparece con frecuencia en las piezas del taller zamorano. Únicamente en Petavonium se han hallado ejemplares de pequeño tamaño en que estas lúnulas aparecen aisladas, formando una composición decorativa diferente (Carretero, 2000, Fig. 292, 185-187) y otras piezas recogidas por Lión en que denomina a estos motivos "horquillas" o "crecientes" (1997: 174, Fig. 2) y también en Asturica Augusta hallamos un fragmento similar a estos dos legionenses, procedente de Melgar, pero también de imposible adscripción por su tamaño (Carro y Mínguez, 2003, Fig. 14, nº 108). 


\section{B) Motivos Vegetales (E. IV)}

Los motivos fitomórficos representan uno de los temas más abundantes en los vasos melgarenses, con la peculiaridad de que se reducen a un único tema, las denominadas hojas de agua con pedúnculo, que adoptan diversas formas (alargadas, circulares, lanceoladas, acorazonadas...)117, y que se disponen en los vasos en diversas posiciones: formando una hilera o varias; horizontales, verticales, oblicuas....; combinándose además con el resto de motivos a la barbotina (círculos, mamelones, perlas, líneas diagonales....), de manera que dan lugar a un elevado número de composiciones extremadamente variadas, en que las hojas de agua constituyen el motivo esencial.

En nuestro caso contamos únicamente con tres fragmentos con este tipo de decoración vegetal (Lám. 56, n 506-508), apreciándose en el último la asociación con otros motivos.

Estas composiciones a base de hojas de agua no son en absoluto privativos de ningún taller o territorio concreto, sino que constituyen uno de los motivos decorativos más comunes y difundidos en la cerámica de paredes finas de diversas zonas del Imperio ${ }^{118}$, y con un ámbito cronológico más amplio.

\section{C) Motivos Antropomorfos (F. I y G)}

La decoración de motivos antropomorfos, especialmente rostros humanos, constituye indudablemente el elemento más representativo para la adscripción de los vasos de paredes finas hispánicas con esta ornamentación al taller de Melgar de Tera.

En el escueto conjunto de piezas melgarenses de este vertedero contamos con una única pieza, muy fragmentada, con este tipo de decoración, ( $n^{\circ} 509$ ), en la que únicamente puede distinguirse los rasgos de un ojo y una ceja realizadas en barbotina, que formarían parte de un rostro, situado por lo general en el centro o parte superior del vaso, perteneciente a la Forma II. (Lám. 56, no 509)

Teniendo en consideración los numerosos hallazgos con esta característica decoración, pueden establecerse, por lo que respecta a la técnica de fabricación, notables diferencias, pues en ocasiones se emplea únicamente la barbotina, pero en muchos casos aparece asociada a otras técnicas como el moldeado o la decoración aplicada.

En el primer caso, los rostros elaborados exclusivamente con la técnica a la barbotina, presentan un aspecto muy esquemático, con ojos almendrados, cejas arqueadas muy marcadas, nariz recta y boca redondeada. Generalmente se combinan con mame-

$117 \mathrm{Vid}$. la clasificaciones en cuanto a formas y disposición para estos motivos elaboradas por GIMENO (1990: 602-608); LIÓN BUSTILLO (1997: Fig 3 y 4: decoraciones 4E, 4F y 4G), así como el cuadro No IV realizado por CARRETERO (2000: 519, Fig. 275) para los vasos con esta ornamentación hallados en Petavonium; las decoraciones con este motivo en Celsa (Beltrán et alii, 1997, 381-382, Figs. 184-185) y, a menor escala, el cuadro sobre estas composiciones aparecidas en el vertedero de la C/Maestro Copín de Legio (FERNÁNDEZ FREILE, 2003: 247, Gráfico IX).

118 Vid. a este respecto VEGAS (1973: 85-87, Fig. 28, tipo 35); MAYET (1975: 7, Pl. LXIX, nº 580-587); ANDERSON (1982: 40, 51). 
lones, que en ocasiones les sirven de marco o bien resaltan determinados rasgos como la barba o los cabellos ${ }^{119}$.

Otro tipo de elaboración de esta peculiar decoración incluye, además de la barbotina, otras técnicas como el moldeado, como puede apreciarse en determinados rasgos de las caras representadas como mejillas, frente y mentón, confiriéndoles un relieve de gran expresividad y naturalismo ${ }^{120}$ o también la decoración aplicada, en la cual el motivo se elabora independientemente del vaso, aplicándoselo posteriormente y dando los últimos retoques una vez adherido al cubilete ${ }^{121}$.

Además de este motivo decorativo mayoritario de rostros humanos, hemos de hacer mención a algunas piezas que, realizadas con la misma técnica, representan otro tipo de figuras, como por ejemplo la cabeza de un león, hallada en el castro asturiano de Chao Samartín (Carrocera, 1995: 269), y los dos ejemplares hallados en Astorga y León, $(G)$ en los que se representan figuras antropomorfas de cuerpo entero, motivo inédito hasta el momento (Amaré et alii, 2000-2001: 159-171). Especialmente la pieza procedente de Asturica, que presenta mayores dimensiones y un estado menos fragmentario que la legionense, realizada sobre una Forma II de gran calibre (su diámetro de boca sobrepasa los $18 \mathrm{~cm}$.), permite apreciar con más detallismo la representación de la figura humana, dispuesta frontalmente, enmarcada por una decoración de círculos y mamelones en barbotina. Está ataviada con una túnica hasta los pies, con abundantes pliegues realizados mediante incisiones. En su mano derecha sostiene un pequeño vaso en actitud oferente, y en la izquierda un elemento alargado de difícil adscripción, que quizá pueda tratarse de una palma u otro motivo vegetal.

Un rasgo que define esta representación es su esquematismo y falta de elaboración en los detalles, aspecto probablemente relacionado con la escasa fabricación de este tipo de decoraciones en los vasos melgarenses.

El ejemplar legionense, hallado en la excavación de un solar contiguo al de este vertedero que estudiamos, se encuentra en un estado mucho más fragmentario, y la representación de la figura humana se reduce al torso y brazos; en su mano derecha

119 En este primer tipo pueden clasificarse ejemplares muy similares hallados en yacimientos de la provincia de León, como Huerña (DOMERGUE Y MARTIN, 1977: Lám. $20 \mathrm{n}^{\circ} 541$ y 542); Asturica Augusta (MAÑANES, 1983: 154-155, Fig. 15, nº 6; CARRO y MÍNGUEZ, 2003: Fig. 11, nº 131 o Legio, donde ha sido hallado en el vertedero de la C/Maestro Copín un numeroso elenco de piezas con estas características, de grandes dimensiones y en perfecto estado de conservación (FERNÁNDEZ FREILE, 2003: 113, Láms. 76, 77 y 78, n 121/27), así como importantes piezas del yacimiento de Petavonium (CARRETERO, 2000: Fig. 293, n 194; Fig. 294, n 201-202).

120 Esta técnica puede advertirse en numerosos ejemplares del yacimiento de Petavonium (CARRETERO 2000: Fig. 293 n ${ }^{\circ}$ 195-196; Fig. 294 n $197-198$ ); Asturica (CARRO y MÍNGUEZ, 2003: Fig. 5, no 5455); Lancia (RABANAL, 1973: Fig. 1; y en la misma ciudad de León, en los materiales procedentes de un solar extramuros excavado por MIGUEL y GARCÍA MARCOS (1993: 196, Fig 9.8).

121 Una muestra excepcional de esta técnica resulta una de las piezas del vertedero de la C/Maestro Copín en León, (FERNÁNDEZ FREILE 2003: Lám 78, n 103/92), representando un rostro muy elaborado en el que se utiliza exclusivamente la técnica del moldeado con una gran destreza, consiguiendo un rostro de un extraordinario realismo (ojos con pupilas abultadas, nariz recta y afilada, boca de labios gruesos y mentón saliente). Destaca además el detallismo de los cabellos trabajados en mechones individualizados y las dos trencillas que presenta a ambos lados del rostro, que hacen pensar en la representación de una máscara teatral. 
sostiene igualmente un vaso, con la peculiaridad de que el recipiente muestra las características de los vasos fabricados en Melgar de Tera, y en su mano izquierda, al igual que el primero, sujeta un elemento alargado, si bien, en este caso, la mayor calidad en la elaboración en general, permitiría calificarlo como un caduceo.

En cuanto a la interpretación de estos personajes masculinos se ha considerado que puede tratarse de divinidades, representando escenas de libación, probablemente con carácter funerario y ctónico (Ibid.: 165), en un momento de asimilación y sincretismo religiosos romano e indígena en el área noroeste.

Sobre la escasez de ejemplares tan peculiares, pero indudablemente atribuibles al taller de Melgar de Tera, hemos de hacer constar el paralelo iconográfico que señala Mínguez (2005: 358), de una pieza modelada en relieve e integrada en una representación más completa, hallado en Saints-du-Nord (Bavai, Francia) e identificado como un Mercurio (Andringa, 2000), que vendría a ratificar el carácter cultual de estos recipientes.

En cuanto a la significación de los vasos con rostros humanos, mucho más abundantes, cuyas características hemos descrito supra y que adquieren una gran difusión en el área noroeste, identificándose como producción original del taller de Melgar, la interpretación más aceptada es que se trata de seres sobrenaturales -como denotan algunos rasgos como los cuernos realizados con mamelones-, con un carácter probablemente apotropaico y, como ha propuesto ya desde un principio su principal investigador, vinculados al ejército o a ambientes militares (Carretero, 2000: 532-536; 2002: 360-362; 2005: 117), teniendo en consideración las similitudes con vasos hallados en otras zonas del Imperio relacionadas con asentamientos castrenses especialmente en Britannia (Braithwaite, 1984: 100) y en el limes renano (Schlinder-Kaudelka, 1975: 130132, forma 126, Lám. 27) y danubiano (Popilian, 1976: PL. XXI, n ${ }^{\circ} 243-245 ;$ PL. XXX, ${ }^{\circ}$ 300-301), así como también en algunas áreas del valle del Ródano en Gallia122.

Así, según plantea dicho autor, este tipo iconográfico podría haber sido importado por la Legio X Gemina tras su estancia en el limes renano a su regreso al campamento de Rosinos de Vidriales, o bien por la Legio VII Gemina en la época de su asentamiento definitivo en León después de su período de servicio en zonas del Rhin y el Danubio. A nuestro parecer, teniendo en cuenta la proximidad de los alfares de Melgar con el campamento de Petavonium, sería más factible que fueran los legionarios acantonados en este recinto militar quienes más directamente transmitieran este motivo decorativo que pronto encuentra amplia difusión en el área noroeste. Así, en Legio y numerosos lugares del territorio leonés (Martín, 2008c: Figs. 10-25) se han hallado, en el importante conjunto de cerámicas de paredes finas de origen melgarense, una notable proporción de vasos decorados con este motivo de rostros antropomorfos, en el que destaca además la variedad formal de las representaciones.

Desde el punto de vista cronológico, la costumbre de la aplicación de rostros o medallones en cerámica de diversos tipos se remonta a épocas pre y protohistóricas. Sin embargo, tiene una larga perduración en el tiempo y resurge en época romana, como se pone de manifiesto en la cerámica de paredes finas itálicas desde fines del

122 Vid. numerosos ejemplos en VERTET (1969: Fig. 18 a); VERTET y AUDIN (1971: 112-113, Fig. 3); GRATALOUP (1988: 76-77, $\mathrm{n}^{\circ}$ 208). 
siglo II a. C. (Marabini, 1973: 64-66, Fig. 6 nº 68; Lám. 100 nº 8 y 9) y en algunos hallazgos más tardíos como en Pompeya (Carandini, 1977: 26, Lám. IX, 9, 14-15). Alcanzan un gran esplendor en época claudiana, cuando comienza su difusión en las principales áreas militares del Imperio, de la mano de los soldados itálicos que integran las legiones acantonadas en Britannia, donde adquieren un gran auge que lleva a instalar diversos talleres para la fabricación de estos vasos, cada uno con sus peculiares características (Braithwaite, 1984; 2007) y en el limes renano y danubiano.

Sobre su funcionalidad ya hemos comentado su probable carácter protector o apotropaico, aspecto estrechamente relacionado con otros elementos que forman parte de la mentalidad del soldado romano.

Aún valorando la preeminencia, la originalidad y la vinculación militar de los "vasos de caras" elaborados en el taller de Melgar de Tera, hemos de hacer constar que este tipo iconográfico, además de no ser exclusivo de la cerámica de paredes finas, aparece también en otras zonas de Hispania en diferentes épocas de la etapa imperial. Así, se documentan hallazgos de vasos de paredes finas con este tipo de motivo decorativo fundamentalmente en el área catalana datadas en época flavia (López Mullor, 1980: 38-40), si bien las peculiaridades tipológicas y determinadas características de clara inspiración local indican una clara singularidad de estos ejemplares, sin ningún tipo de relación con los vasos de Melgar, todo lo cual hace plantear al citado investigador la posibilidad de la existencia de un centro de carácter regional -aún no localizado con exactitud- que abastecería a esta zona nororiental y que estaría en funcionamiento en fechas anteriores al taller zamorano (López Mullor, 1989: 142, 147).

Asimismo, en distintos puntos de la región aragonesa se han localizado vasos de cerámica engobada con decoración de rostros humanos, aunque siguiendo únicamente la técnica de los medallones aplicados en relieve (Mínguez, 1995).

También en Emerita Augusta han aparecido numerosos vasos de paredes finas decorados con caras (Rodríguez Martín, 1996: 155).

Con todo ello, podemos afirmar que la decoración de motivos antropomorfos en los recipientes de cerámica de paredes finas constituye un fenómeno sumamente arraigado en el tiempo y en muy diferentes lugares, en su mayor parte relacionados con la presencia del ejército y en otros casos procedentes de distintos ámbitos civiles, y cuya funcionalidad parece tener en común el significado cultual, simbolizando divinidades a los que se otorga un poder sobrenatural o un carácter apotropaico. 

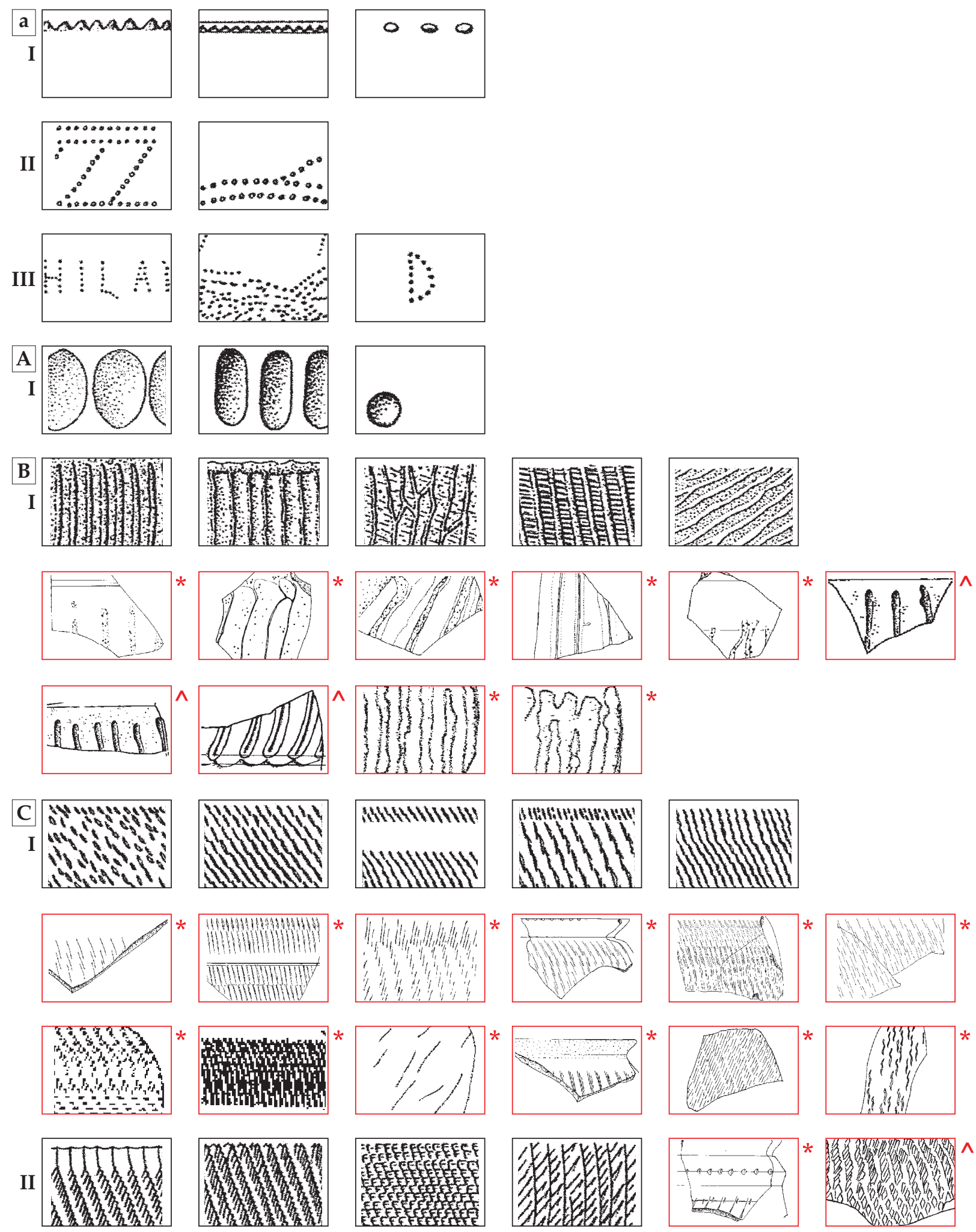

Señalados en rojo las piezas procedentes de Legio y otros hallazgos en diversos puntos de la provincia leonesa.
- LEGIO * 

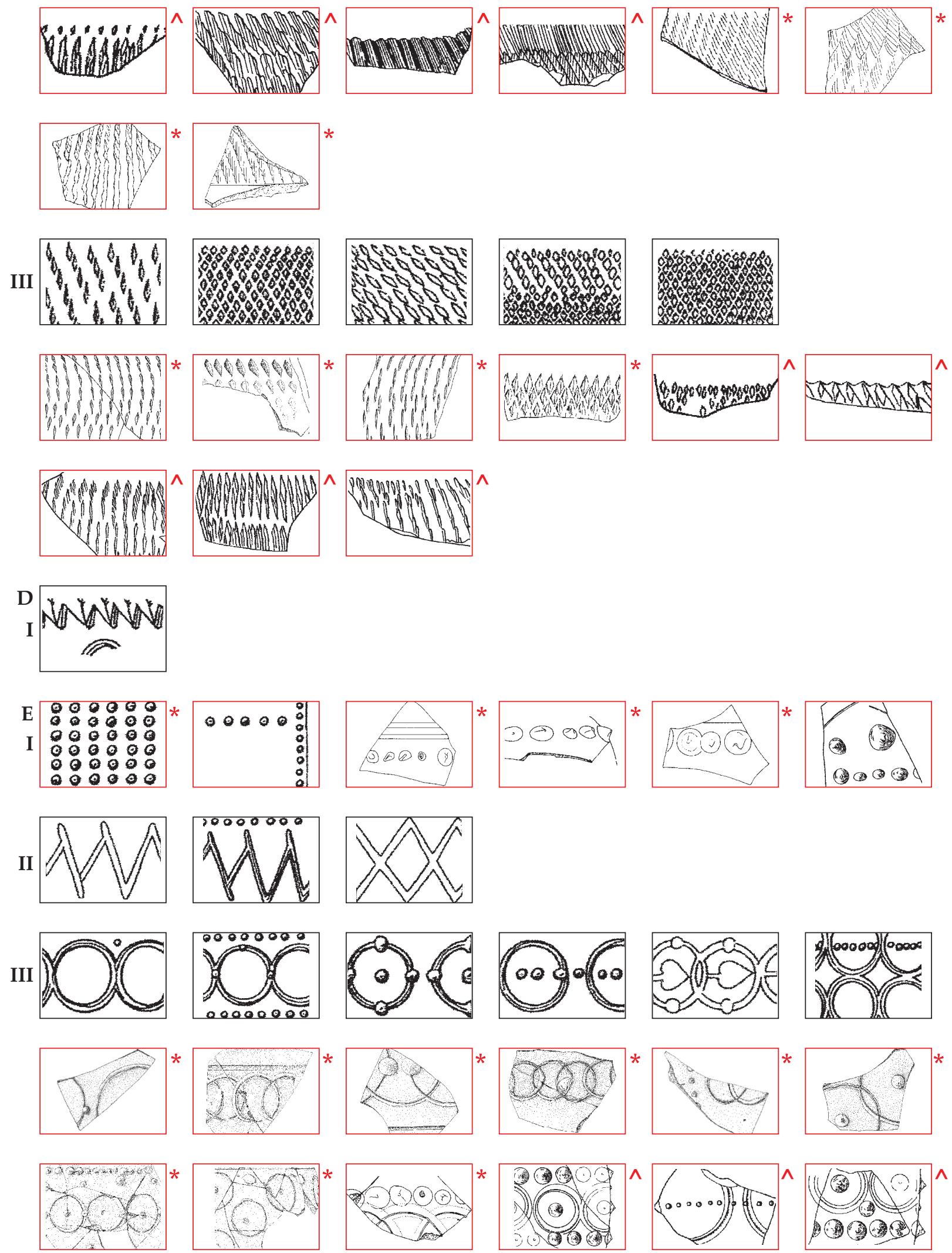


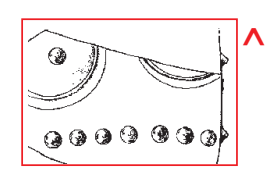

"Q60
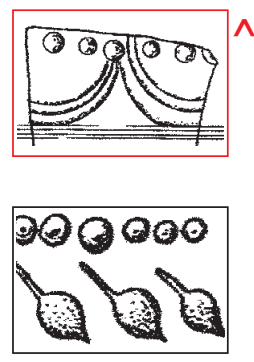

000000000 000000000 0905

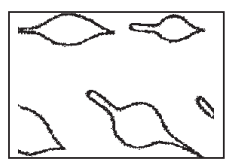

$0_{007}^{000000000}$

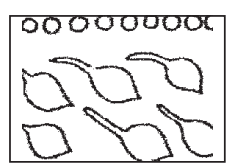

3000
00089
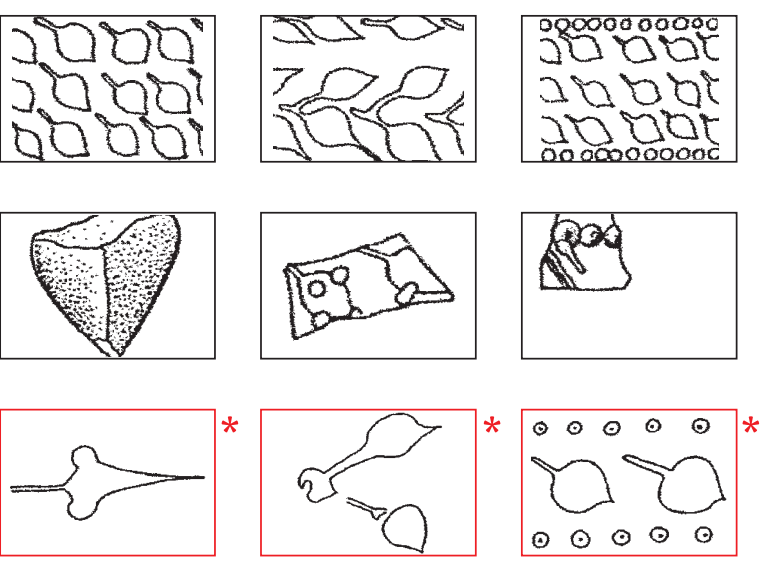

(9) (9)
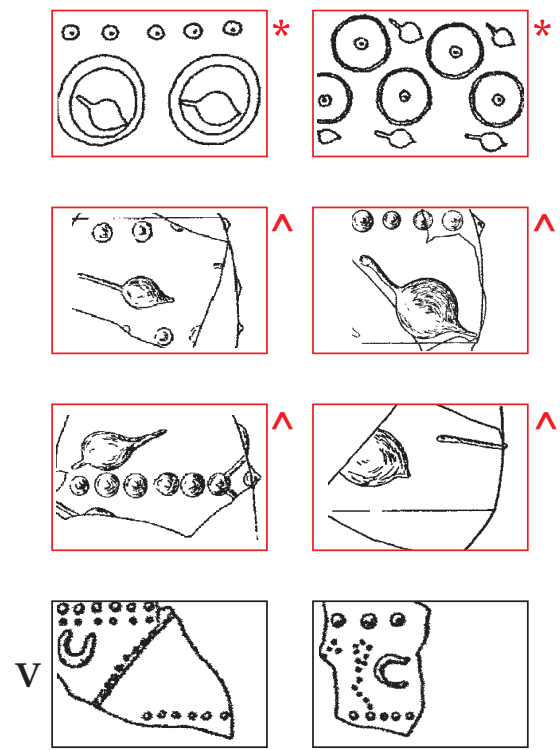

10898
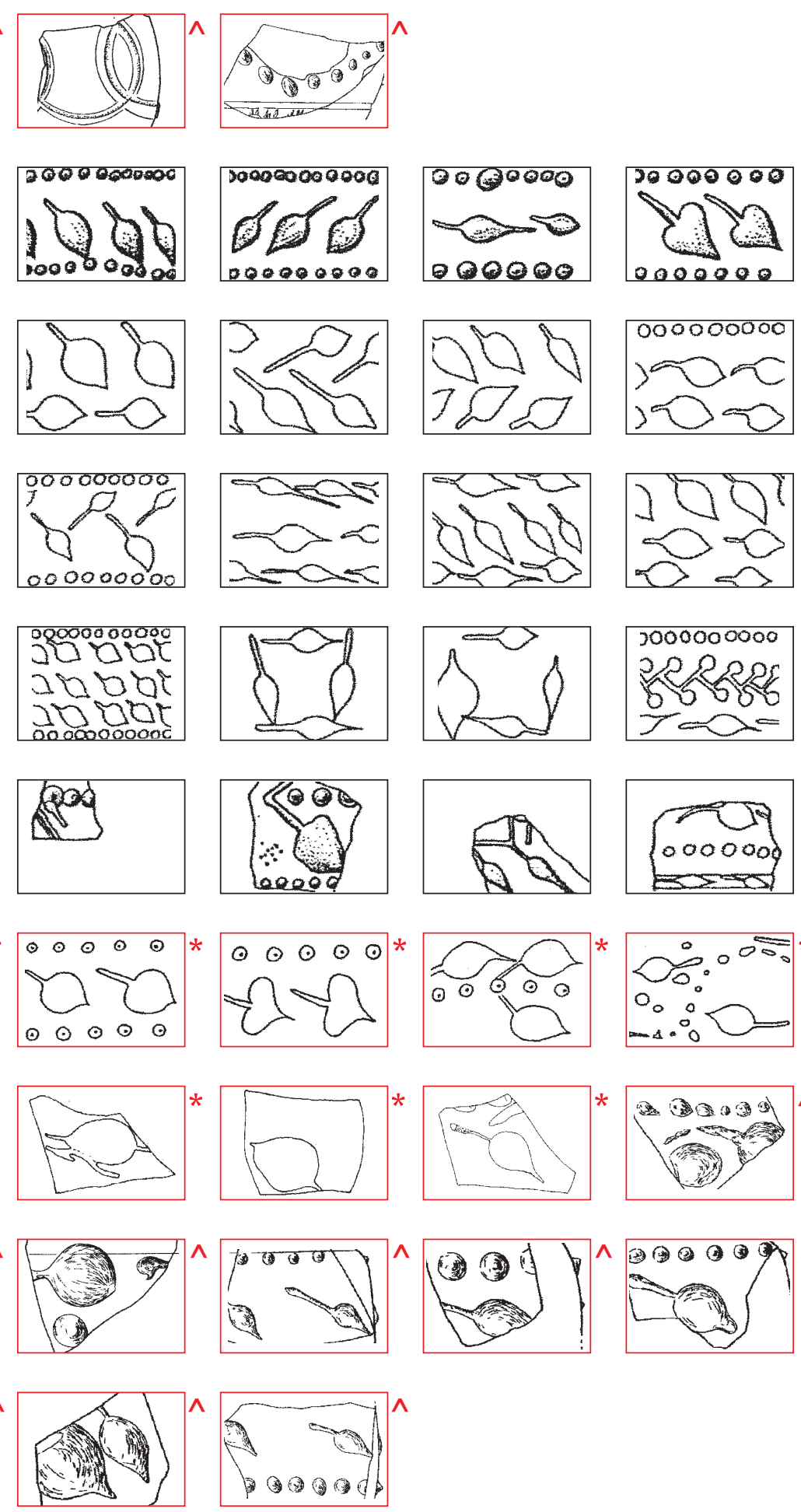

\begin{tabular}{l}
300000000 \\
302505 \\
\hline 5585 \\
\hline
\end{tabular}
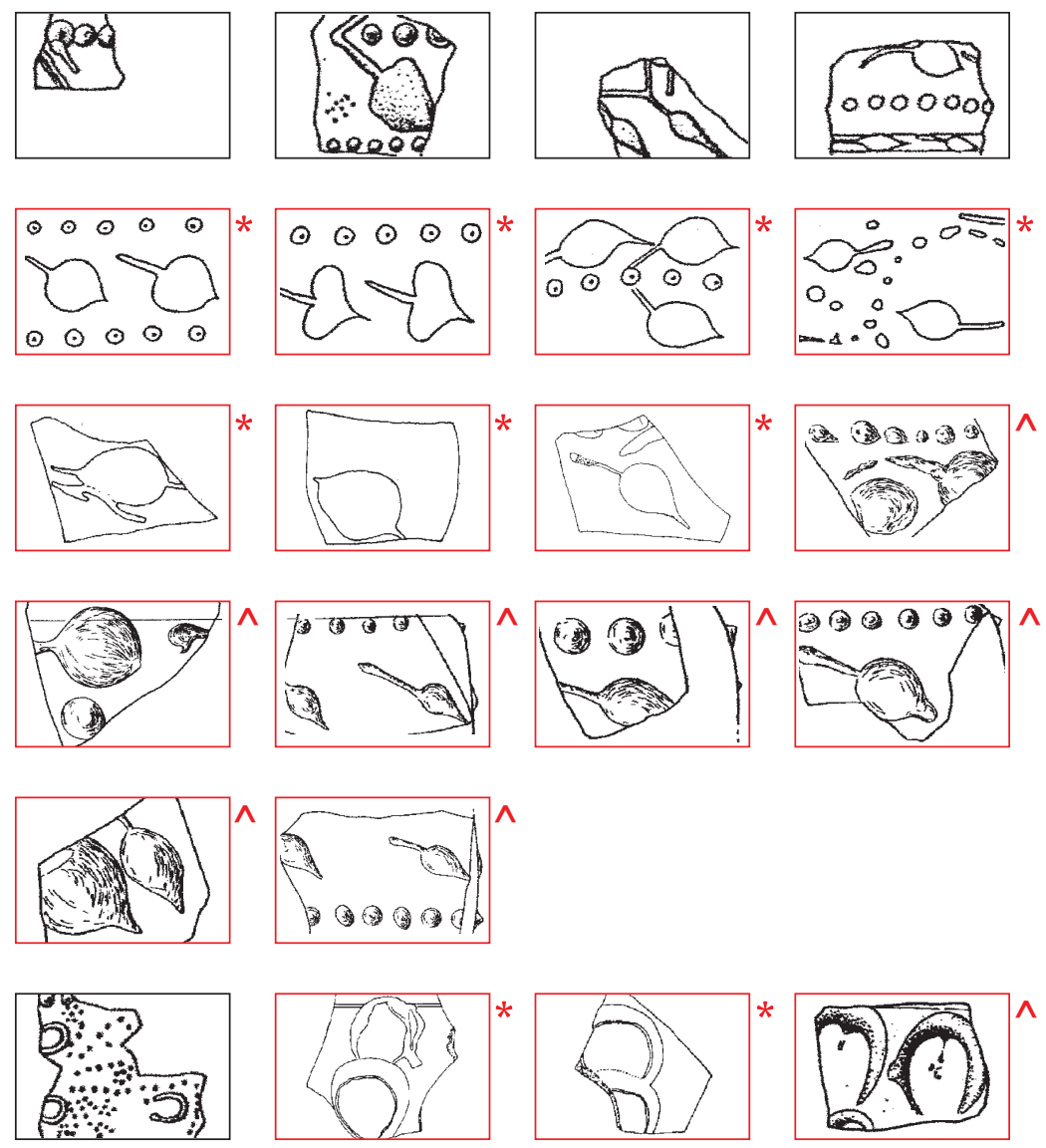
246
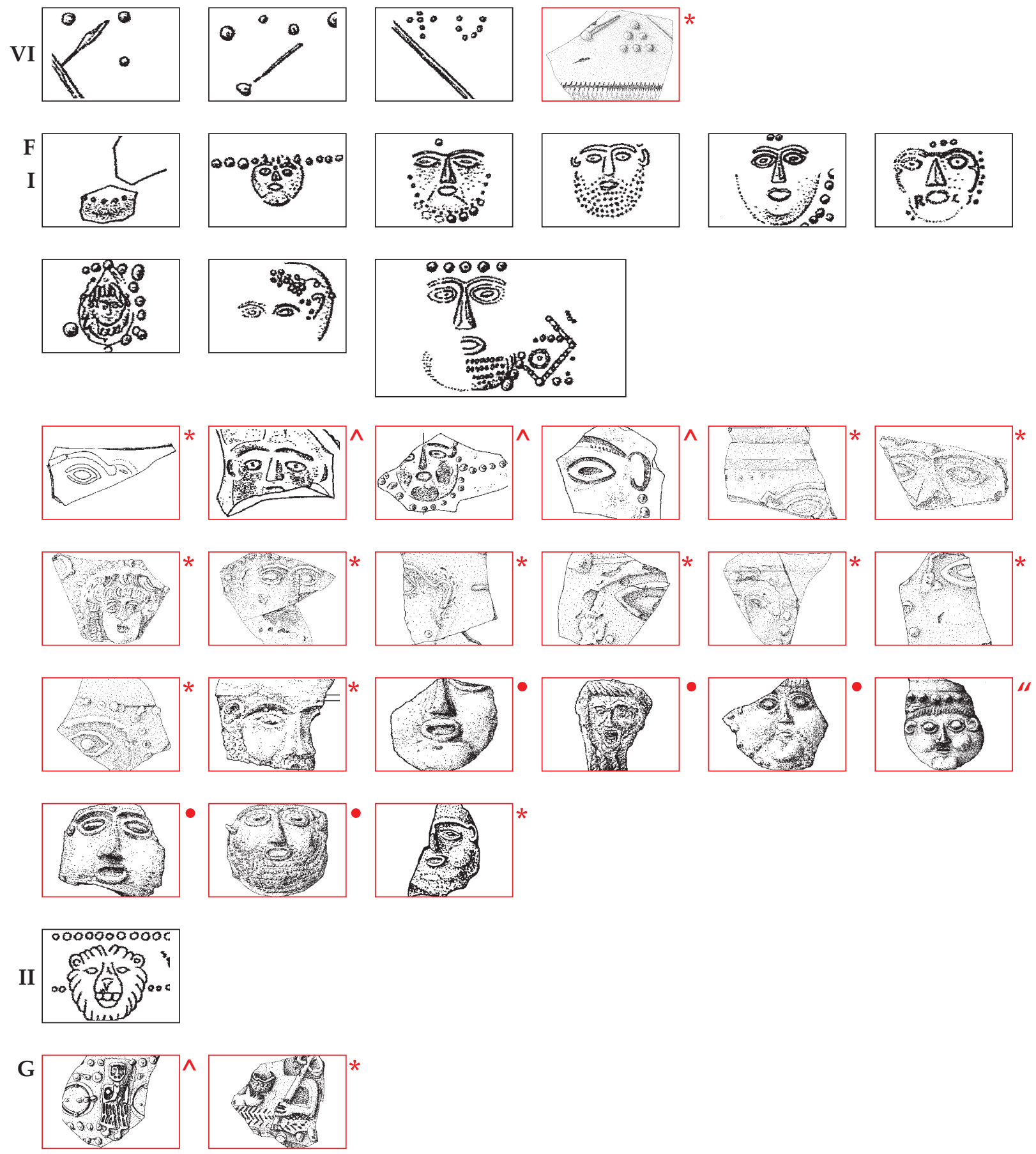


\section{3.- Cronología y Difusión}

A pesar de la extensa distribución de las manufacturas de Melgar de Tera en el área noroeste, en la mayoría de los casos se trata de hallazgos individualizados, careciendo de contextos estratigráficos que permitan obtener una referencia cronológica concreta para estas producciones. Con todo, existen determinados yacimientos con una importante presencia de estos vasos, cuya disposición estratigráfica ofrece datos concluyentes sobre su período de vigencia.

Los ejemplares melgarenses aquí estudiados se localizan en su mayor parte en las UUEE 317 y 306, correspondientes a fines del siglo I y principios del siglo II d. C., sin que podamos establecer un criterio evolutivo morfológico o decorativo entre los distintos vasos, ya que comparten los mismos niveles estratigráficos del vertedero.

Partiendo de otros hallazgos datados con precisión en sus contextos estratigráficos, especialmente los de Petavonium, como principal centro receptor (Carretero, 2000: 540-547) y otros estudiados con anterioridad como en Huerña, donde estas producciones aparecen en la capa IV y en la capa II, datadas en el tercer cuarto del siglo I d. C. y en el siglo II d. C. (Domergue y Martin, 1977: 43-48, Fig.11; 111-113, Fig.28, Lám. 20) o el castro de Corporales, en el que las piezas se fechan entre el 70 y el $120 \mathrm{~d}$. C. (Sánchez-Palencia y Fernández-Posse, 1985: 254, Fig. 118), además de algunos ejemplares hallados en Asturica, atribuidos a época claudio-neroniana (Burón, 1997: 59-60, Fig. 32, $\mathrm{n}^{\circ}$ 242-243), podemos establecer los inicios de la producción del taller melgarense en un momento anterior a la época flavia, a mediados del reinado de Nerón, como propone Carretero (2000: 541) y por tanto anterior a la llegada del Ala II Flavia al campamento de Rosinos. Este momento supondría ya una etapa de esplendor y de fabricación masiva de estas manufacturas para su distribución y comercialización en la zona noroeste.

En cuanto al periodo de permanencia en activo del taller, frente a las primeras opiniones que planteaban una pronta desaparición (Gimeno, 1990: 594), en la actualidad, y basándonos en la información de las estratigrafías de los principales puntos de abastecimiento ${ }^{123}$, pueden situarse sus momentos finales a fines del siglo II d. C. o principios de la tercera centuria.

Por lo que respecta a la difusión de estas producciones, el inicio de la actividad del taller de Melgar de Tera va a constituir un hito decisivo en el panorama de la distribución de la cerámica de paredes finas en el cuadrante noroccidental de la Península. Los hallazgos de estas manufacturas se encuentran en distintas áreas de Galicia124,

123 Un conjunto importante por su porcentaje numérico y por su variedad morfológica y decorativa es el hallado en Legio, en el vertedero de la C/Maestro Copín, cuya completa estratigrafía ha permitido una datación sumamente precisa en el segundo y tercer cuartos del siglo II d. C. (FERNÁNDEZ FREILE, 2003: 115).

Ya anteriormente, en yacimientos como Huerña, el Castro de Corporales o la villa de El Soldán en Santa Colomba de Somoza, se fechan piezas melgarenses en la segunda mitad del siglo II d. C. (DOMERGUE Y MARTIN, 1977: 113; SÁNCHEZ-PALENCIA Y FERNÁNDEZ-POSSE, 1985: 313; MAÑANES, 1976-77: 256).

124 Destacan las investigaciones sobre los hallazgos en la ciudad de Lugo (GONZÁLEZ y PERALTA, 1995: 84-85, Fig.71), así como los procedentes del castro de Villadonga, (La Coruña) y otros hallazgos dispersos en las provincias de Pontevedra y Orense (Ibid., 1990-91: 266). 
Asturias 125 , Cantabria126, y especialmente en las provincias de Zamora y León, donde, además de Asturica Augusta127, la capital del Conventus, se encuentran importantes asentamientos militares como Petavonium ${ }^{128}$ y Legio $^{129}$ que representan los principales centros importadores de estos productos, al igual que otros yacimientos con importantes hallazgos de piezas melgarenses como Huerña, Castro de Corporales, El Soldán..., vinculados a la presencia del ejército en función de las explotaciones auríferas.

A estas zonas de concentración más importantes de los ejemplares del taller zamorano hemos de añadir a los ya comentados, otros hallazgos individualizados que ponen de manifiesto la extensa dispersión de estos vasos, de manera que podemos situar, por el momento, el límite meridional de esta difusión en puntos de la provincia de Salamanca ${ }^{130}$.

En este proceso de distribución de las manufacturas melgarenses hemos de destacar el importante papel que desempeña el entramado de vías de comunicación del noroeste, y en especial las calzadas que unían Bracara con Asturica, y Lucus con Asturica, las principales arterias que articulan las relaciones comerciales y culturales en el área noroccidental, y en cuyas proximidades se ubica además el taller de Melgar. Por otra parte, los pasos y vías menores que conducen a la zona superior de la cordillera Cantábrica servirían asimismo para la distribución en estas áreas más alejadas y de más difícil acceso, sin dejar de lado la posibilidad de algún tramo de transporte por vía marítima en la zona galaica.

125 En la zona asturiana se han localizado ejemplares de Melgar especialmente en castros como San Chuis o Chao Samartín (FERNÁNDEZ OCHOA, 1983: 222; MAYA GONZÁLEZ, 1984: 218).

126 En este punto norteño, uno de los más alejados, se han localizado hallazgos aislados de cerámicas de Melgar en Castro Urdiales y Reinosa (SOLANA; 1981: 297; PUENTE, 1986-88:169).

127 Sobre la cerámica de paredes finas hallada en Astorga y en concreto sobre las piezas de Melgar de Tera, vid. el estudio de CARRO y MíNGUEZ, 2003: 292-335, figs. 1-16).

128 El campamento de Petavonium, en la etapa de ocupación por el Ala II Flavia es, por su proximidad, el principal centro al que se orienta el abastecimiento de las producciones melgarenses, si bien, como hemos podido comprobar por su extensa difusión, no constituye de ningún modo un alfar enfocado al aprovisionamiento exclusivo de este enclave castrense, como sucede en algunos establecimientos militares de otras áreas del Imperio (Gimeno, 1990: 594). En cuanto al conjunto de estas manufacturas halladas en el campamento de Rosinos de Vidriales contamos con el completo estudio de CARRETERO (2000: 496-547) en el que lógicamente la producción de Melgar representa, con diferencia, el principal capítulo en la cerámica de paredes finas.

129 En Legio, además del ya citado conjunto hallado en uno de los vertederos extramuros (FERNÁNDEZ FREILE, 1998-99: 103-125; 2003: 105-116, Láms. 66-78), hemos de citar el hallazgo de una pieza aislada en uno de los solares contiguos a este vertedero, en el Centro Cultural Pallarés (MIGUEL y GARCIA MARCOS, 1993: 191-192, Fig. 9.8), y más recientemente, los estudios de MARTÍN HERNÁNDEZ (2005; 2006: 409-413, Fig. 6; 2006b; 2008: 73-81), con la peculiaridad de que esta autora se refiere a las producciones del alfar zamorano como "cerámicas tipo Melgar". También en el yacimiento próximo de Lancia se halló en su momento una pieza de compleja interpretación (RABANAL, 1973: Fig.1), además de algunos ejemplares que permanecen aún inéditos.

130 Entre ellos cabe destacar el ejemplar localizado en Almaraz de Duero (Zamora) (MARTíN y DELIBES, 1976: 413, Fig. 1, $\mathrm{n}^{\circ}$ 14) y otros en la provincia de Salamanca, como la pieza de Ciudad Rodrigo (MARTÍN VALLS, 1976: 382, Fig. 5, n² 21), además del hallazgo de un ejemplar con decoración de un rostro humano, procedente de la villa romana de Castañeda de Tormes, aún inédito, y del cual hemos tenido noticia por comunicación personal del Dr. J. M. GARCÍA DE FIGUEROLA PANIAGUA, a quien agradecemos el habernos proporcionado amablemente esta información. 
Así, la distribución de la original producción del alfar de Melgar de Tera en un área tan amplia viene a indicar el alto nivel de producción de este taller local que abastece en especial a los asentamientos militares próximos, pero igualmente a núcleos de población civil, adquiriendo la categoría de taller regional cuyas producciones se distinguen especialmente en un área de gran extensión, cubriendo ya desde la etapa flavia y durante toda la segunda centuria, la demanda de cerámica de paredes finas en el cuadrante noroccidental peninsular.

\section{3.- CERÁMICA COMÚN}

El volumen de cerámica común procedente del vertedero situado en la C/Pilotos Regueral, con 5062 piezas recuperadas, supone un 68\% en el total del conjunto de material cerámico. Esta proporción mayoritaria se encuentra dentro de los parámetros habituales en los contextos altoimperiales romanos, si bien, en relación a los otros vertederos aquí estudiados resulta sensiblemente inferior y prácticamente similar a la del vertedero de la C/Maestro Copín. Dado que en las producciones comunes el aspecto cuantitativo no es, en general, indicativo en orden a establecer comparaciones con el resto de contextos de vertidos, haremos hincapié en el ámbito tipológico (diversidad formal, predominio de determinados ejemplares y sus variantes,...) y por tanto funcional, que proporciona información más detallada sobre cuestiones socioeconómicas, susceptibles de ser valoradas en el contexto general de los vertederos legionenses.

Por otra parte, en lo que se refiere al establecimiento de paralelos morfológicos con ejemplares de otros yacimientos, constatados en el análisis de las producciones comunes de los dos vertederos precedentes en este trabajo, procuraremos evitar una excesiva reiteración, añadiendo el cotejo de las piezas de este vertedero con las documentadas en publicaciones más recientes, con una especial atención a las procedentes de contextos de eliminación de residuos.

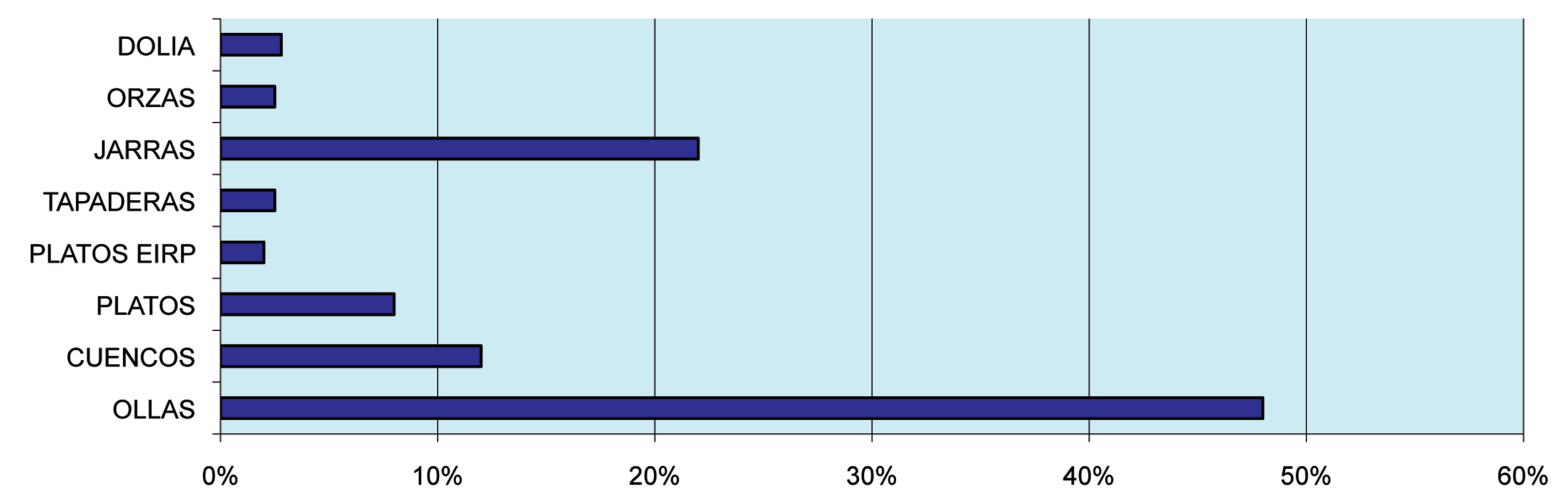

GRÁFICO 19: Formas de la Cerámica Común

\section{1.-OLLAS (Láms. 57-59)}

Las ollas, con un porcentaje del 58\% representan los ejemplares más numerosos en la cerámica común, en sus distintas variantes, siguiendo la norma de la mayoría de los 
yacimientos romanos, pues constituyen, con diferencia, el recipiente más difundido en todas las zonas del Imperio. En este sentido, aunque su representación siempre es mayoritaria, se hace evidente una sensible diferencia entre el grupo de ollas y otros recipientes de uso culinario, y los de la vajilla de mesa, mucho menos significativos numéricamente, marcando así una diferencia notable con otros vertederos como el de San Pedro, en el que ambas proporciones son más igualitarias ${ }^{131}$.

\subsection{1.- Ollas de borde exvasado curvo (Lám. 57)}

Este primer tipo de ollas, cuyo borde vuelto al exterior presenta perfil curvo más o menos engrosado, suele constituir el más frecuente dentro de esta categoría de recipientes, sin embargo en este vertedero podemos detectar un número más equiparable entre los diferentes tipos. Así, en este tipo de borde exvasado curvo se incluyen las piezas ( $\left.n^{\circ} 510-516,519\right)$. Se trata de recipientes de perfil generalmente globular o piriforme y fondo plano, aunque no conservamos ningún ejemplar completo. En este reducido conjunto destaca la variedad en la configuración de los bordes exvasados, con diferente inclinación hacia el exterior. En algunas piezas como la n ${ }^{\circ} 511$ puede advertirse un pequeño cuello en la transición del borde al galbo. Se aprecia un predominio de cocciones reductoras, con tonalidades pardo negruzcas, realizadas con pastas decantadas de buena calidad y granulometría fina. Destaca la gran capacidad de algunas piezas como las $\mathrm{n}^{\circ} 510$ y 511 con 18 y $14,5 \mathrm{~cm}$. de diámetro de boca respectivamente. En cuanto a las marcas, tan escasas en la totalidad del conjunto cerámico que estudiamos, hemos de destacar en la pieza $n^{\circ} 516$, de color ocre, un grafito de lectura " $E$ " profundamente grabado en la parte superior del recipiente.

\subsection{2.- Ollas de borde exvasado recto y oblicuo (Láms. 57-58)}

En esta segunda categoría morfológica de ollas se incluyen igualmente abundantes recipientes $\left(n^{\circ} 517,518,520-522,531-533\right)$, de buena factura, elaborados con pastas de granulometría media, encontrándose por igual cocciones oxidantes y reductoras. Su característica definitoria, el borde oblicuo exvasado, adopta pequeñas variantes, en cuanto a la inclinación (menos pronunciada en la pieza $n^{\circ} 518$ ) o provisto de una concavidad para asiento de la tapadera ( $n^{\circ} 521$ ). En cuanto a su forma, presenta asimismo diversos perfiles, pues a partir de los ejemplares más completos $\left(n^{\circ} 511,517,533\right.$ ) podemos intuir formas globulares, mientras que otros ( $n^{\circ} 518$ ) presentan una trayectoria del galbo más rectilínea y la pieza $n^{\circ} 520$ adopta un perfil carenado en la parte superior del cuerpo bajo el borde. Las dimensiones son también variables, con diámetros de boca de $14 \mathrm{~cm}$. ( $\left.\mathrm{n}^{\circ} 520\right), 18 \mathrm{~cm}$. ( $\mathrm{n}^{\circ} 518$ ) y $21 \mathrm{~cm}$. (n 517$)$. El contexto estratigáfico en el que se documentan las ollas de esta forma se encuentra bien definido, puesto que ocupan niveles muy próximos en la secuencia -una gran parte en la UUEE 312-

131 La cuestión de la diferencia estricta entre los recipientes de cocina, mesa y despensa, que constituyó hasta hace poco tiempo uno de los principales criterios de clasificación de estas producciones, resulta cada vez más relativa, como hemos ido constatando en este estudio, dada la función polivalente de gran parte de estos ejemplares. En este sentido, cabe destacar una de las últimas aportaciones (JÁRREGA, 2009), quien considera, entre un grupo de producciones comunes de Tarraco, una serie de ollas que por sus características podrían servir igualmente para la despensa y para la mesa. 
perteneciente a la segunda mitad del siglo I d. C. y las piezas más completas en las UUEE 320 ( $\left.n^{\circ} 517\right), 306$ ( $\left.n^{\circ} 518\right)$ o 311 ( $\left.n^{\circ} 533\right)$, correspondientes a la etapa flavia.

Mención especial merece en este conjunto el ejemplar $\mathrm{n}^{\circ} 517$, realizado en pasta de tono grisáceo, con una acanaladura a la altura del hombro, bajo la cual se dispondría una banda, y bajo ella decoración de líneas bruñidas formando retícula en algunos sectores. En la parte superior, sobre la acanaladura de separación, se localiza una banda de engobe brillante. Este tipo de recipientes, que responden a los modelos de tradición indígena, son frecuentes en los yacimientos romanos del área noroeste de diferentes épocas, pues perduran largamente en el tiempo. El yacimiento de referencia para estos ejemplares es, sin duda, Lucus Augusti, donde este tipo de formas y decoraciones son características en una parte mayoritaria de las producciones comunes, presentando una amplia y variada tipología (Alcorta, 2001, passim; 2005c: 191-198, Fig. 3, L1-L7, Fig. 013023), alcanzando una amplia difusión, como centro principal de fabricación desde época altoimperial, tras una primera fase de importaciones. Así, se hallan ejemplares de estas características en yacimientos como Conimbriga (Alarçao: 1975: 80-92, Láms. XXIIIXXIX), el castro asturiano de Chao Samartin (Benéitez, Hevia y Montes, 1999: 32, 34, Fig. 7, no 6 y Fig. 8, no 1-3; Hevia y Montes, 2009: 168-170, figs. 143-144) o el campamento de Petavonium (Carretero: 2000: 574-577: Figs. 299, 300, 309; 2000b: 127-149), si bien en este último yacimiento, más que ollas, se documenta una abundante y variada tipología de vasos y jarras, bruñidos y con acabados brillantes y decoraciones similares de tipo geométrico que componen un grupo específico y muy numeroso, denominado por el citado autor "Cerámica de Tradición Astur". Éste, aunque con rasgos peculiares, resultaría equiparable a estas producciones más aisladas que tienen su principal centro en la capital lucense. Por lo que se refiere a Legio, hemos de hacer constar la presencia prácticamente testimonial de estas producciones, pues se reducen únicamente a este ejemplar en el conjunto de cerámica común de los tres vertederos aquí estudiados. En este sentido hay que destacar que en el vertedero de la C/Maestro Copín, se documentan dos de estas piezas de gran calibre y en buen estado de conservación (Fernández Freile, 2003: 125, Lám. 83) que ponen de manifiesto la pervivencia de estos patrones indígenas hasta épocas avanzadas.

\subsection{3.- Ollas de borde recto horizontal (Lám. 58)}

En este contexto alcanza también importante representación numérica el tipo de ollas de borde recto horizontal. Se trata de recipientes de mediano y gran calibre, que superan en algunos casos los $20 \mathrm{~cm}$. de diámetro de boca $\left(\mathrm{n}^{\circ} 524,530\right)$. La configuración del borde recto horizontal presenta algunas variaciones, en lo que se refiere sobre todo a su longitud y a las diferentes formas de su extremo, más redondeado $\left(n^{\circ} 523,527,530\right)$, vertical ( $\left.n^{\circ} 524,526,529\right)$ o más oblicuo (n $\left.n^{\circ} 525,528\right)$. En uno de los ejemplares ( $\left.n^{\circ} 524\right)$ aparecen sobre la superficie plana del borde dos acanaladuras, rasgo también muy frecuente en los cuencos, que contribuye a facilitar el asiento de las tapaderas.

Este tipo es frecuente en los conjuntos de cerámica común romana de los distintos yacimientos peninsulares desde mediados del siglo I d. C. aunque destaca su escasa presencia en los vertederos de San Pedro y San Lorenzo, mientras que en el vertedero legionense del siglo II d. C. se encuentra ampliamente representado (Fernández Freile, 2003: 126-127, Lám. 87), así como en otros contextos hispanos de cronología más avanzada. 
3.1.4.- Ollas de borde vertical de perfil en “L” (Lám. 59)

Este peculiar tipo de ollas en cuyo borde se sitúa una concavidad para la recepción de la tapadera, resulta muy abundante en el vertedero. Este elevado porcentaje suele ser común en la mayoría de yacimientos romanos, y de hecho, alcanzan también, como hemos expuesto, una importante representación numérica en el vertedero de San Pedro. En este sentido, algunos autores consideran este tipo como uno de los más conocidos y difundidos en la cerámica común romana, habiéndose fabricado prácticamente durante todo el Imperio (Sánchez, M. A., 1992b: 248) y encontrándose en las tipologías de los principales yacimientos, como la elaborada recientemente para la cerámica de Augusta Emerita (Bustamante, 2011: 65-66, Fig. 48, nº 20).

En la secuencia estratigráfica los ejemplares de esta forma se encuentran en las tres etapas diferenciadas del vertedero, predominando en las UUEE de mediados y finales del siglo I d. C. y principios del siglo II. De su fabricación en momentos tardíos contamos con ejemplos como el yacimiento madrileño del alfar de Villamanta, en el que se fechan en el siglo IV d. C. (Zarzalejos, 2002: 137-140, Fig. 116).

En el conjunto de este vertedero leonés se documentan algunos ejemplares más completos ( $\left.\mathrm{n}^{\circ} 536\right)$, de 14,5 cm. de diámetro de boca, que permiten inferir cuerpos globulares, y algunos como la citada pieza, portan dos marcadas acanaladuras a la altura del hombro.

En cuanto a la configuración de los bordes, netamente separados del galbo, se encuentran algunas variantes, especialmente en lo que respecta a la altura e inclinación y especialmente al remate del labio, que puede ser engrosado curvo, recto, oblicuo o triangular, constituyendo así un tipo sumamente diversificado.

\subsection{5.- Ollitas (Lám. 59)}

La presencia de estos pequeños recipientes en el vertedero alcanza una importante representación numérica, destacando además por la calidad de su elaboración, con pastas muy finas y decantadas, paredes delgadas y cuidados acabados externos, alisados o espatulados en ocasiones. Desde el punto de vista morfológico, presentan cuerpos globulares u ovoides, y en la configuración de los bordes reproducen la diversidad de tipos de las ollas. El diámetro de boca de estos recipientes oscila entre los $7 \mathrm{~cm}$. $\left(\mathrm{n}^{\mathrm{o}} 542,546\right)$, y $\operatorname{los} 10,80 \mathrm{~cm}$. de la pieza $\mathrm{n}^{\circ} 544$. Todas estas características morfológicas ofrecen claras similitudes con los cubiletes de la cerámica de paredes finas, aspecto que ha hecho plantear la influencia de esta última sobre esta categoría de pequeñas ollas, tanto más cuanto que en ninguno de los casos de los fragmentos conservados se advierten huellas de exposición al fuego, resultando así dudosa su función culinaria132. Por ello, y al igual que hemos constatado al analizar el similar conjunto de ollitas del vertedero de San Pedro, algunos investigadores (Carretero, 2000: 707), ha expuesto esta teoría en el estudio de los ejemplares de Petavonium, remitiendo quizá a la procedencia de los mismos alfares. En este sentido, es de destacar la datación que

132 Otros investigadores, siguiendo la misma línea de descartar cualquier uso culinario para estos peculiares recipientes, han propuesto otras funciones, bien relacionadas con el servicio de mesa, o bien como pequeños contenedores de condimentos o productos como sal, hierbas, miel u otros similares (ALCORTA, 2001: 182-183). 
se desprende de los niveles cronológicos de este grupo en el vertedero legionense, procedentes en su mayor parte de las UUEE 312 y 318, pertenecientes a la tercera etapa, desde mediados del siglo I d. C. y ocupando la época flavia, aspecto que avalaría el argumento expuesto desde el punto de vista cronológico.

\section{2.- CUENCOS (Lám. 60)}

Estos recipientes son profusamente utilizados en el ámbito de la cerámica común romana puesto que su uso es ambivalente, como vasijas para la preparación de alimentos -como muestran las marcas de hollín en muchos ejemplares- así como también empleados en el servicio de mesa. En este vertedero el conjunto de cuencos representa el 12\% de la cerámica común, pudiendo apreciarse una gran variedad en su morfología -aspecto característico del tipo- así como en las pastas utilizadas en su fabricación, predominando los tonos propios de cocciones oxidantes y alternas, con desgrasantes cuarcíticos y micáceos de granulometría media.

Como característica general, los cuencos suelen presentar un diámetro de boca similar al de las paredes, de manera que su anchura sobrepasa siempre a su altura.

En el único ejemplar de perfil completo que conservamos ( $\left.{ }^{\circ} 551\right)$ podemos apreciar los rasgos más comunes de este tipo de recipientes: presenta un diámetro de boca de $18,5 \mathrm{~cm}$. una altura de $6,5 \mathrm{~cm}$. y un perfil hemiesférico con borde simple y fondo plano.

Esta forma del cuerpo es la más común en los cuencos de los diversos yacimientos como en Mérida, donde predominaban en el vertedero de la C/Constantino (Alvarado y Molano, 1995: 291, Fig. 13) y continúan siendo mayoritarios en la reciente tipología elaborada por Bustamante, apuntando que su función sería la del consumo de líquidos o alimentos semisólidos (2011: 69, Fig. 55).

En el conjunto de cuencos de este vertedero leonés se observa igualmente este predominio de galbos hemiesféricos, aunque en algunos se puede intuir una trayectoria un tanto más rectilínea ( $\left.n^{\circ} 552,554,561,562\right)$. Un aspecto a destacar es la ausencia de cuencos de cuerpo carenado -la otra gran variedad tipológica en estos recipientes- que sin embargo suponen una absoluta primacía en el vertedero legionense de la C/Maestro Copín. (Fernández Freile, 2003: 128, Lám. 90). Desconocemos hasta el momento las posibles implicaciones cronológicas de estas variantes, o quizá hayan de atribuirse a otros factores (diferentes centros de fabricación, cambios en los modelos o cuestiones de funcionalidad...) que, dada su dilatada perduración en el tiempo, dificultan la atribución de cronologías precisas.

Con todo, la mayor variedad de estos recipientes no afecta tanto a su perfil como a otros rasgos como el tamaño (con ejemplares que llegan a alcanzar los $40 \mathrm{~cm}$. de diámetro de boca) y también a la configuración de los bordes. Esta última característica podemos advertirla claramente en esta muestra de cuencos, en la que aparecen una mayoría de piezas con borde redondeado simple más o menos grueso ( $\mathrm{n}^{\circ} 551,553$, 557-561), borde recto horizontal ( $\left.n^{\circ} 552\right)$, borde bífido ( $\left.n^{\circ} 562\right)$, y únicamente tres ejemplares con borde exvasado horizontal ( $\left.n^{\circ} 550,554,555\right)$. Este último tipo, característico de los cuencos carenados, resulta sumamente escaso, al igual que en los vertederos de San Pedro y San Lorenzo, si tenemos en cuenta su presencia en otros yacimientos cercanos, como el campamento de Petavonium, donde esta categoría es especialmente abundante (Carretero, 2000: 692-696). 
El volumen de platos hallado presenta una escasa proporción numérica, representando únicamente el $8 \%$ de las piezas de cerámica común y por tanto sensiblemente menor al de los demás vertederos legionenses.

Estos recipientes son generalmente abundantes en los diferentes yacimientos romanos, pues son esenciales en la vajilla de mesa, así como en algunos procesos culinarios, como demuestran las marcas de hollín que presentan numerosos ejemplares. Constituyen así otro de los tipos de cerámica común de uso polivalente que van desdibujando la diferenciación entre recipientes de cocina y mesa.

Este conjunto de platos se caracteriza por una buena calidad en su fabricación, con cocciones oxidantes, reductoras y alternas y pastas bien decantadas con desgrasante cuarcítico y micáceo, con la presencia de este último en algunas piezas muy visible también al exterior. En ello cabría ver una aplicación intencional, con fines decorativos, dado el aspecto brillante que confiere la mica y que constatamos también en los platos del vertedero de San Pedro, siendo también muy abundantes en otros establecimientos militares como Petavonium (Carretero, 2000: 664).

En cuanto a la tipología de estas piezas de paredes convexas y base plana, existe una notable diversidad en los tamaños, forma de las paredes y especialmente en la configuración de los bordes.

Así, en este reducido grupo, el único ejemplar que conserva su perfil completo $\left(\mathrm{n}^{\circ}\right.$ 564) presenta un diámetro de boca que sobrepasa los $20 \mathrm{~cm}$. al igual que las piezas $\mathrm{n}^{\circ}$ 565 y 566, mientras en el n 563 es más reducido, con $15 \mathrm{~cm}$.

En la configuración de las paredes predominan los perfiles hemiesféricos y la diferenciación morfológica se hace patente sobre todo en los bordes, rectos con labio redondeado $\left(n^{\circ} 565,568\right)$ u horizontal $\left(n^{\circ} 564,567\right)$ o los característicos ejemplares de borde reentrante, bien con labio engrosado en la parte superior ( $\left.n^{\circ} 566\right)$ o más fino y alargado ( $\left.n^{\circ} 563\right)$, que confiere a la pieza un aspecto carenado en su parte superior.

Desde el punto de vista cronológico no se aprecian variaciones dignas de mención, si bien podemos apreciar que los ejemplares aquí estudiados se localizan en la tercera fase del vertedero, en época flavia.

\subsection{PLATOS DE IMITACIÓN DE ENGOBE INTERIOR ROJO POMPEYANO (Lám. 61)}

La representación numérica de estas producciones en este contexto, aunque se reduce únicamente a un $2 \%$ de la cerámica común, constituye el volumen más elevado en relación al resto de los vertederos legionenses.

Aún así, el estado sumamente fragmentario en que se encuentran -sin que aparezcan ejemplares de perfil completo- $y$, por otra parte, la homogeneidad en sus rasgos técnicos y morfológicos, hace que en la representación gráfica hayamos incluido un número menor de piezas que en los demás vertederos, en los que su proporción es más reducida pero presentan una notable diversidad en sus características formales, especialmente en el conjunto procedente del vertedero de San Pedro.

En efecto, se trata en general de platos de paredes curvas y abiertas de escaso grosor, adscribibles a la forma Luni 5. En cuanto a los bordes, el elemento que determina 
la variedad tipológica, únicamente hemos documentado el tipo de borde de extremo redondeado ( $\left.n^{\circ} 569\right)$, en algún caso reentrante $\left(n^{\circ} 570\right)$ y el de extremo recto $\left(n^{\circ} 571-\right.$ 572). A partir de las piezas más completas hemos constatado unas dimensiones que oscilan entre los 19 y 21,5 cm. de diámetro de boca, si bien la pieza $\mathrm{n}^{\circ} 569$, con $34 \mathrm{~cm}$. de diámetro podría considerarse en la categoría de fuentes.

En su fabricación se han empleado pastas decantadas con finos desgrasantes cuarcíticos y micáceos, destacando la densidad y consistencia del engobe, que presenta tonos rojizos oscuros y castaños. Este engobe, que da nombre a estas producciones, posee propiedades antiadherentes que facilitarían la preparación de determinados alimentos, indicando la utilización de estas piezas en los procesos culinarios, como corrobora el ennegrecimiento que presentan en parte de su superficie un gran número de los ejemplares, consecuencia de su exposición al fuego. Así, al igual que una proporción importante de recipientes de cerámica común, estos platos tendrían una función polivalente, pues desempeñan también un papel destacado en el servicio de mesa, generalmente, como ya hemos comentado, con un uso individual, dado el predominio de los ejemplares de reducidas dimensiones.

En todos los casos los ejemplares que estudiamos -al igual que en los demás vertederos de Legio- se trata de imitaciones, fenómeno que afecta de forma singular a este tipo de platos, especialmente a partir de la primera mitad del siglo I d. C., pudiendo hallarse en la mayor parte de los yacimientos romanos. Así, como ya hemos expuesto, tras un período de importaciones de estos productos itálicos que alcanzan su auge en época augustea, la demanda comienza a ser cubierta en las diversas provincias con la fabricación de imitaciones en talleres de carácter local o regional.

Un aspecto significativo en función del contexto que estudiamos, ya señalado tempranamente por autores como Goudineau para asentamientos de otras provincias (1970: 159-186) y que han puesto de manifiesto investigaciones recientes en los yacimientos peninsulares, es el importante volumen de hallazgos de estas producciones en los establecimientos militares (Girón y Costa, 2006: 498), lo que indicaría un uso generalizado por los soldados romanos.

Como paralelos más cercanos a las producciones de este vertedero cabe destacar los platos hallados en el campamento de Petavonium (Carretero, 2000: 644-646), cuyo autor incide ya en un esencial consumo militar y para cuya procedencia propone la posibilidad de los talleres del Valle del Ebro, o más probablemente, algún alfar situado en la zona noroeste, como podría ser el caso de Conimbriga.

En el actual estado de la investigación, hemos de contemplar el papel de Lucus Augusti como principal centro de producción local y de distribución de cerámicas comunes en el noroeste peninsular. En lo que respecta a los platos de imitación de engobe rojo pompeyano, se registró una abundante proporción en el estudio del conjunto de la cerámica común de la ciudad (Alcorta, 2001: 182; 344-358; Figs. 144-149), constatándose una gran diversidad tipológica en estas producciones (Ibid.: Fig. 77), a la vez que algunas peculiaridades, como la presencia de sellos en la base de algunos platos que pertenecerían a cinco oficinas diferentes (Ibid: 182, nota 1), todo lo cual contribuye a reafirmar el alto nivel de producción de estas manufacturas en el centro lucense. 


\section{5.- TAPADERAS (Lám. 62)}

Esta categoría de elementos, definidos genéricamente como opercula, resultan generalmente muy frecuentes en los conjuntos cerámicos romanos, dado que sirven de cobertura a recipientes de muy diferente tipología y función (ollas, cuencos, platos, jarras, vasijas de almacenaje...), lo que condiciona su amplia diversidad ${ }^{133}$ en cuanto a morfología, tamaño y otros aspectos técnicos, constituyendo un utensilio de gran plurifuncionalidad en la preparación, el servicio y la conservación de alimentos.

En el contexto de la cerámica común de este vertedero representan un 2,5\% del total de piezas, porcentaje que puede considerarse escaso por los aspectos antedichos, al igual que en los registros de los vertederos de San Pedro y San Lorenzo, en los que no superan el 4\%, mientras que en el de la C/Maestro Copín, con un 8\%, alcanzan una significación numérica más usual, si bien con una mayor homogeneidad morfológica (Fernández Freile, 2003: 129-130, Láms 92-93).

Desde el punto de vista técnico, están fabricadas con los mismos tipos de pasta que los recipientes a los que se asimilan, observándose una proporción equiparable entre las cocciones oxidantes y reductoras con desgrasantes cuarcíticos y micáceos de granulometría media.

Morfológicamente, los diferentes ejemplares se inscriben en el tipo Vegas 17 (1973: 53-54), aunque se constatan numerosas variantes respecto al tipo general. Se trata pues, de piezas de cuerpo troncocónico, definidas por una gran diversidad, tanto en el perfil de sus paredes, en el remate de sus bordes y en la forma del pomo superior, a lo que hay que añadir su variado tamaño, en relación con su función accesoria de recipientes de muy distinto calibre, sin que estas variaciones tengan implicaciones cronológicas, dado que perduran los mismos modelos durante todo el Imperio.

Por lo que respecta a la trayectoria de las paredes y su grado de curvatura, en el conjunto que estudiamos podemos diferenciar, a modo de clasificación, tres tipos fundamentales de tapaderas: de paredes convexas, cóncavas y rectilíneas, con sus diferentes ángulos de inclinación que les confieren perfiles de distintas dimensiones en altura.

En el primer grupo se incluirían las piezas no 574,575 y 581 . El no 574 es el único ejemplar completo conservado en todo el conjunto, con unas dimensiones de $12,5 \mathrm{~cm}$. de diámetro de borde y $4,7 \mathrm{~cm}$. de altura, situándose entre las tapaderas de mediano-pequeño tamaño. Su cuidada factura, con pastas decantadas y finos desgrasantes, además de la ausencia de huellas de hollín, indicarían su uso como cobertura de un recipiente perteneciente a la vajilla fina de mesa. Presenta un borde no diferenciado, de labio redondeado, y un pomo superior discoidal de $3 \mathrm{~cm}$. de diámetro, con su superficie hueca en el interior.

Una morfología muy diferente presenta la pieza $n^{\circ} 575$, con finas paredes convexas de acentuada curvatura pero escaso desarrollo en altura, que define un perfil de clara tendencia horizontal. En cuanto al borde, se diferencia de la trayectoria de la pared, con un extremo recto horizontal, y alberga en su interior una acanaladura que facilitaría el ajuste en el recipiente receptor. Con unas dimensiones de $17 \mathrm{~cm}$. de diámetro de

133 A modo de ejemplo para ilustrar esta característica, podemos citar un reciente estudio sobre la cerámica emeritense, en el que se han individualizado veintidós tipos de tapaderas de producción local (BUSTAMANTE, 2011: 66, Fig. 51). 
boca, por su gran estabilidad, algunas de estas piezas pudieron ser utilizadas para servir a modo de fuentes.

En cuanto al fragmento $\mathrm{n}^{\circ} 581$, únicamente conserva una mínima parte de la pared de tendencia convexa con borde no diferenciado de extremo recto.

En el segundo tipo, definido por la concavidad de sus paredes, se integrarían los ejemplares $n^{\circ}$ 573, 582 y 580. El primero, que carece de su tercio superior, presenta una forma acampanada, con un amplio ángulo de inclinación de sus paredes y un diámetro de borde de $15,5 \mathrm{~cm}$. Sus paredes son de grosor irregular y decreciente desde la zona media del cuerpo, donde se localiza una fina ranura, hacia la parte superior. Todo ello confiere a la pieza un desarrollo vertical. En el extremo del borde se registra una ligera incurvación hacia el interior, y un remate moldurado. El fragmento $\mathrm{n}^{\circ} 582$ presentaría unas características similares al anterior, en función de su orientación, aunque su reducido tamaño no permite apreciar otros rasgos, a excepción de algunas irregularidades en la línea de su pared externa que le dan un aspecto acanalado y un borde de extremo recto. A este mismo grupo pertenecería la pieza $n^{\circ} 580$, correspondiente al extremo de una tapadera con paredes de concavidad muy poco marcada, con un ángulo de inclinación sumamente reducido y un prolongado borde recto horizontal de labio biselado, con lo cual presenta un perfil prácticamente horizontal.

Una tercera forma, muy frecuente, se caracteriza por un cuerpo de paredes rectilíneas, entre las que podemos clasificar los fragmentos n 578 y 579, diferenciándose el primero por su mayor ángulo de inclinación y por tanto tendencia a la verticalidad, y un borde de extremo recto, mientras que el segundo fragmento presenta unas paredes de escaso grosor y un característico borde que rompe la trayectoria rectilínea de la pared con un perfil engrosado de labio redondeado.

Además de estos fragmentos de cuerpos y bordes que reflejan la variada tipología de este conjunto de tapaderas, puede apreciarse asimismo la distinta morfología de los elementos de aprehensión de su extremo superior. Los más comunes presentan una forma circular plana, como en las piezas $n^{\circ} 576$ y 577, si bien podemos observar diferencias en la configuración del punto de unión con las paredes de la pieza, en su grado de concavidad interior y en sus dimensiones, en relación al tamaño de las tapaderas. En algunos casos, como hemos constatado en otros ejemplares de los vertederos aquí estudiados, este tipo de asideros discoidales presentan en su superficie marcas en forma de estrías circulares, resultado del proceso de torneado.

\section{6.- JARRAS (Láms. 63-65)}

La proporción de jarras en el total de la cerámica común de este área de vertidos, es de un $22 \%$, con lo cual resulta prácticamente equiparable al de estos mismos recipientes en el vertedero de San Pedro, con los que guardan además, como veremos, otras analogías. Esta importante significación numérica, que suele seguir al siempre mayoritario volumen de ollas, es un hecho habitual en los yacimientos altoimperiales, y así se constata en los cuatro vertederos legionenses que tratamos en este estudio. De la misma manera, cuentan con una extensa clasificación morfológica que parte de tipos genera- 
les en los que se engloban múltiples variantes y subvariantes ${ }^{134}$. Todo ello viene a indicar que se trata de piezas fundamentales en el marco de la cerámica común, utilizados no únicamente como contenedores y dispensadores de líquidos, su función primordial, sino también -y abundando una vez más en el carácter plurifuncional de los utensilios de cerámica común- como recipientes auxiliares en los procesos culinarios -como denotan las marcas de exposición al fuego en algunas piezas- y también como elementos en el transporte y almacenaje de determinados productos líquidos o semilíquidos.

Antes de proceder a la clasificación tipológica, consideramos de interés poner de relieve una característica común a este conjunto de ejemplares, que hemos subrayado igualmente en las jarras procedentes del vertedero de San Pedro, como es su notable calidad en la fabricación, empleándose pastas muy depuradas, con finos desgrasantes de cuarzo y mica, incluyendo cuidados acabados exteriores en buena parte de las piezas. Predominan las cocciones en atmósfera oxidante, con una variedad de tonalidades desde el rojo-anaranjado, al castaño y otros más blanquecinos.

Esta cuidada elaboración que se aprecia en la mayoría de los recipientes constituye un aspecto significativo tratándose de producciones comunes, en las que normalmente suelen diferenciarse piezas finas y otras más vulgares o toscas. En este sentido cabe destacar el yacimiento del cercano campamento de Petavonium, en el que se hace patente una clara división entre ambos grupos (Carretero, 2000: 651-660 y 673-685), mientras que los conjuntos de jarras extraídas de estos dos vertederos legionenses presentan una notable uniformidad, de modo que un número importante de recipientes se aproximaría a la vajilla fina de mesa.

Con todo, esta diferenciación en la calidad no guarda relación directa con la morfología, puesto que se hallan los mismos tipos con distinto nivel en su manufactura.

Desde el punto de vista morfológico, entre las jarras de este vertedero podemos diferenciar varios tipos, en función de de las características del borde y el desarrollo del cuello (las partes mejor conservadas) ya que no contamos con ejemplares completos, aunque basándonos en las tipologías generales constarían de un cuerpo de tendencia globular u ovoide y fondo plano.

\subsection{1.- Jarras de cuello largo y estrecho (Lám. 63)}

Representan un tipo muy numeroso, con un $37 \%$ del total, en el que podemos distinguir diversos subtipos.

Se caracterizan por un cuello bien diferenciado del cuerpo e importante desarrollo en altura (entre 5 y $7 \mathrm{~cm}$.) que adopta un perfil cilíndrico, como en los ejemplares $\mathrm{n}^{\circ}$ 585,588 y 589 , o bien ligeramente troncocónico $\left(n^{\circ} 584,586\right)$ o de paredes cóncavas $\left(n^{\circ}\right.$ 583). Su diámetro de boca y cuello es muy reducido (entre 2 y $4 \mathrm{~cm}$.), otorgando con todo ello una forma estilizada al recipiente, independientemente de la forma y dimensiones del cuerpo. A partir de los arranques de asa que se conservan bajo el borde de muchos de estos recipientes y de los hallados en otros yacimientos, y especialmente en el vertedero de San Pedro, en el que aparecen tipos similares que conservan este elemento, podemos deducir que se trata en su mayoría, de ejemplares monoansados.

134 Como ejemplo de una clasificación morfológica reciente de estos recipientes cabría citar la realizada para los ejemplares de Augusta Emerita, que recoge veinticuatro tipos diferentes, de fabricación local, con una cronología del siglo I d. C. (BUSTAMANTE, 2011: 58). 
En cuanto al borde, en función de su configuración, pueden distinguirse varios subtipos en esta forma que correspondería al tipo 38 en la tipología de Vegas, definido como "jarras de un asa y cuello largo" (1973: 92-93, Fig. 32).

En un primer subtipo se agruparían las jarras denominadas "con gollete", que presentan un borde estrangulado, esto es, separado del cuello mediante una acentuada acanaladura, y con trayectoria vertical, como muestran los ejemplares $n^{\circ} 587,588$ y 589. En los dos primeros el remate del borde es recto, mientras el tercero adopta un perfíl más redondeado.

Los paralelos que hemos hallado para este subtipo, señalados detalladamente en el análisis de estos ejemplares en el vertedero de San Pedro, en el que son más abundantes y presentan mejor estado de conservación, revelan la escasa difusión de esta forma, reducida a algunos enclaves en la zona noroeste peninsular, y con un marco cronológico que comprende el siglo I d. C. y la mitad de la siguiente centuria. En el mismo período se inscriben las piezas de este vertedero, dos de ellas localizadas en las UUEE 314 y 323, datadas a principios del siglo I d. C. -pertenecientes por tanto a la época de ocupación del campamento por la Legio VI- y el resto en las UUEE 317 y 318, con una cronología de fines de esta centuria y principios de la siguiente, ya en época de pleno asentamiento de la Legio VII Gemina.

Además de sus peculiaridades morfológicas, este tipo de jarras con gollete son características de ámbitos militares, como han puesto de manifiesto investigadores como Carretero (2002: 363)135, a raíz del detallado análisis de estos ejemplares en el campamento de Petavonium (2000: 651-655) y del cotejo con hallazgos similares en otros asentamientos castrenses, a los que habremos de añadir el conjunto de piezas legionenses presentadas en este estudio.

Un segundo grupo estaría integrado por los ejemplares cuyo borde presenta una sección moldurada ( $\mathrm{n}^{\circ} 583,584$ y 586), con la característica común de un cuello largo pero no cilíndrico, como en la pieza $n^{\circ} 583$, con cuello de paredes cóncavas y los ejemplares $\mathrm{n}^{\mathrm{o}} 584$ y 586, que presentan un cuello de perfil ligeramente cónico, en el segundo caso con decoración de estrías en su mitad inferior, rasgo muy común en este subtipo de jarras de cuello largo (Vegas, 1973: 92-93, Fig. 32, nº 9), que alcanza una amplia difusión en los yacimientos romanos especialmente durante la primera centuria de la Era.

Finalmente, como ejemplar de difícil adscripción a otro subtipo o variante, se encuentra la pieza $n^{\circ} 585$, cuyo delgado cuello cilíndrico presenta un borde estrangulado de paredes abiertas y curvas con remate engrosado. Para esta peculiar forma, los paralelos morfológicos son muy escasos en las principales clasificaciones y publicaciones sobre estos recipientes, pudiendo englobarse en las denominadas "botellas", y para la cual podemos proponer una cronología de mediados-finales del siglo I d. C. en función de su ubicación estratigráfica.

135 El mismo autor (Ibid. : 363) apunta la posibilidad como ya hemos señalado, de que este tipo de jarras de boca estrecha con gollete, en función de la calidad de su factura, sus tonalidades y cuidados acabados exteriores, además de la delgadez de sus paredes, formaran un servicio con los vasos ovoides del taller de Melgar de Tera, hipótesis sumamente interesante, que pondría en relación, desde el punto de vista funcional, dos categorías cerámicas distintas, y ambas con especial presencia en ambientes militares. 
3.6.2. Jarras de boca trilobulada con pico vertedor (Lám. 64)

Este tipo de jarras, habitualmente abundantes en los yacimientos romanos, se encuentran escasamente representadas en este vertedero, con un porcentaje de un $3 \%$ respecto a los restantes tipos, a lo que hemos de añadir su estado muy fragmentario, sin que hayamos documentado ningún ejemplar completo. En este aspecto, contrastan con una significativa proporción numérica de esta forma en los vertederos de San Pedro (vid. supra) y de la C/Maestro Copín (Fernández Freile, 2003: 138-139, Láms. 102-105), siendo en este último el grupo más numeroso de estos recipientes. Por el contrario, y por las razones ya aducidas que caracterizan al material de este contexto, no hemos localizado ningún fragmento que pueda adscribirse a este tipo de jarras en el vertedero del conjunto termal de San Lorenzo.

Desde el punto de vista morfológico, se adscriben al tipo 46 en la clasificación de Vegas (1973: 109, Fig. 39), constituyendo una de las formas mejor documentadas en los contextos romanos, con una amplísima difusión espacial y un extenso marco cronológico.

Sus rasgos tipológicos derivan directamente del oinochoe griego, muy extendido en época helenística, sin que se adviertan apenas variaciones formales en su incorporación al elenco cerámico romano.

Se trata de jarras de cuello corto, con cuerpo de perfil globular, ovoide o en ocasiones carenado, y un fondo plano. El elemento definitorio, la boca, presenta un contorno lobulado con un pico vertedor más o menos abierto y un borde exvasado con remate curvo o bífido, bajo el que arranca un asa -generalmente de cinta con una acentuada acanaladura central- que se apoya en el hombro del recipiente.

En ocasiones aparecen elementos decorativos como acanaladuras o estrías en el cuerpo y cuello de estos recipientes, aspecto que no es posible comprobar en el reducido grupo de este vertedero, ya que únicamente conservamos fragmentos de la parte superior de estas jarras.

Algunos rasgos morfológicos como el cuello, pueden presentar sensibles diferencias en sus dimensiones, de manera que en determinados conjuntos como en el de Petavonium, se distinguen dos grupos, de cuello estrecho y de cuello ancho (Carretero, 2000: 673-675, Fig. 338), que configuran en el primer caso ejemplares de mayor esbeltez.

Igualmente, el tamaño de la boca puede experimentar variaciones en función de la entidad del cuerpo de la vasija, de forma que pueden diferenciarse jarras grandes de boca muy abierta, y otras de menor tamaño cuya boca es más reducida con el pico vertedor muy cerrado. Este criterio de clasificación se aplica en el escaso número de jarras de esta morfología halladas en Lucus Augusti (Alcorta, 2001: 282, nota 595), de forma que su investigador diferencia entre ellas, por una parte las jarras monoansadas de pico trilobulado abierto -Tipo J2- generalmente decoradas (Ibid. 282-283, Fig. 118), de aquellas otras monoansadas, groseras, de pico cerrado, sin decoración -tipo J4- (Ibid. 287-288, Fig. 120).

En cuanto al escaso número de ejemplares hallados en este vertedero, hemos de destacar además su estado fragmentario -de manera que únicamente las piezas $\mathrm{n}^{\circ} 590$ y 591 conservan su parte superior-, así como los acabados de las superficies poco cuidados. La primera, fabricada en pasta relativamente fina de color anaranjado, presenta cuello estrecho con asa y arranque del galbo y un diámetro de boca de $4,5 \mathrm{~cm}$. El fragmento $n^{\circ} 591$, de cocción reductora, con una pasta más grosera con desgrasantes 
de granulometría media, muestra en su interior una tonalidad blanquecina, con cuello alto y estrecho, correspondería a un ejemplar de grandes dimensiones, con un diámetro de boca de $9 \mathrm{~cm}$. En cuanto al resto ( $n^{\circ} 592,593$ y 594), se trata en todos los casos de fragmentos de bordes, fácilmente adscribibles a este tipo por su configuración lobulada, y destacando el borde bífido del conjunto de fragmentos $n^{\circ} 594$, definido por una marcada acanaladura central.

En cuanto a su funcionalidad, suelen ser utilizadas para servir vino (la función original del oinochoe griego, como indica el propio término), sin embargo, algunos autores consideran que el oinochoe romano ha tenido un uso menor en este servicio, siendo utilizado también entre los recipientes de cocina, principalmente para conservar, calentar y verter el agua y la leche ${ }^{136}$.

La extensa trayectoria histórica del tipo y su fácil asimilación a los modelos romanos hace que su difusión sea amplísima, hallándose en los diversos territorios del Imperio. Así, según el tradicional estudio de Vegas (1973: 109), se encuentran de forma abundante, especialmente desde época augustea, en asentamientos de Europa septentrional como Haltern, Hofheim o Vindonissa y es muy destacada su presencia en toda la cuenca mediterránea, en yacimientos como Ostia, Albintimilium o Pollentia, durante el siglo I d. C. con una larga perduración en estos lugares hasta épocas muy tardías.

Igualmente, en trabajos más recientes sobre cerámica común, podemos seguir constatando la importante presencia de este tipo de jarras de boca trilobulada en yacimientos peninsulares y extrapeninsulares. Así, destacan obras de conjunto de importante amplitud territorial como la dirigida por M. Bats (1996), sobre las cerámicas comunes de Campania y de la Narbonense, con yacimientos tan emblemáticos como Pompeya, Herculano, y en la región galo-romana: Marsella, Aix-en Provence Fréjus, Nîmes o Languedoc, incluyendo además tres capítulos adicionales sobre las producciones comunes de Ostia, Albintimilium y Aquitania Meridional.

Por lo que respecta a los yacimientos peninsulares, destaca la presencia de estos recipientes en Augusta Emerita (Sánchez Sánchez, 1992: 50-52, Fig. 12; Alvarado y Molano, 1995: 287, Fig. 6; Bustamante, 2011: 68-69, Fig. 52 n 18), en el área Bética (Serrano Ramos, 1995: 227-249, Fig. 11, nº 92), y más concretamente en el territorio malacitano (Serrano Ramos, 2000: 72, 100, 128), en el Valle del Ebro en enclaves como Varea (Luezas y Sáenz Preciado, 1989: 185-186, Lám. XXXI, n 131) o La Rioja (Luezas Pascual, 2002: 119-121, Fig. 43). En la zona Noroeste, a juzgar por los testimonios ya analizados del campamento de Petavonium o Lucus Augusti137, los hallazgos son generalmente escasos, si bien este tipo de ejemplares se registran con cierta asiduidad en yacimientos de la zona del País Vasco (Martínez Salcedo. 2004: 291-292) y en otros puntos del norte y noroeste peninsular.

136 Esta función de las jarras trilobuladas ha sido propuesta por LUEZAS PASCUAL (2002), siguiendo la opinión ya expresada por SANTROT ( 1979: 205).

137 En este aspecto, se hace constar la escasez de estos recipientes en la capital lucense, contrastando con su importante presencia en el cercano campamento de Aquis Querquennis, y en general en todo el convento jurídico bracaraugustano (Alcorta, 2001: 289), atribuyendo esta diferencia de difícil interpretación a distintos modelos en el registro arqueológico de estos recipientes y la elaboración de diferentes catálogos sin criterios unificados. 
En este tercer grupo tipológico se incluye la mayor parte de las jarras halladas en el vertedero, con una proporción del $60 \%$ respecto al total.

Su morfología se define en primer lugar por la amplia dimensión de su boca, que oscila entre 5 y $14 \mathrm{~cm}$. y un cuello ancho y diferenciado del cuerpo, que suponemos de tendencia globular u ovoide, ya que no conservamos ninguna pieza completa.

En este conjunto pueden diferenciarse varios grupos, en función de otros rasgos morfológicos, principalmente la configuración del borde y la presencia de asas.

Están elaboradas con pastas escasamente depuradas, con desgrasantes cuarcíticos y micáceos de granulometría media y en ocasiones muy visibles en superficie. Se advierte un predominio de los ejemplares de cocción oxidante, con tonalidades ocres y anaranjadas y en algunos casos blanquecinas, sin que falten piezas propias de atmósferas reductoras de tonos grises y negruzcos, y otras que presentan cocción alterna.

Otro rasgo común a este tipo de jarras del vertedero de la C/Pilotos Regueral, especialmente a las de mayor capacidad, es la ausencia de acabados cuidados o la aplicación de tratamientos externos, como alisados, bruñidos o espatulados, de manera que presentan en general superficies toscas y rugosas. En este aspecto observamos una clara diferencia con los ejemplares de los recipientes de la misma tipología procedentes del vertedero de San Pedro, caracterizadas por una notable calidad en su factura.

En este conjunto de jarras de boca ancha, se localizan diversas variantes morfológicas, en función de diferentes rasgos; sin embargo partiremos, como principal criterio de clasificación, de la distinta configuración de sus bordes, que permiten definir distintos subtipos, si bien añadiremos en cada uno otras características que también serían susceptibles de marcar peculiaridades morfológicas, formando otros subgrupos.

Así, en un primer grupo se encontrarían aquellas jarras que muestran un borde de tendencia horizontal, como los fragmentos $n^{\circ} 599$, con borde de extremo engrosado y redondeado sobre un cuello de paredes rectas, y el $\mathrm{n}^{\circ} 601$, con borde exvasado de remate vertical recto con cuello cóncavo. En ambos casos, el reducido tamaño de las piezas no nos permite apreciar otras características distintivas.

En un segundo grupo se incluyen aquellas jarras que presentan un borde moldurado. Esta constituye una variante muy difundida en la que se encuentran asimismo múltiples subtipos.

Destacan ejemplares como el n 597 , de $13 \mathrm{~cm}$. de diámetro de boca, con cuello corto cóncavo y borde moldurado de extremo recto y apuntado que facilitaría el ajuste de una tapadera. Más comunes son aquellas piezas como las $\mathrm{n}^{\circ} 598$ y 600, cuyo borde viene configurado por una sucesión de líneas cóncavas y convexas muy acentuadas, y formando, como en el segundo caso, un borde amplio, que constituye uno de los ejemplares más característicos del tipo.

En ninguno de los ejemplares citados se aprecian marcas del arranque de asas, circunstancia que puede deberse a su estado sumamente fragmentario -conservando únicamente el borde y una reducida parte de la sección superior del cuello- aunque también es frecuente en este tipo de jarras la ubicación de las asas en la parte media del cuello, sin descartar la posible carencia de las mismas.

Estas últimas piezas presentan una gran similitud con las halladas en otros vertederos legionenses como el de San Pedro (vid. supra Lám. 22, $\mathrm{n}^{\circ}$ 186-188) o el de la 
C/Maestro Copín (Fernández Freile, 2003: Lám. 107) y se encuentran abundantemente representadas en numerosos yacimientos peninsulares, especialmente en el entorno del Valle del Ebro, como Celsa (Beltrán et alii, 1998: Figs. 208, nº 1, 6, 7; 212, n 2, 3; $214, n^{\circ} 4 ; 215, n^{\circ} 2,8 ; 216, n^{\circ} 4,8,11 ; 220, n^{\circ} 2,3$ ) Varea (Luezas y Sáenz Preciado, 1989: Láms. XXX, n⿳ 119-125; XXXI n 129; XXXIII), en el conjunto de la cerámica común de La Rioja (Luezas, 2002: Figs. 44-47), cuya autora señala las importantes analogías con las fabricadas en el alfar de "La Maja" (Pradejón) (Ibid.: 125) o, más recientemente, en el vertedero doméstico de la C/Predicadores en Caesaraugusta (Gascón, 2011: Fig. 3, $\left.n^{\circ} 2-5\right)$.

En este segundo grupo hemos de situar asimismo los ejemplares que conservan parte de las asas, rasgo propio de una gran parte de este tipo de jarras de boca ancha. De hecho, en conjuntos más numerosos y mejor conservados como el procedente del campamento de Petavonium (Carretero, 2000: 677-681, Figs. 340, 343, 344, n 132) constituye uno de los principales criterios de clasificación, en función de la presencia de una o dos asas, en relación con su tamaño y capacidad.

En este vertedero destacan los ejemplares no 595 y 596, ambos monoansados, arrancando bajo el borde moldurado. En la pieza n ${ }^{\circ} 596$, conservada más completa, se aprecia un cuello ancho, que prácticamente iguala las dimensiones de 13,5 cm. del diámetro de boca.

Este tipo de ejemplares con asas se encuentra abundantemente en los yacimientos citados, especialmente en contextos de finales del siglo I d. C. y comienzos de la segunda centuria.

Igualmente, contamos entre las jarras de boca ancha con borde moldurado con un ejemplar más completo $\left(\mathrm{n}^{\circ} 602\right)$, con un diámetro de boca de $9,5 \mathrm{~cm}$. que presenta cuello ancho cilíndrico y dos asas -de cinta con acanaladura central- que arrancan de la parte media del cuello, apoyándose en la parte alta del cuerpo, de tendencia globular.

Este tipo de recipientes ha sido clasificado también en otras tipologías, recibiendo distintas denominaciones, predominando la de "cántaros", como figura en nuestra clasificación de las jarras del vertedero de la C/Maestro Copín (Fernández Freile, 2003: 142, Lám. 110) y en otros yacimientos como Lucus Augusti (Alcorta, 2001: 290294, Figs. 121-123), para los que se propone una cronología de mediados del siglo I d. C. hasta los decenios centrales de la segunda centuria o Arcóbriga (Sánchez, M. A., 1992b: 253-254, Figs. 8.2.13 no 116; 8.2.14 - 8.2.16), donde son especialmente numerosos, diferenciándose siete tipos distintos, con una gran amplitud cronológica, si bien su etapa de mayor esplendor y difusión se sitúa a lo largo del siglo II de la Era.

\section{7.- CERÁMICA COMÚN DE ALMACENAJE (Lám. 66)}

Los recipientes destinados al almacenamiento y la conservación de diversos productos alimenticios representan un porcentaje del $7 \%$ respecto al total de la cerámica común de este vertedero.

Son vasijas de grandes dimensiones y paredes gruesas, fabricadas con pastas muy poco depuradas, con desgrasantes principalmente cuarcíticos y micáceos, de gran tamaño y visibles en superficie, incluyendo en algunos casos otros desgrasantes de color rojizo y fragmentos arenosos. Presentan cocciones oxidantes y alternas, con una amplia gama de tonalidades, predominando las rojizo-anaranjadas y ocres y especial- 
mente los tonos más claros, amarillentos y blanquecinos. Las superficies se caracterizan por su aspecto tosco y rugoso y la ausencia de alisados u otros acabados externos, así como de apliques decorativos.

La significación numérica de estos recipientes resulta próxima a la de otros vertederos leoneses, sin embargo hemos de hacer constar que en este caso se aprecia una variedad morfológica mucho más escasa en los fragmentos atribuibles a estas vasijas, a juzgar fundamentalmente por la configuración de los bordes, que se limitan prácticamente a dos formas que se repiten en los distintos tipos de pastas y tamaños, de manera que la proporción cuantitativa no guarda relación con el estado más o menos fragmentario de estos ejemplares.

Dada esta homogeneidad, hemos optado por incluir en la representación gráfica únicamente las piezas mejor conservadas que corresponden a los dos tipos mayoritariamente representados.

Esta dicotomía se corresponde, por otra parte, con los dos tipos en que se clasifica de forma general este conjunto de recipientes, en función de sus rasgos morfológicos, como la estructura del cuerpo y la forma del borde, diferenciándose así las denominadas orzas o tinajas y los dolia, ambos representados de forma igualitaria y con muy escasas variantes morfológicas en este vertedero.

\subsection{1.- Orzas o Tinajas}

Este tipo de grandes recipientes de almacenamiento, cuyos rasgos morfológicos -al igual que los tipos más comunes de ollas de cocina-, se definen por bordes curvos de gran desarrollo, exvasados y engrosados, aunque también se registran otras variantes como los bordes de extremo horizontal, recto u oblicuo, como podemos apreciar en ejemplares de otros vertederos de Legio, como el de San Pedro (vid. supra, Lám. 23, n 190, 192, 196, 197, 198), o el de la C/ Maestro Copín, (Fernández Freile, 2003: Lám. 111).

Presentan un cuello corto y en ocasiones en la zona del hombro se disponen acanaladuras, baquetones o digitaciones como elementos decorativos, sin que hayamos constatado esta característica en ningún ejemplar de este vertedero.

En la morfología del cuerpo se advierte un absoluto predominio de los cuerpos de tendencia globular.

El ejemplar más significativo dentro de las orzas halladas en este contexto -que representan un $4 \%$ de la cerámica común- y que, como ya hemos expuesto, muestran características morfológicas muy afines, es sin duda la pieza $n^{\circ} 603$, por su gran calibre, ya que presenta un diámetro de boca de $43 \mathrm{~cm}$. y en la parte central del cuerpo se aproxima a los $50 \mathrm{~cm}$. de manera que constituye un recipiente, de extraordinaria capacidad, si bien un rasgo poco común es el hecho de que sus paredes no muestren un grosor proporcional a estas grandes dimensiones, ya que su espesor oscila entre 1,5 y $2 \mathrm{~cm}$. aspecto que quizá haya que poner en relación con las características y el peso de los productos a contener.

Este tipo de orzas o tinajas alcanzan una gran difusión, hallándose en las diversas zonas del Imperio y en distintos contextos cronológicos. Aún así, esta gran orza, localizada en los niveles de finales del siglo I d. C. y principios del siglo II, encuentra paralelos formales en yacimientos cercanos, especialmente en Lucus Augusti, donde destaca la presencia de las denominadas "tinajas globulares de borde curvo vuelto y cordones aplicados" (Alcorta, 2001: 214-217, Figs. 90-91), similares a las legionenses, excep- 
to por las características bandas aplicadas en estos ejemplares lucenses que desempeñarían una función ornamental, a la vez que contribuirían a reforzar su estructura. También en Petavonium son numerosas las tinajas como vasijas de almacenamiento, predominando los ejemplares con aplicaciones decorativas y cuerpo ovoide (Carretero, 2000: 711, Fig. 256).

\subsection{2.- Dolia}

Este segundo tipo de recipientes para guardar provisiones, caracterizado por un cuerpo de tendencia globular $\mathrm{u}$ ovoide, boca muy ancha y abierta y borde vuelto o entrante, se encuentra asimismo ampliamente representado, con un porcentaje del $3 \%$ del total de la cerámica común del vertedero.

En ocasiones pueden estar dotados de asas y presentar motivos decorativos en la parte superior, a base de incisiones onduladas o determinados apliques.

Un rasgo peculiar de estas grandes vasijas es también la presencia ocasional de estampillas, situadas bajo el borde, que ofrecen importantes datos sobre su procedencia.

Se encuadran en el tipo Vegas 49, hallándose en yacimientos de las diversas etapas el Imperio, lo que dificulta su adscripción cronológica (Vegas, 1973: 117-118, Fig. 42).

Desde el punto de vista morfológico destacan los ejemplares con borde reentrante, como el que presenta la pieza que representamos ( $\left.n^{\circ} 604\right)$, y que es un rasgo común a los dolia de este contexto. En este caso presenta un labio engrosado curvo muy marcado, bajo el que se dispone un fino baquetón que rodea perimetralmente la pieza, sin que podamos documentar la presencia de asas.

Con un diámetro de boca de $34 \mathrm{~cm}$. y teniendo en cuenta la trayectoria de las paredes, muy abiertas, que no se han conservado, se trataría de un recipiente de gran envergadura.

Está fabricado con pasta muy poco depurada, con cocción alternante, presentando un tono anaranjado exterior e interior y un núcleo grisáceo. Los desgrasantes son similares en calidad y granulometría a los que componen las pastas de las orzas o tinajas, aunque en el caso de los dolia las pastas son más groseras y consistentes, configurando unas paredes considerablemente más gruesas.

Si bien no hallamos en este conjunto de dolia ningún ejemplar con asas, motivos decorativos ni estampillas, hemos de destacar el tratamiento exterior que presenta la pieza descrita, consistente en una ligera engalba grisácea, sin que llegue a constituir un engobe propiamente dicho.

Los paralelos morfológicos para estos recipientes destinados al almacenamiento y conservación de productos diversos (generalmente grano y cereales, harina, frutas, líquidos como agua, aceite y vino) son muy numerosos en los distintos yacimientos peninsulares, destacando los de Conimbriga (Alarçao, 1975: Fig. 928) Varea (Luezas y Sáenz Preciado, 1989: 189-191, Láms XXXVIII, no 154-156; XXXIX, nº 160), La Rioja (Luezas, 2002: 133-146, Fig. 51), Petavonium (Carretero, 2000: Fig. 362, nº 260) o Lucus Augusti (Alcorta, 2001: 218- 222, Fig. 92-93), núcleo en el que se registra una gran diversidad morfológica en estos recipientes de almacenaje. 


\section{4.- MORTEROS (Lám. 67)}

Estos recipientes, muy característicos de la cerámica romana por las razones ya aducidas, tienen una escasa representación en el vertedero, con un $2 \%$ del total. En este reducido número ha podido influir el estado fragmentario de las piezas y su deficiente estado de conservación, que dificultan la contabilización de ejemplares.

Estas singulares piezas cuya morfología, función y rasgos evolutivos, ya hemos descrito en otros apartados de este estudio dedicados a los mortaria hallados en las demás áreas de vertidos, alcanzan especial significación en los contextos militares como el que nos ocupa, dado que constituye un utensilio básico en la impedimenta del soldado romano.

En primer lugar, además de su escasa proporción, hemos de hacer hincapié en la homogeneidad morfológica de estos ejemplares, al igual que se ponía de manifiesto en otras categorías cerámicas como los recipientes de almacenaje.

De esta manera, si en otros vertederos legionenses como en el de San Pedro (vid. supra, Lám. 25) o en el de la C/Maestro Copín (Fernández Freile, 2003: 130-132, Láms. 94-96), pueden diferenciarse varias formas en función de sus características morfológicas, técnicas y cronológicas, en las que aparecen rasgos de los dos principales tipos en la clasificación de estas piezas (Dramont D1 y Dramont D2), en este reducido conjunto la clasificación resulta mucho más simple, por la ya comentada uniformidad tipológica.

Se trata en todos los casos de morteros con el borde vuelto al exterior, colgante, presentando en algunos casos como en la pieza $\mathrm{n}^{\circ} 605$, de $23 \mathrm{~cm}$. de diámetro de boca, una ranura perimetral y uno de los orificios con que cuentan algunos de estos recipientes para ser colgados y transportados. En la pieza $n^{\circ} 606$ se aprecia el marcado baquetón con que el borde se une al cuerpo. En el ejemplar $n^{\circ} 607$ la vertedera es apenas sobresaliente, prácticamente integrada en el borde, con dos profundas acanaladuras oblicuas y el cuerpo presenta paredes exvasadas curvas de considerable grosor, que terminarían probablemente en una base plana.

En todos ellos destaca la calidad en su factura, con un predominio de cocciones generalmente oxidantes que proporcionan unas tonalidades ocres y anaranjadas, con desgrasantes cuarcíticos y micáceos de granulometría media, visibles en superficie. El área de frotación incluye piedrecillas y fragmentos arenosos de diversos tamaños, aunque se encuentra cuidadosamente delimitada.

Partiendo de los rasgos morfológicos descritos, estos ejemplares de imitación podrían adscribirse al tipo Dramont D2, más evolucionado conológicamente, que surge en época de Tiberio, perdurando hasta el final de la etapa antonina.

\section{5.- LUCERNAS (Lám. 68)}

El conjunto de material lucernario recuperado en esta fase del vertedero es realmente exiguo, pues su estado extremadamente fragmentario sólo nos indica algunos rasgos técnicos, y hace que contemos únicamente con siete fragmentos con posibilidad de analizar alguna de sus características, fundamentalmente decorativas, pues seis de ellos corresponden a fragmentos de discos decorados y otro a un asa plástica, sin que ningún ejemplar conserve algún otro rasgo morfológico definitorio que permita una adscripción tipológica concreta. 
Este porcentaje tan reducido de fragmentos lucernarios y su pésimo estado de conservación, contrasta con el importante porcentaje de lucernas halladas en la mayoría de las excavaciones de la ciudad ${ }^{138}$, en las que pueden definirse sin demasiada dificultad los distintos tipos, ya que no aparecen en estado tan fragmentario y su conservación permite un análisis más completo y riguroso.

Con todo, tomaremos como base el contexto estratigráfico, con el fin de identificar los tipos más frecuentes del momento y poder esbozar una somera clasificación, además de tratar otros factores relacionados con la fabricación y distribución del material lychcnológico, que presenta especial significación en las áreas militares.

Los fragmentos que analizaremos se localizan en las UU.EE pertenecientes a la segunda mitad del siglo I d. C. tratándose por tanto con toda probabilidad de lucernas de volutas en su mayoría, propias de esta época, si bien en muchos casos perduran hasta la etapa flavia e incluso en algunos contextos de Legio y otros yacimientos del noroeste las hallamos presentes en la segunda centuria.

Desde el punto de vista técnico destaca la gran calidad en las pastas, muy finas y depuradas, predominando los tonos blanquecinos y amarillentos, así como en la ejecución de las orlas y molduras. Sobre todo en el plano decorativo se advierte una gran perfección y detallismo en los diferentes temas iconográficos plasmados en los escasos fragmentos de "disci" conservados con decoración identificable (Lám. 68).

En la pieza $\mathrm{n}^{\mathrm{o}} 608$ aparece representado un tema mitológico, con el torso del dios Júpiter y delante un águila con las alas desplegadas.

Los ejemplares $n^{\circ} 609$ y 610 reflejan escenas de anfiteatro o de tipo gladiatorio, uno de los temas más frecuentes en la iconografía lucernaria. El no 609 representa el torso de un gladiador con casco, escudo, grebas y probablemente una espada, en actitud de lucha, mientras que en el $\mathrm{n}^{\circ}$ 610, que conserva las dos orlas semicirculares de la margo, aparece el brazo de perfil de un gladiador samnita con grebas y su característica espada corta o sica.

La pieza $n^{\circ} 611$, que también conserva las características orlas, muestra un personaje que por sus grotescos caracteres podemos atribuir a un fauno, probablemente tocando algún instrumento musical.

El fragmento $\mathrm{n}^{\mathrm{o}} 612$ reproduce un motivo zoomórfico, parte del cuerpo de un ave, realizado con tal calidad y detallismo que puede identificarse sin ninguna duda con una cigüeña.

La pieza $n^{\circ} 613$ se trata de una de las características asas que portan algunas lucernas y que han tomado la denominación de "asas plásticas", dado que suelen adornarse con diversos motivos decorativos, en algunos casos muy elaborados. En esta pieza, debido a su fragmentación, únicamente podemos reconocer motivos ornamentales vegetales y geométricos.

Finalmente, el fragmento $\mathrm{n}^{\circ} 614$ presenta unas características formales y decorativas que permiten la identificación del tipo morfológico de la lucerna a la que perte-

138 Vid. a este respecto el trabajo de MORILLO sobre las lucernas de la región septentrional, en el que incluye piezas de varios solares leoneses (1999: 446-482), y el material lucernario recuperado en el vertedero de la C / Maestro Copín FERNÁNDEZ FREILE. (2003: 116-119). 
nece, debido a su motivo decorativo principal, una vénera de gallones, típica de las lucernas derivadas del tipo Dressel 3. Aún así, únicamente se conservan parte de las dos molduras y tres gallones.

Este tema constituye asimismo un motivo muy recurrente en las lucernas, teniendo en cuenta la fácil adaptación al discus de esta composición circular a base de gallones cóncavos, lo que implica un alto porcentaje de material lucernario en los yacimientos con esta iconografía139.

Este tipo de lucerna presenta características muy específicas en los yacimientos hispanos, ya que fue localizada en los vertederos de Los Villares de Andújar, conociéndose también por esta circunstancia como "tipo Andújar", que sería el centro productor. Es por tanto, un tipo muy abundante en la Bética en la etapa julio-claudia, aunque se hallan perduraciones hasta la época flavia (López Rodríguez, 1981: 100).

Con todo, algunos investigadores han planteado la existencia de otros alfares de producción en la zona que fabricaran posiblemente imitaciones de este tipo lucernario para abastecer la creciente demanda (Amaré, 1988: 40; Bernal, 1993: 210).

Aunque su principal zona de difusión es el territorio bético, a medida que avanzan las excavaciones son más frecuentes los hallazgos de este tipo de lucernas también en enclaves del norte peninsular y, además, de numerosos hallazgos aislados en toda la zona septentrional (Morillo, 1992: mapa XI).

Resultan especialmente abundantes, según subraya Carretero (2000: 752), en las áreas caracterizadas por la presencia militar, haciendo alusión a los recintos campamentales de León, Astorga y Petavonium, a los que podríamos añadir Herrera de Pisuerga, donde también se han localizado algunos de estos ejemplares, poniendo de manifiesto el preferente uso de los soldados acantonados en estos campamentos del norte por este tipo de lucernas. Ello ha hecho plantear a algunos investigadores, ya que no se constata la importación de otras cerámicas de la Bética, la posibilidad de la existencia de algún taller en esta zona de fabricación de estas lucernas de imitación de las béticas, sin embargo carecemos hasta el momento de toda evidencia arqueológica al respecto.

Más plausible resulta la hipótesis que mantienen los principales investigadores sobre la comercialización de las lucernas del sur a la vez que el aceite bético, al que están estrechamente vinculadas, a través de la Vía de la Plata (Morillo, 1992: 105-106; Bernal, 1993: 219-220; Carretero, 2000: 754), bien desde Andújar, o como propone Carretero (Ibid.: 754), de otros posibles talleres instalados probablemente en Corduba o en Emerita Augusta.

Teniendo en cuenta el lapso cronológico de vigencia de estas lucernas "tipo Andújar", desde mediados del siglo I d. C. podríamos adscribirlas a la etapa de permanencia en el campamento de León de la Legio VI Victrix. Sin embargo, el largo período de permanencia de estos productos -presentes durante la época flavia e incluso durante el siglo II d. C.-, además del gusto desarrollado por este tipo de lucerna por

139 Así, en Herrera de Pisuerga se han localizado cuatro ejemplares (Morillo, 1992: 136; Figs. 11, 3, $5,11)$, además de una serie de fragmentos de muy escaso tamaño; en Astorga han aparecido seis piezas (Morillo, 1999: 245), en León, en el vertedero del depósito de San Pedro aquí estudiado se han hallado seis ejemplares, en el yacimiento de Pallarés dos y uno más en la excavación de la C/Pablo Flórez (Morillo, 1999: 245-246; 245; 481) y en el campamento de Petavonium se han hallado quince piezas muy fragmentadas (Carretero, 2000: 752), de las que destacan cuatro más completas (Ibid. Fig. 378, nº 1-4). 
el elemento militar, como confirman los citados hallazgos en campamentos cercanos, y la consolidación de su eje de comercialización, no descarta que formaran parte de las producciones cerámicas utilizadas por la Legio VII Gemina, aunque fuera con carácter residual.

\section{6.- ÁNFORAS (Lám. 69)}

Al igual que el material lychnológico, el porcentaje de material anfórico en esta área de vertidos es asimismo mínimo, con un $2 \%$ de piezas respecto al total.

Resulta llamativo en este contexto la importante desigualdad entre la representación cuantitativa de las distintas especies cerámicas (aún contando siempre con la mayor representación numérica de la cerámica común, que constituye un rasgo común a todos los contextos), sin embargo en los dos vertederos estudiados anteriormente la distribución se presenta más pareja.

Como ya hemos descrito ampliamente al tratar el material anfórico del vertedero de San Pedro, donde alcanza elevados índices de cantidad y variedad, incidiendo, además en la descripción de las piezas y en los aspectos distributivos y comerciales, así como en la procedencia, centros de fabricación, productos transportados y otros elementos que caracterizan a estos envases y que son propios de áreas militares como la que nos ocupa, nos limitaremos aquí a reseñar sus características técnicas, tipológicas, funcionales, origen y cronología, intentando localizar los paralelos más cercanos.

Las dos primeras piezas ( $\mathrm{n}^{\mathrm{o}} 615$ y 616) presentan un cuello cilíndrico, rematado en un labio de sección redondeada. En la $\mathrm{n}^{\circ} 615$, de $8,5 \mathrm{~cm}$. de diámetro de boca, la pasta es de color ocre rosácea en el interior, aunque este ejemplar presenta cocción alterna, con el exterior de tonalidad anaranjada. Puede apreciarse la utilización de un desgrasante cuarcítico muy fino y pequeñas motitas de mica en la cara interior y exterior. En la cara externa presenta una engalba blanquecina en una capa muy fina muy poco consistente.

La pieza $n^{\circ} 616$ está elaborada con pasta anaranjada en la que se aprecian también desgrasantes cuarcíticos y micáceos de muy pequeña granulometría. En la cara externa muestra una engalba blanquecina consistente y bien adherida.

Estas características indican una cuidada fabricación, pero no se trataría de envases de procedencia campana como los localizados en Asturica (Carreras y Berni, 2003: 645), sino que, por sus rasgos y componentes, su procedencia ha de ubicarse en los talleres del área del Guadalquivir o quizá en los de la Tarraconense, que alcanzan asimismo gran difusión.

Desde el punto de vista morfológico ambos fragmentos se adscriben a uno de los tipos de ánforas más difundidos del Imperio, la denominada Dressel 2-4, a cuya morfología podemos añadir la pieza $n^{\circ} 617$, un asa bífida con perfil en forma de ocho, característica de este tipo de ánfora, dedicada al envase y transporte de vinos.

Sus orígenes se encuentran en puntos del Mediterráneo oriental, en el ámbito griego, hacia el siglo III a. C. y en el siglo II a. C. se localizan en Albintimilium, para alcanzar un mayor esplendor en época de Augusto, comenzando un período de expansión por los principales establecimientos militares del Imperio y otras áreas como el norte de Africa. En Hispania se encuentran numerosos ejemplares de este tipo en Celsa 
(Beltrán, 1997: 70-72; Fig. 27, no 4-12; figs. 29-37) o Arcobriga (Sánchez, J. C. 1992: 287288, Fig. 9, n' 5).

La cronología de su desaparición ha sido más controvertida en la investigación, pero a partir de los nuevos hallazgos puede afirmarse que, tras un auge en la etapa flavia, va desapareciendo progresivamente desde mediados a finales de la segunda centuria, encontrándose incluso algún ejemplar en contextos del siglo III d. C.

Entre las últimas aportaciones en la investigación sobre este tipo de ánfora cabe destacar la individualización en el área de Tarraco, de la producción de un ánfora de rasgos similares en conjunto, pero con algunas características diferenciales, especialmente en la configuración de las asas y el borde y con un mayor tamaño (Járrega y Otiña, 2008: 281-286), definiendo así un nuevo tipo al que se ha dado en llamar "Dressel 2-4 evolucionada". Su cronología es también diferente, encontrándose fundamentalmente en contextos de finales del siglo II d. C. y principios de la tercera centuria. 
LÁMINAS 

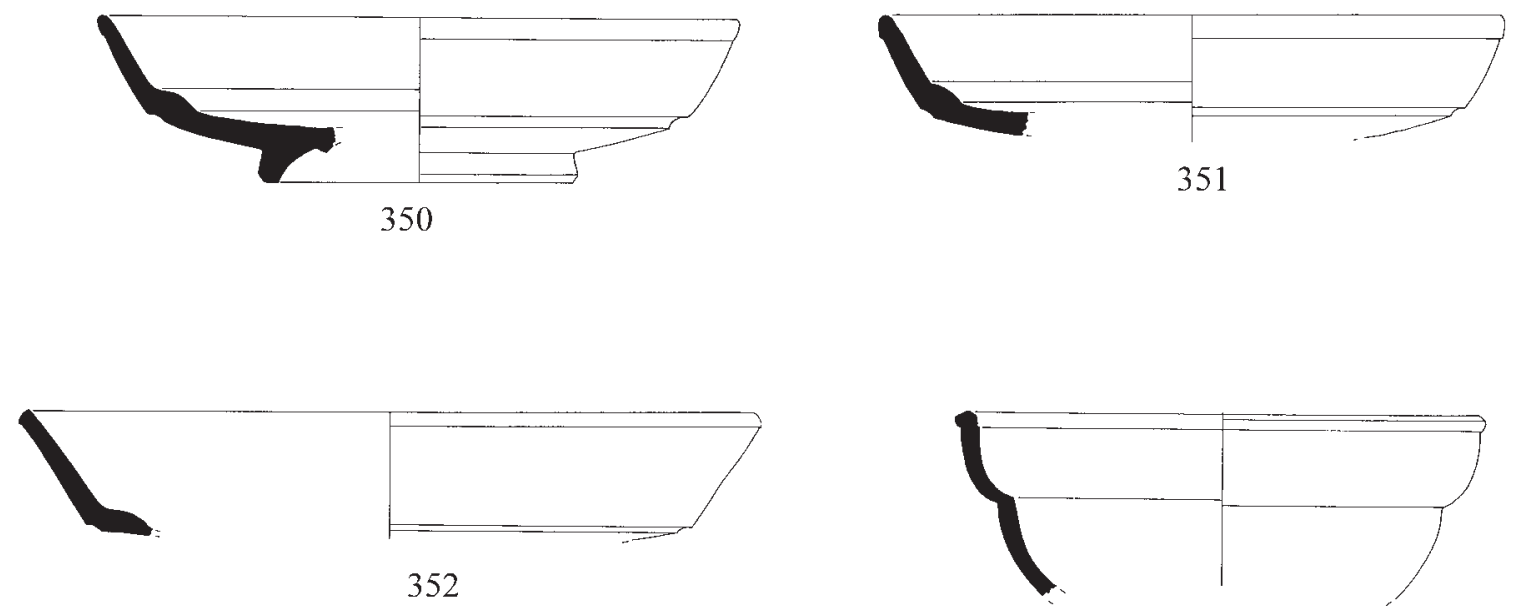

353

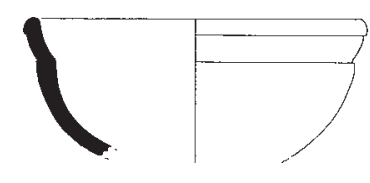

354

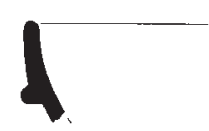

358
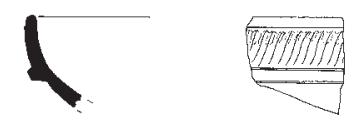

361

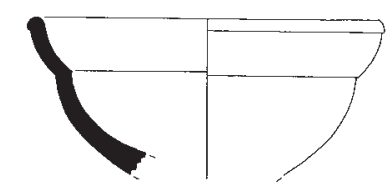

355

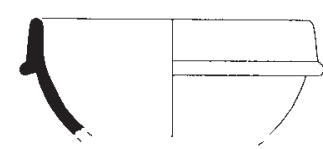

359

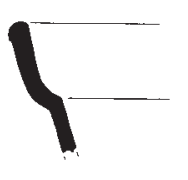

356

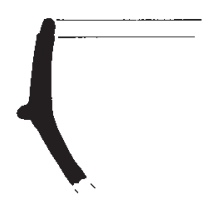

360
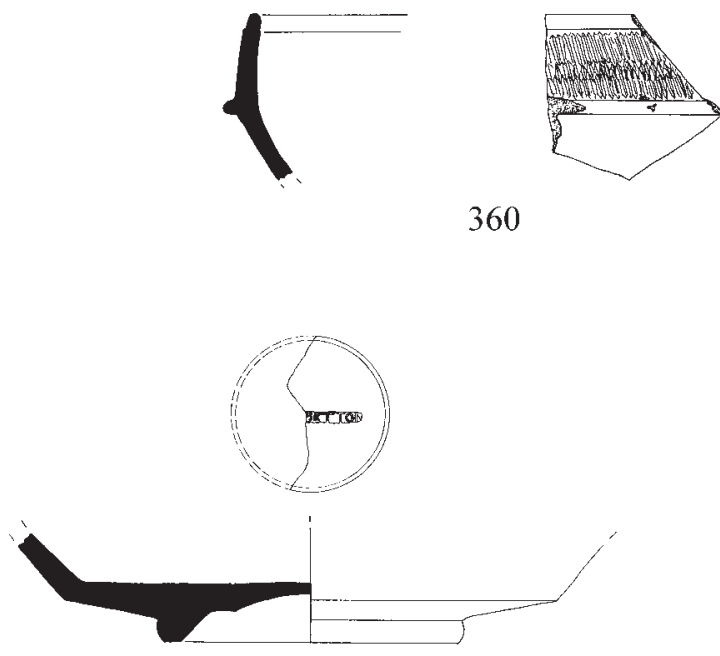

362

Lámina 40 


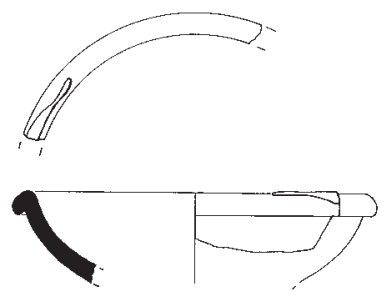

363
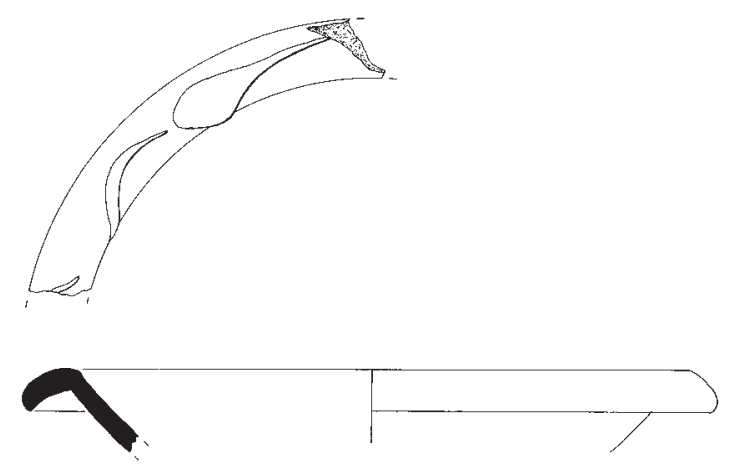

366
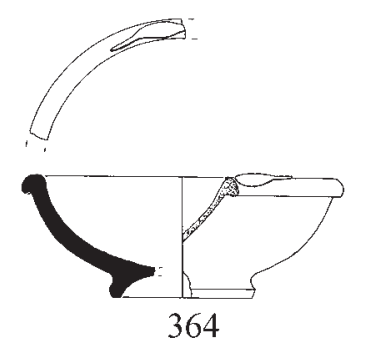

364
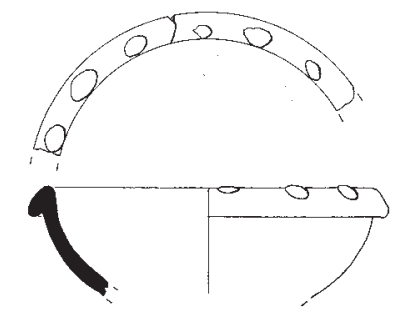

365
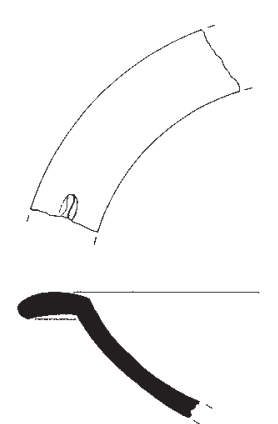

367
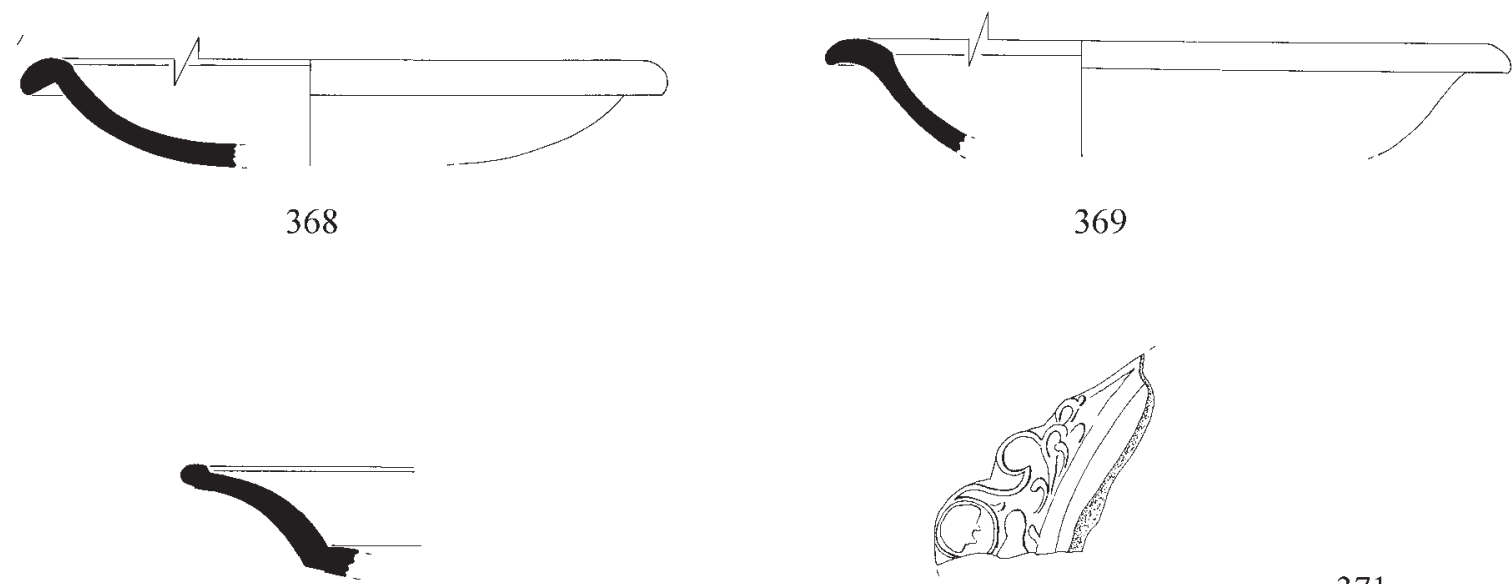

370

Lámina 41 

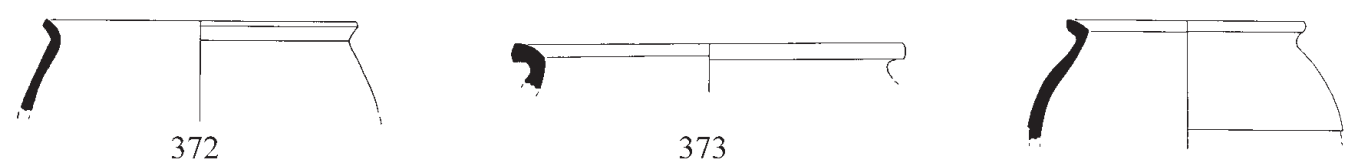

374

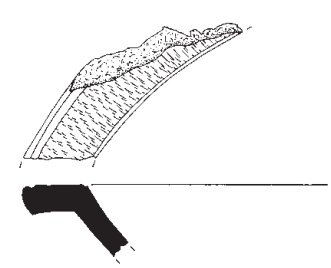

375

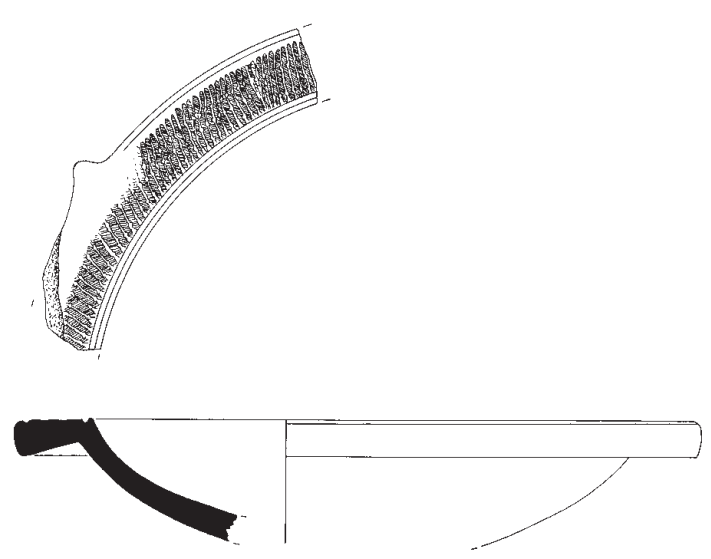

377

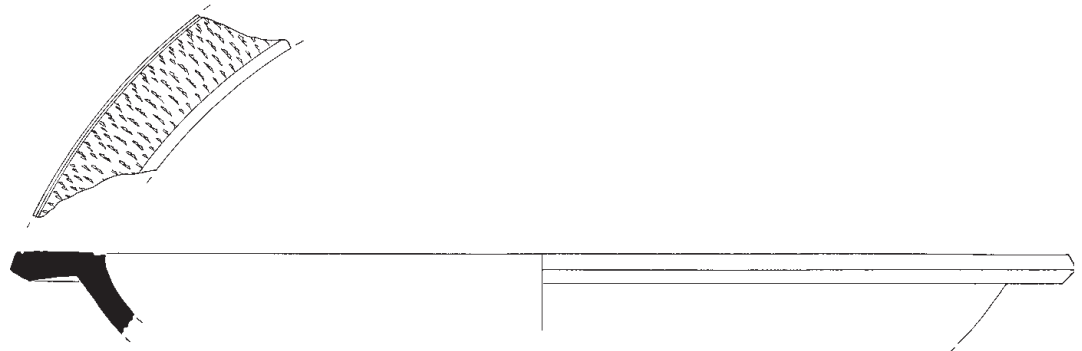

376

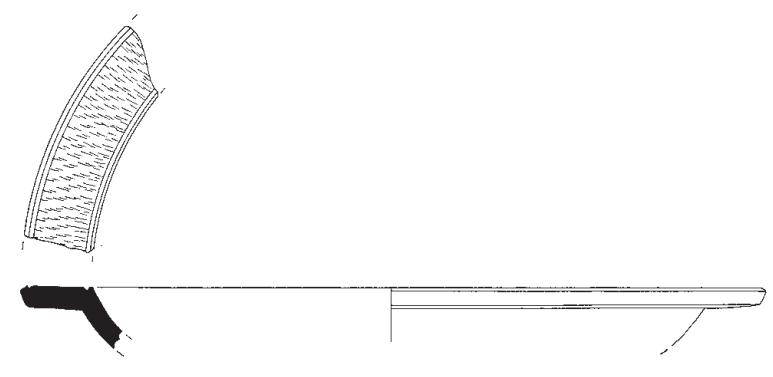

378

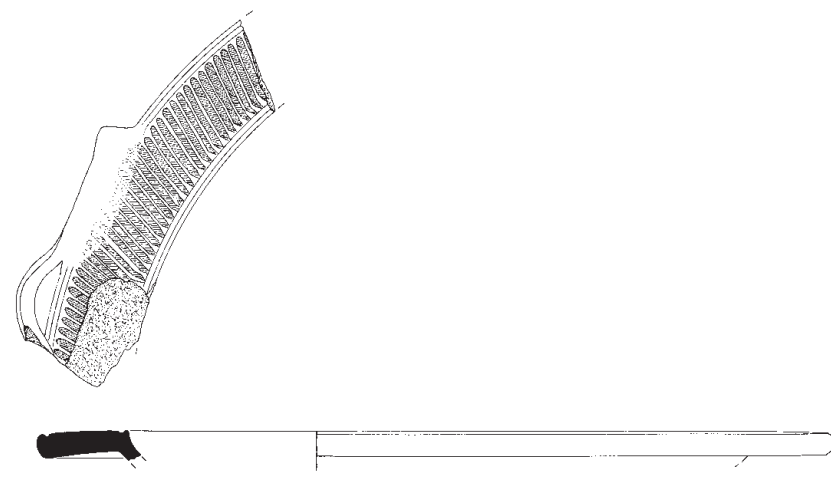

379

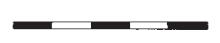

Lámina 42 


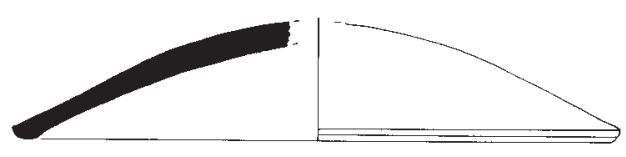

380

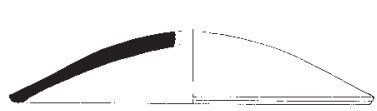

383

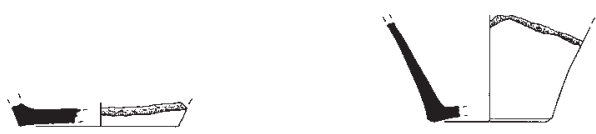

381

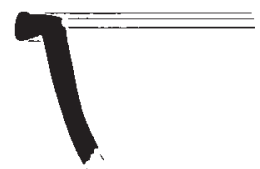

385

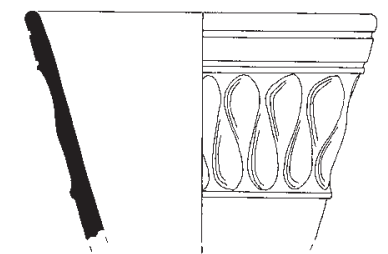

384
386

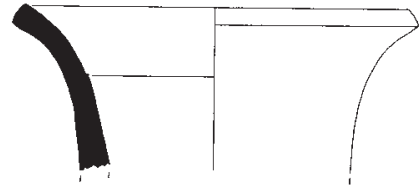

Lámina 43 


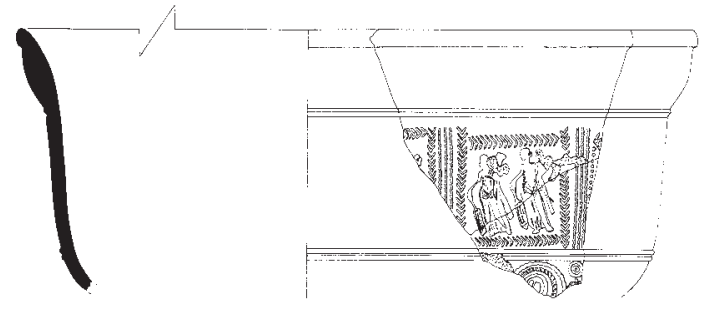

387

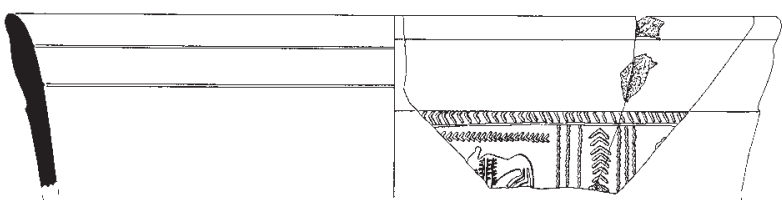

389
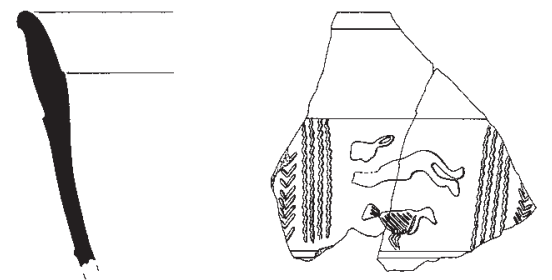

391
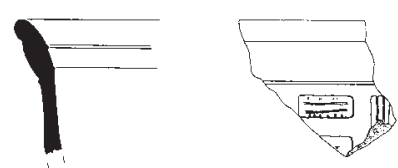

388
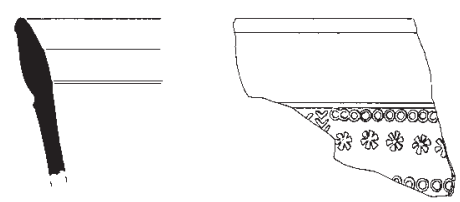

390
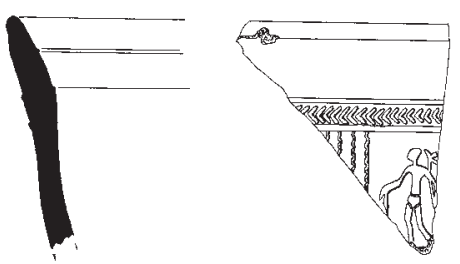

392

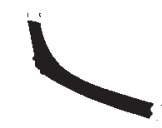

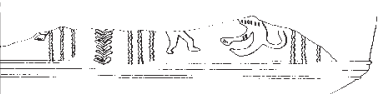
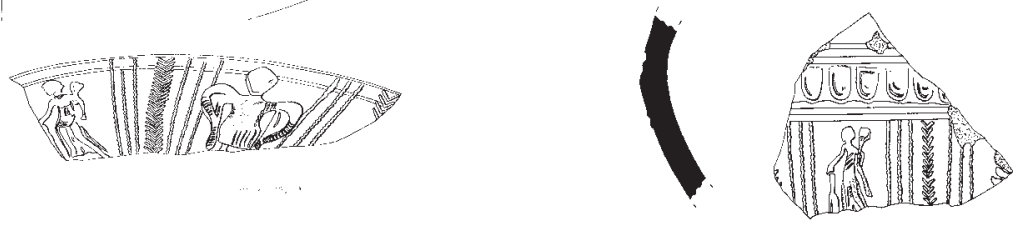

394 

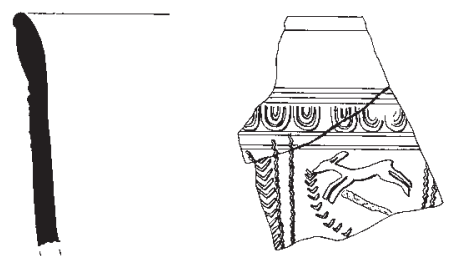

395
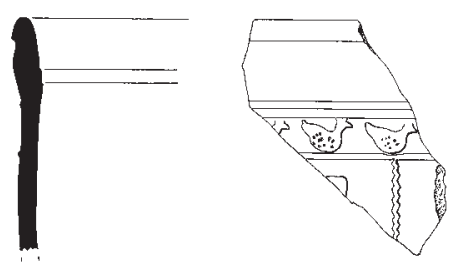

397

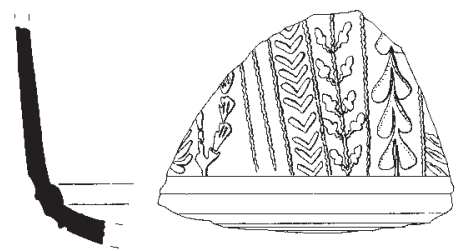

399

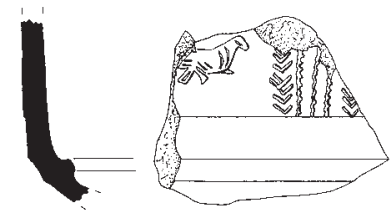

401

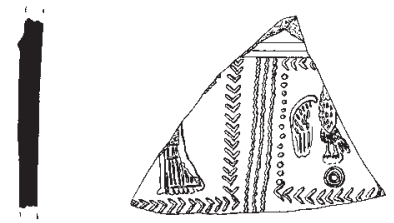

403
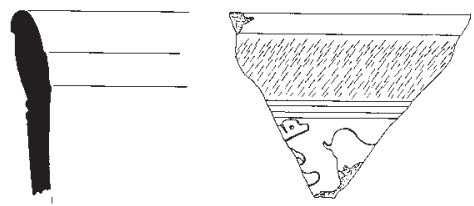

396

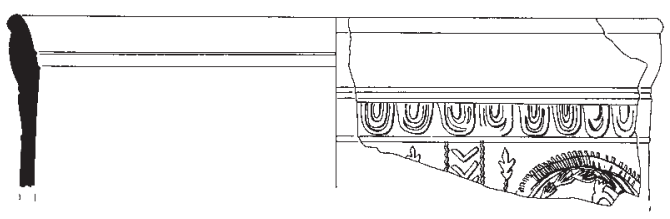

398

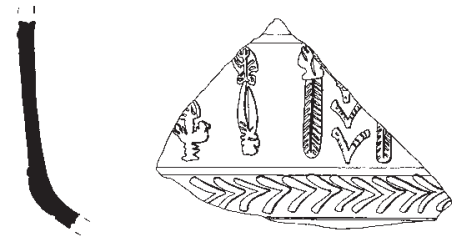

400

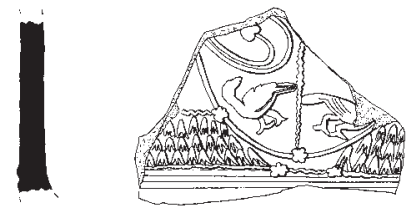

402
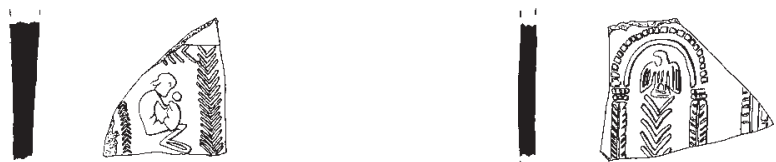

404

405 

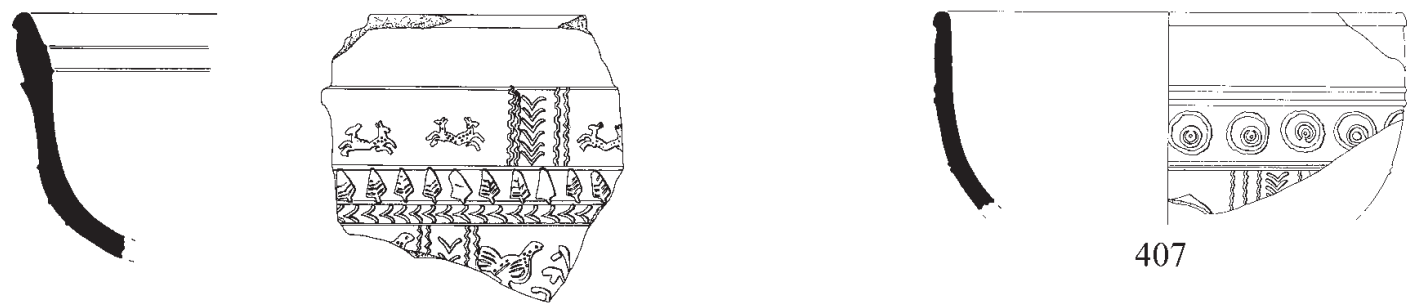

406
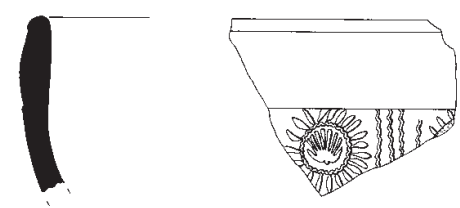

408
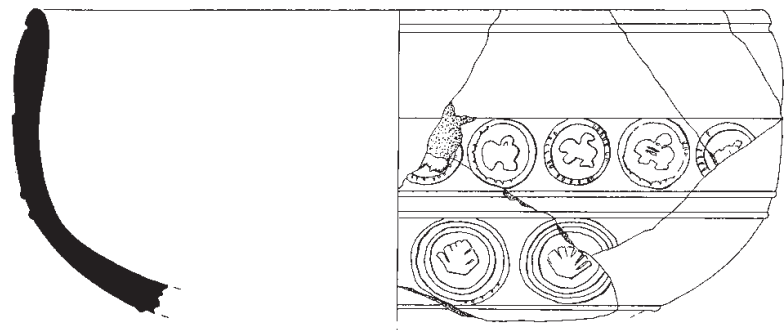

409

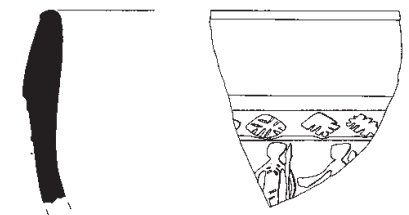

410

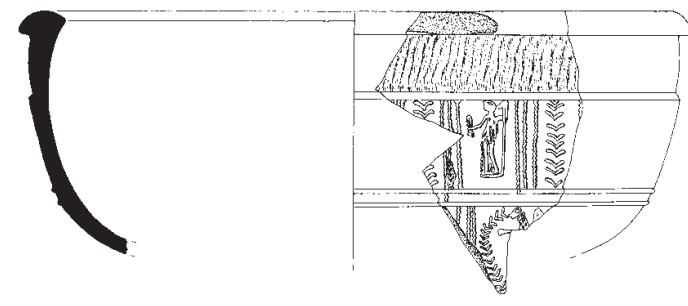

411
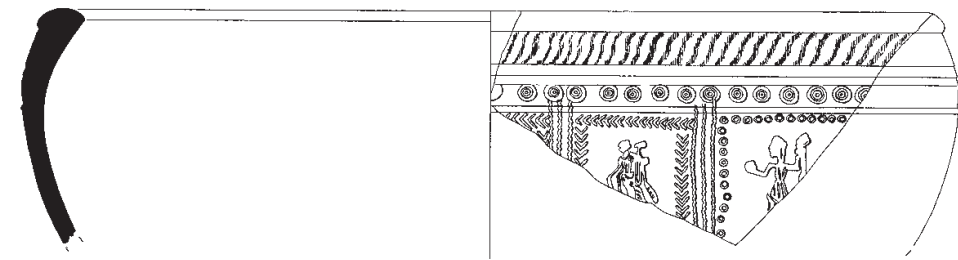

412

Lámina 46 


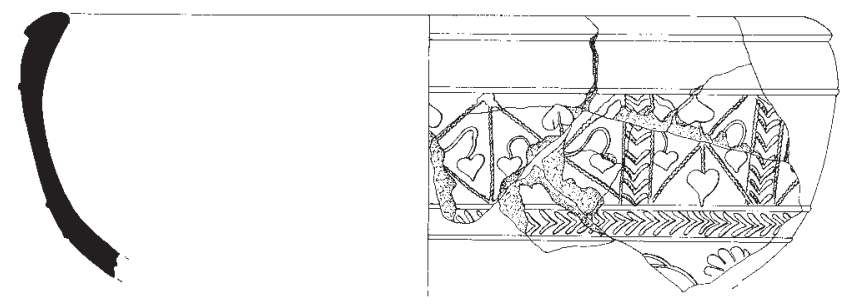

413

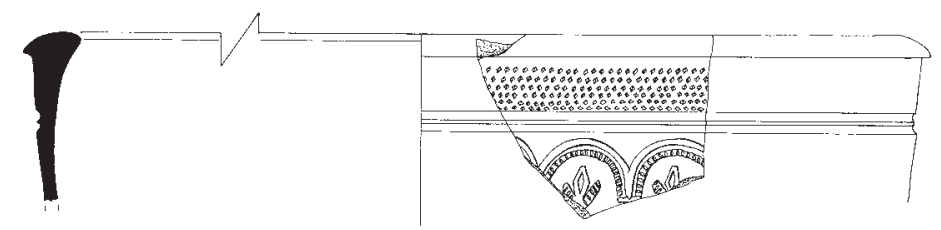

414

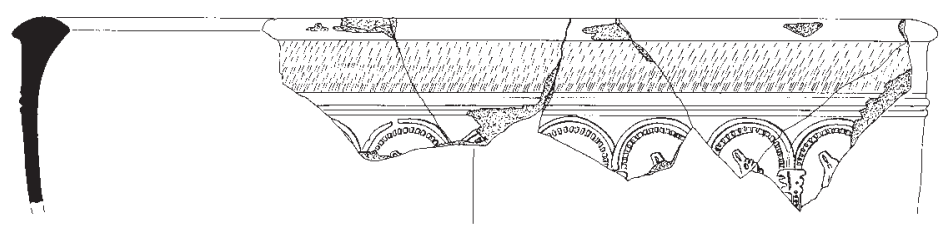

415
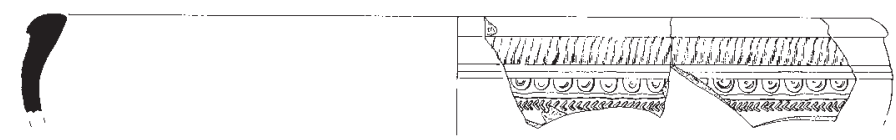

416

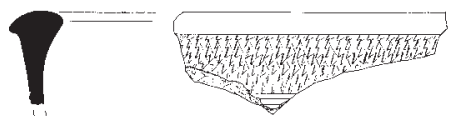

417

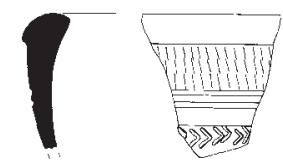

420

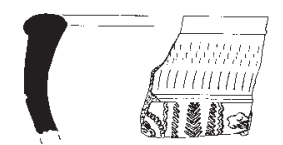

418
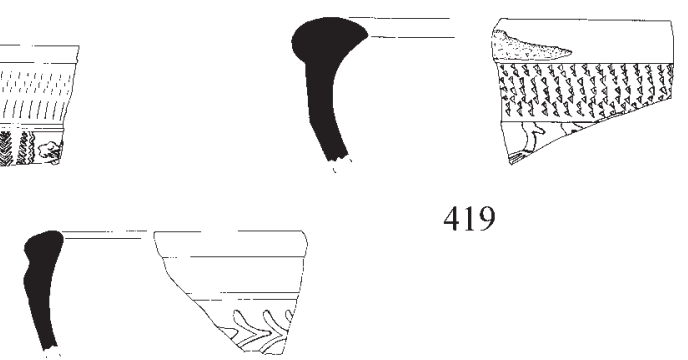

421

Lámina 47 


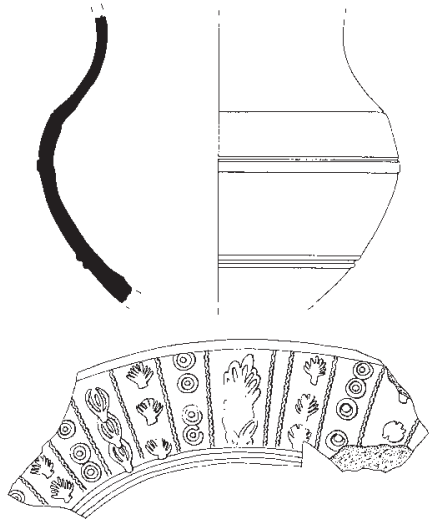

422

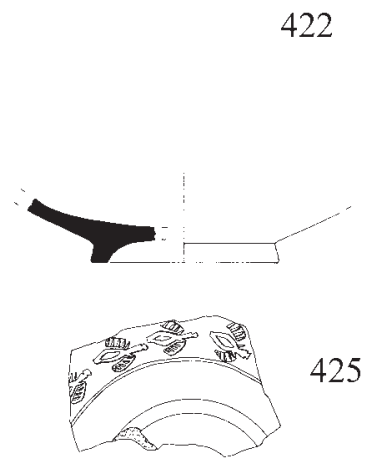

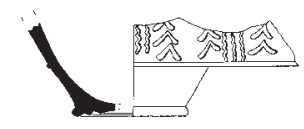

423
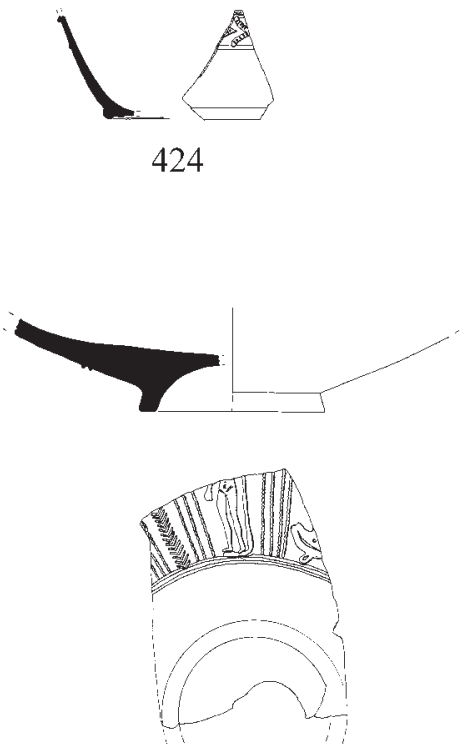

426

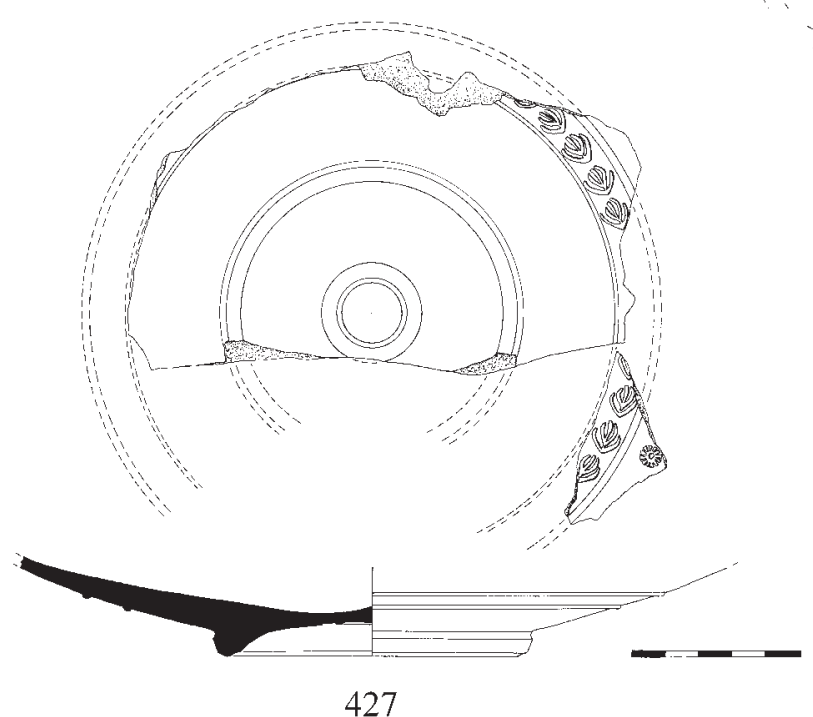

Lámina 48 


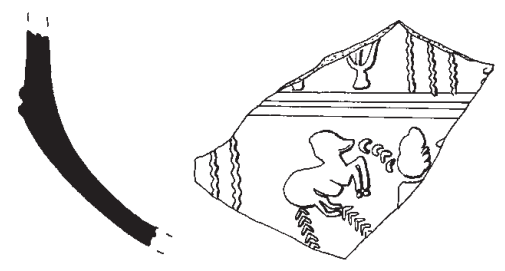

428
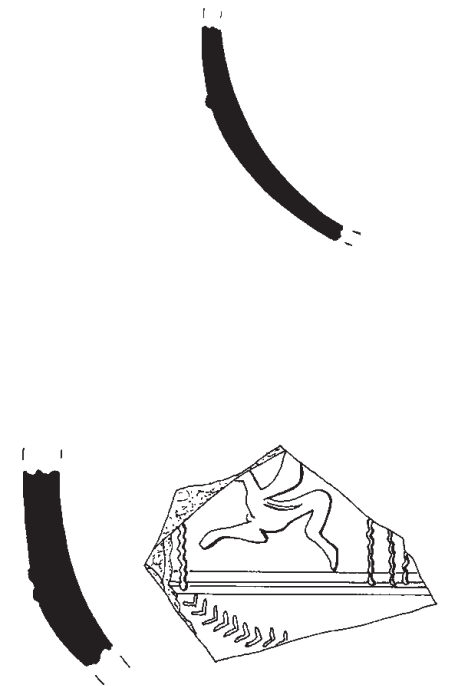

432
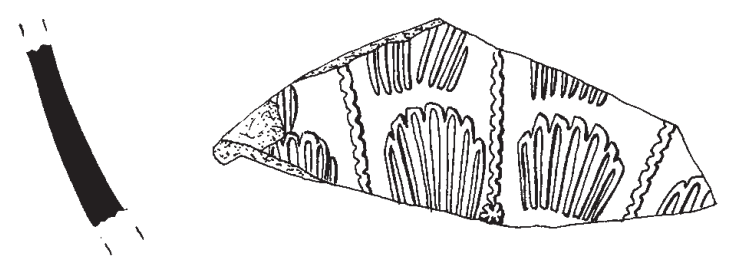

434

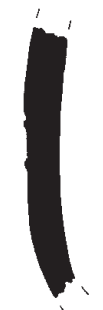

431

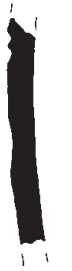

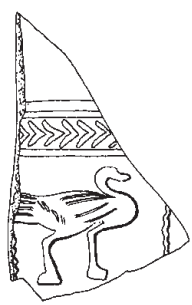

429

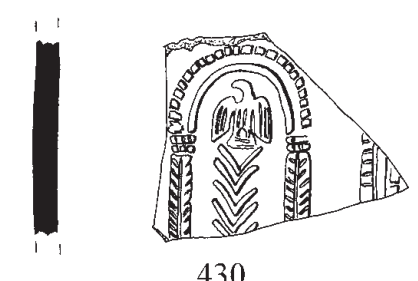

430
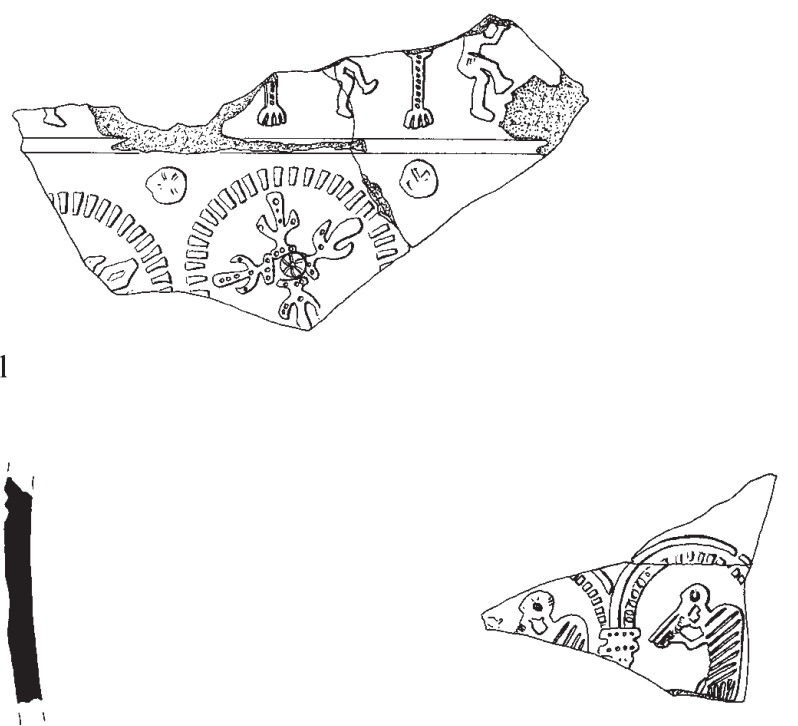

433
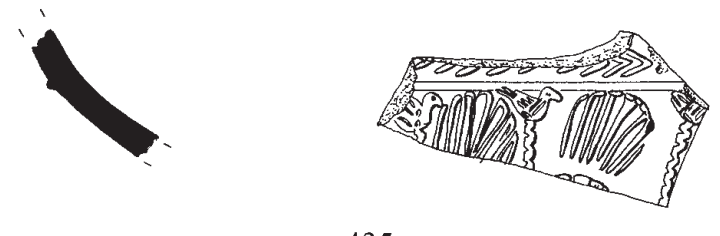

435

Lámina 49 


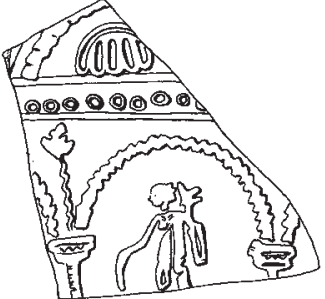

436

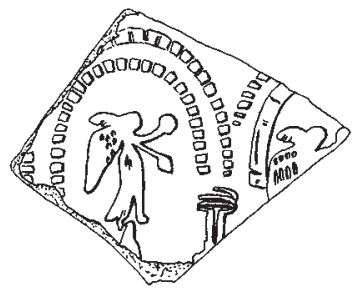

437

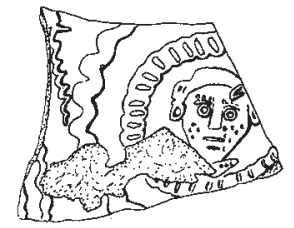

438

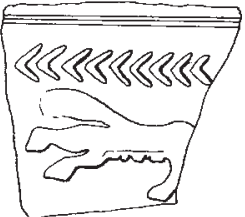

442

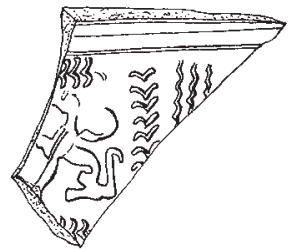

443

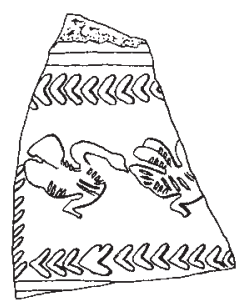

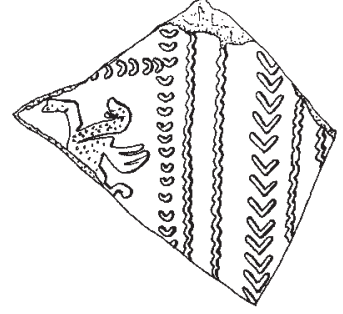

444

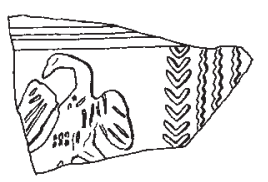

448

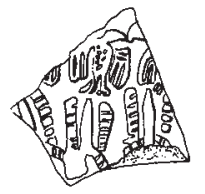

451

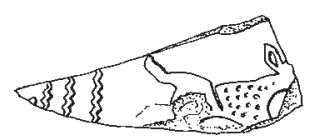

441

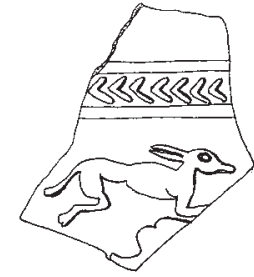

445

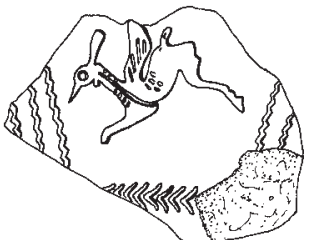

446

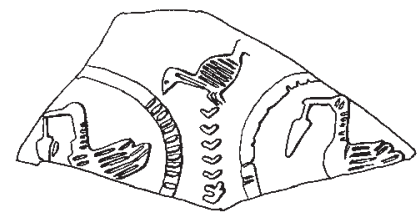

449

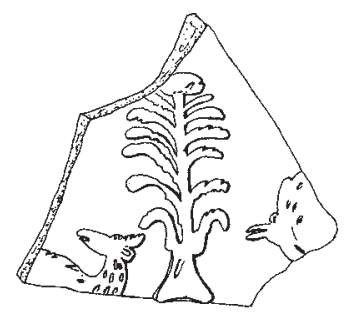

452

Lámina 50 


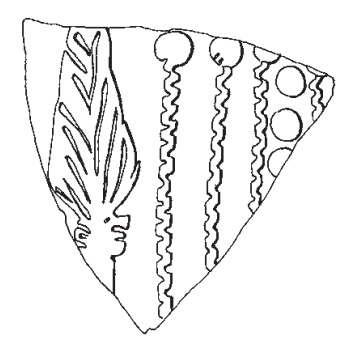

453

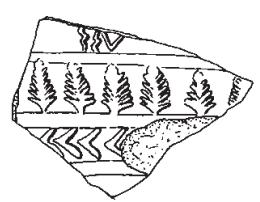

456

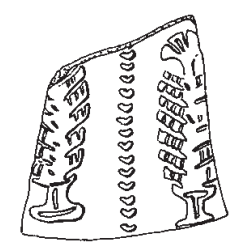

454

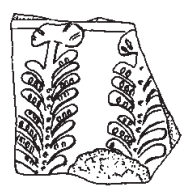

457
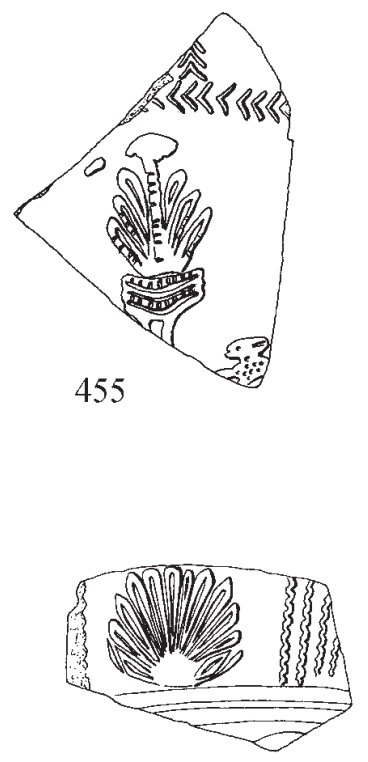

458

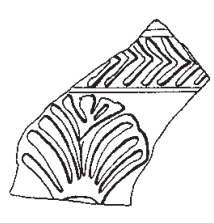

459

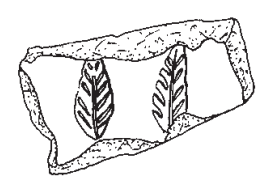

460

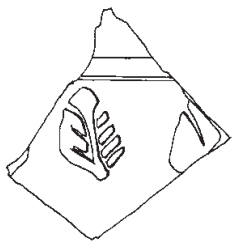

461

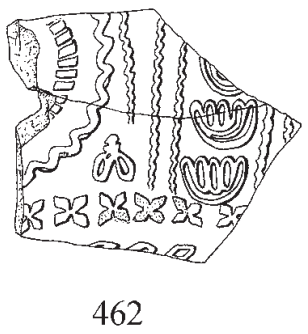

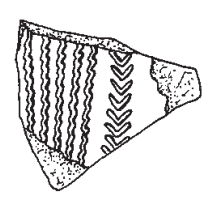

463

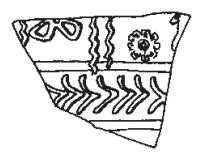

464

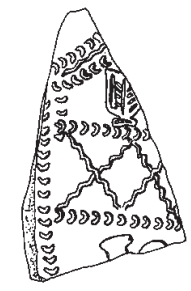

465

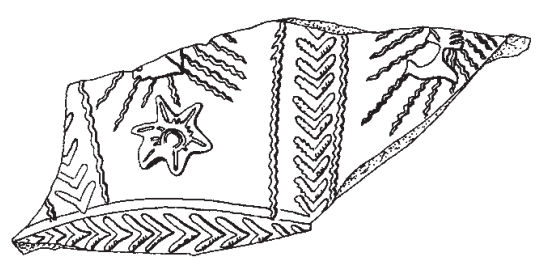

466 

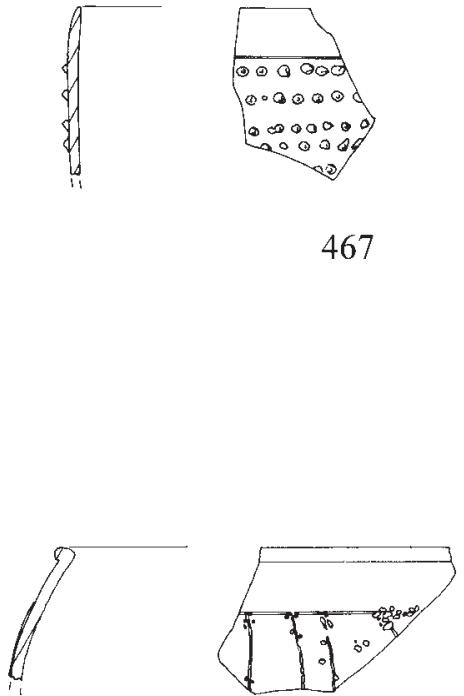

469

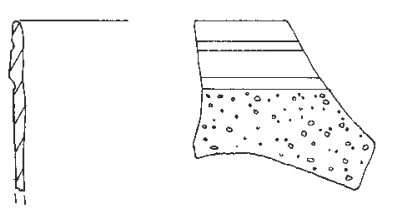

471

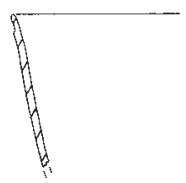

473

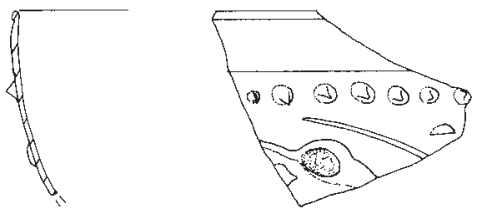

468

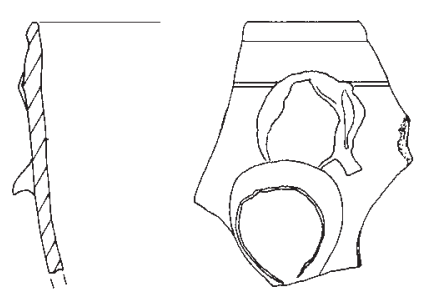

470

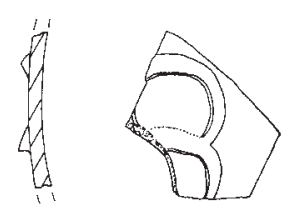

472

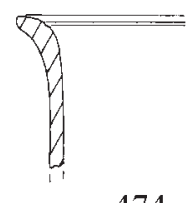

474

Lámina 52 


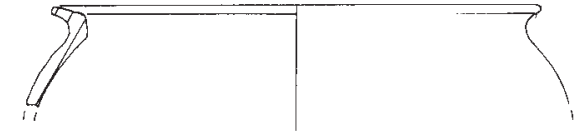

475

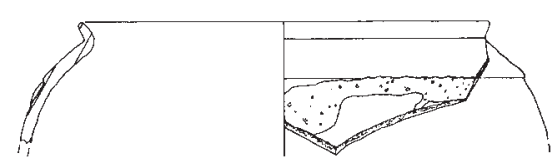

477
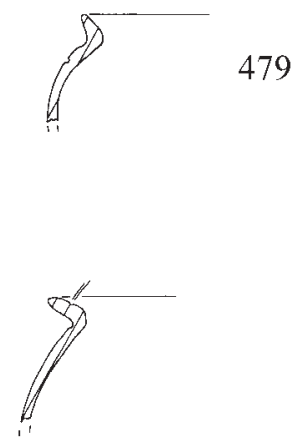

482

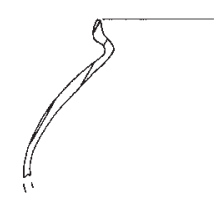

483

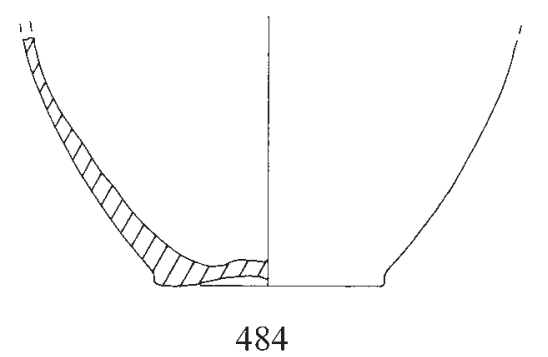

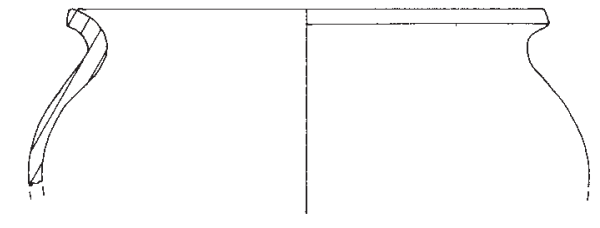

476

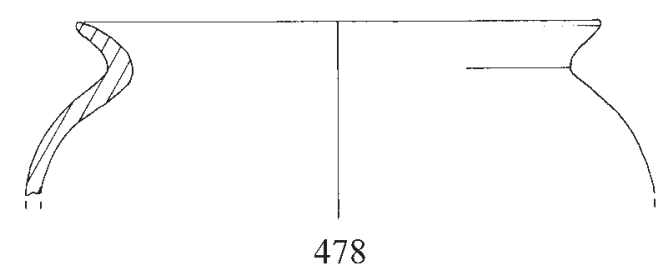

480

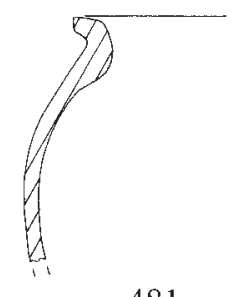

481

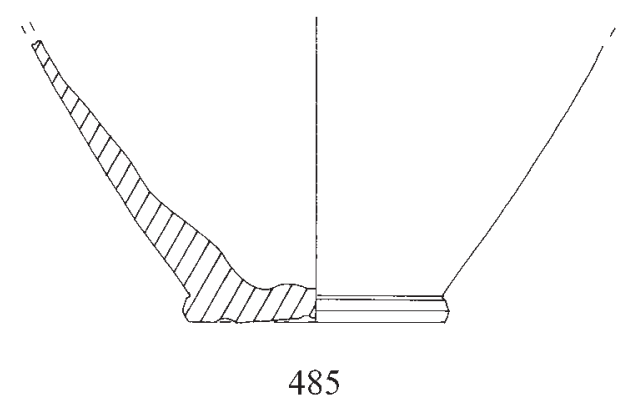

Lámina 53 

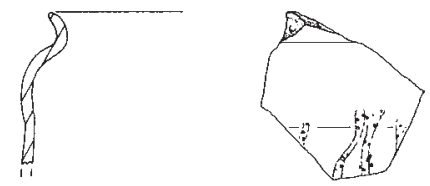

486

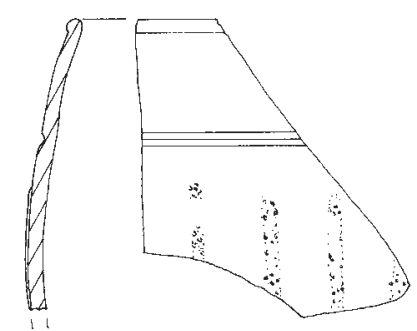

488
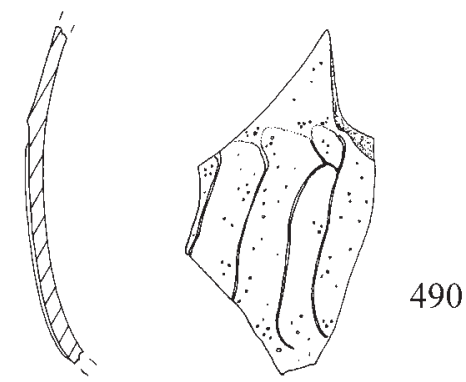

490
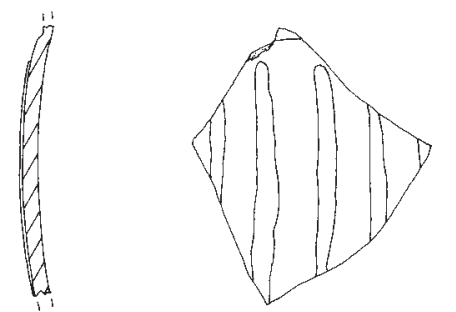

492
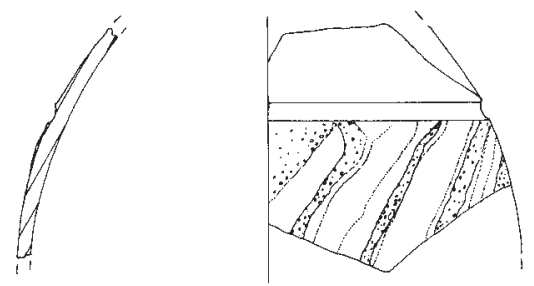

491
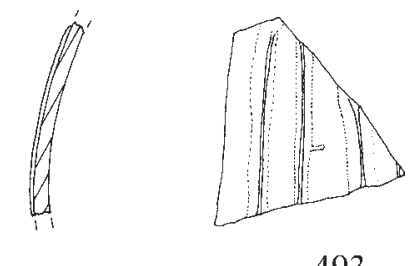

493

Lámina 54 


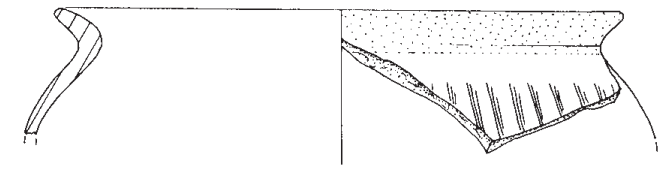

494
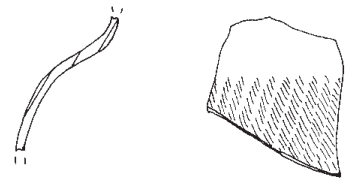

496
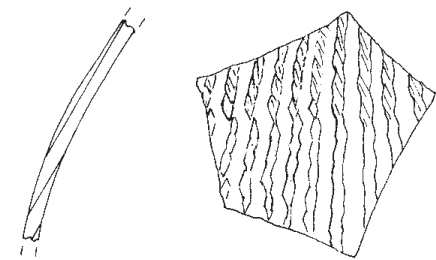

498

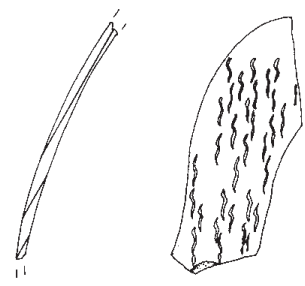

500

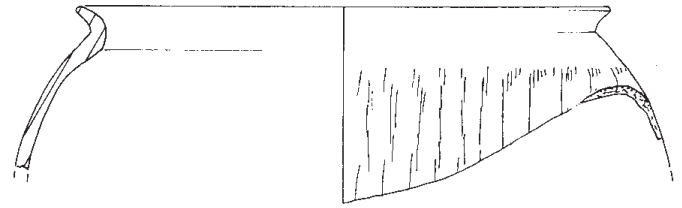

495

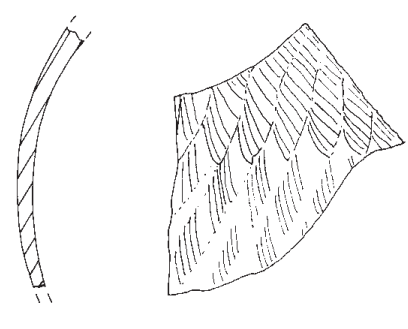

497

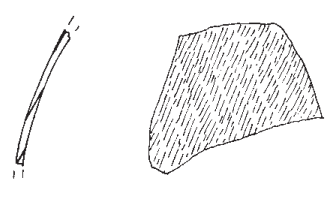

499

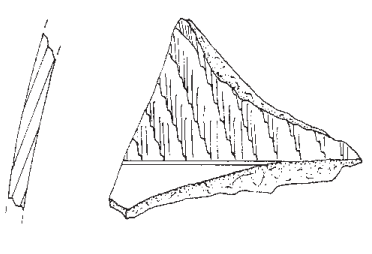

501

Lámina 55 

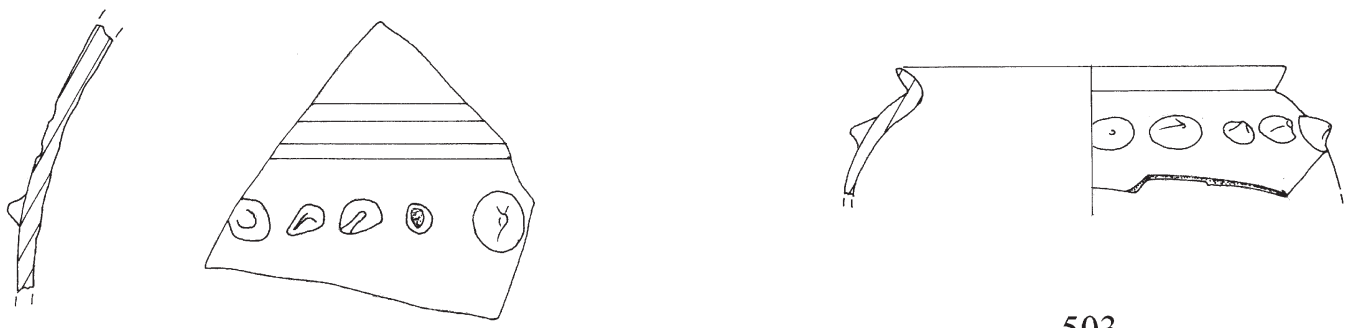

502
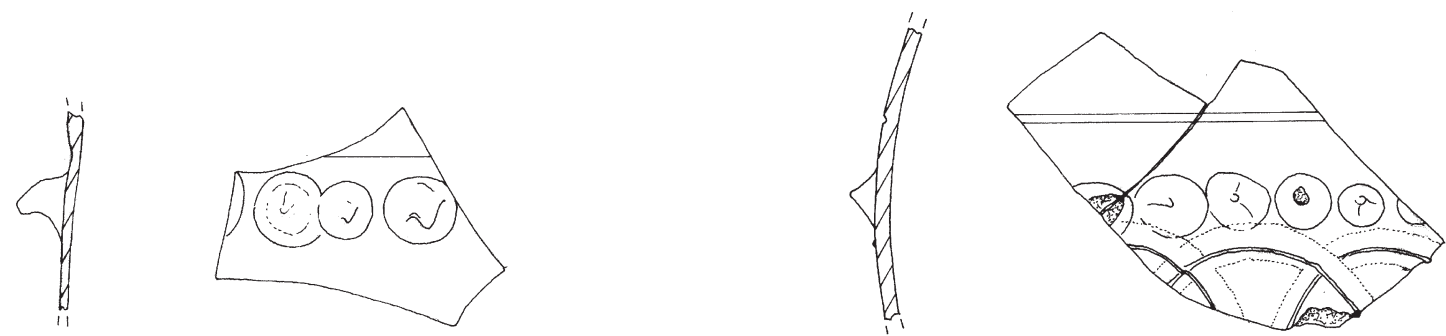

504

505

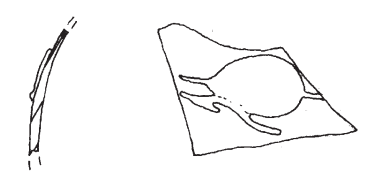

506
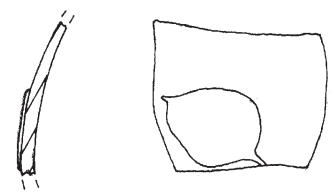

507
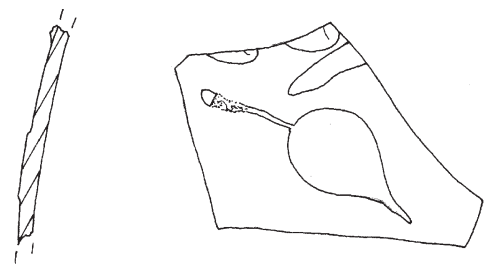

508

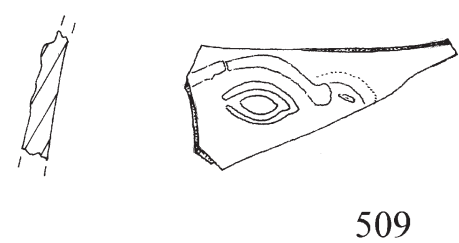

Lámina 56 


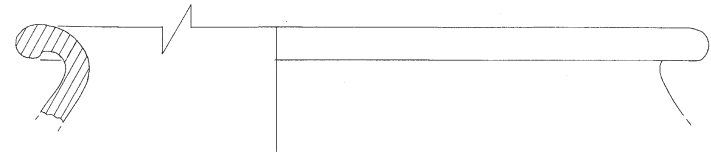

510

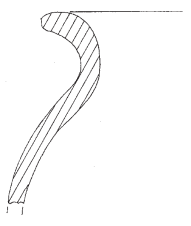

512

514
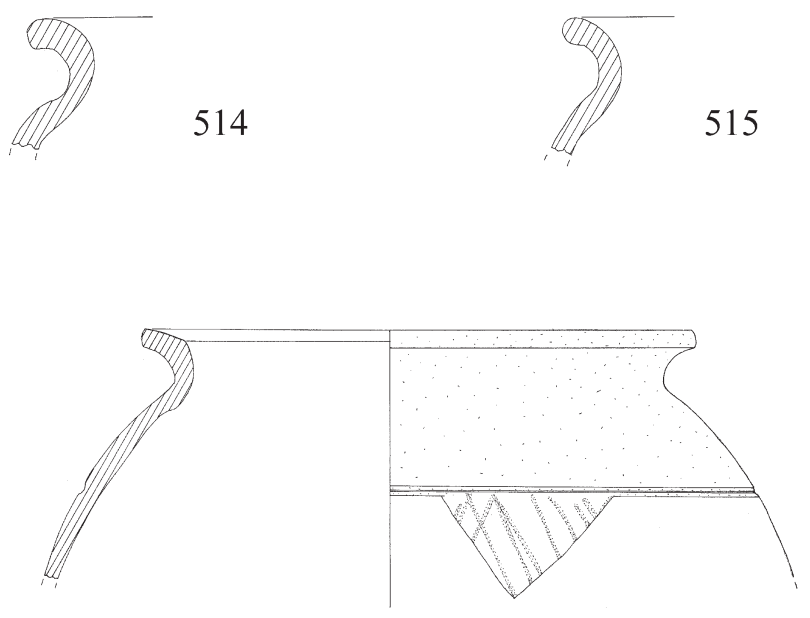

517

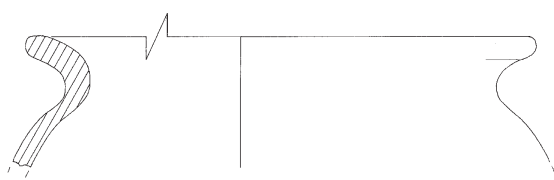

519

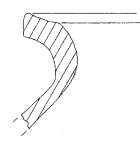

521

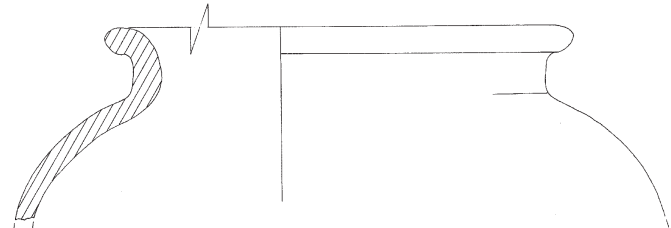

511
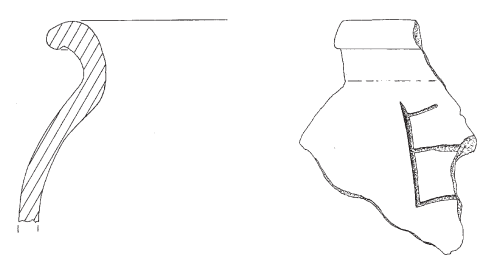

516

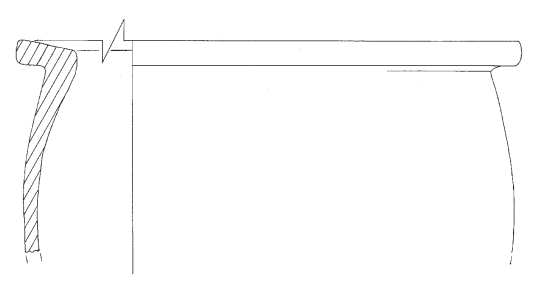

518

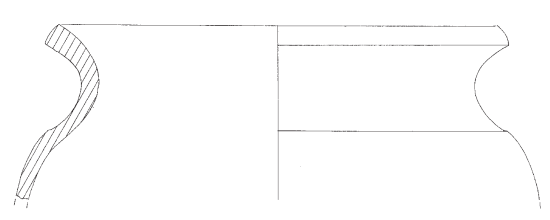

520

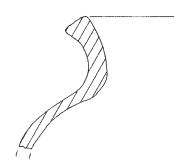

522

Lámina 57 

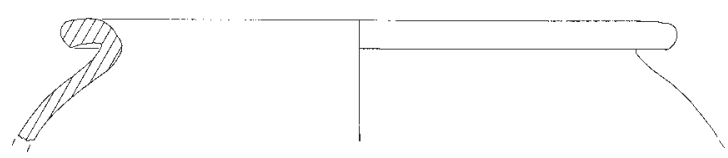

523

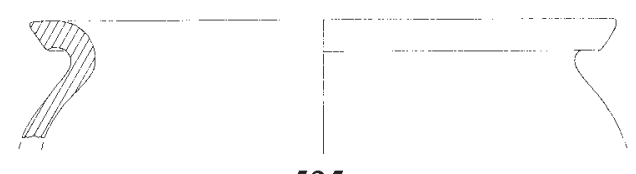

525

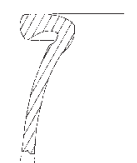

527

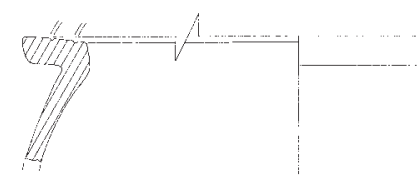

524
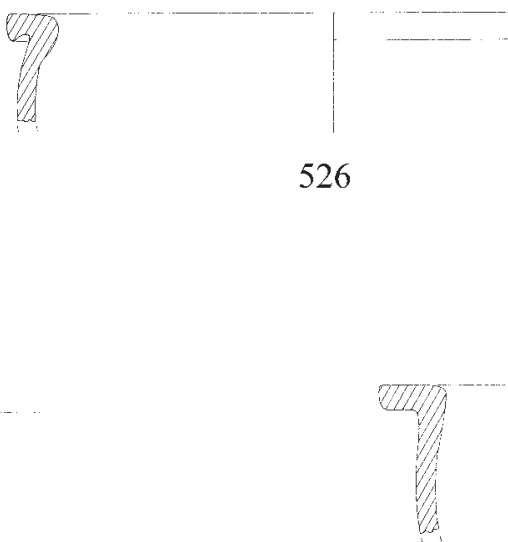

529

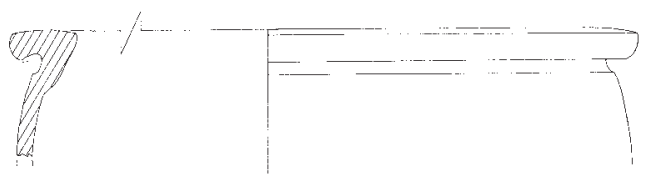

530
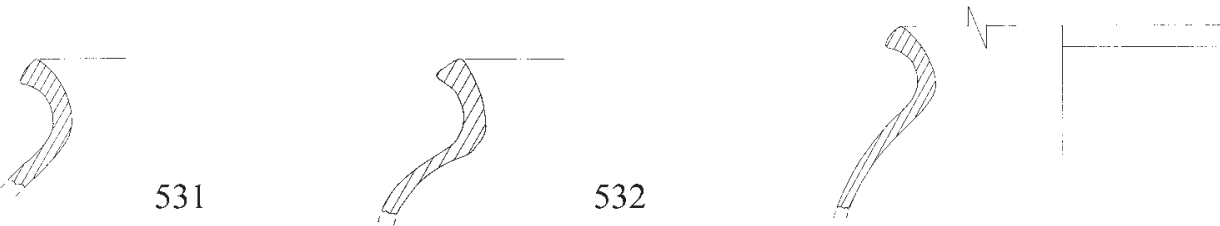

533

Lámina 58 


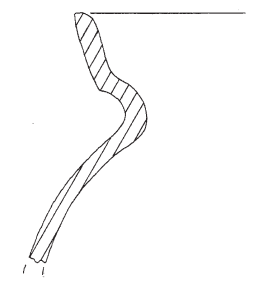

534

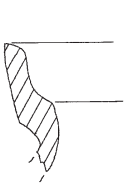

537

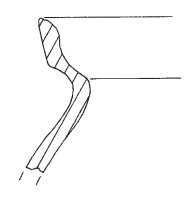

535

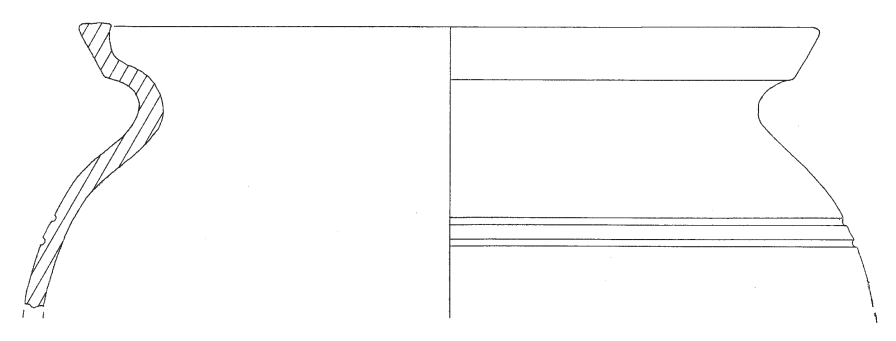

536

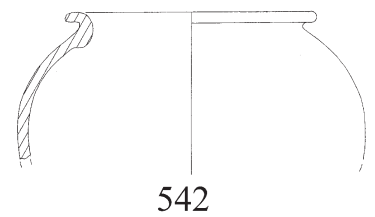

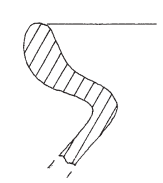

539

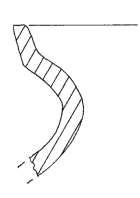

540

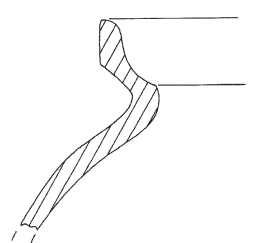

541

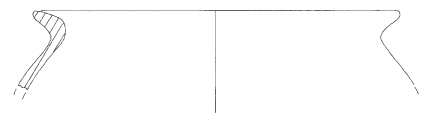

544

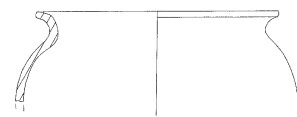

545

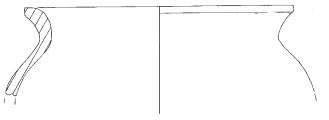

546
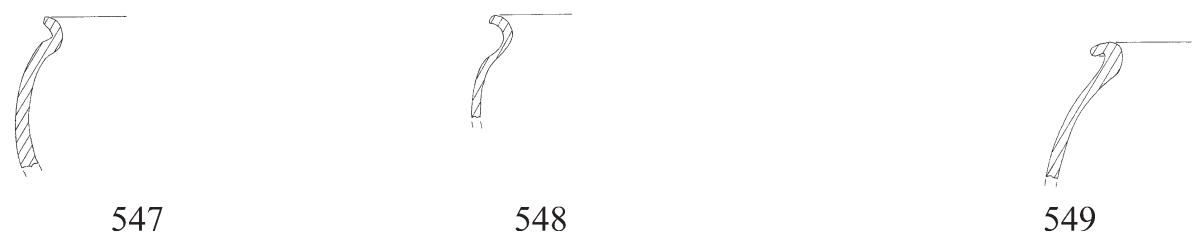

Lámina 59 

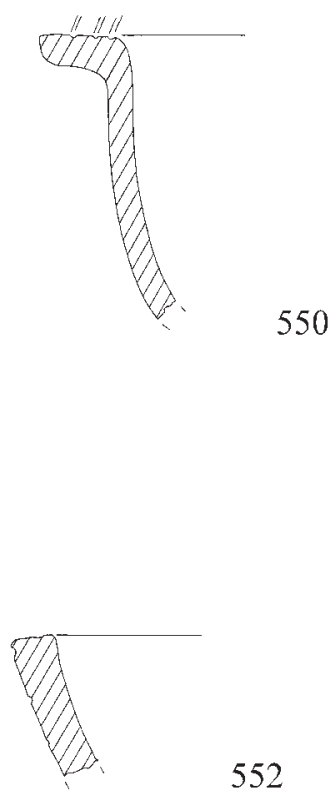

552
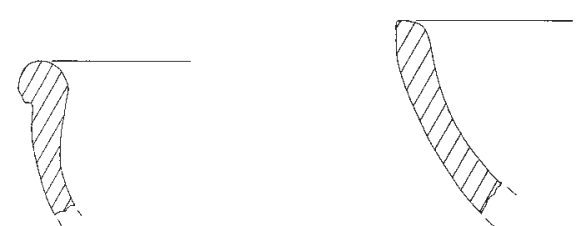

556
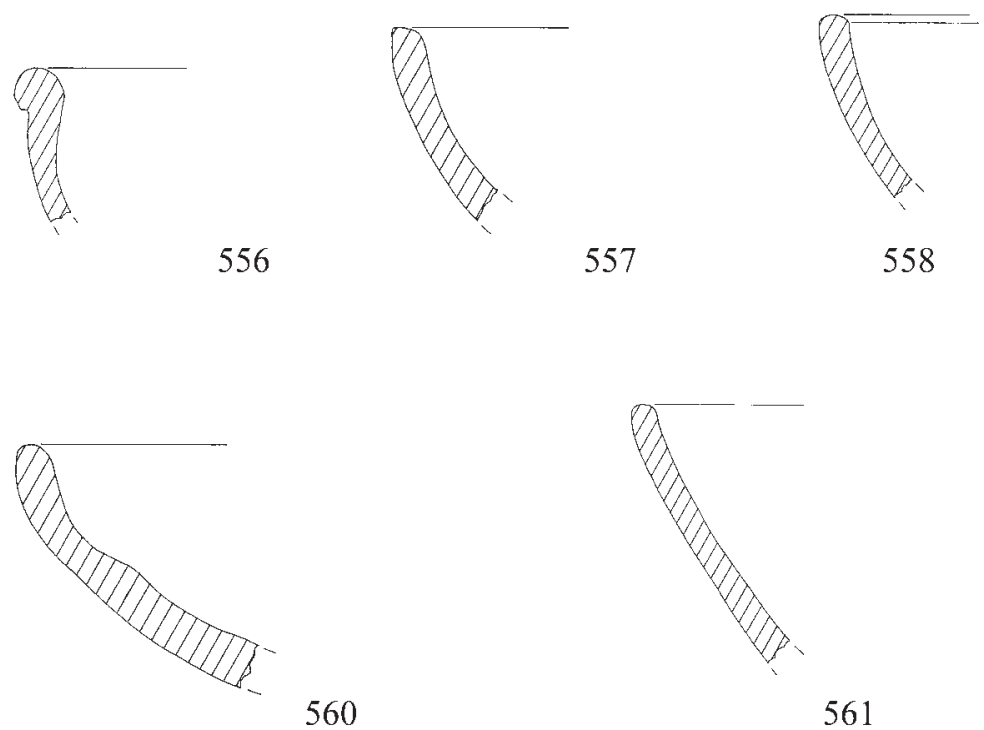

557

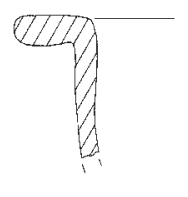

554

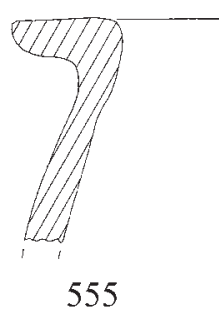

558

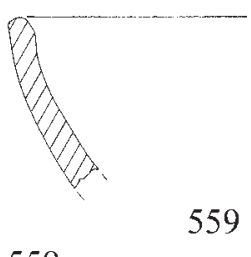

559

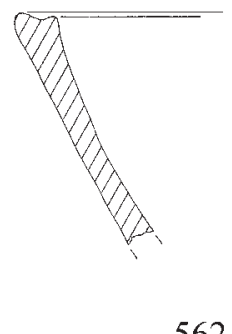

561

562

Lámina 60 


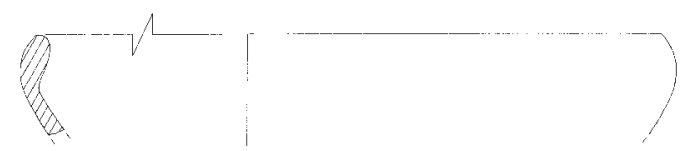

563

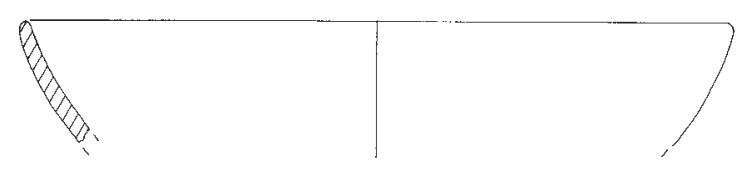

565
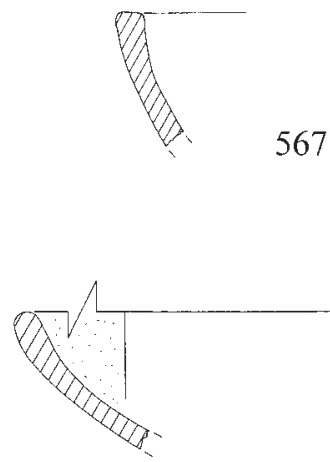

569

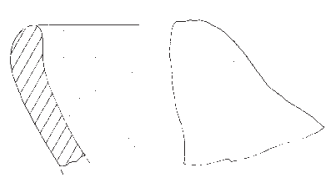

570
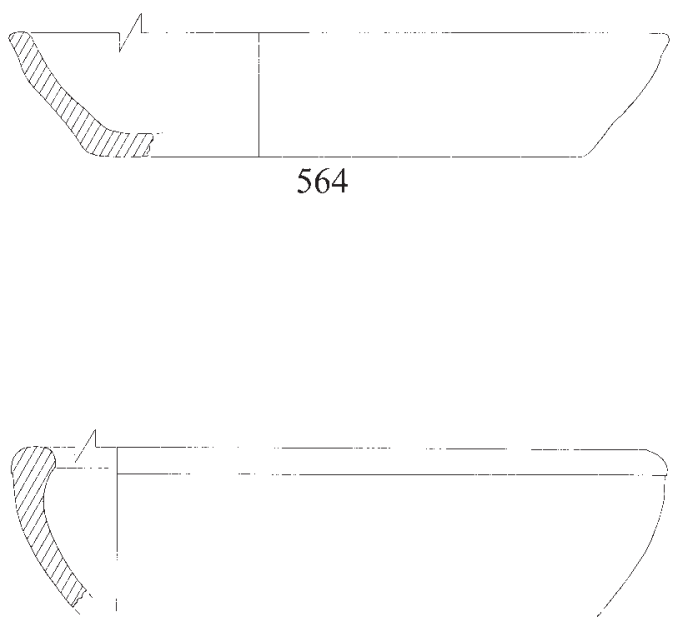

566

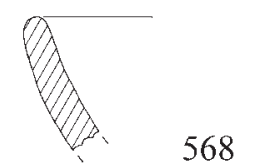

568

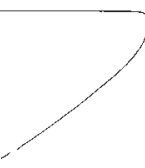

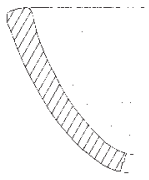

571

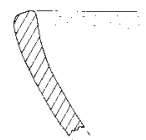

572

Lámina 61 

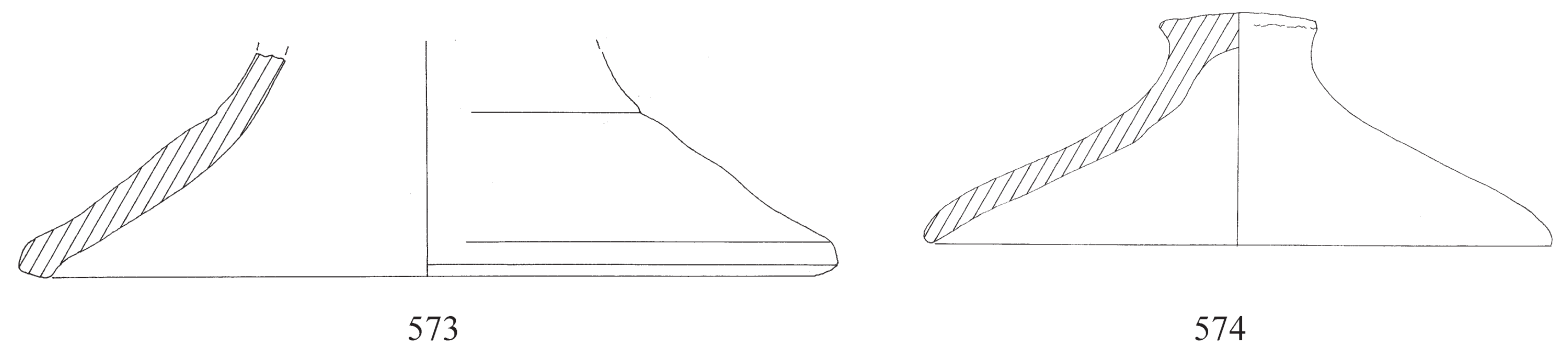

574
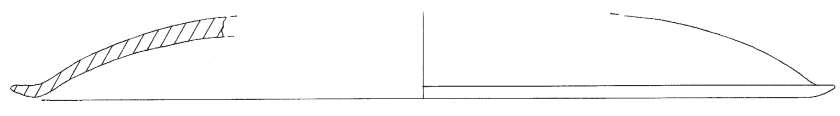

575

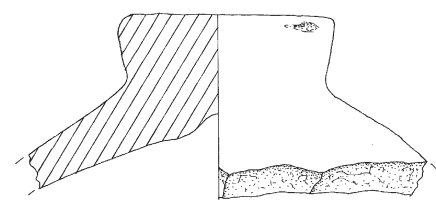

576

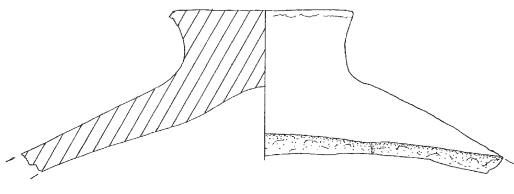

577

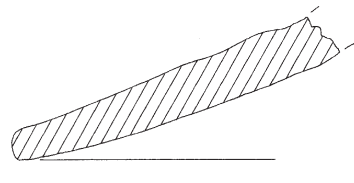

578

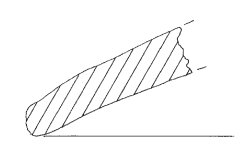

581
582
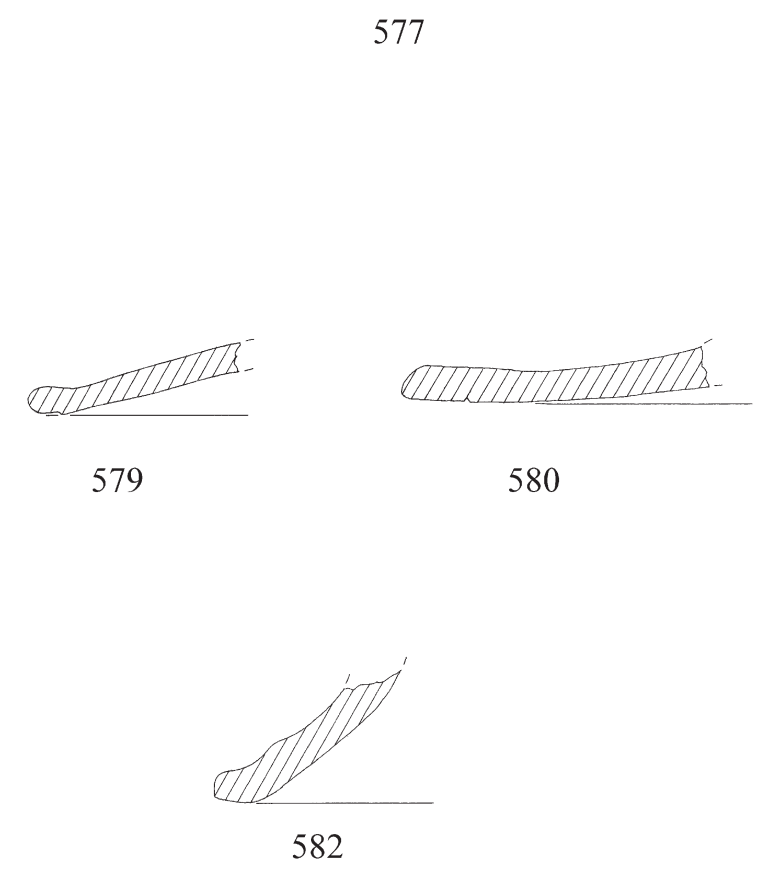

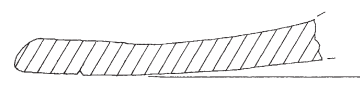

580

Lámina 62 


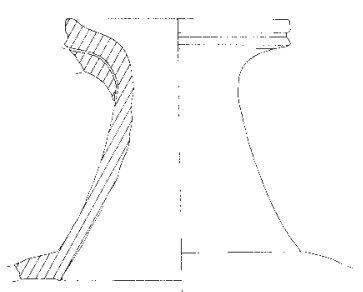

583

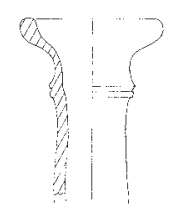

585

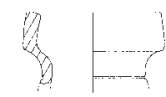

587

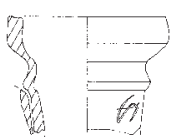

588

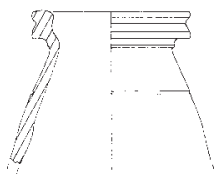

584

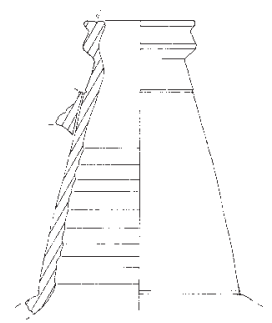

586

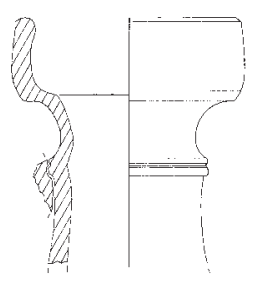

589

Lámina 63 


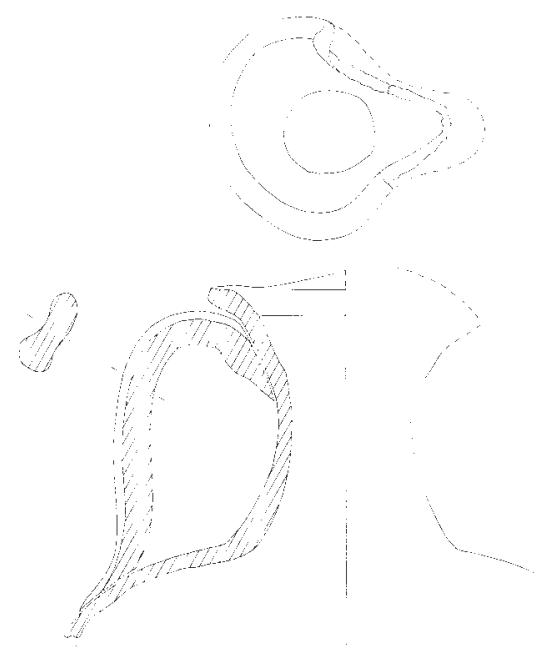

590
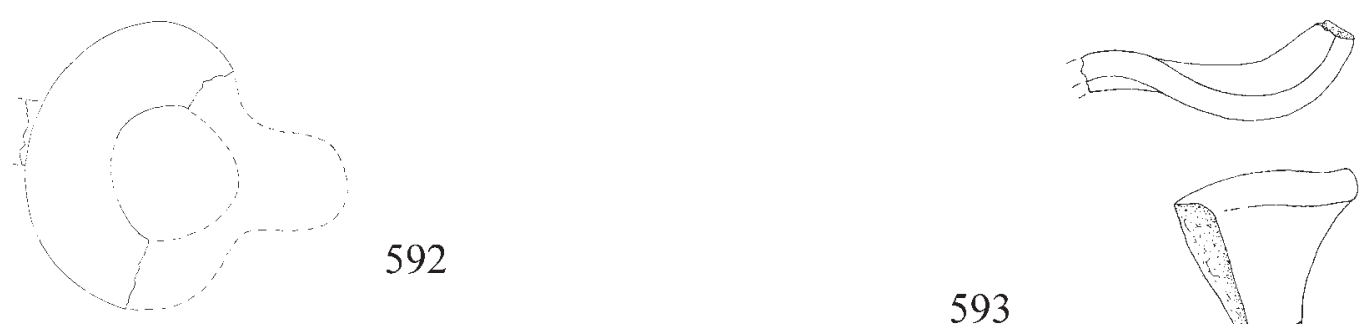

593
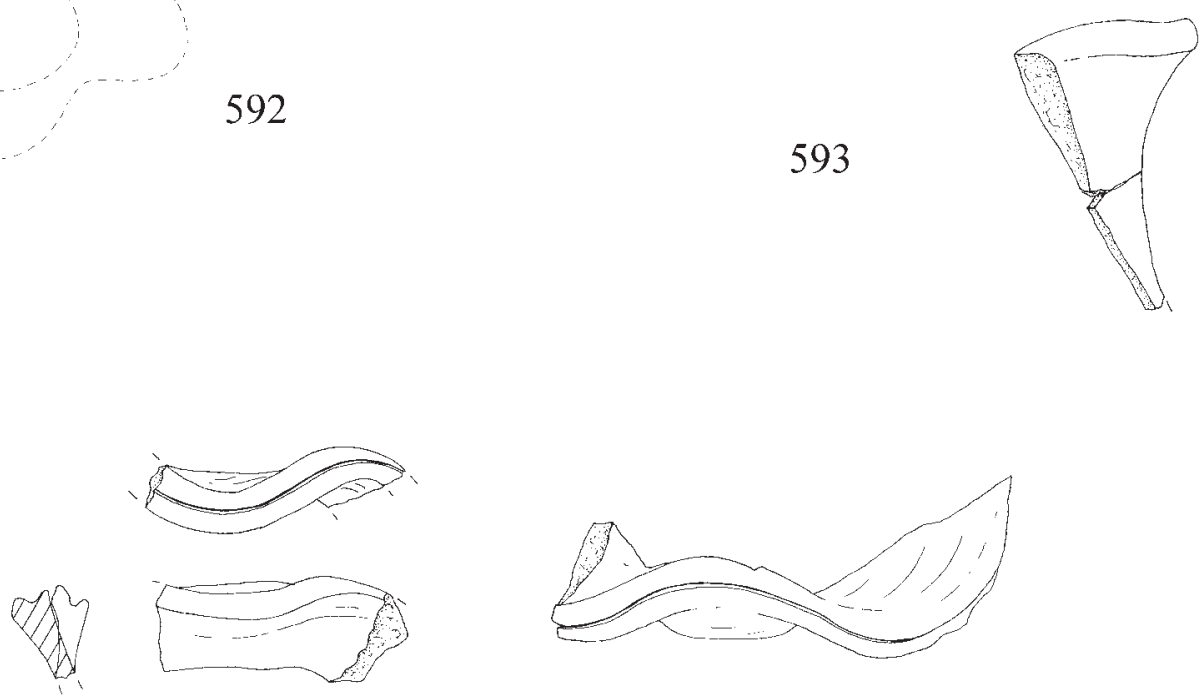

594 

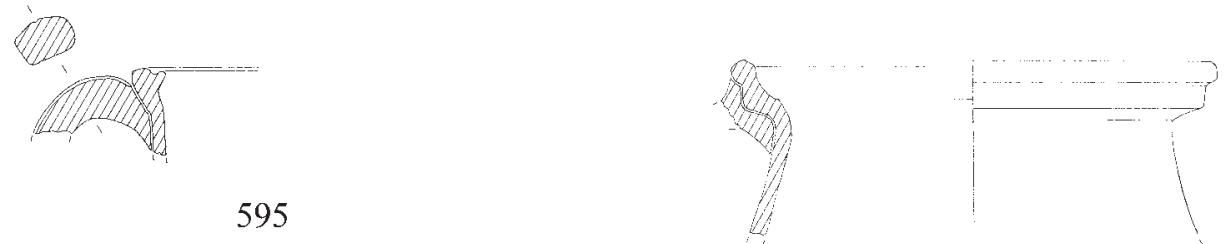

596

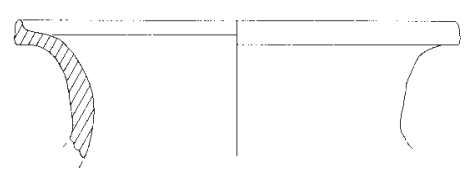

597

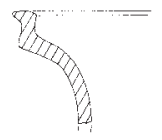

598

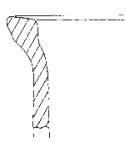

599

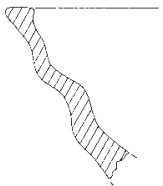

600

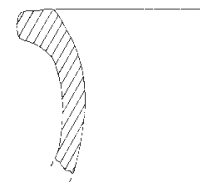

601

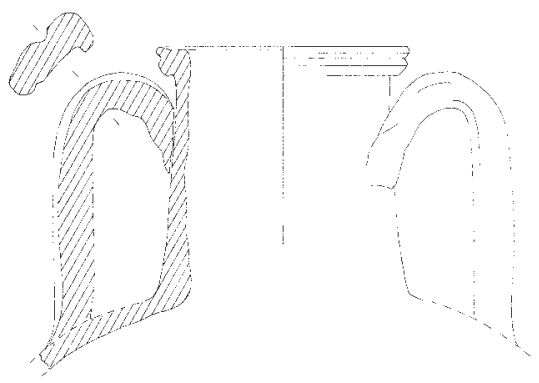

602

Lámina 65 

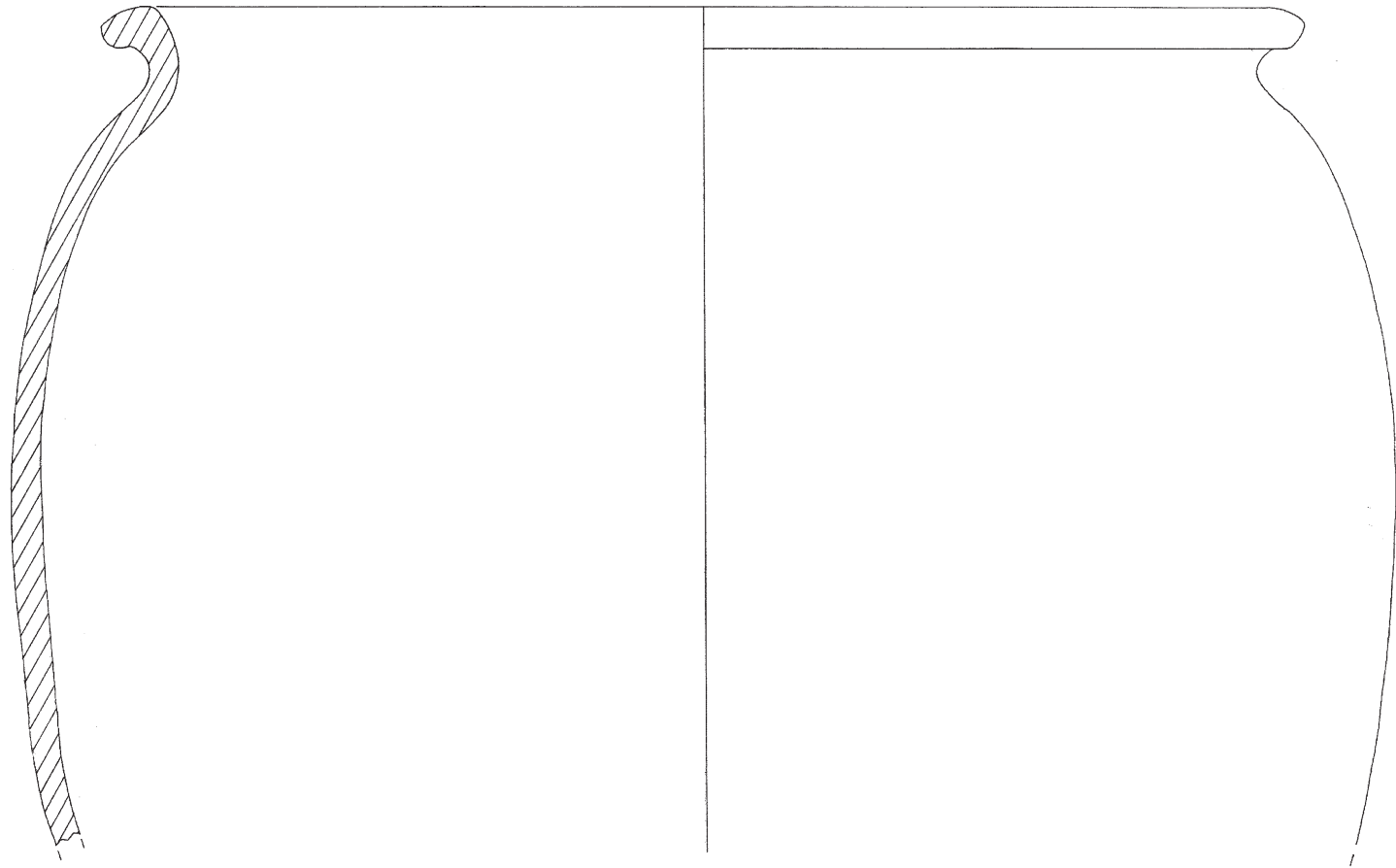

603

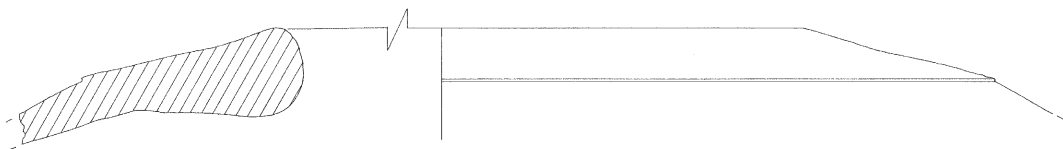



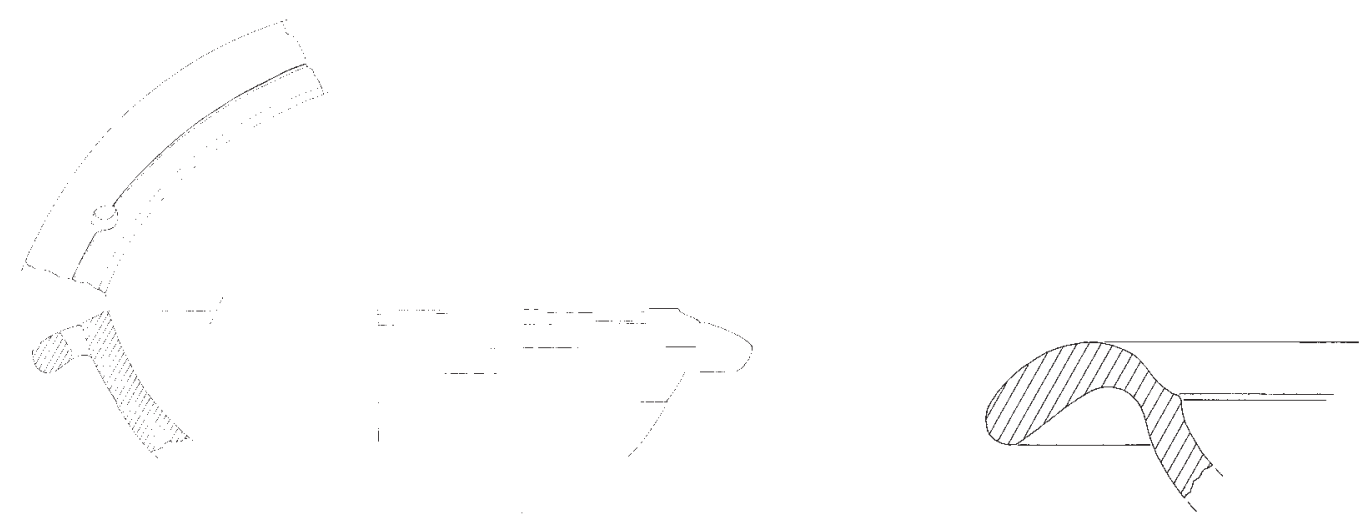

605

606
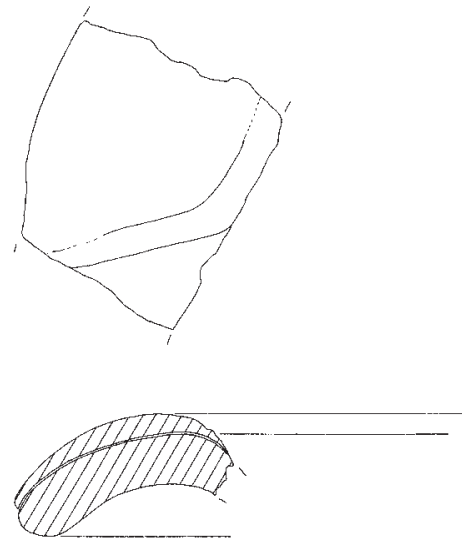

607

Lámina 67 


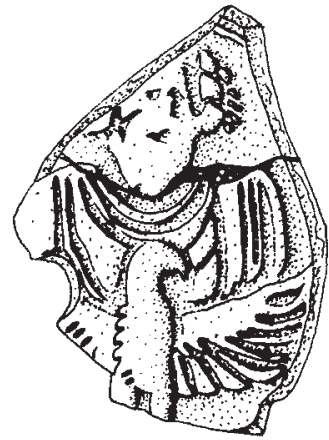

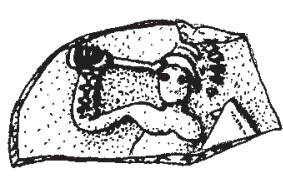

609

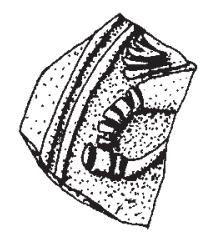

610

608

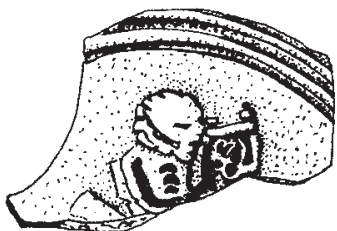

611

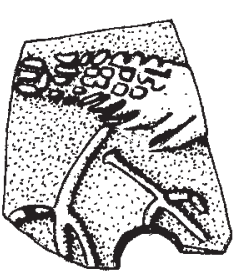

612
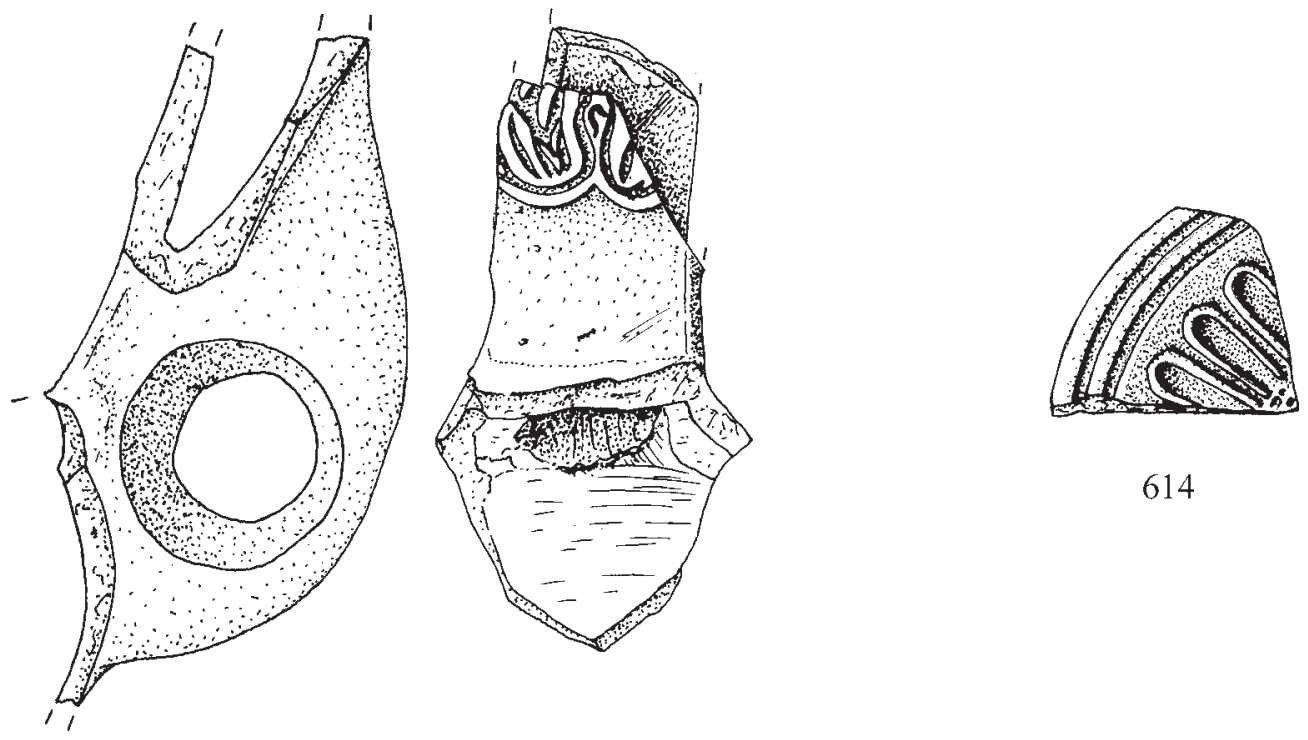

614

613

Lámina 68 

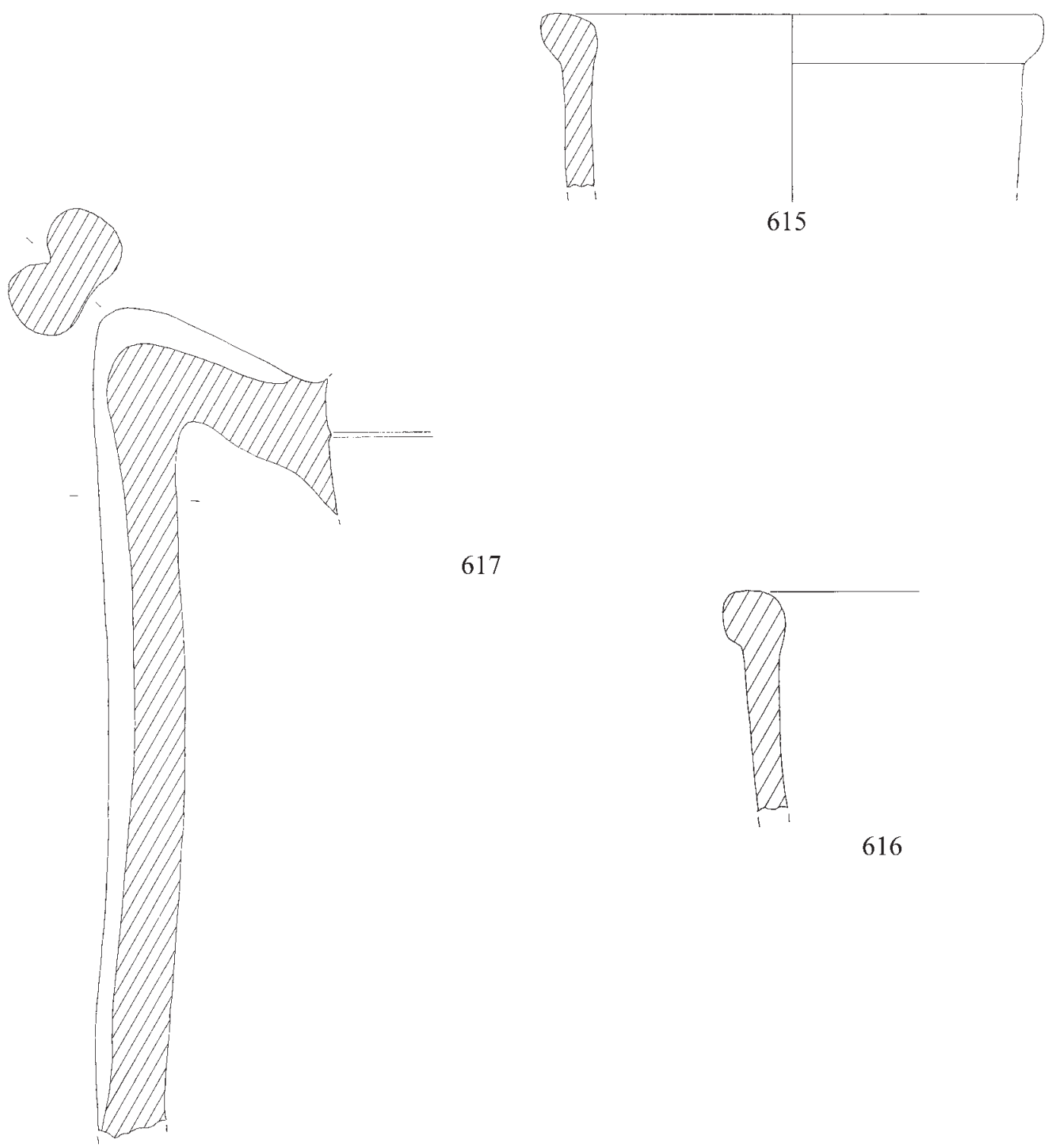

617

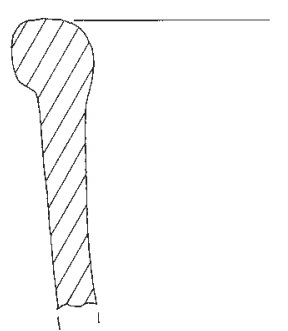

616

Lámina 69 
V.- CONSIDERACIONES FINALES 
A través de lo expuesto a lo largo de este trabajo de investigación, hemos obtenido un conjunto de datos, tanto de carácter general e integrador, como de signo más selectivo y peculiar, que nos permiten reconstruir importantes aspectos sobre el marco político-administrativo, económico y sociocultural en que se inscribe el desarrollo histórico de este asentamiento castrense y sus cannabae.

Por ello, con el propósito de ofrecer una visión complementaria de las diferentes perspectivas desde las que se puede contemplar el presente trabajo, y efectuar así una valoración conjunta, hemos estructurado este capítulo en torno a dos aspectos fundamentales: los vertederos y el ámbito militar.

Así, en un primer apartado, expondremos los principales resultados del análisis sobre cuestiones como la función, características, cronología y criterios de utilización de estos contextos arqueológicos desde el punto de vista de su significación en el ámbito urbanístico. Para ello, partimos de la base de que estas cuatro áreas de vertidos, de importantes dimensiones, constituyen ya un número considerable de cara a efectuar un estudio general sobre el modelo de gestión de los residuos sólidos urbanos en Legio, equiparando en este sentido, este asentamiento militar a otros importantes núcleos urbanos hispanos de carácter civil (Tarraco, Barcino, Augusta Emerita, Caesaraugusta...), con una trayectoria más amplia en el conocimiento y estudio arqueológico de sus vertederos.

En segundo lugar, especificaremos el papel del material cerámico como parte fundamental del contenido artefactual de cada uno de estos contextos, valorando los diferentes aspectos de estas producciones (categorías, volumen cuantitativo, cronología, procedencia, piezas específicas de ambientes militares...) y, lo que es más indicativo, estableciendo comparaciones y relaciones entre los distintos vertederos, correspondientes a diferentes etapas cronológicas, que comprenden desde el último cuarto del siglo I d. C. hasta mediados de la tercera centuria.

Este último punto resulta fundamental, puesto que en cada una de las áreas estudiadas hemos incluido conclusiones sobre las diferentes especies cerámicas de forma individualizada, pero sólo a través de la interrelación de datos que proponemos, podremos obtener una valoración general e integradora de esta secuencia temporal que comprende la estancia de la Legio VII Gemina en el campamento leonés.

Además, dado que se trata de un contexto eminentemente militar, plantearemos conclusiones, a partir de la inestimable información que proporciona el estudio de los distintos tipos de materiales cerámicos, sobre aspectos tan definitorios como los hábitos de consumo de determinados productos o la estructura en que se desarrollan los procesos de comercialización e intercambio de estas manufacturas, hecho que requiere diversas consideraciones sobre el sistema de abastecimiento del ejército romano en Hispania.

Por todo ello, quizá este capítulo dedicado a las consideraciones finales derivadas del estudio puede resultar extenso en exceso, justificándose únicamente esta amplitud por el hecho de efectuar aquí el análisis comparativo de los materiales procedentes de los cuatro contextos estudiados, habida cuenta de la diversa índole de éstos en los 
aspectos topográficos, morfológicos o cronológicos que los individualizan en el entorno urbano del campamento legionario.

Un hecho que queda patente en un trabajo de estas características y que es preciso poner de manifiesto a modo de primera valoración, es que el estudio de los vertederos en época romana no se limita al análisis de su contenido -en nuestro caso los materiales cerámicos-, sino que existen además una serie de variables que es imprescindible tener presentes en este tipo de yacimientos, como su ubicación o su carácter de contenedores, que implica una variada morfología, de manera que forman parte esencial de la planificación urbanística de un asentamiento, proporcionando un determinado contexto topográfico a la diversidad de materiales que contienen y que representan una de las principales fuentes de documentación arqueológica sobre diversos aspectos de la vida en un enclave urbano en un determinado momento de su historia.

De esta manera, a la función de los vertederos periurbanos como receptáculo de residuos sólidos, según la preceptiva legislación ya especificada (en este caso la Lex Ursonensis), se añade su papel como reguladores de la topografía urbana, utilizándose estos niveles deposicionales de desechos para la nivelación del terreno en zonas de irregularidades y declives -de carácter natural o antrópico-, o en los procesos de relleno y desecación de áreas inundables e insalubres. Contribuyen así decisivamente a la uniformización del espacio extramuros, de especial significación en los campamentos militares como el que nos ocupa, ya que es el lugar de asentamiento de la población civil o cannaba.

En relación a este último aspecto, el carácter militar del asentamiento -cuestión significativa, dada la escasez de estudios precedentes en relación a los vertederos de estos enclaves-, hemos de hacer constar, a modo de conclusión, que no hemos hallado diferencias sustanciales, ni de facto ni de iure, respecto a los modelos de gestión de eliminación de residuos respecto a otros núcleos urbanos de carácter civil.

De la misma manera, podemos afirmar que los vertederos legionenses tendrían una función esencialmente militar, destinados a recoger los desechos de las actividades desarrolladas en el campamento. Aún así, dado su emplazamiento extramuros, puede plantearse la posibilidad de un uso civil de estas mismas áreas de vertidos por los habitantes de la cercana cannaba. La investigación que hemos llevado a cabo sobre esta cuestión, analizando el tipo de materiales procedentes de excavaciones realizadas en las cannabae -perfectamente ubicadas y con diversos espacios y edificios bien conservados- de algunos campamentos británicos como el de Caerleon (Evans, 2000), permite inferir la utilización de materiales cerámicos y de otros tipos, similares en general a los hallados en el interior de los recintos militares. Con ello se pone de manifiesto la estrecha relación entre ambos contingentes, haciendo verosímil la posibilidad de un uso mixto -militar y civil- de los vertederos, aunque presuponiendo la supervisión de la autoridad legionaria, al igual que en otras actividades compartidas llevadas a cabo en edificios de carácter público (termas, anfiteatros...) situados en el entorno extramuros de los establecimientos militares.

En cuanto al carácter de los vertederos como contenedores, presentan una variada tipología, que implica métodos de análisis más o menos complejos para la precisa 
delimitación de los contextos estratigráficos, la adscripción cronológica de los materiales y, en suma, la correcta interpretación de los datos extraídos.

En los vertederos estudiados de Legio se hace especialmente patente esta diversidad en la morfología, derivada de su configuración topográfica y de su proceso de formación, en el que inciden de forma determinante la frecuencia y ritmos de utilización.

Así, contamos con dos importantes ejemplos de vertederos denominados "sistemáticos", correspondientes a los situados en la C/Pilotos Regueral y en la C/Maestro Copín c/v San Salvador del Nido, concebidos ya en un principio como tales, con una estratigrafía ininterrumpida y un gran volumen de materiales, aunque presenten secuencias cronológicas muy diversas. Ambos pueden calificarse de vertederos en "área abierta", cuyo contenido responde a los vertidos constantes procedentes de la actividad cotidiana en el campamento.

Por otra parte, se encuentran los vertederos de tipo "secundario" o "de segundo uso", como sería el caso paradigmático del vertedero de San Pedro, que están formados por niveles de relleno en estructuras con una distinta función anterior, en este caso un depósito, ya utilizado también como área de vertidos secundaria en la época de ocupación del campamento por la Legio VI Victrix, amortizándose en el periodo tiberiano. Posteriormente, vuelve a ser usado con el mismo fin a partir del último cuarto del siglo I d. C., ya en la etapa de asentamiento de la Legio VII Gemina.

En estos vertederos secundarios no se aprecia una clara relación con los determinados mecanismos programados de eliminación de residuos, sino que suelen ser resultado de diversas actuaciones en el área urbana, como remociones o refacciones constructivas en espacios concretos, cuyos desechos arrojados a estas estructuras, ya amortizadas en ocasiones, configuran distintos horizontes deposicionales que no siguen siempre un orden correlativo, ni espacial ni cronológicamente. Se plantean así numerosos problemas en el seguimiento de la secuencia estratigráfica, como hemos podido comprobar en el citado vertedero de San Pedro, en el que en una misma unidad estratigráfica se localizan materiales de diferentes épocas. En nuestro caso, esta problemática se ha visto en parte paliada por el numeroso conjunto de materiales y su buen estado de conservación, lo que nos ha permitido determinar adscripciones cronológicas más precisas, haciendo posible la identificación de fenómenos como el carácter residual o la perduración de determinados elementos, al margen de su definido marco temporal.

Y por último, es preciso destacar el tipo de los vertederos "ocasionales", propios ya de una etapa avanzada, a partir del siglo III d. C., que se ubican en edificios en estado total o parcial de abandono, los denominados loci sordentes, aprovechando estructuras negativas como hoyos, zanjas, canalizaciones, fosos, y todo tipo de espacios vacuos o semidestruidos, para su obliteración con aportes de materiales de diferentes épocas. Este sería el caso del pequeño complejo termal de San Lorenzo, cuya construcción dataría de época flavia, para comenzar en la tercera centuria un proceso de deterioro y progresivo abandono en el que se localizan este tipo de vertidos circunstanciales. Ni que decir tiene que esta progresiva degradación de la estructura edilicia complica considerablemente la disposición estratigráfica y la evolución planimétrica del contexto, ya de por sí complejas debido al importante nivel de arrasamiento en que fue hallado el yacimiento y que impidió la reconstrucción de determinadas áreas del edificio balneario. Con todo ello, se plantean serias dificultades en lo que respecta a la disociación 
de materiales pertenecientes al ámbito las termas y los que forman parte de estas colmataciones de vertidos, pues en muchos casos pueden ser datados en fases coetáneas.

Por lo demás, el fenómeno de los vertederos ocasionales afecta de manera general a los núcleos urbanos a partir del siglo III d. C. en que comienza un periodo de importantes transformaciones urbanas, y que tiene también su repercusión en la gestión de vertidos -como elemento que refleja la realidad de un asentamiento en cada momento-, de forma que se abandonan los sistemas tradicionalmente establecidos y avalados legalmente de eliminación de residuos en vertederos extramuros, depositándose los desechos en edificios abandonados y, -como cambio más radical- también en el interior de los recintos amurallados de los núcleos urbanos.

Por lo que respecta a la cronología de los distintos vertederos, si bien ya hemos hecho alusiones a su datación, es preciso delimitar con precisión la secuencia cronológica de cada uno de ellos, derivada del análisis pormenorizado de su contenido en material cerámico.

En este sentido hemos de distinguir, por una parte, aquellos vertederos con una secuencia cronológica más amplia, que comienza a principios del siglo I d. C. en época de la Legio VI Victrix, y cuyas siguientes fases -objeto de nuestro estudio- se inician en la etapa flavia, con el asentamiento de la Legio VII Gemina, como es el caso del vertedero de la C/ Pilotos Regueral y del vertedero secundario del depósito de San Pedro, para finalizar a mediados de la segunda y tercera centuria respectivamente.

En este aspecto, dado que la Legio VII en su instalación en León, superpone en principio sus estructuras campamentales a las del cuerpo legionario precedente, hemos podido comprobar que en el mismo proceso, y a pesar de la muy distinta configuración del recinto amurallado, sigue conservando también durante un dilatado periodo de tiempo, la misma ubicación de los principales vertederos, incluso los ya amortizados, de la Legio VI Victrix.

Por otra parte, se encuentran los vertederos creados ex novo, durante el asentamiento ya permanente de la Legio VII, como el ubicado en la C/Maestro Copín c/v San Salvador del Nido, datado a mediados del siglo II d. C., en época antonina -con un importante volumen de materiales y una etapa de formación muy reducida, que comprende el segundo y tercer cuartos de esta centuria-, así como también el vertedero "ocasional" originado en las termas de época flavia de San Lorenzo, y paralelo a su etapa de destrucción y abandono, que comenzaría probablemente su formación a principios del siglo III d. C. coincidiendo con el fin del periodo de uso del complejo termal, durante la época de derrumbes, reformas y refacciones, prolongándose al menos hasta mediados de esta tercera centuria, con la total destrucción y abandono del edificio balneario. De esta manera, la secuencia cronológica que proponemos para este último tipo de vertedero adolece de una cierta falta de precisión, debido a la complejidad de los distintos niveles estratigráficos ya comentada, así como al estado sumamente fragmentario de los materiales.

Esta significativa diversidad tipológica y cronológica de los vertederos legionenses constituye un factor determinante, en tanto que indica las diferentes necesidades y procesos de acondicionamiento en el desarrollo de este núcleo militar, con hechos 
como pueden ser la colmatación de los vertederos ya existentes, cambios en la planificación del espacio extramuros o variaciones demográficas que precisan otras zonas de eliminación de residuos, entre otras numerosas variantes, que se plasman en la diversa morfología y datación de los vertederos Así, estas diferentes áreas de vertidos, fechadas en momentos distintos, nos marcan una pauta decisiva para elaborar una secuencia prácticamente completa de la evolución del asentamiento, evidenciando una vez más su papel de indicadores básicos de la dinámica urbana.

Partiendo ya de una visión conjunta de los vertederos de Legio, pasaremos a efectuar algunas consideraciones desde el punto de vista de la totalidad de su contenido.

En primer lugar, hemos de señalar que no se ha documentado hasta el momento en Legio ningún tipo de vertedero especializado o exclusivo de determinados materiales, como residuos artesanales, restos faunísticos, o envases cerámicos como las ánforas. Estos últimos son sumamente frecuentes en núcleos urbanos importantes, teniendo como máximo ejemplo el Monte Testaccio en Roma, y destacando los casos de Londinium o Barcino (Carreras, 1998), e incluso campamentos militares como el de Vindonissa, siendo objeto de estudio desde diferentes puntos de vista el desecho especializado de este material (Martin-Kilcher, 2003).

Así, podemos afirmar que los vertederos de Legio tienen como rasgo común el carácter de depósitos de residuos mixtos, en los que además suelen encontrarse los mismos tipos de restos (material arquitectónico, cerámica, vidrio, metales, escasos testimonios numismáticos y restos faunísticos), sin sensibles variaciones, como podemos apreciar en los gráficos de distribución de materiales adjuntos al comienzo de cada uno de los contextos, destacando en todos los casos el porcentaje cuantivamente más abundante del material cerámico, que supone siempre más de la mitad del conjunto total de materiales, con casos especialmente relevantes como el vertedero de San Pedro, en que representa el $92 \%$.

Esta diversidad en el contenido viene a constituir un útil instrumento cuando se trata de aquilatar cronologías, ya que permite la comparación morfotipológica y la consiguiente datación asociada, entre diversos tipos de materiales de una misma etapa.

Por otra parte, el hecho de que los principales vertederos, sistemáticos y secundarios, a pesar de las diferencias ya señaladas, tengan un contenido tan uniforme, permite deducir, a nuestro entender, una estabilidad en la actividad urbana, que genera unos vertidos constantes en la mayoría de los ámbitos, sin destacar importantes modificaciones en volúmenes de determinados restos, que indicarían alteraciones en la propia estructura urbanística o bien cambios sustanciales en los procesos de abastecimiento o en los hábitos de consumo.

Quizá este aspecto haya de ponerse en relación con el carácter militar del asentamiento, en tanto que los campamentos romanos responden a un modelo prefijado en todos los aspectos, y por tanto, menos dado a los cambios en los modos de vida que los núcleos civiles. En efecto, en estos últimos se aprecia una continua transformación, de cara a la adopción de las nuevas costumbres venidas de Roma y de otras zonas del Imperio, en aras de una progresiva prosperidad, contrastando así con la austeridad y regularidad de la vida castrense en un asentamiento permanente, cuyo cometido supera en gran medida la actividad estrictamente bélica a gran escala, que sí implicaría cambios relevantes, con la continua movilidad de un número importante de efectivos o los desplazamientos de la totalidad del cuerpo legionario. 
El análisis de la presencia de las distintas especies cerámicas en los vertederos legionenses desde una perspectiva fundamentalmente cronológica, nos ha permitido extraer conclusiones fundamentadas en este punto, llegando a establecer claras secuencias evolutivas en las principales producciones, a la vez que nos ha proporcionado una información decisiva en lo que respecta a los hábitos de consumo de estas manufacturas en un centro receptor de primer orden, definido por su carácter militar.

De la misma manera, el estudio arqueológico de los conjuntos cerámicos constituye uno de los elementos más reveladores para reconstruir múltiples aspectos del modo de vida en un determinado contexto, ofreciendo datos de carácter económico, social y cultural, propios en este caso de los contextos militares romanos.

$\mathrm{Al}$ igual que ocurre con otros utensilios y su vinculación a los ámbitos militares, el análisis del consumo de productos cerámicos en determinados asentamientos castrenses, como es el caso de Petavonium en su etapa de ocupación por el Ala II Flavia civium Romanorum, (Carretero, 2002: 359-368) ha permitido individualizar algunas producciones, cuya marcada presencia y comparación con el material cerámico predominante en otros campamentos, tanto de la zonas próximas, como de diversas provincias del Imperio, las definen como propias y distintivas de la presencia de unidades del ejército romano, aportando además datos relevantes sobre su origen, producción y procesos de comercialización.

En este sentido, hallamos claras concomitancias con algunas manufacturas procedentes de los vertederos legionenses a partir de época flavia, corroborando así en gran parte estas peculiaridades en los hábitos de consumo de los ambientes militares romanos.

De esta manera, destaca el importante volumen de cerámica de paredes finas, con similar morfología y motivos decorativos. Este aspecto no es en absoluto casual, ya que la procedencia de ambos conjuntos es el centro alfarero de Melgar de Tera.

Además de algunos tipos morfológicos como los vasos ovoides y las diversas combinaciones de motivos geométricos y vegetales elaborados con técnica a la barbotina, que pueden encontrarse en otros campamentos, cabe destacar el singular motivo de los rostros aplicados, que aparecen en Petavonium, Legio, Asturica y especialmente en los asentamientos de los limites renano, británico y danubiano, y cuya interpretación, muy probablemente vinculada al carácter apotropaico, formaría parte de las creencias y la mentalidad de los soldados romanos, en relación con la exposición a los peligros inherentes a la actividad militar.

Aunque en el ámbito de la cerámica común no suelen apreciarse acusadas singularidades, cuando se trata de contextos militares se hacen patentes determinados rasgos comunes en la utilización de recipientes encuadrados en esta categoría cerámica, razón por la cual hemos argumentado que las producciones comunes alcanzan una mayor significación en los asentamientos militares que en los núcleos civiles.

Así, una producción característica y abundante en los campamentos del área noroeste viene representada por aquellos recipientes fabricados en pastas negras y grises, con un alisado o bruñido exterior que les confiere una superficie brillante, presentando en ocasiones decoración en bandas a base de líneas rectas o formado retículas 
bruñidas. Estas piezas, principalmente ollas y jarras, son testimonio de la perduración de la tradición cerámica indígena. A este respecto, encontramos también muestras en Legio de este tipo cerámico, si bien el rasgo que las distingue es su concentración en un único contexto de vertidos, correspondiente a mediados del siglo II d. C., estando totalmente ausentes en los demás vertederos estudiados.

La mayor o menor presencia de estas producciones de tradición indígena cobra especial relevancia, pues suelen integrarse tempranamente en el conjunto de las cerámicas comunes romanas, evidenciando el grado de fusión cultural, incentivado a veces por el ejército en estas zonas norteñas, y que de hecho, se encuentra en abundancia en algunos asentamientos ya "romanizados", circunstancia que no se produce en el marco de las cerámicas importadas, de producción estandarizada.

Además de los asentamientos de esta zona hispana, esta pervivencia de determinadas tradiciones, tanto morfológicas como decorativas, en la elaboración de algunas piezas cerámicas utilizadas por el ejército romano y esta especial tendencia en el uso de recipientes de pastas negras y grises puede constatarse en campamentos de distintas provincias del limes germánico, donde se halla la producción denominada terra nigra, o en Britannia, en cuyos principales campamentos prolifera la llamada black-burnished ware.

A todo ello hay que añadir los intercambios que pueden producirse entre estos tipos autóctonos de los diversos territorios en función de la movilidad de las unidades militares.

Otros tipos y rasgos de piezas de cerámica común características del campamento zamorano, se encuentran asimismo bien documentadas en Legio como las denominadas "jarras de boca estrecha con gollete", de cuidada elaboración, así como la utilización de abundante desgrasante micáceo en recipientes como las jarras de boca trilobulada, cuencos y ollas, cuya ausencia de huellas de exposición al fuego han permitido calificar este rasgo como un elemento ornamental.

Uno de los recipientes más representativos en los contextos castrenses son los morteros, esenciales en el instrumentum domesticum romano, utilizados, como ya hemos descrito, en la elaboración de diversos preparados culinarios de consumo habitual en el mundo romano y que alcanzan una amplia dispersión en las diversas provincias del Imperio, pues constituyen además una pieza esencial en la impedimenta de los soldados romanos. Especialmente indicativo resulta el tamaño de estas piezas, ya que las de menores dimensiones tendrían un uso militar, de carácter individual, mientras que las de mayor tamaño podrían inscribirse en el ámbito de los utensilios culinarios domésticos civiles. A este respecto, hay que subrayar que los ejemplares exhumados en los vertederos de Legio presentan unas dimensiones reducidas, con un diámetro de boca entre $\operatorname{los} 12$ y los $23 \mathrm{~cm}$., pudiendo indicar así su pertenencia al contingente legionario acampado intramuros. Este uso militar vendría avalado por los característicos orificios en el borde que presentan una buena parte de estos pequeños morteros, para ser colgados y transportados más fácilmente en el conjunto de la impedimenta de los legionarios.

En cuanto al tamaño, son claras las similitudes con los ejemplares hallados en otros campamentos como el de Cidadela y especialmente el de Petavonium, si bien en éstos últimos se aprecia una media de diámetro un tanto más amplia, aunque siempre dentro de las medidas características de los morteros vinculados a asentamientos militares. 
En este aspecto, la importante difusión de estas piezas queda patente en su presencia en todos los vertederos estudiados en Legio, en sus distintas épocas y con diferente representación cuantitativa, teniendo en consideración un sesgo de mayor abundancia en este caso, dado el carácter de principal asentamiento militar hispano desde principios de época flavia.

Aún así, el hecho de proceder de áreas de eliminación de residuos puede distorsionar los datos que ofrece el análisis de estos recipientes con respecto a otros asentamientos militares, en los que han sido hallados en el interior de los recintos, en sus probables lugares de uso, como en el campamento de Petavonium donde, a excepción de los fragmentos localizados en niveles de derrumbe, una buena parte de los ejemplares se ha encontrado en el contexto de las estructuras excavadas (Carretero, 2000: 730), relacionadas, a partir de la presencia de otros elementos (horno, dolium), con estancias dedicadas a la preparación o conservación de alimentos. Igualmente, en el enclave castrense de Cidadela, el mayor número de morteros se ha localizado en una zona restringida del campamento, correspondiente al praetorium y las áreas aledañas a este edificio, dado que, según su investigador, sería el único lugar donde se desarrollaba un modo de vida totalmente acorde con la cultura romana (Doval: 1997).

Por otra parte, es preciso puntualizar que los mortaria no son privativos de los contextos militares, de forma que adquieren también una importante representación en el ámbito doméstico de los núcleos civiles, como elemento esencial en los procesos culinarios, aunque en este caso suelen presentar mayores dimensiones. Este hecho conlleva la adopción de importantes cambios en los hábitos culinarios y alimenticios en las áreas de presencia romana, constituyéndose así en indicadores del progresivo proceso de aculturación que se extiende a los más diversos ámbitos de la vida cotidiana.

Asimismo, otras producciones cerámicas con una especial presencia en los ámbitos militares son las imitaciones de platos, cuencos y fuentes de engobe interior rojo pompeyano. Estos recipientes forman parte de un cierto número de piezas de cerámica común vinculadas al ejército romano, aportando datos relevantes sobre el equipamiento y determinados hábitos de los soldados, así como las diferencias en el uso de estas manufacturas según los estadios de la jerarquía militar, que utilizarían vajilla de mesa de mayor calidad integrada por cerámicas de lujo, y a la vez, sobre determinados cambios morfológicos en algunos de estos ejemplares.

Así, en el conjunto de estas producciones, en concreto los platos de reducidas dimensiones adaptados a un uso individual, forman parte del equipo personal de enseres del soldado romano, actuando como material guía por su cronología definida, que no es propia de las producciones comunes.

Sin embargo, hemos de resaltar el hecho de que el campamento de Legio constituiría a este respecto una excepción hasta el momento, a juzgar por los escasos ejemplares de estos recipientes recuperados en sus vertederos.

Igualmente resulta característica en los contextos castrenses la escasez o ausencia de los tipos de cerámica pintada, de arraigada tradición prerrromana en algunas zonas, especialmente las ubicadas en el ámbito celtibérico. En este sentido Legio constituye un claro exponente, pues no hemos hallado ningún ejemplar de estas producciones en la etapa de ocupación de la LegioVII Gemina.

Esta categoría cerámica, denominada "tipo Clunia", en función de la producción que 
se establece en talleres de este núcleo a partir del año $60 \mathrm{~d}$. C. hasta la siguiente centuria (ABASCAL, 1986: 282), presenta rasgos específicos que muestran la fusión de la tradición indígena (las cerámicas ibéricas del Valle del Ebro, tipo Azaila, y de la zona vaccea) con elementos de manufacturas típicamente romanas, dando como resultado unos recipientes de pasta blanquecina con motivos realizados en tonos castaños muy claros.

Conviene destacar, como subraya Carretero (2000: 572) que estas manufacturas podrían suponer un nexo entre la Meseta norte y el Noroeste, en función de la presencia del ejército en esta última zona, en relación con la actividad minera, que atraería trabajadores de origen meseteño y por tanto una presencia de los recipientes de su zona de origen.

Sin embargo, son muy escasos los testimonios de estas manufacturas tanto en los campamentos, pues además del caso emblemático de Legio se encuentra también el de Petavonium -con una cifra insignificante de siete de estos ejemplares-, como en los núcleos relacionados con la minería. Su presencia es un tanto más significativa, en otros enclaves de la zona astur, como Lancia, algunos núcleos zamoranos o Asturica, aunque siempre con carácter esporádico.

Como causa de la escasa representación de las cerámicas "tipo Clunia" en el Noroeste y especialmente en asentamientos militares, es preciso tener en consideración la valoración de Carretero (2000: 571-572), puesto que los recipientes clunienses tendrían la función de vasa potoria, ya cubierta en toda esta zona por las manufacturas del taller de Melgar de Tera, como se hace especialmente evidente en los asentamientos militares.

En lo que respecta a las lucernas, cabe destacar los testimonios del importante uso de las lucernas "tipo Andújar" en los campamentos hispanos del norte y noroeste, con importantes perduraciones, como se pone de manifiesto en Legio.

Por otra parte, al igual que las diferentes unidades del ejército romano acantonadas en los limites norteños en esta época, los contingentes asentados en el noroeste hispano adoptan un tipo común y funcional como son las lucernas de canal o firmalampen, que alcanzan una gran difusión, siendo denominadas por Bailey (1980: 276) como "lucernas de frontera". La abundante presencia de este tipo lucernario en los asentamientos militares responde a determinadas características, como su precio asequible, su sencillez en la configuración, que las hace fáciles de transportar y de efectuar copias en el entorno de los campamentos, constituyendo así un elemento esencial en la vida castrense.

Por último, en cuanto a los materiales vinculados a los asentamientos castrenses, cabría plantear otro rasgo unificador, a la luz de los últimos estudios en diversos campamentos del noroeste hispano, principalmente Petavonium y Legio, consistente en la variedad de los tipos anfóricos, incluyendo algunos de tradición local, aspecto que contrastaría con la menor abundancia de este material -a excepción de núcleos importantes como Asturica- en los enclaves civiles del Noroeste.

Centrándonos ya en las consideraciones derivadas del estudio del material cerámico, hemos de partir de uno de los rasgos comunes ya subrayados en los vertederos legionenses, que reviste especial trascendencia, como es la homogeneidad en su contenido en cuanto al material cerámico, de forma que en todos ellos hallamos, en mayor o 
menor medida, las mismas especies (terra sigillata hispánica, cerámica de paredes finas, cerámica común, morteros, lucernas y ánforas). En los casos en que no está presente alguna de ellas, suele deberse a la planificación de los estudios, como ya hemos expuesto en el capítulo metodológico, pero aún así, hemos intentado recabar los datos principales derivados de estas diversas investigaciones.

Esta uniformidad también en las categorías cerámicas, constituye un elemento fundamental, ya que facilita en gran manera nuestro objetivo de establecer comparaciones y relaciones entre las mismas. A la vez, contando con otra variable esencial de estos vertederos leoneses -su distinta adscripción cronológica sin importantes interrupciones-, nos permitirá seguir la línea evolutiva de las diferentes producciones cerámicas desde una perspectiva diacrónica, habida cuenta del importante volumen de documentación que proporciona uno de los principales centros receptores de la zona NW, como es Legio en esta etapa de su ocupación.

En primer lugar, es preciso incidir en la radical transformación que se produce en el ámbito del ejército hispano a partir de época flavia y que tendrá importantes repercusiones en el sector de la producción y consumo de las manufacturas cerámicas.

Así, una vez conquistada y pacificada la zona noroeste, se produce una reorganización de las unidades militares aquí acantonadas, que parten hacia otras áreas del Imperio, de forma que la llegada, en el año 74 d. C. de la Legio VII Gemina para su asentamiento definitivo en el solar leonés, así como de algunos cuerpos auxiliares que se establecen en enclaves próximos, como el Ala II Flavia Civium Romanorum en Petavonium, entre otros, constituirán los únicos efectivos militares asentados de forma permanente, garantes de la estabilidad político-estratégica y de la infraestructura económica del territorio hispánico.

Es a partir de este momento cuando finalizan las importaciones de productos cerámicos y se inicia una etapa caracterizada por el autoabastecimiento, con la proliferación de talleres locales y regionales regentados por civiles en todo el territorio peninsular constituyendo un hito fundamental en la evolución de la cerámica de época romana en Hispania y especialmente en la Tarraconense, con lo que, en términos de Beltrán LLorís (2008: 15), supone el “inicio de las producciones propias".

Esta producción de manufacturas civiles sigue teniendo como principales puntos de abastecimiento los asentamientos castrenses del noroeste y, en este contexto, no cabe duda de que el campamento de la Legio VII Gemina supondría un núcleo vital de consumo para las diferentes producciones cerámicas.

Es así como el estudio de los restos cerámicos de Legio a partir de esta etapa, acumulados en sus vertederos extramuros de diferentes momentos, adquiere una especial significación de cara a un conocimiento cada vez más preciso de la dinámica del mercado cerámico peninsular hasta época bajoimperial.

Desde esta perspectiva, el análisis de la presencia de las distintas especies cerámicas en cada vertedero, especialmente desde el punto de vista de su volumen cuantitativo y de su cronología, nos permitirá definir rasgos generales en el consumo cerámico de Legio en esta etapa, a la vez que identificar características peculiares de cada área de vertidos, en función de distintas variantes que explicaremos en cada caso. 
Siguiendo el orden cronológico propuesto para los distintos vertederos, hemos de comenzar por los fechados en el último cuarto del siglo I d. C., uno sistemático (C/Pilotos Regueral) y otro secundario (Depósito de San Pedro), asentados ambos sobre vertederos de la Legio VI.

A ellos debemos añadir el pequeño complejo termal de San Lorenzo, construído en esta época flavia, si bien, como se ha incidido en el texto, los materiales de este primer momento pertenecerían en su mayor parte a la etapa de uso de las termas, puesto que los vertidos ocasionales han sido localizados en una época tardía, de derrumbe y destrucción del edificio balneario.

De esta manera, se pretende evidenciar un desarrollo cronológico de los cuatro vertederos estudiados a través de las características de los distintos materiales cerámicos que contienen, que marcan una línea evolutiva, desde sus inicios en época flavia, hasta las etapas finales, situadas en torno a la tercera centuria.

En lo que respecta a la terra sigillata, hispánica en su totalidad, presenta las características técnicas y tipológicas de los alfares pertenecientes al complejo riojano de Tritium Magallum, que inicia su actividad a mediados del siglo I d. C. y constituye el principal centro abastecedor de estas producciones en la Península Ibérica, junto con el centro jiennense de Andújar, pero cuya difusión de productos supera con creces a la de este último, incluso en la Bética. La producción tritiense alcanza asimismo zonas extrapeninsulares como la Mauritania Tingitana y, de forma más esporádica, algunos puntos del sur de la Gallia y de la Península Itálica.

Por otra parte, la ingente demanda de esta cerámica fina de mesa fabricada en el complejo de Tricio, cuyos alfares se extienden a lo largo del Valle del Najerilla, implica, ya en época de auge de la producción, en época flavia, el surgimiento de nuevos talleres, de carácter local o regional, principalmente en la zona noreste peninsular y en la meseta, para abastecer a las áreas más alejadas. Con ello se irá diversificando el panorama y, con el tiempo tendrá lugar una descentralización de la producción, si bien hay que subrayar la más o menos patente hegemonía del centro tritiense durante todo el proceso.

De todas maneras, ambos fenómenos, tanto la distribución tradicional entre los dos grandes centros productores hispánicos, como la proliferación de talleres que imitan las manufacturas tritienses y las relaciones entre ellos, han sido objeto de importantes matizaciones y nuevas interpretaciones, a la luz de los numerosos hallazgos y continuas aportaciones bibliográficas, sobre todo en el ámbito de la estructura y organización del mercado, que han planteado nuevas e interesantes líneas en la investigación sobre la producción y consumo de la sigillata hispánica. Por ello, trataremos estos aspectos con más amplitud en el apartado final, sobre la comercialización y los sistemas de abastecimiento de las distintas producciones cerámicas halladas en el asentamiento militar de la Legio VII Gemina.

En cuanto a su volumen cuantitativo en los distintos vertederos es considerable, y supone la especie cerámica con mayor representación numérica, siempre en segundo lugar después de la cerámica común, cuyo predominio es habitual en la mayoría de los contextos cerámicos romanos, con algunas excepciones reseñables, como el campamento de Petavonium, donde representa el tercer lugar después del ingente volumen de cerámica de paredes finas aparecida en las estructuras del recinto castrense. Así, en 
los fechados en el último cuarto del siglo I y primeros decenios del siglo II (C/ Pilotos Regueral y San Pedro), las producciones hispánicas representan el 20\% y 19\% respectivamente, y en el de la C/Maestro Copín, de mediados del siglo II, asciende a un $25 \%$. Por último en el pequeño complejo termal de San Lorenzo, en uso durante el siglo II y convertido en vertedero ocasional desde mediados de la tercera centuria, el porcentaje es mínimo, con un $10 \%$, frente al $90 \%$ de la cerámica común, ya que son las dos únicas categorías cerámicas halladas en este espacio.

Esta diferenciación cuantitativa, constatable en la mayor parte de los contextos arqueológicos romanos, podría explicarse por el hecho de que la cerámica fina se conserva y se mantiene mejor, y por ello aparece en los yacimientos en mejores condiciones de conservación y menos fragmentada, mientras que la cerámica común tiene un uso más diversificado -por lo que son necesarios más recipientesy menor precio, razón por la que se utiliza y deteriora más y por ello se encuentra más representada.

Con todo, hemos de tener siempre presente en lo que respecta a la representación numérica de las distintas especies cerámicas y de determinadas piezas, al efectuar comparaciones con los porcentajes de otros yacimientos -en los que los materiales se hallan en los distintos espacios y estructuras en su fase de uso-, que en Legio nos encontramos en contextos de vertederos. Esta circunstancia, como ya hemos tratado en el capítulo metodológico, tiene importantes implicaciones, ya que no se trata de materiales hallados en estructuras en su periodo de utilización, que pueden proporcionar una cronología concreta, sino de materiales desechados, arrojados a los vertederos, sin que exista la posibilidad de conocer el período de uso de las piezas, que puede haber sido más o menos dilatado, dificultando una adscripción cronológica precisa a partir de su permanencia en el vertedero.

En los dos primeros grandes vertederos, en el lapso temporal del que parte nuestro estudio, en época flavia, se aprecia claramente, desde el punto de vista morfológico, la presencia de formas lisas y decoradas que caracterizan a los inicios de la producción tritiense. Así, destaca el predominio de las formas Drag. 15/17 y 27 y del servicio Drag. 35 y 36, si bien presentan algunos rasgos inversos, en cuanto a otros porcentajes, como el de la forma Drag. 24/25, propia de los comienzos de la TSH. Ésta aparece en un número más elevado en el vertedero de San Pedro, junto con la escasa presencia de formas puramente hispánicas (aparecen únicamente la Hisp. 49, 7 y 10), a excepción de esta última, el pequeño vaso Hisp. 10, que ostenta la mayor representación cuantitativa de todo el conjunto de producciones lisas y cuya explicación habremos de atribuir a algún fenómeno de carácter coyuntural. Por el contrario, en el vertedero de la C/Pilotos Regueral, además de algunas formas escasamente representadas como la Drag. 39 y la Ludowici TB, se hace notar un marcado descenso de las formas iniciales de la producción (Drag. 24/25 y Drag. 18), mientras se detecta una importante proporción de formas de inspiración hispánica, como la Hisp. 2, 3, 4, 7, 10 y 49, sobresaliendo ampliamente el número de platos de la forma Hisp. 4, de diferentes tamaños y elementos decorativos. Este fenómeno parece indicar una comercialización un tanto más tardía, aunque sin sobrepasar los límites de esta fase temprana de la producción riojana, y una ruptura más radical respecto a los productos de la etapa 
anterior, además de una posible menor perduración de estas primeras formas en este vertedero en estos primeros momentos de la etapa flavia.

En cuanto a las formas decoradas, contribuyen a acentuar esta misma tendencia, puesto que en este mismo vertedero, esta producción (cuyo porcentaje supera al de las formas lisas, contraviniendo así la distribución habitual entre ambas) se registra una abundante presencia de las formas Drag. 29 y Drag. 30, predominando las composiciones metopadas, en las que se aprecia la variedad de motivos y la calidad en la ejecución de los alfareros tritienses en estas formas de tradición sudgálica que se encuentran ya en sus últimas fases, de manera que mediante formas híbridas como la Drag. $29 / 37$, se produce la transición hacia la forma Drag. 37, que surge en estos momentos, con sus dos variantes coetáneas, la 37A, de borde sencillo, y la 37B, de borde almendrado, convirtiéndose en la forma decorada hispánica por antonomasia. En efecto, en ella se plasman en diferentes frisos, los tres estilos decorativos elementales -de imitación, metopado y de círculos- con sus fases intermedias, sucediéndose cronológicamente, aunque se producen coexistencias entre ellos, así como la presencia de algunos estilos también habituales, a base de frisos continuos con repetición de punzones. Los vasos de la forma 37 acaparan prácticamente la producción decorada en esta etapa, si bien es preciso señalar la diferencia existente en cuanto a su período de vigencia, pues mientras la 37 de borde almendrado se circunscribe prácticamente a este período, la 37 de borde simple presenta una perduración hasta épocas más avanzadas.

En cuanto a la distribución de sus porcentajes en este vertedero, no deja de resultar un tanto inusual el elevado predominio numérico de la Drag. 37B, con piezas que portan en su mayor parte decoración burilada de diversas formas e incluso hileras de perlitas y pequeños frisos de ovas bajo el borde, distribuyéndose la decoración en frisos metopados muy elaborados y también recurriendo al motivo menos usual ya aludido de frisos continuos, en este caso con arquerías -elemento de reminiscencias sudgálicasque repiten el mismo motivo central. Por el contrario, en la forma 37A se combinan los esquemas metopados con los círculos, y aparecen ya composiciones únicamente a base de círculos con motivo central, aspecto este último que nos ha inducido a ampliar un tanto la cronología del vertedero, cuyo final se situaría en los primeros decenios del siglo II d. C., estimando que puede prolongarse hasta mediados de esta centuria, cuando se produce ya una preeminencia absoluta del estilo decorativo de series de círculos en sus diversas variantes.

Por otra parte, en este floruit de la TSH decorada representada en la forma 37, hemos de mencionar también la presencia de otras formas decoradas como la Hisp. 2 y la jarra Hisp. 20, cuya representación numérica es meramente testimonial.

Siguiendo la tendencia inversa, en el vertedero del depósito de San Pedro, como ya se pone de manifiesto en las producciones lisas -con la excepción de la presencia de algunos fragmentos asignables a la forma Drag. 44, considerada como una continuación de la Drag. 24/25, y cuyo origen se sitúa en la primera mitad del siglo II d. C., pudiendo considerarse como un fenómeno intrusivo-, la cronología inicial de este contexto, en lo que respecta a nuestro estudio, podría establecerse con mayor precisión unos decenios antes, desde época claudioneroniana, teniendo en consideración el fenómeno de las perduraciones, propio de gran parte de las áreas de vertidos.

Esta asignación cronológica más temprana a partir de la TSH, se hace aún más patente en las características de la producción decorada. En primer lugar, se registra un 
importante porcentaje de las formas más antiguas de influencia sudgálica, la Drag. 29 y la Drag. 30, que superan más ampliamente a la Drag. 37, surgida en los inicios del período flavio. Con todo, el elemento más significativo que confirmaría el comienzo más temprano de esta fase del vertedero incluida en nuestro ámbito de estudio, es la presencia en estos niveles estratigráficos de dos ejemplares de la forma Drag. 29 (Lám $4, n^{\circ} 32$ y 33), que se conservan prácticamente completos y que presentan los rasgos técnicos y decorativos que caracterizan a las denominadas "producciones precoces", firmadas por alfareros como ASIATICVS, MATERNVS, MCR o VLLO, que siguen aún los patrones sudgálicos, con determinadas licencias que hacen sumamente características a estas manufacturas. Su valor y significación son, pues, fundamentales como precursoras de la producción puramente hispánica, aunque desconozcamos en la mayoría de los casos la ubicación concreta de sus talleres y los momentos finales de su producción.

Así pues, si el vertedero de la C/Pilotos Regueral se localiza cronológicamente de forma clara en época flavia y principios del siglo II, en el vertedero de San Pedro, por las razones aducidas, es preciso adelantar la cronología de sus inicios para la época que estudiamos. Ello plantea una problemática en cuanto a la atribución de los ejemplares más antiguos, ya que esta etapa correspondería a un momento de transición, en el que pueden encontrarse materiales de extensa perduración utilizados por la Legio VI Victrix, junto con restos cerámicos de los comienzos de la estancia de la Legio VII Gemina en el campamento, dada la irregularidad de la estratigrafía, a lo que se añade la peculiar problemática cronológica de los vertederos que se hace aún más evidente en los de carácter secundario como en este caso.

Por lo demás, tanto la TSH como las demás especies cerámicas exhumadas en el vertedero, se encuentran representadas en época flavia y en la segunda centuria, hasta una etapa final, ya avanzado el siglo III d. C., en que los ejemplares de terra sigillata hispánica evidencian una decadencia técnica y estilística, formando el grupo de las denominadas producciones "avanzadas", "transicionales" o "intermedias" que dan paso a las producciones de Terra Sigillata Hispánica Tardía.

En este contexto la TSHT se encuentra muy escasamente representada, destacando una pieza decorada a molde, datada en la segunda mitad del siglo IV d. C. o principios del $\mathrm{V}$-que constituye muy probablemente un elemento intrusivo y por tanto ocasional, procedente de un nivel de relleno con apariencia de hoyo basurero, según el registro estratigráfico-, de manera que no supondría un claro término post quem para establecer la cronología final del vertedero, que podemos fijar a partir de mediados del siglo III d. C. aunque con claros indicios de una ocupación postromana sobre el depósito, como muestran hoyos basureros ocasionales con materiales de época medieval.

Por último, y siguiendo la secuencia cronológica de la TSH hallada en los vertederos legionenses, hemos de hacer referencia al exiguo conjunto procedente del complejo termal de San Lorenzo, construido en época flavia, pero cuya función de vertedero comienza en la etapa final de destrucción del edificio, a mediados del siglo III d. C.

De todos modos, dejando clara la cuestión de que los materiales ubicados cronológicamente en la etapa flavia y segunda centuria no pertenecerían a un área de vertidos, sino al período de uso de las termas, citaremos las principales formas de terra sigillata hispánica del escaso y deteriorado conjunto recuperado en este espacio, destacando entre las formas lisas las formas Drag. 15/17, 27, 35 e Hisp. 2, mientras las 
producciones decoradas corresponden fundamentalmente a galbos de las formas Drag. 37A y 37B.

Por lo que respecta a otra de las categorías cerámicas, la cerámica de paredes finas, hemos de resaltar el hecho de que únicamente se encuentra representada en uno de estos tres vertederos más antiguos iniciados en época flavia, el situado en la C/Pilotos Regueral. Las piezas recuperadas suponen una escasa proporción cuantitativa, con un $7 \%$ respecto al conjunto total de material cerámico. Presentan además un elevado índice de fragmentación, sin que se conserve ningún ejemplar completo, y, en conjunto, un deficiente estado de conservación. Aún así, y a pesar de ciertas dudas sobre las piezas más tempranas, tanto la valoración de las características técnicas como de los aspectos morfológicos y decorativos, indican una indudable procedencia del conjunto del taller zamorano de Melgar de Tera -centro abastecedor del cercano campamento de Petavonium- que inicia su actividad productiva a finales de la época neroniana, pasando a significar en los siguientes decenios el principal centro distribuidor de estas manufacturas en el noroeste peninsular.

En el área de vertidos de la C/ Pilotos Regueral aparecen en los niveles más tempranos, de principios de la etapa flavia, fragmentos de ejemplares denominados "de cáscara de huevo" y otros con una factura y decoración propia de los talleres béticos, al igual que en el asentamiento de Petavonium, aspectos que pueden ratificar la hipótesis de investigadores como Carretero (2000: 815), en tanto que no se trate de importaciones, sino que sean resultado de una participación de alfareros meridionales en la etapa de creación del alfar melgarense, especialistas en la fabricación de estas producciones con vistas al abastecimiento en el área noroeste. En los siguientes niveles, ya de plena época flavia, podemos apreciar un predominio de los fragmentos pertenecientes a los característicos vasos de forma ovoide, fenómeno común en las producciones de paredes finas de todo el Imperio. Algunos presentan una superficie lisa, pero se aprecia una tendencia a la decoración a base de la combinación de líneas de barbotina e impregnación arenosa, que constituirían las decoraciones típicas de la primera etapa de la producción, junto con las depresiones y las lúnulas o herraduras realizadas con barbotina, representadas todas ellas en este conjunto de fragmentos.

Aparecen asimismo, ya a finales del siglo I d. C., las dos principales formas que caracterizan a este alfar: Melgar I y Melgar II (con hombro) y varias de las técnicas y motivos decorativos típicos del taller, como el burilado -con numerosas variaciones-, o la barbotina, mediante la cual se realizan motivos vegetales -como las características hojas de agua-, geométricos -mamelones y círculos- y motivos antropomorfos, fundamentalmente rostros humanos, que constituyen un rasgo especialmente original de este alfar, con claras connotaciones militares. Otra de las características de la decoración de los vasos melgarenses es la combinación de los diferentes motivos decorativos en una misma pieza, formando complejas composiciones, aunque el reducido tamaño de los ejemplares hallados en este vertedero no nos permite apreciar este rasgo, que se desarrollará durante la primera mitad del siglo II d. C. cuando estas producciones alcancen su máximo esplendor, como queda de manifiesto en el vertedero datado a mediados de esta centuria.

Siguiendo el orden correlativo en el estudio de materiales, pasaremos a exponer los datos más significativos que nos ha proporcionado el estudio del amplio volumen de 
cerámica común, cuya presencia es siempre mayoritaria cuantitativamente en relación a las demás especies. Esta circunstancia se hace evidente en los cuatro contextos estudiados, pues en todos ellos, independientemente de sus características, cronología, ubicación u otros aspectos diferenciales, las producciones comunes suponen siempre más de la mitad del material cerámico exhumado, con unos valores que oscilan entre el $67 \%$, y $76 \%$ en los vertederos que contienen varias categorías cerámicas, y que alcanzan el $90 \%$ en los contextos menos diversificados en este sentido, como en el caso del conjunto termal de San Lorenzo.

A pesar de esta preeminencia cuantitativa, la cerámica común implica importantes dificultades en cuanto a la datación, que se hacen especialmente evidentes cuando se trata de elaborar, como en este caso, una secuencia cronológica a partir de varios contextos. Ello se debe a la inalterabilidad morfológica de estos recipientes de uso cotidiano y escaso valor estético, que no experimentan importantes cambios formales durante extensos períodos de tiempo. De esta manera, su adscripción cronológica debe efectuarse en función del resto de materiales presentes en la secuencia estratigráfica.

Buena prueba de ello la encontramos en la clasificación formal en tipos y subtipos que elaboramos en su momento para las producciones comunes de uno de los vertederos, y en la que se inscriben, prácticamente sin apenas alteraciones, las diferentes formas de los conjuntos de cerámica común procedentes del resto de áreas de vertidos, conformando así un amplio marco cronológico, desde el último cuarto del siglo I d. C. hasta mediados de la tercera centuria.

Por otra parte, este rasgo de la patente uniformidad morfológica de las manufacturas comunes puede ser arqueológicamente significativo cuando se utiliza el método comparativo, como en nuestro caso, analizando distintos contextos del mismo carácter -áreas de deposición de residuos- en un mismo yacimiento arqueológico, en el sentido de que la percepción de variantes en esta tipología tan definida puede ser un indicador de determinados cambios o aportar información sobre aspectos de carácter tecnológico, económico o socio-cultural.

Así, trataremos de forma conjunta las características de estas producciones en los cuatro contextos estudiados, pues uno de los aspectos más significativos de la cerámica común exhumada en estos vertederos legionenses es su homogeneidad morfológica, inscribiéndose la totalidad de las piezas en la clasificación general propuesta, corroborando una vez más el mantenimiento la amplia perduración temporal de estas formas cerámicas, pues se documentan en contextos de diferente cronología, sin presentar signos evidentes de cambio o evolución.

En cuanto a la representación numérica de las distintas formas, hemos de subrayar que se constatan asimismo unos valores similares en los diferentes contextos. El porcentaje más elevado corresponde siempre a las ollas, el recipiente más utilizado en los procesos culinarios y de gran variedad formal, clasificadas aquí en seis subtipos en función de la configuración de sus bordes, aunque se documenta también una gran diversidad en otros aspectos, como las dimensiones o el perfil del cuerpo, predominando los de tendencia globular.

Igualmente, en todos los vertederos, el segundo recipiente más abundante proporcionalmente son las jarras, cuya clasificación engloba una gran variedad de tipos con múltiples variantes, ofreciendo datos de mayor valor cronológico, funcional y cultural. Partiendo de la homogeneidad formal en los distintos contextos, su catalogación 
se ha podido reducir en todos ellos a tres tipos fundamentales: jarras de cuello largo y estrecho, de boca trilobulada y de boca ancha.

Los ejemplares más característicos se inscriben en el primer grupo, presentando un característico estrangulamiento en la parte superior del cuello, que ha llevado a denominarlas como "jarras con gollete", localizadas en Legio en los vertederos del depósito de San Pedro (Lám 20, nº 163, 164, 171-174), Pilotos Regueral (Lám. 63, n 587-589) y Maestro Copín (Fernández Freile, 2003: Lám. 101). Su cronología se fija a finales del siglo I d. C., hasta mediados de la segunda centuria, con una restringida difusión, localizándose únicamente en determinados ámbitos militares del noroeste peninsular y pudiéndose vincular a los vasos de Melgar de Tera, con los que podrían formar servicio, como se pone de manifiesto en los ejemplares de Petavonium. Por el contrario, las jarras de boca trilobulada, con una amplia tradición y difusión en el contexto mediterráneo, abarcan un amplio marco cronológico difícil de precisar, hallándose presentes hasta épocas tardías, y con perduraciones que sobrepasan el período romano, mientras el tercer tipo es común en los yacimientos peninsulares durante los dos primeros siglos de la Era.

Por lo que respecta al resto de recipientes de cerámica común, principalmente cuencos, platos, tapaderas o vasijas de almacenaje (orzas y dolia), presentan una proporción sensiblemente más reducida y bastante equiparable en las diferentes áreas de vertidos, manteniendo la diversidad morfológica que caracteriza a estas producciones.

Especialmente indicativa resulta la presencia de imitaciones de platos de engobe interior rojo pompeyano, puesto que, como ya hemos señalado, cuentan con una cronología más precisa, si bien los ejemplares hallados en Legio son muy poco abundantes en los dos vertederos de época flavia y en el de época tardía de San Lorenzo, perteneciendo estos últimos a la etapa anterior de uso del complejo termal -finales del siglo I y segunda centuria- y se encuentran totalmente ausentes en el datado a mediados del siglo II d. C. Se elaboran asimismo cuencos de borde horizontal con este mismo tipo de engobe, que formarían servicio con los platos, de los que no hemos documentado ninguna evidencia en los vertederos de Legio, mientras resultan especialmente representativos en otros asentamientos militares como Petavonium, procedentes de talleres locales y que portan en ocasiones la marca del alfarero, como los productos de Rufiano, encontrándose únicamente en enclaves de la zona noroeste.

A partir de estas precisiones, podría considerarse, de forma general, que la cerámica común adquiere mayor relevancia, en relación con algunas de sus producciones específicas, en estos ámbitos militares que en los núcleos exclusivamente civiles.

Generalmente adscritos a la categoría de cerámica común en numerosas clasificaciones, se encuentran los morteros, que en este estudio hemos tratado de forma individualizada, dadas las singulares características de estos recipientes que significan una aportación decisiva del instrumentum domesticum romano, con una amplia difusión en las distintas zonas del Imperio, puesto que constituyen una pieza fundamental en la impedimenta del soldado romano. Presentan una variada tipología en función de la diversa morfología de su amplio borde y la ubicación del pico vertedor, la configuración de la base y su altura y dimensiones, rasgos que definen una evolución cronológica, con lo cual poseen, además de su valor intrínseco, un valor añadido para la datación, que los diferencia de la mayor parte de los tipos de la cerámica común. 
En cuanto a los mortaria hallados en los vertederos más antiguos de Legio, el primer rasgo destacable es la disparidad cuantitativa según los distintos vertederos, siendo el área deposicional de San Pedro en la que se encuentra el mayor porcentaje, mientras destaca su escasez en los vertederos de la C/Pilotos Regueral y San Lorenzo. Con todo, esta diferenciación numérica no parece responder a condicionantes de tipo funcional o cronológico, pues en vertederos de la misma época -la etapa flavia- se localiza la mayor abundancia de estos recipientes (San Pedro) a la vez que una escasísima representación de los mismos (C/Pilotos Regueral), aspecto que quizá haya que relacionar con determinadas pautas en los vertidos con el fin de regularizar la morfología de algunos sectores de los vertederos, o simplemente, sean producto de otras circunstancias propias del azar, carentes de toda intencionalidad en este ámbito.

Desde el punto de vista morfológico, los dos tipos fundamentales que hemos diferenciado, en los que aparecen características propias de los morteros itálicos tipos Dramont D1 y Dramont D2, pues en muy raras ocasiones se da una adscripción total a una de estas dos formas originales, constituiría otro rasgo que pone de manifiesto el proceso de imitación en talleres locales y regionales. Así, la Forma 1 corresponde a los morteros de borde plano horizontal, mientras en la Forma 2 se incluyen los morteros de borde vuelto al exterior con labio colgante. La representación morfológica, con un marcado predominio de los morteros de la Forma 2 en las cuatro áreas de vertidos, viene determinada por la cronología de las mismas, de manera que en el vertedero de San Pedro, aparecen en la etapa flavia aún varios ejemplares de la Forma 1 de borde horizontal, en el que sería su período final, aunque con perduraciones en la centuria siguiente. La escasez de morteros en el vertedero coetáneo de la C/Pilotos Regueral no permite apreciar esta distribución de formas, puesto que se documenta una homogeneidad morfológica con ejemplares pertenecientes únicamente al segundo tipo. Este predominio absoluto de los morteros de la Forma 2 se aprecia en las piezas prácticamente completas del vertedero de la C/Maestro Copín, fechado a mediados del siglo II d. C. y, aunque mucho menos abundantes y muy fragmentados, también en el vertedero de San Lorenzo, poniendo de manifiesto el amplio lapso cronológico de vigencia de esta segunda forma, desde mediados del siglo I d. C. hasta principios del siglo III d.C.

A excepción de los escasos ejemplares procedentes del vertedero de San Lorenzo, de muy deficiente calidad en su elaboración, destaca la excelente factura del resto de mortaria hallados en Legio, de cocción generalmente oxidante, con pastas consistentes y desgrasantes cuarcíticos y micáceos de granulometría media, además de una superficie de frotación formada por la incrustación de piedrecillas en su base interna, perfectamente delimitada.

Frente a la uniformidad de estas últimas producciones y su escasa aportación en el ámbito cronológico -con las excepciones señaladas- el resto de especies cerámicas presentes en los vertederos de etapa flavia, como lucernas y ánforas, permiten continuar diferenciando distintas etapas en la secuencia cronológica de estos contextos, ya definida esencialmente por las producciones de la vajilla fina de mesa.

Así, en cuanto al material lucernario, el primer rasgo destacable es su heterogeneidad, que afecta especialmente a su volumen numérico en contextos de similar cronología, así como también a la calidad de los materiales empleados en su elaboración, 
que determinan su mayor o menor consistencia y, por ende, la conservación de sus rasgos principales o por el contrario, un elevado índice de fragmentación que dificulta en muchos casos la adscripción tipológica, además de indicar distintos puntos de procedencia.

En este sentido, no deja de resultar un fenómeno anómalo esta caracterización tan dispar en el material lucernario procedente de los dos vertederos más antiguos, el depósito de San Pedro y el situado en la C/Pilotos Regueral, ubicados ambos sobre áreas de vertidos precedentes, correspondientes a la época de ocupación del campamento por la Legio VI Victrix. Este hecho contribuirá a complicar la clara delimitación del inicio de la etapa que estudiamos -a partir del último cuarto del siglo I d. C. con la definitiva instalación de la Legio VII Gemina en el recinto leonés-, debido al fenómeno de las perduraciones, así como a la importante presencia de elementos residuales, que impiden trazar una línea relativamente continua en el proceso de datación lucernaria, siendo preciso recurrir a un minucioso análisis de las secuencias estratigráficas y de su contenido en materiales guía asociados, que permitan establecer cronologías precisas y definir fases evolutivas en esta categoría cerámica.

En el contexto más productivo en esta categoría cerámica, el vertedero del depósito de San Pedro, se ha documentado un numeroso conjunto de lucernas, fabricadas con pastas de buena calidad y en cuya clasificación tipológica (Morillo, 1999: 460-473) destaca el predominio prácticamente absoluto de las distintas formas de las lucernas de volutas y escasos fragmentos de las derivadas de la forma Dressel-Lamboglia 3, conocidas como "tipo Andujar" por su procedencia meridional de este centro alfarero, enmarcándose el conjunto en un lapso cronológico desde época tiberiana hasta finales del período neroniano. Con todo, la presencia de algunos fragmentos aislados de lucernas de canal de importación y de las variantes más antiguas de ejemplares de disco, suponen para el citado autor un testimonio más de la importante transformación que se produce en la estructura del recinto campamental leonés a principios de la etapa flavia, pudiendo adscribir estos incipientes nuevos tipos, así como importantes perduraciones de las formas de volutas más modernas y del tipo Andújar -de especial vinculación con el ejército-, a los niveles de ocupación de la Legio VII Gemina.

En contraposición, es de destacar la exigua representación del material lucernario en el vertedero de la C/Pilotos Regueral, debido fundamentalmente al estado sumamente fragmentario que presenta en este contexto y que impide la adscripción tipológica de los ejemplares conservados, elaborados con pastas muy finas y decantadas. Estos pertenecen en su mayor parte a fragmentos de discos en los que se plasman diversos temas decorativos de cuidada elaboración, entre los que se encuentra una pieza que presenta parte de una vénera de gallones, que constituye así la única pieza identificable tipológicamente, dado que se trata del motivo característico de las lucernas "tipo Andujar". La presencia de este tipo en niveles adscritos a la ocupación de la Legio VII Gemina en este contexto vendría a corroborar la cronología establecida para el período de vigencia de estas lucernas, desde la primera mitad del siglo I d. C. con perduraciones hasta época flavia, a la vez que incide en la continuidad de la tradición de su uso en ambientes militares.

En efecto, la difusión en la Meseta norte durante buena parte del siglo I d. C. de este tipo de lucernas fabricadas en el alfar jiennense y en talleres que producen imitaciones localizados en Corduba y Emerita Augusta, se encuentra asociada al comercio del aceite bético -el principal combustible utilizado para la iluminación-, constatándose 
una especial abundancia de estas producciones en asentamientos militares como Asturica, Legio o Petavonium. La ubicación de estos núcleos en el eje de comunicación tradicional con el área lusitana indicaría la comercialización de estos productos a través de la vía de la Plata, y el consiguiente papel de Emerita Augusta como centro productor y redistribuidor de distintas manufacturas y de la producción oleícola.

A partir de estos datos podemos inferir que el material lucernario documentado en los primeros momentos de la instalación de la Legio VII Gemina en el solar leonés, en el último cuarto del siglo I d. C. está definido por la importancia de las perduraciones de formas propias de etapas anteriores, principalmente algunos tipos de lucernas de volutas y las derivadas de Dressel-Lamboglia 3 o "tipo Andújar", así como por la aparición de escasos testimonios de los tipos que se generalizarán en la siguiente centuria, como las denominadas de disco y las de canal.

Por lo que se refiere al material anfórico recuperado en estos contextos legionenses, teniendo en consideración que estos envases constituyen uno de los productos cerámicos más significativos en los vertederos, hasta el punto de existir zonas de vertidos exclusivas de ánforas, en función del valor que poseen de cara a distintos procesos posteriores de reciclaje y reutilización. Esta cuestión ha sido estudiada con profundidad en vertederos romanos de ciudades francesas (Martin-Kilcher, 2003: 231-257), analizando los puntos de llegada de estos envases y su contenido, su distribución en las distintas zonas urbanas, así como la organización de su evacuación, con las áreas de vertidos más idóneas para su reutilización. De esta manera, el análisis cualitativo de los vertidos de ánforas ofrece datos relevantes para el conocimiento de la topografía social de una ciudad, las estructuras comerciales y determinados modos de vida urbanos. En el mismo sentido se pronuncian otros investigadores como Carreras (1998), valorando la importante fuente de información que constituye la elección de determinadas áreas para desechar los residuos cerámicos, especialmente los restos anfóricos, a la vez que incide sobre el valor arqueológico de los vertederos en sí mismos, no únicamente como zonas de amortización. Para ello toma coma como base el caso de dos ciudades emblemáticas, Londinium y Barcino, poniendo de relieve la información que proporcionan los distintos contextos de vertidos de ánforas para la reconstrucción urbanística. El caso de Barcino, en cuanto a los residuos sólidos y especialmente las ánforas, es tratado por el mismo autor y otros colaboradores en la obra conjunta sobre la eliminación de residuos en Hispania (Beltrán de Heredia y Carreras, 2012: 246-254), exponiendo aquí el hallazgo de varias figlinae localizadas extramuros, con sus respectivos vertederos, situados muy próximos a la muralla, a la vez que se elaboran diversos mapas de densidades de ánforas según su tipología en diversos puntos de la ciudad, para concluir que su dispersión en época altoimperial coincide con la presencia extramuros de talleres y vertederos controlados.

Partiendo de algunos de estos presupuestos de base, hemos efectuado un análisis comparativo del conjunto de materiales anfóricos hallados en los vertederos de León en su primera etapa de ocupación por la Legio VII Gemina. En primer lugar, hemos de hacer notar la reducida representación cuantitativa de las ánforas en relación a otras especies cerámicas -a excepción de las lucernas, aún más escasas-, oscilando ente el 5\% de los hallazgos en el vertedero del depósito de San Pedro, un 3\% en el de la C/ Pilotos Regueral y menos de un $1 \%$ en el área de Maestro Copín, sin que se haya registrado 
ningún ejemplar en el vertedero del pequeño complejo termal de San Lorenzo. Con todo, a pesar de esta escasa presencia de restos de ánforas y de su estado fragmentario, ya que no contamos con ningún ejemplar completo en ninguno de los contextos, es preciso poner de manifiesto la diversidad morfológica y técnica que hemos apreciado en un conjunto tan escueto, de manera que constituyen un material que contribuye de forma destacada a completar la secuencia cronológica en cada vertedero.

Dado que la tipología de estos envases es indicador de su contenido, el análisis de los fragmentos más identificativos -especialmente los bordes- y de la composición de las pastas utilizadas en la fabricación de determinados ejemplares nos ha proporcionado valiosa información sobre el nivel de consumo de determinados productos y su procedencia. A ello tenemos que añadir que el hecho de tratarse de un establecimiento militar, permite constatar en algunos casos, o al menos plantear hipótesis fundamentadas, sobre determinadas pautas en el particular proceso de avituallamiento del ejército en el noroeste hispano, al igual que sucede con el abastecimiento del resto de productos manufacturados cerámicos, también dependientes de la administración militar, con las diferencias y singularidades propias de cada material.

En el conjunto de ánforas procedentes de los vertederos más antiguos, cabe señalar, en primer lugar, la acusada diferencia entre ambos, sobresaliendo el vertedero del depósito de San Pedro, donde estos envases presentan, además de un mayor volumen numérico, una considerable diversificación morfológica, mientras en el área de la C/Pilotos Regueral, además del escaso porcentaje de restos registrados, resulta llamativa la adscripción de todos ellos a un único tipo (Dressel 2/4).

Aún considerando las importantes aportaciones del material anfórico extraído del vertedero del depósito de San Pedro, hemos de poner de relieve la complejidad que plantea en cuanto a la atribución cronológica de los ejemplares, sumamente difícil de precisar, dado que en la mayoría de los casos se trata de recipientes de amplia tradición -como en el caso de las ánforas greco-itálicas- y generalmente con una prolongada perduración, que se advierte especialmente en las ánforas vinarias. Así, uno de los tipos más representativos, como las Dressel 2/4 presentan una dilatada trayectoria desde el siglo III a. C., con un auge en época augustea y julio-claudia, para desaparecer a lo largo del siglo II d. C., estando presente en todos los vertederos estudiados. Únicamente algunos tipos, como la Haltern 70, contenedor de productos conservados en vino, como el denominado defructum, cuentan con un lapso cronológico más definido, desde la primera mitad del siglo I a. C. hasta la etapa flavia, con lo cual hemos de atribuir nuestro ejemplar del vertedero de San Pedro al consumo de la Legio VI Victrix, o quizá al de la Legio VII Gemina, aunque en este último caso tendría probablemente un carácter residual. La misma problemática presentan otros envases contenedores de vino hallados en el mismo vertedero, y de atribución a uno u otro cuerpo legionario, teniendo en cuenta el fenómeno de las perduraciones, que afectaría así al ánfora rodia, cuya vigencia se estima hasta mediados del siglo II d. C., y al fragmento del tipo Pascual I, el cual, según los diferentes investigadores, desaparece, bien gradualmente en época tiberiana, o bien puede alcanzar la etapa flavia.

En este sentido, las ánforas tipificadas como Beltrán IIA y Beltrán IIB, dedicadas al transporte de las salazones béticas, cuentan con un marco cronológico más preciso, desde los inicios del período flavio, hasta su progresiva desaparición a mediados del siglo II d. C. 
Por otra parte, la adscripción cronológica de los envases anfóricos reviste una especial dificultad en aquellos fragmentos de ejemplares cuya composición petrológica y su morfología no se adscribe en sus principales rasgos (labios moldurados, asas curvas) a los tipos anfóricos establecidos y a los que hemos atribuido un probable origen local-regional en el área del valle del Duero. Su datación, que precisará un análisis morfoestratigráfico comparativo de las piezas localizadas hasta el momento principalmente en los enclaves de Petavonium, Asturica y Legio, a las que se unirán futuros hallazgos, depararía asimismo, además de su vigencia cronológica, otros rasgos comunes que singularizan a esta peculiar producción.

Para finalizar, en los vertederos flavios de Legio se detecta, al igual que en la mayor parte de los emplazamientos militares del noroeste, una total ausencia de ánforas olearias del tipo Dressel 20, aspecto que constituye aún una de las cuestiones más complejas en el ámbito de la relación entre tipología y contenido anfóricos, teniendo en consideración además su abundancia en los campamentos ubicados en los distintos limites del Imperio, especialmente británico y germánico, en los que representan un ingente nivel de comercialización del aceite bético en su tipo anfórico característico. Sobre esta cuestión, que constituye un tema aún abierto en la investigación, trataremos más adelante, en el apartado dedicado más concretamente al consumo y sistemas de abastecimiento de diferentes productos a las unidades militares acantonadas en la zona noroeste hispánica.

A partir de estas apreciaciones, podemos afirmar, desde una perspectiva de conjunto, que el material cerámico procedente de los vertederos más antiguos, de época flavia, a excepción de los fenómenos de perduración que hemos señalado, se inscriben cronológicamente en este último cuarto del siglo I d. C. en cuanto a sus inicios y etapa de mayor auge de las distintas producciones, si bien su período de utilización se extiende durante la etapa inicial del siglo II d. C., llegando a alcanzar la mitad de esta centuria y prolongándose, en los casos de los vertederos del depósito de San Pedro y el complejo termal de San Lorenzo hasta etapas más tardías.

Como contexto imbricado en esta secuencia cronológica, hemos de valorar el vertedero de la C/Maestro Copín c/v San Salvador del Nido, uno de cuyos rasgos distintivos es la calidad que presenta el material exhumado y una estratigrafía uniforme, que han permitido una datación precisa de este contexto, situándose todas las producciones cerámicas en un lapso temporal relativamente reducido que abarca los decenios centrales del siglo II d. C.

Así, en el ámbito de la terra sigillata hispánica recuperada en los vertederos de Legio destaca este último conjunto, tanto por su mayor volumen numérico (un $25 \%$ del total), como por la calidad en la factura de los diferentes ejemplares y su variedad morfológica y decorativa.

En lo que respecta a las formas lisas, con un marcado predominio sobre las decoradas, se encuentra un numeroso repertorio formal, en el que destaca la supremacía numérica del plato 15/17 y el cuenco 27, presentando ambos en sus rasgos morfológicos las características evolutivas propias de una fase media, si no avanzada de la producción. En una proporción mucho más escasa aparecen el servicio Drag. 35 y 36 (que conservan la decoración a la barbotina en el borde), así como también el servicio formado por la forma Drag. 46 y el plato Ludowici Tb. Se encuentran también ejempla- 
res de Drag 39, Drag. 44, de aparición más tardía, y Drag. 51. En cuanto a las formas Hispánicas, se registra un escaso porcentaje de las formas Hisp. 2, 4 y 7 y un mayor número de la Hisp. 49 facetada.

Más peculiar resulta la presencia de formas que ya han dejado de comercializarse en su mayor parte como la Ritt. 8, la Drag. 18 y la Drag. 24/25, que se encuentra conviviendo así con la que se considera su sucesora, la Drag. 44 . En este aspecto es preciso tener en consideración el fenómeno de las perduraciones de algunas formas que no se fabrican en esta etapa o se encuentran ya muy esporádicamente en los yacimientos, haciéndose presente el carácter de vertedero del contexto, pues puede tratarse de piezas que han estado en uso durante un dilatado período de tiempo, al igual que puede suceder con las producciones denominadas "precoces" que aparecen en el vertedero del depósito de San Pedro.

Al igual que en el conjunto de formas lisas, en la producción decorada de este vertedero se hace quizá más evidente la pervivencia de formas de la primera época, como la Drag. 29, 30 y 29/37, que ya han sido sustituidas tiempo atrás por la forma 37. En las dos variedades de esta última se constata aún un porcentaje importante de la forma 37B que desaparece a principios del siglo II d. C. La mayor proporción de formas decoradas corresponde a la Drag. 37A, en la que se despliegan los principales motivos decorativos -también algunos procedentes del alfar de la Cereceda- en composiciones metopadas y más frecuentemente, en frisos a base de círculos con motivos centrales zoomórficos y vegetales.

Con todo ello, los rasgos característicos de los ejemplares procedentes de esta área de vertidos responden a una cronología más avanzada que en los vertederos anteriores, si bien resulta significativo que, aunque en menor proporción, se encuentren formas y motivos decorativos característicos de la época flavia y principios del siglo II, la etapa considerada de mayor auge de los productos tritienses.

Por otra parte, tampoco se aprecian signos de una menor calidad técnica o disminución de la variedad morfológica y decorativa, que comienzan a manifestarse en el complejo riojano hacia mediados de la segunda centuria. Más bien al contrario, este conjunto de TSH se distingue por una excepcional calidad técnica y la presencia de una gran variedad de formas que responden a las innovaciones formales y decorativas del emporio tritiense, aunque documentadas en una etapa más tardía.

Así, podríamos hablar del lapso cronológico de este vertedero como la auténtica etapa de esplendor de la TSH riojana analizada en un centro de consumo, cuando en el centro productor comienza a advertirse un cierto estancamiento y retroceso en la producción y distribución de estas manufacturas, aspecto que pone de manifiesto una vez más la peculiar dimensión cronológica de los vertederos respecto a otros contextos de uso contemporáneo de los materiales, puesto que desconocemos la etapa de uso de las piezas, desde su producción hasta su desecho y llegada al área de vertidos.

Partiendo de estas consideraciones, hemos de valorar como una de las principales aportaciones del estudio de la TSH procedente de estos vertederos del campamento de la Legio VII Gemina, la posibilidad de reconstruir la amplia secuencia cronológica y las distintas etapas evolutivas de la producción del complejo alfarero de Tritium Magallum en un centro de consumo de este calado, desde una perspectiva diacrónica y sin interrupciones importantes, a partir de los datos de los registros estratigráficos de los diferentes contextos. 
En esta dilatada línea, hemos incardinado los criterios evolutivos tradicionales -morfológicos y decorativos-, que definen esta industria alfarera, principalmente hasta finales del siglo II d. C. ya que las producciones de la siguiente centuria han sido objeto de un tradicional desconocimiento y por tanto, escasa valoración arqueológica. En ello han influido, tanto la carencia de contextos estratigráficos fiables para esta época compleja en los centros urbanos, como la falta de definición de sus rasgos tipológicos, dada la escasez de conjuntos atribuibles a este período, resultado de la importante recesión que experimenta la producción tritiense en esta etapa.

De esta manera, la caracterización de la sigillata riojana del siglo III d. C. se ha efectuado hasta el momento en función de los rasgos de degradación y adocenamiento que presenta en relación a los productos de las etapas precedentes, sin que se muestren aún las peculiaridades de la producción de la TSH tardía de los siglos IV y V d. C., que contará con una tipología y caracterización propias y diferenciales.

Por ello cobran especial relevancia en esta secuencia temporal aquellos ejemplares de TSH procedentes de los dos vertederos que alcanzan el siglo III d. C., a pesar de su escasa cuantía y de la complejidad de los niveles estratigráficos, pero que permite definir una producción con entidad propia, caracterizada por una deficiente calidad técnica y una extrema reducción del repertorio formal, y cuyos esquemas decorativos se limitan a series de círculos aislados de línea variable. Estas características pueden apreciarse en algunas piezas del contexto del complejo termal de San Lorenzo (Lám. 31, $\left.n^{\circ} 269\right)$ y especialmente en ejemplares del vertedero del depósito de San Pedro (Lám. 6, no 51; Lám. 9, nº 81 y 82).

Estas especiales producciones alcanzan una mayor representación en algunos yacimientos como Bilbilis (SÁENZ PRECIADO, J. C., 1997) y han recibido la denominación de producciones "avanzadas", "intermedias" o "transicionales", en tanto que preludian el inicio de las producciones tardías.

En esta dilatada secuencia cronológica quedan también reflejadas algunas peculiaridades de cada vertedero en el ámbito cronológico, evidenciando particulares desajustes, pudiendo interpretarse éstos en función de la irregularidad de la estratigrafía en algunos casos, relacionados igualmente con algunos aspectos ya comentados de la problemática cronológica de los vertederos, o bien como resultado de ciertas preferencias formales o decorativas, que determinan algunas intrusiones y sobre todo perduraciones de ciertos ejemplares más allá de la cronología ortodoxa, sin que estos factores lleguen a alterar de forma sustancial la secuencia cronológica evolutiva que definen estas cuatro áreas de vertidos respecto a la producción y consumo de la TSH riojana.

Continuando con las producciones de vajilla fina de mesa en este vertedero ex novo, es de destacar el importante conjunto de vasa potoria, constituido por la cerámica de paredes finas. Ésta representa un porcentaje del 7\%, escaso cuantitativamente en relación a otras especies cerámicas, aunque muy significativo desde el punto de vista cualitativo, pues se trata de piezas de una gran calidad y variedad, procedentes en su totalidad del alfar de Melgar de Tera, en las que se plasma la mayor parte de su repertorio formal y decorativo (Fernández Freile, 2003: 105-116, Láms. 65-78). En el aspecto cronológico, este conjunto resulta decisivo en el sentido de que nos permite reconstruir de forma lineal la secuencia evolutiva de las producciones de este centro en Legio partiendo de contextos estratigráficos fiables, hasta el momento únicamente localizados, además de en el campamento zamorano de Petavonium -principal centro receptor 
de estas manufacturas-, en algunos yacimientos mineros de la provincia leonesa como Huerña o Corporales. En efecto, la presencia de cerámica de paredes finas de origen melgarense en su totalidad en uno de los vertederos flavios ( $\mathrm{C} /$ Pilotos Regueral), en el que supone idéntica proporción numérica, aunque contrasta por su muy deficiente estado de conservación y la ausencia de piezas completas, hace posible constatar esta evolución, pues los ejemplares han sido datados con claridad en los momentos iniciales de la producción del taller que comienza a finales de época neroniana (piezas de "cáscara de huevo", vasos de forma ovoide con diferentes decoraciones), estando totalmente ausentes en este vertedero datado en la mitad de la segunda centuria. Así, las formas Melgar I y Melgar II, que aparecen a finales del siglo I d. C., como se refleja en el citado vertedero de época flavia, integran en el contexto de vertidos de la C/Maestro Copín, la totalidad del elenco formal, definiéndose con precisión las características y períodos de vigencia cronológica de cada una de ellas.

Así, desde el punto de vista morfológico, queda patente la menor representación cuantitativa de los ejemplares de la Forma I, así como su período de vigencia cronológica más reducido, hasta mediados del siglo II d. C. A ello hay que añadir que, junto a las piezas lisas, este primer tipo formal presenta con exclusividad decoración burilada, si bien es preciso destacar la variedad en la forma, orientación, trazado o situación en las paredes del vaso de los motivos lineales incisos realizados con esta técnica.

Se marca así una clara diferencia con la Forma II, más numerosa y mejor documentada, con una perduración hasta momentos muy avanzados de la segunda centuria. En los vasos de esta forma se representa la totalidad del repertorio decorativo del taller melgarense, formando múltiples y complejas combinaciones, constituyendo así el tipo formal más original y distintivo de este centro alfarero.

Igualmente, en el plano decorativo se pone de manifiesto en este conjunto leonés la riqueza ornamental característica de este alfar, con sus peculiares técnicas y motivos, de los que pueden derivarse también ciertas implicaciones cronológicas. Se documenta la técnica del burilado, asociada a la Forma I, que no suele sobrepasar la primera mitad del siglo II d. C., si bien cuando se plasma en los escasos ejemplares de la Forma II su pervivencia cronológica es más amplia. Sin embargo, en este vertedero cuyo arco cronológico abarcaría el comedio de esta segunda centuria, se constata un predominio absoluto de las técnicas de barbotina y de decoración aplicada, con sus motivos característicos, que continuará hasta finales de siglo. Partiendo de un estudio detallado de estas piezas en su contexto estratigráfico, resulta también posible confirmar la línea evolutiva planteada para estos esquemas decorativos que se desarrollan en un período de tiempo tan dilatado.

De esta manera, en esta etapa, con la técnica a la barbotina se plasman en un primer momento sencillos motivos geométricos como la decoración de mamelones, continuando una etapa de esplendor caracterizada por la representación de grandes círculos (tangentes o secantes) combinados con mamelones y motivos vegetales, especialmente las características hojas de agua, que adoptan también diversas formas y posiciones, componiendo con todo ello muy diversos y complejos esquemas ornamentales que decoran los vasos de la Forma II, en ocasiones de grandes dimensiones, ofreciendo una amplia superficie decorativa que cubre totalmente las paredes del recipiente.

En cuanto a la decoración aplicada, su motivo principal es la representación de figuras antropomorfas y sobre todo de rostros humanos, característico de los entornos militares, plasmados igualmente en la Forma II y que constituyen el motivo más original e identificativo del taller de Melgar. 
Por otra parte, a través del análisis de las piezas con estas representaciones, tanto las legionenses como las procedentes de otros puntos del noroeste, se confirma la hipótesis que descarta el empleo de moldes en su fabricación, como demuestra el hecho de que todos son diferentes y responden a modelos individualizados realizados mediante la asociación de distintas técnicas y probablemente fabricados en distintos talleres de este centro alfarero.

En el aspecto cronológico se plantea la posibilidad de trazar un determinado proceso evolutivo en el aspecto exclusivamente ornamental. El criterio básico en este sentido sería la diferente ubicación de estos motivos en las paredes del recipiente, de manera que en las piezas más antiguas los rostros ocuparían el centro del vaso, mientras que ya en el siglo II d. C. se situarían en la parte superior de los recipientes, bajo el hombro, según señala Carretero (2000: 547) para los ejemplares de Petavonium. Esta característica de los vasos de cronología más avanzada es predominante en las piezas de este vertedero de Legio, si bien se trata en su mayor parte de rostros de grandes dimensiones -en relación al considerable tamaño de algunos de estos recipientescuyos rasgos están elaborados con gruesos trazos en barbotina.

En función de estas consideraciones, podemos concluir que el análisis de los rasgos morfológicos y decorativos de los ejemplares de este conjunto legionense corrobora en buena medida los criterios cronológicos propuestos en los estudios de los materiales de Petavonium, así como otros aspectos relativos a la producción y distribución de estas manufacturas melgarenses.

Sobre otras categorías cerámicas, como el material lychnológico, el vertedero de la C/Maestro Copín (Fernández Freile, 2003: 116-119) nos proporciona valiosa información sobre el uso de lucernas en esta etapa del siglo II d. C., cuando el cuerpo legionario se encuentra ya plenamente asentado, con la construcción de las nuevas estructuras campamentales y un alto grado de organización en el abastecimiento de otras especies cerámicas.

En este aspecto cabe reseñar, en primer lugar, su reducido porcentaje cuantitativo respecto al resto de materiales cerámicos, cuestión que constituye una constante en los diferentes contextos legionenses. Ahora bien, en este último caso, se trata de piezas más completas, cuya atribución tipológica resulta por tanto más precisa, y permiten evidenciar la evolución cronológica y la decisiva implantación de nuevos tipos, que alcanzarán especial relevancia en los ámbitos militares de las diferentes áreas del Imperio. De esta manera, pueden individualizarse dos grupos en este conjunto de material lucernario: por una parte, la perduración de ejemplares de volutas, a través de dos fragmentos que conservan completos el rostrum y parte de la margo y el disco, pertenecientes a los tipos Dressel 9 B y Dressel 11B, que cabría considerar como propios de los últimos momentos de este tipo de amplia vigencia cronológica; y, por otra parte, un grupo más numeroso, con cinco ejemplares, uno de ellos completo, de las denominadas lucernas de canal o firmalampen que, surgidas en el siglo I d. C., alcanzan a mediados de esta segunda centuria una amplia difusión, en función de su simplicidad formal y, por tanto, asequible precio, encontrando así gran aceptación en los establecimientos militares de los limites septentrionales. Es por ello que son conocidas también como "lucernas de frontera" (Bailey, 1980: 276), y llegan a superar en volumen de fabricación y uso a otro de los tipos surgidos en la centuria anterior, como las "lucernas de disco", cuya presencia se localiza especialmente en la zona mediterránea. 
Las peculiares características morfológicas de las lucernas de canal o firmalampen, que deben esta última denominación a las marcas de taller en relieve de alfareros norteitálicos (Fortis, Sextus, Vibius, Atimetus...) que suelen portar en la base, facilitan la fabricación en serie de estos recipientes, orientada a su masiva comercialización en las áreas citadas. Así, el predominio de la funcionalidad, lleva a prescindir de la decoración, presentando unos rasgos formales muy simplificados y uniformes, con un disco generalmente plano, amplia margo en la que se localizan varios apéndices cuadrangulares y, en algunos casos, grafitos como se evidencian en varios ejemplares leoneses (Fernández Freile, 2003: Lám. 80, 118/39) o marcas geométricas, como en fragmentos de Petavonium (Carretero, 2000: Fig. 382, $\mathrm{n}^{\circ}$ 72).

Ello implica una escasa variedad tipológica, constituyendo los principales elementos diferenciadores la configuración del canal, abierto o cerrado, y la longitud del rostrum.

En el contexto que nos ocupa, la totalidad de los ejemplares pertenecen a la modalidad de canal abierto, consideradas cronológicamente posteriores a las de canal cerrado, con un claro apogeo en el siglo II d. C. y perduraciones a lo largo de la siguiente centuria.

$\mathrm{Al}$ igual que en el caso de las lucernas, el material anfórico representa en este vertedero un porcentaje exiguo (en torno al 1\%). Con todo, hemos de resaltar su valor cualitativo en lo que respecta a las peculiaridades en los rasgos de algunos tipos ya presentes en los vertederos flavios y, especialmente, a la documentación de nuevos tipos, resultado todo ello de determinadas pautas en la evolución cronológica de estos envases cerámicos. Ello queda atestiguado por la presencia de restos de ánforas vinarias del tipo Dressel 2/4, si bien muy escasos y en estado fragmentario. Aún así pueden constatarse claras diferencias en la constitución de sus pastas respecto a los envases del mismo tipo hallados en los vertederos más antiguos y que, como analizaremos en el apartado correspondiente, responderían probablemente a una diversa procedencia.

Desde el punto de vista morfológico, destaca la mayor representación de ánforas de los tipos Beltrán IIA, destinadas al envase de derivados de salazones como garum, muria o liquamen, afamados y costosos productos hispánicos elaborados en la costa bética, que adquieren gran aceptación en otras provincias del Imperio y en la propia Roma, como queda atestiguado asimismo en las fuentes escritas. Estas producciones, cuyo marco cronológico se ha fijado fundamentalmente desde época flavia hasta finales del siglo II d. C., son meramente testimoniales en el vertedero flavio de San Pedro, pues únicamente han aparecido restos de uno de los envases -Beltrán IIA-, destinados al transporte de este contenido. Por el contrario, las ánforas contenedoras de salazones béticas son las más abundantes en el vertedero de la C/Maestro Copín, documentándose los tipos Beltrán IIA en sus dos variantes (Beltrán IIA 1 y Beltrán IIA 2) y Beltrán IIB. La datación de este último tipo se ha determinado con mayor precisión, con una producción inicial en el segundo cuarto del siglo I d. C. y una desaparición gradual a mediados de la centuria siguiente.

Asimismo, en el plano tipológico, es preciso hacer referencia a los hallazgos, tanto en el vertedero de San Pedro como en el de la C/Maestro Copín (Fernández Freile, 2003: 144-145, Lám. 116, 121/55), de diversos fragmentos de ejemplares cuya morfología no se adscribe en sus principales rasgos (labios moldurados, asas curvas) a los tipos anfóricos establecidos. De la misma manera, resulta especialmente característica 
la común configuración de sus pastas, de tonalidad gris anaranjada o rojo ladrillo, de constitución granulosa y fácilmente deleznable, con abundante desgrasante de amplia granulometría y composición fundamentalmente caliza, micácea y cuarcítica en los análisis de visu, pues estudios petrológicos de muestras realizados tanto en piezas de Legio y otros asentamientos próximos como Asturica y Petavonium, han revelado la presencia de otros componentes también específicos de estas producciones (Carreras y Berni, 2003: 650-651), sin parangón en otras zonas. Aún así, es preciso profundizar en este aspecto, elaborando análisis físico-químicos más exhaustivos en este campo, con el fin de corroborar el probable origen local o regional de estos envases.

En cuanto a la función de estas peculiares ánforas, cuyos rasgos tipológicos conocidos, que configurarían envases de escasa resistencia, que no permitirían largos trayectos de transporte -aspecto que apoya igualmente su procedencia local-, no se conserva ninguna evidencia, considerándose como contenedores de líquidos, probablemente vino, o quizá una especie de cerveza (zythos), de consumo tradicional en esta zona desde época prerromana.

Al igual que en los vertederos más antiguos, tampoco se ha documentado en éste ningún testimonio de la presencia de ánforas del tipo Dressel 20, contenedoras de aceite bético, siguiendo así los parámetros generales ya reseñados que determinan una ausencia de estos envases en los enclaves militares del noroeste.

Como rasgo peculiar, además de los fragmentos descritos atribuibles en general a formas comunes de la tipología anfórica -a excepción de los envases considerados de producción local o regional-, hemos de hacer alusión a una serie de piezas localizadas únicamente en esta área de vertidos (Fernández Freile, 2003: 146-147, Lám. 115), y calificadas como "anforiscos", que forman parte de la morfología de las ánforas, con la función de tapones de las mismas. Se trata de tres ejemplares bastante completos y morfológicamente uniformes, que permiten reconstruir el tipo de forma general: constan de un cuerpo de tendencia piriforme, con una dimensiones de unos 5 a $8 \mathrm{~cm}$. en su parte globular, en la que presentan gruesas acanaladuras horizontales, con un cuello estrecho y estilizado que termina en una boca ancha con ranura interior, mientras la base remata en un pequeño pivote cilíndrico. Partiendo de estos rasgos generales, algunas de estas piezas presentan ciertas peculiaridades, lo cual ha dado lugar al establecimiento de una tipología específica elaborada por Beltrán (1970), en la cual nos basamos para distinguir las variantes Beltrán D y Beltrán E, para los que se encuentran paralelos especialmente en Albintimilium y Ostia, destacando en el territorio interior hispano los ejemplares de Arcobriga (Sánchez, J. C., 1992b: 283, Fig. 9.1, nº. 1-3) y, más próximo a nuestro ámbito de estudio, hemos de destacar el anforisco hallado en el campamento de Petavonium (Carretero, 2000: 741, Fig. 377, n 19).

En los tres casos se encuentran fabricados con una pasta de color amarillento o blanquecino, con desgrasantes cuarcíticos y micáceos de pequeña granulometría, que pueden ponerse en relación con alguna de las ánforas que presentan pastas similares, pero en ningún caso resultan completamente idénticos.

Cronológicamente se sitúan en el siglo I d. C., si bien su origen se ha documentado en época protoaugustea, generalizándose su utilización en el siglo I d. C., con una amplia dispersión desde la zona mediterránea occidental hasta Pannonia, perdurando hasta la tercera centuria (VEGAS, 1973: 247).

En lo que respecta al cierre y sellado de las ánforas romanas, se han utilizado asimismo varios sistemas, que comprenden desde elementos de materia orgánica (cor- 
cho, madera) o inorgánica (cal, puzzolana) y, sobre todo, los denominados opercula, fragmentos cerámicos recortados con elemento de aprehensión y base con pestaña, de los que no se ha conservado ninguna evidencia en Legio. Estos elementos han sido exhaustivamente estudiados por autores como Bernal y Sáez (2008: 455-472), poniendo de manifiesto su valor como indicadores cronológicos en función de su evolución morfológica, e incidiendo en su importante aportación sobre aspectos como la procedencia, fabricación o comercialización de los envases anfóricos.

La secuencia cronológica de los cuatro vertederos estudiados puede completarse de forma diacrónica, partiendo de la perduración de dos de estas áreas -el depósito de San Pedro y el complejo termal de San Lorenzo- hasta el siglo III d. C.

Especialmente indicativo en este sentido es este último contexto, pues ya en su función de vertedero, en este caso ocasional, a principios del siglo III d.C., se hallan piezas en niveles o estructuras más tardías que contienen aportaciones antrópicas de materiales de épocas anteriores, o bien en niveles posteriores con carácter residual. En un momento posterior se encuentran acumulaciones de residuos en estructuras negativas o en niveles de arrasamiento o amortización, siguiendo para ello una lectura lo más precisa posible del complejo registro estratigráfico de este contexto. En este sentido, son numerosas estas acumulaciones eventuales de desechos en la etapa de destrucción y abandono del edificio, fechado a partir de mediados de la tercera centuria, en función de la cronología aportada por el material latericio sellado empleado en las cubiertas, y localizado ya en niveles de derrumbe.

Más reseñables resultan en este aspecto los escasos fragmentos lisos torneados de Terra Sigillata Hispánica Tardía (Lám. 31, n 274-277) hallados en los niveles más modernos de la secuencia estratigráfica, cuya técnica y morfología nos sitúan cronológicamente desde mediados-finales del siglo III d. C. y el siglo IV, perteneciendo ya a la etapa de vertidos ocasionales en que se convierte este espacio una vez abandonada su función balnearia.

De esta manera, hemos de destacar la importancia de este contexto, en su fase final como vertedero eventual, en tanto que, a pesar del escaso volumen de materiales, hemos contado con los datos fundamentales del registro estratigráfico para establecer una cronología no únicamente basada en el análisis tipológico, como era habitual hasta hace pocos años en los contextos del siglo III d. C. Así, la TSH puede continuar utilizándose como material director en estas etapas tardías, pero con un mayor rigor científico, basándose en estratigrafías fiables, dado que además, la tercera centuria constituye aún una fase poco conocida desde el punto de vista del material cerámico, en la que se produce la decadencia, abandono o transformación de muchos centros urbanos hispanos, con la consiguiente repercusión en las estructuras de producción y distribución de las manufacturas cerámicas.

Por otra parte, a partir del estudio pormenorizado del material cerámico recuperado en los vertederos de Legio en cuanto a su cronología y características morfológicas y funcionales, hemos obtenido datos concluyentes sobre la procedencia y carácter de los centros productivos de las distintas categorías cerámicas. 
Así, en lo que respecta a la terra sigillata hispánica, de los datos únicamente cuantitativos, podemos colegir que ya desde época temprana (contamos con ejemplos de algunas de las producciones denominadas "precoces") existió un importante consumo de producciones riojanas en el campamento de legionense, sin que se aprecien cambios relevantes en los hábitos de este importante centro receptor, sino un constante incremento durante el siglo II d. C. Ello se aprecia en el vertedero de mediados de esta centuria, en el que se encuentran además las piezas de mayor calidad y variedad del repertorio tritiense, reflejando una etapa de auge en el mercado de estas manufacturas, en un contexto de expansión en varios sectores de la economía en Hispania.

Todo ello viene a indicar, en principio, una plena consolidación y organización del asentamiento legionario en un reducido período de tiempo desde su llegada, en el que establece con firmeza los que van a ser sus centros de aprovisionamiento de las diferentes especies cerámicas, conservando probablemente algunos elementos de la Legio VI Victrix.

En el caso de la TSH, será el complejo alfarero de Tricio el que cubra la demanda de estas manufacturas en Legio en todas las fases evolutivas de su producción, tal como se refleja en los hallazgos de los vertederos de las diferentes etapas. De esta manera, parece establecerse un paralelismo entre el centro productor y el receptor, una estrecha relación de mercado entre ambos, que quedaría también claramente de manifiesto con el exiguo volumen numérico de estas producciones hallado en contextos de la tercera centuria, que evidencian la clara decadencia del centro productor tritiense, en el mismo ámbito de recesión que afecta a sus principales núcleos receptores, como el campamento de la Legio VII Gemina y sus cannabae.

Dadas las implicaciones que conlleva para establecer determinados rasgos en la fabricación de estas producciones, hemos de hacer referencia a otra particularidad que caracteriza al conjunto completo de TSH en los vertederos de inicio en época flavia, como es la extrema escasez de estampillas o marcas de alfarero, en lo que se refiere especialmente a los vertederos más antiguos, mientras que en el datado a mediados de la segunda centuria, aparece un significativo número de marcas, de manera que únicamente hemos hallado una en el vertedero de la C/Pilotos Regueral en las producciones lisas, de lectura abreviada de "BRITTON", situada en el fondo interno de un plato Drag. 18 (Lám 40, n 362), y otra intradecorativa bajo el borde de una Drag. 29 (Lám. 44, no 388) en una pequeña cartela rectangular con líneas y signos ilegibles.

En un elenco tan numeroso y significativo, por cuanto correspondería a la etapa de auge de la producción tritiense, no deja de resultar realmente irregular esta práctica ausencia de sellos de alfarero.

En este sentido, es preciso señalar esta misma circunstancia en otros asentamientos militares próximos, como el campamento de Petavonium, en cuyo conjunto de TSH tritiense se ha localizado también un reducido número de marcas, algunas de ellas inéditas (Carretero, 2000: 435, Fig. 267).

Ello nos ha hecho plantearnos explicaciones de diverso carácter, como la particular dinámica cronológica de cada taller o su estructura socioeconómica, así como el volumen de mercado y determinadas pautas en la distribución de la producción, o incluso la posible relación de los sellos con la tipología de los recipientes, aunque sin encon- 
trar explicaciones convincentes, considerando así únicamente como razón que pueda justificar este hecho, el carácter aleatorio que conlleva la reintegración y posterior estudio de piezas de cerámica fragmentada.

Con todo, la única marca localizada localizada en contextos de época flavia, correspondiente al alfarero "Britton", se encuentra presente en varios yacimientos peninsulares (Asturica, Conimbriga, Bracara, Emerita) y norteafricanos (Cotta), evidenciando un importante volumen productivo durante un amplio período cronológico, pues los alfares en que se ha ubicado dentro del complejo tritiense-Attius Britto en Tricio (Los Pozos) y Britto en Arenzana de Arriba- (Sáenz Preciado, M. P.; Sáenz Preciado, J. C., 1999: 92, 94) indican un temprano inicio de su producción. No en vano el taller de Arenzana se ha considerado el más antiguo del entorno de Tritium Magallum, siendo trasladado posteriormente a La Cereceda, taller cuyas manufacturas están especialmente presentes en Legio. Por otra parte, ha sido datado también en yacimientos próximos como Caesaraugusta en una etapa inicial de la industria (Sáenz Preciado, J. C., 2007, 389), alcanzando su apogeo en época flavia y principios de la siguiente centuria.

Un dato relevante que viene a corroborar en buena medida esta cuestión sobre el escaso número de estampillas procedentes de este taller, es la afirmación de su principal investigadora, quien subraya el alto volumen de material recogido en el entorno del alfar, constatando la escasez de marcas de alfareros encontradas (Sáenz Preciado, M. P. y J. C., 2006: 201), a la vez que avalaría la cronología propuesta.

De esta manera, teniendo en cuenta que la forma que porta la estampilla -un plato Drag. 18, que se caracteriza según Mayet (1984: 108), por el reducido número de marcas, debido a la escasa representación de la propia forma en la TSH- corresponde también a las producciones tempranas, vendría a señalar el principio de una especial importancia de este taller concreto del complejo tritiense en el abastecimiento al campamento de la Legio VII Gemina, como se pone de manifiesto en este y los demás contextos de vertidos en los que se localizan producciones del alfar de La Cereceda.

Aún así, en el centro alfarero de La Cereceda se ha ido localizando un mayor número de marcas, entre las que destacan AEMILIVS RVFVS, BLASTIVS, LVTEVS, PATERNVS, CAIVS VALERIVS VERDVLA, FESTVS, NOMVS VETIVS, VALERIVS REBVRRINVS (estas tres últimas en cartela in planta pedis) y otras, cuya presencia se constata únicamente en este taller, si bien a través del fenómeno de las asociaciones su producción se extendería a otros puntos de la Península (Sáenz Preciado, M. P. 1994: passim), siendo especialmente significativa la aparición de firmas y grafitos muy similares en el centro de Andújar, hecho que indicaría la posible instalación de alfareros tritienses en el alfar jiennense (Sáenz Preciado, M. P., 1998: 144-147).

Con todo, no es este el caso de Legio, donde, como veremos, no se documentan conjuntos de marcas significativos hasta mediados de la segunda centuria.

Por otra parte, hemos de subrayar la particular problemática que presenta siempre la producción decorada en relación a las estampillas, ya que las firmas intradecorativas son poco frecuentes en la TSH, lo que implica un importante obstáculo para su estudio y correcta atribución. De ahí que algunos especialistas como Romero, presten especial atención a este ámbito decorativo (1998: 200-203) para identificar estilos distintivos y, a través de ellos, productos de talleres concretos ubicados en grandes com- 
plejos o bien otros, objeto de la fabricación a menor escala en alfares de carácter local o regional. En cualquier caso, esta investigadora hace especial hincapié en la necesidad de un profundo estudio de los conjuntos decorados hallados en los centros receptores, que proporcionan información esencial para la reconstrucción de determinados criterios de producción y distribución propios de los numerosos y diferenciados grupos decorados de manufacturas de TSH en los principales centros de consumo. A este respecto, únicamente cabría añadir que, siguiendo el proceso señalado como única vía para la caracterización de grupos de piezas decoradas, en la actualidad contamos con la posibilidad de una importante comprobación a través de los análisis arqueométricos, en los que las producciones decoradas de rasgos comunes son identificadas como procedentes o no del mismo taller o entorno a través del análisis de la composición química de sus pastas.

Así, siguiendo en principio el procedimiento habitual, hemos individualizado en el conjunto de TSH de este vertedero un grupo de piezas que presentan elementos y motivos decorativos peculiares de diferentes alfareros conocidos y denominados, ante la carencia de firmas, por la utilización de estos mismos motivos en sus vasos (alfarero "de las hojas de trébol", "de los bastoncillos segmentados"), que pueden reconocerse en un primer análisis comparativo como pertenecientes al ya citado alfar tritiense de La Cereceda, como hemos descrito en el texto en las piezas más significativas.

Este origen ha sido confirmado por los análisis arqueométricos realizados sobre un importante número de muestras, señalando, dentro de un origen de fabricación común, una procedencia equiparable o probablemente mayoritaria que la de Tricio, de producciones lisas y decoradas de este taller concreto durante la totalidad de su período de vigencia que comprende diferentes fases, desde los inicios de su producción a mediados del siglo I d. C., con un especial apogeo en época flavia y principios del siglo II, y permaneciendo activo durante esta centuria, hasta enlazar con las producciones de Terra Sigillata Hispánica Tardía del siglo IV.

Un rasgo diferenciador en lo que respecta a la general escasez de sellos de alfarero viene marcado por el abundante número de estampillas conservadas en el vertedero de la C/Maestro Copín, (Fernández Freile, 2003: 92-103, Lám. 63), pertenecientes a conocidos alfareros de los diversos centros tritienses, como MATERNVS BLANDVS, adscrito al centro de Tricio (taller de Rivascaídas), IVLIVS MATERNVS, localizado en este mismo centro, o SATVRNINVS, ubicado en Arenzana de Arriba (La Puebla), y otros como LVCIVS SEMPRONIVS, GAIVS SCRIBONIVS, IVLIVS, que trabajan en el complejo de Tritium, sin que se hayan localizado con exactitud los centros o talleres de su producción.

En cuanto a las estampillas fragmentadas o de difícil lectura, hemos de mencionar la presencia en este conjunto de un alfarero inédito hasta el momento, de lectura abreviada $O F \cdot F A \cdot A E$, que firma el mayor número de piezas -más de una veintena-, entre las que se encuentran principalmente las formas Drag. 15/17, 27 y 36, ejemplares de extraordinaria calidad y que presentan las características tecnológicas del emporio tritiense. Esta peculiar producción ha sido objeto de análisis por nuestra parte en un estudio más pormenorizado Fernández Freile, 2001. 89-115) y cuya posible adscripción y significado trataremos más detalladamente en estas consideraciones finales, en el apartado dedicado al aprovisionamiento de estas manufacturas a Legio. 
Así pues, el estudio de las marcas de ceramista en los conjuntos de TSH resulta fundamental, ya que proporciona un importante nivel de información en cuanto a la procedencia de las manufacturas, la trayectoria económica y la difusión de éstas, con las implicaciones cronológicas que este proceso conlleva y otros aspectos relacionados con la producción, como la estructura y organización de los talleres (asociaciones, participación de trabajadores de condición servil, ...), o la distribución de sus productos en áreas concretas o condicionada por determinadas preferencias en los centros de consumo por algunos alfareros.

De esta manera, resultaría de gran interés la realización de un estudio comparativo de las marcas aparecidas en los distintos vertederos legionenses y de las procedentes de las excavaciones realizadas en el interior del campamento, pero la ausencia de estampillas en los otros tres contextos de vertidos y el carácter inédito de los hallazgos en el recinto castrense impide de momento esta posibilidad.

Otra de las cuestiones esenciales sobre la que hemos obtenido datos concluyentes hace referencia a la identificación de algunos centros y talleres concretos de procedencia en este conjunto de TSH legionense, dentro del ámbito del gran complejo alfarero de Tritium Magallum.

Entre estos centros, que toman su denominación del municipio en que se ubican y que engloban a su vez distintos talleres, destacan los de Arenzana de Arriba, Bezares, Arenzana de Abajo, Tricio, Camprovín, Manjarrés y Baños de Río Tobía.

La individualización de la producción de algunos de ellos en los centros de consumo de sigillata tritiense se inscribe en las últimas tendencias de la investigación sobre esta especie cerámica, con el fin de obtener información más detallada sobre determinadas redes de distribución y comercialización en un emporio alfarero de la magnitud de Tritium Magallum.

Con todo ello, teniendo en consideración las características generales expuestas de la TSH en este conjunto, pasaremos a tratar en un apartado específico, los principales criterios de atribución de este taller concreto (estampillas, estilos decorativos, punzones...), pudiendo avanzar a modo de conclusión, que los resultados obtenidos han resultado en todo similares y coincidentes a los de la primera fase, con las decisivas implicaciones que ello conlleva, pues permiten afirmar ya de forma más taxativa una clara preeminencia en la procedencia de estas manufacturas del centro de Arenzana de Arriba, con sus dos talleres "La Puebla" y "La Cereceda", destacando el predominio de este último, al que se desplaza la producción pasado un tiempo.

Al respecto hemos de plantear que el hecho de extender estos específicos criterios de atribución al conjunto de TSH de todos los vertederos estudiados en este trabajo, con dos importantes áreas más (depósito de San Pedro y pequeño complejo termal de San Lorenzo) -algunos de los cuales han quedado reflejados ya en el capítulo de estudio de materiales en la descripción de determinadas piezas procedentes de cada uno de ellos-, ha supuesto un importante incremento de información en todos los aspectos que conciernen a las pautas de producción y distribución de las manufacturas de este taller y su relación de mercado con Legio, uno de sus principales centros consumidores, que expondremos de manera conjunta, incorporando las innovaciones antedichas. 
En cuanto al primero de los criterios de atribución cuando se trata de determinar la procedencia de un conjunto cerámico, es, además de la caracterización tecnológica de las piezas, a la que ya hemos aludido para diferenciar su origen tritiense (extraordinaria calidad de las pastas: duras, compactas y con finos desgrasantes, así como de los barnices: muy adherentes, compactos y brillantes), la localización y estudio de las estampillas presentes en los ejemplares, siempre mayoritaria en las producciones lisas, aunque valorando el interés de las marcas intradecorativas y otros rasgos epigráficos como grafitos o signos anepígrafos en el conjunto de recipientes.

El elenco de TSH procedente de los vertederos legionenses se caracteriza, como ya hemos comentado reiteradamente, por una extrema escasez de marcas de ceramista, de forma que únicamente hemos localizado un sello en el vertedero de la C/Pilotos Regueral y un grupo un tanto más numeroso y variado en el ubicado en la C/Maestro Copín, sin que haya aparecido ninguna estampilla en los vertederos de San Pedro y San Lorenzo.

Esta situación resulta por tanto, equiparable especialmente al taller de La Cereceda, donde el gran volumen de material hallado y su variedad contrastan con la escasez de marcas, constatándose únicamente en principio el sello ANNIVS---MART., correspondiente a un fabricante de moldes. En un segundo momento el panorama fue diversificándose con el hallazgo de un número más completo, aunque siempre particular y heterogéneo de marcas y grafitos (Sáenz Preciado, M. P., 1994).

En el conjunto de la sigillata legionense hemos localizado únicamente como adscrito al centro de Arenzana de Arriba la marca BRITTON, concretamente ubicado en el taller más antiguo de La Puebla, procedente de la fase del vertedero citado correspondiente a época flavia y principios del siglo II , así como el sello SATVRNINVS, localizada en el mismo taller y procedente del vertedero de la C/Maestro Copín, datado a mediados del siglo II d. C., en el que, como ya hemos expuesto, el resto de estampillas se inscriben en el centro de Tricio sin más referencias y las que carecen de adscripción a un centro o taller concretos, no ofrecen dudas, incluso en los casos de marcas inéditas, de la ubicación de los alfareros que firman estos productos en el complejo alfarero riojano desarrollado en torno al río Najerilla.

De esta forma, la pronunciada escasez de marcas en el taller de la Cereceda determinó para la caracterización de la producción decorada, la denominación de diferentes alfareros en función de sus característicos estilos decorativos, destacando en este aspecto los alfareros " de las hojas de trébol", "de los bastones segmentados" o "de las escenas de caza" (Sáenz Preciado, M. P., 1993).

Así, independientemente del aumento de la nómina de ceramistas de este centro producto de las investigaciones de los últimos años, y de algunos de sus peculiares rasgos que evidencian interesantes relaciones entre diversos centros-, emplearemos como principal criterio de atribución el de las citadas producciones decoradas individualizadas de estos diferentes alfareros para corroborar el origen y especial vinculación de una parte importante de la sigillata legionense con este concreto alfar del complejo de Tritium.

En cuanto a los alfareros denominados por sus estilos decorativos, se encuentran presentes en este conjunto de TSH en diferentes proporciones. De esta manera, hallamos piezas atribuibles al alfarero "de las hojas de trébol" especialmente en fragmen- 
tos del vertedero de la C/Pilotos Regueral en que aparece este punzón de pequeño tamaño (Lám. 51, n ${ }^{\circ} 462,464$ ), y en el de la C/Maestro Copín, formando un friso central a base de hojas treboladas (Fernández Freile, 2003: Lám. 43, n 120/67). Además del motivo que le da nombre, son características de este alfarero las representaciones de jinetes, escenas circenses y gladiatorias, o de personajes tocando instrumentos musicales. Estas últimas son menos abundantes, si bien destaca la pieza n 431 (Lám. 49) en que se representa en el friso superior una sucesión de figuras danzantes y tocando instrumentos musicales, y en el inferior una composición típica de este ceramista. Aunque la adscripción resulta difícil, debido al estado fragmentario de estas piezas, podríamos atribuir la escena del fragmento $n^{\circ} 410$ (Lám. 46) a dos gladiadores, así como la de la metopa superior de la pieza n 393 (Lám. 44) a una lucha entre un gladiador y un animal, y la posible identificación con un gladiador de una figura humana armada con escudo y lanza entre dos motivos de separación vertical en el friso superior de una forma Drag. 37A procedente del vertedero de la C/Maestro Copín (Fernández Freile, 2003: Lám. 41 n 110/29).

Otro de los motivos típicos de este ceramista son las aras, que suelen portar diversos elementos en su parte superior, y de las que sí hallamos una nutrida representación en este conjunto.

El denominado alfarero "de los bastones segmentados", cuyo rasgo definitorio es la utilización de líneas o bastoncillos segmentados como motivo de separación vertical, en lugar de las habituales líneas onduladas y ángulos, se encuentra también representado en los diferentes contextos, como en el vertedero de San Pedro (Lám. 5, n ${ }^{\circ} 34$; Lám. 7, n 54; Lám. 8, no 69), en el de la C/ Pilotos Regueral (Lám. 47, nº 418) o en el de la C/Maestro Copín (Fernández Freile, 2003: Lám. 37, n 127/71), destacando esta última pieza, correspondiente a una Drag. 37A en cuyo friso central se disponen grupos de líneas verticales segmentadas enmarcando la figura de un amorcillo en pie de considerable tamaño.

En la producción de este alfarero se encuentra una característica sumamente peculiar, ya que representa bustos o retratos de la familia flavia en sus vasos, con una composición de tipo monetiforme, que alcanzan gran difusión, pero de los que no se ha hallado ningún ejemplar en Legio.

Por lo que respecta a las escenas de caza, constituyen un grupo muy numeroso y variado en el repertorio decorativo de la sigillata hispánica, con una gran diversidad de composiciones. Sin embargo, en el taller de La Cereceda se han hallado únicamente dos moldes perfectamente conservados, cuya temática ha dado nombre al alfarero "de las escenas de caza", aunque carecemos de ejemplares con las escenas exactamente reproducidas. En ambos casos se trata de piezas con dos frisos decorativos metopados, disponiéndose los motivos zoomórficos -principalmente cérvidos, cánidos y lagomorfos en actitud de salto- en el friso inferior, en esquemas metopados con motivos de separación vertical a base de ángulos y líneas onduladas.

Así, una buena parte de los punzones de motivos zoomórficos de este conjunto de TSH legionense puede identificarse con los del centro de Arenzana, si bien hemos de excluir de esta adscripción aquellas escenas que hemos calificado como cinegéticas o venationes.

Al igual que las producciones decoradas individualizadas de los citados alfareros, constatamos la presencia de motivos decorativos característicos y punzones propios 
del taller de La Cereceda, que inciden en este peculiar predominio en la TSH de Legio, si bien expondremos únicamente los más significativos y de alguna manera "exclusivos" de este alfar, pues en buena parte son comunes al resto de la producción tritiense.

Así, cabe destacar entre los motivos de imitación, las guirnaldas, en sus dos variantes: rematadas en hojas lanceoladas, lobuladas o acorazonadas (Lám. 8, nº 72) o de lazo (Lám. 6, n 52), predominando las de punzones de tipo floral que se difundirán al resto de centros tritienses.

Además de las arquerías, festones o gallones, uno de los motivos más característicos de la primera etapa de este alfar son las composiciones cruciformes, que no se atienen al influjo gálico, sino que desarrollan un estilo único y original, caracterizado por la complejidad de estas representaciones, formadas por la intersección de líneas rectas y onduladas rematadas por diversos motivos vegetales de considerable tamaño (Lám. 6, no 46; Lám. 7, no 56, 62). Frecuentemente se utilizan estos esquemas cruciformes, de diagonales entrecruzadas, combinados con otros motivos geométricos -como los verticales de separación-, o figurativos -fundamentalmente animales y vegetales-, dando lugar a composiciones decorativas abigarradas, que producen una sensación de "horror vacui" (Lám. 45, n 399, 402; Lám. 47, n 413), características de algunos ejemplares de este taller. En este apartado de composiciones cruciformes cabe destacar la realización de motivos a mano alzada, especialmente las líneas onduladas, que se representan entrecruzadas formando series de rombos o en esquemas radiales partiendo de un motivo central (Lám. 51, nº 465, 466).

Además de estos motivos distintivos, aparecen ya en este taller de la primera época del complejo riojano los principales motivos que compondrán el repertorio decorativo de la sigillata tritiense (figuras humanas y divinidades, motivos zoomórficos, vegetales, circulares, elementos verticales de separación o frisos), distinguiéndose por la gran calidad de los punzones, lo que les confiere una gran perfección y detallismo a las representaciones figurativas, destacando así sobre los demás centros tritienses.

En cuanto a los motivos geométricos, además de los círculos que se presentan en todas sus variantes y combinaciones, así como conteniendo motivos centrales, hay que destacar como motivos verticales de separación de metopas, los formados por grupos de varias líneas onduladas o combinadas con ángulos o bifoliáceas. Igualmente, entre los frisos, compuestos por motivos muy variados, son característicos aquellos formados por la sucesión de pequeños trazos verticales o "de comas", aunque en el conjunto legionense se advierte un claro predominio de los frisos constituídos por series de ángulos o bifoliáceas de gran tamaño, a lo que hemos de añadir la presencia de un friso compuesto por una serie de motivos supuestamente vegetales (Lám. 5, n 35), que sólo hemos hallado en el conjunto de punzones del alfar de La Cereceda.

La identificación de este predominio de las producciones del alfar concreto de La Cereceda en Arenzana de Arriba, dentro del amplio complejo tritiense, que se hace evidente en los distintos vertederos, ha sido confirmado por los análisis arqueométricos realizados sobre un significativo número de muestras, señalando, dentro de un origen de fabricación común, en el área riojana, una procedencia mayoritaria de este centro respecto al de Tricio.

Todo ello nos indica la existencia de determinadas pautas en la distribución de la TSH que muestran, desde época temprana, repartos o preferencias por producciones individualizadas o por determinados alfareros en los distintos centros de consumo, de 
manera que a los principales centros receptores de las manufacturas del taller de La Cereceda, como Bilbilis, Mallén, Numancia, Arcobriga, Tiermes, Saldaña o Mérida, podemos añadir Legio, en su etapa de ocupación por la Legio VII Gemina.

En cuanto a la cerámica de paredes finas, una de las producciones especialmente vinculada a los asentamientos militares, podemos afirmar que el campamento de la Legio VII Gemina y sus cannabae tienen un único centro de procedencia de vasa potoria en el complejo alfarero de Melgar de Tera, que monopolizará a partir del último cuarto del siglo I d. C. la producción y distribución de estos recipientes en el sector noroccidental peninsular, tanto en enclaves militares como civiles.

En este sentido puede establecerse una semejanza en cuanto a la procedencia también exclusiva de la terra sigillata hispánica, con origen en su totalidad en el complejo riojano de Tritium Magallum, según han demostrado los análisis arqueométricos, a pesar de la constatación de talleres locales o regionales que actúan como sucursales tritienses, en algunos casos más cercanos al entorno de este asentamiento militar.

Esta circunstancia -la existencia de unos centros productores determinados e invariables para el abastecimiento de las especies cerámicas finas- constituye un indicador de que las redes de comercialización y distribución de las cerámicas que llegan a Legio se encuentran firmemente establecidas desde la etapa inicial, detectándose además un progresivo afianzamiento de las mismas, poniendo de manifiesto la efectividad y regularidad, de signo militar, en la organización de las estructuras de mercado del campamento desde los primeros momentos de la instalación de la Legio VII Gemina.

Por otra parte, otro punto coincidente, es la presencia de efectivos de la Legio VII en el entorno de ambos centros productores; en Tricio con funciones de vigilancia y control de un punto viario estratégico, además de la ubicación de la más importante industria alfarera peninsular, y en el campamento de Petavonium -en las cercanías de Melgar y por tanto el principal centro receptor de sus manufacturas- en un momento previo o coetáneo al asentamiento de una de sus unidades auxiliares, el Ala II Flavia Civium Romanorum, en el espacio del recinto que ocupará este cuerpo de caballería, con una función poco definida hasta el momento, que se supone de control militar de la zona, y acreditada por la aparición de material latericio sellado por la legión, quizá relacionado con la construcción de alguna estructura campamental.

Estas relaciones contribuirían indudablemente a reforzar los vínculos entre estos dos principales centros productores y el importante centro de consumo legionense que, en el caso de la cerámica de paredes finas, alcanzará una extraordinaria expansión en el ámbito militarizado del noroeste, desde su centro productivo en el complejo alfarero de Melgar de Tera, cuya actividad comienza a finales del período neroniano, en época de la ocupación del campamento de Petavonium por la Legio X Gemina -receptora y transmisora de varios motivos decorativos propios de otras áreas militarizadas del Imperio-, con una etapa de esplendor a partir del asentamiento en el mismo del Ala II Flavia y manteniendo su preeminencia en la distribución de estos productos en esta zona hasta finales del siglo II d. C. y primeros momentos de la tercera centuria.

Con todo ello, es preciso hacer constar que la producción de cerámica de paredes finas del alfar de Megar de Tera (en el que también se elaboran otros tipos cerámicos), alcanza una gran diversidad en todos sus aspectos, tanto en el plano morfológico 
como en el decorativo, como demuestran los numerosos y variados hallazgos localizados en los últimos años en la zona noroeste. Esta falta de homogeneidad de los productos melgarenses, teniendo en cuenta la extensa vigencia temporal del alfar que posibilita trazar -como hemos expuesto en función de los conjuntos leoneses y su cotejo con el elenco de Petavonium- una línea diacrónica en la evolución de los tipos formales y ornamentales, con las consecuentes variaciones, ha dado lugar a controvertidas interpretaciones por parte de algunos investigadores (Martín, 2008), tanto en lo referente a la cronología como a la preeminencia de este taller en la producción y distribución en el sector noroeste.

Estas hipótesis, que rechazan la evolución de las producciones melgarenses, llegan a proponer la existencia de un taller local de cerámica de paredes finas en el campamento de León a mediados del siglo I d. C., en su época de ocupación por la Legio VI Victrix en el que se imitarían las características de las manufacturas del alfar de Melgar, coexistiendo así productos locales e importados. Ello implicaría adelantar considerablemente el inicio de la actividad del taller zamorano -fijada ya con firmeza sobre la base de las estratigrafías de Petavonium a finales del período neroniano-, o bien considerar que no es el centro productor de origen ni el único o principal abastecedor de la zona noroccidental peninsular, existiendo varios talleres que seguirían una moda regional.

Estos planteamientos, basados en suposiciones, derivadas en ocasiones del estudio de contextos de compleja estratigrafía, o bien de análisis arqueométricos superficiales sobre la cocción de las piezas fácilmente rebatibles, carecen de cualquier confirmación arqueológica en el actual estado de la investigación que, por otra parte, va corroborando las propuestas mantenidas por el principal investigador del alfar de Melgar (Carretero, 2000; 2005) a partir de los estudios de conjuntos importantes de cerámica de paredes finas de indudable procedencia melgarense, hallados en centros receptores en diversas etapas de la actividad del taller.

Sin embargo, un planteamiento más verosímil sobre esta considerable variedad de la producción radicaría en el proceso de especialización que tiene lugar en el complejo alfarero de Melgar, en el que se localizan distintos talleres y alfareros que, sobre unas pautas generales, fabrican vasos de muy distinta morfología y decoración. Así, en la producción de cada uno de ellos influyen además otros factores como el gusto estético o las cuestiones económicas que pueden condicionar la distribución de sus manufacturas en determinadas zonas o la particular duración temporal de los distintos tipos.

Todo ello permite valorar la categoría de Melgar de Tera no como un exclusivo taller de manufacturas homogéneas, sino como un gran complejo alfarero que integra diversos talleres, con esquema productivo y distributivo de sus producciones similar, aunque a menor escala -en este caso regional- , al de otros complejos de fabricación de distintas especies cerámicas, como el más emblemático de Tritium Magallum y sus múltiples talleres de elaboración de terra sigillata hispánica, en la que se registran las peculiaridades de los distintos artesanos que trabajan en cada centro.

Una vez expuestas las consideraciones finales derivadas del análisis de los principales conjuntos de la vajilla que puede considerarse fina o de lujo (TSH y cerámica de paredes finas), pasaremos ahora a extraer los datos más significativos que nos ha proporcionado el estudio del amplio volumen de cerámica común procedente de los vertederos de Legio. 
En primer lugar, y aunque evitando la generalización tradicional sobre esta cuestión, como hemos podido comprobar en el caso de Legio -con varios puntos posibles de origen de estas manufacturas-, hemos de considerar que, al igual que en la mayoría de los yacimientos romanos, una buena parte de este voluminoso conjunto de cerámica común hallado en los vertederos ha de ser de producción local, probablemente fabricada en talleres ubicados en la cannabae, que satisfarían la demanda de este contingente de población civil de cerámicas de uso doméstico, a la vez que suministran este tipo de productos cerámicos menos elaborados al grueso de la tropa legionaria acantonada en el campamento.

Efectuando una valoración de este amplio conjunto de cerámicas comunes, hemos determinado algunas características generales y diferenciadoras, dada su notable uniformidad, en orden a establecer alguno de sus centros de procedencia, ya que, en contra de la tendencia general imperante hasta épocas recientes -en que este tipo de cerámica se consideraba habitualmente en la mayoría de los casos producto de una fabricación local y más aún en los núcleos importantes-, no se ha documentado arqueológicamente hasta el momento en Legio ningún taller de elaboración de estas manufacturas, por lo cual hemos de suponer que una parte de la cerámica común legionense sería también importada, generalmente de alfares regionales instalados en la zona noroeste a partir de esta etapa flavia en importantes núcleos civiles que actúan como centros redistribuidores, como el caso paradigmático de Lucus Augusti o Asturica Augusta, en los que se han localizado talleres de estas producciones comunes que comercializarían en sus respectivos territorios conventuales.

Entre los rasgos que pueden resultar orientativos en este sentido, cabría destacar en primer término, la escasa presencia en Legio de recipientes de tradición indígena, caracterizados por cocciones reductoras que les confieren tonalidades grisáceas o negras y por acabados exteriores bruñidos o espatulados, portando simples motivos decorativos geométricos -líneas verticales paralelas o en retícula- situados en su parte superior. De hecho, únicamente se ha documentado un fragmento de olla en el vertedero de la C/ Pilotos Regueral, de época flavia y principios del siglo II, mientras que en el vertedero de la C/Maestro Copín, de mediados del siglo II, los testimonios son un tanto más representativos, hallándose ollas y diversos tipos de jarras de esta peculiar variante, que supone la integración de la tradición alfarera hispana del NW y los nuevos modelos romanos a lo largo del proceso de aculturación, permitiendo una importante pervivencia de las costumbres locales prerromanas. En este punto puede apreciarse una sustancial diferencia con otros asentamientos militares próximos como Petavonium, donde cobran especial importancia, tanto cuantitativa como cualitativa, estos tipos cerámicos de raigambre prerromana como las denominadas "Cerámica de tradición astur" (Carretero, 2000: 571-602, Figs. 299-309; 2000a: 127-149) y “Cerámica de inspiración vaccea" (Ibid., 2000: 613-628, Figs. 310-313), además de la especial difusión de estas producciones, como las denominadas "jarritas grises" de pastas de tonalidades gris y negra generalizada en la zona noroccidental.

De todos modos, no se registra en las áreas de la zona astur un fenómeno tan acusado de amplia perduración de la cerámica común de tradición indígena, como sucede en el caso emblemático de Lucus Augusti. En este aspecto, las producciones comunes locales, de gran riqueza en el repertorio formal y decorativo, tienen un predominio prácticamente absoluto sobre los nuevos tipos romanos durante gran parte de la primera cen- 
turia, hasta época flavia. Es entonces cuando Lucus se erige en un importante centro de producción local de cerámica común, coexistiendo la fabricación de tipos tradicionales indígenas con el elenco formal romano. Se trata de un centro productor integrado por numerosos talleres instalados en el área periurbana de la ciudad, con un cierto carácter de aglomeración industrial, en el que se han implantado también las nuevas formas de distribución y comercialización de los productos cerámicos, de manera que la capital lucense se constituye en el principal centro abastecedor de un mercado de carácter regional que se extiende por la zona más occidental de la región, con un claro auge en la segunda y tercera centurias, continuando su actividad hasta época bajoimperial.

Así, este centro galaico, en su calidad de núcleo esencial de abastecimiento, constituiría otro de los posibles puntos de procedencia de parte de las producciones comunes legionenses, como se evidencia en algunas piezas, cuyos paralelos con las cerámicas fabricadas en Lugo hemos señalado en el análisis de la cerámica común de los distintos vertederos, considerando éste su posible lugar de origen.

Sin embargo, hemos de puntualizar que los tipos lucenses no representan una importante proporción cuantitativa en el conjunto total, habida cuenta de que otro rasgo característico de las manufacturas leonesas es la práctica ausencia de ornamentación en los distintos tipos de recipientes, aspecto que marcaría una considerable diferencia con las típicas piezas de cocina y mesa de Lucus Augusti, que presentan, a lo largo de las diferentes etapas de su producción, una gran variedad de motivos decorativos de cuidada elaboración.

Examinando pues, los principales talleres productores de cerámica común de difusión regional activos en época flavia documentados hasta el momento, que puedan aprovisionar al campamento de la Legio VII Gemina, hemos de contemplar el papel de Asturica Augusta, donde se localiza una importante tradición alfarera local en el caso de las cerámicas comunes, ya desde época temprana, en su etapa campamental de ocupación por la Legio X Gemina, período en el que existe una coexistencia de tipos indígenas e importados en estas producciones (Burón et alii, 1997, 2006). En este sentido se advierte un marcado contraste con la señalada preeminencia de las manufacturas de tradición autóctona en Lucus Augusti en el mismo lapso cronológico, que se extiende más allá de la mitad del siglo I d. C. en ambas capitales conventuales.

La documentación de talleres locales de cerámica común en Asturica reviste una especial trascendencia desde el punto de vista de la probable procedencia de algunos ejemplares legionenses de este núcleo, ya de carácter exclusivamente civil desde mediados de la primera centuria, y que alcanza un importantísimo desarrollo urbano, en su rango de capital del convento jurídico astur, como centro neurálgico donde radican los mecanismos administrativos y de control económico de la zona septentrional peninsular. De este modo, Asturica se constituye en un importante centro productor además de la cerámica común, se han descubierto talleres de fabricación de lucernas o material constructivo- y sobre todo, redistribuidor, de todo el mercado cerámico del noroeste y otras áreas peninsulares, en virtud de su ubicación estratégica, ya que se configura como un esencial nudo de comunicaciones, punto de confluencia de las principales vías de la Hispania romana del Noroeste. Ello propiciará el intercambio de productos cerámicos de las más variadas procedencias y de gran diversidad de mercancías propias de los distintos circuitos comerciales del Imperio en esta época, contribuyendo decisivamente a la diversificación y difusión de las distintas especies cerá- 
micas, algunas de las cuales llegarán a Legio, dada su proximidad y la facilidad del transporte para enviar estas manufacturas hacia este importante núcleo de consumo de carácter militar.

Lamentablemente, en lo que respecta a la cerámica común, aunque conocemos el hallazgo de una importante cantidad de recipientes de esta especie (ollas, jarras, platos....), procedentes de las numerosas excavaciones realizadas en la capital astur, no se ha publicado hasta el momento un estudio detallado sobre la tipología de este conjunto, que sería sumamente valioso para el cotejo con las manufacturas legionenses. Aún así, nuestra participación en proyectos de investigación sobre materiales cerámicos de Astorga, nos ha brindado una importante oportunidad para una observación de visu de buena parte de estas producciones comunes, lo cual nos ha permitido apreciar una notable similitud con algunos tipos hallados en los vertederos legionenses.

Por otra parte, además de los citados centros de producción y distribución de producciones comunes más importantes de este momento, es preciso contar con la posibilidad de la importación de algunas de estas manufacturas como producto asociado a los grandes cargamentos procedentes de los principales centros abastecedores de vajilla de lujo, como Tritium Magallum para la TSH o Melgar de Tera para la cerámica de paredes finas, dado que en ambos complejos alfareros está documentada la fabricación de otras especies cerámicas, entre ellas las cerámicas comunes. Así, en los talleres riojanos, especialmente en Tricio y La Cereceda en Arenzana de Arriba, se elabora una gran variedad de recipientes comunes como ollas, platos, jarras, vasijas de almacenaje y las únicas imitaciones de platos de engobe interior rojo pompeyano constatadas hasta el momento en el Valle del Ebro. El mismo proceso tiene lugar en el complejo de Melgar de Tera, destacando entre las producciones comunes las denominadas "ollitas", que guardan gran semejanza morfológica con los vasos de paredes finas, así como también piezas con abundante desgrasante micáceo en su superficie externa, que en opinión de los principales investigadores (Carretero, 2002: 363) constituiría un recurso ornamental, también muy apreciado en los ambientes militares.

De todos los productos de estos centros de posible abastecimiento, tanto de los proveedores más habituales de estas manufacturas, como de los que sería un producto secundario, hallamos múltiples ejemplares en los vertederos legionenses, aún contando con la complejidad de dilucidar las distintas procedencias, dada la uniformidad de los recipientes de cerámica común, de manera que se precisaría la realización de análisis arqueométricos para determinar con seguridad los lugares de origen de parte de estas producciones comunes.

En cuanto a la procedencia de otra de las producciones especialmente relacionadas con los ambientes militares como son los morteros, el conjunto de estos recipientes hallados en los vertederos legionenses presenta una mayor problemática, ya que en ningún caso los ejemplares conservan estampillas y, al igual que para la cerámica común, carecemos de análisis arqueométricos que pudieran indicar un punto concreto de origen. Así, podría suponerse la existencia de un taller de carácter local o regional encargado de abastecer de estas manufacturas a los asentamientos militares y a los principales núcleos civiles del noroeste. Sin embargo, determinados rasgos distintivos 
permiten diversificar el origen de los morteros hallados en los distintos recintos castrenses. De esta manera, los aparecidos en Petavonium tendrían una probable procedencia en el cercano centro alfarero de Melgar de Tera, principal abastecedor del campamento del amplio conjunto de producciones de cerámica de paredes finas, así como también de cerámicas comunes, lucernas y material constructivo. Por su parte, algunos morteros del campamento de Cidadela presentan digitaciones y otras marcas precocción que indicarían una cercana relación con los artesanos que fabrican estos recipientes, quizá integrados en la infraestructura del ejército, o bien de carácter civil, situados en las aglomeraciones de población -cannabae o vici-próximas al recinto campamental, contando asimismo con los mortaria que señalan un origen en el próximo centro productor de Lucus Augusti, que portan marcas similares y en ocasiones bandas con diferentes motivos incisos que constituyen elementos decorativos más elaborados. Esta práctica se ha documentado en establecimientos militares de otras zonas del Imperio, principalmente en los limites británico y germánico, como Colchester (Swan, 1980: 17-19, Fig. XI, nº 62, Fig. XII, nº 74) o Saalburg (VVAA, 1993: 15), donde han aparecido mortaria con grafitos grabados antes de la cocción con nombres de centuriones o contubernia.

Por lo que respecta al conjunto de morteros procedentes de los vertederos de Legio, hemos de tener en consideración la importancia del próximo núcleo de Asturica Augusta, capital conventual y principal centro productor (cerámica común, lucernas) y redistribuidor de diversas manufacturas cerámicas, entre las cuales se encontrarían estos recipientes, esenciales no únicamente en el ámbito militar, sino también en contextos plenamente romanizados como la propia capital asturicense. A este probable centro de procedencia de la mayor parte de los mortaria, hemos de añadir, al igual que en el caso de parte de las cerámicas comunes, la posibilidad de la llegada a Legio de morteros fabricados en los mismos talleres que las producciones de vajilla fina de mesa (terra sigillata hispánica de los alfares riojanos y cerámica de paredes finas del taller de Melgar de Tera), utilizando el mismo transporte como producto secundario. En este aspecto continuaría además la tradición itálica de fabricación de morteros en los talleres de material constructivo, para formar parte del mismo cargamento en la distribución, aunque con una venta independiente de la de los materiales principales.

Una problemática semejante en cuanto a la definición de centros productivos concretos presenta una buena parte del material lucernario hallado en los vertederos legionenses. Así, a excepción del origen específico de ciertos tipos presentes en los vertederos más antiguos, de época flavia, como las lucernas "tipo Andújar", el resto, en especial el conjunto de lucernas de canal o firmalampen, más tardías y propias de los ámbitos militares, carecen de marcas de ceramista en el fondo, con lo cual ignoramos su procedencia. Con todo, habríamos de pensar en alguno de los enclaves próximos citados a continuación. La presencia de este tipo de firmas de taller -aunque también se encuentran lucernas anepígrafas- es ya habitual en este momento en establecimientos como Asturica, Melgar de Tera o Tritium, donde se localizan desde mediados del siglo II d. C. talleres de fabricación de lucernas empleando fundamentalmente la técnica del sobremoldeado, de manera que van disminuyendo progresivamente las importaciones itálicas, en función de las producciones de imitación locales. En algunos centros como Asturica Augusta, donde se encuentra la mayor representación numérica de lucernas de canal de la zona septentrional peninsular, resulta evidente la 
convivencia de ejemplares locales e importados, partiendo de las sensibles diferencias en la calidad de las pastas y la perfección en la fabricación, propia de las piezas de importación y la tosquedad de los productos locales. Los hallazgos de un importante número de moldes lucernarios en la capital astur, pertenecientes a la variante Loeschcke X (Amaré y García Marcos, 1994: 275), indica la existencia de alfares locales especializados en material lychnológico. Este sería el caso de un ceramista que, según las marcas de moldes y piezas, respondería a la firma inédita Virillio, cuyas producciones se distinguen por su escasa calidad técnica y decorativa (algunos ejemplares presentan en el disco la representación de una Victoria sosteniendo una corona), de forma que su difusión es sumamente reducida, limitándose al centro astur (Amaré y García Marcos, 1994: 273-285; Morillo, 2003: 133-134, Figs. 56, 59-61), a un hallazgo aislado en el campamento de Petavonium (Carretero, 2000: 780-781, Fig. 381, $\mathrm{n}^{\circ}$ 47) y, posiblemente, otro en Legio (Morillo, 1999: 138).

En cuanto a las firmalampen producidas en el taller de Melgar de Tera, se aprecia una clara similitud en la calidad de las pastas y otros rasgos técnicos, con la cerámica de paredes finas, la producción mayoritaria del alfar. De la misma manera, en el aspecto decorativo se localiza en el disco de un ejemplar un rostro humano aplicado, uno de los motivos definitorios en la decoración de las piezas de este taller, y generalmente relacionado con la presencia del ejército (Carretero, 2000: 766-767, Figs 389 y $\left.383, n^{\circ} 37\right)^{140}$.

Por su parte, las lucernas de canal procedentes de los talleres tritienses, realizadas en terra sigillata hispánica, a pesar de su carácter minoritario, alcanzan una cierta expansión, asociada a la comercialización de las producciones riojanas, hallándose ejemplares en Petavonium (Carretero, 2000: Fig. 380, $\mathrm{n}^{\circ}$ 44) o Asturica (Morillo, 2003: 136-138).

Especialmente llamativo en cuanto a los hallazgos de estos tipos de lucernas, resulta el campamento de Cidadela (Caamaño y Fernández, 2006: 173-176), no tanto desde el punto de vista cuantitativo (en torno a 20 fragmentos), sino en lo que respecta a la variedad de su procedencia. Se han hallado lucernas de producción local, o quizá regional, y de importación. En algunos casos las lucernas locales, de muy escasa calidad, fabricadas sin la técnica a molde y con pastas muy toscas, no se adscriben con facilidad a la tipología comúnmente empleada. Sin embargo se conserva una lucerna de canal completa de importación tipo Deneuve Xa. Por otra parte, los elementos más significativos son fragmentos de lucernas elaboradas en cerámica de paredes finas -sin que sea posible atribuirlo al taller de Melgar de Tera-, y otro fabricado en sigillata, correspondiente a una forma 50, que constituye el único ejemplar de este tipo hallado en Galicia y cuya procedencia puede apuntar con más seguridad a los talleres riojanos. Sin duda, la presencia de estos fragmentos, poco habituales en establecimientos de mayor entidad y situados en el entorno de rutas importantes, el campamento galaico se encuentra en una zona relativamente apartada, hace pensar en formas de difusión muy diversas del material lucernario en el zona norte peninsular, probablemente relacionadas con el comercio a mayor escala de otros materiales cerámicos, entre los

140 Aunque con disposición y dimensiones considerablemente diferentes a esta singular pieza de Petavonium, hemos hallado un posible paralelo en uno de los ejemplares de lucernas de canal firmados por Fortis, que porta en el centro del disco un pequeño rostro aplicado barbado y posiblemente diademado, hallado en una de las necrópolis militares de Aqincum (Pannonia) (TOPÁL, 2003: Plate 208, 58/7). 
cuales se incluye algún elemento de calidad, prácticamente en el ámbito de los productos de lujo para la iluminación.

En una visión de conjunto del material lychnológico procedente de los principales yacimientos del área septentrional peninsular, documentados esencialmente en las dos primeras centurias de la Era, puede apreciarse una numerosa representación de elementos iconográficos y diferentes calidades de fabricación en función de su condición de productos importados prácticamente en su totalidad en un primer momento, que presentan una excelente factura, o bien con una elaboración menos cuidada, consecuencia del proceso de descentralización productiva que se afianza en la segunda centuria, impulsando la instalación de talleres locales que elaboran imitaciones de los diferentes productos noritálicos con mayor o menor éxito, mediante la técnica del sobremoldeado.

Con todo, en todos los yacimientos citados puede advertirse una escasa representación numérica de las lucernas en relación a las demás especies cerámicas. Constituye ésta una cuestión ampliamente tratada, pero cuya causa sigue siendo hoy día motivo de cierta controversia en la investigación. De modo general, aunque se han planteado diversas explicaciones de carácter socio-cultural para esta escasez de lucernas en la zona norte, últimamente parece existir un cierto acuerdo entre los distintos investigadores (Morillo, 1999: 326; 2003: 288; Carretero, 2000: 747), relacionando esta escasa representación lucernaria con los problemas y encarecimiento del transporte del aceite, el principal elemento para la iluminación, aunque en los campamentos el ejército aseguraría su aprovisionamiento y en los importantes núcleos civiles la mayor parte de la población podría hacerse cargo de este producto básico de consumo.

De esta manera, se ha propuesto -como analizaremos más ampliamente al tratar algunos aspectos del material anfórico- un sistema de abastecimiento oleícola que contempla la posibilidad de la procedencia del principal combustible lucernario de zonas más próximas, como el entorno del valle del Ebro, también productoras de aceite, aunque a menor escala y sin la reconocida calidad del aceite bético suministrado a las principales provincias del Imperio.

La determinación de la procedencia y carácter de los centros productivos de ánforas presenta, por el contrario, determinados rasgos que pueden contribuir de forma decisiva a la adscripción a centros de producción más concretos. En este aspecto influyen tanto el contenido de estos envases, ligado a su tipología, como su cronología y, especialmente, la composición de las pastas empleadas en su fabricación.

Así, en cuanto a determinados tipos hallados en los vertederos más antiguos como el depósito de San Pedro, como la Haltern 70, cuyo contenido de productos -fundamentalmente olivas- maceradas en vino, a la vez que su cronología más precisa, sitúa su origen en el ámbito del consumo de productos de lujo procedentes del Mediterráneo oriental. En el mismo sentido podemos considerar el también único ejemplar de ánfora rodia, localizado igualmente en este vertedero, contenedor de uno de los vinos de mayor calidad y más afamados del Imperio.

Dejando aparte estos casos más excepcionales, destaca la presencia de ánforas vinarias como los tipos Pascual I y Dressel 2/4. Respecto al primero, continente en origen de vinos de calidad del área campana itálica, alcanza una amplia difusión en las diferentes provincias del Imperio, y el análisis de la composición de sus pastas nos inclina a adscribir en este momento a estos ejemplares una procedencia de la Tarraconense, elaborados en los talleres de la actual costa catalana y destinados al 
transporte de los vinos de esta zona. Idéntico origen hemos propuesto para los envases vinarios del tipo Dressel 2/4, generalmente continentes de vino bético. Sin embargo, el análisis pormenorizado de la calidad de sus pastas, señala su procedencia y contenido de la Tarraconense, sustituyendo progresivamente al tipo anterior y siendo igualmente utilizados para el transporte y distribución de los vinos layetanos.

La localización de múltiples talleres de elaboración de ánforas en esta zona de la Tarraconense está siendo dada a conocer en estudios muy recientes (Járrega y Clariasa, 2013: 399-411; Járrega, 2013: 411-421), con la innovación que supone respecto al predominio bético de uno de los envases anfóricos más difundidos.

La diversidad de los centros productivos en los mismos tipos anfóricos constituye otro rasgo propio de estos envases en los vertederos legionenses.

Ello puede apreciarse en las ánforas vinarias del tipo Dressel 2/4 localizadas en el vertedero de la C/Pilotos Regueral, igualmente datado en época flavia, y cuyo origen, en función de los rasgos y componentes de sus pastas, presenta ciertas dificultades de atribución, en cuanto a su fabricación en los talleres del área del Guadalquivir o del noreste de la Tarraconense, aunque cabe destacar la idéntica morfología y composición que presentan estos escasos restos, indicando en todo caso el mismo centro de procedencia.

Igualmente, en los restos anfóricos de este mismo tipo en el vertedero más tardío de la C/Maestro Copín, pueden constatarse claras diferencias en la composición de sus pastas respecto a los envases Dressel 2 / 4 hallados en lás áreas de vertidos de etapa flavia, de manera que puede argumentarse una procedencia probablemente de la Bética, sin que hasta el momento sea posible determinar de forma certera su fabricación en los talleres costeros o en los ubicados en el interior de esta provincia.

Menos dudas ofrece la atribución a centros productivos de las ánforas de los tipos Beltrán IIA y Beltrán IIB, presentes en el vertedero flavio del depósito de San Pedro y en el datado a mediados de la segunda centuria ubicado en la C/ Maestro Copín, si bien en este último aparecen en mayor proporción y más diversificadas, con diversas variantes de estos tipos principales. Estos ejemplares, destinados al envase de derivados de salazones como garum, muria o liquamen, provienen de distintos centros productivos ubicados principalmente en la costa bética, si bien se ha constatado la fabricación de este tipo de salsas en diversos puntos de las zonas costeras atlántica o cantábrica (Fernández Ochoa y Martínez Maganto, 1994).

Una de las principales aportaciones derivadas del conjunto de material anfórico de los distintos vertederos de Legio es la identificación de un nuevo tipo, de características muy específicas en la configuración de las pastas empleadas en su fabricación, ya descrita en el análisis precedente de estas piezas, al igual que sus escasos rasgos morfológicos conocidos, de forma que nos ha llevado, siguiendo a otros investigadores como Carreras y Berni (2003: 650-651) a proponer para estos envases, localizados en otros puntos importantes del noroeste como Asturica Augusta o Petavonium, una procedencia local o regional para estos envases, ubicada en el Valle del Duero.

$\mathrm{Al}$ igual que contamos con datos para establecer con mayor o menor seguridad la procedencia de los distintos tipos de ánforas localizadas en Legio, es preciso hacer mención a una de las cuestiones más complejas en el ámbito de la relación entre tipología y contenido anfóricos y por tanto de su procedencia, representada por la ausencia de ánforas olearias béticas del tipo Dressel 20, característica general de otros núcleos importantes del noroeste hispánico como Asturica Augusta o Petavonium. 
En la explicación arqueológica de este fenómeno se han propuesto diferentes hipótesis como alternativa a la procedencia bética de los envases contenedores de aceite, que expondremos en el siguiente apartado dedicado a los sistemas de abastecimiento y comercialización de productos cerámicos y otras mercancías asociadas a los enclaves castrenses de la zona norte peninsular, mencionando únicamente aquí la posibilidad, contemplada por la mayor parte de los investigadores, de la existencia de una producción de aceite en esta época en el área del alto Valle del Ebro, si bien para su suministro no se utilizarían los envases anfóricos típicos ni probablemente de carácter cerámico, con lo cual no se conservan evidencias en el registro arqueológico.

Una vez analizadas las diferentes producciones cerámicas y sus características en cada uno de los cuatro vertederos estudiados, estableciendo, a partir de este análisis comparativo, pautas muy determinadas en el consumo de estos productos manufacturados por el contingente de la Legio VII Gemina y sus cannabae, expondremos una serie de valoraciones finales sobre el abastecimiento y sistemas de comercialización de estos materiales a este cuerpo legionario.

Con ello será posible establecer las marcadas diferencias en este sentido con el aprovisionamiento de la legión precedente -la Legio VI Victrix-, independientemente de que algunos ejemplares resulten en ocasiones de difícil atribución a una u otra, como hemos señalado en diversas piezas a lo largo de este estudio.

En efecto, a partir de la época flavia se impone una nueva política en el aprovisionamiento de productos cerámicos a los asentamientos militares -reducidos al campamento de la Legio VII Gemina en León y algunas unidades auxiliares instaladas en el sector noroeste-, consistente en la sustitución de las importaciones extrapeninsulares y de otros centros hispanos, con la instalación de talleres de carácter local o regional que asegurarán el abastecimiento de las mismas producciones a estos enclaves castrenses, recurriendo en muchos casos al fenómeno de las imitaciones de las manufacturas anteriormente importadas. Ello supone una considerable simplificación en el sistema de abastecimiento al ejército de este tipo de productos manufacturados, marcando una considerable diferencia con el período anterior en el que los contingentes militares, como es el caso ilustrativo de la Legio VI Victrix -asentada previamente en el campamento leonés hasta la llegada de la Legio VII Gemina en época de los Flavios- cuyo abastecimiento de cerámica incluye importaciones itálicas y gálicas, a la vez que cuenta con alfareros civiles cuya producción de imitaciones de terra sigillata itálica se orienta exclusivamente al consumo de este cuerpo militar acantonado en Legio desde los albores de la primera centuria.

Así, la evolución y mejora en el sistema de suministro a estos acantonamientos es palpable, y en ello incide decisivamente el período cronológico en el que nos situamos, el asentamiento de la Legio VII en el solar leonés ya en la etapa flavia, en la que podemos valorar la influencia decisiva de cuatro factores que permiten la llegada de estas mercancías al campamento legionense en un proceso distributivo y comercial organizado y dinámico: el desarrollo de un importante entramado viario que facilita el transporte terrestre de todo tipo de productos en el ámbito peninsular; la consolidación de la annona militaris como medio de aprovisionamiento de la administración estatal al ejército; en tercer lugar, la organización de una red de intercambios de materiales cerá- 
micos en la que se encuentran centros redistribuidores / productores, con un importante papel de los intermediarios en la comercialización de estos productos, y por último, las numerosas producciones locales y regionales de carácter civil propiciadas por la presencia del ejército, destino fundamental del consumo de esta gran cantidad y variedad de materiales cerámicos.

1) El primero de los factores es la existencia de un entramado viario que permita una fluida comunicación entre centros productores y receptores. En este aspecto, durante la etapa flavia, además del impulso a la política municipalizadora, tiene lugar la construcción de nuevas vías de comunicación cuya misión está ya desprovista de una función esencialmente militar, centrándose en su carácter comercial, facilitando los intercambios entre los principales centros peninsulares.

En este momento, Asturica Augusta, la capital del Conventus, se configura como un centro estratégico de primer orden, donde confluyen las principales vías de comunicación entre los núcleos importantes. A su vez, la proximidad del asentamiento de la Legio VII Gemina, con su organización militar y funciones de vigilancia y control de los recursos auríferos y mantenimiento viario y sus necesidades de abastecimiento de manufacturas cerámicas, harán de esta zona del noroeste un territorio esencial en el tráfico y recepción de mercancías.

Las principales fuentes sobre los ejes de comunicación en la Hispania romana (El Itinerario de Antonino, el Ravennate, o las controvertidas "Tablas del Barro de Astorga"), reflejan en esta época una importante actividad constructiva viaria, en relación indudablemente con la expansión económica que se constata en la provincia hispana desde finales del siglo I d. C. y que continuará durante la segunda centuria de la Era.

En este contexto, se construye una nueva vía que comunica Asturica y Bracara, la Via XVIII en el Itinerario de Antonino, también conocida como "Vía Nova" (Item alio itinere a Bracara Asturicam), que une ambas capitales conventuales a través del sur del actual territorio gallego, aunque ya existían comunicaciones anteriores (las vías XIX y XX de este Itinerario), que conectaban ambos núcleos siguiendo otros trazados. La importancia de esta nueva calzada es decisiva como vía minera, pero supone un gran avance en las comunicaciones en todos los aspectos, con un largo y complejo itinerario, exhaustivamente documentado recientemente por algunos investigadores (Mañanes, 2002; 2003b).

Por otra parte, Asturica se encuentra comunicada con el Valle del Ebro -una zona de crucial importancia para el abastecimiento de productos alimenticios y manufacturados- a través de varías vías con diferentes itinerarios que prácticamente articulan toda la zona norte peninsular. Así Asturica enlazaba con Caesaraugusta a través de las vías XXVI (Item ab Asturica Caesaraugustam) y XXVII (Item ab Asturica per Cantabria Caesaraugustam) del citado Itinerario, en el que aparecen asimismo señaladas la vía XXXII (Item Asturicam Tarracone), que comunica Asturica con la capital de la provincia Tarraconense, y la vía XXXIV (De Hispania in Aquitania. Ab Asturica Burdigalam), que cruza los Pirineos hasta enlazar con la actual Burdeos. Finalmente, una vía que cobra especial relevancia en esta fuente itineraria es la que recibe el $\mathrm{n}^{\circ} \mathrm{I}$ (De Italia in Hispanias ad Leg. VII Geminam), ya que, partiendo de Mediolanum, la actual Milán, atraviesa importantes núcleos proveedores como Tarraco o Tritium Magallum, para desembocar en Legio. Configura así una ruta que, tanto por su punto de partida como por su des- 
tino (un enclave militar), tendría un decisivo valor estratégico, de forma que algunos investigadores han planteado su relación con la annona militaris (Roldán, 1975: 38-39), sin bien de forma individualizada, sin llegar a los presupuestos de otros autores que consideran la mayor parte de las rutas del Itinerario de Antonino como vías para el abastecimiento militar.

Además de estas rutas que conforman una eficaz red de comunicaciones en esta época, hemos de señalar la vital trascendencia de la Vía de la Plata, como enlace natural desde tiempos prerromanos, y relanzada en época romana en su principal trazado de unión de Emerita Augusta con Asturica Augusta, el principal eje axial al que deben añadirse prolongaciones y diversos ramales a lo largo de esta itinerario principal (Roldán, 1971; Fernández Ochoa et alii, 2002).

A ello se añade el recurso a las rutas marítimas atlánticas y cantábricas, destinadas al transporte de determinados productos, y a partir de los puertos de descarga, la utilización de numerosos caminos secundarios, e incluso tramos de transporte fluvial, que permitirían el abastecimiento de los enclaves ubicados más al interior, al margen de los importantes circuitos viarios.

Finalmente, un aspecto que pone de manifiesto el nivel de organización de esta compleja infraestructura que supone la comercialización de productos cerámicos, es la relación que diversos investigadores (Juan Tovar, 1990; Amaré, 1993), han establecido entre la ubicación de los centros alfareros importantes en función de la existencia en sus proximidades de vías de comunicación a través de las cuales se distribuirán sus manufacturas.

2) Otro de los factores esenciales para el desarrollo de la distribución y comercialización de las diferentes producciones cerámicas se encuentra en el sistema de aprovisionamiento estatal al ejército de los diferentes productos, la denominada annona militaris, que se encuentra ya en este momento plenamente consolidada y estructurada, teniendo en cuenta que constituyó uno de los grandes problemas logísticos para el estado romano en la época de mayor expansión, cuando sus legiones se encontraban acantonadas en las más diversas provincias del Imperio, alejadas de los centros productores.

El precedente de este sistema de abastecimiento -que incluye además de los productos de primera necesidad como víveres, una parte importante de producciones manufacturadas entre las que destacan la cerámica, armamento, indumentaria, moneda y demás-, parece situarse en época de Augusto, cuando se crea la Praefectura Annonae, de la que también dependían los suministros de la capital del Imperio. En este proceso resulta esencial la figura del Procurator Augusti, encargado del abastecimiento de las unidades militares asentadas en su provincia, quien coordina y centraliza la labor de cada uno de los Praefectus Castrorum, a cargo del abastecimiento de cada acantonamiento castrense.

Sobre estas bases, el sistema annonario fue desarrollándose progresivamente, alcanzando mayor desarrollo y perfección a partir del reinado de Claudio.

A partir de la instalación de la Legio VII Gemina en el solar leonés, hacia el 74 d. C., será este cuerpo legionario el único permanente en Hispania, acompañado de varias unidades auxiliares en el área noroeste peninsular en Petavonium, Cidadela y Aquis Querquennis, podemos afirmar que el sistema de la annona militaris se encuentra ya plenamente afianzado y reglamentado. Por otra parte, esta importante reducción de efec- 
tivos del ejército habría de facilitar considerablemente el abastecimiento de estos enclaves campamentales. Progresivamente, el sistema de aprovisionamiento militar va adquiriendo mayor efectividad, y a partir del 79 d. C. se crea la figura del Procurator per Asturia et Callaecia, que representa el nivel más alto en la jerarquía de la administración annonaria.

De esta manera, durante este período que comprende desde el último cuarto del siglo I d. C., el siglo II, y los inicios de la tercera centuria, contamos con una gran variedad de testimonios arqueológicos que nos proporcionan información sobre los procesos de suministro de Legio y de los asentamientos de sus tropas auxiliares, tanto en lo que respecta al abastecimiento de productos alimenticios, así como de productos manufacturados, especialmente a través de la cerámica que, a diferencia de otras producciones, permanece inalterable en el registro arqueológico.

En cuanto al avituallamiento de víveres (cereales, aceite, vino, salazones, aceitunas,...) hemos corroborado su distribución en envases anfóricos, siguiendo distintas rutas y con procedencias diversas, a excepción del aceite bético, para el que posiblemente se utilizarían envases perecederos que no han dejado constancia arqueológica.

Del mismo modo, tampoco disponemos de testimonios de la distribución de uno de los productos de primera necesidad para los soldados, como el grano, que sería transportado en ingentes cantidades, utilizando sacos o serones (Morillo y Salido, 2010: 150) para ser almacenado en grandes estructuras u horrea, construidas en un primer momento en madera y posteriormente en piedra, y otros contenedores de productos alimenticios como las propias ánforas, dolia y otros. A este respecto, uno de los ejemplos mejor conservados, que sigue el modelo constructivo de estas edificaciones en otras zonas del Imperio, se encuentra en la fortaleza auxiliar de Aquis Querquennis (Rodríguez Colmenero, 2002: 230-240, Figs. 9 y 10; Rodríguez Colmenero y Ferrer Sierra, 2006: 98-106; Morillo y Salido, 2010: 155, Figs. 10 y 11). En Legio habrían de existir uno o varios horrea para el almacenaje de víveres, dada la entidad del contingente militar que alberga el campamento, sin embargo las excavaciones arqueológicas únicamente han constatado la existencia de un gran edificio, de los denominados "almacenes en torno a patio" -como ya hemos comentado en la introducción, sobre las estructuras interiores campamentales-, cuya función es difícil de dilucidar, habiendo de recurrir a los materiales asociados. En este caso, la intervención deparó el hallazgo de varios fragmentos de armamentaria, con lo cual no parece posible atribuir de momento a esta estructura una posible función de granero o almacén de productos alimenticios.

En lo que respecta a los productos manufacturados, también competencia de la administración de la annona, destaca especialmente la cerámica, especialmente las producciones de vajilla fina como la terra sigillata hispánica o la cerámica de paredes finas, así como algunas piezas específicamente militares como los morteros, cuyo aprovisionamiento analizaremos más detalladamente, añadiendo algunas pautas en la fabricación de cerámicas de carácter local e imitaciones que llegan a los acantonamientos castrenses al margen la annonna militaris.

Este complejo sistema irá adecuándose a los cambios que se producen en el Imperio, de forma que en el 170 d. C. se crea el Subprefectus Annonae, como máxima autoridad sobre el abastecimiento de las unidades militares, sin experimentar variaciones importantes hasta el siglo III d. C. 
3) Junto con los dos factores tratados, el desarrollo de una compleja red viaria que hace posible el intercambio de mercancías entre los principales núcleos peninsulares, y el eficaz funcionamiento de la annona militaris como sistema administrativo de abastecimiento al ejército, es preciso añadir además otra cuestión fundamental en el proceso de aprovisionamiento a los enclaves militares: la existencia de una definitiva organización de las redes comerciales a partir de época flavia y una estructura afianzada en el intercambio de productos cerámicos que permite un suministro estable y regularizado.

En todo ello hay que valorar el importante papel de determinados núcleos urbanos, como Lucus Augusti, Emerita Augusta, Caesaraugusta y, en especial, por lo que respecta a nuestro entorno, Asturica Augusta, que, en función de su ubicación estratégica, actúan como centros redistribuidores de las distintas manufacturas, y en ocasiones, también como centros productores de algunas especies cerámicas locales y de imitación, que son también objeto de distribución en los campamentos del territorio astur.

De la misma manera, en este sistema de aprovisionamiento de productos cerámicos, resulta de especial relevancia la figura de los denominados beneficiarii, que actuarían como enlace entre los procuratores y los mandos de los distintos cuerpos militares, ejerciendo una labor de administración y control sobre los suministros. El papel de los beneficiarii, cuyas características y atribuciones analiza detalladamente Palao basándose en las numerosas fuentes escritas y arqueológicas referidas a los portadores de este cargo integrantes de la Legio VII Gemina (2006: 147-158), ha sido especialmente subrayado por investigadores como Carreras (1997), como elemento clave en el proceso de aprovisionamiento militar, en provincias como Britannia o Hispania, aunque los testimonios de su labor se hallan igualmente en las provincias danubianas y en el limes germánico.

En su amplitud de funciones, se encargaban asimismo de supervisar el tráfico comercial terrestre en aquellos nudos de comunicaciones de particular importancia, como en el caso del norte hispánico en la statio Segisamensium, en las proximidades de Sasamón (Burgos) -cuya entidad y significación es ampliamente descrita por autores como Gómez-Pantoja (1992) o Palao (2006: 303-305)- vigilando el flujo regular de mercancías, recaudando peajes -portoria- y ejerciendo un cierto control policial en estas zonas.

Junto a los beneficiarii, aunque con menores atribuciones, se encontraba la figura de los stratores, especialmente importante en estos enlaces y puntos de trasvase de mercancías. Más controvertido resulta el papel de los denominados frumentarii (vid. Palao, 2006: 141-147) en un principio vinculados al abastecimiento de grano, como indica su nombre, y posteriormente realizando funciones de policía y correos imperiales, durante la época de los primeros Antoninos, en la que según algunos investigadores se crea este cuerpo de funcionarios centralizado en Roma (Menéndez Argüín, 2009: 339). A pesar de estas disquisiciones en cuanto a su creación y funciones, estos frumentarii seguirían perteneciendo a sus legiones de origen, y de hecho, contamos con varios testimonios epigráficos de estos funcionarios vinculados a la Legio VII Gemina en diferentes puntos del Imperio, de forma que, según autores como Carreras (1997: 156, 167168), cabe la posibilidad de que participasen en el transporte y abastecimiento intraprovincial, encargados de los cargamentos oficiales, tanto los destinados fuera de una provincia, como los que llegaban a la misma procedentes de otras zonas del Imperio.

Por último, aún en un sistema de abastecimiento controlado por la administración estatal, hemos de hacer referencia a aquellos comerciantes, que actuando como intermediarios o negotiatores, en el ámbito privado, forman también parte importante del 
entramado comercial, especialmente en el suministro de determinadas manufacturas, al margen o en ocasiones en connivencia, con determinados circuitos oficiales del aprovisionamiento militar.

4) Como factor decisivo en el abastecimiento cerámico, es preciso hacer hincapié en el decisivo papel del ejército como elemento incentivador de la creación de talleres de industrias cerámicas locales, regentados por civiles, asegurando así el autoabastecimiento de estas producciones, a la vez que se produce una integración entre civiles y militares a través del mercado, con intercambios de muy diverso signo que rebasan el nivel meramente económico (desde aspectos técnicos a hábitos alimenticios o transmisión de elementos iconográficos reflejo de diversas mentalidades) que vienen a contribuir a la consolidación del proceso romanizador en el norte de Hispania.

Partiendo de la interacción de los factores citados, podemos colegir la efectividad del sistema de abastecimiento de manufacturas cerámicas procedentes de los principales centros productores hispanos a los asentamientos militares del noroeste.

El aprovisionamiento de los principales cargamentos de vajilla fina de mesa (terra sigillata hispánica y cerámica de paredes finas), de lucernas y ánforas así como de determinados recipientes de uso cotidiano esenciales en la impedimenta del soldado romano como los morteros, son competencia de la administración militar.

En cuanto a la terra sigillata hispánica, todos los criterios atribución aplicados a las producciones halladas en Legio indican una procedencia segura de los talleres del complejo alfarero riojano de Tritium Magallum. La ingente producción cerámica de este centro, abastecedor de núcleos civiles y militares en toda la Península Ibérica, que alcanza su mayor esplendor a partir de época flavia y durante la segunda centuria, cuenta con una compleja red de distribución para sus manufacturas, a través de las numerosas vías de comunicación terrestres que surcan esta zona del valle del Ebro, con múltiples ramificaciones, además del papel de centro redistribuidor de Caesaraugusta, comunicada con los principales núcleos urbanos del norte peninsular. A todo ello hay que añadir que los alfares tritienses tuvieron la posibilidad de distribuir sus mercancías mediante el transporte fluvial, a través del puerto de Vareia, hacia el área noreste.

En lo que respecta al abastecimiento de estas producciones hispánicas al campamento de la Legio VII Gemina, pudieron utilizarse varios itinerarios, como la Via I del itinerario de Antonino "De Italia in Hispanias... Ad Legionem", que atraviesa el enclave de Tricio, donde podían estructurarse los cargamentos, siendo el enclave legionense su destino final. Por otra parte, cabe la posibilidad, en un momento más avanzado de la producción, de la utilización del complejo entramado viario de esta zona, con centro en Caeasaraugusta, capital que enlaza con Asturica Augusta, convertida ya en un importante centro redistribuidor para el área de la meseta y el noroeste en función de la extensa red de calzadas que permiten llegar estas mercancías tanto a los núcleos importantes como a los puntos más alejados del noroeste.

Por otra parte, en el vertedero de mediados del siglo II d. C. contamos con un buen número de marcas de conocidos alfareros de distintos centros y alfares tritienses (MATERNVS BLANDVS, LVCIVS SEMPRONIVS, GAIVS SCRIBONIVS, IVLIVS, SATURNINVS,...), si bien unas veinte piezas de gran calidad y diferente morfología 
presentan una firma de lectura $O F \cdot F A \cdot A E$, que consideramos inédita, y para cuya explicación barajamos diferentes hipótesis de trabajo, aunque sin contemplar en ningún momento la existencia de contratos exclusivos de abastecimiento para Legio (Fernández Freile, 2001: 89-115; 2003: 93-95, Láms. 13, 22, 23 y 63),

Hemos valorado asimismo la posibilidad de la existencia de un alfar de carácter local o regional, a modo de sucursal de Tritium, dada la proliferación en esta época de este tipo de talleres ante la imposibilidad del complejo tritiense de satisfacer la masiva demanda de sus productos, y más teniendo en cuenta el elevado consumo de un asentamiento legionario, si bien el comercio de moldes y punzones permite mantener la homogeneidad de la producción, constatándose siempre el predominio del emporio riojano. Con todo, la localización de un pieza Drag. 33 en el conjunto de TSH de Ercavica con la misma marca (Sánchez-Lafuente, 1990: 336, Fig. 135, nº 4), haría descartar esta posibilidad, dada la considerable distancia entre ambos núcleos, a no ser que aparecieran más conjuntos similares en la meseta norte.

Finalmente, los análisis físico-químicos de pastas de algunas de estas piezas de Legio han despejado completamente la incógnita, permitiendo añadir este alfarero a la lista de alfareros tritienses y probablemente al alfar de la Cereceda, corroborando así el predominio de las producciones de este taller en la sigillata hispánica de uno de los grandes centros receptores de estas manufacturas hasta época tardía.

La preponderancia en algunos centros de consumo, tanto de determinados talleres concretos, como de algunos alfareros en particular, no constituye un fenómeno inusual, pues investigadores como Sáenz Preciado y Mínguez (2008: 176) hacen referencia a estos "repartos" en los sistemas de distribución de la producción tritiense, así como Romero y Ruíz Montes (2005: 194), ponen de manifiesto las significativas diferencias -dentro de una aparente uniformidad- en los ámbitos de distribución de los productos de los distintos ceramistas de Tritium Magallum, documentándose en unos casos en todo el área de difusión de la sigillata riojana, mientras otros se restringen a una zona determinada e incluso a algunos centros concretos, reflejando así divisiones y pautas establecidas en las redes de comercialización de esta industria. A todo ello podríamos añadir las peculiares tendencias o la predilección en algunos centros consumidores, por los productos de determinados talleres o alfareros, incidiendo todos estos factores de forma decisiva en el complejo y diversificado proceso de abastecimiento de la terra sigillata hispánica.

En las producciones de cerámica de paredes finas, el importante y variado conjunto de vasa potoria recuperado en los vertederos de la Legio VII Gemina presenta una indudable procedencia del taller zamorano de Melgar de Tera, principal centro abastecedor del cercano campamento de Petavonium. Los aspectos morfológicos, la singularidad decorativa, así como la evolución cronológica de estas manufacturas, implica su aprovisionamiento en este complejo alfarero, cuya relativa proximidad y la red de comunicaciones bien acondicionada, facilitarían el transporte terrestre de estas frágiles producciones. Incluso contemplamos la posibilidad de que algunos ejemplares hallados en el vertedero de la C/Pilotos Regueral, datados a principios de la etapa flavia, a los que hemos asignado una procedencia bética, tengan igualmente su origen en el taller melgarense, en el que también se encuentran estos tipos en los inicios de la producción, tratándose no tanto de importaciones, que se reducen considerablemente a partir de este período, sino, según afirma el principal investigador del taller 
(Carretero, 2000: 815) resultado de la presencia de alfareros de la Bética o Lusitania en Melgar en los primeros momentos de configuración del taller, que fabrican estos productos típicamente meridionales para su expansión en el noroeste por incentivación militar.

En esta categoría cerámica se pone claramente de manifiesto el mencionado cambio en el sistema de abastecimiento en época flavia, pues si en este momento la Legio VII Gemina cuenta con un único centro de aprovisionamiento de esta manufacturas, en la etapa inmediatamente anterior, de ocupación del campamento por la Legio Vi Victrix, aunque se documentan algunos productos melgarenses -dada la creación del taller a finales de época neroniana-, el conjunto de cerámica de paredes finas perteneciente a la ocupación de este primer contingente legionario está integrado por producciones de importación, fundamentalmente itálicas y gálicas, así como por los fabricados en los principales centros hispanos ubicados en la Bética, Emerita, Valle del Ebro, Lugo o Herrera de Pisuerga entre otros, con la consiguiente complejidad en el proceso de comercialización de unas piezas de costoso y difícil transporte y distribución.

Por lo demás, podemos concluir que el complejo alfarero de Melgar de Tera, con su original y dilatada producción que se hace extensiva a todo el territorio noroeste, constituye el centro de abastecimiento de la práctica totalidad de la cerámica de paredes finas, un elemento esencial en los enclaves militares, durante la etapa de ocupación de la Legio VII Gemina en su acuartelamiento leonés, extendiéndose posteriormente a los ámbitos civiles del noroeste.

Las cerámicas comunes, suelen presentar un origen local, pudiendo ser fabricadas en talleres ubicados en las cannabae o en las proximidades de los campamentos, o bien en centros redistribuidores y productores cercanos, como el caso de Asturica Augusta respecto a Legio, constatándose también la presencia de algunos ejemplares de cerámica común procedentes de otros grandes centros productores como Lucus Augusti.

De la misma manera, se localiza en algunos talleres de estos importantes núcleos civiles como Asturica, o en officinae del complejo alfarero de Melgar de Tera, la producción de imitaciones de especies cerámicas tradicionalmente importadas, como algunos tipos de lucernas obtenidas mediante sobremoldeado o la fabricación de platos de engobe interior rojo pompeyano.

En el ámbito del abastecimiento y los cauces de comercialización cobran especial relevancia los envases anfóricos, que presentan importantes peculiaridades en este aspecto.

En primer lugar es preciso subrayar, en lo que respecta a las ánforas vinarias, la importante proporción que adquieren las producciones fabricadas en la Tarraconenense, en figlinae del actual área catalana, y que transportan los vinos layetanos de la zona. En este proceso de comercialización desempeñarían un importante papel algunos centros redistribuidores, como sería el caso de Baetulo, donde tendía lugar el embarque de grandes cantidades de ánforas par abastecer de vino a diversas zonas del Imperio, reservando probablemente una parte o trasvasando a otros envases de diferente morfología el producto destinado al territorio norteño hispano. El carácter comercial y de trasbordo de esta mercancía en este enclave ha sido definido precisamente a partir del hallazgo de dos importantes vertederos de 
ánforas vinarias de diversa tipología y varios dolia con el mismo contenido (Comas y Padrós, 2008: 75-86).

Más compleja resulta, la individualización de las características definitorias y por tanto de sus cauces de distribución, de una producción de carácter local o regional, de estos envases atribuida a la zona del Valle del Duero, hasta el momento minoritaria, pero con representación en tres de los principales establecimientos norteños como Asturica, Legio y Petavonium.

En este caso, teniendo en consideración la preponderancia de las ánforas de la Tarraconense y el considerable número de fragmentos de estos envases atribuidos a una producción en el área del Valle del Duero, podríamos inferir un significativo comercio interior de ambas producciones de vinos en la zona norte y noroeste, quizá en función de su menor calidad y su transporte y comercialización menos costosos, para abastecer a las tropas acantonadas en los enclaves septentrionales.

En el abastecimiento de los contenedores anfóricos en el interior peninsular destaca, como ya hemos aludido en el estudio y procedencia de los materiales cerámicos de los distintos contextos, la ausencia de ánforas del tipo Dressel 20, envase fabricado en la Bética, destinado al contenido del aceite procedente de región, mientras se encuentra en ingentes cantidades en los campamentos ubicados en los distintos limites del Imperio, especialmente británico y germánico, en los que representan un ingente nivel de comercialización del aceite bético en su tipo anfórico característico, a través del sistema de avituallamiento militar de carácter estatal, que formaría parte de la annona militaris.

Esta nula presencia o inexplicable escasez de estos envases se encuentra igualmente en otros establecimientos militares del área noroeste, como Asturica o Petavonium, que serían objeto asimismo del abastecimiento de aceite al ejército a través del mismo proceso de suministro. Esta cuestión ha sido ya tratada más someramente en la explicación de la escasez de lucernas en los asentamientos del noroeste, condicionada por el mismo factor, exponiendo la teoría hoy aceptada que explicaría esta peculiaridad de ambas categorías cerámicas en este espacio.

En la explicación arqueológica de este fenómeno se han propuesto diferentes hipótesis, ya planteadas ampliamente en el texto en el estudio del material anfórico de uno de los vertederos (el depósito de San Pedro), aceptándose finalmente como teoría consensuada por los principales investigadores en este ámbito (Carreras, 1996; Carretero, 2000; Carreras y Berni, 2003), la influencia determinante del elevado coste del transporte terrestre de estos productos desde la Bética, implicando el recurso a las rutas marítimas atlánticas y cantábricas para su distribución. En éstas se localizan importantes puertos, como Portus Blendium o Brigantium, para hacer llegar estas mercancías a los núcleos castrenses del interior, probablemente a través de puntos de redistribución fluvial o terrestre, aún no localizados con exactitud, y con la posible intervención de beneficiarii cuya actividad en el control del abastecimiento militar es fundamental, sin descartar la participación de negotiatores o intermediarios, ya encuadrada en el comercio privado. En este proceso, el producto sería trasvasado a envases más aptos y menos costosos para el transporte terres- 
tre, como podrían ser odres o pellejos (Beltrán et alii, 1996: 145-149; Morillo, 2000b: 629) que, por su naturaleza perecedera, no han dejado constancia alguna en el registro arqueológico.

Por otra parte, se trataría de una ruta ya establecida para el abastecimiento de aceite bético a los establecimientos campamentales de los limites gálico, británico y germánico, efectuándose la descarga de una proporción de contenedores anfóricos destinados al consumo del noroeste hispánico en estos enclaves portuarios.

Partiendo de esta argumentación y, a modo de hipótesis, cabría plantear la posibilidad de que este procedimiento de abastecimiento de aceite a través de circuitos marítimos -transporte para el que está concebido el envase anfórico- pudiera hacerse extensivo a determinados tipos de ánforas contenedoras de otros productos, como vino o salazones, con la misma procedencia del área meridional hispana.

Partiendo de estas consideraciones, a través del material anfórico, queda patente el nivel de consumo de determinados productos, su diversa procedencia y algunos de los sistemas empleados para el abastecimiento de los mismos al campamento ocupado por la Legio VII Gemina.

En este proceso cabe destacar asimismo las implicaciones de tipo social que conlleva la presencia de determinados tipos de ánforas contenedores de productos exóticos o de lujo, especialmente vinos greco-itálicos o salazones béticas, que indicarían un consumo de los mismos por parte de las altas jerarquías de la oficialidad militar -de procedencia esencialmente itálica- y que mantienen algunas costumbres romanas propias de su elevado rango social. La consecución de dichos productos se realizaría en ocasiones utilizando los cauces de la annona militaris, o bien de forma privada, a través de intermediarios, al margen de los circuitos regulares de abastecimiento en estos establecimientos militares del noroeste hispano, tan alejados del lujo y exotismo de Roma y otras áreas del Imperio.

Este consumo de mercancías de lujo resulta aún más evidente, a través del material anfórico hallado, en otros núcleos como Asturica Augusta (Carreras y Berni, 2003). Sin embargo, el hecho de constituir éste un asentamiento civil de primer orden, como capital del Conventus asturicense, indicaría la existencia de una importante clase social plenamente romanizada y con alto poder adquisitivo, constituida por altos cargos administrativos y de gobierno, miembros del orden senatorial y/o ecuestre, en la mayoría de los casos procedentes de la capital del Imperio.

Aún así, hemos de constatar que en Legio y otros asentamientos militares como Petavonium, en el que también se han documentado evidencias del consumo de estos productos de lujo, la proporción de las ánforas que los contienen es sensiblemente menor que en los núcleos civiles, y en ocasiones puramente anecdótica, respondiendo a la restringidas y espóradicas adquisiciones ya comentadas por parte de los altos mandos militares, pues el consumo de los soldados estaría marcado por la distribución uniforme y austera de los productos alimenticios de primera necesidad que precisan su envasado y transporte en ánforas.

Algunas de estas tendencias y rasgos comunes en determinadas producciones cerámicas que las definen como propias de los entornos castrenses, como hemos podido comprobar estableciendo el cotejo entre los asentamientos de Petavonium y Legio, en 
la segunda fase de ocupación de ambos recintos -a partir de época flavia-, cuando las unidades el ejército romano se encuentran acantonadas únicamente en la zona noroeste peninsular, nos permitiría asimismo valorar una característica que, según algunos investigadores como Carreras (1997: 172-173), constituye un aspecto sumamente original en el sistema de abastecimiento del ejército hispano, como es la "regionalización", a diferencia del resto de las provincias occidentales. De esta manera, mientras en otras provincias como Britannia, el mecanismo de aprovisionamiento militar se encuentra más centralizado y jerarquizado, en Hispania la red de suministros a las tropas aparece más regionalizada en este territorio noroccidental, probablemente debido a las dificultades y elevados costes en los transportes de determinadas mercancías desde otras zonas peninsulares.

Al respecto cabe mencionar el hecho de que esta regionalización o descentralización en el abastecimiento militar puede vislumbrarse ya en la fase anterior julioclaudia, como se aprecia en los sistemas de aprovisionamiento de los contingentes legionarios acantonados en esta etapa. Éstos recurren a la producción de diferentes categorías cerámicas como la terra sigillata por alfareros militares (como el figlinarius Terentius para la Legio IIII Macedonica) o civiles (los diferentes alfareros que elaboran estas producciones para la Legio VI Victrix) o el material constructivo en el caso de la Legio X Gemina, que además impulsa la producción de cerámica de paredes finas en el taller de Melgar de Tera, prefigurando determinados sistemas de abastecimiento y comercialización de estas manufacturas en la zona noroeste en los siglos posteriores.

Todo ello viene a indicar la extrema complejidad que supone para la administración imperial la organización del sistema de abastecimiento de productos cerámicos a los cuerpos militares asentados en las distintas provincias, cuestión en la que han hecho hincapié diferentes investigadores como Peacock (1997: 183- 219) o Greene (1992: 13-15; 1997), señalando la incidencia de factores de muy diversa índole en este proceso, que dificultan la definición de un patrón uniforme en los mecanismos de suministro de cerámica al ejército a partir exclusivamente de los datos arqueológicos. En este sentido, una de las cuestiones más problemáticas sería la posible producción de manufacturas cerámicas por personal militar en algunos campamentos o los contratos efectuados por la oficialidad con alfareros civiles y el alcance de los mismos, además de la proporción entre la producción local y foránea que incluye el comercio a larga distancia, influyendo todo ello de forma decisiva en la economía provincial.

Así, aunque puede constatarse una cierta koiné en el consumo de ciertas producciones cerámicas en los ámbitos militares, ello no implica una uniformidad en sus procesos de producción y distribución, que dependen de los diferentes sistemas de aprovisionamiento según las provincias, regiones y, en ultima instancia, de las peculiaridades de cada asentamiento castrense.

Es así como, a partir del estudio individualizado de los distintos tipos cerámicos hallados en los diversos asentamientos militares es posible reconstruir aspectos como la procedencia, los sistemas de distribución y comercialización, así como rasgos comunes y hábitos singulares de consumo de cada unidad del ejército romano. 
Las implicaciones que conlleva este material cerámico, contextualizado en este particular entorno arqueológico e histórico, que interactúa decisivamente en su ámbito espacio-temporal, es sin duda otro de los elementos que intervienen en el proceso que determina la presencia del ejército como factor esencial de romanización, especialmente en el ámbito noroccidental.

En esta línea, los resultados del estudio de los diferentes tipos de materiales cerámicos procedentes de los ricos vertederos extramuros de Legio, contextos de estrecha vinculación a la evolución del asentamiento, nos han aportado datos sumamente relevantes, plasmados a lo largo de estas páginas, que han contribuido, a través de una valoración conjunta, a aumentar el conocimiento sobre importantes aspectos político-estratégicos, económicos y sociales que refleja la distribución de las distintas producciones cerámicas. Igualmente, determinados criterios en la utilización y desecho de estas producciones nos han proporcionado valiosa información sobre los principales hábitos de consumo de una unidad legionaria, y en suma, sobre diversos ámbitos definitorios de la actividad cotidiana de un establecimiento militar, incluyendo sus específicas manifestaciones culturales. Todo ello se hace presente en el principal recinto castrense que representa durante un decisivo y prolongado período la presencia del ejército romano en Hispania y su evolución cronológica, como es el campamento de la Legio VII Gemina. 
VI.- BIBLIOGRAFÍA 
ABAD CASAL, L.; KEAY, S.; RAMALLO, S. (eds.) (2006): Early Roman Towns in "Hispania Tarraconensis", JRA, Supplementary Series 62, Cambridge.

ABASCAL PALAZÓN, J. M. (1986): “La Legio VII Gemina. Balance de la investigación y perspectivas", Actas del I Congreso Internacional Astorga Romana, Astorga, pp. 317-328.

ABASCAL, J. M. (2009): “El ejército romano en los siglos I-IV d. C.", en O'DONNEL, H. et alli (coords.), Historia militar de España. Prehistoria y Antigüedad, pp. 282-288.

ABÁSOLO, J. A. (1993): “La ciudad hispanorromana en la submeseta norte”, La Ciudad Hispanorromana, Barcelona, pp. 190-205.

ABÁSOLO, J. A. (1998): “La ciudad de Segisamo”, en RODRÍGUEZ COLMENERO, A. (coord.), Congreso Internacional Los orígenes de la ciudad en el Noroeste Hispánico, Lugo, pp. 585-598.

ABÁSOLO, J. A. et alli (1984): Excavaciones en el yacimiento de la Morterona, Saldaña (Palencia), Palencia.

ACERO PÉREZ, J. (2011): AUGUSTA EMERITA, en REMOLÀ, J. A.; ACERO. J. (eds.), La gestión de los residuos urbanos en Hispania. Xavier Dupré Raventós (1956-2006). In Memoriam. Anejos de AEspA LX, Mérida, pp. 147-180.

ALARÇAO J.; ETIENNE, R. (1975): Fouilles de Conimbriga V. La céramique commune locale et régionale, París.

ALARÇAO, J. et alii (1979): Fouilles de Conimbriga VII. Trouvailles diverses- Conclusions Génerales, París.

ALCAMO, J. C. (1986): La dénomination des productions de vaisselle commune, RAS, horsserie $n^{\circ} 29$, Avignon.

ALCORTA IRASTOZA, E. J. (1991): “Cerámica de cocina e mesa na Galicia romana a través dos achádegos de Lucus Augusti", Larouco 1, pp. 40-41.

ALCORTA IRASTOZA, E. J. (1995): “Avance al estudio de la cerámica común romana de cocina y mesa de Lucus Augusti", en VV. AA. (1995): Ceràmica comuna d'època Alto-Imperial a la Península Ibèrica. Estat de la qüestió. Monografies Emporitanes VIII, Empúries, pp. 201-226.

ALCORTA IRASTOZA, E. J. (2001): LVCVS AVGVSTI. II. Cerámica común romana de cocina y mesa hallada en las excavaciones de la ciudad, Pontevedra.

ALCORTA IRASTOZA, E. J. (2005): “Lucus Augusti como centro de producción y consumo cerámico", en FERNÁNDEZ OCHOA y GARCÍA DÍAZ (eds.), Unidad y diversidad en el Arco Atlántico en época romana, BAR International Series 1371, Oxford, pp. 191-202. 
ALFÖLDY, G. (1969): Fasti Hispanienses. Reichsbeamte und Officiere in den Spanischen Provinzen des römischen Reiches von Augustus bis Diokletian, Wiesbaden.

ALFÖLDY, G. (1970): “Die senatorischen Kommandeure der Legio VII Gemina”, en VV. AA., Legio VII Gemina, León, pp. 385-399.

ALFÖLDY, G. (1998): “Hispania bajo los Flavios y los Antoninos: Consideraciones históricas sobre una época”, MAYER, M.; NOLLA, J. M.; PARDO, J. (eds.), De les estructures indígenes a l'organització provincial romana de la Hispania Citerior, Ítaca. Annexos, 1, Barcelona, pp. 11-32.

ALMAGRO-GORBEA, M. (coord.) (2009): Historia militar de España. Prehistoria y Antigüedad, Madrid.

ALONSO, B. (1986): “Vía romana de Braga a Astorga: variantes do distrito de Bragança entre vale de Telhas e Babe", I Congreso internacional Astorga Romana, vol. I, pp. 257-270.

ALVARADO GONZALO, M.; MOLANO BRIAS, J. (1995): “Aportaciones al conocimiento de las cerámicas comunes altoimperiales en Augusta Emerita: el vertedero de la Calle Constantino", en VV. AA. (1995): Ceràmica comuna d'època Alto-Imperial a la Península Ibèrica. Estat de la qüestió. Monografies Emporitanes VIII, Empúries, pp. 281-295.

ÁLVAREZ JIMÉNEZ, D. (2009): “La legio VII gemina y la defensa del litoral levantino en tiempos de Maximino el Tracio", en MORILLO, Á.; HANEL, N.; MARTÍN, E. (eds.), LIMES XX. Estudios sobre la Frontera Romana, Anejos de Gladius 13, Vol. II, pp. 607-614.

ÁlVAREZ ORDÁS, J. C.; RODRÍGUEZ GONZÁLEZ, P.; MARTÍNEZ MURCIEGO, N. (2000-2001): “Instrumental médico procedente de la excavación del yacimiento de época romana de la carretera del cementerio. Puente Castro. León. Una aproximación", Lancia 4, León, pp. 141-158.

ÁLVAREZ SANTOS, J. A. (2005): La terra Sigillata en Cantabria. Fondos del Museo de Prehistoria y Arqueología de Cantabria y del Museo Arqueológico Nacional, Santander.

AMANTE, M. (1993): Lucernas romanas de la región de Murcia. Hispania Citerior, Murcia.

AMARÉ TAFALLA, M. T. (1984): “Avance al estudio de un posible alfar romano en Tarazona: III. La cerámica engobada decorada”, Turiaso V, Tarazona, pp. 107-140.

AMARÉ TAFALLA, M. T. (1986): Las lucernas romanas en el Convento Jurídico Cesaraugustano, Tesis Doctoral inédita, Universidad de Zaragoza.

AMARÉ TAFALLA, M. T. (1987): Lucernas romanas de Bilbilis, Zaragoza. 
AMARÉ TAFALLA, M. T. (1987b): Lucernas romanas: generalidades y bibliografía, Monografías Arqueológicas 26, Zaragoza.

AMARÉ TAFALLA, M. T. (1988): Lucernas romanas en Aragón, Zaragoza.

AMARÉ TAFALLA, M. T. (1989-90): “Lucernas romanas en Hispania (las lucernas romanas de cerámica en la Península Ibérica hasta el siglo IV: introducción y elementos de trabajo)", Anas 2-3, Mérida, pp. 135-172.

AMARÉ TAFALLA, M. T. (1993): “La cerámica y las vías de comunicación: una aproximación al problema de sus relaciones en la Lusitania", Cuadernos de San Benito. Encuentros sobre el Tajo: El territorio y las comunicaciones, pp. 100-105.

AMARÉ TAFALLA, M. T. (2008): “Producciones cerámicas de época romana en la provincia de León”, SFECAG, Actes du Congrès de L'Escala-Empúries, pp. 237-240.

AMARÉ, M. T.; AGUAROD, M. C. (1987): “Pervivencia de tradiciones cerámicas celtibéricas en época imperial romana", I Simposio sobre Celtiberos, Zaragoza, 97-104

AMARÉ, M. T.; GARCÍA, V. (1994): “Una producción de lucernas en Asturica Augusta", Zephyrus XLVII, Salamanca, pp. 273-285.

AMARÉ, M. T. et alli (1997): “Una producción cerámica de época romana inédita”, Lancia 2, pp. 271-281

AMARÉ, M. T.; FERNÁNDEZ FREILE, B. E.; GARCÍA MARCOS, V.; MORILLO, Á. (2000-2001): “Dos nuevas decoraciones en piezas cerámicas del alfar de Melgar de Tera", Lancia 4, León, pp. 159-171.

AMARÉ TAFALLA, M. T.; ÁLVAREZ VEGA, E. (2006): “Material latericio de la Legio VII procedente del Polígono de "La Palomera" (León)", en MORILLO, Á. (ed.), Arqueología militar romana en Hispania. Producción y abastecimiento en el ámbito militar, León, pp. 725-732.

AMORES, F.; KEAY, S. J. (1999): “Las sigillatas de imitación o una serie de hispánicas precoces", en ROCA ROUMENS M.; FERNÁNDEZ GARCÍA, M. I. (coords.), Terra Sigillata Hispánica. Centros de fabricación y producciones altoimperiales, Univ. de Jaén/ Univ. de Málaga, pp. 235- 252.

ANDERSON, A. C. (1982): Guide de la céramique romaine à parois fines. RAS, hors-serie, 17, Avignon.

ANDERSON, A. C.; ANDERSON, A. S. (eds.) (1981): Roman Pottery Research in Britain and North-West Europe (Part II), BAR, International Series 123 (II), Oxford.

AQUILUÉ, X.; SANTOS, P.; TREMOLEDA, J. (2008): “L'evolució dels contextos ceràmics d'Empúries entre els segles II a. C. i VII d. C.", SFECAG, Actes du Congrès de L'Escala-Empúries, pp. 33-62. 
ARANEGUI GASCÓ, C. (1987) : “La cerámica gris de tipo ampuritano: las jarritas grises", en Céramiques Hellénistiques et Romaines II, París, pp. 87-97.

ARCE, J. (2009 reed.): El último siglo de la España romana, 284-409, Madrid.

ARCELIN, P.; TUFRREAU LIBRE, M. (dirs.) (1998): La quentification des céramiques. Conditions et protocole, Bibracte 2, Glux-en-Glenne, Centre Archéologique Européen de Mont Beubray.

ARIÑO GIL, E. et alli (1991): “Las vías Italia in Hispanias y ab Asturica Terracone", Bolskan 8, Huesca, pp. 243-270.

AURRECOECHEA, J. (2006): “Talleres dedicados a la producción de equipo militar en los campamentos romanos de León, con especial referencia a los restos de "lorica segmentata" en MORILlO, Á. (ed.), Arqueología militar romana en Hispania II. Producción y abastecimiento en el ámbito militar, León, pp. 309-334.

AURRECOECHEA, J. (2006b): “Roman military equipment in Spain”, en MORILLO, Á.; AURRECOECHEA, J. (eds.), The Roman Army in Hispania. An Archeological Guide, León, pp. 167-179.

AURRECOECHEA, J. (2007): “Las armaduras segmentadas (loricae segmentatae) en los yacimientos romanos de la provincia de León. Un estudio de conjunto", $A E A$ 80, pp. 153-182.

AURRECOECHEA J. (2009): “Evolución y cronología de las armaduras segmentadas romanas (loricae segmentatae), basada en los hallazgos hispánicos" en MORILLO, Á.; HANEL, N.; MARTÍN, E. (eds.), LIMES XX. Estudios sobre la Frontera Romana, Anejos de Gladius 13, Vol. I, pp. 433-444.

AURRECOECHEA, J.; GARCÍA MARCOS, V. (2006): “Un pectoral de armadura con decoración repujada hallado en el campamento de la Legio VII en León", Sautuola 12, pp. 112-119.

AURRECOECHEA, J. et alli (2008): “Un protector de brazo (manica) procedente del campamento de la Legio VII Gemina en León (España)”, AEA 81, pp. 255-264.

AVELlO, J. L. (1985): “Calle de la Abadía y Plaza de Santo Martino, León”, Arqueología 83. Memoria de las Excavaciones Programadas en el año 1983, Madrid, p. 132.

AVELLO, J. L. (1993): “El ejército romano y el origen del urbanismo en la actual provincia de León", Actas del VIII Congreso Nacional de Historia del Arte, Mérida, pp. 939943.

AVELLO, J. L.; SÁNCHEZ-LAFUENTE, J. (1999): “García y Bellido en León”, I. E. S. Antonio García y Bellido, León, pp. 8-10. 
BAILEY, D. M. (1988): A Catalogue of the Lamps in the British Museum. III: Roman Provincial Lamps, Londres.

BALIL, A. (1965): “Materiales para un índice de marcas de ceramista en Terra Sigillata Hispánica", AEspA XXXVIII, pp. 139-170.

BALIL, A. (1969): Estudios de cerámica romana I, S. A. 4, Santiago de Compostela.

BALIL, A. (1970): “La defensa de Hispania en el Bajo Imperio", en VV. AA., Legio VII Gemina, León, pp. 603-620.

BALIL, A. (1975): "Para un planteamiento de estudio de la T.S.H.", BSAA XL-XLI, Valladolid, pp. 592 ss.

BALIL, A. (1977): “Notas de cerámica romana”, BSAA 43, Valladolid, pp. 379-388.

BALIL, A. (1980): Estudio sobre lucernas romanas II, S. A. 62, Valladolid.

BALIL, A. (1982): “Lvcius Terentius, alfarero de la Legión IV Macedonica”, Sautuola III, Santander, pp. 171-173.

BALIL, A. (1984): "Estudios sobre lucernas romanas IV", BSAA, Valladolid, pp. 190-195.

BALLET, P.; CORDIER, P.; DIEUDONNÉ-GLAD, N. (dirs.) (2003), La ville et ses déchets dans le monde romain: rebuts et recyclages, Montagnac.

BANHA DA SILVA, R. (2011): OLISIPO, en REMOLÀ, J. A.; ACERO. J. (eds.), La gestión de los residuos urbanos en Hispania. Xavier Dupré Raventós (1956-2006). In Memoriam. Anejos de AEspA LX, Mérida, pp. 203-212.

BARBULESCU, M. (1997): Castrul Legionar de la Potaissa (Turda), Zalaula.

BATIGNE VALLET, C. (ed.) (2012): Les céramiques comunes dans leur contexte regional: facies de consommation et mode d'approvisionemment, Lyon.

BATS, M. (dir.) (1996): Les céramiques comunes de Campanie et de Narbonaise (I s. av. J-C II s. ap. J-C). La vaiselle de cuisine et de table, Centre Jean Bérard, Nápoles.

BEDON, R. (ed.) (1998): Suburbia. Les Faubourgs en Gaule Romaine et dans les régions voisines, Caesarodurum XXXII, Université de Limoges.

BELCHIOR, C. (1969): Lucernas romanas de Conimbriga, Coimbra.

BELTRÁN FORTES, J.; RODRÍGUEZ GUTIÉREZ, R. (eds.) (2012): Hispaniae Urbes. Investigaciones arqueológicas en ciudades históricas, Madrid.

BELTRÁN LLORIS, M. (1970): Las ánforas romanas en España, Zaragoza. 
BELTRÁN LLORIS, M. (1990): Guía de la cerámica romana, Zaragoza.

BELTRÁN LLORIS, M. (1998): “Consumo y transporte”, en VV. AA. Colonia Victrix Iulia Lepida-Celsa: El Instrumentum Domesticum de la Casa de los Delfines, Zaragoza, pp. 65-107.

BELTRÁN LLORIS, M. (2008):"La cerámica romana en la Tarraconense: el inicio de las producciones propias", SFECAG, Actes du Congrès de L'Escala-Empúries, pp. 15-31.

BELTRÁN, J.; CARRERAS, C. (2011): BARCINO, en REMOLÀ, J. A.; ACERO. J. (eds.), La gestión de los residuos urbanos en Hispania. Xavier Dupré Raventós (1956-2006). In Memoriam. Anejos de AEspA LX, Mérida, pp. 233-254.

BELTRÁN, M.; ORTIZ, M. E.; PAZ, J. (1996): “La vajilla relacionada con el vino en Hispania", UAM VARIA 4, II Simposio de Arqueología del vino, Jerez, pp. 129-200.

BÉMONT, C. (1976): “Vases à parois fines de Glanum: formes et décors”, Gallia XXXIV, París, pp. 237-302.

BÉMONT, C.; JACOB, J. P. (dirs) (1986): La terrre sigillée gallo-rorromaine. Documents d'Archéologie Française 6, Paris.

BENDALA, M. et alli (eds.), La Arqueología Clásica peninsular ante el Tercer Milenio, En el centenario de A. García y Bellido (1903-1972), Anejos de AespA, Madrid.

BENDALA, M.; RICO, CH.; ROLDÁN, L. (eds.) (1999): El ladrillo y sus derivados en la época romana, Monografías de Arquitectura Romana 4, Madrid.

BENÉITEZ, C.; HEVIA, S.; MONTES, R. (1999): “Cerámica común romana del Chao Samartín (Grandas de Salime, Asturias) I. Vajilla de mesa y despensa”, Lancia 3, León, pp. 11-48.

BENITO DOMÍNGUEZ, A. M.; EMPARAN MUÑOZ, R. (1995): “Jarras de cerámica común romana de Santa María del Juncal (Irún)", CNA XXI, Zaragoza, pp. 10111028.

BÉRARD, D. (1992): “Territorium legionis: camps militaires et agglomérations civiles aux premiers siècles de l'Empire", Cahiers du Centre C. Glotz 3, pp. 75-105.

BÉRARD, F. (1993): “Vikani, kanabenses, consistentes, remarques sur lórganisation des agglomérations militaires romaines", L'epigrafia del villagio (Forli, 1990), Faenza, pp. 61-90.

BERMÚDEZ MEDEL, A. (2004): "La gestión del patrimonio histórico desde el punto de vista arqueológico", en PÉREZ, C.; ILLARREGUI, E. (coords.), Arqueología militar romana en Europa, Valladolid, pp. 259-267. 
BERNAL, D. (1990-91): “Figuli hispani: testimonios de manufactura peninsular de lucernas en época romana", Opus IX-X, pp. 147-160.

BERNAL, D.; SÁEZ, A. M. (2008): “Opérculos y ánforas romanas en el círculo del Estrecho", RCRF, Acta 40, pp. 455-472.

BERNAL, D.; RIBERA, A. (eds.) (2008): Cerámicas hispanorromanas. Un estado de la cuestión, Cádiz.

BERNAL, D. et alli (2011): BAELO CLAUDIA, en REMOLÀ, J. A.; ACERO. J. (eds.), La gestión de los residuos urbanos en Hispania. Xavier Dupré Raventós (1956-2006). In Memoriam. Anejos de AEspA LX, Mérida, pp. 65-92.

BERNAL, D.; RIBERA, A. (eds.) (2012): Cerámicas Hispanorromanas II. Producciones regionales, Univ. de Cádiz.

BERNAL, D. et alli (eds.) (2013): Hornos, Talleres y Focos de produccion alfarera en Hispania, Univ. de Cádiz.

BERTOLDI, T. (2001): Ceramiche comuni del suburbio di Roma, Roma.

BIDWEL, P. (1985): The Roman Fort of Vindolanda, Archeological Report 1, London.

BIDWEL, P. (1997): Roman Forts in Britain, London.

BIDWEL, P.; HODGSON, N.; GRIFFITHIS, B. (2000): “Los asentamientos del extremo oriental del Muro de Adriano (Reino Unido)", en VV. AA. Espacios de ocio, convivencia y cultura en el arco atlántico. Los baños públicos como símbolo de la romanidad, Gijón, pp. $49-60$.

BINFORD, L. (1988): En busca del pasado, Barcelona.

BLAGG T. F. C.; KING, A. C. (eds.) (1984): Military and Civilian in Roman Britain. Cultural relationships in a Frontier Province, BAR 136, International Series, Oxford.

BLANCO GARCÍA, P.; JUAN TOVAR, L. C. (1996): “Acerca de M. C. R. y otros alfareros hispánicos: marcas y grafitos en terra sigillata hispánica de Cauca (Coca, Segovia)", Boletín de la Asociación Española de Amigos de la Arqueología 36, pp. 147-155.

BLÁZQUEZ CERRATO, C. (2005): “Vías de comunicación y circulación monetaria en la meseta Norte y el Noroeste", en FERNÁNDEZ OCHOA y GARCÍA DÍAZ (eds.), Unidad y diversidad en el Arco Atlántico en época romana, BAR International Series 1371, Oxford, pp. 235-244.

BLÁZQUEZ CERRATO, C.; GÓMEZ BARREIRO, M. (2006): “La circulación monetaria de 'Augusta Emerita' y 'Caesaraugusta' en los campamentos del norte de la península Ibérica" en MORILLO, Á. (ed.), Arqueología militar romana en Hispania II. Producción y abastecimiento en el ámbito militar, León, pp. 241-246. 
BLECH, M. (2006): “Adolf Schulten, the German Archeological Institute and field research in Hispania", en MORILLO, Á.; AURRECOECHEA, J. (eds.), The Roman Army in Hispania. An Archeological Guide, León, pp. 25-35.

BLOEMERS, J. H. F. (1980): “Nimegen: ROB excavations 1974-1979 in the Roman forts, cemeteries and canabae legionis", Roman Frontier Studies XII, pp. 471-474.

BOUBE, S. (1965): “La terra sigillata hispanique en Maurétanie Tingitane, I: Marques de potiers", ETAM I, Rabat.

BOUBE, S. (1966): “La terra sigillata hispanique en Maurétanie Tingitane: Supplément au catalogue des marques de potiers, BAM VI, Rabat, pp. 115-142.

BOUBE, S. (1968-1972): “La terra sigillata hispanique en Maurétanie Tingitane: Supplément II au catalogue des potiers", BAM VIII, Rabat, pp. 67-108.

BOUET, A. (ed.) (2003): THERMAE GALLICAE. Les thermes de Barzan (CharenteMaritime) et les thermes des provinces gauloises, Aquitania, Supplément 11, Bordeaux.

BOURGEOIS, A.; MAYET, F. (1991): Belo VI. Les Sigillées, Fouilles de Belo, Madrid.

BRAITHWAITE, G. (1984): “Romano- British Face Pots and Head Pots”, Britannia 15, pp. 99-115.

BRAITHWAITE, G. (2007): Faces from the past. A Study of Roman face pots from Italy and the western provinces of the Roman Empire, BAR. International Series 1651, Oxford.

BREEZE, D. J. (1983): Roman forts in Britain, Aylesbury.

BRÖDNER, E. (1992): Die Römischen Thermen und das antike Badewesen. Eine Kulturhistorische betrachtung, Darmstadt.

BRODRIBB, G. (1979): “Markings on Tile and Brick”, en MC WHIRR, A. (ed.), Roman Brick and Tile, BAR International Series 68, Oxford, pp. 211-220.

BUCKLAND, P. C.; MAGILTON, J. R. (1986): The archeology of Lancaster 1. The Roman Civil Settlement, BAR British Series 148, Oxford.

BURÓN ÁlVAREZ, M.; GARCÍA GIMÉNEZ, R.; SUÁREZ VEGA, R. (1999): “Composición mineralógica de materiales cerámicos romanos de época altoimperial producidos en Asturica Augusta (Astorga. León). La posible existencia de un alfar", CNA XXIV, vol. 4, Murcia, pp. 323-331.

BURÓN, M.; SUÁREZ VEGA, R. (2006): “Convivencia de `producciones importadas y locales durante la ocupación militar previa a la fundación de 'Asturica Augusta", en MORILLO, Á. (ed.), Arqueología militar romana en Hispania II. Producción y abastecimiento en el ámbito militar, León, pp. 389-397. 
BUSTAMANTE, M. (2011): La cerámica romana en Augusta Emerita en la época Altoimperial. Entre el consumo y la exportación, Mérida.

BUSTAMANTE, M. (2011b): “Nuevas consideraciones cronológicas en torno a la producción de paredes finas emeritenses", Zephyrus 67, pp. 161-170.

BUSTAMANTE, M. (2012). "Cerámicas comunes altoimperiales de Augusta Emerita" en BERNAL, D.; RIBERA, A (eds.) (2012): Cerámicas Hispanorromanas II. Producciones regionales, Univ. de Cádiz, pp. 405-433.

BUSTAMANTE, M. (2013): Terra Sigillata Hispánica en Augusta Emerita (Mérida, Badajoz). Valoración tipocronológica a partir de los vertederos del suburbio norte, Anejos de $A E s p A L X V$, Madrid.

BUTZER, K.W: (1989): Arqueología, Un ecología el hombre.

BUXEDA I GARRIGOS J.; TUSET I BERTRÁN, F. (1995): “Revisió critica de las bases cronològiques de la terra sigillata hispánica", Pyrenae 26, Barcelona, pp. 171-188.

CAAMAÑO J. M. (1979): “Marcas de alfarero en cerámica romana encontradas en Galicia", Gallaecia 5, Santiago de Compostela, pp. 63-99.

CAAMAÑO, J. M. (1984): “Excavaciones en el campamento romano de Cidadela (Sobrado dos Monxes. A Coruña), N A H 18, Madrid, pp. 233-254.

CAAMAÑO, J. M. (1989): “Estampillas de la Cohors I Celtiberorum halladas en el campamento romano de Cidadela, Gallaecia 11, pp. 209-229.

CAAMAÑO, J. M. (1997): “Sondeos arqueológicos en la muralla del campamento romano de Cidadela, Gallaecia 16, pp. 265-284.

CAAMAÑO, J. M. (1998): “El urbanismo del campamento romano de Cidadela" en RODÍGUEZ COLMENERO, A. (coord.), Congreso Internacional Los orígenes de la ciudad en el Noroeste Hispánico, Lugo, pp. 1253-1264.

CAAMAÑO, J. M.; LÓPEZ RODRÍGUEZ, J. R. (1984): “Sigillatas del Castro de Viladonga (Lugo)", Gallaecia 7-8, Santiago de Compostela, pp. 158-177.

CAAMAÑO, J. M.; FERNÁNDEZ RODRÍGUEZ, C. (2000): “Excavaciones en el campamento romano de Cidadela (A Coruña), Brigantium 12, pp. 199-208

CAAMAÑO, J. M.; FERNÁNDEZ RODRÍGUEZ, C. (2002): “Novedades sobre el campamento romano de Cidadela (Sobrado dos Monxes, A Coruña)", en MORILLO, Á. (coord.), Arqueología Militar Romana en Hispania, Gladius Anejos 5, pp. 213-226.

CAAMAÑO, J. M.; FERNÁNDEZ RODRÍGUEZ, C. (2002b): “Excavaciones en el campamento de Cidadela (A Coruña), Brigantium 2, pp. 499-416. 
CAAMAÑO, J. M.; FERNÁNDEZ RODRÍGUEZ, C. (2006): “Producción y comercialización en el campamento romano de Cidadela (Sobrado dos Monxes, A Coruña)" en MORILLO, Á. (ed.), Arqueología militar romana en Hispania II. Producción y abastecimiento en el ámbito militar, León, pp. 167-184.

CAAMAÑO, J. M. et alii (2000): “Evidencias materiales en el campamento romano de Cidadela (Sobrado dos Monxes, A Coruña), Actas del $3^{\circ}$ Congreso de Arqueología Peninsular VI, Porto, pp. 281-292.

CABALLERO ZOREDA, L. (dir.) (1992): Arcobriga II. Las cerámicas romanas, Zaragoza.

CABERO, V. (1983): El espacio geográfico castellano-leonés, Valladolid.

CABOTSE, J. L. (1962): “Essai de clasification de la céramique 'commune' gallo-romaine du site de la 'Nouvelle Poste' à Roanne (Loire)", OGAM XIV, fasc. 1, pp. 116-124.

CAMPBELL, B. (1994): The Roman Army 31 BC- AD 337. A Sourcebook, London- New York.

CAMPBELL, D. B. (2006): Roman Legionary Fortresses. 27 BC- AD 38, London.

CAMPOMANES ALVAREDO, E. (1997): “Algunas cuestiones en torno a la primera muralla de la Legio VII Gemina”, Lancia 2, León, pp. 129-148.

CAMPOMANES ALVAREDO, E. (1999): “Hallazgo de un complejo metalúrgico romano en la ciudad de León. Excavación en la Calle Plegarias con vuelta a la Calle Ramiro III en la ciudad de León", Lancia 3, León, pp. 269-279.

CAMPOMANES ALVAREDO, E. (2006): “El acueducto de la Legio VII Gemina y sus producciones latericias", en MORILLO, Á. (ed.), Arqueología militar romana en Hispania. Producción y abastecimiento en el ámbito militar, León, pp. 439-453.

CAMPOMANES ALVAREDO, E.; SÁNCHEZ-MORA DÍEZ, M. C. (1989): “El abastecimiento de aguas en León en época romana", Tierras de León 76, León, pp. 61-67.

CAMPOMANES ALVAREDO, E. et alii (2002): “Ocupaciones anteriores a llegada de la Legio VII a la ciudad de León”, en MORILLO, Á. (coord.), Arqueologia militar romana en Hispania, Gladius, Anejos 5, pp. 339-347.

CAPEL MARTÍNEZ, J. (ed.) (1999): Arqueometría y Arqueología, Granada.

CARANDINI, A. (1977): "La ceramica a paretti sottili di Pompei e dell Museo Nazionale di Napoli", Cuaderni di Cultura Materialli, Roma, pp. 25-31.

CARANDINI, A. (2000): “I rifiuti finalmente accolti. Appunti per l'utilizzo investigativo delle immondizie e per una teologia della purificazione", en DRUPÉ, X.; REMOLÀ, J. A. (eds), SORDES URBIS. La eliminación de residuos en la ciudad romana, Roma, pp.1-2. 
CARO, A. (2002): Ensayo sobre cerámica en Arqueología, Sevilla.

CARREÑO GASCÓN, M. C. (1997): “Marcas de alfarero sobre terra sigillata halladas en Lucus Augusti", Anejos de Larouco 3, La Coruña, pp. 5-107.

CARREÑO, C. (1992): “Baños privados y termas públicas en el Lugo romano”, Espacio, Tiempo y Forma, Serie II, 5, pp. 337-350.

CARRERAS MONFORT, C. (1994): Una reconstrucción del comercio en cerámicas: La red de transportes en Britannia, Cuadernos de Arqueología 7, Barcelona.

CARRERAS MONFORT, C. (1996): "El comercio en Asturia a través de las ánforas", en FERNÁNDEZ OCHOA, C. (ed.), Coloquio Internacional sobre Los Finisterres Atlánticos en la Antigüedad. Época Prerrromana y Romana, Gijón, pp. 205-209.

CARRERAS MONFORT, C. (1997): “Los 'beneficiarii' y la red de aprovisionamiento militar de 'Britannia' e 'Hispania'“, Gerión 15, Madrid, pp. 151-176.

CARRERAS MONFORT, C. (1998): “Els abocadors en el món romà: el cas de Londinium i Barcino", Pyrenae 29, pp.147-160.

CARRERAS MONFORT, C. (2011): “Urbanismo y eliminación de residuos urbanos”, en REMOLÀ, J. A.; ACERO, J. (eds.), La gestión de los residuos urbanos en Hispania. Xavier Dupré Raventós (1956-2006). In Memoriam. Anejos de AEspA LX, Mérida, pp. 17-26.

CARRERAS, C.; FUNARI, P. P. A. (1988): “Britannia y el Mediterráneo. Estudio sobre el abastecimiento del aceite bético y africano en Britania", Collecciò Instrumenta 5, Barcelona.

CARRERAS, C.; BERNI, P. (2003): “Las ánforas de Astorga”, en AMARÉ TAFALLA, M. T. (dir.): Astorga IV: Lucernas y ánforas, León, pp. 635-673.

CARRERAS, C.; GONZÁLEZ, H. (2012): “Ánforas tarraconses para el limes germánico: una nueva visión de las Oberaden 74" en BERNAL, D.; RIBERA, A. (eds.), Cerámicas Hispanorromanas II. Producciones regionales, Univ. de Cádiz, pp. 207-230.

CARRETERO VAQUERO, S. (1991): "Petavonium. Historia de dos campamentos romanos", $R$ A 125, Madrid, pp. 30-39.

CARRETERO VAQUERO, S. (1993): “El cuadrante noroeste peninsular en época romana: los efectivos militares y sus establecimientos", Brigecio 3, pp. 47-73.

CARRETERO VAQUERO, S. (1998): “Grafitos del campamento romano de Petavonium (Rosinos de Vidriales, Zamora)", Brigecio 8, pp. 47-84.

CARRETERO VAQUERO, S. (1999): “El ejército romano del Noroeste peninsular durante el Alto Imperio. Estado de la cuestión", Gladius XIX, pp. 143-156. 
CARRETERO VAQUERO, S. (2000): El campamento romano del Ala II Flavia en Rosinos de Vidriales (Zamora). La cerámica. Zamora.

CARRETERO VAQUERO, S. (2000b): “Hacia la definición de un nuevo grupo vascular del noroeste hispánico en época romana: la cerámica de Tradición Astur", BSAA LXVI, pp. 127-149.

CARRETERO VAQUERO, S. (2002): “Gusto y tendencias en el consumo cerámico del Ala II Flavia en Petavonium”, en MORILLO, Á. (coord.), Arqueología Militar Romana en Hispania, Gladius Anejos 5, pp. 359-368.

CARRETERO VAQUERO, S. (2005): "Producción y consumo cerámico en el ámbito militar durante el Alto Imperio en el Noroeste Peninsular", en FERNÁNDEZ OCHOA y GARCÍA DÍAZ (eds.), Unidad y diversidad en el Arco Atlántico en época romana, BAR International Serie. 1371, Oxford, pp. 109-124.

CARRETERO VAQUERO S. (2006): "Petavonium (Rosinos de Vidriales, Zamora). Introducción histórica y arqueológica" en GARCÍA-BELLIDO, M. P. (coord.), Los campamentos romanos en Hispania (22 a.C.- 192 d.C.). El abastecimiento de moneda, Vol. I, pp. 171-194.

CARRETERO VAQUERO, S. (2008): "Producciones cerámicas militares en la Tarraconense", SFECAG, Actes du Congrès de L'Escala-Empúries, pp. 255-264.

CARRETERO VAQUERO, S. (2009): "Petavonium, el hogar hispano de la legión X gemina y del ala II Flavia", Anuario del Instituto de Estudios Zamoranos Florián de Ocampo 26, pp. 13-44.

CARRETERO VAQUERO, S.; ROMERO CARNICERO, M. V. (1996): Los campamentos romanos de Petavonium (Rosinos de Vidriales, Zamora), Zamora.

CARRETERO VAQUERO, S.; ROMERO CARNICERO, M. V. (1999): “Petavonium: Un núcleo civil surgido al abrigo del ejército", Actas da Mesa Redonda 'Émergência e Desenvolvimento das Cidades Romanas no Norte da Península Ibérica', Porto, pp. 157170.

CARRETERO VAQUERO, S.; ROMERO CARNICERO, M. V. (2004): "Castra Petavonium", en PÉREZ, C.; ILLARREGUI, E. (coords.), Arqueología militar romana en Europa, Valladolid, pp. 219-229.

CARRETERO VAQUERO, S.; ROMERO, M. V.; MARTÍNEZ GARCÍA, A. B. (1999): “Las estructuras defensivas del campamento del Ala II Flavia en Petavonium (Rosinos de Vidriales, Zamora)", II Congreso de Arqueología Peninsular, Zamora, pp. 183-194.

CARRETERO VAQUERO, S.; ROMERO CARNICERO, M. V. (2009): “Materiales y técnicas de construcción en Petavonium”, en MORILLO, Á.; HANEL, N.; MARTÍN, E. (eds.), LIMES XX. Estudios sobre la Frontera Romana, Anejos de Gladius 13, Vol. I, pp. 407-418. 
CARRIÉ, J. M. (1991): “El soldado”, en GIARDINA, A. et alli: El hombre romano, pp. 121-160.

CARRO, F. (2003.): "La terra sigillata de la Colección "Escarpizo", en AMARÉ TAFALLA, M. T. (dir.): Astorga II: Cerámica romana del vertedero de Las Lolas. León, pp. 11283.

CASAS. J.; NOLLA, J. M. (2012): “La cerámica gris (y oxidada) ampuritana”, en BERNAL, D.; RIBERA, A. (eds.), Cerámicas Hispanorromanas II. Producciones regionales, Univ. de Cádiz, pp. 639-654.

CASAS. J.; NOLLA, J. M. (2012):"Cerámica común altoimperial en el nordeste peninsular", en BERNAL, D.; RIBERA, A. (eds.), Cerámicas Hispanorromanas II. Producciones regionales, Univ. de Cádiz, pp. 469-485.

CASTALDO PARIS, L. (1996): Necesidad e importancia de la cerámica como manifestación humana, Cadernos do Seminario de Sargadelos, A Coruña.

CAUUET, B. (1986): “Les mins d'or antiques en alluvions du nord-ouest du Bierzo", I Congreso Internacional Astorga Romana, vol. II, Astorga, pp. 137-152.

CEÁN-BERMÚDEZ, J. A. (1832): Sumario de las Antigüedades romanas que hay en España, en especial las pertenecientes a las Bellas Artes, Madrid.

CELIS, J.; GUTIÉREZ, M. J. (coords.) (1999): Lancia. Historia de la Investigación Arqueológica. Homenaje a Francisco Jordá Cerdá, León.

CELIS BELTRIÚ, R. (2005): “Las lucernas”, en ROCA ROUMENS, M.; FERNÁNDEZ GARCÍA, M. I. (coords.), Introdución al estudio de la cerámica romana. Una breve guía de referencia, Univ. de Málaga, pp. 405-464.

CEPAS PALANCA, A. (1997): Crisis y continuidad en la Hispania del siglo III, Anejos AEspA XVII, Madrid.

CÉSAR VILA, M.; LÓPEZ PÉREZ, M. C. (2008): “Aportaciones al conocimiento del comercio de sigillata en la fachada atlántica del noroeste peninsular", SFECAG, Actes du Congrès de L'Escala-Empúries, pp. 241-254.

CHAPA BRUNET, M. T.; QUEROL FERNÁNDEZ, M. A. (1996): “Patrimonio arqueológico urbano: conflictos entre investigadores y administración”, Complutum 6 (II), pp. 307-316.

CIPRÉS, P. (1984): “Marcas y grafitos aparecidos en la terra sigillata hispánica procedente del yacimiento romano de Arcaya (Álava)", Veleia 1, Vitoria, pp. 193-215.

CIPRÉS, P. (1987): Terra sigillata hispánica de Arcaya (Álava). Estudio de las formas lisas y decoradas, Vitoria. 
CISNEROS CUNCHILLOS, M.; LÓPEZ NORIEGA, P. (1998): "Vias romanas o caminos antiguos en el sector central de la cordillera Cantábrica", XXIII CNA, pp. 61-67.

CLEARY, S. E. (1987): Extra-Mural Areas of Romano British Towns, BAR., British Series 169 , Oxford.

COLL CONESA, J. (coord.) (2005): Recientes investigaciones sobre producción cerámica en Hispania, Valencia.

COLL CONESA, J. (2008): “Hornos romanos en España: aspectos de morfología y tecnología", en BERNAL, D.; RIBERA, A. (eds.), Cerámicas hispanorromanas. Un estado de la cuestión, Cádiz, pp. 113-125.

COMAS i SOLA, M.; PADRÓS i MARTÍ, P. (2008): “Deux grands dépotoirs d'amphores léetaniennes, bétiques et gauloises, hors les murs de la ville de Baetulo (Badalone): Un lieu de transbordement de merchandises", SFECAG, Actes du Congrès de L'Escala-Empúries, pp. 75-86.

COMFORT, H. (1939): Some Roman Barbotine Bowls and their Conections, The Art Bulletin 21, Londres.

CONOLLY, P. (1986): Las legiones romanas, Madrid.

CONOLLY, P. (1989): Las legiones romanas. Ejércitos de la Historia, Madrid.

CONNOLLY, P. (1998): Greece and Rome at War, London.

CORTÉS, J. L. (1992): Intervención arqueológica en la necrópolis tardorromana de Vegazana, Valladolid.

COSTA GARCÍA, J. M.; CASAL GARCÍA, R. (2009): “De cibo castrorum”: la comida en el mundo militar romano y su impacto en los territorios conquistados", SEMATA, Ciencias Sociais e Humanidades, vol 21, pp. 15-43.

COSTABILE, F.; LICANDRO, O. (2000): Tessera Pameobrigensis. Un nuovo editto di Augusto dalla 'Transduriana provincia' e l'imperium proconsulare del princeps, Minima Epigraphica et Papyrologica, sep.1, Roma.

DAREMBERG, CH.; SAGLIO, E. (1873-1919): Dictionaire des Antiquités grecques et romaines, Paris.

DAVIES, R. W. (1971): “The Romam Military diet”, Britannia 2, pp. 122-142.

DAVISON, D. P. (1989): The Barracks of the Roman Army from the Ist to 3rd Centuries AD, $B A R$, International Series 472, Oxford.

DE LOS RÍOS, D. (1895): La catedral de León, 2 vols., Madrid. 
DEL CASTILLO, A. (ed.) (1985): Ejército y sociedad. Cinco estudios sobre el mundo antiguo, Univ. de León.

DEL OLMO, J. (1994-1995): “Arqueología aérea en tres núcleos campamentales de Zamora y León”, Brigecio 4-5, pp. 109-118.

DEL VAL, J.; ESCRIBANO, C. (2004): “La conservación y valoración social del Patrimonio Arqueológico en Castilla y León. Arquitectura militar en época romana", en PÉREZ, C.; ILLARREGUI, E. (coords.), Arqueología militar romana en Europa, Valladolid, pp. 123-129.

DELAINE, J. (1988): “Recent research of Roman Baths”, JRA 1, pp. 11-32.

DELGADO, M.; MAYET, F.; MOUTINHO DE ALARÇAO, A. (1976): Fouilles de Conimbriga, IV. Les Sigillées, París.

DESBAT, A. (2003): “La gestion des déchets en milieu urbain. L'exemple de Lyon à la période romaine”, BALLET, P.; CORDIER, P.; DIEUDONNÉ-GLAD, N. (dirs.), La ville et ses déchets dans le monde romain: rebuts et recyclages, pp. 117-120.

DIAS, L. (1999): “Arquitectura com tijolo en Tongobriga: Estudio dos materiais das termas e dos aparelhos dos muros", en BENDALA, M.; RICO, CH.; ROLDÁN, L. (eds.), El ladrillo y sus derivados en la época romana. Monografías de Arquitectura Romana 4, Madrid, pp. 277-290.

DÍAZ RODRÍGUEZ, J. J. (2008): “De la arcilla a ala cerámica. Aproximación a los ambientes funcionales de los talleres alfareros en Hispania", en BERNAL, D.; RIBERA, A. (eds.), Cerámicas hispanorromanas. Un estado de la cuestión, Cádiz, pp. 93-111.

DIEGO, F. (1986): Inscripciones romanas de la provincia de León, León.

DIEUDONNÉ, N.; RODET-BELARBI, I. (2003): “La gestion des déchets artisanaux et domestiques: actions individuelles ou concertés? L'exemple d'une agglomération secondaire de Gaule romaine", BALLET, P.; CORDIER, P.; DIEUDONNÉ-GLAD, N. (dirs.), La ville et ses déchets dans le monde romain: rebuts et recyclages, pp. 181-193.

DOMERGUE, C. (1970): “Introductión à l'étude des mines d'or du nord-ouest de la Péninsule Ibérique dans lántiquité", en VV. AA., Legio VII Gemina, León, pp. 255286.

DOMERGUE, C. (1986): «Dix-huit ans de recherche (1968-1986) sur les mines d'or romaines du nord-ouest de la Péninsule Ibérique», I Congreso Internacional Astorga Romana, vol. II, Astorga, pp. 7-102.

DOMERGUE, C.; MARTIN, T. (1977): Minas de oro romanas de la provincia de León. II. Huerña: excavaciones 1972-1973, E A E 94, Madrid. 
DOMERGUE, C.; SILLIÈRES, P. (1977): Minas de oro romanas de la provincia de León, EAE 93, Madrid.

DOMÍNGUEZ, R. M. et alli (1994): “Empresas de arqueología y arqueología urbana: investigación, negocio, profesión”, Arqueología y Territorio Medieval 1, pp. 83-92.

DORE, J.; GREENE, K. (eds.) (1977): Roman Pottery Sudies in Britain and Beyond, BAR S. 30, Oxford.

DOROTIU-BOILA, E. (1972): «Territoriul militar al legiunii V Macedonica la Dunarea de Jos», Studii si Cercetari de Istoire Veche si Archeologie 23, pp. 45-61.

DOVAL GALÁN, J. F. (1990): Cerámica común romana del campamento de Cidadela (La Coruña), Tesis Doctoral inédita, Univ. de Santiago de Compostela.

DROUHOT, J. (1966): “Trouvailles autour de Chellah”, B A M VI, Rabat, pp. 145-187.

DUBANT, D. (2003): “Une décharge publique gallo-romaine (fin I-début II s. ap. J.-C.) à Tours (Indre-et-Loire, France)", BALLET, P.; CORDIER, P.; DIEUDONNÉ-GLAD, N. (dirs.), La ville et ses déchets dans le monde romain: rebuts et recyclages, pp. 165-179.

DUPRÉ, X.; CARRETÉ, J. M. (1993): L'Antiga Audiència: un acceso al foro provincial de Tarraco, EAE, 165 Madrid.

DUPRÉ, X.; REMOLÀ, J. A. (eds.) (2000): SORDES URBIS. La eliminación de residuos en la ciudad romana, Roma.

DUPRÉ, X.; REMOLÀ, J. A. (2000b):"Per concludere...", en DUPRÉ, X.; REMOLÀ, J. A. (eds.), en SORDES URBIS. La eliminación de residuos en la ciudad romana, Roma, pp. 95-105.

DUPRÉ, X.; REMOLÀ, J. A. (2002):" A propósito de la gestión de los residuos urbanos en Hispania" Romula I, pp. 39-56.

DURÁN CABELLO, R. (2006): “La arquitectura militar romana en la obra de García y Bellido: notas sobre sus intervenciones arqueológicas en Herrera de Pisuerga y León" en MORILLO, Á. (ed.), Arqueología militar romana en Hispania II. Producción y abastecimiento en el ámbito militar, León, pp. 707-724.

DURÁN CABELLO, R. (2009): “Reflexiones sobre la técnica constructiva de la muralla de León”, en MORILLO, Á.; HANEL, N.; MARTÍN, E. (eds.), LIMES XX. Estudios sobre la Frontera Romana, Anejos de Gladius 13, Vol. II, pp. 793-805.

DYCZECK, P. (2009): “Flavian baths of Legio I Italica from Castrum Novae" en MORILLO, Á., HANEL, N.; MARTÍN, E. (eds.), LIMES XX. Estudios sobre la Frontera Romana, Anejos de Gladius 13, Vol. III, pp. 1477-1486. 
EGEA, A. et alli (2011): CARTHAGO NOVA, en REMOLÀ, J. A.; ACERO. J. (eds.), La gestión de los residuos urbanos en Hispania. Xavier Dupré Raventós (1956-2006). In Memoriam. Anejos de AEspA LX, Mérida, pp. 281-296.

ELVIRA BARBA, M. A. (1981): “Los dioses romanos en la terra sigillata hispánica”, en La religión romana en Hispania, Madrid, pp. 59-67.

ERDKAMP, P. (ed.) (2002): The Roman Army and the Economy, London.

ESCRIVÁ, V. (1989): La cerámica romana de Valencia. La TS Hispánica, Serie Arqueológica Municipal 8, Valencia.

ESCRIVÁ, V. (1995): "Cerámica común romana del Municipium Lidia Edetanorum. Nuevas aportaciones al estudio de la cerámica de época altoimperial en la Hispania Tarraconensis", en VV.AA., "Ceràmica comuna romana d'època Alto-Imperial a la Península Ibérica. Estat de la questio. Monografies Emporitaines VIII, pp. 167-186.

ESCUDERO, F.; GALVE, M. P. (2011): CAESARAUGUSTA, en REMOLÀ, J. A.; ACERO. J. (eds.), La gestión de los residuos urbanos en Hispania. Xavier Dupré Raventós (19562006). In Memoriam. Anejos de AEspA LX, Mérida, pp. 255-280.

ESTEBAN DELGADO, M. et alli (2008): “Del Ebro al Cantábrico. Producciones cerámicas de época romana en los actuales territorios de Navarrra, La Rioja y el País Vasco", SFECAG, Actes du Congrès de L'Escala-Empúries, pp. 195-217.

ETTLINGER, E. et alli (1990): Conspectus formarum terra sigillata italico modo confectae, Materialien zur römich-germanischen keramik 10, Bonn.

ETTLINGER, E. (1951): “Legionary Pottery from Vindonissa”, JRS 41, pp. 105-111.

ETTLINGER, E.; SIMONNET, CH.; OHLENROTH, L. (1952): Römische Keramik aus dem Schutthügel von Vindonissa (Céramique romaine d'un monticule de débris de Vindonissa), Brugg.

EVANS, E. (2000): The Caerleon Canabae. Excavations in the civil settlement 1948-80. Britannia, Monogaph Series $N^{o} 16$, London.

EVANS, J.; HARTLEY, K. F.; WILIAMS, D. (1985): “The Coarse Pottery”, BIDWEL, P. T., The Roman fort of Vindolanda, Archeological Report 1, London, pp. 172-184.

FABIAO, C. (2006): "The Roman army in Portugal"; en MORILLO, Á; AURRECOECHEA, J. (eds.), The Roman Army in Hispania. An Archeological Guide, León, pp. 107-126.

FABIAO, C. (2008): “Las ánforas de Lusitania”, en BERNAL, D.; RIBERA, A. (eds.), Cerámicas hispanorromanas. Un estado de la cuestión, Cádiz, pp. 725-745.

FAGAN, G. G. (2002): Bathing in Public in the Roman World. 
FELLMANN, R. (1966): “Hölzerne Schwertgriffe aus dem Schutthügel von Vindonissa", Helvetia Antiqua, Zurich, 215-222.

FERNÁNDEZ ALLER, M. C. (1982): Legio VII Gemina. Aportaciones a la historia romana de León, Tesis Doctoral inédita, Univ. de Salamanca.

FERNÁNDEZ ALLER, M. C. (1982b): “Un grafito latino hallado en la muralla romana leonesa", Estudios Humanísticos 4, León pp. 163-188.

FERNÁNDEZ FERNÁNDEZ, A. (2008): “Cerámicas del mundo castrexo del NO peninsular. Problemática y principales producciones", en BERNAL, D.; RIBERA, A. (eds.), Cerámicas hispanorromanas. Un estado de la cuestión, Cádiz, pp. 221-243.

FERNÁNDEZ FREILE, B. E. (1998-1999): “Producciones de cerámica engobada y de paredes finas del alfar de Melgar de Tera en la ciudad de León”, Lancia 3, León, pp. 103-125.

FERNÁNDEZ FREILE, B. E. (1999): "Producciones de vidrio romano altoimperial halladas en la ciudad de León", CNA XXV, Valencia, pp. 480-484.

FERNÁNDEZ FREILE, B. E. (2001): “Un conjunto arqueológico de mediados del siglo II d. C. en Legio (León, España): El material cerámico”, RCRF Acta 37, pp. 163-169.

FERNÁNDEZ FREILE, B. E. (2001b): “La maca OF.FA.AE: una producción inédita de terra sigillata hispánica hallada en Legio", CVDAS 2, Granada, pp. 89-115.

FERNÁNDEZ FREILE, B. E. (2002): “Aportaciones del estudio arqueológico de un solar extramuros al recinto campamental de Legio", en MORILLO, Á. (coord.) Arqueología Militar romana en Hispania, Gladius Anejos 5, Madrid, pp. 349-357.

FERNÁNDEZ FREILE, B. E. (2003): León I. La época romana en León: aspectos arqueológicos. Estudio arqueológico de un vertedero romano situado en la C/Maestro Copín clv San Salvador del Nido en la ciudad de León. León.

FERNÁNDEZ FREILE, B. E. (2006): “Pautas para el establecimiento de redes de abastecimiento de TSH en el campamento de la Legio VII Gemina: la presencia de producciones individualizadas del complejo riojano de Tritium Magallum", en MORILLO, Á. (ed.), Arqueología Militar Romana en Hispania II. Producción y abastecimiento en el ámbito militar, León, pp. 419-429.

FERNÁNDEZ FREILE, B. E. (2011): “Estudio arqueológico de tres vertederos altoimperiales en Legio", en REMOLÀ, J.; ACERO, J. (eds.), La gestión de los residuos urbanos en Hispania. Xavier Dupré Raventós (1956-2006) In Memoriam, AEspA LX, Mérida, pp. 361-367.

FERNÁNDEZ FREILE, B. E.; SÁNCHEZ-LAFUENTE PÉREZ, J. (2003): “Cerámica vidriada romana en el interior de la Península Ibérica", RCRF Acta 38, pp. 315-322. 
FERNÁNDEZ FREILE, B. E.; AMARÉ TAFALLA M. T. (2004- 2005): “Lucernas romanas procedentes de las excavaciones arqueológicas en la Calle Pilotos Regueral (Banco Herrero)", Lancia 6, León, pp. 265-267.

FERNÁNDEZ GARCÍA, M. I. (1988): Los diversos estilos decorativos de la sigillata hispánica de Andújar, Univ. de Granada.

FERNÁNDEZ GARCÍA, M. I. (1998): “Características de la sigillata fabricada en Andújar" en FERNÁNDEZ GARCÍA, M. I. (ed.), Terra Sigillata Hispánica. Estado actual de la investigación, Univ. de Jaén, pp. 49-103.

FERNÁNDEZ GARCÍA, M. I. (1999): Breve introducción al estudio de la Terra Sigillata, Granada.

FERNÁNDEZ GARCÍA, M. I. (ed.) (1998): Terra Sigillata Hispánica. Estado actual de la investigación, Univ. de Jaén.

FERNÁNDEZ GARCÍA, M. I.; RUIZ MONTES, P. (2005): “Sigillata Hispánica de origén bético" en ROCA ROUMENS, M.; FERNÁNDEZ GARCÍA, M. I. (coords.), Introdución al estudio de la cerámica romana. Una breve guía de referencia, Univ. de Málaga, pp.139-182.

FERNÁNDEZ GARCÍA, M. J.; RUÍZ PARRONDO, A.; RUÍZ MONTES, P. (2007): "Indicios de jararquización en el centro de producción de los Villares de Andújar (Jaén)”, CVDAS 3-4, pp. 73-85.

FERNÁNDEZ GARCÍA, M. I.; ROCA ROUMENS, M. (2008): “Producciones de Terra Sigillata Hispánica", en BERNAL, D.; RIBERA, A. (eds.), Cerámicas hispanorromanas. Un estado de la cuestión, Cádiz, pp. 307-332.

FERNÁNDEZ IBÁÑEZ, C. (2002): Metalistería bélica de la Legio IIII Macedonica procedente de su campamento en Herrera de Pisuerga (Palencia, España), en MORILLO, Á. (coord.), Arqueología Militar Romana en Hispania, Gladius Anejos 5, pp. 381393.

FERNÁNDEZ MARTÍNEZ, V. M. (1983): "El taller de cerámica sigillata de Tiermes", Homenaje al profesor Martín Almagro Basch IV, Madrid, pp. 21-30.

FERNÁNDEZ MIRANDA, M. (1968): “Cerámica sigillata hispánica en Mérida: marcas de alfarero", CNA XXI, Mérida, pp. 811-814.

FERNÁNDEZ MIRANDA, M. (1970): “Contribución al estudio de la cerámica sigillata hispánica en Mérida", Trabajos de Prehistoria 27, pp. 290-299.

FERNÁNDEZ OCHOA, C. (1983): “Aspectos del proceso romanizador de Asturias. La cerámica romana", Actas del II Seminario de Arqueología del Noroeste, Santiago de Compostela, Madrid, pp. 219-223. 
FERNÁNDEZ OCHOA, C. (1993): “La ciudad hispanorromana en los territorios septentrionales de la Península Ibérica", La Ciudad Hispanorromana, Barcelona, pp. 224245.

FERNÁNDEZ OCHOA, C. (1994): Una industria de salazones de época romana en la Plaza del Marqués (Gijón, Asturias), Gijón.

FERNÁNDEZ OCHOA, C. (1995b): “Astures y Roma: La configuración del territorio, en VV.AA., Astures. Pueblos y culturas en la frontera del Imperio Romano, pp. 99-111.

FERNÁNDEZ OCHOA, C. (2002): Las termas romanas de Campo Valdés. Gijón.

FERNÁNDEZ OCHOA, C. (coord.) (1996): Coloquio Internacional sobre los Finisterres Atlánticos en la Antigüedad. Época Prerromana y Romana, Gijón.

FERNÁNDEZ OCHOA, C. (ed.) (2003): Gijón puerto romano. Navegación y comercio en el Cantábrico durante la Antigüedad, Gijón.

FERNÁNDEZ OCHOA, C.; GARCÍA ENTERO, V. (eds.) (2000): Termas romanas en el occidente del Imperio. II Coloquio Internacional de Arqueología en Gijón, Gijón.

FERNÁNDEZ OCHOA, C.; GARCÍA DÍAZ, P. (eds.) (2002): Unidad y diversidad en el Arco Atlántico en época romana, BAR International Series 1371, Oxford.

FERNÁNDEZ OCHOA, C. et alii (2004): “El proyecto 'Ruta de la Plata' en el Concejo de Gijón (Asturias)”, en PÉREZ, C.; ILLLARREGUI, E. (coords.), Arqueología Militar Romana en Europa, Valladolid, pp. 103-115.

FERNÁNDEZ OCHOA, C. et alli (2006): "Proyecto termas romanas en Hispania. Balance de una década de investigación (1993-2003)", CUPAUAM 30, Madrid.

FERNÁNDEZ OCHOA, C.; DURÁN CABELLO, R. (2006): “García y Bellido y la arqueología urbana hispanorromana. De los sondeos a la planificación integral", La Arqueología Clásica peninsular. En el centenario de A. García y Bellido, pp 113-136.

FERNÁNDEZ OCHOA, C.; MORILLO, Á. (1991): “Fortificaciones urbanas de época bajoimperial en Hispania. Una aproximación crítica (Primera parte)" CuPAUAM 18, pp. 227-259.

FERNÁNDEZ OCHOA, C.; MORILLO, Á. (1992): “Fortificaciones urbanas de época bajoimperial en Hispania. Una aproximación crítica (Segunda parte)" CuPAUAM 19, pp. 319-360.

FERNÁNDEZ OCHOA, C.; MORILLO, Á. (1994): “De Brigantium a Oiasso. Una aproximación al estudio de los enclaves marítimos cantábricos en época romana", Temas de Arqueología 3, Madrid. 
FERNÁNDEZ OCHOA, C.; MORILLO, Á. (1997): “La muralla de Iruña en el contexto de las fortificaciones urbanas bajoimperiales de la región septentrional de la Península Ibérica" Isturitz 9, pp. 735-742.

FERNÁNDEZ OCHOA, C.; MORILLO, Á. (1999): La tierra de los astures. Nuevas perspectivas sobre la implantación romana en la antigua Asturia, Gijón.

FERNÁNDEZ OCHOA, C.; MORILLO, Á. (2002): “Entre el prestigio y la defensa: la problemática estratégico-defensiva de las murallas tardorromanas en Hispania”, en MORILLO (coord.), Arqueología Militar romana en Hispania, Gladius Anejos 5, pp. 577-589.

FERNÁNDEZ OCHOA, C.; MORILLO, Á (2005): La Arqueología Hispanorromana a fines del siglo XX. Bibliografía temática y balance historiográfico, Trabajos de Arqueología hispánica 2, Madrid.

FERNÁNDEZ OCHOA, C.; MORILLO, Á. (2006): “The army and the urban walls in Late Roman Spain: defence and strategy", en MORILLO, Á.; AURRECOECHEA, J. (eds.), The Roman Army in Hispania. An Archeological Guide, León, pp. 189-209.

FERNÁNDEZ OCHOA, C.; QUEROL, M. A. (2000): “La Arqueología urbana en España", III Congreso de Arqueología Peninsular, Porto, pp. 11-20.

FERNÁNDEZ OCHOA, C.; ZARZALEJOS, M. (1993): “Las producciones de Terra Sigillata Altoimperial de Sisapo (La Bienvenida, Ciudad Real) II. Terra Sigillata Hispánica", Espacio, Tiempo y Forma, Serie II, Ha Antigua t.6, pp. 161-206.

FERNÁNDEZ OCHOA, C.; ZARZALEJOS, M. (1996):" Técnicas constructivas en las termas romanas de Campo Valdés (Gijón): el material latericio", AEspA 69, pp. 109-118.

FERNÁNDEZ OCHOA, C.; ZARZALEJOS, M. (1999): Reflexiones sobre una producción peculiar de cerámica común romana localizada en el tercio norte de la península Ibérica y el sur de Aquitania. Los materiales de la ciudad de Gijón (España), Gijón.

FERNÁNDEZ OCHOA, C.; MORILLO, Á.; ZARZALEJOS, M. (1995): “Material latericio en las termas romanas de Hispania", Actas de la Table Ronde La Brique e ses derivés à l'époque romaine. Production, utilisation et dfifusion dans les provinces Occidentales (Hispanie, Gaule et Italie), Madrid.

FERNÁNDEZ OCHOA, C.; MORILLO, Á.; ZARZALEJOS, M. (1999): “Material latericio en las termas romanas de Hispania", en BENDALA, M.; RICO, CH.; ROLDÁN, L. (eds.), El ladrillo y sus derivados en la época romana, Monografías de Arquitectura Romana 4, Madrid, pp. 291-305.

FERNÁNDEZ OCHOA, C.; MORILLO, Á.; ZARZALEJOS, M.; GARCÍA ENTERO, V. (1997): “Las termas romanas de Hispania: balance historiográfico y perspectivas de investigación", Actas del I Congreso Peninsular de Termalismo Antiguo, Madrid, pp. 381-389. 
FERNÁNDEZ PÉREZ, M. I.; MARTÍNEZ PÉREZ, J. R. (1994): “Marcas de alfarero en Terra Sigillata", RA 163, Madrid, pp. 22-29.

FERNÁNDEZ RODRÍGUEZ, C.; CAAMAÑO, J. M. (1996): El campamento romano de Cidadela (A Coruña, Galicia): Análisis del registro faunístico, Munibe 48, pp. 95106.

FERNÁNDEZ RODRÍGUEZ, C.; FUERTES, N. (2003):"Análisis de la fauna de Maestro Copín y San Salvador del Nido (León)", en FERNÁNDEZ FREILE, B. E.: La época romana en León: aspectos arqueológicos. Estudio arqueológico de un vertedero romano situado en la C/Maestro Copín clv San Salvador del Nido en la ciudad de León, pp. 199232.

FERNÁNDEZ RODRÍGUEZ, C.; FUERTES PRIETO, N. (2004): “La alimentación en el campamento de la legio VII en León: la información arqueológica", Promonumenta IV, pp. 34-39.

FERNÁNDEZ, A.; REMOLÀ, J. A. (2008): “Tarraco: contextos ceràmics d'època altoimperial (segles I-III)", SFECAG, Actes du Congrès de L'Escala-Empúries, pp. 87102.

FERRER SIERRA, S.; RODRÍGUEZ COLMENERO, A. (2006): Sobre los 'principia del campamento de 'Aquis Querquennis' (Portoquintela, Ourense): estado de la cuestión” en MORILLO, Á. (ed.), Arqueología militar romana en Hispania II. Producción y abastecimiento en el ámbito militar, León, pp. 517-522.

FILLOY NIEVA, I.; GIL ZUBILLAGA, E. (1993): “Memoria de las intervenciones arqueológicas en el yacimiento de Uralde (Condado de Treviño). 1989", Estudios de Arqueología Alavesa 18, Vitoria, pp. 101-139.

FITA, F. (1866): Epigrafía romana de la ciudad de León, León.

FITA, F. (1872-1918): “Legio VII Gemina (León)”, M.E.A. I, IV, XI, Madrid.

FORBES, R. J. (1966): “Glass”, Studies in Ancient Teccnology 5, Leiden, pp. 110-231.

FORNI, G. (1970): "Lóccupazione militare romana della Spagna Nord-occidentale: analogie e paralleli", en VV. AA., Legio VII Gemina, León, pp. 205-225.

FOY, D. (2003): “Recyclage et réemplois dans l'artesanat du verre. Quelques exemples antiques et médievaux", BALLET, P.; CORDIER, P.; DIEUDONNÉ-GLAD, N. (dirs.), La ville et ses déchets dans le monde romain: rebuts et recyclages, pp. 271-276.

FRANZEN, P. (2009): “The Nimegen canabae legionis (71-102/105 AD). Military and civilian life on the frontier" en MORILLO, Á.; HANEL, N.; MARTÍN, E. (eds.), LIMES XX. Estudios sobre la Frontera Romana, Anejos de Gladius 13, Vol. III, pp. 12711284. 
FUENTES DOMÍNGUEZ, A. (1996):"La romanidad tardía en los territorios septentrionales de la Península Ibérica", en FERNÁNDEZ OCHOA, C. (coord.), Coloquio Internacional sobre los Finisterres Atlánticos en la Antigüedad. Época Prerromana y Romana, pp. 213-221.

FUENTES DOMÍNGUEZ, A. (1997): “Aproximación a la ciudad hispana de los siglos IV y V d. C.", Congreso Internacional La Hispania de Teodosio, vol. 2, pp. 477-496.

FUENTES, A. (2001)."El vidrio ¿el primer material reciclado de la Historia?", en FUENTES, A.; PAZ, J.; ORTIZ, E. (eds.), Vidrio romano en España. La revolución del vidrio soplado, (Octubre 2001-Marzo 2002, La Granja de Segovia), Cuenca, pp. 147149.

GANDOLFI (a cura di) (2005): La Ceramica e i Materiali di Età Romana. Classi, produzioni, commerci e consumi, Istituto Internazionale di Studi Liguri, Bordiguera.

GARABITO, T. (1978): Los alfares romanos riojanos. Producción y comercialización, BPH XVI, Madrid.

GARABITO, T. (1983). “El centro de producción de sigillata hispánica tardía en Nájera", I Coloquio sobre historia de La Rioja, Logroño, pp. 187-197.

GARABITO, T.; SOLOVERA, M. E. (1976): Terra sigillata hispánica de Tricio II. Marcas de alfarero, $S$ A 40, Valladolid.

GARABITO, T.; SOLOVERA, M. E. (1976b): Terra sigillata hispánica de Tricio III. Formas decoradas, $S$ A 43, Valladolid.

GARABITO, T.; SOLOVERA, M. E. (1990): “Excavaciones arqueológicas en Tritium Magallum. Tricio (La Rioja). Descubrimiento de nuevos alfares", Estrato 2, Logroño, pp. 36 ss.

GARABITO, T.; AMARÉ, M. T.; SOLOVERA, M. E. (1993): “La producción de lucernas en Tricio", Estrato 5, Logroño, pp. 35-40.

GARABITO, T.; LUEZAS, R. A.; SOLOVERA, M. E. (1994): “La officina de Maternus Blandus (Tricio, La Rioja): La producción de imitaciones de platos de engobe interno rojo pompeyano", Estrato 6, pp. 70-75.

GARABITO, T.; SOLOVERA, M. E; PRADALES, D. (1985): “Los alfares romanos riojanos y la comercialización de sus productos en la región de Galicia", Museo de Pontevedra XXXIX, Pontevedra, pp. 165-195.

GARABITO, T.; SOLOVERA, E.; PRADALES, D. (1986): “Los alfares romanos de Tricio y Arenzana de Arriba: estado de la cuestión", Segundo Coloquio sobre Historia de La Rioja, Logroño, pp. 129-142. 
GARCÍA DE FIGUEROLA, M.; GARCÍA-BELIDO, M. P. (2002): “Las contramarcas monetarias de la legio VI. Consideraciones soobre la presencia militar de esta unidad militar en Hispania", en MORILLO, Á. (coord.), Arqueología Militar Romana en Hispania, Gladius Anejos 5, pp. 451-469.

GARCÍA-DILS DE LA VEGA S. (2011): ASTIGI, en REMOLÀ, J. A.; ACERO. J. (eds.), La gestión de los residuos urbanos en Hispania. Xavier Dupré Raventós (1956-2006). In Memoriam. Anejos de AEspA LX, Mérida, pp. 53-63.

GARCÍA ENTERO, V. (1999): “Las termas de las villae leonesas: Modelos arquitectónicos y funcionales", CNA XXIV, vol. 4, Murcia, pp. 375-382.

GARCÍA HERAS, M.; OLAETXEA, C. (1992): “Métodos y análisis para la caracterización de cerámicas arqueológicas. Estado actual de la investigación en España", AEspA 65, Madrid, pp. 263-289.

GARCÍA MARCOS, V. (1986): Estudio sobre la Terra Sigillata hispánica hallada en la ciudad de León. Las formas decoradas, Memoria de Licenciatura inédita, Universidad de León.

GARCÍA MARCOS, V. (1990): “Marcas de alfarero en sigillata hispánica halladas en la ciudad de León”, Tierras de León 77 y 78, León, pp. 91-104.

GARCÍA MARCOS, V. (1994): Descubrimiento de unas nuevas termas públicas de Asturica Augusta, Cuadernos Municipales 2, Astorga.

GARCÍA MARCOS, V. (1996): “La Romanización Urbana: Asturica Augusta y la implantación Romana en León”, en VV. AA., ArqueoLeón. Historia de León a través de la Arqueología, León, pp. 69-81.

GARCÍA MARCOS, V. (1997): “Excavaciones arqueológicas en la ciudad de León (1993-1995)", Lancia 2, León, pp. 303-314.

GARCÍA MARCOS, V. (2002): “Novedades acerca de los campamentos romanos de León", en MORILLO, J. (coord.), Arqueología Militar Romana en Hispania, Gladius, Anejos 5, pp. 167-211.

GARCÍA MARCOS, V. (2004): “Los campamentos de las legiones VI Victrix y VII Gemina en León”, en PÉREZ, C.; ILLARREGUI, E. (coords.) Arqueología militar romana en Europa, Valladolid, pp. 167-195.

GARCÍA MARCOS, V. (2005): “Importación de terra sigillata itálica y producciones locales de tradición itálica en la meseta norte y el noroeste peninsular", en FERNÁNDEZ OCHOA, C.; GARCÍA DÍAZ, P. (eds.), Unidad y diversidad en el Arco Atlántico en época romana, BAR International Series. 1371, Oxford, pp. 87-108.

GARCÍA MARCOS, V. (2006): “Las producciones de terra sigillata local de tradición itálica en el campamento de la legio VI Victrix en León”, en MORILLO, Á. (ed.), 
Arqueología militar romana en Hispania II. Producción y abastecimiento en el ámbito militar, León, pp. 97-110.

GARCÍA MARCOS, V.; BURÓN, M. (2000): “Las termas menores de Asturica Augusta", Termas romanas en el Occidente del Imperio, Gijón, pp. 207-214.

GARCÍA MARCOS, V.; CAMPOMANES ALVAREDO, E. (1995): “El León Romano", ProMonumenta 1, León, pp. 14-23.

GARCÍA MARCOS, V.; CAMPOMANES ALVAREDO, E. (1998): “La excavación arqueológica de Puerta Obispo", ProMonumenta II, León, pp. 43-47.

GARCÍA MARCOS, V., MIGUEL, F. (1996): “A new view on the military occupation in the North-West of Hispania during the First Century: the case of León", Proccedings of the XVI International Congress of Roman Frontier Studies, Oxbow Monograph 91, pp. 355-360.

GARCÍA MARCOS, V.; MORILLO, Á. (2000-2001): “El campamento de la Legio VII Gemina en León. Novedades sobre su planta y sistema defensivo", Lancia 4, León pp. 103-126.

GARCÍA MARCOS, V.; MORILLO, Á. (2002): “The legionary fortress of Legio VI Victrix at León (Spain). The new evidence", BAR, International Series 1084 (II), Congress of Roman frontier Sudies, Amman, pp. 791-800.

GARCÍA MARCOS, V.; VIDAL ENCINAS, J. M. (1995): “Asturica Augusta y Castra Legionis Geminae en la Asturia Cismontana”, en VV. AA., Astures. Pueblos y Culturas en la Frontera del Imperio Romano, Gijón, pp. 113-129.

GARCÍA MARCOS, V.; VIDAL ENCINAS, J. M. (1996): “Novedades sobre el origen del asentamiento romano de León y de la Legio VII Gemina", en FERNÁNDEZ OCHOA, C. (coord.), Coloquio Internacional sobre Los Finisterres Atlánticos en la Antigüedad. Época prerromana y romana, Gijón, pp. 147-155.

GARCÍA MARCOS, V.; VIDAL ENCINAS, J. M. (1998): “Asturica Augusta: De asentamiento militar a urbs magnifica”, en RODRÍGUEZ COLMENERO, A. (coord.), Congreso Internacional Los orígenes de la ciudad en el Noroeste Hispánico, Lugo, pp. 911944.

GARCÍA MARCOS, V.; CAMPOMANES, E.; MIGUEL, F. (2004): “El solar y el entorno urbano de Santa María de Regla (siglos I-XV)", en YARZA, J.; HERRÁEZ, M. V,; BOTO, G. (eds.), La catedral de León en la Edad Media, León, pp. 23-44.

GARCÍA MARCOS, V.; DURÁN, R.; MORILLO, Á. (2006): “La muralla tetrárquica de Legio: aproximación al conocimiento de su sistema constructivo", en RODRÍGUEZ COLMENERO, A. y RODÁ, I. (eds.), Congreso Internacional Murallas de Ciudades Romanas en el Occidente del Imperio, pp. 381-399. 
GARCÍA MARCOS, V.; MORILLO, Á.; CAMPOMANES, E. (1997): “Nuevos planteamientos sobre la cronología del recinto defensivo de Asturica Augusta (Astorga, León)", Congreso Internacional La Hispania de Teodosio, pp. 515-531.

GARCÍA MARTÍNEZ, S. M. (2000): La base campamental de la Legio VII y sus canabae en León. Análisis epigráfico, León.

GARCÍA MERINO, C.; SÁNCHEZ SIMÓN, M.; BURÓN ÁLVAREZ, M. (2008): “Un depósito cerrado del siglo III: La habitación de la Casa de los Plintos de Uxama (Osma, Soria)", SFECAG, Actes du Congrès de L'Escala-Empúries, pp. 277-280.

GARCÍA MERINO, C.; SÁNCHEZ SIMON, M.; BURÓN ÁlVAREZ, M. (2009). "Cultura material del siglo III en un ambiente doméstico de la meseta: el conjunto cerrado de la casa de los plintos de Uxama", AEA 82, pp. 221-253.

GARCÍA MORENO, L. A. (2002): “Asentamientos militares tardorromanos en las Españas”, en MORILLO, Á. (coord.), Arqueología Militar Romana en Hispania, Gladius Anejos 5, pp. 625-636.

GARCÍA VARGAS, E.; BERNAL CASASOLA, D. (2008): “Ánforas de la Bética”, en BERNAL, D.; RIBERA, A. (eds.), Cerámicas hispanorromanas. Un estado de la cuestión, Cádiz, pp. 661-687.

GARCÍA Y BELLIDO, A. (1950): “La Legio VII Gemina Pia Felix y los orígenes de la ciudad de León", BRAH 227, pp.449-479.

GARCÍA Y BELLIDO, A. (1960): “L. Terentius, figlinarius en Hispania de la Legio IIII Macedonica”, Hommages a León Hermann. Col. Latomus XLIV, Bruxelles, pp. 374-382.

GARCÍA Y BELLIDO, A. (1961): “El 'Exercitus Hispanicus' desde Augusto a Vespasiano", AEA 34, Madrid, pp. 114-160.

GARCÍA Y BELLIDO, A. (1966): “Nuevos documentos militares de la Hispania romana", AEspA XXXIX, pp. 24-40.

GARCÍA Y BELLIDO, A. (1966b): “León y la Legio VII Gemina con motivo del XIX centenario de su creación", Tierras de León 7, pp. 15-25.

GARCÍA Y BELLIDO, A. (1968): Nueve estudios sobre la Legio VII y su campamento en León, León.

GARCÍA Y BELLIDO, A. (1968): “Catálogo de los sellos latericios de la Legio VII Gemina en España", Nueve estudios sobre la Legio VII y su campamento en León, pp. 49-63.

GARCÍA Y BELLIDO (1970): “Nacimiento de la Legión VII Gemina”, en VV. AA., Legio VII Gemina, pp. 303-329. 
GARCÍA Y BELLIDO, A. (1970b): “Estudios sobre la Legio VII y su campamento en León", en VV. AA., Legio VII Gemina, pp. 571-599.

GARCÍA Y BELLIDO, A. (1970c): “Novedades sobre la Legio VII Gemina Pia Felix", Tierras de León 12, pp. 15-21.

GARCÍA Y BELLIDO, A. (1975): “El llamado 'Itinerario del Barro', BRAH 172, III, pp. 547-563.

GARCÍA Y BELLIDO, A. (1976): “El ejército romano en Hispania”, AEA 49, Madrid, pp. 59-101.

GARCÍA Y BELLIDO, A.; FERNÁNDEZ DE AVILÉS, A; GARCÍA GUINEA, M. A. (1970): Excavaciones y exploraciones arqueológicas en Cantabria, Anejos de AEspA $\mathrm{V}$, Madrid.

GARCÍA-BELLIDO, M. P. (2002): “Labores mineras militares en Hispania: explotación y control", en MORILLO, Á. (coord.), Arqueología Militar Romana en Hispania, Gladius Anejos 5, pp. 19-46.

GARCÍA- BELLIDO, M. P. (coord.) (2006): Los campamentos romanos en Hispania (27 a. C.-192 d. C.). El abastecimiento de moneda, 2 vols. Anejos de Gladius 9, Madrid.

GARZETI, A. (1970): “Legio VII Hisp (ana)”, en VV. AA., Legio VII Gemina, León, pp. 333-339.

GASCÓN LASCAS, A. P. (2011): “Un vertedero doméstico altoimperial en el suburbium occidental de la ciudad de Caesaraugusta: C/Predicadores, 24-26", en REMOLÀ, J. A.; ACERO. J. (eds.), La gestión de los residuos urbanos en Hispania. Xavier Dupré Raventós (1956-2006). In Memoriam. Anejos de AEspA LX, Mérida, pp. 369-381.

GELICHI, S. (2000): "L'eliminacione dei rifiuti nelle città romane del nord Italia tra Antichità ed Alto Medioevo", en DUPRE, X.; REMOLÀ, J. A. (eds.), SORDES URBIS. La eliminación de residuos en la ciudad romana, Roma, pp. 13-23.

GIARDINA, A. et alli (1991): El hombre romano, Madrid.

GIL, E.; FILLOY, I. (1991): “El basurero romano de Uralde”, RA 124, Madrid, pp. 6-11.

GIL ZUBILLAGA, E. (1995): Atxa. Memoria de las excavaciones arqueológicas 1982-1988, Memoria de yacimientos alaveses, Vitoria.

GILES, R. D. (2012): Roman Soldiers and the Army. A study of military life from archeological remains, BAR, British Series 562.

GIMENO GARCÍA-LOMAS, R. (1990): “El alfar romano de Melgar de Tera”, I Congreso de Historia de Zamora, Zamora, pp. 587-610. 
GIRÓN, M. L.; COSTA GARCÍA, J. M. (2009):"La cerámica de imitación de engobe rojo pompeyano en los yacimientos militares peninsulares. Un estado de la cuestión", en MORILLO, Á.; HANEL, N.; MARTÍN, E. (eds.), LIMES XX. Estudios sobre la Frontera Romana, Anejos de Gladius 13, Vol. I, pp. 497-512.

GOGUEY, R.; REDDÉ M. (eds.) (1995): Le camp légionnaire de Mirebeau, Mainz.

GOLDSWORTHY, A. (2003): El ejército romano, Madrid.

GÓMEZ MORENO, M. (1909): “La Legio VII Ilustrada”, BRAH 54, Madrid.

GÓMEZ MORENO, M. (1925): Catálogo monumental de España. Provincia de León, Madrid.

GÓMEZ PANTOJA, J. (1992): “La estación de Segisamo”, Gerión 10, pp. 259-273.

GÓMEZ-PANTOJA, J. L. (2004): “Ejército y civiles en La Hispania romana”, en PÉREZ, C.; ILLARREGUI, E. (coords.), Arqueología militar romana en Europa, Valladolid, pp. 45-52.

GONZÁLEZ ÁLVAREZ, D. (2011): “Vias romanas de montaña entre Asturias y León. La integración de la Asturia transmontana en la red viaria de Hispania", Zephyrus 67, pp. 171-192.

GONZÁLEZ FERNÁNDEZ, E. (2011): LUCUS AUGUSTI, en REMOLÀ, J. A.; ACERO. J. (eds.), La gestión de los residuos urbanos en Hispania. Xavier Dupré Raventós (19562006). In Memoriam. Anejos de AEspA LX, Mérida, pp. 297- 311.

GONZÁLEZ FERNÁNDEZ, E. et alli (2002): “Muralla romana de Lucus Augusti: Nuevas aportaciones a su estudio y conocimiento", en MORILLO (coord.), Arqueología Militar Romana en Hispania, Gladius Anejos 5, pp. 591-608.

GONZÁLEZ FERNÁNDEZ, M. L. (1994): “Necrópolis tardorromana en el solar del Monasterio de San Claudio", Numantia 5, pp. 107-122.

GONZÁLEZ FERNÁNDEZ, M. L. (1996): “Consideraciones sobre el origen militar de Asturica Augusta", en FERNÁNDEZ OCHOA, C. (coord.), Coloquio Internacional sobre los Finisterres Atlánticos en la Antigüedad. Época Prerromana y Romana, pp. 85-90.

GONZÁLEZ FERNÁNDEZ, M. L. (1997): La fortificación campamental de Asturica Augusta, Cuadernos Municipales 3, Astorga.

GONZÁLEZ FERNÁNDEZ, M. L.; VIDAL ENCINAS, J. H. (2004): “La Legio X Gemina y Asturica Augusta (Astorga, León)", en PÉREZ, C.; ILLARREGUI, E. (coords.), Arqueología militar romana en Europa, Valladolid, pp. 207-218. 
GONZÁLEZ FERNÁNDEZ, M. L.; VIDAL ENCINAS, J. M. (2005): “Recientes hallazgos sobre el campamento de la Legio VII Gemina en León: La situación de los 'principia' y la configuración de los 'latera praetorii', BSAA LXXI, pp. 161-184.

GOODMAN, P. I. (2007): The Roman City and Periphery From Rome to Gaul, London.

GOSTAR, N. (1979): “L'armée romaine dans les guerres daciques de Trajan”, Dacia XXIII, Bucarest.

GOUDINEAU, CH. (1970): “Note sur la céramique à engobe interne rouge-pompeien", Mélanges d'Archéologie et Histoire 82, pp. 159-186.

GRATALOUP, C. (1988): Les céramiques à parois fines. Rue des Fargues à Lyon, BAR International Series 457, Oxford.

GRAU LOBO, L. (1996): “Eruditos, pioneros e historiadores de la arqueología leonesa", en VV.AA., ArqueoLeón. Historia de León a través de la Arqueología, León, pp. 225-239.

GREENE, K. (1977): “Legionary pottery and the Significance of Holt”, en DORE, J.; GREENE, K. (eds.), Roman Pottery Studies in Britain and Beyond, BAR 30, Oxford, pp. 113-127.

GREENE, K. (1997): “Defining the Romano-British Economy. The Significance of Pottery and the Army", RCRF Acta 35, pp. 27-32.

GUDEA, N. (1976): "Legio VII Gemina in Dacia", Studii si Cercetari de Istorie Veche XXVII, pp. 109-114.

GUDEA, N. (1978): “Descoperiri archeologice si epigrafice mai vechi sau mai noi la Porolissum", Acta Musei Porolissensis II, Zalav, pp. 65-75.

GUDEA, N. (1997): Castrul roman de pe vârful dealului Moigrad-Pomet. Porolissum 1, Zalau.

GUENIN, A.; VERNHET, A. (dirs.) (2002): Céramiques de La Graufesenque et autres productions d'époque romaine. Nouvelles recherches, Hommages à Bettina Hoffmann, Montagnac.

GUERY, R. (1979): “Les marques de potiers sur terra sigillata découvertes en Algérie, I. Sigillées provinciales (hispanique et gallo-romaine)”, AA 13, París, pp. 23-97.

GUIRAL PELEGRÍN, C. (1997): “Un basurero romano en Madrid”, Espacio, Tiempo y Forma, Serie I, t. 10, Madrid, pp. 479-525.

GURT i ESPARRAGUERA, J. M. ; MARTÍNEZ FERRERAS, V. (2008): “Aportaciones de la Arqueometría al conocimiento de las cerámicas arqueológicas. Un ejemplo 
hispano", en BERNAL, D.; RIBERA, A. (eds.), Cerámicas hispanorromanas. Un estado de la cuestión, Cádiz, pp. 787-806.

GUTIÉRREZ GONZÁLEZ, J. A.; BENÉITEZ GONZÁLEZ, C. (1996): “Los tiempos oscuros: La transición a la Edad Media en tierras leonesas", en VV. AA., ArqueoLeón. Historia de León a través de la Arqueología, León, pp. 107-120.

GUTIÉRREZ GONZÁLEZ, J. A.; ARIAS PÁRAMO, L. (2009): “Novedades sobre el recinto amurallado de Astorga (León)", en MORILLO, Á. HANEL, N.; MARTÍN, E. (eds.), LIMES XX. Estudios sobre la Frontera Romana, Anejos de Gladius 13, Vol. II, pp. 757-772.

HANEL, N. (2000): “Militärische Thermen in Niedergermanien-Eine Bestandsaufnahme", Termas romanas en el Occidente del Imperio, Gijón, pp. 23-33.

HANEL, N. (2003): Die amphoren der Ausgrabungen 1998 im hauptstützpunktder Classis Germanica "Alteburg" dei der Colonia Claudia Ara Agrippinensium-ein vorbericht, RCRF Acta 38, Abingdon, pp. 361-364.

HANEL, N. (2007): "Military camps, canabae and vici. The archeological evidence", ERDKAMP, P. (ed.), A companion to the Roman Army, pp. 395-416.

HARTLEY, K. F. (1973): “La difusión des mortiers, tuiles et autres produits en provenance des fabriques italiennes", Cahiers D'Archéologie Subaquatique II, 49-60.

HARTMANN, M. (1984): Le camp légionaire de Vindonissa. Guide Archéologique de la Suisse.

HASSAL, M. (1979): “Military Tile-Stamps from Britain”, MAC. WHIRR (ed.), Roman Brick and Tile. Studies in Manufacture, Distribution and Use in the Western Empire, BAR, International Series 68, Oxford, pp. 261-266.

HATT, J. J. (1952-1953): “Découverte d'un dépotoir d'atelier céramique militaire à Strasbourg", Bull., de la Soc. Nat., des Antiq., de France, pp. 170-171.

HAYES, J. W. (1972): Late Roman Pottery, London.

HELEN, T. (1975): Organization of Roman Brick Production in the First and Second Centuries A. D. An Interpretation of Roman Brick Stamps, Annales Academiae Scientiarum Fennicae. Dissertationes Humanarum Litterarum 5, Helsinki.

HERAS MORA, F. J. et alli (2011): “El vertedero del suburbio norte de Augusta Emerita, Reflexión sobre la dinámica topográfica en el solar de la calle Almendralejo $\mathrm{n}^{\circ}$ 41", en REMOLÀ, J. A.; ACERO. J. (eds.) (2011), La gestión de los residuos urbanos en Hispania. Xavier Dupré Raventós (1956-2006). In Memoriam. Anejos de AEspA LX, Mérida, pp. 345-360. 
HERNÁNDEZ PRIETO, M. A. (1998): “Varia”, en VV. AA., Colonia Victrix Iulia LepidaCelsa (Velilla de Ebro, Zaragoza). El Instrumentum domesticum de la Casa de los Delfines, pp. 87-695.

HEVIA, S.; MONTES, R. (2009): “Cerámica común del siglo I d. C. en el castro del Chao Samartín (Grandas de Salime, Asturias). Notas sobre el repertorio en un ambiente militarizado", en MORILLO, Á. HANEL, N.; MARTÍN, E. (eds.), LIMES XX. Estudios sobre la Frontera Romana, Anejos de Gladius 13, Vol. II, pp. 639-654.

HEVIA, S.; MONTES, R. (2009b): Cerámica romana Altoimperial de fabricación regional del Chao Samartín (Grandas de Salime, Asturias)", CuPAUAM 35, pp. 27-190.

HEVIA, S.; MENÉNDEZ, A.; SÁNCHEZ, E. (1999): “Terra sigillata del Chao Samartín (Grandas de Salime, Asturias), Lancia 3, León, pp. 159-190.

HOFFMAN, B. (1986): La cerámique sigillée, Paris.

ILLARREGUI, E. (1998): “Camesa-Rebolledo: Asentamiento militar al sur de Cantabria", en RODRÍGUEZ COLMENERO, A. (coord.), Congreso Internacional Los orígenes de la ciudad en el Noroeste Hispánico, Lugo, pp. 559-583.

ILLARREGUI, E. (2002):“Acerca de los campamentos altoimperiales de Herrera de Pisuerga y su entorno", en MORILLO, Á. (coord.), Arqueología Militar Romana en Hispania, Gladius Anejos 5, pp. 155-165.

ILLARREGUI, E. (2008): “Los estudios de cerámica romana en las zonas interiores de la Península Ibérica. Algunas reflexiones", en BERNAL, D.; RIBERA, A. (eds.), Cerámicas hispanorromanas. Un estado de la cuestión, Cádiz, pp. 83-91.

ILLARREGUI, E.; SARABIA, P. (2008):" Actuaciones arqueológicas en el yacimiento de Herrera de Pisuerga (Palencia). 2005-2008" Oppidum 4, Segovia, pp. 113-132.

ISINGS, C. (1957): Roman Glass from Dated Finds, Groningen/Djakarta.

JÄGER, U. (1998): Romischer Weissenburg. Kastel Biriciana. Große Thermen. Römermuseum, Treuchtlingen.

JÁRREGA, R. (1991): Cerámicas finas tardorromanas y del Mediterráneo oriental en España. Estado de la cuestión. Anejos de AEspA XI, Madrid.

JÁRREGA, R. (2009): “Una nueva producción de cerámica común de mesa romana de época medioimperial (finales del s. II - inicios del s. III) en la zona de Tarraco (Tarragona)", SECAH, Boletín 01, pp. 22-25.

JÁRREGA, R. (2013). "Producción anfórica, figlinae y propiedad en el territorium de Tarraco (Hispania Citerior): últimas aportaciones", en BERNAL, D. et alli (eds.), Hornos, Talleres y Focos de produccion alfarera en Hispania, Univ. de Cádiz, Vol. I, pp. 399-410. 
JÁRREGA, R.; OTIÑA, P. (2008): “Un tipo de ánfora tarraconense de época medioimperial (siglos I-III): La Dressel 2-4 Evolucionada", SFECAG, Actes du Congrès de L'escala-Empúries, pp. 281-286.

JIMÉNEZ SANCHO, A. (2011): "ITALICA. La red de alcantarillado”, en REMOLÀ, J. A.; ACERO. J. (eds.), La gestión de los residuos urbanos en Hispania. Xavier Dupré Raventós (1956-2006). In Memoriam. Anejos de AEspA LX, Mérida, pp. 145-154.

JOHNSON, A. (1983): Roman Forts of the Ist and 2nd centurias AD in Britain and German Provinces, London.

JOHNSON, S. (1983): Late Roman Fortifications, London.

JONQUERAY, J. P. (1972): “Contribution à l'étude de l'epave Dramont D, à SaintRaphael, d'apés les travaux du G.S.M.S.R.", Cahiers D'Archéologie Subaquatique II, pp. 11-34.

JONQUERAY, J. P. (1976): “Essai de classification des amphores découvertes lors de fouilles sous-marines", Cahiers d'Archéologie Subaquatique, Frejus, pp. 3-50.

JONES, R. F. J. (1976): “The roman military occupation of North-West Spain”, JRS 76, pp. 45-66.

JORDÁ CERDÁ, F. (1962): Lancia, EAE 1, Madrid.

JUAN TOVAR, L. C. (1985): “Recensión a Ma Angeles Mezquíriz: Terra Sigillata Hispanica”, B. M.A.N. VI, Madrid, pp. 93-95.

JUAN TOVAR, L. C. (1990): “Alfares y vías de comunicación en la Hispania romana. Acercamiento a una relación”, La red viaria en la Hispania romana, Zaragoza, pp. 293299.

JUAN TOVAR, L. C. (1992): “Terra sigillata hispánica”, en CABALLERO ZOREDA, L. (dir.). Arcobriga II. Las cerámicas romanas, Zaragoza, pp. 35-134.

JUAN TOVAR, L. C. (1997): “Las industrias cerámicas hispanas en el Bajo Imperio. Hacia una sistematización de la Sigillata Hispánica Tardía", Congreso Internacional La Hispania de Teodosio, vol. 2, pp. 543-568.

JUAN TOVAR, L. C. (2000): "La terra sigillata de Quintanilla de la Cueza", en GARCÍA GUINEA, M. A. (ed.), La villa romana de Quintanilla de la Cueza (Palencia).

JUAN TOVAR, L. C.; PÉREZ GONZÁLEZ, C. (1987): “Un horno hispano-romano de materiales de construcción en Relea (Palencia) y otros alfares de la cuenca del Duero", I Congreso de Historia de Palencia, Palencia, pp. 657-674.

JUAN TOVAR, L. C.; PÉREZ GONZÁLEZ, C. (1995): “Un vertedero del siglo IV d. C., 
en Relea (Saldaña): campaña 1985", Actas del III Congreso de Historia de Palencia, vol. I, pp.381-400.

KASPRZYK, M.; LABAUNE, Y. (2003): “La gestion des déchets à Augustodunum (Autun, Saone-et-Loire) durant l'époque romaine: les données archéologiques", BALLET, P.; CORDIER, P.; DIEUDONNÉ-GLAD, N. (dirs.), La ville et ses déchets dans le monde romain: rebuts et recyclages, pp. 99-116.

KATYSZAK, Ph. (2010): Legionario. El manual del soldado romano, Madrid.

KLEE, M. (1995): Die Saalburg, Theiss, Stuttgart.

LAMBOGLIA, N. (1950): Gli scavi di Albintimilium e la cronologia della ceramica romana, Bordighera.

LAMBOGLIA, N. (1972): "La ceramica come mezzo e la ceramica come fine", I problemi della ceramica romana di Ravenna, della Valle padana e dell'alto Adriatico, Bologna., pp. 37-43.

LARRÉN, H., BLANCO, J. F. (2003): "Ensayo de sistematización de la cerámica tardoantigua en la cuenca del Duero", en CABALLERO, L.; MATEOS, P.; RETUERCE, M. (eds.), Cerámicas tardorromanas y altomedievales en el Península Ibérica, Anejos de AEspA XXVIII, pp. 273-306.

LE BOHEC, Y. (1992): "Les estampilles de l'armée romaine sur briques et tuiles", Epigraphica 54, pp. 43-62.

LE BOHEC, Y. (ed.) (2000): Actes du Congrès Les Légions de Rome sous le Haut- Empire, Lyon.

LE ROUX, P. (1979):"Histoire et Archeologie de la Péninsule Ibérique II. Histoire militaire", REA LXXXI, pp. 160-164.

LE ROUX, P. (1982): L'Armée romaine et l'organisation des Provinces Ibériques d'Auguste à l'invasion de 409, París.

LE ROUX, P. (1985): “L'exercitus hispanicus et les guerres daciques de Trajan”, Mélanges de la Casa de Velázquez, Madrid, pp. 77-97.

LE ROUX, P. (1990): «L'amphithêatre et le soldat sous l'Empire Romaine», DOMERGUE, C.; LANDES, C.; PALIER, J. M. (eds.), Spectacula I. Gladiateurs et amphiteatres, Toulouse, pp. 203-215.

LE ROUX, P. (1995): Romains d'Espagne. Cités et politique dans les provinces II siècle av. J. C.-III siècle ap. J. C., París.

LE ROUX, P. (1997): "Los ejércitos provinciales: el papel del soldado", Hispania Romana. Desde tierra de conquista a provincia del Imperio, pp. 127-129. 
LE ROUX, P. (1999): “Briques et tuiles militaires en la Péninsule Ibérique: Problèmes de production et de diffusion", en BENDALA, M.; RICO, CH.; ROLDÁN, L. (eds.), El ladrillo y sus derivados en la época romana. Monografías de Arquitectura Romana 4, pp. 111-123.

LE ROUX, P. (2000): “Legio VII Gemina (pia) felix”, LE BOHEC, Y. (ed.), Actes du Congrès Les Légions de Rome sous le Haut- Empire, Lyon, pp. 383-396.

LEMAÎTRE, S. (2003): “Les amphores en contexte funéraire: modes de réutilisation”, BALLET, P.; CORDIER, P.; DIEUDONNÉ-GLAD, N. (dirs.), La ville et ses déchets dans le monde romain: rebuts et recyclages, pp. 243-257.

LIBERATI, A.; SILVERIO, F. (1992): Organizzacione militare: essercito. Vita e costumi dei romani antichi, Roma.

LIEBESCHUETZ, W. (2000): “Rubbish Disposal in Greek and Roman Cities" en DUPRÉ, X.; REMOLÀ, J. A. (eds.), SORDES URBIS. La eliminación de residuos en la ciudad romana, Roma, pp. 51-61.

LINEROS, R.; ROMÁN, J. M. (2011): CARMO, en REMOLÀ, J. A.; ACERO. J. (eds.), La gestión de los residuos urbanos en Hispania. Xavier Dupré Raventós (1956-2006). In Memoriam. Anejos de AEspA LX, Mérida, pp. 93-122.

LIÓN, M. C. (1988). “Excavaciones en el alfar de cerámica de paredes finas en Melgar de Tera", Instituto de Estudios Zamoranos 'Florián de Ocampo', Anuario de 1988, Zamora, pp. 99-100.

LIÓN, M. C. (1997): “El alfar de cerámica de paredes finas de Melgar de Tera (Zamora, España)", RCRF Acta 35, pp. 173-178.

LIZ GUIRAL, J.; AMARÉ TAFALLA, M. T. (1993): Necrópolis tardorromana del Campus de Vegazana y las producciones latericias de la Legio VII Gemina, León.

LIZ GUIRAL, J.; CELIS, J.; GUTIÉRREZ. M. J. (2000): “Las termas de Lancia (Villasabariego, León, España)", Termas romanas en el Occidente del Imperio, Gijón, pp. 221-228.

LOESCHCKE, S. (1919): Lampen aus Vindonissa, Zurich.

LOEWINSON, E. (1965): Una calzada y dos campamentos romanos del conventus asturum" AEspA, XXXVIII, pp. 26-49.

LOEWINSOHN, E. (1994-1995): “La Vía de la Plata en sus extremos septentrionales”, Brigecio 4-5, pp. 99-107.

LÓPEZ MULLOR, A. (1979). “Cerámicas de paredes finas con decoración a molde halladas en la costa catalana", CNA XV, Zaragoza, pp. 1027-1046. 
LÓPEZ MULLOR, A. (1980): “Una peculiar producción de cerámica de paredes finas en la costa catalana", RSL XLVI, pp. 33-40.

LÓPEZ MULLOR, A. (1986): “Producción e importación de cerámicas de paredes finas en Cataluña", SFECAG, Congrés de Toulouse, pp. 57-72.

LÓPEZ MULLOR, A. (1989): La cerámica de paredes finas en Cataluña, Quaderns Cientifics i Tecnics, Barcelona.

LÓPEZ MULLOR, A. (2008):"Las cerámicas de paredes finas en la fachada mediterránea de la Península Ibérica y las Islas Baleares" en BERNAL, D.; RIBERA, A. (eds.), Cerámicas hispanorromanas. Un estado de la cuestión, Cádiz, pp. 343-383.

LÓPEZ MULLOR, A.; MARTÍN MENÉNDEZ, A. (2008): “Las ánforas de la Tarraconense", en BERNAL, D.; RIBERA, A. (eds.), Cerámicas hispanorromanas. Un estado de la cuestión, Cádiz, pp. 689-724.

LÓPEZ MULLOR, A.; MARTÍN MENÉNDEZ, A. (2010): “Un nuevo centro productor de ánforas tarraconenses, paredes finas y otras cerámicas en Can Rodon de l'Hort (Cabrera de Mar), Barcelona", RCRF Acta 41, Bonn, pp. 397-410.

LÓPEZ PÉREZ, C. (2004): El comercio de Terra Sigillata en la provincia de A Coruña, A Coruña.

LÓPEZ PÉREZ, C. (2006): “La importación de 'terra sigillata' en el campamento de Cidadela (Sobrado dos Monxes, A Coruña)" en MORILLO, Á. (ed.), Arqueología militar romana en Hispania II. Producción y abastecimiento en el ámbito militar, León, pp. 431-437.

LÓPEZ RODRÍGUEZ; J. R. (1985): Terra Sigillata Hispánica Tardía decorada a molde en la Península Ibérica, Salamanca.

LÓPEZ TRIGAL et alii (2002): Las ciudades leonesas. Guía Crítica desde la Geografía, León.

LÓPEZ, A.; AQUILUÉ, X. (coords.), La producción i el comerç de les àmfores de la Provincia Hispana Tarraconensis. Homenatge a Ricard Pascual i Guasch, Barcelona.

LUEZAS PASCUAL, R. A. (2002): Cerámica común romana en la Rioja. Logroño.

LUEZAS PASCUAL, R. A.; SÁENZ PRECIADO, M. P. (1989): La cerámica romana de Varea, Logroño.

MAGALLÓN BOTAYA, M. A. (1995): "Relaciones e influencias en el Valle del Ebro en época romana", XXI CNA, pp. 1141-1163.

MALISSARD, A. (2001): Los romanos y el agua (La cultura del agua en la Roma antigua), Barcelona. 
MANACORDA, D. (2000): "Sui “Mondezzari" di Roma tra Antichità e età Moderna" en DUPRÉ, X.; REMOLÀ, J. A. (eds.), SORDES URBIS. La eliminación de residuos en la ciudad romana, Roma, pp. 63-73.

MANGAS, J.; MARTÍNEZ CABALLERO (eds.) (2007): El agua y las ciudades romanas, Madrid.

MAÑANES, T. (1972): "Terra sigillata de Astorga", BSAA XXXVIII, Valladolid, pp. 189-210.

MAÑANES, T. (1973): Estudios de cerámica romana, IV, SA 21, Valladolid.

MAÑANES, T. (1975): “La cerámica romana del Bierzo”, León y su Historia III, pp. 427467.

MAÑANES, T. (1976-77): “Materiales cerámicos de la villa romana de El Soldán. Santa Colomba de Somoza (León)", Sautuola II, Santander, pp. 227-261.

MAÑANES, T. (1983): “La implantación romana en el territorio leonés”, Lancia 1, León, pp. 139-185.

MAÑANES, T. (1983b): Astorga romana y su entorno. Estudio Arqueológico, Valladolid.

MAÑANES, T. (1997): “Roma en León”, Historia de León, vol. I, León, pp. 158-352.

MAÑANES, T. (2000): “Cerámica romana de Astorga y su entorno”, León y su Historia, León, pp. 41-66.

MAÑANES, T. (2002): “La Via Nova, Item alio itinere a Bracara Asturica, en la provincia de León", Argutorio 9, pp. 12-14.

MAÑANES, T. (2003): “Asturica Augusta como epicentro viario en época romana”, Larouco 3, pp. 63-93.

MAÑANES, T. (2003b): “La Vía Nova (II)”, Argutorio 10, pp. 35-37.

MAÑANES, T. (2003c): “La Vía Nova (y III)”, Argutorio 11, pp. 6-7.

MAÑANES, T.; SOLANA, J. M. (1985): Ciudades y vías romanas en la cuenca del Duero (Castilla y León), Valladolid.

MARABINI, M. T. (1973): “The Roman Thin Walled Pottery from Cosa (1948-1954)”, MAAR XXXIII, Roma.

MARCOS HERRÁN, F. J. (2002): Vidrios romanos de Herrera de Pisuerga (Palencia), Palencia. 
MARCOS HERRÁN, F. J. (2006): “La producción de vidrio de la 'Legio IIII Macedonica': el vertedero de San Millán (Herrera de Pisuerga, Palencia)", en MORILLO, Á. (ed.), Arqueología militar romana en Hispania II. Producción y abastecimiento en el ámbito militar, León, pp. 455-465.

MARICHAL, R. (1988): Les graffites de La Graufesenque. Suplemento de Gallia nº 47, París.

MARTÍN BUENO, M. (2001-2002): “El monumento como fuente documental: la materialidad útil", Saldvie II, pp. 247-266.

MARTÍN HERNÁNDEZ, E. (2002-2003): “Dos décadas de arqueología romana de León (1980-2002). Balance historiográfico", Lancia 5, León, pp. 199-250.

MARTÍN HERNÁNDEZ, E. (2003): “Campamentos romanos en la Península Ibérica”, LeónCiencia, León, pp. 17-18.

MARTÍN HERNÁNDEZ, E. (2006): “La cerámica romana de paredes finas en el cuadrante noroccidental de la península ibérica", Sautuola 11, pp. 169-188.

MARTÍN HERNÁNDEZ, E. (2006b): “Paredes finas de época julioclaudia en el campamento de la legio VI Victrix. El depósito de San Pedro (Polígono de La Palomera, León)", en MORILlO, Á. (ed), Arqueología Militar Romana en Hispania, Producción y abastecimiento en el ámbito militar; León, pp. 399-417.

MARTÍN HERNÁNDEZ, E. (2008): Cerámica romana de paredes finas de época julioclaudia en el campamento de la legio VI victrix en León. León.

MARTÍN HERNÁNDEZ, E. (2008b). “La céramique romaine à paroi fine Dans le quart nord-ouest de la Péninsule Ibérique", SFECAG, Actes du Congrès de L'EscalaEmpúries, pp. 219-236.

MARTÍN HERNÁNDEZ, E. (2008c): “Los vasos "de caras" en cerámica de paredes finas, bagaje cultural del ejército romano. Nuevas aportaciones a su estudio en territorio leonés", Saldvie 8, pp. 153-177.

MARTÍN HERNÁNDEZ, E. (2011): “Nuevas formas cerámicas y talleres militares del noroeste de la Península Ibérica. El caso de León y Lancia", en NOGALES, T.; RODÂ, I. (eds.), Roma y las Provincias: modelo y difusión, pp. 1053-1060.

MARTÍN HERNÁNDEZ, E. (2012): “Cerámica gris romana el Noroeste. Los vasa potoria”, en BERNAL, D.; RIBERA, A. (eds.), Cerámicas Hispanorromanas II. Producciones regionales, Univ. de Cádiz, pp. 661-680.

MARTÍN HERNÁNDEZ, E.; RODRÍGUEZ MARTÍN, G. (2008): “Paredes finas de Lusitania y del cuadrante noroccidental", en BERNAL, D.; RIBERA, A. (eds.), Cerámicas hispanorromanas. Un estado de la cuestión, Cádiz, pp. 385-406. 
MARTÍN HERNÁNDEZ et alii (2011): “Arqueometría de la cerámica romana de paredes finas: la producción de un alfar en León", Tierra y Tecnología, Revista de Información Geológica, nº 40, pp. 28-32.

MARTÍN VALLS, R.; DELIBES, G. (1976): “Hallazgos arqueológicos en la provincia de Zamora (III), BSAA XLII, Valladolid, pp. 426-427.

MARTÍN VALLS, R; DELIBES, G. (1979): “Marcas de alfarero sobre materiales romanos de construcción" en "Hallazgos arqueológicos en la provincia de Zamora (VI)", $B S A A X L V$, Valladolid, pp. 142 ss.

MARTÍN VALLS; DELIBES, G.; MAÑANES, T. (1975): Sobre los campamentos de Petavonium, S A 36, Valladolid.

MARTÍN VALLS, R.; ROMERO, M. V.; CARRETERO, S. (2002): “Marcas militares en material de construcción en Petavonium", en MORILLO (coord.), Arqueología Militar Romana en Hispania, Gladius, Anejos 5, pp. 137-154.

MARTIN, T. (2008): “Note préliminaire sur un important lot de sigillées hispaniques découvert à Oloron-Sainte Marie/Iluro (Pyrénées-Atlantiques, France)", RCRF, acta 40 , pp. 443-454.

MARTÍNEZ GARCÍA, A. B. (1999): El vidrio en el campamento romano del Ala II Flavia Civium Romanorum en Petavonium (Rosinos de Vidriales, Zamora), Zamora.

MARTÍNEZ GONZÁLEZ, M. (2005): “La producción de Terra Sigillata Hispánica Tardía en el área riojana. Valoración de los datos arqueológicos disponibles", Iberia 8, pp. 113-134.

MARTÍNEZ GONZÁLEZ, M. (2006-2007):"Consideraciones previas al estudio de la producción de Terra Sigillata Hispánica Tardía en el área riojana. Problemas detectados en la información disponible", Lancia 7, León pp. 131-142.

MARTÍNEZ MAGANTO, J.; CARRERAS, C. (1993): “Ánforas de salazón y navegación comercial vía atlántica en época romana.La conexión Baetica-Britannia”, XXII CNA I, Vigo, pp. 101-110.

MARTÍNEZ SALCEDO, A. (2004): La cerámica común de época romana en el País Vasco, Vitoria-Gasteiz.

MARTIN-KILCHER, S. (2003): “Dépôts en milieu urbain et amphores: évacuation organisée-réutilisation-déchets", BALLET, P.; CORDIER, P.; DIEUDONNÉ-GLAD, N. (dirs.), La ville et ses déchets dans le monde romain: rebuts et recyclages, pp. 231-242.

MASON, D. J. P. (1987): “Chester, the canabae legionis”, Britannia 18, London, pp. 143-168.

MATEO, J. (1981): Origen, Evolución y Decadencia del Recinto Amurallado de León, León. 
MATILLA VICENTE, E. (1981):"Sobre la romanización de León", Estudios Humanísticos 3, León, pp. 95-103.

MATILLA VICENTE, E. (1983): “La Legio VII Gemina y León”, Lancia 1, León, pp. 263271.

MAXFIELD, V. A. (1981): The Military Decorations of the Roman Army, London.

MAYET, F. (1973): “Marques de potiers sur sigillée hispanique à Conimbriga", Conimbriga XII, pp. 1-61.

MAYET, F. (1975): Les céramiques à parois fines dans la Péninsule Ibérique, Paris.

MAYET, F. (1975 b): “les sigilliées hispaniques" en ALARÇAO, J. A.; ETIENNE, R. (dirs.), Fouilles de Conimbriga IV. Les sigillées, Paris, pp. 153-248.

MAYET, F. (1976): “Céramiques à parois fines”, en ALARÇAO, J.; ETIENNE, R. (dirs.), Fouilles de Conimbriga VI. Céramiques diverses et verres, Paris, pp. 27-37.

MAYET, F. (1980): “Les céramiques à parois fines: État de la question", Céramiques Hellénistiques et Romaines, Annales littéraires de l'Université de Besançon, 242 París, pp. 201-229.

MAYET, F. (1984): Les céramiques sigillées hispaniques. Contribution à l'histoire économique de la Péninsule Ibérique sous l’Empire Romain, París.

MAC WHIRR, A. (ed.) (1979): Roman Brick and Tile. Studies in Manufacture, Distribution and Use in the Western Empire, BAR International Series 68, Oxford.

MEDRANO MARQUÉS, M.; DÍAZ SANZ, M. A. (2000): “El alfar romano, villa y necrópolis de Villarroya de la Sierra (Zaragoza), Salduie 1, pp. 273-282.

MÉNDEZ -REVUELTA, C. (1975): “Materiales para el estudio de la figura humana en el temario decorativo de la terra sigillata hispánica”, BSAA XL-XLI, Valladolid, pp. 95-143.

MENÉNEZ ARGUÍN, A. R. (2002): “Consideraciones sobre la dieta de los legionaros romanos en las provincias fronterizas del NW del Imperio", Habis 33, pp. 447-457.

MENÉNDEZ ARGÜIN, A. R. (2009): “Organización administrativa de los abastecimientos destinados al ejército romano altoimperial”, en MORILLO, Á.; HANEL, N.; MARTÍN, E. (eds.), LIMES XX. Estudios sobre la frontera romana, Gladius, Anejos 13, pp. 335-343.

MENÉNDEZ LLORENTE, A. (2000): La comarca de Valdeorras en época romana: la cerámica sigillata, Orense. 
MESPLÉ, P. (1957): “L'atelier de potier gallo-romaine de Galane à Lombez (Gers)", Gallia XV, París, pp. 11-71.

MESPLÉ, P. (1966): “L'atelier de potier gallo-romaine de Galane à Lombez (Gers). Fouilles de 1964", Gallia XXIV-1, París, pp. 161-178.

MEZQUÍRIZ, M. A. (1961): Terra sigillata hispánica, Valencia.

MEZQUÍRIZ, M. A. (1976): “Hallazgo de un taller de sigillata hispánica en Bezares (Logroño)", Príncipe de Viana 144-145, Pamplona, pp. 299-304.

MEZQUÍRIZ, M. A. (1983): “Cerámica sigillata hispánica. Historia y criterios tipológicos", B. MAN I. 2, Madrid, pp. 133-139.

MEZQUÍRIZ, M. A. (1983b): “Tipología de la Terra Sigillata hispánica”, B. MAN I.2 Madrid, pp. 123-132.

MEZQUÍRIZ, M. A. (1985): “Terra sigillata Hispanica”, Atlante delle forme ceramiche, II, EAA, Roma, pp. 99-183.

MEZQUÍRIZ, M. A. (1997-98): “Hallazgo de un vertedero de época Altoimperial en Pompaelo", Trabajos de Arqueología Navarra 13, pp. 49-73.

MIGUEL HERNÁNDEZ, F.; GARCÍA MARCOS, V. (1993): “Intervención arqueológica en el patio del Centro Cultural Pallarés (León)”, Numantia 4, Valladolid, pp. 175-206.

MÍNGUEZ MORALES, J. A. (1990): La cerámica romana de paredes finas en el valle medio del Ebro: la colonia Vicrix Iulia Lepida Celsa y su relación con el territorio del actual Aragón, Tesis Doctoral, Universidad de Zaragoza.

MÍNGUEZ MORALES, J. A. (1991): La cerámica romana de paredes finas, Zaragoza.

MÍNGUEZ MORALES, J. A. (1991-1992):"Cerámica de paredes finas en la Colonia Lepida Celsa (Velilla de Ebro, Zaragoza). Su relación con el territorio aragonés", Zephyrus XLIV-XLV, pp. 457-470.

MÍNGUEZ MORALES, J. A. (1995): “Cerámica engobada romana con decoración de medallones en relieve en Aragón: La forma 81.6587. A", BSAA LXV, Valladolid, pp. 145-171.

MÍNGUEZ, MORALES, J. A. (1998): “La cerámica de paredes finas”, en VV. AA: Colonia Victrix Iulia Lepida-Celsa (Velilla de Ebro, Zaragoza). III. 1. El instrumentum domesticum de la Casa de los Delfines. Zaragoza, pp. 322-383.

MÍNGUEZ, MORALES, J. A. (2002): “Tipos y producciones en las crámicas de paredes finas procedentes del Municipium Augusta Bilbilis (Huérmeda-CalatayudZaragoza)", BSSA 68, pp. 105-130. 
MÍNGUEZ MORALES, J. A. (2005): “La cerámica de paredes finas”, en ROCA ROUMENS; FERNÁNDEZ GARCÍA (coords.), Introducción al estudio de la cerámica romana. Una breve guía de referencia, Univ. de Málaga, pp. 317- 404.

MÍNGUEZ MORALES, J. A. (2010): "Las producciones de paredes finas del valle medio el Ebro", RCRF, Acta 41, pp. 429-436.

MÍNGUEZ MORALES, J. A. (2012): “La fabricación de vasos para beber de paredes finas en el valle medio del Ebro", en BERNAL, D.; RIBERA, A. (eds.), Cerámicas Hispanorromanas II. Producciones regionales, Univ. de Cádiz, pp. 83-96.

MÍNGUEZ, J. A.; CARRO, F. (2003.): “La cerámica de paredes finas" en AMARÉ TAFALLA (dir.): Astorga II: Cerámica romana del vertedero de Las Lolas. León, pp. 285335.

MIRÓ, J. (1988): La producción de ánforas en Catalunya. Un estudio sobre el comercio del vino en la Tarraconense (siglos I a. C. - I d. C.), BAR International Series, 473, Oxford.

MÓCSY, A. (1953): "Das territorium legionis und die canabae in Panonien", Acta Archeologica Hungarica, III, Budapest, p. 184.

MONTEIL, M. et alli (2003): “Dépotoirs domestiques et déchets artisanaux: l'exemple de Nîmes (Gard) au Haut-Empire", BALLET, P.; CORDIER, P.; DIEUDONNÉGLAD, N. (dirs.), La ville et ses déchets dans le monde romain: rebuts et recyclages, pp. 121-131.

MORA, G. (1981): “Las termas romanas en Hispania”, AEA 54, pp. 37-89.

MORA, G. (2006): "Roman military archeology in Spain: a history of research", en MORILlO, Á.; AURRECOECHEA, J. (eds.), The Roman Army in Hispania. An Archeological Guide, León, pp. 11-24.

MORAIS, R. (2010): “Estudio preliminar de la Terra Sigillata Hispánica Tardía de Bracara Augusta", RCRF Acta 41, pp. 437-461.

MORENO, J. (1990): Lucernas romanas de la Bética, Madrid.

MORENO, M. (2003): “Avance al estudio de un basurero de cerámica tardía en el entorno del templo romano de Córdoba", Anales de Arqueología Cordobesa, 13-14, Universidad de Córdoba, pp. 229-249.

MORILLO, Á. (1991): "Fortificaciones campamentales de época romana en Hispania", AEA 64, Madrid, pp. 135-190.

MORILlO, Á. (1992): Cerámica romana de Herrera de Pisuerga (Palencia): las lucernas, Santiago de Chile. 
MORILLO, Á. (1993): “Una nueva producción militar de lucernas en la península Ibérica: el taller militar de Herrera de Pisuerga en Palencia (España)", I Congreso de Arqueología peninsular, I, Porto, pp. 351-364.

MORILLO, Á. (1993b): “Campamentos romanos en España a través de los textos clásicos", Espacio, Tiempo y Forma. Historia 6, pp. 379-396.

MORILLO, Á. (1996): “Los campamentos romanos de la Meseta Norte y el Noroeste: ¿un limes sin frontera?", en FERNÁNDEZ OCHOA, C. (coord.), Coloquio Internacional sobre los Finisterres Atlánticos en la Antigüedad. Época Prerromana y Romana, Gijón, pp. 77-83.

MORILLO, Á. (1998): “Asentamientos militares y civiles en el origen del fenómeno urbano en el noroeste peninsular", en RODRÍGUEZ COLMENERO, A. (coord.), Congreso Internacional Los orígenes de la ciudad en el Noroeste hispánico, Lugo, pp. 339-354.

MORILLO, Á. (1999): Lucernas romanas en la región septentrional de la Península Ibérica. Contribución al conocimiento de la implantación romana en Hispania, Monographies Instrumentum 8, Montagnac.

MORILLO, Á. (2000): “La legio IIII Macedónica en la península Ibérica. El campamento de Herrera de Pisuerga (Palencia), en LE BOHEC, Y. (ed.), Actes du Congrès Les Légions de Rome sous le Haut- Empire, Lyon, pp. 609-624.

MORILLO, Á. (2000b): “Ánforas y envases parecederos. Nuevas aportaciones sobre la comercialización del aceite bético durante la época romana en la Península Ibérica", Actas del Congreso Internacional EX BAETICA AMPHORAE región septentrional de la, Écija, pp. 621-635.

MORILLO, Á. (coord.) (2002): Arqueología Militar Romana en Hispania, Gladius Anejos 5. Madrid.

MORILLO, Á. (2002b): “Conquista y estrategia: el ejército romano en el período augusteo y julioclaudio en la región septentrional de la Península Ibérica", en MORILLO, Á. (coord.), Arqueología militar romana en Hispania, Gladius, Anejos 5, pp. 67-94.

MORILLO, Á. (2003): "Hispania en la estrategia militar del Alto Imperio", en FERNÁNDEZ OCHOA, C.; GARCÍA DÍAZ, P (coords.), Unidad y diversidad en el Arco Atlántico en época romana, BAR International Series 1371, pp. 19-33.

MORILLO, Á. (2003b): “Los campamentos romanos de Astorga y León”, Espacio, Tiempo y Forma, Serie II, Historia Antigua, 16, pp. 83-110.

MORILLO, Á. (2005): “La Arqueología Militar Romana en Hispania: nuevas perspectivas", en BENDALA, M. et alii (eds.), La Arqueología Clásica peninsular ante el Tercer Milenio. En el centenario de A. García y Bellido (1903-1972), AEspA XXXIV, pp. 161-185. 
MORILlO, Á. (ed.) (2006): Arqueología militar romana en Hispania II. Producción y abastecimiento en el ámbito militar, León.

MORILLO, Á. (2006b): “Abastecimiento y producción local en los campamentos de la región septentrional de la península Ibérica”, en MORILLO, Á. (ed.), Arqueología militar romana en Hispania II. Producción y abastecimiento en el ámbito militar, León, pp. 33-74.

MORILLO, Á. (2006c): “Los Dióscuros y la 'legio VII gemina': algunas reflexiones sobre el apelativo y el emblema de la legión”, en MORILLO, Á. (ed.), Arqueología militar romana en Hispania II. Producción y abastecimiento en el ámbito militar, León, pp. 747-758.

MORILLO, Á. (2006d): "Roman military productions in Spain”, en MORILLO, Á.; AURRECOECHEA, J. (eds.), The Roman Army in Hispania. An Archeological Guide, León, pp. 181-188.

MORILlO, Á. (2006e): “The Roman Army in Spain”, MORILLO, Á.; AURRECOECHEA, J. (eds.), The Roman Army in Hispania. An Archeological Guide, León, pp. 85106.

MORILLO, Á. (2008): “Producciones cerámicas militares en Hispania”, en BERNAL, D.; RIBERA., A. (eds.), Cerámicas hispanorromanas. Un estado de la cuestión, Cádiz, pp. 275-293.

MORILLO, Á. (2008b): “Criterios arqueológicos de identificación de los campamentos romanos de Hispania", Saldvie 8, pp. 73-93.

MORILLO, Á. (2008c): “Cultos militares y espacios sagrados de la Legio VII Gemina en León”, Gerión 26, pp. 379-405.

MORILLO, Á. (2009): “Ejército y sociedad en la Hispania romana”, en O’ DONNEL, H. et alli (coords.), Historia militar de España. Prehistoria y Antigüedad, pp. 338-346.

MORILLO, Á. (2009b): “Los campamentos romanos en Hispania”, en O’ DONNEL, H. et alli (coords.), Historia militar de España. Prehistoria y Antigüedad, pp. 313-324.

MORILLO, Á. (2010): “Sistemas defensivos en los campamentos romanos de León", Las técnicas y las construcciones en la ingeniería romana, pp. 461-477.

MORILLO, Á.; AMARÉ, M. T.; GARCÍA MARCOS, V. (2005): “Asturica Augusta como centro de producción y consumo cerámico", en FERNÁNDEZ OCHOA y GARCÍA DÍAZ (eds.), Unidad y diversidad en el Arco Atlántico en época romana, BAR International Series. 1371, Oxford, pp. 139-161.

MORILlO, Á.; AURRECOECHEA, J. (eds.) (2006): The Roman Army in Hispania. An Archeological Guide, León. 
MORILLO, Á.; FERNÁNDEZ OCHOA, C. (2009): “El ejército romano durante el Bajo Imperio", en O' DONNEL, H. et alli (coords.), Historia militar de España. Prehistoria y Antigüedad, pp. 328-337.

MORILLO, Á.; GARCÍA MARCOS, V. (2000): “Nuevos testimonios acerca de las legiones VI Victrix y X Gemina en los territorios septentrionales de la Península Ibérica", en LE BOHEC, Y. (ed.), Actes du Congrès Les Légions de Rome sous le Haut- Empire, Lyon, pp. 589- 607.

MORILLO, Á.; GARCÍA MARCOS, V. (2001): "Producciones cerámicas militares de la época augusteo-tiberiana en Hispania", RCRF, Acta 37, pp. 147-155.

MORILLO, Á.; GARCÍA MARCOS, V. (2002): “Twenty years of Roman Military Archeology in Spain", RFS 2000, pp. 779-789.

MORILLO, Á.; GARCÍA MARCOS, V. (2003): “Legio VII Gemina and its Flavian fortress at León", JRA 16, pp. 275-286.

MORILLO, Á.; GARCÍA MARCOS, V. (2003b): “The defensive sistem of the legionary fortress of Legio VII gemina at León (Spain). The porta principalis sinistra". Limes XX. Proceedings of the XIXth International Congress of Roman Frontier Studies, Pécs, pp. 569-585.

MORILLO, Á.; GARCÍA MARCOS, V. (2003c): “Importaciones itálicas en los campamentos del norte de Hispania durante el período augusteo y julioclaudio" RCRF, Acta 38, pp. 295-304.

MORILLO, Á.; GARCÍA MARCOS, V. (2004): “Arqueología romana en la ciudad de León: Balance de dos décadas de excavaciones", en Antonio García y Bellido y su legado a la arqueología española (1903-1972), Varia 5, Madrid, pp. 263-291.

MORILLO, Á.; GARCÍA MARCOS, V. (2006): “Legio (León): cronologías estratigráficas", en GARCÍA-BELLIDO, M. P. (coord.), Los campamentos romanos en Hispania (27 a. C. - 192 d. C.). El abastecimiento de moneda, Anejos de Gladius 9, pp. 244-257.

MORILLO, Á.; GARCÍA MARCOS, V. (2009): “The Roman Camps at León (Spain): State of the Research and News Approaches", en MORILLO, Á.; HANEL, N.; MARTÍN, E. (eds.), LIMES XX. Estudios sobre la frontera romana, Anejos de Gladius 13, pp. 389-405.

MORILLO, Á.; GARCÍA MARCOS, V.; FERNÁNDEZ OCHOA, C. (2002): Imágenes de Arqueología Leonesa. Antonio García y Bellido y el Noroeste peninsular en la Antigüedad, Valladolid.

MORILLO, Á.; GÓMEZ BARRERO, M. (2006): “Circulación monetaria en los campamentos romanos de León", en GARCÍA-BELLIDO, M. P. (coord.), Los campamentos romanos en Hispania (27 a. C. - 192 d. C.). El abastecimiento de moneda, Anejos de Gladius 9, pp. 258-298. 
MORILLO, Á.; MARTÍN, E. (2005): “El ejército romano en la Península Ibérica. De la 'Arqueología filológica' a la arqueología militar romana", Estudios Humanísticos. Historia. $\mathrm{N}^{\mathrm{o}} 4$, pp. 177-207.

MORILLO, Á.; RODRÍGUEZ MARTÍN, G. (2008): "Lucernas hispanorromanas", en BERNAL, D.; RIBERA, A. (eds.), Cerámicas hispanorromanas. Un estado de la cuestión, Cádiz, pp. 407-427.

MORILLO, Á. et alli (eds.) (2003): Defensa y territorio en Hispania de los Escipiones a Augusto, León-Madrid.

MORILLO, A. et alii (2011): "Estudio mineralógico en materiales latericios procedentes de León (España)" Macia $n^{\circ} 15$ Revista de la sociedad española de mineralogía, pp. $145-146$.

MORILLO Á.; HANEL, N.; MARTÍN, E. (eds.) (2009), LIMES XX. Estudios sobre la frontera romana, Gladius, Anejos 13.

MORILLO, Á.; MARTÍN HERNÁNDEZ, E. (2013): “Un contexto cerámico de mediados del siglo I d. C., en el campamento de la legio VI Victrix en León. La intervención de 1995 en el depósito de San Pedro", en BERNAL, D. et alli (eds.), Hornos, Talleres y Focos de produccion alfarera en Hispania, Univ. de Cádiz, Vol. II, pp. 209-227.

MORILLO, Á; SALIDO, J. (2011-2012): “La decoración arquitectónica del campamento de la legio VII en León", CuPAUAM 37-38, pp. 599-623.

MUÑOZ, F.; CAMPOMANES, E., ÁLVAREZ, J. C. (2002): “El período tardoantiguo en la ciudad de León. Reformas en algunas estructuras altoimperiales", en MORILLO, Á (coord.), Arqueología Militar Romana en Hispania. Gladius, Anejos 5, pp. 651-659.

NAIZET, F. (2003): “Les déchets et leur traitement: éléments de terminologie à l'usage des archéologues", BALLET, P.; CORDIER, P.; DIEUDONNÉ-GLAD, N. (dirs.), La ville et ses déchets dans le monde romain: rebuts et recyclages, pp. 13-17.

NAVARRO CABALLERO, M. (1989-90): “Una guarnición de la Legio VII Gemina en Tritium Magallum", Caesaraugusta 66-67, Zaragoza, pp. 217-226.

NAVEIRO LÓPEZ, J. L. (1988): “Arqueología urbana en A Coruña y definición del asentamiento romano", La ciudad y el mundo urbano de Galicia, Santiago de Compostela.

NAVEIRO LÓPEZ, J. L. (1991): El comercio antiguo en el Noroeste Peninsular, La Coruña.

NAVEIRO LÓPEZ, J. L. (1996): “Registro cerámico e intercambios en el Noroeste en la época romana", en FERNÁNDEZ OCHOA, C. (coord.), Coloquio Internacional sobre los Finisterres Atlánticos en la Antigüedad. Época Prerromana y Romana, Gijón, pp. 201204. 
NEIRA FALEIRO, C. (2005): La "Notitia Dignitatum". Nueva edición crítica y comentario histórico, Madrid.

NELIS-CLEMENT, J. (2000): Les beneficiarii: militaires et administrateurs au service de l'empire (I s. a. C. - VI s. p. C.), Paris.

NIELSEN, I. (1990): Thermae et Balnea. The Architecture and Cultural History of Roman Public Baths, Aarhus.

NIETO, X.; ROCA, M.; VERNHET, A.; SCIAU, P. (eds.): “La difusió de la terra sigillata sudgàllica al Nord d'Hispania", Monografies del Museu d'Arqueologia de Catalunya 6, Barcelona.

NIN, N.; LEGULLOUX, M. (2003): “La gestion des déchets à Aix-en Provence dans l'Antiquité", BALLET, P.; CORDIER, P.; DIEUDONNÉ-GLAD, N. (dirs.), La ville et ses déchets dans le monde romain: rebuts et recyclages, pp. 133-163.

NOVOA JAÚREGUI, C. (2009): Arqueología de paisaje y producción cerámica: los alfares romanos del valle del Najerilla (la Rioja) y su distribución espacial, Tesis doctoral, Universidad de Salamanca.

NOVOA JAÚREGUI, C. (2010): “Definición de contextos materiales en áreas alfareras. Prospección intensiva en el territorio de Tritium Magallum (La Rioja, España)", RCRF Acta 41, pp. 473-489.

OLCESE, G. (2003): Ceramiche comuni a Roma e in area romana: produzione, circolazione e tecnologia (tarda età republicana e prima età imperiale), Roma.

OLTEAN, J. A.; HANSON, W. S. (2001): “Military vici in Roman Dacia. An aerial perspective", Acta Musei Napocensis 38/I, Cluj- Napoca, pp. 123-136.

ORFILA, M. (1993): “Terra Sigillata Hispánica Tardía Meridional”, AEA, 167-168, Madrid., pp. 125-147.

OSWALD, F. (1983, reed., de 1964): Index des Estampilles sur Sigillée, RAS, Hors Serie $\mathrm{n}^{\circ}$ 21, Avignon.

OSWALD, F.; PRYCE, T. D. (1966): An introduction to the study of Terra Sigillata, London.

OXÉ, A.; COMFORT, H.; KENRICK, Ph. (2000): Corpus Vasorum Arretinorum. A Catalogue of the Signatures, Shapes and Chronology of Italian Sigillata, Bonn.

PADILLA, C.; MAICAS, R.; CABRERA, P. (2002): Diccionario de materiales cerámicos, Madrid.

PADRÓS, P. et alli (2013): “El complejpo alfarero de Illa Fradera y el papel de Baetulo en el comercio del vino layetano, siglos I a. C. / I d. C.", en BERNAL, D. et alli (eds.), 
Hornos, Talleres y Focos de produccion alfarera en Hispania, Univ. de Cádiz, Vol. I, pp. 439-454.

PADRÓS, P.; SÁNCHEZ, J. (2011): BAETULO, en REMOLÀ, J. A.; ACERO. J. (eds.), La gestión de los residuos urbanos en Hispania. Xavier Dupré Raventós (1956-2006). In Memoriam. Anejos de AEspA LX, Mérida, pp. 215-231.

PALAO VICENTE, J. J. (1998): “Los veterani de la Legio VII Gemina: un ejemplo de integración", Historia Antiqua. XXII, pp. 175-202.

PALAO VICENTE, J. J. (2002): "El medio militar asturicense. El caso de la Legio VII Gemina", en MORILLO, Á. (coord.), Arqueología Militar Romana en Hispania, Gladius Anejos 5, pp. 545-553.

PALAO VICENTE, J. J. (2006): Legio VII Gemina (Pia) Felix. Estudio de una legión romana, Salamanca.

PALAO VICENTE, J. J. (2006b): “La presencia de civiles en los campamentos de Petavonium", Actas del II Congreso de Historia de Zamora, pp. 99-110.

PALAO VICENTE, J. J. (2009): “Los asentamientos civiles en los campamentos romanos durante el Alto Imperio", en MORILLO, Á.; HANEL, N.; MARTÍN, E. (eds.), LIMES XX. Estudios sobre la Frontera Romana, Anejos de Gladius 13, Vol. I, pp. 525-540.

PALAO VICENTE, J. J. (ed.) (2010): Militares y civiles en Roma. Dos mundos diferentes, dos mundos unidos, Salamanca.

PALOL I SALELLAS, P. DE et alii (1991): “Clunia. Centro productor y receptor de Terra Sigillata Hispánica", en PALOL, P. et alli, Excavaciones de Clunia 0, Burgos, pp. 399-408.

PALOL, P.; CORTÉS, J. (1974): La villa romana de La Olmeda (Pedrosa de la Vega (Palencia). Excavaciones de 1969 y 1970, Acta Arqueológica Hispánica 7, Madrid.

PANCIERA, S. (2000): "Netezza urbana a Roma. Organizacione e responsabili", en DUPRÉ, X.; REMOLÀ, J. A. (EDS.), SORDES URBIS. La eliminación de residuos en la ciudad romana, Roma, pp. 95-105.

PANINI, F. C. (1993): Terme romane e vita cuotidiana, Modena.

PARKER, H. M. D. (1971): The Roman Legions, Cambridge.

PAZ PERALTA, J. A. (1991): Cerámica de mesa romana de los siglos III al VI d. C. en la provincia de Zaragoza (Terra sigillata hispánica tardía, african red slip ware, sigillata gálica tardía y phocaean red slip ware), Zaragoza.

PAZ PERALTA, J. A. (2008): “Las producciones de terra sigillata hispánica intermedia y tardía", en BERNAL, D.; RIBERA, A. (eds.), Cerámicas hispanorromanas. Un estado de la cuestión, Cádiz, pp. 497-539. 
PEACOCK, D. P. S. (1982): Pottery in the Roman World. An Etnoarcheological Approach, London.

PEACKOCK, D. P. S. (1997): La ceramica roamana, tra archeologia e etnografia, Bari.

PEACOCK, D. P. S.; WILLIAMS, D. F. (1986): Amphorae and the Roman Economy, London.

PEINADO ESPINOSA, M. V. (2012): “Las cerámicas de cocina en el Alto Guadalquivir, siglos I-II d. C.," en BERNAL, D.; RIBERA, A (eds.), Cerámicas Hispanorromanas II. Producciones regionales, Univ. de Cádiz, pp. 395-406.

PEÑA CERVANTES, Y. (2010): Torcularia. La producción de vino y aceite en Hispania, Tarragona-Murcia.

PEÑIL, J.; LAMALTA, C.; FERNÁNDEZ, C. (1985-86): “Las cerámicas de paredes finas del alfar de Rubielos de Mora (Teruel)”, Kalathos 5-6, pp. 189-197.

PERALTA LABRADOR, E. (2009): “Las Guerras Cántabras”, en O’ DONNEL, H. et alli (coords.), Historia militar de España. Prehistoria y Antigüedad, pp. 247-265.

PEREA YÉBENES, S. (1997): “Baños para soldados y el culto a Fortuna”, en Termalismo Antiguo, I Congreso Peninsular, Madrid, pp. 149-167.

PÉREZ ARANTEGUI, J. et alli (1996): “Arqueometría y caracterización de materiales arqueológicos", Cuadernos del Instituto Aragonés de Arqueología IV, Teruel, pp. 497.

PÉREZ GONZÁLEZ, C. (1986): “El desarrollo urbanístico en Herrera de Pisuerga (Palencia) según la repartición de las marcas de alfarero en T. S.", Arqueología Espacial 10, Teruel, pp. 45-56.

PÉREZ GONZÁLEZ, C. (1989): Cerámica romana de Herrera de Pisuerga (PalenciaEspaña). La terra sigillata, Univ. Internacional SEK, Santiago de Chile.

PÉREZ GONZÁLEZ, C. (1996): “Asentamientos militares en Herrera de Pisuerga”, en FERNÁNDEZ OCHOA, C. (coord.) (1996), Coloquio Internacional sobre los Finisterres Atlánticos en la Antigüedad. Época Prerromana y Romana, Gijón, pp. 91-102.

PÉREZ GONZÁLEZ, C. (1998): “Pisoraca (Herrera de Pisuerga): Urbanismo militar y civil de época romana", en RODRÍGUEZ COLMENERO, A. (coord.) (1996), Congreso Internacional Los orígenes de la ciudad en el Noroeste Hispánico, Lugo, pp. 535555.

PÉREZ GONZÁLEZ, C. (1999): “La Terra Sigillata de Rebolledo-Camesa. Campañas de los años 1983-1985", Sautuola VI, Santander, pp. 375-393. 
PÉREZ GONZÁLEZ, C. (2004): “Ejército romano y arqueología”, en PÉREZ, C.; ILLARREGUI, E. (coords), Arqueología militar romana en Europa, Valladolid, pp. 15-27.

PÉREZ GONZÁLEZ C.; ILLARREGUI, E. (coords) (2004): Arqueología militar romana en Europa, Valladolid.

PÉREZ GONZÁLEZ, C.; ILARREGUI, E. (2006): “Produccionres militares en el campamento de la 'legio IIII Macedonica' en Herrera de Pisuerga", en MORILLO, Á. (ed.), Arqueología militar romana en Hispania II. Producción y abastecimiento en el ámbito militar, León, pp. 111-133.

PÉREZ GONZÁLEZ, C.; ILLARREGUI, E.; FERNÁNDEZ IBÁÑEZ, C. (1991): "Pisoraca. Un importante conjunto arqueológico", RA 120, Madrid, pp. 18-26.

PÉREZ GONZÁLEZ, C.; ILLARREGUI, E.; FERNÁNDEZ IBÁÑEZ, C. (1998): “Marcas de alfareros sobre terra sigillata en Cantabria", en MAYER, M.; NOLLA, J. N.; PARDO, J. (eds.), De les estructures indigenes a l'organització provincial romana de la Hispania Citerior, Ítaca- Annexos I, Barcelona, pp. 501-516.

PÉREZ MAESTRO, C. (2007): “Un área de vertedero / puticulum de época altoimperial localizado extramuros en la zona noreste de la ciudad", Mérida Excavaciones Arqueológicas 2004, 10, pp. 153-170.

PÉREZ-JUEZ GIL, A. (2006): Gestión del Patrimonio Arqueológico, Barcelona.

PETIT, P. (dir.) (2000): Le complexe des thermes de Bliesbruck (Moselle). Un quartier public au coeur d'une agglomération secondaire de la Gaule Belgique, Paris.

PETRIKOVITS, H. VON (1981): “Die Canabae Legionis”, Festschrift 150 Jahre Dai, Berlin

PETRIKOVITS, H. VON (1970): “Die speziälgebaude Römischer legionslager”, en VV. AA., Legio VII Gemina, León, pp. 227-252.

PFLAUM, D. H.-G. (1970): “Les officiers ecuestres de la Legion VII Gemina”, en VV. AA., Legio VII Gemina, León, pp. 355-381.

PISO, I. (2000): “Les légions dans la province de Dacie”, LE BOHEC, Y. (ed), Actes du Congrès Les Légions de Rome sous le Haut-Empire, Lyon, pp. 205-225.

PITILAS SALAÑER, E. (2007): “Función integradora del ejército romano de ocupación en tierras del Norte y Noroeste de Hispania durante la etapa de postconquista", Historia Antiqua XXXI, pp. 11-126.

POLO LÓPEZ, J. (1999): “Cerámicas finas y de importación en Complutum durante el Bajo Imperio", en GARCÍA MORENO, L. A.; RASCÓN MARQUÉS, S. (eds.), Complutum y las ciudades hispanas en la antigüedad tardía. Acta Antigua Complutensia I, Alcalá de Henares, pp. 225-248. 
POPILIAN, G. (1976): Ceramica Romana din Oltenia, Craiova.

POULTER, A. G. (1980): "Rural communities (vici and komai) and theis roke in the organisation of the limes of Moesia Inferior", Roman Frontier Studies XII, pp. 729-744.

POULTER, A. G. (1989): “Gli insediamenti presso i campi militari: canabae e vici”, en WACHER, J.: Il mondo di Roma Imperiale. Vita urbana e rurale (vol. 2), Bari, pp. 69-97

POVEDA NAVARRO, A. M. (1999): “Las producciones de terra sigillata hispánica y su comercialización en el Sureste de Hispania", en ROCA ROUMENS M.; FERNÁNDEZ GARCÍA, M. I. (coords.), Terra Sigillata Hispánica.Centros de fabricación y producciones altoimperiales, Univ. de Jaén/Univ. de Málaga, pp. 209-230.

PRINCIPAL, J. (2008): “El Mediterráneo Occidental como espacio periférico de imitaciones", en BERNAL, D.; RIBERA, A. (eds.), Cerámicas hispanorromanas. Un estado de la cuestión, Cádiz, pp. 127-143.

PUCCI, G. (1975): “Cumanae Testae”, La Parola del Passato XXX, pp. 368-371.

PUENTE SAÑUDO, M. A. (1985): “Cerámica común romana de Rebolledo-Camesa”, Sautuola IV, Santander, pp. 269-280.

PUENTE, M. A. (1987): “Casa de La Matra (Flaviobriga. Castro Urdiales). Cerámica común", Sautuola V, Santander, pp. 161-197.

QUEROL, M. A.; MARTÍNEZ DÍAZ, B. (1996): La gestión del patrimonio arqueológico en España, Madrid.

RABANAL ALONSO, M. A. (1973): “Una mascarilla de terracota en Lancia (León)”, Habis 4, Sevilla, pp. 237-240.

RABANAL ALONSO, M. A. (1984): "Vías de época romana entre Asturias y León", Memoris de Historia Antigua VI, pp. 137-154.

RABANAL ALONSO, M. A. (1986): “Vias mineras y de administración en el Conventus Asturum", Actas I Congreso Internacional Astorga Romana, Astorga, pp. 75-90.

RABANAL ALONSO, M. A. (1988): “La Legio VII Gemina: Mandos y soldados”, Stud. Hist. H. Ant. VI, pp. 145-155.

RABANAL ALONSO, M. A. (1988b): Vias romanas de la provincia de León, León.

RABANAL ALONSO, M. A. (1990): La romanización de León, León.

RABANAL ALONSO, M. A. (1992): "Enlaces viarios entre España (Zamora) y Portugal", Hispania Antiqua XVI, pp. 165-170. 
RABANAL, M. A.; GARCÍA MARTÍNEZ, S. (1996): “La red viaria en el noroeste hispanorromano: su importancia y significado”, Hispania Antiqua XX, pp. 271-294.

RABANAL, M. A.; GARCÍA MARTÍNEZ, S. M. (2001): Epigrafía romana de la provincia de León: revisión y actualización, León.

RASCÓN, S.; POLO, J.; MAESO, F. (1994): “Grafitos sobre Terra Sigillata hispánica hallados en un vertedero del siglo I en la casa de Hippolytus (Complutum)", CUPAUAM 21, Madrid, pp. 235-270.

REGUERA RODRÍGUEZ, A. T. (1996): La ciudad de León: Espacios y tiempos, León.

REINOSO DEL RÍO, M. C. (2002): “Cerámicas de paredes finas en el asentamiento militar de Herrera de Pisuerga (Palencia), en MORILLO, Á. (coord.), Arqueología Militar Romana en Hispania, Gladius Anejos 5, pp. 369-380.

REIS, M. P. et alli (2011): CONIMBRIGA, en REMOLÀ, J. A.; ACERO. J. (eds.), La gestión de los residuos urbanos en Hispania. Xavier Dupré Raventós (1956-2006). In Memoriam. Anejos de AEspA LX, Mérida, pp. 181-201.

REIS, P. (2004): Las termas y balnea romanos de Lusitania, Madrid.

REMESAL RODRÍGUEZ, J. (1986): La annona militaris y la exportación de aceite bético en Germania, Madrid.

REMOLÀ, J. A. (2000): “Sobre la interpretación arqueológica de los vertederos", en DUPRÉ, X.; REMOLÀ, J. A. (eds.), SORDES URBIS. La eliminación de residuos en la ciudad romana, Roma, pp. 107-121.

REMOLÁ, J. A.; ACERO, J. (eds.) (2011): La gestión de los residuos urbanos en Hispania. Xavier Dupré Raventós (1956-2006). In Memoriam. Anejos de AEspA LX, Mérida.

REUMAUX, F. (2003): "La ville et ses déchets dans le monde Romaní. Rebuts et recyclages. Quelques propositions d'un autre point de vue", BALLET, P.; CORDIER, P.; DIEUDONNÉ-GLAD, N. (dirs.), La ville et ses déchets dans le monde romain: rebuts et recyclages, pp. 315-320.

RIBERA LACOMBA, A. (coord.) (2013): Manual de cerámica romana: del mundo helenistico al Imperio romano, Madrid.

RIBERA, A.; ROMANÍ, N. (2011): VALENTIA, en REMOLÀ, J. A.; ACERO. J. (eds.), La gestión de los residuos urbanos en Hispania. Xavier Dupré Raventós (1956-2006). In Memoriam. Anejos de AEspA LX, Mérida, pp. 313-342.

RICCI, A. (1981): "I vasi a pareti sottili", en VV. AA., Merci, mercati e scambi nel Mediterraneo, Roma-Bari, pp. 123-138. 
RICCI, A. (1985). "Ceramica a pareti sottili", Atlante delle forme ceramiche II, EAA, Roma, pp. 231-256.

RICHMOND, I. (1968): Hod Hill, II, London.

RISCO, M. (1784): España Sagrada XXXIV, Madrid. (ed., facs, León 1987).

RISCO, M. (1792): Historia de la ciudad y corte de León y de sus reyes, Madrid. (ed. facs, León 1987).

RITTERLING, E. (1295): “Legio”, RE XII, 2.

ROCA ROUMENS M.; FERNÁNDEZ GARCÍA, M. I. (coords.) (1999): Terra Sigillata Hispánica. Centros de fabricación y producciones altoimperiales, Univ. de Jaén/Univ. de Málaga.

ROCA ROUMENS, M. (1976): Sigillata hispánica producida en Andújar (Jaén), Jaén.

ROCA ROUMENS, M. (1981): “Terra sigillata hispánica: una aproximación al estado de la cuestión", Cuadernos de Prehistoria de la Universidad de Granada nº 6, pp. 385-410.

ROCA ROUMENS, M. (1995): “Estado actual de la investigación de las cerámicas comunes de época romana en la Península Ibérica", en VV. AA., Ceràmica comuna romana d'època Alto-Imperial a la Península Ibèrica. Estat de la qüestió, Monografies Emporitanes VIII, Empúries, pp. 9-12.

ROCA ROUMENS, M. (1998): “Historia de la investigación de la terra sigillata hispánica”, en FERNÁNDEZ GARCÍA, M. I. (ed.), Terra Sigillata Hispánica. Estado actual de la investigación, Univ. de Jaen, pp. 13-30.

ROCA ROUMENS, M. (1998b): “Reflexiones acerca de las estructuras de producción de sigillata en el centro de Andújar" en FERNÁNDEZ GARCÍA, M. I. (ed.), Terra Sigillata Hispánica. Estado actual de la investigación, Univ. de Jaen, pp. 105-122.

ROCA ROUMENS, M., y FERNÁNDEZ GARCÍA, M. I. (coords.)(2005): Introdución al estudio de la cerámica romana. Una breve guía de referencia, Univ. de Málaga.

RODÁ DE LLANZA; I. (2006). “Militares en el área inerme de la 'Hispania Citerior'”, en MORILlO, Á. (ed.), Arqueología militar romana en Hispania II. Producción y abastecimiento en el ámbito militar, León, pp. 205-218.

RODRÍGUEZ, J. (1970): “Las vías militares romanas en la actual provincia de León”, en VV.AA., Legio VII Gemina, León, pp. 405-439.

RODRÍGUEZ ALMEIDA, E. (2000): “Roma, una città self-cleaning?”, en DUPRÉ, X.; REMOLÀ, J. A. (eds.), SORDES URBIS. La eliminación de residuos en la ciudad romana, Roma, pp. 123-127. 
RODRÍGUEZ COLMENERO, A. (ed.) (1996): Lucus Augusti I. El amanecer de una ciudad, A Coruña.

44 RODRÍGUEZ COLMENERO, A. (1996b): “Integración administrativa del Noroeste hispánico en las estructuras romanas", Lucus Augusti I. el amanecer de una ciudad, pp.265-300.

RODRÍGUEZ COLMENERO, A. (coord.) (1998): Congreso Internacional Los orígenes de la ciudad en el Noroeste Hispánico, Lugo.

RODRÍGUEZ COLMENERO, A. (2002): "El campamento auxiliar de Aquis Querquennis (Baños de Bande, Orense)", en MORILlO, Á. (coord.), Arqueología Militar Romana en Hispania, Gladius, Anejos 5, pp. 227-244.

RODRÍGUEZ COLMENERO, A; FERRER, S.; HERVES, F. M. (1998): “El complejo arqueológico romano de 'Aquis Qerquennis'. Porto Quintela (Ourense) en RODÍGUEZ COLMENERO, A. (coord.), Congreso Internacional Los orígenes de la ciudad en el Noroeste Hispánico, Lugo, pp. 891-910.

RODRÍGUEZ GONZÁLEZ, J. (2001): Historia de las Legiones Romanas, Signifer, Madrid.

RODRÍGUEZ MARTÍN, F. G. (1996): Materiales de un alfar emeritense: paredes finas, lucernas, sigillatas y terracotas, Cuadernos Emeritenses-11, Mérida.

RODRÍGUEZ MARTÍN, F. G. (2006): “La comercialización de productos emeriotenses hacia los campamentos astures durante el Alto Imperio", en MORILLO, Á. (ed.), Arqueología militar romana en Hispania II. Producción y abastecimiento en el ámbito militar, León, pp. 185-203.

RODRÍGUEZ NEILA, J. F. (2011): “Problemas medioambientales urbanos en el mundo romano", en REMOLÀ, J. A.; ACERO. J. (eds.), La gestión de los residuos urbanos en Hispania. Xavier Dupré Raventós (1956-2006). In Memoriam. Anejos de AEspA LX, Mérida, pp. 27-49.

RODRÍGUEZ PÉREZ, D. (2009): "La religión de la legio VII gemina a través de la epigrafía: Los Dióscuros en las lápidas de Villalís (León, España)", en MORILLO, Á.; HANEL, N.; MARTÍN, E. (eds.), LIMES XX. Estudios sobre la Frontera Romana, Anejos de Gladius 13, Vol. II, pp. 665-670.

RODRÍGUEZ TREMIÑO, I. (2004): Arqueología urbana en España, Barcelona.

RODRÍGUEZ, J. (1970): “Las vías militares romanas en la actual provincia de León”, en VV.AA., Legio VII Gemina, León, pp. 400-439.

ROGER, D. (2003): “La salubrité dans un quartier résidentiel de l'agglomération secondaire gallo-romaine de Famars (Nord) aux II et III s., ap. J.-C., BALLET, P.; CORDIER, P.; DIEUDONNÉ-GLAD, N. (dirs.), La ville et ses déchets dans le monde romain: rebuts et recyclages, pp. 89-97. 
ROLDÁN GÓMEZ, L. (2008): “El material constructivo latericio en Hispania. Estado de la cuestión" en BERNAL, D.; RIBERA, A. (eds.), Cerámicas hispanorromanas. Un estado de la cuestión, Cádiz, pp. 749-773.

ROLDÁN HERVÁS, J. M. (1971): Iter ab Emerita Asturicam. El Camino de la Plata, Salamanca.

ROLDÁN HERVÁS, J. M. (1972-1973): "Las Tablas de barro de Astorga ¿una falsificación moderna?", Zephyrus 23-24, pp. 221-232.

ROLDÁN, J. M. (1975): Itineraria Hispana. Fuentes antiguas para el estudio de las vías romanas en la Península Ibérica, Valladolid.

ROLDÁN, J. M. (1985): “La incidencia del ejército en el poblamiento en el NO de España", en DEL CASTILLO, A. (ed.), Ejército y sociedad. Cinco estudios sobre el mundo antiguo, Univ. de León, pp. 11-49.

ROLDÁN HERVÁS, J. M. (1997 reed.): Hispania y el Ejército Romano. Contribución a la historia social de la España Antigua, León.

ROLDÁN HERVÁS, J. M. (1998b): “El ejército romano en Hispania”, Hispania, el legado de Roma, pp. 65-71.

ROMERO CARNICERO, M. V. (1977): "Vasos de terra sigillata hispánica de Numancia. Formas Dragendorf 29 y 30", S A 45, Valladolid, pp. 5-414.

ROMERO CARNICERO, M. V. (1979): Vllo, un alfarero de terra sigillata hispánica, SA 55, Valladolid

ROMERO CARNICERO M. V. (1980): "La sigillata hispánica y sus relaciones con el vidrio: la forma Mezquíriz 48”, BSAA XLVI, Valladolid pp. 188-193.

ROMERO CARNICERO, M. V. (1984a): “En torno a ciertas producciones precoces de sigillata en la Península Ibérica II. Los ceramistas Asiaticus, Maternus y nuevos vasos de M. C. R.", BSAA L Valladolid pp. 91-112.

ROMERO CARNICERO, M. V. (1984b): "En torno a ciertas produccions precoces de sigillata en la Península Ibérica", Actas del I Symposium de Arqueología Soriana, Soria, 341-359.

ROMERO CARNICERO, M. V. (1985): Numancia I. La Terra Sigillata, EAE 146, Madrid.

ROMERO CARNICERO, M. V. (1998): “La terra sigillata hispánica en la zona septentrional de la Península Ibérica. Algunas reflexiones acerca de su estudio y grado de conocimiento", en FERNÁNDEZ GARCÍA, M. I. (ed.), Terra Sigillata Hispánica. Estado actual de la investigación, Univ. de Jaen, pp. 189-208. 
ROMERO CARNICERO, M. V. (1999): “El taller de las palmetas”, en ROCA ROUMENS M., y FERNÁNDEZ GARCÍA, M. I. (coords.), Terra Sigillata Hispánica.Centros de fabricación y producciones altoimperiales, Univ. de Jaén/Univ. de Málaga, pp. 169208.

ROMERO CARNICERO, M. V. (1999b): “Producciones singulares”, en ROCA ROUMENS M.; FERNÁNDEZ GARCÍA, M. I. (coords.), Terra Sigillata Hispánica. Centros de fabricación y producciones altoimperiales, Univ. de Jaén/Univ. de Málaga, pp. 253-258.

ROMERO CARNICERO, M. V. (dir.) (2012): Producción y consumo de cerámicas de mesa en la meseta norte durante el Alto Imperio. La Terra Sigillata, SA 97, Valladolid.

ROMERO M. V.; CARRETERO, S. (1997): “Cerámica del campamento romano del Ala II Flavia en Petavonium (Rosinos de Vidriales, Zamora, España)", RCRF Acta 35, pp. 55-61.

ROMERO, M. V.; CARRETERO, S. (1998): “Los campamentos y la ciudad de Petavonium", en RODRÍGUEZ COLMENERO, A. (coord.), Congreso Internacional Los orígenes de la ciudad en el Noroeste Hispánico, Lugo, pp. 1077-1108.

ROMERO, M. V; CARRETERO, S. (2006): “Rosinos de Vidriales. Camp, Fort and Vicus", en MORILLO, Á.; AURRECOECHEA, J. (eds.), The Roman Army in Hispania. An Archeological Guide, León, pp. 347-356.

ROMERO CARNICERO, M. V.; RUÍZ MONTES, P. (2005): “Los centros de producción de T.S.H. en la zona septentrional de la Península Ibérica”, en ROCA ROUMENS, M.; FERNÁNDEZ GARCÍA, M. I. (coords.), Introdución al estudio de la cerámica romana. Una breve guía de referencia, Univ. de Málaga, pp. 184-223.

ROMERO CARNICERO M. V. et alli (2006): “La comercialización de productos cerámicos en Petauonium", en MORILLO, Á. (ed.), Arqueología militar romana en Hispania II. Producción y abastecimiento en el ámbito militar, León, pp. 135-166.

ROMERO CARNICERO, M. V. et alli (2008): “El centro de producción cerámica de Uxama (Osma/El Burgo de Osma, Soria)", SFECAG, Actes du Congrès de L'EscalaEmpúries, pp. 319-330.

ROOK, T. (1992): Roman baths in Britain, London.

ROUVIER-JEANLIN, M. (1972): Les figurines gallo-romaines en terre cuite au Musée des Antiquités Nationales, XXIV Supplément à Gallia, CNRS, París.

RUÍZ MONTES, P.; PEINADO ESPINOSA, M.V. (2010): “Aportaciones al conocimiento técnico y tipológico de los hornos romanos en la provincia de Jaén (España). El caso de los Villares de Andújar", RCRF Acta 41, pp. 497-507. 
SÁENZ DE URTURI, F. (1978): “Nuevos hallazgos romanos en Álava: marcas de alfarero y monedas", EAAl 9, Vitoria, pp. 293-296.

SÁENZ DE URTURI, F. (1983): “Marcas de alfareros y epígrafes sobre T. S., de yacimientos alaveses", EAAl 16, Vitoria, pp. 557 ss.

SÁENZ PRECIADO, J. C. (1992): “Marcas de alfarero romanas aparecidas en las excavaciones de la Plaza de Santa María de El Juncal (Irún- Guipúzcoa)”, Cesaraugusta 69, Zaragoza, pp. 145 ss.

SÁENZ PRECIADO, J. C. (1995): “Los alfares de época tardorromana del valle del río Najerilla", Berceo 128, pp. 113-15.

SÁENZ PRECIADO, J. C. (1997): La terra sigillata hispánica del Municipium Augusta Bilbilis, Tesis Doctoral inédita, Universidad de Zaragoza.

SÁENZ PRECIADO, J. C. (2000): “Las primeras producciones de sigillata hispánica: Asiaticus y M. C. R.: dos alfareros precoces en Bilbilis (Calatayud, Zaragoza)", Salduie I, pp. 283-394.

SÁENZ PRECIADO, J. C. (2007): “Nuevas perspectivas en el estudio de la terra sigillata hispánica", Caesaraugusta 78, Zaragoza, pp. 387-394.

SÁENZ PRECIADO, J. C. (2012): “Las producciones de sigillata locales y regionales del 'Municicipium Augusta Bilbilis'”, en BERNAL, D.; RIBERA, A. (eds.), Cerámicas Hispanorromanas II. Producciones regionales, Univ. de Cádiz, pp. 63-81.

SÁENZ PRECIADO, J. C.; SÁENZ PRECIADO, M. P. (1993): “Marcas y grafitos en sigillata aparecidos en Libia (Herramélluri- La Rioja)", Estrato 5, Logroño, pp. 27-34.

SÁENZ PRECIADO, J. C.; MÍNGUEZ MORALES, J. A. (2008). “Algunas reflexiones sobre los centros de producción de terra sigillata hispánica altoimperial del valle medio del Ebro", SFECAG, Actes du Congrès de L'Escala-Empúries, pp. 169-180.

SÁENZ PRECIADO, M. P. (1993): La terra sigillata hispánica en el Valle Medio del Ebro. El centro alfarero de Tritium Magallum (Tricio-La Rioja), Tesis Doctoral inédita, Universidad de Zaragoza.

SÁENZ PRECIADO, M. P. (1994): “Marcas y grafitos del centro alfarero de la Cereceda (Arenzana de Arriba)", Berceo 127, pp. 79-113.

SÁENZ PRECIADO, M. P. (1996-1997): “Retratos de la familia flavia como motivos decorativos en la terra sigillata hispánica", Annals de l'Institut d'Estudis Gironins, pp. 549-562.

SÁENZ PRECIADO, M. P. (1998): “El complejo alfarero de ‘Tritium Magallum’ (La Rioja): alfares altoimperiales" " en FERNÁNDEZ GARCÍA, M. I. (ed.), Terra Sigillata Hispánica. Estado actual de la investigación, Univ. de Jaén, pp. 123-163. 
SÁENZ PRECIADO, M. P.; SÁENZ PRECIADO, J. C. (1999): “Estado de la cuestión de los alfares riojanos: la terra sigillata hispánica altoimperial", en ROCA ROUMENS M.; FERNÁNDEZ GARCÍA, M. I. (coords.), Terra Sigillata Hispánica. Centros de fabricación y producciones altoimperiales, Univ. de Jaén/Univ. de Málaga, pp. 61-136.

SÁENZ PRECIADO, M. P.; SÁENZ PRECIADO, J. C. (2006): “El centro alfarero de la Cereceda (Arenzana de Arriba, la Rioja). Las producciones del alfarero de las hojas de trébol y del alfarero de los bastoncillos segmentados", Salduie 6, pp. 195-211.

SÁENZ PRECIADO, M. P.; SÁENZ PRECIADO, J. C. (2013): “Figlinae romanas de Vareia y Calagurris (La Rioja)" en BERNAL, D. et alli (eds.), Hornos, Talleres y Focos de produccion alfarera en Hispania, Univ. de Cádiz, Vol. I, pp. 469-478.

SALIDO. J. (2009): “Los graneros romanos militares de Hispania”, en MORILLO, Á.; HANEL, N.; MARTÍN, E. (eds.), LIMES XX. Estudios sobre la Frontera Romana, Anejos de Gladius 13, Vol. II, pp. 679-694.

SALIDO, J.; MORILLO, Á (2010): “El aprovisionamiento del ejército en Hispania. Transporte, almacenaje y redistribución" en PALAO VICENTE, J. J. (ed.), Militares y civiles en la antigua Roma. Dos mundos diferentes. Dos mundos unidos, pp.135-165.

SALIOU, C. (2003): “Le nettoyage des rues dans l'Antiquité: fragments de discours normatifs", BALLET, P.; CORDIER, P.; DIEUDONNÉ-GLAD, N. (dirs.), La ville et ses déchets dans le monde romain: rebuts et recyclages, pp. 37-49.

SAN ROMÁN, F. et alli (2006): "Novedades en el campamento de la Legio VII Gemina", en MORILlO, Á. (ed.), Arqueología militar romana en Hispania II. Producción y abastecimiento en el ámbito militar, León, pp. 733-745.

SAN VICENTE, J. I. (2007): “Galba, el Ala Tauriana y el Ala Sulpicia”, Historia Antiqua XXXI, pp. 87-110.

SÁNCHEZ FERNÁNDEZ, M. A. (1983): “Cerámica común romana del Portus Illicitanus", Lucentum II, Alicante, pp. 285-313.

SÁNCHEZ HIDALGO, E.; MENÉNDEZ GRANDA, A. (2000): “Terra sigillata en Asturias. La serie cerámica del Chao Samartín", RA 232, Madrid, pp. 46-53.

SÁNCHEZ SÁNCHEZ, M. A. (1992): “Cerámica común romana de Mérida (Estudio peliminar)", Series de Arqueología Extremeña no 3, Cáceres.

SÁNCHEZ VELASCO, J. (2011): CORDUBA, en REMOLÀ, J. A.; ACERO. J. (eds.), La gestión de los residuos urbanos en Hispania. Xavier Dupré Raventós (1956-2006). In Memoriam. Anejos de AEspA LX, Mérida, pp. 123-143.

SÁNCHEZ, J. C. (1992): "Ánforas de Arcobriga”, en CABALERO ZOREDA, L. (dir.), Arcobriga II. Las cerámicas romanas, Zaragoza, pp. 287-292. 
SÁNCHEZ, J. C. (1992b): “Anforiscos”, en CABALLERO ZOREDA, L. (dir.) Arcóbriga II. Las cerámicas romanas, Zaragoza, pp. 283-285.

SÁNCHEZ, M. A. (1992): “Cerámica de paredes finas”, en CABALERO ZOREDA, L (dir.): Arcobriga II. Las cerámicas romanas, Zaragoza, pp. 145-150.

SÁNCHEZ, M. A. (1992b): “Cerámica común”, en CABALERO ZOREDA, L. (dir.), Arcobriga. Las cerámicas romanas, Zaragoza, pp. 247-281.

SÁNCHEZ, M. A. (1992c): “Lucernas”, en CABALERO ZOREDA, L. (dir.), Arcobriga II. Las cerámicas romanas, Zaragoza, pp. 231-236.

SÁNCHEZ-LAFUENTE, J. (1985): Comercio de cerámicas romanas en Valeria, Cuenca.

SÁNCHEZ-LAFUENTE, J. (1990): Terra sigillata de Segobriga y ciudades del entorno: Valeria, Complutum y Ercavica, Col. Tesis Doctorales de la Universidad Complutense $\mathrm{n}^{\mathrm{o}} 210 / 90$, Madrid.

SÁNCHEZ-LAFUENTE, J. (1998): “Notas sobre epigrafía menor en Complutum”, en VV.AA., Complutum. Roma en el interior de la Península Ibérica, Alcalá de Henares, pp. 139-145.

SÁNCHEZ-PALENCIA, F. J.; FERNÁNDEZ-POSSE, M. D. (1985): La Corona y el Castro de Corporales I. Truchas (León). Campañas de 1978 a 1981, EAE. 141, Madrid.

SÁNCHEZ-PALENCIA, F. J. (ed.) (2000): Las Médulas (León). Un paisaje cultural en la Asturia Augustana, León.

SÁNCHEZ-PALENCIA, F. J. et alli (2006): "Roman Gold mines of the North-Western Hispania", en MORILlO, Á.; AURRECOECHEA, J. (eds.), The Roman Army in Hispania. An Archeological Guide, León, pp. 127-150.

SÁNCHEZ-PALENCIA, J. (1986): “El campamento romano de Valdemeda, Manzaneda (León): ocupación militar y explotación aurífera en el Noroeste peninsular", Numantia II, pp. 227-231.

SANFELIÚ LOZANO, D.; CEBRIÁN FERNÁNDEZ, R. (2006): “Un taller de terra sigillata en Segobriga (Sahelices, Cuenca)", Lvcentvm XXV, pp. 159-193.

SANTANDER, M. (1970): “Notas sobre el acueducto romano de León”, BSAA XXXVI, Valladolid, pp. 467-474.

SANTOS YANGUAS, N. (1988): El ejército romano y la romanización de los astures. Conquista y anexión del Noroeste de la península Ibérica, Oviedo.

SANTOS YANGUAS, N. (2007): "El ejército romano de conquista en el norte de la península Ibérica", Historia Antiqua XXXI, pp. 51-86. 
SANTOS YANGUAS N. (2008): "Presencia militar romana en el norte peninsular en tiempos de los Antoninos: un ejército para la paz" Lancia 7, León, pp. 9-15.

SANTOS YANGUAS, N. (2009): "Ejército romano y urbanismo en territorio de los astures", Gerión 27 (I), pp. 361-385.

SANTROT, M. H. (1979): Céramiques comunes galorromaines d'Aquitaine, París.

SASTRE, I.; SÁNCHEZ- PALENCIA F. J. (2002): “La red hidráulica minera del Noroeste: aspectos jurídicos, administrativos y políticos", AEspA 75, pp. 215-234.

SCHULTEN, A. (1928): “Campamentos romanos en España”, Investigación y Progreso 5, pp. 34-36.

SCIALlANO, M.; SIBELlA, P. (1991): Amphores. Comment les identifier?, Aix-en Provence.

SERRA, J. (1965): “Vertedero de época romana en el Cerro de la Trinitat (Barcelona)", Boletín de la Sección de Estudios del Centro Excursionista de Puig de Castellar 1, pp. 10-11.

SERRANO RAMOS, E. (1978): “Cerámica común del alfar de La Cartuja (Granada)”, Baetica 1, pp. 243-271.

SERRANO RAMOS, E. (1991): Terra Sigillata Hispánica de los alfares de Singilia Barba, Málaga.

SERRANO RAMOS, E. (1995): “Producciones de cerámicas comunes locales de la Bética", en VV.AA., Cèramica comuna d'epoca Altoimperial a la Península Ibérica. Estat de la questio. Monografies Emporitaines VIII, Empúries, pp. 227-249.

SERRANO RAMOS, E. (1998): “Centros productores de terra sigillata hispánica en los territorios malacitanos", en FERNÁNDEZ GARCÍA, M. I. (ed.), Terra Sigillata Hispánica. Estado actual de la investigación, Univ. de Jaén, pp. 165-187.

SERRANO RAMOS, E. (1999): “Centros productores de T.S.H. en las provincias de Granada y Málaga", en ROCA ROUMENS M.; FERNÁNDEZ GARCÍA, M. I. (coords.), Terra Sigillata Hispánica. Centros de fabricación y producciones altoimperiales, Univ. de Jaén/Univ. de Málaga, pp. 137-167.

SERRANO RAMOS, E. (1999b): "Produciones hispánicas precoces", en ROCA ROUMENS M.; FERNÁNDEZ GARCÍA, M. I. (coords.), Terra Sigillata Hispánica. Centros de fabricación y producciones altoimperiales, Univ. de Jaén/Univ. de Málaga, pp. 231233.

SERRANO RAMOS, E. (2000): Cerámica común romana: siglos II a. C. al VII d. C. Materiales importados y de producción local en el territorio malacitano, Málaga. 
SERRANO RAMOS, E. (2004):" Alfares y producciones cerámicas en la provincia de Málaga. Balance y perspectivas", en BERNAL, D.; LAGÓSTENA, L. (eds.), Figlinae Baeticae, BAR, Oxford, pp. 161-194.

SERRANO RAMOS, E. (2008): “El mundo de las cerámicas comunes altoimperiales de Hispania" en BERNAL, D.; RIBERA, A. (eds.), Cerámicas hispanorromanas. Un estado de la cuestión, Cádiz, pp. 471-488.

SERRANO, E.; ATENCIA, R. (1981): “Marcas de alfareros sobre terra sigillata en la provincia de Málaga", Baetica 4, Málaga, pp. 89-109.

SERRANO, E.; ATENCIA, R.; BELTRÁN, J. (1987): “Marcas de alfareros sobre terra sigillata en la provincia de Málaga (II)", Baetica 10, Málaga, pp. 219-225.

SEVILLANO, A. (2004): "La implantación urbana en Asturica Augusta (Astorga, León)", en PÉREZ, C.; ILLARREGUI, E. (coords.), Arqueología militar romana en Europa, Valladolid, pp. 197-206.

SEVILLANO, A.; VIDAL, J. M. (2000): “Las termas mayores de Astorga", Termas romanas en el Occidente del Imperio, Gijón, pp. 199-205.

SEVILLANO, A.; VIDAL, J. M. (2002): Urbs Magnifica. Una aproximación a la arqueología de Asturica Augusta (Astorga, León). Museo Romano (guía-catálogo), Astorga.

SHULTEN, A. (1928 b): Numantia. Die Ergebnisse der Ausgrabungen 1905-1912. III. Die Lager des Scipio, München.

SHULTEN, A. (1928): Numantia. Die Ergebnisse der Ausgrabungen 1905-1912. IV. Die Lager bei Renieblas, München.

SILVA CAEIRO, J. O. da (1977): "Quatro peças ineditas de "sigillata hispânica", Conimbriga XVI, pp. 139-144.

SILVA CAEIRO, J. O. da (1977): "O espólio da Heredade do Reguengo, Vaiamonte, AP, serie III, VII-IX, 1974-1977, pp. 227-241.

SOLANA SÁINZ, J. M. (2002). “Las unidades militares permanentes en Hispania entre los años 68 y 193 d. C.", en MORILLO, Á. (coord.), Arqueología Militar Romana en Hispania, Gladius Anejos 5, pp. 95-119.

SOLANA SÁINZ, J. M.; SAGREDO SAN EUSTAQUIO, L. (2006): La red viaria romana en Hispania. Siglos I-IV d. C., Valladolid.

SOLOVERA, M. E. (1987): Estudios sobre la historia económica de la Rioja romana, Logroño.

SOLOVERA, M. E.; GARABITO, T. (1985): “Los nombres de los ceramistas romanos de la Rioja: nuevas aportaciones", II Coloquio sobre Historia de La Rioja, Vol. I, Logroño, pp. 117-126. 
SOMMER, C. B. (1984): The military vici of Roman Britain, BAR 129, Oxford.

SOTOMAYOR, M. (1977): Marcas y estilos en la sigillata decorada de Andújar, Jaén.

SOTOMAYOR, M. (1977-78): "Alfares de sigillata riojanos y alfares de Andújar", Pyrenae 13-14, Barcelona, pp. 319-330.

SOTOMAYOR, M. (1983): "Problemas de atribución y cronología en vertederos de TSH", B. MAN I. 2, Madrid, pp. 137-140.

SOTOMAYOR, M. (1998): “Los Villares de Andújar. Historia de la investigación”, en FERNÁNDEZ GARCÍA, M. I. (ed.), Terra Sigillata Hispánica. Estado actual de la investigación, Univ. de Jaén, pp. 31-47.

SOTOMAYOR, M., ROCA, M.; FERNÁNDEZ GARCÍA, M. I. (1999): “Centro de producción de los Villares de Andújar (Jaén)", en ROCA ROUMENS M.; FERNÁNDEZ GARCÍA, M. I. (coords.), Terra Sigillata Hispánica.Centros de fabricación y producciones altoimperiales, Univ. de Jaén/Univ. de Málaga, pp. 19- 60.

STEINBY, M. (1975): “La chronologia delle figlinae doleari urbane dalla fine dell'età repubblicana fino all'inizio del III secolo", B C R 84, Roma, pp. 7-132.

STEINBY, M. (1979): “La produzione latericia”, Pompei 79, pp. 265-271.

SUÁREZ VEGA, R.; BURÓN ÁLVAREZ, M. (2009):"Estratigrafía e interpretación del contexto militar de Asturica Augusta, Astorga (León)", en MORILLO, Á.; HANEL, N.; MARTÍN, E. (eds.), LIMES XX. Estudios sobre la Frontera Romana, Anejos de Gladius 13, Vol. I, pp. 375-388.

SWALD, F. (1964, reed.): Index of Figure-types on Tterra Sigillata, London.

SWAN, V. G. (1995): "Legio VI Victrix in the early century: the ceramic evidence", RCRF Acta 34, pp. 199-203.

SYME, R. (1970): “The conquest of North-West Spain”, en VV.AA., Legio VII Gemina, pp. 78-107.

TARRADELL, M. (1975): “La expansión del aceite y el uso de lucernas. Un elemento metodológico para la historia agraria del Mediterráneo antiguo", Jornadas de Metodología Aplicada a las Ciencias Históricas, Santiago de Compostela, pp. 173-184.

TARRADELLAS, C. (1997): “Transformaciones urbanas en la zona del conjunto termal de Legio VII Gemina (León)", Termalismo Antiguo I. Congreso Peninsular, Madrid, pp. 503-510.

TARRATS, F. (2000): “Tárraco, topografía y arqueología de los vertederos”, en DUPRÉ, X.; REMOLÀ, A. (eds.), SORDES URBIS. La eliminación de residuos en la ciudad romana, Roma, pp. 129-137. 
TED'A (TALLER ESCOLA D'ARQUEOLOGIA) (1989): Un abocador del segle $V$ d. C., en el forum provincial de Tàrraco, Tarragona.

TEJA, R. (2005): “Ad legionem consistentibus: las cannabae de la Legio VII Gemina en una Epístola de San Cipriano de Cartago", en PÉREZ, C.; ILLARREGUI, E. (coords.), Arqueología militar romana en Europa, Valladolid, pp. 305-307.

THOMPSON, F. H. (1959): Deva: Roman Chester, A Publication of The Grosvenor Museum, Chester.

TIR (1993): Tabula Imperii Romani. Hoja K-30. Caesaraugusta-Clunia, Madrid.

TYERS, P. (1996): Roman Pottery in Britain, London.

TOMASEVIC, T. (1970): Die keramik der XIII legion aus Vindonissa, Vindonissa- Museum Brugg, VII.

TOMÉ FERNÁNDEZ, S. (1997): “Los factores geográficos del campamento romano" en (Idem.), León, los ríos en el paisaje urbano, Universidad de Oviedo, pp. 13-16.

TOPÁL, J. (2003): Roman Cemeteries of Aquinqum (Pannonia). The western cemetery (Bécsi Road) II, Budapest.

TORRECILLA AZNAR, A. (1999): “Materiales de construcción en las termas de Hispania romana, a propósito de los materiales hallados en la villa de El Saucedo (Talavera la Nueva, Toledo)", XXIV CNA, vol. 4, Murcia.

TRANOY, A. (1981): La Galice Romaine. Recherches sur le Nord-Ouest de la Péninsule Ibérique dans l'Antiquité, París.

TRUMM, J. (2009): “Vindonissa. Intra Muros. Extra Muros. Ausgrabungen 2003-2006 im süden des Legionslagers Windich”, en MORILLO, Á.; HANEL, N.; MARTÍN, E. (eds.), LIMES XX. Estudios sobre la Frontera Romana, Anejos de Gladius 13, Vol. III, pp. 1371-1382.

TSIOLIS, V. G. (1997): “Las restricciones de la producción tegularia en la Lex Ursonensis", Studia Historica. Historia Antigua 15, pp.119-136.

TUFFREAU-LIBRE, M. (1980): La céramique commune gallo-romaine (Nord. Pas de Calais), Lille.

TUFFREAU-LIBRE, M. (1996): “Le Haut- Empire, une période d'apogée pour la production de la céramique commune", Dossier d'Archéologie 215, pp. 72-77.

ULBERT, G. (1969): “Das frührömische kastel Reingönheim. Die funde aus den jahren 1912 und 1913", Limesforschungen 9, Berlín. 
ULBERT, G. (1970): Das römische Donau- Kastel Rißtissen, Teil 1: die Funde aus Metall, Horn und Knochen, Stuttgart.

VÁZQUEZ, X. L.; DOVAL, J. F. (1996): “Cerámica común romana de A Coruña”, Larouco 2, pp. 119-125.

VEGA AVELAIRA, T. (1998): “Las aglomeraciones civiles (vici y kanabae) de los campamentos romanos: aspectos urbanísticos", en RODRÍGUEZ COLMENERO, A. (coord.), Congreso Internacional Los orígenes de la ciudad en el Noroeste Hispánico, Lugo, pp. 1265-1289.

VEGA AVELAIRA, T. (2002): “Armamento romano procedente del campamento auxiliar de Aquae Querquennae" (Portoquintela, Ourense)", en MORILLO, Á. (coord.), Arqueología Militar Romana en Hispania, Gladius Anejos 5, pp. 395-406.

VEGA AVELAIRA, T. (2007): “Los campamentos permanentes del ejército romano como semilla de núcleos civiles", Larouco 4, pp. 73-98.

VEGA AVELAIRA, T. (2010): “Novedades sobre las termas legionarias en Britannia", $V$ Congreso de Obras Públicas Romanas, pp. 299-324.

VEGA, T.; FERRER, S.; RODRÍGUEZ COLMENERO, A. (2009): “Los principia del campamento romano de Aquae Querquennae (Portoquintela, Ourense, España). Excavaciones arqueológicas de los años 2003-2005", en MORILLO, Á.; HANEL, N.; MARTÍN, E. (eds.), LIMES XX. Estudios sobre la Frontera Romana, Anejos de Gladius 13, Vol. I, pp. 465-480.

VEGAS, M. (1973): Cerámica común romana del Mediterráneo Occidental, Barcelona.

VELADO GRAÑA, B. (1986): “La carta sinodal de San Cipriano y otros 36 obispos africanos a las comunidades cristianas de Astorga, León y Mérida", I Congreso Internacional Astorga Romana, Astorga, pp. 289-295.

VENTURA, S. (1950): "Las marcas alfareras de la Terra Sigillata hallada en Tarrragona", Memorias de los Museos Arqueológicos Provinciales, vol. IX-X (1948-1949), Madrid, pp. 131-165.

VERNHET, A. (1976): “Création flavieenne de six services de vaisselle à La Graufesenque", Figlina 1, Lyon, pp. 13-27.

VERTET, H. (1969): “Observations sur les vases à médaillons d'applique de la vallée du Rhone", Gallia XXVII, París, pp. 93-133.

VERTET, H.; AUDIN, A. (1971): “Enquête sur une série d'appliques rhodaniennes représentant des visages de profil et des masques de face", RCRF Acta XIII, pp. 112117. 
VIDAL ENCINAS, J. M: (2003): “Notas sobre el anfiteatro romano de León”, Astorica, Astorga, pp. 55-66.

VIDAL ENCINAS, J. M.; MARCOS CONTRERAS, G. (2002-2003): “Una construcción romana singular y unas pequeñas termas en el área suburbana de León, Lancia 5, León, pp. 121-137.

VIDAL ENCINAS, J. M. (1986): “Arqueología urbana en León. Precedentes y aportaciones recientes", Archivos Leoneses 79-80, León, pp. 365-380.

VIDAL ENCINAS, J. M. (1993): “León”, Numantia 4, Valladolid, pp. 313-315.

VIDAL ENCINAS, J. M. (1994): “León”, Numantia 5, Valladolid, pp. 267-269.

VIDAL ENCINAS, J. M. (1996): “León”, Numantia 6, Valladolid, pp. 313-319.

VIDAL ENCINAS, J. M. (1996b): “Una década de gestión de la arqueología en la provincia de León", en VV.AA., ArqueoLeón, Historia de León a través de la Arqueología, pp. 241-259.

VIDAL ENCINAS, J. M. (1999): “León”, Numantia 7, Valladolid, pp. 257-259.

VIDAL ENCINAS, J. M. (2005): “La inmodélica gestión de la arqueología en España: de servicio público a mercancía", Criterios. Boletín del Instituto Andaluz del Patrimonio Histórico 53, pp. 78-82.

VIDAL ENCINAS, J. M.; GARCÍA MARCOS, V.; MIGUEL HERNÁNDEZ, F. (1990): "León", Numantia III, Valladolid, pp. 264-266.

VIDAL ENCINAS, J.; GONZÁLEZ FERNÁNDEZ, M. L. (2005): “Recientes hallazgos sobre el campamento de la Legio VII Gemina en León: La situación de los principia y la configuración de los latera praetorii", BSSA, Valladolid, pp. 161-184.

VIGIL, M. (1961): “Ala II Flavia Hispanorum Civium Romanorum”, AEspA, XXXIV, pp. 104-113.

VILA MARTÍNEZ, M. (1984): “Terra sigillata de la ciudad de Lugo en el Museo Provincial", Boletín do Museo Provincial de Lugo II, pp. 63-84.

VILA MARTÍNEZ, M. (1992): “Terra sigillata de la ciudad de Lugo en el Museo Provincial. II. Formas lisas", Gallaecia 13, pp. 177-214.

VILA, C.; LÓPEZ PÉREZ, M. C. (2008): “Aportaciones al conocimiento del comercio de sigillata en la fachada atlántica del noroeste peninsular", SFECAG, Actes du Congrés de L’Escala-Empuries, pp. 241-254.

VITTINGHOFF, F. (1970): “Die Entstehung von städtischen Gemeinwesen in der 
Nachbarschaft römischer Legionslager. Ein Vergleich Leons mit den Entwicklunslinien im Imperium Romanum", en VV. AA., Legio VII Gemina, León, pp. 339-352.

VITTINGHOFF, F. (1971): “Die rechtliche Stellung der 'canabae legionis' und die Herkunftsangabe castris", Chiron 1, pp. 301-303.

VITTINGHOFF, F. (1974): “Das problem des militärterritorium in des vorseverischen Kaiserzeit", Acc. Naz. Lincei, no 194, Roma, pp. 109 y ss.

VIZCAÍNO SÁNCHEZ, J. (1999): “Transformaciones del urbanismo tardoantiguo en Cartagena. El caso de los vertederos", AnMurcia 15, pp. 87-98.

VV. AA. (1970): Legio VII Gemina, León.

VV. AA. (1983): “Terminología y criterios de atribución”, Boletín del Museo Arqueológico Nacional, I.2, Madrid, pp. 116-122.

VV. AA. (1984): Producción y Comercio del Aceite en la Antigüedad. II Congreso Internacional, Madrid.

VV. AA. (1985): Arqueología de las ciudades modernas superpuestas a las antiguas, Madrid.

VV. AA. (1991): Les thermes romains. Actes de la table ronde organisée par l'École francaise de Roma (Rome, 1998), Roma.

VV. AA. (1993): Le camp romain de la Saalburg, Saalburgmuseum, Saalburg-kastell.

VV. AA. (1994): Museu Monográfico de Conimbriga. Colecçoes. Instituto Português de Museus, Lisboa.

VV. AA. (1995): Ceràmica comuna d'època Alto-Imperial a la Península Ibèrica. Estat de la qüestió. Monografies Emporitanes VIII, Empúries.

VV. AA. (1995b): Astores. Pueblos y culturas en la frontera del Imperio Romano, Gijón.

VV. AA. (1996): ArqueoLeón. Historia de León a través de la arqueología, León.

VV. AA. (1997): Termalismo antiguo. I Congreso Peninsular (Armedillo, 1996), Madrid.

VV. AA. (1997b): Hispania Romana. Desde tierra de conquista a provincia del Imperio, Madrid.

VV. AA. (1998): Colonia Victrix Iulia Lepida-Celsa (Velilla de Ebro, Zaragoza): El Instrumentum Domesticum de la Casa de los Delfines, Zaragoza.

VV. AA. (1998b): Hispania. El legado de Roma, Zaragoza. 
VV. AA. (2000): Espacios de ocio, convivencia y cultura en el arco atlántico. Los baños públicos como simbolo de la romanidad, Gijón.

VV. AA. (2004): “La arqueología urbana en España en la actualidad. ¿un tiempo para la esperanza?", Apuntes de Arqueología. Boletín del CDL de Madrid 59, pp. 13-27.

VV. AA. (2008): La Vía de la Plata: una calzada y mil caminos, Mérida.

WALDHERR, G. H. (2001): Auf den Spuren der Romer ein stadtführer durch Regensburg, Regensburg.

WARD, M.; CARRINGTON, P. (1981): “A quantitative study of the pottery from a Roman extramural building at Chester", Roman Pottery Research in Britain and NorthWest Europe, BAR, S. 123, Oxford, pp. 25-38.

WATSON, G.R. (1969): The Roman Soldier, Bristol.

WEBSTER, G. (1985): The Roman Imperial Army of the First and Second Centuries AD, Londres.

WILMOTT, A. (2009): “New excavation at the amphitheatre of the legionary fortress of Chester (Deva), Britain”, en MORILLO, Á.; HANEL, N.; MARTÍN, E. (eds.), LIMES XX. Estudios sobre la Frontera Romana, Anejos de Gladius 13, Vol. III, pp. 1157-1162.

WILSON, P. R. (1999): "Military and civilian baths at Catterick (Cataractonium), Yorkshire", en DE LAINE, J.; JOHNSON, D. E. (eds.), Roman Baths and bathing, JRA, 37 Portsmouth, pp. 239-244.

YARZA, J.; HERRÁEZ, M. V.; BOTO, G. (eds.), La catedral de León en la Edad Media, León,

YEGÜL, F. K. (1992): Baths and bathing in Classical Antiquity, New York.

ZARZALEJOS, M. (1991): El yacimiento romano de Velilla de San Antonio. La Terra Sigillata, Madrid.

ZARZALEJOS, M. (2001): “La terra sigillata de Mentesa Oretana (Villanueva de la Fuente, Ciudad Real). Campañas de 1998 a 2000", en BENÍTEZ de LUGO (ed.), Mentesa Oretana. 1998-2000, Ciudad Real.

ZARZALEJOS, M. (2002): El alfar romano de Villamanta (Madrid), Madrid.

ZARZALEJOS, M. (2005): “Comercio y distribución de cerámicas romanas en Asturias", en FERNÁNDEZ OCHOA y GARCÍA DÍAZ (eds.), Unidad y diversidad en el Arco Atlántico en época romana, BAR International Series. 1371, Oxford, pp. 163-190.

ZARZALEJOS, M.; MORILLO, Á. (1994): "Terra sigillata procedente de la Cueva de los Cabañiles (Huete, Cuenca)", CuPAUAM 21, Madrid. 


\section{ARQUEOMETRÍA: BIBLIOGRAFÍA COMPLEMENTARIA}

AITCHISON, J. (1986): The Statistical Analysis of Compositional Data, Chapman and Hall, London.

AITCHISON, J. (2005): A concise guide to compositional data analisys. $2^{\circ}$ Compositional Data Analysis Workshop, Girona.

BURÓN, M.; GARCÍA GIMÉNEZ, R.; SUÁREZ VEGA, R. (1999): “Composición mineralógica de materiales cerámicos romanos de época altoimperial producidos en Asturica Augusta (Astorga, León). La posible existencia de un alfar", XXIV CNA, vol. 4, Murcia, pp. 323-330.

BUXEDA, J.; CAMPILLO, J. (2001): “Identificació arqueológica i arqueomètrica de noves productions de Terra Sigillata Hispànica a l'àrea dels Pirineus catalans", Pyrenae 31-32, pp. 113-131.

CAPEL, J. (ed.) (1999): Arqueometría y Arqueología, Granada.

COMPAÑA, J. M.; LEÓN-REINA, L.; ARANDA, M. A. G. (2010): “Archeometric characterization of Terra Sigillata Hispánica from Granada Workshops", Boletín de la Sociedad Española de Cerámica y Vidrio 49, pp. 113-119.

CUOMO DI CAPRIO, N. (1985): La Ceramica in Archeologia. Antiche tecniche di lavorazione e moderne metodi d'indagine, Roma.

CUOMO DI CAPRIO, N. (1992): “Tecnologia Della ceramica e análisis archeometicere", Archeometria della ceramica. Problemi di metodo, Atti VIII Simposio Iternazionale della Ceramica, Rimini, pp. 67-70.

ECHAILLIER, J. C. (1984): “Élements de technologier céramique et d'analyse des terres cuites archéologiques", Documents d'Archélogie Méridionale. Serie Méthodes et Techniques $n^{\circ}$ 3, Lambesc.

GARCÍA GIMÉNEZ, R. et alli (1999): “Consideraciones sobre los centros productores de lucernas tipo Andújar. Análisis arqueométrico de materiales procedentes de los Villares de Andújar (Jaén) y de la Submseta Norte", Arqueometría y Arqueología. II Reunión de Arqueometría, Granada, pp. 187-195.

GARCÍA HERAS, F. (1997): Caracterización arqueométrica de la producción cerámica numantina, Tesis Doctoral, Universidad Complutense de Madrid.

GARCÍA HERAS, M. (1994): “Viaje al interior de una cerámica. El valor de la caracterización en el estudio de la cerámica arqueológica”, RA 159, pp. 26-35. 
GARCÍA HERAS, M.; OLAETXEA, C. (1992): “Métodos y análisis para la caracterización de cerámicas arqueológicas. Estado actual de la investigación en España", AEA 65, pp. 263-289.

GARCÍA, R.; MÁRQUEZ, P. A.; SUÁREZ, R.; BURÓN, M. (2002): “Cerámicas romanas altoimperiales de Asturica Augusta (Astorga, León). Arqueometría y manufactura experimental", Actas del IV Congreso Nacional de Arqueometría, Valencia (edición digital), pp. 137-141.

GURT I ESPARRAGUERA, J.; MARTÍNEZ FERRERAS, V. (2008): “Aportaciones de la Arqueometría al conocimiento de las cerámicas arqueológicas. Un ejemplo hispano", RCRF, pp. 787-806.

HEIMANN, R. (1989): “Assesing the Technology of Ancient Pottery: The Use of Ceramic Phase Diagrams, Archeomaterials 3, pp. 123-148.

HEIN, A. et alli (2002): "Standardisation of elemental analitycal techniques applied to provenance Studies archaeological ceramics: an inter laboratory calibration study", Analyst 127, pp. 542-553.

JORNET, A. (1984): “Arqueometría: estudios sobre cerámica arqueológica”, RA 35, pp. 18-27.

JORNET, A. (1984): “La cerámica en la arqueometría”, BMAN 2, pp. 77-84.

KEMPE, D.R.C.; HARVEY, A. P. (eds.) (1983): The Petrology of Archeological Artefacts, Oxford.

KILKOGLOU, V.; MANIATIS, Y.; HEIN, A. (eds.) (2002): Modern trends in ancient ceramics, BAR International Series 1011, Oxford.

MADRID, M. (2005): Estudi arqueològic i caracterizació arqueomètrica de la terra sigilada de la ciutat de Baetulo (Badalona), Tesis Doctoral Universidad de Barcelona (TDX0105106-091209), Barcelona.

MADRID, M.; BUXEDA, J. (2010): Estudio de caracterización arqueométrica de las producciones cerámicas de paredes finas, de tradición ibérica pintadas, de tipo Peñaflor, lucernas y terra sigillata del centro productor de Andújar, Informe inédito, Barcelona.

PÉREZ ARANTEGUI, J. (1991): Caracterización de restos arqueológicos aragoneses. Aportaciones al desarrollo de la Arqueometría Analítica, Tesis Doctoral, Universidad de Zaragoza.

PÉREZ ARANTEGUI, J. et alli (1996): Arqueología y caracterización de materiales arqueológicos, Cuadernos del Instituto Aragonés de Aarqueología IV, Teruel. 
PICON, M. (1973): Introduction à l'étude technique des céramiques sigillées de Lezoux, Centre de Recherches sur les techniques Greco-romaines 2, Université de Dijon.

PICON, M. (1984): “Recherches sur les compositions des sigillées hispaniques. Techniques de fabrication et groupes de production", en MAYET, F., Les céramiques sigilléeshispaniques. Contribution à l'histoire économique de la Péninsule Ibérique sous l'Empire Romain, pp. 303-317.

RICE, P. H. (1987): Pottery analisis. A Sourcebook, Chicago.

RINCÓN, J. M. (1985): “Composición mineralógica y microestructural de cerámicas de Terra Sigillata de la Península Ibérica", en BLÁZQUEZ, J. M. et alli (dirs.), Castulo V, EAE 140, pp. 346-362.

RINCÓN, J. M.; ROMERO, M. V. (1995): “Archeometric characterizacion of "Terra Sigillata hispánica' ceramics from Spain", en VICENTINI, P. (ed.), Proceedings of the International Symposium. The Ceramics Cultural Heritage, Faenza, pp. 325330.

SÁENZ PRECIADO, M. P. (1993): La terra sigullata hispánica en el Valle Medio del Ebro. El centro alfarero de Tritium Magallum (Tricio-La Rioja), Tesis Doctoral inédita.

SARABIA, F. J.; DELIBES, G.; MARTÍN, F. J. (1995): “Análisis químicos en Arqueología: FRXED y AAS", XXI CNA, pp. 445-451.

SCHMITT, A. (1989): Métodes géochimiques, pétrographiques et mineralogiques apliques à la détermination de l'origine des céramiques archéologiques, Thèse de Doctorat, Université de Bordeaux.

TUSET i BERTRAND, F. (1991): La Terra Sigillata de Clunia: una propuesta metodológica para el estudio de las producciones altoimperiales, Tesis Doctoral, Universidad de Barcelona.

VICENTINI, P. (ed.), Proceedings of the International Symposium. The Ceramics Cultural Heritage, Faenza 


\section{ÍNDICE DE ABREVIATURAS BIBLIOGRÁFICAS}

$A A$

$A E A$

$B A M$

$B A R$

$B C R$

B MAN

BPH

BRAH

$B S A A$

CUPAUAM

$C D L$

CNA

$E A A$

EAAl

$E A E$

EPAM

ETAM

JGS

JIAR

$J R A$

JRS
Antiquités Africaines

Archivo Español de Arqueología

Bulletin d'Archéologie Marocaine

British Archaeological Reports

Bulletino Communale di Roma

Boletín del Museo Arqueológico Nacional

Bibliotheca Praehistorica Hispana

Boletín de la Real Academia de la Historia

Boletín del Seminario de Estudios de Arte y Arqueología

Cuadernos de Prehistoria y Arqueología de la Universidad Autónoma de Madrid

Colegio de Licenciados en Filosofía y letras y en Ciencias de Madrid

Congreso Nacional de Arqueología

Enciclopedia dell' Arte Antica

Estudios de Arqueología Alavesa

Excavaciones Arqueológicas en España

Estudios de Prehistoria y Arqueología Madrileñas

Études et Travaux d'Archéologie Marocaine

Journal of Glass Studies

Jornades Internacionales d'Arqueología Romana

Journal of Roman Archeology

Journal of Roman Studies 
MAAR Memoirs of the American Academy in Rome

NAH Noticiario Arqueológico Hispánico

QCM Quaderni di Cultura Materiale

$R A \quad$ Revista de Arqueología

RAS Revue Archéologique Sites

RCRF Rei Cretariae Romanae Favtores

REA Revue d'Études Anciennes

RFS Roman Frontier Studies

RSL Revista di Studi Liguri

$S A$

Studia Archeologica

SECAH

Sociedad de Estudios de la Cerámica Antigua en Hispania

SFECAG Societé Française d'Étude de la Céramique antique en la Gaule 
APÉNDICE I 


\section{INFORMES TÉCNICOS CONSULTADOS SOBRE INTERVENCIONES ARQUEOLÓGICAS EN LA CIUDAD DE LEÓN.}

- FERNÁNEZ ORDÁS (2007): Informe No 391/07: C/ Misericordia c/v C/ Santa Cruz.

- FERNÁNDEZ ORDÁS (2002): Informe 280 / 09: C/ Rúa 47.

- GARCÍA MARCOS, V. y CAMPOMANES, E. (1995): Informe $\mathrm{N}^{\circ}$ 2/95: Rehabilitación Botines.

- GONZÁLEZ FERNÁNDEZ, M. L (2004): Informe No 164/04: C/ Escurial, 3.

- MIGUEL HERNÁNDEZ, F. (1994): Informe Nº 2/94. Centro Cultural Pallarés

- RODRÍGUEZ GONZÁLEZ, P. (2002): Informe Nº 75 / 02: C/ La Paloma II.

- RODRÍGUEZ GONZÁLEZ, P. (2004): Informe N 511/04: C/ Tarifa 9.

- GARCÍA MARCOS, V. y CAMPOMANES, E. (1996): Informe No 5/96: Plaza Puerta Obispo

- TALACTOR, S. L. (1997): Informe No 17/97: C/ Plegarias c/v Ramiro II.

- TALACTOR, S. L. (2001): Informe No 14/95: C/ Salvador del Nido, n².

- TALACTOR, S. L. (2003): Informe No 529/03: C/ San Lorenzo, 6 y 8.

-TALACTOR, S. L. (2004): Informe No 107/04: C/ Don Gutierre c/v C/Carbajalas.

- TALACTOR, S. L. (2004): Informe No 419/04: C/ San Pedro, c/v C/ Panaderos.

- TALACTOR, S. L. (2006): Informe Nº 333/06: C/ Los Cubos, 6, c/v C/ Ave María.

- TALACTOR, S. L. (2007): Informe No 404/06: Plaza de Don Gutierre, 5. 
- TALACTOR, S. L. (2007): Informe No 495/07: C/ Los Cubos 14 (sector 3 aglomeración Legio VII).

- TALACTOR, S. L. (2007): Informe N 527/07: C/ Padre Isla, 94.

- TALACTOR, S. L. (2007): Informe $N^{\circ}$ 590/07: Puerta Obispo, 8, c/v Plaza San Pedro, 9.

- TALACTOR, S.L. (2008): Informe No 8/08: Ruíz de Salazar, 10.

- TALACTOR, S. L. (2008): Informe No 286/07: Plaza Puerta Obispo, 9.

- TALACTOR, S. L. (2009): Informe Nº 280/09: C/ Rúa 30. 

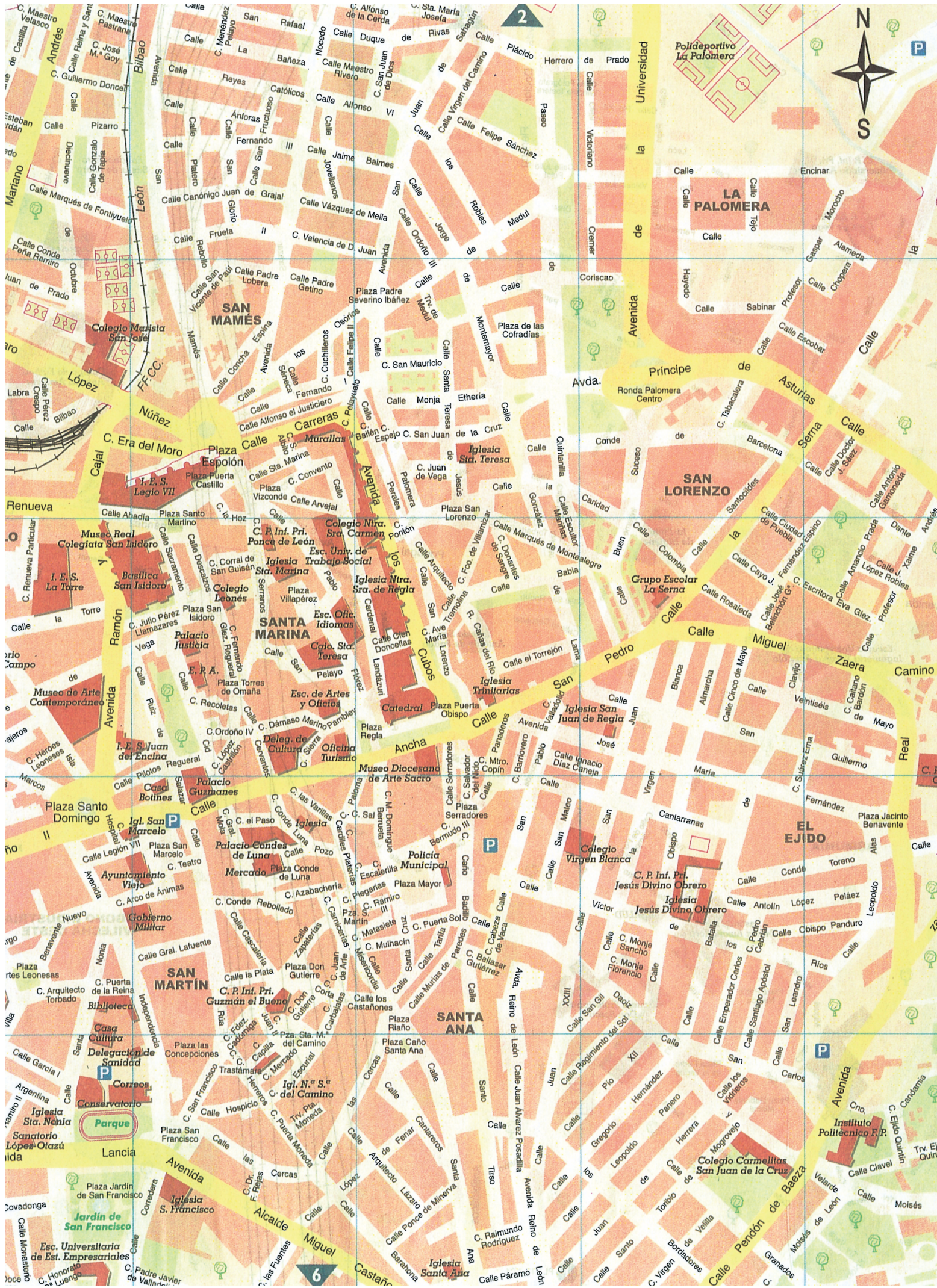

Plano de la actual ciudad de León. 
APÉNDICE II 
En ese apéndice recogemos de forma literal los datos extraidos de los análisis de pastas efectuados sobre diversos fragmentos procedentes de los distintos vertederos, con especial atención a las muestras pertenecientes a TSH y TSHT, así como también algunas de cerámica común. Dichos análisis han sido efectuados por la Dra. Da Josefina Pérez Arantegui, en el Departamento de Química Analítica de la Universidad de Zaragoza, mostrándose los resultados tal y como aparecen en el informe, sin que haya mediado intervención por nuestra parte, a excepción de las interpretaciones que hemos plasmado anteriormente en diferentes capítulos de este trabajo.

\title{
ESTUDIO DE LA COMPOSICIÓN QUÍMICA DE LAS PASTAS DE CERÁMICAS DE TERRA SIGILLATA HISPÁNICA Y COMUNES (LEÓN).
}

\author{
Josefina Pérez Arantegui, Dpto. Química Analítica. Universidad de Zaragoza.
}

Seis muestra de cerámica Terra Sigillata hispánica y dos de cerámica común fueron seleccionadas para el análisis de sus pastas de Espectrometría e emisión atómica con Plasma de acoplamiento inductivo (ICP).

\section{PREPARACIÓN Y DISOLUCIÓN DE LAS MUESTRAS.}

Para comenzar el estudio, de cada una de las ocho muestras fue necesario tomar una equeña parte, del interior de la cerámica para considerar sólo la pasta. Esta operación se realizó mediante el eliminado de la capa superficial de decoración con una broca con cabeza de diamante, el corte con sierra de diamante de una parte de la pasta cerámica y su posterior trituración en mortero de ágata, de esta forma la muestra obtenida estaba ya en forma de polvo.

Para proceder a su análisis era necesario disolver dichas muestras previamente, ya que las medidas deben hacerse introduciendo las muestras en forma de disolución. Para ello se tomaron $50 \mathrm{mg}$. de cada muestra (pesados con exactitud) y se disolvieron por un ataque con ácidos en tubos abiertos de Teflón, con ácidos nítrico, fluorhídrico y perclórico, calentando en baño de arena. Una vez que las muestras estuvieron disueltas, se llevaron a un volumen final de $50 \mathrm{ml}$. 
En cada una de las ocho muestras, se determinaron los siguientes elementos: calcio, magnesio, hierro, potasio, sodio, manganeso, titanio, bario y estroncio, por espectrometría de emisión atómica con plasma-ICP y siguiendo la correspondiente calibración mediante patrones analíticos. Estos elementos fueron elegidos unos por ser los componentes mayoritarios de las pastas cerámicas y otros por ser componentes minoritarios relevantes, todos ellos son claves para definir la composición química particular de una pasta cerámica y por tanto, relacionarla con el origen de fabricación de los objetos.

Los resultados obtenidos de la composición química de las ocho muestras fueron expresados como \% en peso de los correspondientes óxidos, excepto para bario y estroncio cuyos resultados se dan en $\mu \mathrm{g} \cdot \mathrm{g}^{-1}$ (ppm) (ver tabla 1).

Como puede observarse en los datos, las pastas de estas muestras corressponden a pastas no calcáreas o poco calcáreas $(\% \mathrm{CaO}<8 \%)$, pero hay algunas de ellass que ya se considerarían calcáreas, mostrando bastante variedad composicional entre los fragmentos analizados.

\section{TRATAMIENTO DE LOS RESULTADOS ANALÍTICOS.}

Ante la diversidad de composiciones, los fragmentos de cerámica común no fueron incluidos en el tratamiento estadístico ya que tienen unas pastas completamente diferentes: la muestra L3 es la única con composición no-calcárea $(0,84 \% \mathrm{CaO})$, además de otros elementos significativos (Sr), y la L8 tiene contenidos en Mn y Ba que la separan de las demás. Ello demuestra que los fragmentos de Terra Sigillata estudiados tienen un origen completamente diferente o que están preparados a partir de una pasta especial para ellos y totalmente distinta de la de Cerámica común.

Los resultados de la composición química de las otras seis pastas van a ser relacionados con los posibles grupos de muestras que resulten tener una composición similar y, por tanto, con un posible origen de fabricación común, que podrá compararse con trabajos publicados por otros investigadores.

Para ello, se procedió a un tratamiento estadístico de los mismos por Análisis de agrupaciones (Cluster Analysis), a través de las distancias euclidianas entre dos muestras, con el programa NTSYS. Los resultados estadísticos de este tratamiento se muestran mediante el dendrograma de la figura 1.

Los resultados de las seis muestras estudiadas se compararon con los obtenidos en cerámicas halladas en la Rioja, dado que se supone un origen de fabricación común. Estos últimos datos corresponden a parte de los análisis realizados para el estudio de Terra Sigillata hispánica de la tesis doctoral de Dña. Pilar Saenz Preciado, sobre el complejo alfarero de Tritium Magallum.

En el dendrograma (figura 1) puede verse que las pastas cerámicas se agrupan en un conjunto principal (primer recuadro en gris), más importante por el número de mues- 
tras que aparecen en él, que corresponde con los fragmentos procedentes del centro alfarero de La Cereceda (Arenzana de Arriba) y que incluía las muestras números 1 al 28. El segundo recuadro en gris señala un pequeño grupo de muestras que incluye la número 21 (molde) y la 22 (mortero), atribuidas inicialmente a La Cereceda y la 31, de una variante de Tricio y la 35, de Tricio. El resto de muestras procedentes de la Rioja aparecen ya aisladas, porque pertenecen a fragmentos de Terra Sigillata paleocristiana (32, 33 y 37) hallados en Nuestra Sra. De los Arcos (Tricio) o a otros alfares, como la 30, procedente de Los Morteros (Bezares) o la 41, molde de La Maja (Pradejón). Se han incluido también en el tratamiento las muestras de Terra Sigillata hallada en León y analizada con anterioridad (TS1-6, cuadro en blanco, figura 1 y tabla 2).

Las seis muestras de las que se ocupa este estudio (L1, L2, L4, L5, L6 y L7) aparecen en el dendrograma entre varios grupos. La muestra L7 es la única que queda perfectamente agrupada con las muestras que procedían del centro productor de La Cereceda. Los fragmentos L1 y L4 quedan cerca de estos grupos, pero a una distancia mayor.

La muestra L5, por su mayor contenido en $\mathrm{CaO}(11,2 \%)$, queda agrupada con fragmentos que se separaban de la composición general del centro de La Cereceda, como el TSH30 (de Bezares) o el TSH41 (La Maja).

Finalmente, L2 y L6 queda aislados con una composición diferente al resto de fragmentos comparados y sin un posible origen al que puedan adscribirse, aunque estos están más próximos al grupo que podría representar la composición de los talleres de Tricio (ya que además se relacionan también con la Terra Sigillata paleocristiana procedente también de Tricio), pero quedan aparte.

En la tabla 3, se ha incluido la composición química media de las pastas de los grupos (La Cereceda y Tricio) para facilitar la comparación con los resultados de las otras seis muestras. En la composición del primer grupo de La Cereceda está incluida también la muestra 29 procedente de La Puebla (Arenzana de Arriba), pero en su composición media no se ha contado con la muestra 7 (molde atribuido a La Cereceda) porque se observaron unas mayores diferencias en sus datos para algunos elementos.

Para una comparación más extensa con otros análisis de Terra Sigillata hispánica de cerámicas de la misma zona puede recurrirse a los análisis publicados por M. Picon (Mayet, 1984). En la tabla 4 se ha incluido un resumen de diferentes composiciones de Terra Sigillata de orígenes variados que pueden servir de referencia.

Como conclusiones, se puede decir que sólo la muestra L7 puede quedar definida como procedente de los talleres de La Cereceda, mientras que L1 y L4 podrían provenir de este centro aunque con un menor porcentaje de seguridad. El fragmento L5 parece estar cercano a otros talleres de la zona, como Bezares o La Maja, aunque el menor número de muestras analizadas de estos talleres no lo permite concluir con seguridad y podría darse el caso de que procediese de La Cereceda pero fuese algún fragmento con mayor contenido de calcio. Para los otros dos casos, L2 y L6, no se puede dar con seguridad un centro alfarero de procedencia. El pequeño número de muestras que forman cada uno de estos subgrupos y el hecho de que además en varios de los talleres que pueden servir de referencia (tabla 4) no se conozcan los contenidos de algunos elementos (como sodio, bario o estroncio) impide hacer una comparación estadística más clara. 


\section{REFERENCIAS}

Argyropoulos, V. (1995): "A characterization of the compositional variations of Roman Samian pottery manufactured at the Lezoux production centre". Archaeometry, 37 (2), 271-285.

Lasfargues, J., Picon, M. (1981): en “Die Unverzierte Terra Sigillata aus Haltern" (S. Von Schnurbein), Bodenaltertümer Westfalens, 19 (1), 6-21.

Maggetti, M., Küpfer, T. (1977): “Composition of the Terra Sigillata from La Péniche (Vidy/Lausanne, Switzerland)". Archaeometry, 20 (2), 183-188.

Mirti, P., Zelano, V., Aruga, R., Ferrara, E., Appolonia, L. (1990): “Roman pottery from Augusta Praetoria (Aosta, Italy): a provenance study". Archaeometry, 32 (2), 162175.

Picon, M., Vichy, M., Meille, E. (1971): “Composition of the Lezoux, Lyon and Arezzo Samian Ware". Archaeometry, 13 (2), 191-208.

Picon, M. (1973): "Introduction à l'étude technique des céramiques sigillées de Lezoux". Centre de recherche sur les techniques gréco-romaines, 2, Dijon.

Picon, M., Vichy, M. (1974): "Recherches sur la composition des céramique de Lyon". Revue Archéologique de l'Est et du Centre-Est, XXV (1), 37-59.

Picon, M., Carre, C., Cordoliani, M. L., Vichy, M., Hernandez, J. A., Mignard, J. L. (1975): "Composition of the La Fraufesenque, Banassac and Montans Terra Sigillata". Archaeometry, 17 (2), 191-199.

Pollard, A. M., Hatcher, H., Symonds, R. P. (1981): “Provenance studies of Renish pottery by comparison with Terra Sigillata". Revue d'Archéométrie, II (5), 177-185.

Schneider, G. (1978): “Anwendung quantitativer Materialanalysen auf Herkunftsbestimmungen antiker Keramik", Berliner Beitrage zur Archaeometrie, 3, 63-122.

Soricelli, G., Schneider, G., Hedinger, B. (1995): “L'origine della 'Tripolitanian Sigillata' Produzione A Della Baia di Napoli". 67-87.

Vendrell-Saz, M., Pradell, T. (1992): “Caracterización química y mineralógica de la cerámica sigillata tardía producida en Clunia (s. IV al VII)". Boletín de la Sociedad Española de Mineralogía, 15, 31-40.

Widemann, F., Picon, M., Asaro, F., Michel, H. V., Perlman, I. (1975): “A Lyons branch of the pottery-making firm of Ateius of Arezzo". Archaeometry, 17 (1), 45-59. 
Tabla 1. Composición química de las muestras de Terra Sigillata y de cerámica común (los resultados de los ocho óxidos están dados en \%, mientras que el bario (Ba) y el estroncio (Sr) están expresado en $\mu \mathrm{g} \cdot \mathrm{g}^{-1}$, ppm).

\begin{tabular}{|c|c|c|c|c|c|c|c|c|c|c|c|}
\hline & $\mathrm{Al}_{2} \mathrm{O}_{3}$ & $\mathrm{Fe}_{2} \mathrm{O}_{3}$ & $\mathrm{CaO}$ & $\mathrm{MgO}$ & $\mathrm{K}_{2} \mathrm{O}$ & $\mathrm{Na}_{2} \mathrm{O}$ & $\mathrm{TiO}_{2}$ & $\mathrm{MnO}$ & $\mathbf{B a}$ & $\mathrm{Sr}$ & \\
\hline L3 COMÚN & 11,33 & 3,66 & 0,84 & 1,59 & 2,06 & 0,25 & 0,44 & 0,042 & 511 & 1174 & SAN LORENZO \\
\hline L8 COMÚN & 12,99 & 5,44 & 7,12 & 2,63 & 1,62 & 0,17 & 0,58 & 0,123 & 1085 & 529 & SAN PEDRO \\
\hline L7 TSH & 20,09 & 6,70 & 9,12 & 3,00 & 3,91 & 0,42 & 0,72 & 0,058 & 693 & 419 & SAN PEDRO \\
\hline L1 TSH & 18,79 & 5,87 & 10,73 & 2,73 & 2,73 & 0,93 & 0,62 & 0,051 & 659 & 456 & SAN LORENZO \\
\hline L5 TSH & 19,27 & 6,64 & 11,23 & 2,89 & 3,18 & 0,78 & 0,73 & 0,074 & 541 & 235 & PILOTOS REGUERAL \\
\hline L2 TSHT & 16,87 & 5,82 & 6,87 & 1,69 & 3,53 & 0,39 & 0,58 & 0,088 & 1300 & 420 & SAN LORENZO \\
\hline L6 TSHT & 16,68 & 5,50 & 9,06 & 1,84 & 3,89 & 0,47 & 0,57 & 0,083 & 646 & 424 & SAN PEDRO \\
\hline
\end{tabular}

Tabla 2. Composición media de los análisis realizados anteriormente e otras muestras de Terra Sigillata halada en León.

\begin{tabular}{lcccccccccc}
\hline & $\mathrm{Al}_{2} \mathrm{O}_{3}$ & $\mathrm{Fe}_{2} \mathrm{O}_{3}$ & $\mathrm{CaO}$ & $\mathrm{MgO}$ & $\mathrm{K}_{2} \mathrm{O}$ & $\mathrm{Na}_{2} \mathrm{O}$ & $\mathrm{TiO}_{2}$ & $\mathrm{MnO}$ & $\mathrm{Ba}$ & $\mathrm{Sr}$ \\
\hline Media & $\mathbf{1 9 , 3 7}$ & 5,60 & 7,05 & $\mathbf{2 , 5 7}$ & 3,77 & $\mathbf{0 , 4 4}$ & $\mathbf{0 , 6 6}$ & $\mathbf{0 , 0 5 4}$ & $\mathbf{5 9 3}$ & $\mathbf{1 9 2}$ \\
DS & 0,75 & 0,34 & 0,32 & 0,09 & 0,12 & 0,01 & 0,04 & 0,002 & 20 & 11 \\
DSR (\%) & 3,89 & 5,99 & 4,53 & 3,66 & 3,21 & 1,60 & 6,59 & 3,69 & 3,43 & 5,96 \\
\hline
\end{tabular}

DS: Desviación Estándar.

DSR: Desviación Estándar Relativa o Coeficiente de Variación

Tabla 3. Composición química media (en \%) de los fragmentos del centro productor de La Cereceda (20 muestras) y del centro de Tricio (4 muestras).

\begin{tabular}{llcllllll}
\hline GRUPO & & $\mathrm{Al}_{2} \mathrm{O}_{3}$ & $\mathrm{Fe}_{2} \mathrm{O}_{3}$ & $\mathrm{CaO}$ & $\mathrm{MgO}$ & $\mathrm{K}_{2} \mathrm{O}$ & $\mathrm{TiO}_{2}$ & $\mathrm{MnO}$ \\
\hline La Cereceda & $\begin{array}{l}\text { media } \\
(\mathrm{n}=20)\end{array}$ & $\mathbf{1 8 , 4 0}$ & $\mathbf{6 , 8 0}$ & $\mathbf{8 , 0 4}$ & $\mathbf{2 , 6 7}$ & 3,58 & $\mathbf{0 , 8 1}$ & $\mathbf{0 , 0 5 7}$ \\
& $\mathrm{DS}$ & 1,17 & 0,31 & 1,17 & 0,46 & 0,30 & 0,03 & 0,008 \\
\hline Tricio & $\begin{array}{l}\text { media } \\
(\mathrm{n}=4)\end{array}$ & $\mathbf{1 5 , 1 8}$ & $\mathbf{5 , 4 9}$ & $\mathbf{7 , 6 9}$ & $\mathbf{2 , 0 5}$ & $\mathbf{3 , 2 9}$ & $\mathbf{0 , 6 9}$ & $\mathbf{0 , 0 4 6}$ \\
& $\mathrm{DS}$ & 0,82 & 0,41 & 0,59 & 0,13 & 0,15 & 0,04 & 0,005 \\
\hline
\end{tabular}




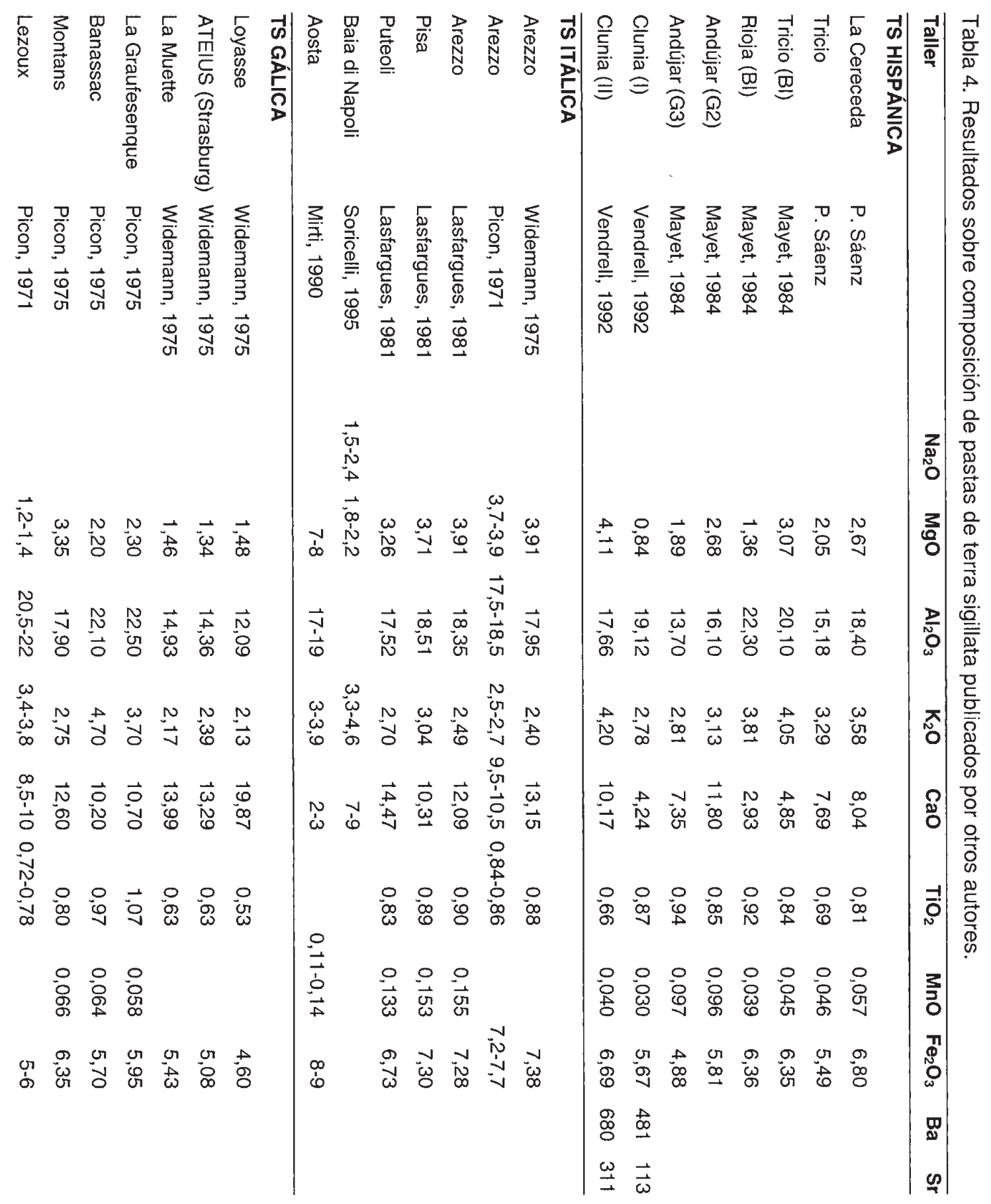




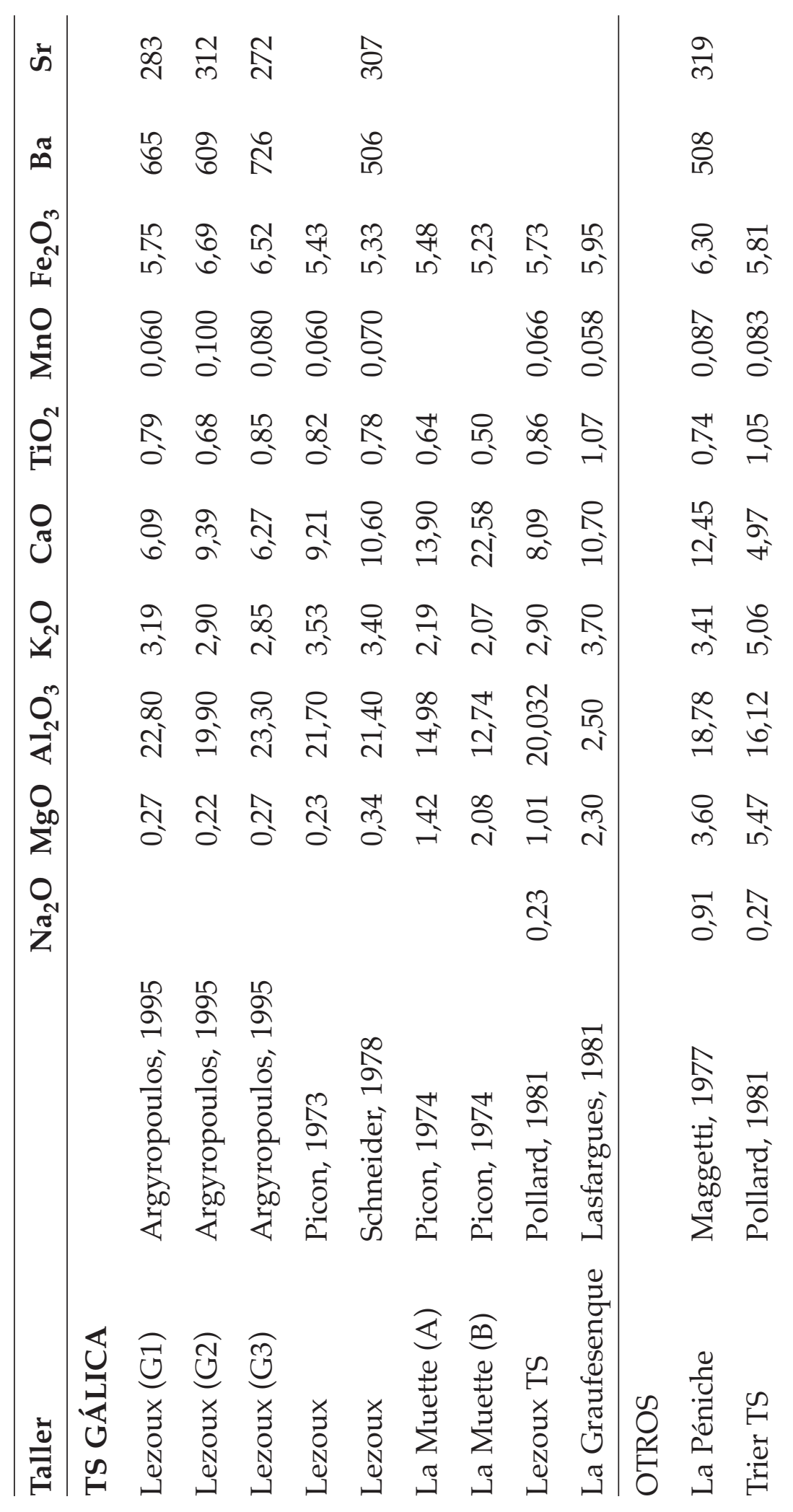


Figura 1. Dendograma e comparación entre distintas muestras de Terra Sigillata hispánica.

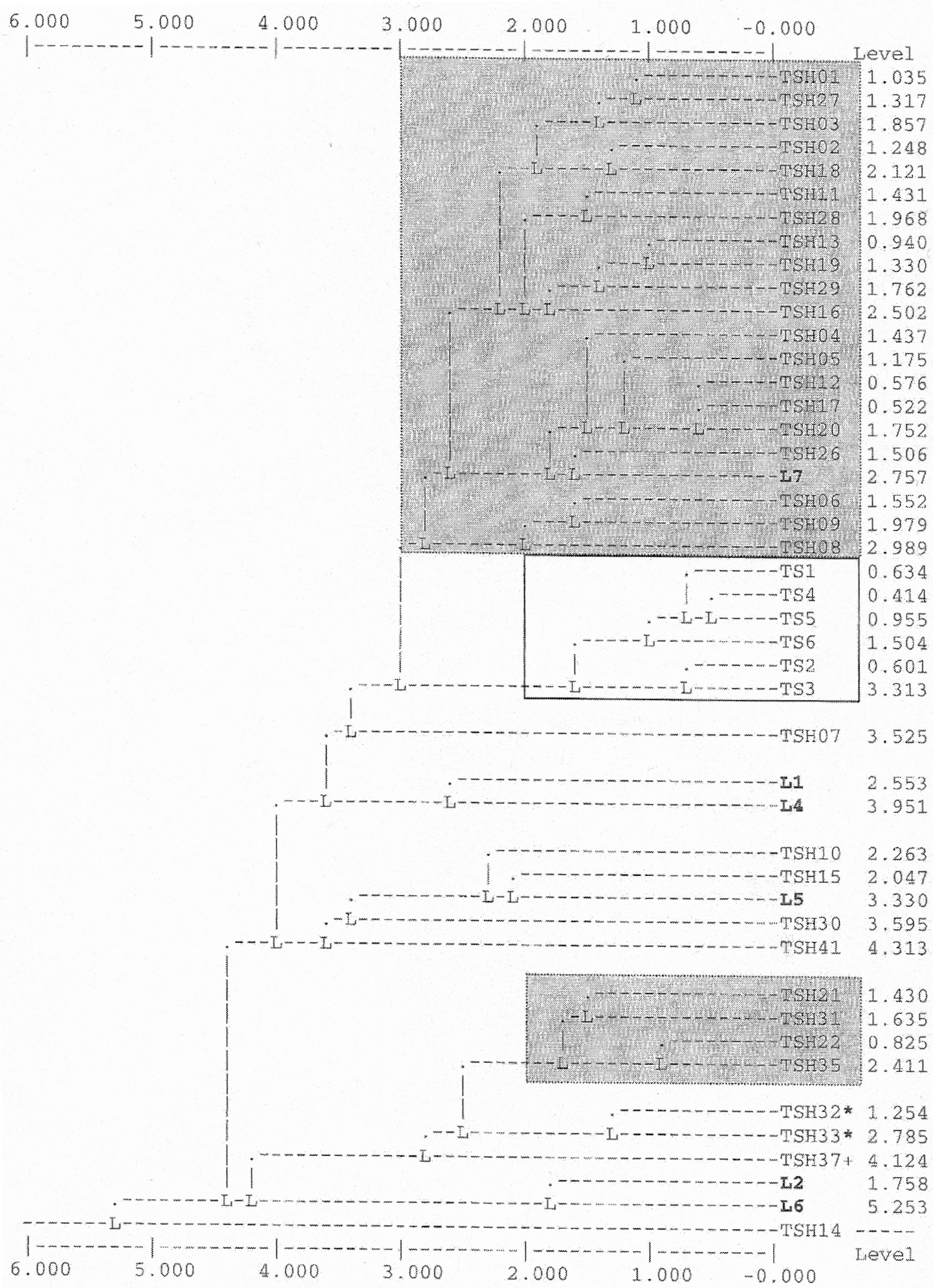

- En el primer recuadro gris aparecen las muestras pertenecientes al centro alfarero de la Cereceda.

- En el segundo recuadro gris se encuentran las muestras 31 (de una variante de Tricio) y 35 (de Tricio).

$\left(^{*}\right)$ Terra Sigillata paleocristiana gris.

(+) Terra Sigillata paleocristiana. 